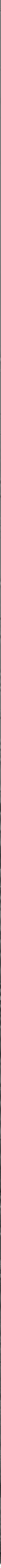




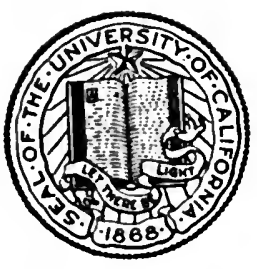

THE LIBRARY

OF

THE UNIVERSITY

OF CALIFORNIA

LOS ANGELES

SCHOOL OF LAW

Gift of

bencer-Miuss Co. 


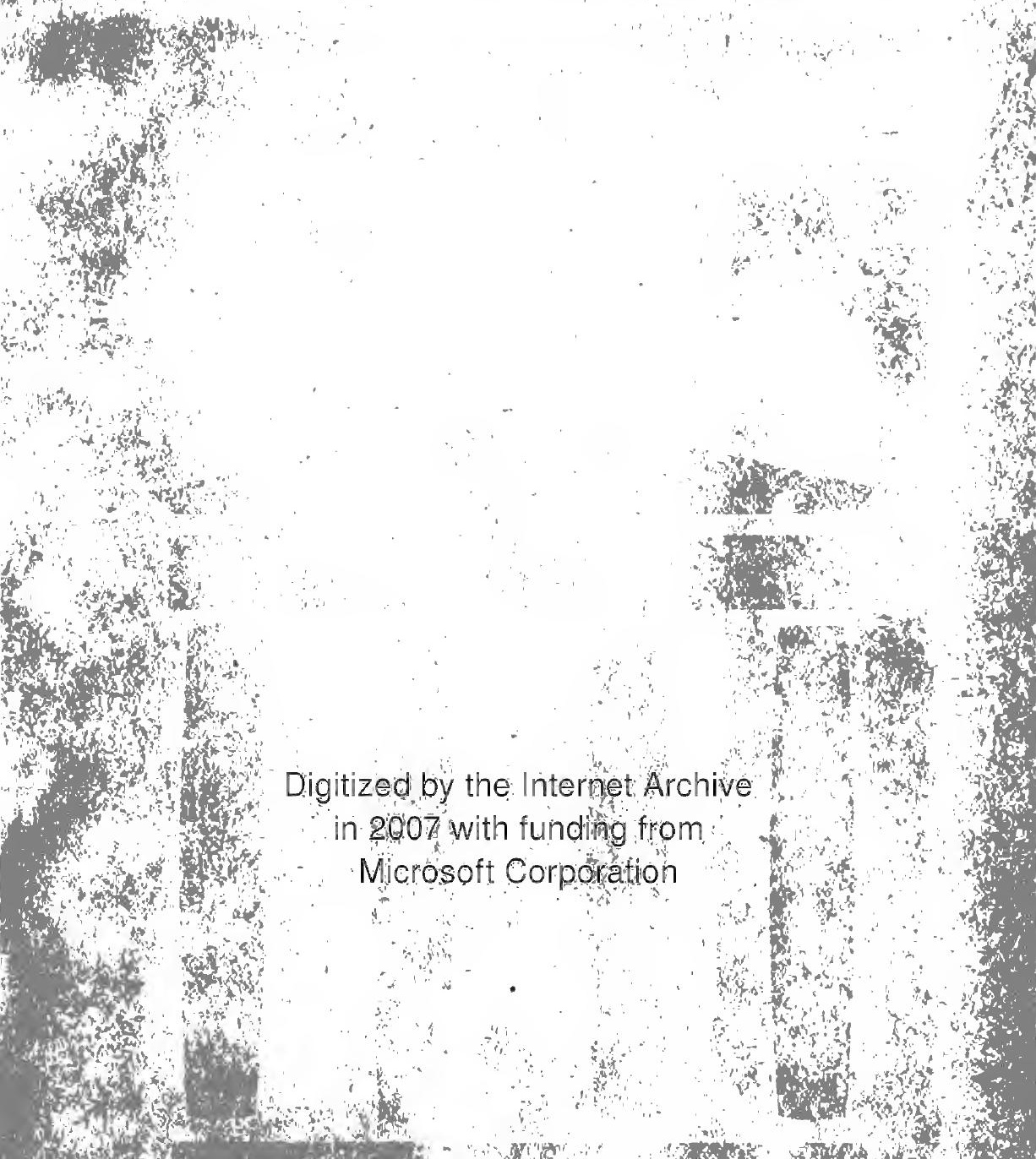

ons ind bet Arotise ring.

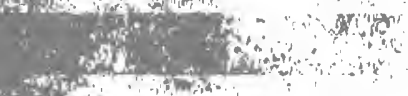
Cand now

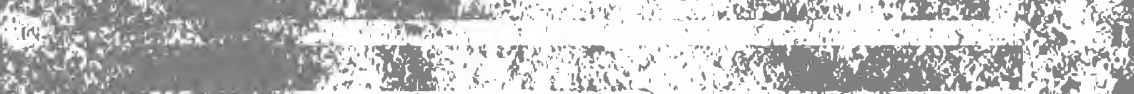

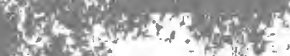

$3 x$ rengr.

43

(1)

\section{oj 0 kn}

(istis

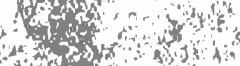
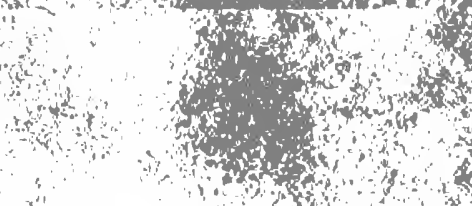

(n) 

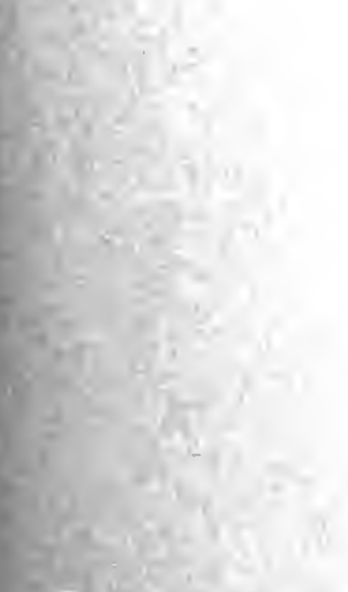

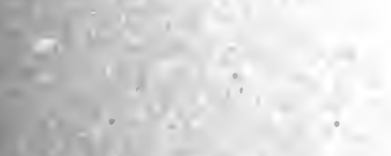

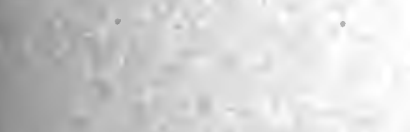

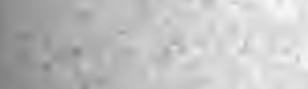

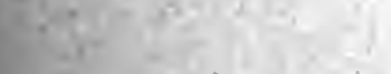
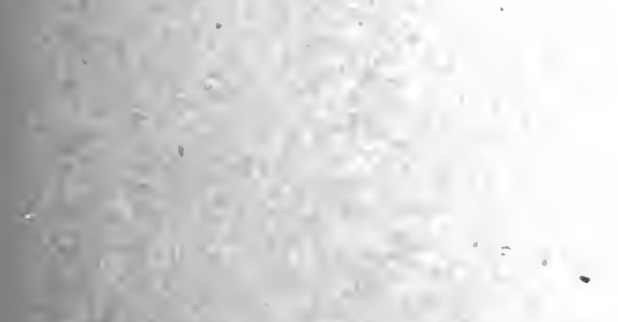

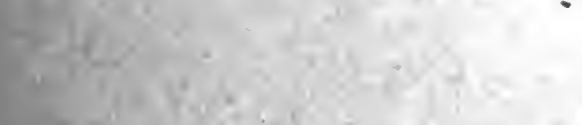
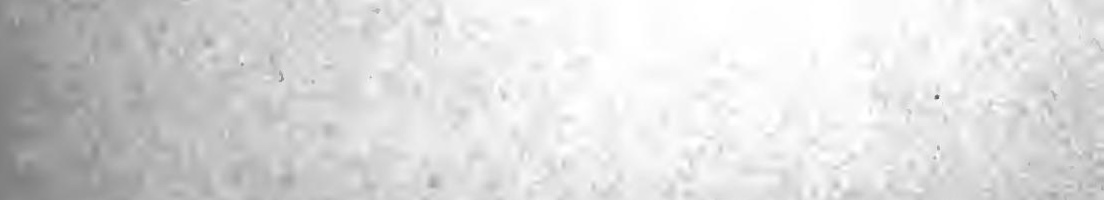

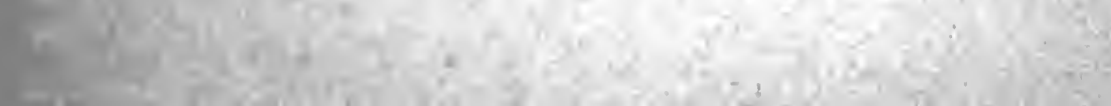






\section{THE LAW \\ OF \\ ACCIDENT AND EMPLOYERS' \\ LIABILITY INSURANCE}

BY HUBERT BRUCE FULLER, A. M., LL. M.

OF THE CLEVELAND, OHIO, BAR

KANSAS CITY, MO.

VERNON LAW BOOK COMPANY

1913 


$$
\begin{gathered}
\text { T } 9587 \text { a } \\
1913 \\
\text { CoPYBIGHT, } 1913 \\
\text { BY } \\
\text { HUBERT BRUCE FULLER }
\end{gathered}
$$

(Fulleb Acc.Ins.) 
To My Wife

(iii)*

\section{3}





\section{PREFACE}

ACCIDENT insurance is of comparatively modern origin. In the seventeenth century the idea of insuring individuals against accidents seems to have been first contemplated in France. But not until the middle of the nineteenth century was the first English company formed for this purpose. The first American company was not organized until about 1860 . In England the policies were framed for the purpose of paying definite indemnities for specific injuries, such as the loss of a limb, blindness, etc. The earliest American policies were based on their English prototypes. They were not adapted to the newer country, with its different customs and habits of life, its varied occupations and risks, and the companies which had embarked in the business met with disaster and failure. Shortly the pioneers in the industry undertook the scientific construction of a system of accident insurance, evolving new tables of rates, new classifications of risks, and new methods of business, based upon conditions in the United States. In a short time it was demonstrated that by a statistical and mathematical calculation a table of risks could be prepared on the same principie employed in the construction of mortality tables by life insurance companies, upon which could be based a reliable and equitable system of accident insurance.

In the United States accident insurance was inaugurated with the sale of so-called "accident tickets" to travelers on railroads covering only risks of travel, and in most instances good only for periods of twenty-four hours or the duration of specific trips. These tickets were sold at railroad stations. It soon became manifest that only a small percentage, not above ten per cent., of accidents resulted from traveling. Gradually the policies were made broader and more comprehensive in their scope. A modern treatise on the law of ac- 
cident insurance, therefore, becomes an analysis of the wider scope of the standard policies. While accident insurance is in many respects similar to life insurance, in its analogy it more closely resembles fire insurance, since it is a contract for indemnity, except in cases of death, when it becomes a special form of life insurance.

The forms of policies have been frequently changed in an effort to adjust them to judicial decisions upon controverted points. It is a matter of regret that the insurance companies have not shown a greater disposition to retain the conditions and forms which have been judicially construed, and in that way gradually evolve a contract in which the rights of both parties might be approximately exact in their construction. The introduction of new obligations and changes of phraseology mark the date of legal controversies, and thus become an index to the maturing law of this branch of insurance. Naturally an exact limitation of risks on the one hand and obligations on the other is vital to the business of insurance-in all of its branches, and nowhere more vital than in accident insurance.

The question of accident insurance has been treated in a more or less fragmentary manner in general works on insurance. But one who has made a study of the subject cannot fail to be impressed with the lack of an accurate and complete work on this field of law, which discusses exhaustively the many mooted questions which arise. To this end this volume has been prepared.

Employers' liability insurance is a development of accident insurance, and now constitutes a well-defined branch of the subject, which is constantly assuming greater importance. An effort has been made to discuss thoroughly all questions dealing with this branch of the subject also.

There are certain well-defined principles of law which are applicable to all kinds of insurance, life, fire, and marine as well, and it has been thought best not to do more than discuss them generally, lest those portions of the book become at best 
scarcely more than a summary of larger works in which they are treated in detail. But every possible effort has been made to exhaust those questions which are peculiar to the law of accirlent and employers' liability insurance, and to cite the decisions of our courts thereon. Where it has been possible, these decisions have been harmonized, though this task has been made the more difficult by the large number of variant and distinct types of policies and the varying verbiage in which the conditions thereof are clothed. While every endeavor has been made to gather into the footnotes of this volume all the reported cases, nothing can possibly be more delusive than the hope that any collection of cases could ever be complete.

So many of our states have enacted statutes providing for compulsory or optional employers' liability insurance that it has been deemed best to confine the treatment of that branch of the law to the general principles as they have been laid down by the courts and to ignore statutory insurance. A discussion of the subject of statutory employers' liability insurance at this time could be at best but evanescent, since the constant changes by amendment and enactment must make this subject as variable as the shifting sands and the flowing streams. It is hoped that this volume will supply a want in the somewhat crowded field of legal bibliography.

The author gladly accepts this opportunity to express his appreciation of the courtesy of valued friends, who by advice and suggestion have made easier the preparation of this work.

Cleveland, OHio, March 26, 1913. Hubert Bruce Fuller. 



\section{TABLE OF CONTENTS}

\section{CHAPTER I}

\section{CONTRACTS OF ACCIDENT INSURANCE}

Nature of the Contract. . . .............................. Page

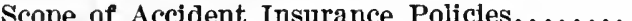

Parties to Contracts............................ 4

Oral Contracts of Accident Insurance................. 5

Duration of Contracts of Accident Insurance............. 6

Warranties and Representations..................... 10

Concealment ................................... 13

Nonpayment of Premiums........................ 19

Term Policies................................. 21

Waiver of Rights by the Insurer................... 23

Cancellation of the Policy........................ 26

\section{CHAPTER II}

\section{CAOSE OF INJURY OR DEATH}

What Constitutes an Accident..................... 27

What are External and Vlolent Means of Injury........... 37

What Included in RIsks of Occupation................. 43

Traveling Policles-Passengers-Public Conveyance.......... 55

Time Within Which Death or Disability must Ensue After an Ac-

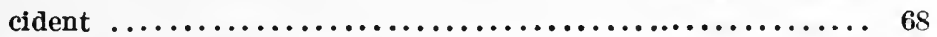

Pleading and Practice......................... 76

Rules of Evidence........................... 80

\section{CHAPTER III}

\section{EXCEPTED RISKS}

Conditions Exempting Insurer from Certain Risks.......... 87

Excepted Risks in Accident Policies................. 103

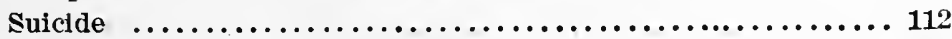

External and Visible Signs of Injury................ 119

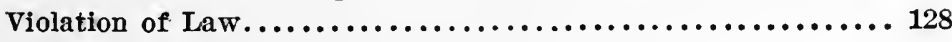

Fuller Acc.Ins.

(ix) 


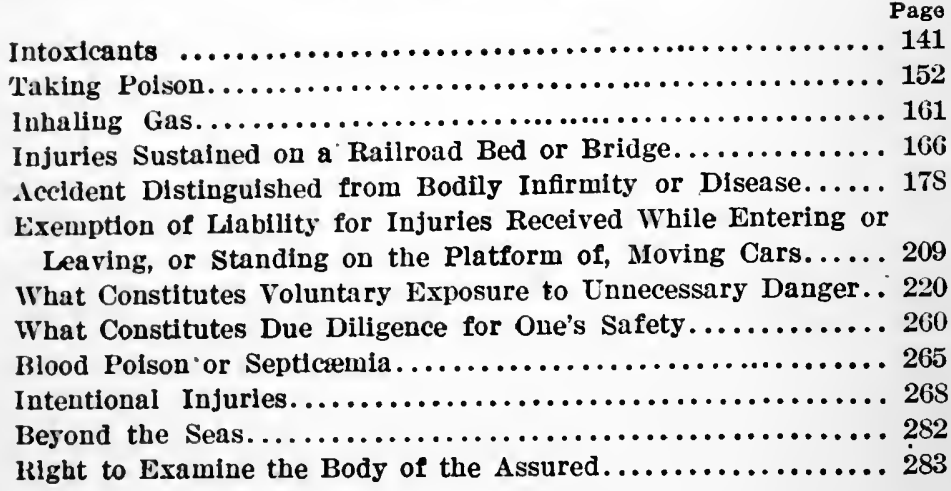

\section{CHAPTER IV}

\section{AMOUNT OF LIABILITY}

Death Distinguished from Disability................. 289

Total Disablihty................................. 291

What is Permanent or Continuing Disability............. 306

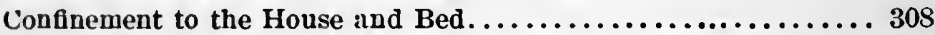

General Principles Determining Amount of Liability of Insurer 313 Jouble Lability and Amount of Indemnity Determined by the

Cause of Injury or Death-Passengers-Public Conveyance.. 327

Amount of Liability Determined by the Occupation of the As-

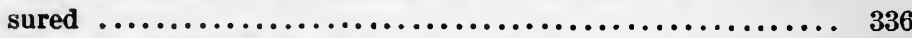

Injurles Inflicted by Robbers........................ 349

Liabillty for Particular Injuries..................... 349

The Loss of an Eye................................ 356

Broken Leg or Arm.............................. 358

Accldents in Elevators............................. 359

Burning Bullding............................... 360

Public Highway.................................. 361

Pleading and Evidence.............................. 362

\section{CHAPTER V}

\section{NOTICE AND PROOFS OF ACCIDENT OR DEATH}

Notlce and Proots of Loss.......................... 367

When Notlce and Proofs Must be Furnished...................... 370

Immedlate Notice............................... 372 
Impossibility of Giving Notice Within Specified Time......... 3 ,

Method of Computing 'lime...................... 391

Who may Furnish Proofs....................... 392

Proper Service of Notice and Proofs of Loss............. 395

What Constitutes Sufficient Proof.......................

Amount of Proof Required...................... 402

Pleading and Practice........................... 404

Proofs of Loss as Evidence......................4 406

Waiver of Notice and Proofs of Death or Injury......... 409

Neglect or Refusal to Furnish Blank Forms............ 414

Waiver by Request for Further Information............4 416

Acceptance of Subsequent Premiums............... 421

Failure to Object to Defects in Notice or Proofs of Death or In-

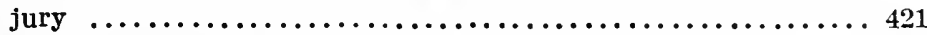

Waiver by Denial of Liability..................... 424

Pleading and Evidence.........................428

\section{CHAPTER VI}

\section{LIABILITY-PAYMENT-DISCHARGE}

Arbitration of Liability and Submission to Fraternal Tribunals. . 430 Beneficiaries and Right to Proceeds................. 434 Payment of Policies.......................... 435

Suits on Accident Insurance Policies..................447

\section{CHAPTER VII}

\section{EMPLOYERS' LIABILITY INSURANCE}

Employers' Liability Insurance..................4 438

Violation of Law............................447

Death or Bodily Injuries......................450

Contingent Liability .........................450

When Insurance Company Liable Under Its Policy..........451

Policies of Indemnity Against Loss Sustained............ 455

What Constitutes Payment of Loss.................. 458

Insolvency of the Assured...................... $46^{2}$

Right of Injured Employe to Recover from the Insurance Com-

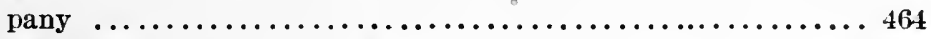

Assignment of Causes of Action...................469

Notice of Injury and Action for Damages.............. 470

Notice of Claim for Damages...................... 477 
Wairer of Notice.............................478

Limitation of Time for Bringing Suit. . . . . . . . . . . . . 479

Agreement to Defend Suit.......................481

Refusal of the Insurance Company to Defend............. 484

IAmit of Liability of Insurer . . . . . . . . . . . . . . . . . 491

Imnediate Surgical Relief........................493

Liability for Costs. . . . . . . . . . . . . . . . . . . . . 495

Fallure to Pay Premium.........................498

\section{TABLE OF CASES CITED}

(Page 505)

\section{INDEX}

(Page 527)

$+$ 


\section{THE LAW}

OF

\section{ACCIDENT AND EMPLOYERS LIABILITY INSURANCE}

\section{CHAPTER I}

\section{CONTRACTS OF ACCIDENT INSURANCE}

Nature of the Contract.

Scope of Accident Insurance Policies.

Parties to Contracts.

Orai Contracts of Accident Insurance.

Duration of Contracts of Accident Insurance.

Warranties and Representations.

Concealment.

Nonpayment of Premiums.

Term Policies.

Waiver of Rights by the Insurer.

Cancellation of the Policy.

Nature of the Contract.-A policy of accident insurance is a contract to indemnify against loss arising from death or injuries resulting from accidental causes. In the general view of the law, all policies which indemnify against death resulting from accidents are essentially life insurance policies, and as such are governed by statutes which control the issuance of policies of life insurance. ${ }^{1}$ Policies of accident

1 Logan v. Fidelity \& Casualty Co., 146 Mo. 114, 47 S. W. 948. Here the court held that the fact that a policy contains an agreement to indemnify against disability not resulting in death does not alter

Fuller ACc.INs.-1 
insurance differ in theory from policies of life insurance merely in that they cover a limited number of risks-that is, death from accidental rather than natural causes.

So, too, the courts have held that contracts insuring an employer for liability arising from accidents to others are contracts of life insurance. ${ }^{2}$ And even an offer by a newspaper to pay a specified sum of money to the legal heir of any one who meets death by accident, provided a copy of the newspaper containing a certain coupon be found on his person at the time of the acrident which results in death, constitutes a contract of insurance. ${ }^{3}$

its essential character as a policy of life insurance. See, however, Pickett v. Pacific Mut. Life Ins. Co., 144 Pa. 79, 22 Atl. 871, 13 L. R. A. 601, 27 Am. St. Rep. 618, where under the Pennsylvania statute policies insuring against disabllity merely are not regarded as life insurance policies. See, also, Standard Life \& Accident Ins. Co. $\checkmark$ Carroll, 86 Fed. 567,30 C. C. A. 253,41 L. R. A. 194, to the same efrect.

2 Employers' Liability Assur. Corp. v. Merrill, 155 Mass. 404, 29 x. F. 529. Here the court held that "policles of insurance to indemnify the assured, as owner of a horse, vehicle, or elevator causing accidental personal injuries for which he may be legally liable, against claims for compensation therefor, or as landlord or tenant for such injuries to persons other than employés or persons injured by elevators, or as a builder or contractor for such injuries to workmen employed by other contractors, and to the public, caused by the assured and bis own workmen, but not caused by a subcontractor or his workmen, all cover legitimate varieties of accident in. surance, and may lawfully be issued by a foreign insurance company IIcensed to issue accident policies and employers' liability policies, or by any company organized under the insurance act of 1887, c. $214, \$$ 29, cl. 5; and the fact that a foreign insurance company has issued such policies is not a cause for the revocation of its license."

3 Commonwealth v. Philadeiphia Inquirer, 3 Pa. Dist. R. 742. Here the newspaper made the following printed offer in its columns:

"\$500 insurance for one cent. Tuesday, Feb. 23, 1892. The Philadelphia Inquirer Insurance Coupon.

"The Philadelphia Inquirer will pay $\$ 500$ to the legal heir of any one who meets death by accident while pursuing his ordinary avocation, proviling this coupon, or a copy of the Inquirer containing it, be found on his or her jerson at the time of the accident which resulted in deati. Thls insurance begins at 2:30 a. m., Feb. 23, 1892, 


\section{Scope of Accident Insurance Policies.-In most states in-} surance companies are limited by statute in the kind of policies which they are permitted to issue. For example, where by statute or by the articles of incorporation the company is permitted to issue policies for the payment of insurance on the death of the assured, they will not be permitted to issue a policy payable upon the occurrence of total disability ${ }^{4}$ and a company authorized only to issue policies of in-

and ends at 2:30 a. m. Feb. 24, 1892. Notification of death must be sent to the business office of the Inquirer within twenty-four hours, and satisfactory proof within forty-eight hours of the time of death, that the above conditions were fulfilled.

"If more than one coupon is found on any such person, only one will be paid.

The Philadelphia Inquirer,

"929 Chestnut Street, Philadelphia, Pa."

The court said: "In the case of a purchaser who is induced to buy a single copy, or of a subscriber who makes his subscription because of the offer, contained in each issue, it seems to us that all the elements of a contract of insurance are present, namely, a proposition to insure, an acceptance of that proposition, and a consideration, which, though small, and though paid in part for the newspaper, and only in part for the insurance, is yet a real pecuniary consideration. Indeed, the true situation is so plain to my own mind that it is somewhat embarrassing to discuss it. It is too clear for denial-and no denial is made-that the defendant is seeking to increase the circulation of its journal, and for that purpose is offering to insure purchasers or subscribers against accident. The cousideration which the defendant receives, or hopes to receive, is a large total revenue, and in riew thereof it promises to each possessor of its journal who signs his name in the blank space left for the purpose the temporary protection of an accident insurance policy. In other words, it promises to pay to certain persons, who are to be identified by having its journal in their possession, a definite sum of money upon the happening of a specified contingency. This we understand to be insurance, and we think a simple test will demonstrate the correctness of this conclusion. If an accident insurance company was doing precisely what is now in question, would it enter the mind of any one to suppose that the transaction was not the issuing and acceptance of a policy such as it was authorized to issue?"

4 Preferred Masonic Mut. Life Ins. Co. v. Giddings, 112 Mich. 401, $70 \mathrm{~N}$. W. 1026. In Michigan by statute companies are required in their articles of association to state definitely the object of their incorporation. This company stated in its articles of association that 
surance against accidents sustained in traveling cannot issue policies insuring against accidents caused otherwise, even though the language of the policy is sufficiently comprehensive to embrace all classes of injuries; ${ }^{*}$ or a company organized to insure against disability resulting from accidents cannot insure against disability resulting simply from illness. ${ }^{\circ}$

Parties to Contracts. - The parties to a contract of accident insurance occupy the same relation to the insurance company as those under a policy of life insurance. If a policy of accident insurance based upon the life of the assured is issued to a third party, who pays the premiums therefor, it is clearly a contract between the insurance company and such third party. Therefore it follows that whether the beneficiary is a party to the contract will depend upon whether the policy was issued to him. Where the policy is issued to the assured himself, though it may designate another as the beneficiary, the policy holder is

Its purpose was to issue policles to be paid only in the event of the death of the Insured. The court held that under such articles of incorporation the company could not issue a policy payable upon the occurrence of total disability.

s Mlller v. American Mut. Acc. Ins. Co., 92 Tenn. 167, 21 S. W. 39, 20 L. IR. A. 765 . Here the court held that an accident insurance company, limited by the express terms of its charter to the insurance of persons against accldents sustained "in traveling," is not liable for an injury sustained while cleaning a shotgun, although the language of the policy was sufficlently comprehensive to embrace it. Insurance agalust such an injury is uitra vires and vold.

- Knowlton v. Bay State Beneficiary Ass'n, 171 Mass. 455, 50 N. E. 029, and also Knowiton $\nabla$. Berkshire Health \& Accident Ass'n, 171 Mass. 458, 50 N. E. 930. See, also, Employers' Liability Assur. Corp. v. Merrill, 155 Mass. 404, 29 N. E. 529. Here the court held that, where an insurance company is licensed to issue accldent policies and emplosers' llabllity policles, it could issue a policy to indemnify the assured against claims for compensation for injuries caused by vehlcles owned by the assured, or injuries resulting from his own negligence or the negligence of his employes. 
the party to the contract. In such cases the beneficiary during the lifetime of the assured has no present interest, and at most enjoys until the death of the insured only an inchoate or contingent interest in the contract. ${ }^{\text {? }}$

Oral Contracts of Accident Insurance.-Although practically all contracts of insurance are made in writing in accordance with the custom of the companies, none the less, in the absence of statutory provision, an oral contract of accident insurance will be binding. ${ }^{8}$ In some states, though, by statutory regulation, a valid contract of accident insurance cannot be made by parol. ${ }^{\circ}$

7 Hoffman v. Manufacturers' Accident Indemnity Co., 56 Mo. App. 301. Here the policy required notice of injuries to be given within ten days after the accident. The assured died forty days later without having given the required notice. The court held that the insurance company could not refuse payment to the beneficiary on the ground that she failed to furnish the required notice, inasmuch as she had no tangible interest in the contract until the death of the assured, and said: "The beneficiary, until the death of the insured, had, at most, only an inchoate and contingent interest in the policy. The insurer could not, until that event occurred, recognize her as a party to the contract, having a present interest therein. She could have no claim under the coutract until the death of the insured, and therefore she could give no notice of the accident or injury until that event occurred."

8 Fidelity \& Casualty Co. v. Ballard, 105 Ky. 253, 48 S. W. 1074.

o Fowler v. Preferred Acc. Ins. Co., 100 Ga. 330, 28 S. E. 398. Here the court said: "If in any event a valid contract of accident insurance can in this state be made in parol, such a contract does not result from oral conversations and negotiations between an applicant for insurance and an agent of an insurance company, whose conclusions and stipulations in the premises are finally reduced to writing and embraced in two instruments, the one an application for a policy of insurance signed by the applicant, and the other a receipt signed by the agent for a specified amount as the first quarterly premium of the policy to be issued." The court held, moreover, that, where the policy declares that it shall not be in force until actually issued from the company's office, a verbal assurance by the agent to the applicant that he is insured from the date of the appllcation and the delivery of the receipt do not together constitute a contract of insurance upon which an action can be maintained. 
Duration of a Contract of Accident Insurance.-The conclusion of the contract of insurance, in the absence of a condition to the contrary, marks the commencement of the risk and the liability of the company under its policy for an accidental death or injury. The contract may be concluded upon the acceptance of the application of the assured by the insurance company. ${ }^{10}$ Or the policy may commence on the date of the application, necessitating the predating of the policy to the date on which the application was made. The contract is generally formally concluded by the delivery of the policy which denotes the commencement of the risk. A contract for future insurance will take effect from its date. ${ }^{11}$

Generally speaking policies of accident insurance become effective on the date on which they are issued and delivered to the assured. Although an actual manual delivery of the policy is not necessary to complete the contract, an indorsement of a policy, either on the back or on its face, stating that it shall take effect on a certain date, will prevail over a gen-

10 Allen v. Massachusetts Mut. Acc. Ass'n, 167 Mass. 18, 44 N. E. 1053. By a clause in this policy the assured agreed that the company should not be liable before the receipt and acceptance of the appilcation by the home office of the company.

11 Fowler v. Preferred Acc. Ins. Co., 100 Ga. 330, 28 S. E. 398. Here the assured claimed a verbal agreement, made August 7, 1894, with the agents of the company, to the effect that be was insured from the date of the application, and in support thereof presented a receipt purporting to be for the first quarterly premium. The application contained couditious to the effect that it could not be altered by any agent, that the basis of the contract should be the application and premium paid, that no statement of any agent could bind the company unless indorsed upon the application, that the application should not be binding on the company until accepted by its secretary, and that the policy should not become effective until actually Issued from the main office of the company. The policy was dated August 30,1894, and insured the plaintiff for a term of three months from that date. On August 13 th the assured received an accldental injury, for which he claimed damages. Held, that he could not recorer for any injury receired prior to noon of August 30th. 
eral provision that it shall take effect when issued and delivered. ${ }^{12}$.

The ability of the agent to waive conditions in the application and issue a policy making the insurance company liable prior to the acceptance of the application will depend upon the power of the agent to make such an agreement, and an agent who is authorized merely to solicit insurance and receive applications has no legal authority to bind the company by a contract of insurance, or to vary the date on which the insurance will become effective. The insurance company, of course, may show the restricted character of the authority of the agent. ${ }^{13}$

12 Gordon v. United States Casualty Co. (Tenn. Ch. App.) 54 S. W. 98. In this case the assured on the 1st day of March, 1898, made a written application for a policy of accident insurance. The policy was issued and delivered on March 18th to the complainant, who then paid the premium on the policy, although by that time the injury on which the suit was based had occurred. On the back of the policy was the following indorsement: "Insurance begius March 1, 1898." A similar indorsement appeared on the face of the policy. A general condition of the policy provided that it should not take effect until issued and delivered to the assured. The court held that wherever an insurance policy was indorsed on the back as beginning at a certain time, and the same time was stated on its face, though there was a provision on its face that it was not to take effect until issued and delivered to the insured, after it has been issued and delivered it takes effect from the date stated by its terms, and not from the date of delivery.

13 United States Mut. Acc. Ass'n of City of New York v. Kittenring, 22 Colo. 257, 44 Pac. 595. October 27, 1890, the plaintiff made application for a policy of accident insurance, which was received at the main office of the company on October 30th. Among the provisions of the policy was a clause providing that the company should not be liable for any death or bodily injury happening "prior to the receipt and acceptance of this application." December 19th the policy was issued, to be effective from and after that date. December $2 d$ the assured sustained an injury for which he sought to recover. Evidence was introduced to show that the solicitor orally assured the plaintiff that the policy would be issued and of force from the date of the application. The court held that the agent had no a uthority other than to solicit insurance and recelve and forward applications, and that oral evidence could not be admitted to show 
Where a policy under a general clause provides that it shall be effective for a given length of time, the insurer will not be permitted to defeat the purposes of that clause by a subsequent condition totally repugnant thereto. Thus, for example, where an accident policy purports to insure for a period of twelve months from a certain date, a subsequent clause would be invalid which provides that the policy shall not cover any disability contracted within fifteen days from the date borne by the policy. ${ }^{14}$

Oral evidence of a local agent will not be admitted to contradict the express provisions of an application, ${ }^{15}$ though

that the agent walred the condition of the policy and entered into a binding contract whereby the insurance was to be in force from the date of application. To the contrary, see Mathers $\nabla$. Union Mut. Acc. Ass'n, 78 Wis. 588,47 N. W. 1130,11 L. R. A. 83, where the court held that under a Wisconsin statute an oral agreement for present insurance, made by the agent of an accident association, was binding upon the assoclation, although the application, signed by the person to be insured, unknown to the applicant, contained a provision that the association should not be liable for any injury happening prior to the recelpt and acceptance of the application and member's fee by the general manager. Here the policy subsequently issued bore date two days later than the oral agreement. This case is not in harmony with the generally accepted rule of insurance law.

14 Bean v. Atna Life Ins. Co., 111 Tenn. 186, 78 S. W. 104. Here the policy was issued purporting to insure the plaintiff for a period of twelve months from noon of October 25,1901 . By a subsequent clanse it was provided that the policy should not cover any disabllity contracted within fifteen days from noon of the date borne by the policy. The court held that, the second clause being irreconcllably repugnant to the first provision, the chief purpose of the contract was roid.

16 Allen v. Massachusetts Mut. Acc. Ass'n, 167 Mass. 18, 44 N. E. 1053. July 31,1895 , the assured signed an application for accident insurance, whlch he delivered to the local agent of the company, together with the premium. The agent stated that the application would be forwarded the same day, and the policy would be delirered the next day. A condition in the application stated that the insurance company would not be liable before the receipt and acceptance of the application at the main office. The application was received at the main office August 1st. August $2 \mathrm{~d}$ the assured received an aecidental injury, of whlch the defendant learned on August 5th. 
parol evidence may be admitted, where by reason of an omission or ambiguity in the policy the time when the instrument becomes operative is left in doubt. ${ }^{10}$

Frequently policies of accident insurance are issued to apply only to persons between certain ages. ${ }^{17}$

Accident policies, which provide for the payment of the premium by installments, are contracts for separate and definitive periods of time. ${ }^{18}$

Thereupon the insurance company communicated with the agent declining the application. The court held that no contract had been made, and that, even if the insurance company had received the application and had intended to accept it, it had a right to change that intention when it leard of the accident. The court held that the lower court rightly excluded evidence tending to show that the agent told the plaintiff that he was insured from the moment of signing the application.

16 Modern Woodmen Acc. Ass'n v. Kline, 50 Neb. 345,69 N. W. 943. Here the court held that parol evidence was admissible for the purpose of supplying omissions or resolving ambiguities in the policy.

17 Wheeler v. United States Casualty Co., 70 N. J. L. 370,57 Atl. 124. Here the policy provided that it should apply only to persons "over sixteen years of age and under sixty-five years of age." The court held that the insurance company was not liable for an accident happening after the person taking out the policy had passed the age of sixty-five years. See, also, Hause v. Standard Acc. Ins. Co. (Mich.) 137 N. W. 694, where the assured did not know of an age limitation clause in a post card accident policy.

18 Employers' Liability Assur. Corp. v. Rochelle, 13 Tex. Civ. App. 232 , $35 \mathrm{~S}$. W. 869 . Here the policy provided for the payment of the premium by installments in four consecutive months; the first payment rendering the policy effective for two months, the second for four months, the third for seven months, and the last for twelve months. It also declared that the premiums named were for consecutive periods of two, three and five months. The court held that this was a contract of insurance for separate periods, and not for a single period of an entire year. But where the complaint in an action on a polley alleges that the insurance was for a period of fifty-two weeks, this is not a material variance, where the policy provides for this term under independent contracts by months. See Standard Life \& Accident Ins. Co. v. Koen, 11 Tex. Civ. App. 273, 33 S. W. 133. 
Warranties and Representations.-The declarations made by the assured in his application for a policy of accident insurance, if fundamental to the contract of insurance, constitute warranties; but if in their nature they form no part of the contract, but are merely collateral thereto, they constitute merely representations. Representations may properly be termed the source of the contract, while warranties are stipulations which form a part of the contract and are inherent thereto. ${ }^{21}$ The same general rules which govern the construction and application of policies of life insurance apply also to contracts of accident insurance. In view of the fact that the subject of warranties and representations is so thoroughly discussed in current works devoted to the law of life insurance, it seems unwise to do more here than state the general principles which govern these questions, and to go into detail in those elements only which are peculiar to contracts of accident insurance.

Generally speaking, a warranty stipulates the accuracy of the statement made, and is therefore material to the contract and must be strictly complied with, while a representation is less material and need only be substantially true. Where, however, the application warrants the truthfulness of all the statements made therein, and the policy specifically declares that it is issued thereon and the application is made a part of the contract, then all such statements become warranties. If the policy expressly provides that the statements in the applica-

21 Spence v. Central Acc. Ins. Co., 236 Ill. 444, 86 N. E. 104, 19 L. R. A. (N. S.) 88. Here the court declared that a warranty enters into and is a part of the contract, and must be literally true to permit a recovery on the policy, while a representation is not a part of the contract, but an inducement thereto. A representation may relate to a materlal matter, but is only required to be substantially true. See, also, United States Casualty Co. v. Campbell, $148 \mathrm{Ky}$. $5.4,146 \mathrm{~S}$. W. 1121, where the court declared that under the Kentucky statute a representation is material only when, if the truth had been known, the pollcy would not have been issued. 
tion shall be deemed warranties, they will, by reason of this contractual obligation, become such, though they may not be material to the agreement. ${ }^{22}$ In many states statutes have been enacted declaring that, despite any condition in the policy to the contrary, answers in the application shall be deemed warranties, and their falsity will defeat the contract, only when they are material to the risk.

Where a statement is naturally based upon facts not within the knowledge of the assured, it is a mere representation, since there can be no warranty of matters not based upon knowledge of the applicant. ${ }^{23}$ And so, also, where the statement is merely a matter of opinion upon the part of the assured, or is modified in such a way as to show that it was not the intention of the applicant to vouch for its truthfulness.

From the foregoing it follows that, if the fact warranted is untrue, there is a breach of condition and the policy is there-

22 Centrai Acc. Ins. Co. v. Spence, 126 Ill. App. 32.

23 Standard Life \& Accident Ins. Co. v. Lauderdale, 94 Tenn. 635, $30 \mathrm{~S}$. W. 732 . Here the assured falsely stated in his application for a policy of accident insurance that his habits were "correct and temperate," and the truth of that statement was warranted and made a condition precedent to the validity of the policy. As a matter of fact he was intemperate in his habits, and his death resulted apparently from upsetting a lighted coal oil lamp while in an intoxicated condition. The court held the policy void and said: "We are of the opinion that the statements made by the assured in his application for the policy, in respect to his habits, were not mere representations, but absolute warranties. Those statements were made in respect to a material matter that vitally affected the contract, and, if untrue, invalidated the whole insurance, whether the misstatement was willful and intentional, or made through inadrertence. Indeed, in this view of the case, it is immaterial whether such statements be called representations or warranties. * * * The materiality of the applicant's statement in respect to his habits on the subject of temperance will not be controverted. ** * Accident insurance companies avoid such risks (on the life of men of intemperate habits), for the reason that such indulgences render the assured incapable of discerning danger, and especially incapacitate him for avoiding its consequences after it is discovered." 
by avoided. ${ }^{24}$ This is true, even though the statement may be immaterial to the risk, if it is still made as a warranty. ${ }^{25}$ But where the statements are not made a part of the policy, so as to become warranties, their inaccuracies merely become misrepresentations, and do not avoid the policy, unless they involve facts essential to the risk. ${ }^{26}$ Good faith and lack of knowledge on the part of the assured will not excuse a breach of warranty, unless the answers are qualified by some statement, such as to the effect that they are made to the best of the knowledge and belief of the applicant. ${ }^{27}$ And so to avoid a policy for a misrepresentation, not a warranty, the statement must have been made by the applicant with fraudulent intent, and must have been relied upon by the insurance company.

The presumption of law is that all warranties and representations are true and are made in good faith, and the burden of proof to establish their untruthfulness or fraud rests upon the insurer. These questions, together with the materiality of the statements, upon conflicting evidence, are matters of fact for the determination of the jury. ${ }^{28}$

24 Pacific Mut. Life Ins. Co. v. Van Fleet, 47 Colo. 401, 107 Pac. 1057; Standard Life \& Accident Ins. Co. จ. Lauderdale, 94 Tenn. 635,30 S. W. 732, supra.

25 Bayley v. Employers' Liability Assur. Corp. (Cal.) 56 Pac. 638. Here the assured in his application alleged that he had never received compensation for any accident, while, as a matter of fact, he had received such compensation upon two distinct occasions. The court said: "The statement was a warranty, and the objection of immateriality cannot be urged against a warranty, unless in very exceptional instances." See, also, Central Accident Ins. Co. v. Spence, 126 Ill. App. 32.

26 North American Accident Ins. Co. v. Rehacek, 123 Ill. App. 219.

27 Standard Life \& Accident Ins. Co. v. Sale, 121 Fed. 664, 57 C. C. A. 418,61 L. R. A. 337 , where the court held that, "if the fact is not as stated by insured, the warranty is breached, and it makes no difference that insured acted in good faith in making the statement."

28 . Miller v. Maryland Casualty Co., 193 Fed. 343, 113 C. C. A. 267; Lnited States Heaith \& Accident Ins. Co. v. Bennett's Adm'r, 105 
Concealment.-Manifestly it is the duty of the applicant to reveal in his application all facts which may be material, and a failure to do so will render the policy void. Most policies contain a warranty that all answers in the application are "full and correct." The question of concealment turns largely upon the intent of the assured, though some cases hold that a concealment will invalidate the policy, whether innocent or intentional. ${ }^{28}$ For example, false statements as to age, deliberately made, will render the policy void. ${ }^{30}$ And an untrue answer as to the amount of income enjoyed by the assured will invalidate the policy; ${ }^{31}$ or a false answer as to whether his application for insurance had ever been rejected by any other company, or compensation refused for disability; ${ }^{32}$ or where the applicant falsely warrants that the beneficiary is his wife. ${ }^{38}$

A false answer as to his occupation, or a failure on the part of the assured to state his occupation, will avoid the policy,

S. W. 433, 32 Ky. Law Rep. 235; United States Casualty Co. v. Campbell, $148 \mathrm{Ky}$. 554, 146 S. W. 1121; Standard Accident \& Life Ins. Co. of Detroit, Mich., v. Wood, 116 Md. 575, 82 Atl. 702.

29 Dineen v. General Acc. Ins. Co., 110 N. Y. Supp. 344, 126 App. Div. 167.

30 Brink v. Guaranty Mut. Acc. Ass'n, 7 N. Y. Supp. 847, 55 Hun, 606, affirmed without opinion in $130 \mathrm{~N}$. Y. 675,29 N. E. 1035 . Here the applicant merely gave the agent the year in which he was boru. The agent made a miscalculation, and wrote down the wrong age. The court held that there was no misrepresentation on the part of the assured. See, also, Central Acc. Ins. Co. v. Spence, 126 Ill. App. 32, and Spence v. Central Acc. Ins. Co., 236 Ill. 444, 86 N. E. 104, 19 L. R. A. (N. S.) 88, supra ; Ætna Life Ins. Co. v. Claypool, $128 \mathrm{Ky}$. 43, 107 S. W. 325, 32 Ky. Law Rep. 856; 'Travelers' Ins. Co. V. Leibus, 28 Ohio Cir. Ct. R. 700.

31 Everson v. General Accident, Fire \& Life Assur. Corp., Limited, of Perth, Scotland, 202 Mass. 169, 88 N. E. 658; Heintz v. Continental Casualty Co., 105 N. Y. Supp. 519, 121 App. Div. 75.

32 Wright v. Fraternities Health \& Accident Ass'n, 107 Me. 418, is Atl. 475,32 L. R. A. (N. S.) 461.

33 Continental Casualty Co. v. Lindsay, 111 Va. 3\$9, 69 S. E. 344; the evidence showing that he was unmarried and that the beneficiary was his concubine. 
where the application contains such an interrogatory. ${ }^{34}$ The rate of the premiums and the allowance of the policy in many instances depend upon the calling pursued by the applicant. But where the applicant makes a full disclosure, without any concealment, a slight discrepancy between the occupation named in the application and that actually followed by him will not avoid the policy. ${ }^{35}$ This question is treated more at length elsewhere under the question of Change of Occupation and Liability of Insurer Dependent upon Occupation of the Assured. $^{36}$ Where the answer of the applicant is evasive and not responsive to the question, the company is put on its guard to make further inquiry. ${ }^{37}$ Where the classification is determined by the agent of the insurer upon a full statement of facts by the applicant, the company cannot disavow the act of its agent and claim an avoidance of the policy because of in-

s4 Standard Life \& Accident Ins. Co. v. Ward, 65 Ark. 295, 45 S. W. 1065 . Here the applicant warranted as true the statement in the application that his occupation was that of "ice dealer and proprletor of transportation company." The court held that the policy was vold if the applicant was also engaged in the business of buying and selling cattle. Cram v. Equitable Acc. Ass'n, 11 N. Y. Supp. 462, 58 liun, 11, where assured stated that his occupation was "oil producer, superrising only," and where it was shown that he was the lessee of oil lands, on which he alone managed and operated several wells. Murphey v. American Mut. Acc. Ass'n, 90 Wis. 206, 62 N. W. 1057 , where the assured gave his occupation as "carpenter and millwright," when in reality he was at the time engaged in cutting cordwood.

85 For example, see Ford v. United States Mut. Acc. Relief Co., 148 Iass. 153,19 N. E. 169,1 L. R. A. 700 , where the application stated that assured was a "leather merchant," when in fact he was a leather cutter and merchant; Everson v. General Accident, Fire \& Life Assur. Corp., Limited, of Perth, Scotland, 202 Mass. 169, 88 N. E. 658; Dalley v. Preferred Masouic Mut. Acc. Ass'n, 102 Mich. 289,57 N. W. 184, 26 L. R. A. 171; Taylor v. Illinois Commercial Men's Ass'n, 84 Neb. 799, 122 N. W. 41; Brink v. Guaranty Mutual Accident Ass'n, 55 Hun, 606, 7 N. Y. Supp. 847; Neafle v. Manufacturers' Accldent Indemnity Co., 8 N. Y. Supp. 202, 55 Hun, 111.

so See pages 43 and 330 .

87 Paciflc Mut. Life Ins. Co. v. Van Fleet, 47 Colo. 401, 107 Pac. 1057. 
correct classification. ${ }^{38}$ The question of the occupation of the applicant for insurance is determined by his regular business on which he relies for a livelihood, and does not refer to occasional acts of a different nature. ${ }^{39}$ The application refers to the occupation at the time thereof, and the answer cannot be

38 Pacific Mut. Life Ins. Co. v. Snowden, 58 Fed. 342,7 C. C. A. 264 , where the court laid down the following rule: "Where an applicant for insurance against accident makes a true and full statement of his occupation to the company's agent, the company is bound, after loss, by the classification which the agent gives him; and if he is wrongly classified, according to the company's rules, the fact that he certifies to an understanding of the company's classification of risks, and that he belongs to the class given, is immaterial, when in fact his only means of understanding such classification is through the representations of the agent." See, also, New York Acc. Ins. Co. v. Clayton, 59 Fed. 559, 8 C. C. A. 213, where with full knowledge that the applicant was a junk dealer, which belonged in a more hazardous class, the general agent of the insurance company classified him as "merchant." Carpenter v. American Acc. Co., 46 S. C. 541,24 S. F. 500, where the court sustained the following charge: "An insurance company cannot plead wrong classification, if the evidence shows that their agents had a full knowledge of the facts, and that they made the classification."

39 Standard Life \& Accident Ins. Co. v. Fraser, 76 Fed. 705, 22 C. C. A. 499 , where the assured, classified as "proprietor of a bar and billiard room, not tending bar," was shown to tend bar to the extent of relieving his bartenders occasionally at meal hours. Simmons v. Western Travelers' Acc. Ass'n, 79 Neb. 20, 112 N. W. 365. Here the policy provided for a limitation in the amount of the liability if the assured should change his occupation to one more hazardous than that specified in his application. The assured, classified as a traveling man, lost his position, and while out of work stayed on his father's ranch, but drew no pay. While looking for another position in his regular line of work, he was killed. The court held that there had been no change of occupation to that of stock farmer or superintendent, classed under the policy as more hazardous than commercial traveler. Stone's Adm'rs v. United States Casualty Co., 34 N. J. Law, 371, where the assured, classified as a "teacher," was killed while in a general way superintending the construction of two houses which he was having built. Brink v. Guaranty Mut. Acc. Ass'n, 7 N. Y. Supp. 847, 55 Hun, 606, affirmed without opinion 130 N. Y. 675,29 N. E. 1035 , where the assured, classified as a "lirery stable proprietor (not working)," with duties "such as were required of him in that occupation," was shown to sometimes bitch up horses himself and drive persons out. See, also, pages 43 and 336 . 
required to warrant that the assured shall not change his business. ${ }^{40}$

False statements as to the existence of other insurance held by the applicant will invalidate the policy. Answers by the assured as to his habits and temperance will, if false, avoid the policy, since they are manifestly material to the risk involved. ${ }^{41}$ A declaration that the applicant is temperate, however, does not require that he be a total abstainer from the use of intoxicants.

The courts have generally held that answers of the assured to queries in the application with regard to his health and general physical condition are material, and if incorrect will avoid the policy. ${ }^{42}$ The tendency of the courts is somewhat toward

to Simmons v. Western Travelers' Acc. Ass'n, 79 Neb. 20, 112 N. W. 365 ; Denoyer v. First Nat. Acc. Co., 145 Wis. 450, 130 N. W. 475. Here the policy declared that fraud or concealment of any fact in the application would avold the contract. The applicant represented his occupation as that of "miller," but at the time of making the application for the policy, or shortly thereafter, he attached to his tlour mill a circular saw for cutting logs into lumber. The court held that, though operating a circular saw was a prohibited occupation, the applicant had made no false representations as to his occupation.

11 Standard Life \& Accident Ins. Co. v. Lauderdale, 94 Tenn. 642, $30 \mathrm{~S}$. W. 732, where the assured stated that he was temperate and his habits good. On the contrary, it was shown that he was intemperate, and his death was caused by his upsetting a lighted coal oil lamp while intoxicated.

42 Standard Life \& Accident Ins. Co. v. Sale, 121 Fed. 664; 57 C. C. A. 418,61 L. R. A. 337 , where the court held that the answers were warranties, and not mere representations resting on the belief of the assured, and therefore the policy was avoided if they were incorrect, without regard to the good faith of the applicant in making them. A more liberal rule is laid down in Miller v. Maryland Casualty Co., 193 Fed. 343, 113 C. C. A. 267, and in Modern Woodmen Acc. Ass'n v. Shryock, 54 Neb. 250,74 N. W. 607, 39 L. R. A. 826 , where the court held that in order to avoid the policy it must be shown that the answers were faise in some particular material to the insurance risk, that they were made intentionally by the assured, and that the insurance company relied and acted upon such statements. The more generally accepted rule is that set forth in the Sale Case. See, also, Duiany v. Fidelity \& Casualty Co., 106 
relaxing the severity of this rule, and not infrequently the particular conditions of each case will govern the construction adopted by the courts. In any event bodily infirmities will not be construed to include mere temporary ailments not calculated to weaken the constitution, impair the strength of the system, or shorten life, which are curable, and disappear rapidly under proper treatment, such, for example, as a cold, a case of grippe or indigestion, ailments to which all men are more or less subject. ${ }^{43}$ They refer rather to chronic diseases or organic disorders, which reduce the vitality of the assured and render him more liable to injury and death. ${ }^{44}$ In any event, the knowledge or ignorance of the applicant with regard to his own physical condition and the existence of latent diseases is frequently the controlling element in determining the truth or falsity of his answer. And the warranty of the assured that he enjoys good health is not to be construed literally into meaning that he is free from slight and temporary ailments, but merely represents that he is free from diseases likely to shorten his life or lower his vitality.

The same general rules apply to the answers of the applicant to inquiries as to whether he has ever suffered any previous injury or bodily infirmity. A slight injury or bodily infirmity

Md. 17, 66 Atl. 614; French v. Fidelity \& Casualty Co. of New York, 135 Wis. 259, 115 N. W. 869, 17 L. R. A. (N. S.) 1011.

13 United States Health \& Accident Ins. Co. v. Bennett's Adm'r, 105 S. W. 433, $32 \mathrm{Ky}$. Law Rep. 235, where assured had at different times, prior to making the application, suffered from slight attacks of piles. See, also, Cady v. Fidelity \& Casualty Co. of New York, 134 Wis. 322, 113 N. W. 967; French v. Fidelity \& Casualty Co. of New York, 135 Wis. 259, 115 N. W. 869, 17 L. R. A. (N. S.) 1011, where the assured had previously suffered from an acute attack of bronchitis, from which he had fully recovered.

44 Standard Life \& Accident Ins. Co. v. Sale, 121 Fed. 664, 57 C. C. A. 418,61 L. R. A. 337 , where the assured stated in his application that he was in sound mental and physical condition, but it was claimed by the insurer that he was in fact at the time suffering from Bright's disease.

Fuller Acc.Ins.-2 
of a temporary nature, not calculated to impair the physical vitality of the assured, or suffered a great many years prior to the application, will not amount to a breach of the warranty that the assured has not been the victim of any injury or bodily ailment. To come within the purview of the rule avoiding the policy, it must have been such an injury or infirmity as will increase the hazard and render the assured more liable to death or subsequent injuries. ${ }^{45}$

45 Bernays v. United States Mut. Acc. Ass'n (C. C.) 45 Fed. 455, where the assured had had and was subject to erysipelas, but stated in his application that he had never had and had not then any bodily infirmity or mental disease. The court said: "As the insurance was against accident, * * * it is fair to presume that the insurer desired information as to whether the deceased then had, or had ever had, any bodily or mental infirmity that would render him more than ordinarily liable to accident, or that would increase the risk of death in case an injury was sustained, and that the question in response to which the warranty was given was asked with a view to eliciting such information, and for no other purpose. It must also be presumed that the assured both understood and answered the question in that sense, and, in effect, only warranted that he had never had, and did not then have, any infirmity of mind or body that would increase the risk of accident, or the risk of death therefrom in case an injury was sustained. This aplears to me to be a reasonable interpretation of the warranty, cousidering the character of the policy and the purpose that the insurer had in view." Cotten v. Fidelity \& Casualty Co. (C. C.) 41 Fed. 506, where the assured was near-sighted, and the court held this not to be a bodily infirmity within the meaning of the warranty. Manufacturers' Accident Indemity Co. v. Dorgan, 58 Fed. 945, 7 C. C. A. 581, 22 L. R. A. 620 , where the court held that an anæmic murmur, indicating no structural defect of the heart, but arising simlly from a temporary debility or weakened condition of the body, was not within the meaning of the term "bodily or mental infirmity." llere Judge Wm. H. Taft said: "The statement in the application by the assured did not, either in his contemplation or that of the company, refer to any mere temporary ailment or indisposition, which did not tend to weaken and undermine the constitution at the time of taking membership." Standard Life \& Accident Ins. Co. v. Martin, 133 Ind. 376,33 N. E. 105 . Here it was shown that when a boy the assured had received an injury to one foot, from which he had entirely recovered. The court said: "The reasonable interpretation of the clause is that the decedent was at the time free from serious physical Injury, and that any injuries which he may have 
Where the death or injury of the assured is a direct consequence of the matters which have been concealed or misrepresented by the applicant, there is no question but what the policy will be declared void, and the general rule prevails that where the fact misrepresented or concealed has a direct bearing on the risk the policy will be void, even though it did not in the particular instance occasion the death or disability of the policy holder. ${ }^{40}$

Nonpayment of Premiums.-Most policies of accident insurance expressly declare that they will be forfeited by the failure of the assured to pay the premiums thereon. In the absence of any provision in the contract, or any statute to the contrary, the policy will be forfeited by a default in the premium payments without notice from the company to the assured. But in order that a policy shall be forfeited by the nonpayment of a note given for the amount of the

suffered in the course of his previous life had disappeared and left no trace behind that would render him an unfit subject for accident insurance; that he was as to such accidents, and their results, free from bodily ailments." Brink v. Guaranty Mut. Acc. Ass'n, 7 N. Y. Supp. 847 , 55 Hun, 606, affirmed without opinion 130 N. Y. 675, 29 N. E. 1035 , where the court held there had been no misrepresentation where the assured had not stated that he had on several occasions been thrown from his carriage and injured. Follette v. United States Mutual Acc. Ass'n, 107 N. C. 240,12 S. E. 370,12 L. R. A. 315,22 Am. St. Rep. 878 ; Id., 110 N. C. 377,14 S. E. 923 , 15 L. R. A. 668,28 Am. St. Rep. 693. Here, while the court held that deafness constituted a bodily infirmity, yet the representation was waived by the personal knowledge of the agent of the: fact. See, also, Maryland Casualty Co. v. Gehrmann, 96 Md. 634, 54 Atl. 67s.

46 Standard Life \& Accident Ins. Co. v. Sale, 121 Fed. 664, 57 C. C. A. 418, 61 L. R. A. 337, supra. To the contrary, however, see Standard Life \& Accident Ins. Co. v. Martin, 133 Ind. 376, 33 N. E. 105; Blackstone v. Standard Life \& Accident Ins. Co., 74 Mich. 592, 42 N. W. 156, 3 L. R. A. 486; Modern Woodmen Acc. Ass'n v. Shryock, 54 Neb. 250,74 N. W. 607,39 L. R. A. 826 . In many states statutory enactments provide that no misrepresentation shall avoid the policy unless it directly contributes to the death or injury of the assured. 
premium, the policy must expressly so provide; otherwise the mere nonpayment of the note will not forfeit the policy without further action on the part of the insurer.

In the absence of any agreement to the contrary, the insurer is not bound to give the policy holder notice of the maturity of premiums on the policy. This rule applies to policies with fixed premiums. But where in the policy the company does agree to give such notice, the assured may rely upon this understanding. In most states the form and manner of giving notice are expressly prescribed by statute. As a general rule a notice duly directed to the assured's last known address, and properly postpaid and mailed, is sufficient, and the company need not show that it was actually received by the policy holder.

In the absence of an allowance of days of grace, or any agreement for the extension of time, all premiums must be discharged promptly, and the failure to pay a premium on or before the very day of its maturity will forfeit the policy. An extension of time for the payment of the premium, made after it has fallen due, must be supported by estoppel or a proper consideration. Premiums should be paid at the place and in the manner prescribed by the policy. And the policy will not be forfeited where the premium has been placed in the mails, properly addressed, and within time to reach the insurer in due course on or before the date of the maturity thereof, but because of delay, not the fault of the assured, does not reach the insurance company until after the premium has actually become due. The company makes the mail its own agent, and is therefore responsible for any of its delays or any miscarriage. An act of God or of the law may excuse a delay in the payment of premiums, but mere sickness is not included in this category. These same general rules apply as well to the forfeiture of certificates of membership in mutual aid and bene- 
fit societies for the nonpayment of dues or assessments. A forfeiture for failure to pay premiums according to the terms of the policy may be waived by any duly authorized agelit of the insurer. ${ }^{47}$

Term Policies.-Premiums on policies of accident insurance are frequently paid by the assured giving to the insurer or its agents orders on his employer for a portion of his wages, such orders to be payable at certain times and to cover the policy for specified periods. The acceptance of the order on the employer by the insurance company does not of itself amount to a payment of the premium covered thereby. In order to constitute a payment, the insurer must actually receive the amount thereof. ${ }^{48}$

Most of these agreements contain a stipulation to the effect that, in the event the assured fails to leave in the hands of his employer any installment of premium as it falls due, the policy shall be void. But there is no default in the payment of an installment until the arrival of pay day. ${ }^{49}$ Any failure on the part of the employer to deduct and pay the amount of the order from the wages of the assured is at the risk of the policy holder, and not of the insurance company, though it is the duty of the insurer to present the orders for payment, and if it fails to

47 North American Acc. Ins. Co. v. Bowen (Tex. Civ. App.) 102 S. W. 163.

48 Landis v. Standard Life \& Accident Ins. Co., 6 Ind. App. 502, $33 \mathrm{~N}$. E. 989, where the assured, instead of leaving the money subject to the order in his employer's hands, drew the full amount of his wages, leaving nothing with which to satisfy the orders and failed to pay the premiums. See, also, York v. Railway Officials' \& Employés' Acc. Ass'n, 51 W. Va. 38, 41 S. E. 227, where the orders were filed with the paymaster of the assured's employers, but the assured continued to draw all his wages, the premiums covered by the orders, by inadvertence, not being deducted, and the premium was not actually paid. 447.

49 Gilmore v. Continental Casualty Co., 58 Wash. 203, 108 Pac. 
do so it is estopped from setting up the nonpayment of the premiums in an action to recover on the policy. ${ }^{30}$

That the assured continued to work for his employer, with whom such orders had been deposited, does not constitute evidence that the premiums have been paid. It must be shown that the amount has actually been paid, or has been left with the employer for that purpose. So where the assured draws all his wages, or leaves his employment, so that no wages are due him there can be no payment. ${ }^{51}$

so Brown v. Pacific Mut. Life Ins. Co., 109 Mro. App. 137, 82 S. W. 1122 , where the court held that "it was not the duty of the employer to deduct the preminu and pay the same." Cotten v. Fidelity \& Casualty Co. (C. C.) 41 Fed. 506. The court here said: "The failure to present the order for the payment of the installments of the premiums as they fell due, when they would have been paid if presented, estops the defendant from setting up this defense, even if the premium had not been afterwards demanded and paid." See, also. Patton v. Continental Casualty Co., 119 Tenn. 364, 104 S. W. 305.

51 Reed v. Travelers' Ins. Co., 117 Ga. 116, 43 S. E. 433. Here the assured did not work and earned no wages during the second insurance period, and thus defaulted payment thereon. There could be no recovery for his accidental death during that period. To the same effect, see Employers' Liability Assur. Corp. v. Rochelle, 13 'Tex. Clv. App. 232, 35 S. W. 869 . And this is true, even though the assured should later return to work for the same employer. Bane v. Travelers' Ins. Co., $85 \mathrm{Ky}, 677,4$ S. W. 787.

McMrahon v. Travelers' Ins. Co., 77 Iowa, 229, 42 N. W. 179, where assured had left the company's employment and drawn all his earnlngs, so that the insurance terminated for the nonpayment of the order. See, also, Pritchett v. Continental Casualty Co., $117 \mathrm{Ky}$. 923, 80 s. W. 181, $25 \mathrm{Ks}$. Law Rep. 2064; Herbert v. Standard Life \& Accident Ins. Co., 23 ohlo Cir. Ct. R. 225; Pride v. Continental Casualty Co., 69 Wash. 428, 125 Pac. 787. An interesting case is that of Johnson v. Standard Life \& Accident Ins. Co. (Tex. Civ. App.) $97 \mathrm{~s}$. W. 831. Here a policy of accident insurance was issued in consideration of the assured, a railroad employe, giving an order on the rallroad, "which is to be considered an assignment of moneys therein specified." The assured, an illiterate, had been told by the agent of the insurance company that he need only give the assignment directing the railroad company to pay the premiums, and they would be deducted, as his hospital fees, the railroad company thereby becoming the agent of the insurer. The order was duly given. The assured, practically unable to read, demanded of the rail- 
Practically all such policies are issued for terms of consecutive periods of two, two, three, and five months respectively, and the courts are a unit in construing them as policies of insurance for limited periods of two, two, three, and five months, and not as a continuing policy of one year. ${ }^{52}$

Waiver of Rights by Insurer.-Inasmuch as most conditions are inserted in insurance policies for the benefit of the insurer, their violation may be waived, either expressly

road company all that was due him and received it without the premium having been deducted. The assured supposed the premium had been withheld and did not know how much was actually due him. The court held that the insurer could not set up the defense of a forfeiture of the policy under the condition stipulating that it should be void if the assured failed to leave with the railroad company any premium due.

In Farrell v. American Employers' Liability Ins. Co., 68 Vt. 136 , 34 Atl. 478, the court said: "When the plaintiff introduced the policy, as showing her right of recovery, it gave her no such right, unless she also showed that it had been continued in force by the payment of the premium falling due for the month of August, agreeably to the terms of the order. The fact that the insured continued to work for the railroad company until the accident tended to show that he might have earned money enough to enable him to make the payment, but did not tend to show that he made it."

The fact that the assured's pay checks amount to less than his monthly wages, but the difference is less than the amounts of the premium orders, does not of itself constitute sufficient evidence to establish payment. York v. Railway Officials' \& Employés' Acc. Ass'n, 51 W. Va. 38, 41 S. E. 227. And the receipt by the widow of the assured of all pay due him from his employer does not prevent her from enforcing the collection of the amount of the insurance, where she was ignorant of the fact that the employer held a premium order which he had not paid, and where she further did not know whether the policy had been canceled prior to the death of her husband. Travelers' Ins. Co. v. Jones, 32 Tex. Cir. App. 146, 73 S. W. 978.

52 Reed v. Travelers' Ins. Co., 117 Ga. 116, 43 S. E. 433; Roberts v. Atna Life Ins. Co., 212 Ill. 382, 72 N. E. 363, affirming 101 Ill. App. 313; Landis v. Standard Life \& Accident Ins. Co., 6 Ind. App. 502, 33 N. E. 989; McMahon v. Travelers' Ins. Co., 77 Iowa, 229, 42 N. W. 179; Employers' Liability Assur. Corp. v. Rochelle, 13 Tex. Civ. App. 232, 35 S. W. 869 ; Farrell v. American Employers' Llability Ins. Co., 68 vt. 136, 34 Atl. 478. See, also, Popovitz v. United States Health \& Acc. Ins. Co., 78 Misc. Rep. 148, 137 N. Y. Supp. 788. 
or by implication, by the insurance company. Thus the insurer may waive a warranty or misrepresentation in the application as to any matters inserted for its benefit. But it is necessary for the company to have knowledge, or be chargeable with knowledge, of the facts which would avoid the policy, since one manifestly cannot waive rights of whose existence he is ignorant. And, generally speaking, waiver, being of the legal nature of an estoppel, does not require a consideration to support its validity. The conditions of a policy may be waived by the act or statement of any agent within the scope of his authority, real or apparent. As a general proposition, mere soliciting agents do not possess that power, though it may be otherwise by statutory enactment. And most policies of insurance contain a provision expressly limiting the power of its agents to bind the company by representation, warranty, or otherwise, and the assured is bound by such a clause, provided he has knowledge thereof.

It should be stated, however, that the assured, acting in good faith, is not bound by any fraud or misrepresentation of the agent of the insurance company in making out his application or policy. ${ }^{53}$ Thus where the assured truthfully re-

32 Sawyer v. Equitable Acc. Ins. Co. (C. C.) 42 Fed. 30 ; New York Acc. Ins. Co. v. Clayton, 59 Fed. 559, 8 C. C. A. 213 ; Miller v. Maryland Casualty Co., 193 Fed. 343, 113 C. C. A. 267; Metropolitan Acc. Ass'n v. Clifton, 63 Ill. App. 197; United States Health \& Accident Ins. Co. v. Olark, 41 Ind. App. 345,83 N. E. 760 ; Standard Life \& Aceident Ins. Co. v. Davis, 59 Kan. 521, 53 Pac. 856; Washburn v. United States Casualty Co., 108 Me. 429, 81 Atl. 575; Dailey v. Preferred Masonic Mut. Acc. Ass'n, 102 Mich. 289, 57 N. W. 184, 26 L. R. A. 171; Travelers' Ins. Co. v. Snowden, 60 Neb. 263, 83 N. W. 66 ; Brink v. Guaranty Acc. Ass'n, 55 Hun, 606, 7 N. Y. Supp. 847; North American Ace. Ins. Co. v. Trenton (Tex. Civ. App.) 99 S. W. 740; French v. Fidelity \& Casualty Co., 135 Wis. 259, 115 N. W. 869, 17 L. R. A. (N. S.) 1011.

In Bonewell v. North American Ace. Ins. Co., 167 Mich. 274, $132 \mathrm{~N}$. W. 1067 , affirming on rehearing 160 Mich. $137,125 \mathrm{~N}$. W. 59 , the nolicy declared that statements as to other insurance applications, 
plies to the questions contained in the application, but his answers are incorrectly stated by the agent, either intentionally or by error, the insurance company cannot take advantage of the fraud or mistake of its representative, and set up a breach of warranty in defense to an action thereon. This rule applies, whether the answers are warranties or merely representations. As a result of these rules, and the natural zeal of agents in securing policies of insurance, many contracts contain a provision requiring that all waivers, in order to be binding, must be in writing and signed by the proper officers of the company. The courts, none the less, hold that even such a condition may be subsequently waived by parol.

A contract of insurance cannot be avoided when the policy has been delivered after full knowledge of the facts which would invalidate it; thus, for example, where the assured gives incomplete or evasive answers to questions propounded in the application. Any breach of conditions which would invalidate the policy may be waived by the company in several ways: By treating the policy as still in force; by any act or declaration inducing the policy holder to undergo expense or trouble on the strength of the policy;

etc., were warranted to be true. The agent was only authorized to receive applications and forward them to the home office. The assured, on the advice of the agent, falsely stated that he had never been rejected by any other company and had never received indemnity for any accident. The court held that the connivance of the agent did not relieve the assured from the effect of the breach of warranty.

In Turner v. American Casualty Co. (Wash.) 124 Pac. 4S6, the assured had an atrophied leg, and disclosed its condition to the agent of the insurer at the time of applying for the policy, and the agent had misrepresented its condition. The court held that the insurance company could not rely upon the false statement thus made by the agent as constituting a breach of warranty. 
by admitting its liability under the policy by accepting further premiums. ${ }^{54}$

The plaintiff, in an action on the policy, should plead any waiver on which he relies, and where a breach of warranty is set up by the company the burden of establishing the waiver is on the claimant. As a general rule it is for the jury to determine, under proper instructions, as a question of fact, whether there has actually been a waiver.

Cancellation of the Policy.-Many policies expressly provide that they may be canceled by the insurance company at its option without the consent of the policy holder; but in the absence of such a clause the policy cannot be canceled, except by the mutual consent of the parties. Such a condition, providing for the cancellation of the policy at the pleasure of the insurer, will be most strictly construed by the courts. ${ }^{35}$ And proper notice thereof must be forwarded to the assured and received by him within the terms of the policy in order to release the insurer. All unearned premiums must also be returned by the company.

Policies of accident insurance are generally canceled by the assured by nonpayment of the premiums as a result of which they lapse. But where he has been induced by fraud to take a policy he can insist upon its cancellation and recover back the premiums paid.

54 The general subject of waiver, as affecting policies of accident insurance, is treated in detail under the question of Notice and Proofs of Death or Disability. See page 409 .

ss In Jones v. Commercial Travelers' Mut. Acc. Ass'n of America, 134 Apl. Div. 936, 118 N. Y. Supp. 1116, affirming (Sup.) 114 N. Y. Supp. 559, the court held that, notwithstanding an accident policy provided for a cancellation at the option of the insurer, the insurer is estopped to cancel the policy after injury to assured on the ground that he had become an extrahazardous risk, where the injury itself rendered the risk more hazardous. 


\section{CHAPTER II}

\section{CAUSE OF INJURY OR DEATH}

What Constitutes an Accident.

What are External and Violent Means of Injury.

What Included in Risks of Occupation.

Traveling Policies-Passengers-Public Conveyance.

Time Within Which Death or Disability must Lnsue After an Accident.

Pleading and Practice.

Rules of Evidence.

What Constitutes an Accident.-Generally speaking, an accident is a circumstance which happens without the foresight or expectation of the one affected thereby. However, policies of accident insurance as a rule cover only death or disability which happen as the result of "external, violent and accidental means." Manifestly there exists a distinction between an accident per se and a mishap resulting from "accidental means." One may perform a certain act in the manner intended, with a result which was not intended, and yet the result may not ensue from accidental means or causes. 'The United States courts have defined "accidental means" as "those which produce effects which are not their natural and probable consequences." Thus an effect which is a natural and probable consequence of an act is not an accident. But one which is not the natural and probable consequence of an act is produced by accidental means and is an accident. The distinction is well illustrated in a recent case decided by the federal courts, where the assured, while assisting another to carry a door along a level street, said to his companion that he was tired and suddenly fell down and expired. ${ }^{1}$ An autopsy show-

1 Shanberg v. Fidelity \& Casualty Co. (C. C.) 143 Fed. 651, affirmed by 158 Fed. 1, 85 C. C. A. 343, 19 L. R. A. (N. S.) 1206. 
ed that his death resulted from a rupture of the heart, which was badly diseased. The court said: "While the deceased was diseased, yet, if he met with such an accident, such an unforeseen condition of affairs or chance happening, that his death was caused independently of the condition of the heart, the company may be maintained liable. For instance, suppose this man's heart was ready to burst, and in such condition that the carrying of this door would burst it, yet from the way he had lived, guarding himself from peril, because of the known fact, if he had been struck by lightning, been kicked by a horse, had received some unforeseen blow, or had taken into his system a poisonous fluid, or substance, by accident, without knowledge that it was that kind of a thing, or had he inhaled poisonous and noxious gas by accident, then in such case the condition of the heart could have nothing to do with the death. On the other hand, suppose no accident happened; suppose he walked rapidly upstairs, and death had resulted, as it might have done in the light of the diseased condition of this man's heart; * * * and suppose, being in a hurry, we should rush upstairs to see some one, or suppose we should walk rapidly uphill, thus, of course, exciting the heart action, or suppose we should pick up a load of something and carry it, as we might do in the ordinary course of our business affairs, and everything should be done just as we intended to do it, we carried our load just as we intended, we rushed upstairs just as we had intended, or we ran up the bill just as we intended, and the exertion ruptured the heart and we fell dead. Can we hold it to have been in contemplation of the parties in making the indemnity contract that the company should pay for the death resulting in such a case, where, as in this, the heart was badly diseased? To my mind, in such cases, there can be no doubt, because there is no accident. The death resulted in such case because of natural causes, nothing accidental having 
happened, all having been done as intended. * * * The trouble with the case at bar is, I do not find deceased did anything he did not intend to do. From the testimony he did not slip, did not stumble, did not fall. He walked along to a certain place, carrying the load he intended to carry. He did just exactly what he intended to do. He had that which he did not know and which he did not contemplate, a defective heart; but the very thing he undertook to do, the very thing he carried out, the very thing, without anything else happening to him that was unforeseen or a matter of chance, engaged in the business of his voluntary undertaking, carried out just as he intended, resulted in his death. For that reason I am of the opinion in this case the death was not accidental." 2

2 United States Mut. Acc. Ass'n v. Barry, 131 U. S. 100, 9 Sup. Ct. 755, 33 L. Ed. 60, affirming Barry v. United States Mut. Acc. Ass'n (C. C.) 23 Fed. 712. Here the United States Supreme Court said: "If a result is such as follows from ordinary means, voluntarily employed, in a not unusual or unexpected way, it cannot be called a result effected by accidental means; but if, in the act which precedes the injury, something unforeseen, unexpected, unusual, occurs which produces the injury, then the injury has resulted through accidental means."

In Western Commercial Travelers' Ass'n v. Smith, 85 Fed. 401, 29 C. C. A. 223,40 L. R. A. 653 , the court said: "The word [accidental] is descriptive of means which produce effects which are not their natural and probable consequences. * * * An effect which is the natural and probable consequence of an act or course of ac. tion is not an accident, nor is it produced by accidental means. It is either the result of actual design, or it falls under the maxim that every man must be held to intend the natural and probable consequences of his deeds. On the other hand, an effect which is not the natural or probable consequence of the means which produced it, an effect which does not ordinarily follow and cannot be reasonably anticipated from the use of those means, an effect which the actor did not intend to produce, and which he cannot be charged with the design of producing under the maxim to which we have adverted, is produced by accidental means. It is produced by means which were neither designed nor calculated to cause it. Such an effect is not the result of design, cannot be reasonably anticipated, 
And, if the assured sustains an injury from an act done voluntarily and in the ordinary way, with no unforeseen or involuntary movement of the body, it cannot be said to have resulted from accidental means. ${ }^{3}$ In short, though the result

and is produced by an unusual combination of fortuitous circum. stances; in other words, it is produced by accidental meanş."

See, also, Ripley v. Railway Passengers' Assur. Co., 16 Wall. (83 U. S.) 336,21 L. Ed. 469 , affirming 20 Fed. Cas. 823 ; Travelers' Ins. Co. v. Selden, 78 Fed. 285,24 C. C. A. 92 ; Atna Life Ins. Co. v. Vandecar, 86 Fed. 282, 30 C. C. A. 48; Richards v. Travelers' Ins. Co., 89 Cal. 170, 26 Pac. 762, 23 Am. St. Rep. 455; Omberg v. United States Mut. Acc. Ass'n, 101 Ky. 303, 40 S. W. 909, 72 Am. St. Rep. 413; Railway Officials' \& Employés' Acc. Ass'n of Indianapolts v. Drummond, 56 Neb. 235,76 N. W. 562 , where an accident in policles of accident insurance was defined as including "any event which takes place without the foresight or expectation of the person acted upon or affected thereby." Paul v. Travelers' Ins. Co., 112 N. Y. 472,20 N. E. 347,3 L. R. A. 443,8 Am. St. Rep. 758, where an accident was defined as "the happening of an event without the aid and the design of the person and which is unforeseen." United States Mut. Acc. Ass'n v. Hubbell, 56 Ohio St. 516, 47 N. E. 544, 40 L. R. A. 453, where an accident was defined as "any event which takes place without the foresight or expectation of the person acted upon or affected by the event." North American Life \& Accident Ins. Co. v. Burroughs, 69 Pa. 43, 8 Am. Rep. 212 ; Hey v. Guarantors' Liability Indemnity Co., $181 \mathrm{~Pa} .220,37$ Atl. 402, 59 Am. St. Rep. 644; In re Scarr (1905) 1 K. B. 387, 1 Ann. Cas. 787; Sinclair v. Maritlme Passengers' Assur. Co., 3 Ellis \& Ellis (Q. B.) 478.

3 McCartlyy v. Travelers' Ins. Co., 8 Biss. 362, 15 Fed. Cas. 1254. Here the assured died from a ruptured blood vessel, sustained while exercising with Indian clubs. The court held that if the assured used the clubs for exercise in the ordinary way, and without the interference of any unusual circumstances, the injury was not aceidental; but if there occurred any unforeseen accident or involuntary morement of the body, which, in connection with the use of the clubs, brought about the injury, then such means were accidental and within the terms of the policy. Thus where a man carries a door, and dies from rupture of the heart without any unexpected incident, the company is not liable. Shanberg v. Fidelity \& Casualty Co., 158 Fed. 1,85 C. C. A. 343,19 I. R. A. (N. S.) 1206, affirming (C. C.) 143 Fed. 651, supra. See, also, Fidelity \& Casualty Co. of New York v. Stacey's Ex'rs, 143 Fed. 271, 74 C. C. A. 409, 5 L. R. A. (N. S.) 657, 6 Ann. Cas. 955, reversing 137 Fed. 1012, where assured committed an assault upon another, who did not resist, and injured his hand, in which blood poisoning developed. The court 
of the act may not be designed, foreseen, or expected, yet, if it be the natural and direct effect of acts voluntarily done, or of conditions voluntarily assumed, it cannot be said to be accidental. There is a distinction between death or injury accidental in its nature, and a death or injury resulting from accidental means.

held that the injury was the natural and logical result of an intentional act, and therefore could not have been produced by accidental means. Hastings v. Travelers' Ins. Co. (C. C.) 190 Fed. 258. The assured, in apparent good health, while raising and lowering himself in a Morris chair, suddenly died, and it developed upon a post mortem examination that his heart was enlarged and the valves hardened. In an excellent opinion the court held that, as the exertions of the assured were voluntary and intended, the only element of accident was the result, for which there was no liability under the policy. The court said: "In this case I do not see how a recovery can be had without abolishing the distinction between accident and heart disease." Southard v. Railway Passengers' Assur. Co., 34 Conn. 574, 22 Fed. Cas. 810, where assured was ruptured while hurriedly leaving a train and running a considerable distance. Cobb v. Preferred Mut. Acc. Ass'n, 96 Ga. 818, 22 S. E. 976, where assured, while in a feeble condition, while carrying his baggage, weighing 60 or 80 pounds, some 50 yards, strained himself so that after putting it down a defect in the vision of one of his eyes became apparent. Feder v. Iowa State Trareling Men's Ass'n, 107 Iowa, 538, $78 \mathrm{~N}$. W. 252, 43 L. R. A. 693, 70 Am. St. Rep. 212, where assured ruptured an artery while reaching to close a window in the ordinary manner. Smouse v. Iowa State Traveling Men's Ass'n, 118 Iowa, 436, $92 \mathrm{~N}$. W. 53, where one conralescing from a sickness was suddenly called to dress, and in a somewhat dazed condition arose and hurriedly started to put on his clothes, and broke a blood vessel while entangled in his garments. Lehman v. Great Western Acc. Ass'n (Iowa) 133 N. W. 752. Here the assured, while bowling, strained his side, and in a few days developed appendicitis. The court said: "It is to be borne in mind that in this case there is no evidence whatever of any slipping or falling, or of any straining of the muscles, other than the intentional strain put upon them in the voluntary and intentional act of bowling. Such a strain was not an accidental strain, and, if it produced an unintentional result and consequent injury, nevertheless the resulting injury, and not the means producing 1t, was accidental." Niskern v. United Brotherhood of Carpenters and Joiners of America, 87 N. Y. Supp. 640, 93 App. Div. 364 , where a carpenter, suffering from arterial sclerosis, broke a blood vessel while lifting heavy timbers in the ordinary course of 
Within the rules and limitations set forth the following have been declared the result of accidental means: Being thrown from a frightened horse; " rupture of a blood vessel, from a sudden wrenching of the body in swinging Indian clubs; ${ }^{\circ}$ drowning; ${ }^{6}$ blood poison, resulting from cutting a corn with a knife; ${ }^{7}$ poison, resulting from an abrasion on the toe produced by wearing new shoes; ${ }^{8}$ a fall, due to stumbling; ${ }^{\circ}$

his work; Appel $\nabla$. Atna Life Ins. Co., 83 N. Y. Supp. 238, 86 App. Div. 83, where the assured died from septic peritonitis resulting from an inflammation of the appendix, caused by the regular movement of the psoas muscle while he was riding his bicycle; In re Scarr (1905) 1 K. B. 387, 1 Ann. Cas. 787, where assured died from heart failure, due to the violent physical exertion, voluntarily undertaken, of ejecting a drunken man from his premises.

On the other hand, see United States Mut. Acc. Ass'n v. Barry, 131 U. S. 100,9 Sup. Ct. 755,33 L. Ed. 60, where the assured received fatal injuries from jumping a few feet from a platform to the ground; North American Life \& Accident Ins. Co. v. Burroughs, $69 \mathrm{~Pa} .43,8 \mathrm{Am}$. Rep. 212, where assured strained himself while unloading hay; Horsfall v. Pacific Mut. Life Ins. Co., 32 Wash. 132, 72 Pac. 1028, 63 L. R. A. 425, 98 Am. St. Rep. 846, where assured, in perfect health, strained himself by lifting a heavy weight.

The distinction is most clearly illustrated in General Accident \& Life Assur. Corp. v. Meređith, $141 \mathrm{Ky} .92,132$ S. W. 191, where assured in hurrying to catch a train failed to notice when he reached the end of the parement, where there was a step of 8 inches. When he made this step, he received a severe jolt and fell, injuring his bowels, as the result of which he died. The court held his death resulted from accidental means within the provisions of the policy.

4 Unthank v. Travelers' Ins. Co., Fed. Cas. No. 16,795.

b McCarthy v. Travelers' Ins. Co., 8 Biss. 362, 15 Fed. Cas. 1254.

- Manufacturers' Accident Indemnity Co. v. Dorgan, 58 Fed. 945, 7 C. C. A. 581,22 L. R. A. 620 ; Peele v. Provident Fund Soc., 147 Ind. 543, 44 N. E. 661,46 N. E. 990 ; Konrad v. Union Casualty \& Surety Co., of St. Louis, Mo., 49 La. Ann. 636, 21 South. 721; MalIory v. 'Travelers' Ins. Co., 47 N. Y. 52, 7 Am. Rep. 410; United States Mut. Acc. Ass'1 v. Fubbell, 56 Ohio St. 516, 47 N. E. 554, 40 L. R. A. 453; Knickerbocker Casualty Co. v. Jordan, 6 Ohío Dec. 1145, 10 Am. Law Rec. 625.

7 Nax v. Travelers' Ins. Co. (C. C.) 130 Fed. 985.

8 Western Commercial Travelers' Ass'n v. Smith, 85 Fed. 401, 29 C. C. A. 223,40 L. R. A. 653.

- Equitable Acc. Ins. Co. . Osborn, 90 Ala. 201, 9 South. 869, 13 L. R. A. 267 . 
strain, from lifting ; ${ }^{10}$ death by taking poison by mistake for water or other harmless beverage, or, knowing that he is taking a poisonous substance, but by accident taking an overdose ${ }^{11}$ blood poison, produced by the prick of a needle which had been used in embalming a body; ${ }^{12}$ unintentionally falling from a moving train ${ }^{13}$ blood poison, from the sting of a venomous insect $;{ }^{14}$ death, from injection of anti-tetanus serum after assured had been kicked by a horse ${ }^{15}$ blood poison, from the use of a hypodermic needle $;^{16}$ death by fright, in trying to control a runaway horse $;{ }^{17}$ injury sustained in stealing a base in a baseball game; ${ }^{18}$ lynching by a mob; ${ }^{19}$ the

10 Standard Life \& Accident Ins. Co. v. Schmaltz, 66 Ark. 588, 53 S. W. $49,74 \mathrm{Am}$. St. Rep. 112; North American Life \& Accident Ins. Co. v. Burroughs, 69 Pa. 43, 8 Am. Rep. 212; Horsfall v. Pacific Mut. Life Ins. Co., 32 Wash. 132, 72 Pac. 1028, 63 L. R. A. 425, 98 Am. St. Rep. 846.

11 McGlother v. Provident Mut. Acc. Co., 89 Fed. 685, 32 C. C. A. 318; Mutual Acc. Ass'n of the Northwest, v. Tuggle, 39 Ill. App. 509; Dezell v. Fidelity \& Casualty Co., 176 Mo. 253, 75 S. W. 1102; Hill v. Hartford Acc. Ins. Co., 22 Hun (N. Y.) 187; Penfold v. Universal Life Ins. Co., 85 N. Y. 317, $39 \mathrm{Am}$. Rep. 660; Pollock v. United States Mut. Acc. Ass'n, 102 Pa. 230, 48 Am. Rep. 204. See, also, Carnes v. Iowa State Traveling Men's Ass'n, 106 Iowa, 281, $76 \mathrm{~N}$. W. 683, $68 \mathrm{Am}$. St. Rep. 306, where the assured died from an overdose of morphine, and the court held the insurance company liable, provided the assured took more than he intended, but otherwise where he took the amount he intended, but misjudged its effects.

12 Simpkins v. Hawkeye Commercial Men's Ass'n, 148 Iowa, 543, 126 N. W. 192.

13 Smith v. Atna Life Ins. Co., 115 Iowa, 217, 88 N. W. 368, 56 L. R. A. 271, 91 Am. St. Rep. 153.

14 Omberg v. United States Mut. Acc. Ass'n, $101 \mathrm{KJ} .303,40$ S. W. 909, 72 Am. St. Rep. 413.

15 Gardner v. United Surety Co., 110 Minn. 291, 125 N. W. 264.

16 Bailey v. Interstate Casualty Co., 40 N. Y. Supp. 513, 8 App. Div. 127, affirmed without opinion in $158 \mathrm{~N}$. Y. $723,53 \mathrm{~N}$. E. 1123.

17 McGlinchey v. Fidelity \& Casualty Co., 80 Me. 251, 14 Atl. 13, 6 Am. St. Rep. 190.

18 Ludwig v. Preferred Acc. Ins. Co., 113 Minn. 510, 130 N. W. 5. 19 Fidelity \& Casualty Co. v. Johnson, 72 Miss. 333, 17 South. 2, 30 L. R. A. 206.

Fuller Acc.Ins. -3 
bite of a dog; ${ }^{20}$ asphyxiation by unconsciously inhaling gas $;{ }^{21}$ death from swallowing a hard piece of food, which lodged in the intestines; ${ }^{22}$ loss of an eye, due to gonorrheal infection from splashing water while washing clothes; ${ }^{23}$ disability of a healthy person, resulting from dilation of the heart due to shock in taking a cold bath. ${ }^{24}$

Inasmuch as an accident includes any event which takes place without the foresight or expectation of the person affected, injuries which are intentionally inflicted upon the assured by others may still be accidental to him. This rule applies particularly to cases where the injury is not the result of the misconduct or the participation of the assured, but where they are to him unforeseen and unexpected..$^{25}$ As a

20 Farner v. Massachusetts Mut. Acc. Ass'n, 219 Pa. 71, 67 Atl. 927, 123 Am. St. Rep. 621.

21 Paul v. Travelers' Ins. Co., 112 N. Y. 472, 20 N. E. 347, 3 L. R. A. 443,8 Am. St. Rep. 758 , affirming 45 Hun (N. Y.) 313 ; Pickett v. Yacific Mut. Life Ins. Co., 144 Pa. 79, 22 Atl. 871, 13 L. R. A. 661, 27 Am. St. Rep. 618.

22 Miller v. Fidelity \& Casualty Co. (C. C.) 97 Fed. 836.

23 Sullivan v. Modern Brotherhood of America, 167 Mich. 524, $133^{-}$ N. W. 486 .

24 Johnson r. New Amsterdam Casualty Co., Cleveland, Ohio, October, 1912, Subdivision 3, Fourth District, Ohio Common Pleas, not reported.

25 RIpley v. Railway Passengers' Assur. Co., 16 Wall. (83 U. S.) 336, 21 I. Ed. 469, aftirming 20 Fed. Cas. 823, where the assured was assaulted by thugs who had waylaid him in order to commit robbery. Berger v. Pacific Mut. Life Ins. Co. of California (C. C.) 88 Fed. 241, and Corley v. Travelers' Protective Ass'n, 105 Fed. 854, 46 C. C. A. 278 , in each of whlch the assured was shot by an insane person. IrobInson v. United States Mut. Acc. Ass'n (C. C.) 68 Fed. 825, where the assured, unarmed, was shot during a quarrel by an armed adversary. Phonix Accident \& Sick Ben. Ass'n v. Stiver, 42 Ind. App. $636,84 \mathrm{~N}$. E. 772 , where assured while on a public highway was cut and stabbed, wlthout warning or provocation, by an insane man. Jones v. United States Mrut. Acc. Ass'n of City of New York, 92 Iowa, 652, $61 \mathrm{~N}$. W. 485 , where assured was shot during a quarrel. Campbell v. Fldelity \& Casualty Co., $109 \mathrm{Ky}$. 661, $60 \mathrm{~S}$. W. 492, 22 Ky. Law Rep. 1295, where assured was killed by a man whom he had assaulted, and the court held that the plaintiff could recover, 
result of the construction by the courts that injuries intentionally inflicted by others are accidental as regards the assured, insurance companies have very generally inserted in their policies a condition exempting themselves from liability for injuries or death intentionally inflicted upon the policy

unless he foresaw the danger to which he had exposed himself in committing the assault. Furbush v. Maryland Casualty Co., 131 Mich. 234, 91 N. W. 135, 100 Am. St. Rep. 605, where the testimony indicated that the assured had been murdered by a highwayman. Collins v. Fidelity \& Casualty Co., 63 Mo. App. 253, where assured was shot during a brawl. Hester v. Fidelity \& Casualty Co., 69) Mo. App. 186, where assured was murdered. Accident Ins. Co. of North America v. Bennett, 90 Tenn. $256,16 \mathrm{~S}$. WV. 723, $25 \mathrm{Am}$. St. Rep. 685, where assured was found murdered. Union Casualty \& Surety Co. v. Harroll, 98 Tenn. 591, 40 S. W. 1080, 60 Am. St. Rep. 873, where the assured was killed while advancing in a threatening manner upon his slayer. The court here held that the plaintiff could recover if the assured did not know at the time, and had no reason to believe, that his adversary was armed with and would use a deadly weapon.

Some cases, however, rule that where the assured is the aggressor in a controrersy, and thus by his invitation and aggressiveness invites the assault, it cannot be said to be an accident, and the insurance company will not be liable. See Taliaferro v. Travelers' Protective Ass'n, 80 Fed. 368, 25 C. C. A. 494, where the assured was shot in a quarrel in which he was the aggressor, and where he violently attacked his adversary with a pistol, accompanying the act with the exclamation that he would have revenge, and for his opponent to make ready for a fight. The court said: "Where a person thus invites another to a deadly encounter, and does so voluntarily, his death, if he sustains a mortal wound, cannot be regarded as accidental by any definition of that term which has heretofore been adopted. It might as well be claimed that death is accidental when a man intentionally throws himself across a railroad track in front of an approaching train, or leaps from a high precipice, or swallows a deadly poison." See, also, Supreme Council Order of Chosen Friends v. Garrigus, 104 Ind. 133, 3 N. E. 818, 54 Am. Rep. 298, where the court held that the claimant could recover for an injury received by the assured in a common-law affray, where no fault on his part is shown. Hutchcraft's Ex'r v. Travelers' Ins. Co., 87 Ky. 300, 8 S. W. 570, 12 Am. St. Rep. 484, where the court limited recovery to injuries in an affray, where the assured did not encourage the conflict and was not responsible therefor. However, in Lovelace v. Travelers' Protective Ass'n of America, 126 Mo. 104, 28 S. W. 877,30 L. R. A. 209,47 Am. St. Rep. 638 , where the as- 
holder, either by himself or by others. ${ }^{26}$ However, even where the policy contains a clause exempting the insurance company from liability for injuries intentionally inflicted upon the assured by another, the insurer will be liable where his assailant is insane, on the theory that an insane man is

sured was shot while attempting to eject a drunken man from a hotel where he was stopping, the court held that the beneficiary could recover, where he had, as here, voluntarily engaged in the fight, provided he did not anticipate the result which followed.

An interesting case is presented in Erb $\nabla$. Commercial Mut. Acc. Co., $232 \mathrm{~Pa}$. 215, 81 Atl. 207. Here the assured was on hostile terms with his sister-in-law, who had been forbidden his house. During a quarrel the policy holder abused his wife, who retreated into her room after he had pointed a revolver at her. Seeing his sister-inlaw approaching, he pointed the revolver at her and advanced toward her in a threatening manner. She seized his arm and secured possession of the weapon, and in the struggle beat him over the head. He retreated toward the door as she shot the revolver unconsciously and without intending to kill him. The court said: "Under the words of the policy the death of an insured would not be effected by accidental means, if it were the natural and probable consequence of his own act and should have been foreseen. It would not be accidental if the result of a duel, or of a deadly assault commenced by him, where he had reason to expect a deadly defense, and generally where by his conduct he had invited violence, the reasonable consequence of which he should have anticipated. But under the facts of this case the insured had no occasion to anticipate danger when he began the assault. He continued the struggle after he had lost the pistol to prevent its use against himself, and had withdrawn from the confljet when he received the fatal wound." It was held that the claimant could recover.

26 Orr r. Travelers' Ins. Co., 120 Ala. 647, where the assured was shot by a man with whose wife the assured was committing adultery. Richards v. Travelers' Ins. Co., 89 Cal. 170, 26 Pac. 762, 23 Am. St. Rep. 455, where the court held that the beneficiary could recover, unless it was shown that the assallant intended to kill or injure the assured and that the condition did not cover every case where a blow, not intended to kill, unfortunately and undesignedly produced death. American Accident Co. of Louisville v. Carson, $99 \mathrm{Ky}$. 441, 36 S. W. 169, 34 L. R. A. 301, 59 Am. St. Rep. 473, where the assured, a police officer, was shot by one whom he had placed under arrest. Here the case turned upon the peculiar phraseology of the condition in the policy. Hutchcraft v. Travelers' Ins. Co., $87 \mathbf{K y}$. 300, 8 \&. W. 570, 12 Am. St. Rep. 484, supra. Phelan v. Travelers' 
incapable of forming a rational intent or understanding the nature and quality of his act. ${ }^{27}$

What are External and Violent Means of Injury.-In order to protect insurance companies against fraud, most policies of accident insurance contain a condition that, in order to render the company liable for death or disability, the injury must be the result of accidental means and it must also be caused by external and violent means. In this manner the company seeks to protect itself from liability for hidden or secret diseases resulting in injury, where there is no manifestation of harm to the external body. This language is employed, not for the purpose of restricting liability to any particular kind of accidents, but to guard the companies from liability for injuries not originating from accidental causes, but which are liable to occur at any time from natural causes. A fall, a kick, or a blow on the person are all clearly external and violent, and within the terms of such a clause. ${ }^{28}$ And the company is liable in such a case, even though the fall itself may be occasioned by some purely temporary and unexpected physical disorder or derangement. ${ }^{29}$

Ins. Co., 38 Mo. App. 640, where the injury of the assured was evidently the result of a preconcerted attempt to assassinate him.

This subject is treated more at length under Intentional Injuries as an Excepted Risk. See p. 268.

27 Berger v. Pacific Mut. Life Ins. Co. of California (C. C.) 88 Fed. 241, where the assured was shot by an insane person. Corley v. Travelers' Protective Ass'n, 105 Fed. 854, 46 C. C. A. 278, where the court said: "We think it is the true rule that if the deceased was killed by one incapable of distinguishing between right and wrong, or forming a rational intent to do the act, then the death would not be intentional, any more than it would be if it happened through some unforeseen accident."

28 Equitable Acc. Ins. Co. v. Osborn, 90 Ala. 201, 9 South. 869, 13 L. R. A. 267 . Here the assured, while running toward a train, stumbled and fell against the steam chest of the locomotive, receiving fatal injuries.

29 Meyer v. Fidelity \& Casualty Co., 96 Iowa, 378, 65 N. W. 328, $59 \mathrm{Am}$. St. Rep. 374. Here the assured died as the result of in- 
But the liability of the company is not limited to such apparent cases, as where the injury was occasioned by such physical causes as a blow. Under the phrase under consideration it is sufficient that the cause of the injury or death shall come from the outside; that is, be external to the person, even though it acts internally. The sting or bite of a rattlesnake or of a poisonous insect is external, violent, and accidental within the meaning of such a policy. ${ }^{30}$ In brief, that which causes the injury must be external, though the injury itself need not be external. Where one chokes to death by food lodging in the windpipe, the company will be liable $;^{31}$ or where death is caused by the assured eating or swallowing hard pieces of food, which perforate the intestines. ${ }^{32}$ And so where death is caused by

juries due to a fall. Shortly before he fell the evidence showed that he was seen to stagger, which might have been caused by fits or rertigo, or some sudden or unexpected indisposition, as dizziness, or fainting, or acute indigestion. The question was left to the jury to deternine whether the disorder was of a temporary character. See, also, Interstate Casualty Co. v. Bird, 18 Ohio Cir. Ct. R. 488,10 O. C. D. 211 , where the facts of the case were much the same.

30 Omberg v. United States Mut. Acc. Ass'n, $101 \mathrm{Ky}, 303,40 \mathrm{~S}$. 'W. 909, $72 \mathrm{Am}$. St. Rep. 413. Here the assured, while in bed, was bitten by a mosquito. Subsequently blood poisoning developed in the wound, from which the assured died. The court properly declared the death to have been effected through "external, violent, and accidental means." See, also, Bacon v. United States Mut. Acc. Ass'n, 123 N. Y. 304, 25 N. E. 399,9 L. R. A. 617,20 Am. St. Rep. 748, reversing 44 Hun (N. Y.) 599.

81 American Acc. Co. v. Reigart, 94 Ky. 547, 23 S. W. 191, 21 L. R. A. $651,42 \mathrm{Am}$. St. Rep. 374. Here the assured choked to death while eating a piece of beefsteak, which lodged in the windpipe. The court here draws a distinction between the facts in issue and a case where the steak had been putrid, and had poisoned the stomach or caused indigestion.

32 Miller v. Fidelity \& Casualty Co. (C. C.) 97 Fed. 836. Here the policy insured the holder against "bodily injuries sustained through external, violent, and accidental means." The court said: "The hard, pointed, and resistant substances of food appear from the allegations to have been external, violent, and accidental means, for 
fright, as by a horse running away or other similar external means. ${ }^{3 / 3}$

It is well settled that an involuntary death by drowning is a death by external, violent, and accidental means. Although the drowning is the result of the action of water internally, yet the water is an external force, which acts internally by cutting off respiration. ${ }^{34}$

they origlnated outside of the body, and were accidentally violent, although the accidental effect took place within. The insurance is not, by the clause quoted, limited to an external effect, nor to one beginning at the surface. The accidental operation of externai means may be wholly internal." The company was held liable.

33 McGlinchey v. Fidelity \& Casualty Co., 80 Me. 251, 14 Atl. 13, 6 Am. St. Rep. 190. Here the assured was driving with his children, when the animal took fright at a load of hides, and sprang from one side of the road to another, and barely escaped colliding with other teams, and only after rumning a considerable distance was brought under control. The assured immediately afterwards was taken violently sick and suffered great pain. Going directly to his home, he died within an hour of the accident. Death was apparently caused by a ruptured blood vessel about the heart, caused by the extraordinary physical and mental exertion put forth by the assured to save himself and his children from injury. The pbysical strain and mental shock conspired to produce death. The court declared the death to be the result of external, violent, and accidental means.

34 Manufacturers' Acc. Indemnity Co. v. Dorgan, 58 Fed. 945, 7 C. C. A. 581, 22 I. R. A. 620 ; United States Mut. Acc. Ass'n v. Hubbell, 56 Ohio St. 516, 47 N. E. 544, 40 L. R. A. 453 , where the court said: "It is now settled by uniform adjudication that, although the drowning is the result of the action of the water internally, yet the water is external, and that accidental death by drowning is produced through external, violent, and accidental means within the import of an accident policy." See, also, De Van v. Commercial Travelers' Mut. Acc. Ass'n, 92 Hun, 256, 36 N. Y. Supp. 931 ; Mallory v. Travelers' Ins. Co., 47 N. Y. 52, 7 Am. Rep. 410; Knickerbocker Casuaity Co. v. Jordan, 6 Ohio Dec. 1145, 7 Ohio Wkly. Law Bul. 71, 10 Am. Law Rec. 625; Travelers' Ins. Co. v. Rosch, 23 Ohio Cir. Ct. R. 491, where the assured, a steerage passenger, disappeared from the ship while in mid-ocean, being last seen late at night, the presumption being that he fell overboard and was drowned; Tucker v. Mutual Ben. I,ife Ins. Co., 50 Hun, 50, 4 N. Y. Supp. 505, affirmed without opinion in $121 \mathrm{~N}$. Y. 718,24 N. E. 1102, where the assured was drowned 
Death or injury resulting from a strain or dislocation is held to result from violent and external means. ${ }^{35}$

Death from asphyxiation by gas is by external and violent means within the meaning of such a policy. The gas in the atmosphere is external, and in its effect upon the assured is a violent agency. ${ }^{36}$ But where the assured dies as

while attempting to rescue the crew of a boat which had been driven ashore; Wehle v. United States Mut. Acc. Ass'n, 11 Misc. Rep. 36, 31 N. Y. Supp. 865 ; Id., 153 N. Y. 116, 47 N. E. 35, 60 Am. St. Rep. 598. Leading English cases are Trew v. Railway Passengers' Assur. Co., 6 Hurl. \& Norm. 839, where the assured fell into the water and was drowned while on a fishing trip; Winspear v. Insurance Co., 6 Q. B. Div. 42, affirming 42 Law T. 900 ; Reynolds $\nabla$. Insurance Co., 22 Law T. (N. S.) 820 .

85 Hamlyn v. Crown Accidental Ins. Co., (1893) 1 Q. B. 750. Here the assured, stooping to pick up a marble dropped by a child, dislocated the cartilage of his knee. The court held the injury to have been the result of accidental, violent, and external means. Horsfall v. Pacific Mut. Life Ins. Co., 32 Wash. 132, 72 Pac. 1028, 63 L. R. A. 425, 98 Am. St. Rep. 846, where the assured, a strong, healthy man, who was a blacksmith by trade, and as such accustomed to lifting heary weights, while at work helped to carry an iron bar. After setting it down, he turned pale and was taken violently sick. Shortly afterwards he died as the result of hypertrophy of the heart. The court held the company liable, and the death to have been "caused solely by external, violent, and accidental means." North American Life \& Accident Ins. Co. v. Burroughs, 69 Pa. 43, $8 \mathrm{Am}$. Rep. 212, where the company was beld liable for the death of the assured, which resulted from peritonitis caused by straining the abdominal muscles while helping to haul and unload hay. Martin v. Tra velers' Ins. Co., 1 Fost. \& F. 505, where the spine of the assured was injured as the result of lifting. See, however, Cobb v. Preferred Mut. Acc. Ass'n, 96 Ga. 818, 22 S. E. 976, where the assured, while in a feeble and emaciated condition, carried his baggage a few yards and, upon setting it down, a defect in the vision in one of his eyes became apparent. The court held that, even If the injury was occasioned by carrying the baggage, "it was not effected by 'external,' 'violent,' or 'accldental' means, in the sense in which these words are used in the policy."

86 Paul v. Travelers' Ins. Co., 112 N. Y. 472, 20 N. E. 347,3 L. R. A. 443,8 Am. St. Rep. 758, affirming 45 Hun (N. Y.) 313 . Here the assured was found dead in his bed in a room at a hotel, having been asphyxiated by the gas from one of the jets. The court said: "As to the point raised by the appellant that the death was not caused 
the result of chloroform administered to perform an operation the company will not be liable. ${ }^{2.7}$ Where the assured accidentally or inadvertently swallows an excessive quantity of deadly drug, taken by mistake, which occasions his death, it results from an external and violent cause within the policy. ${ }^{38}$ So poison taken into the stomach is an ex-

by external and violent means, within the meaning of the policy, we think it a sufficient answer that the gas in the atmosphere, as an external cause, was a violent agency, in the sense that it worked upon the intestate so as to cause his death. That a death is the result of accident, or is unnatural, imports an exterual and violent agency as the cause." Pickett v. Pacific Mut. Life Ins. Co., 144 Pa. 79, 22 Atl. 871, 13 L. R. A. 661, 27 Am. St. Rep. 618. In this ease the assured went down into a well to make repairs to a pump and in a short time was found dead in the well, asphyxiation having resulted from the inhalation of poisonous gas at the bottom of the well. The court in its opinion sald: "The deadly but invisible gas by which he was unconsciously and accidentally enveloped was undoubtedly the external and violent cause of his injury and death. The deceased was accidentally, violently and fatally asphyxiated by the unknown presence of a fluid foreign to his person. It that fluid had been oil, smoke, water, or molten metal, the result would have been substantially the same. Death caused, not so much by the inhalation of the fluid, as by its action in excluding life-supporting air, would have inevitably resulted." Trone v. General Acc. Assur. Corp., 13 Ohio Dec. (N. P.) 298.

37 Westmoreland v. Preferred Acc. Ins. Co. (C. C.) 75 Fed. 244. Here chloroform was administered to the assured for the purpose of performing an operation.

38 Healey v. Mutual Acc. Ass'n of the Northwest, 133 11l. 556, 25 N. E. 52, 9 L. R. A. 371,23 Am. St. Rep. 637 , reversing 35 Ill. App. 17. Here the assured accidentally drank an overdose of chloral, which resulted in his death. The court declared: "We think that the decided weight of authority is in support of the view that death in this case was caused by external and violent means." The court declared death by accidentally drinking poison analogous to death from inhaling poisonous gas, or drowning. Travelers' Ins. Co. v. Dunlap, 59 Ill. App. 515, affirmed by 160 Ill. 642, 43 N. E. 765, 52 Am. St. Rep. 355. The assured came to his death by drinking a quantity of carbolic acid for peppermint, a medicine which he desired to take for sickness. The company was liable on the ground, at least, that the injury or death was produced by violent and external means. See, also, to the same effect, Nutual Acc. Ass'n of the Northwest $\nabla$. 
ternal force or substance which operates internally to produce the death.

Death by suicide is violent, and, even where it is the direct result of the act of the assured himself, it is also external within the terms of the policy. ${ }^{39}$ The decisions declare that death by suicide is external, whether occasioned by the assured shooting or hanging himself, or by such means as throwing himself in front of a moving train or from a bridge into a river and drowning. While thus sui-

Tuggle, 39 Ill. App. 509, where the assured took an orerdose of laudanum.

See, however, Hill v. Hartford Acc. Ins. Co., 22 Hun (N. Y.) 187, where the assured, a physician, in the course of his duties mixed some poison in water in a goblet which he thereafter drank, mistaking it for water, and without any intention of taking his life. The court held that death was not occasioned through external and violent means, and said: "The injury was effected through the action of the poison internally. Death was not caused by any external act, nor by anything acting externally, nor by any violent external means." This decision is against the accepted welght of authority. See, also, Bayless v. Travelers' Ins. Co., 2 Fed. Cas. 1077, where the assured, while sick, by inadvertence took more opium than he intended, and more than was prescribed by the physician. Here the beneficiary was not permitted to recover on the strength of a ciause in the policy which provided that the insurance should not extend "to any death or disability which may have been caused wholly or in part by any surgical operation or medical or mechanical treatment for disease." The court also intimated that in its opinion such a death was not occasioned by external and violent means.

39 Blackstone v. Standard Life \& Accident Ins. Co., 74 Mich. 592, $42 \mathrm{~N}$. W. $156,3 \mathrm{~L}$. R. A. 486 . In this case the assured, while insane, committed suicide by cutting his throat. The court said: "We think, where one is so far beside himself, his intellect so darkened and obscured, that he may be neither morally nor legally responsible for his own acts and conduct, and in such condition produces his own death, it cannot be any more said to be his act than as though the act had been committed by another, or the assured had placed himself upon some dangerous height, and had fallen involuntarily and been dashed to pieces." See, also, Accident Ins. Co. v. Crandal, 120 U. S. 527, 7 Sup. Ct. 685, 30 L. Ed. 740, affirming Crandal v. Accident Ins. Co. (C. C.) 27 Fed. 40, where the assured committed suicide by hanging himself. 
cide may be death by external and violent means within the terms of the policy, yet at the same time the insurance company may be not liable because of another condition in the policy exempting death by suicide.

Among other injuries which the courts have declared to be the result of external and violent means are: Death caused by scalding water accidentally falling into the ear of the assured; ${ }^{40}$ death from burns on the body caused by acids, or hot metals ; ${ }^{41}$ blood poison by the prick of a needle used for embalming; ${ }^{42}$ loss of an eye from gonorrheal infection by accidentally splashing water into the eye. ${ }^{43}$ Where the evidence is conflicting, it is for the jury to determine whether the means are external and violent within the meaning of the policy. ${ }^{44}$

What Included in Risks of Occupation.-Where there is no condition or warranty in the policy of accident insurance that the assured will not engage either permanently or temporarily in any occupation other than that in which he is classified in the policy, or limiting the liability of the company to injuries received while engaged in that particular occupation, the insurance company will be liable, even if the assured is injured while engaged in some occupation

40 Driskell v. United States Health \& Accident Ins. Co., 117 Mo. App. 362,93 S. W. 880 .

41 Preferred Acc. Ins. Co. v. Fielding, 35 Colo. 19, 83 Pac. 1013, 9 Ann. Cas. 916.

42 Simpkins v. Hawkeye Commercial Men's Ass'n, 148 Iowa, 543, 126 N. W. 192.

43 Sullivan v. Modern Brotherhood of America, 167 Mich. 524, 133 N. W. 486 .

44 Etna Life Ins. Co. v. Fitzgerald, 165 Ind. 317,75 N. E. 262, 1 L. R. A. (N. S.) 422,12 Am. St. Rep. 232,6 Ann. Cas. 551. Here the assured, while asleep and lying with his head upon his hand turned orer so that his hand lay on the edge of the bed rail, causing compression of the tissues and blood ressels, resulting in periostitis, and the court said: "The degree of violence is not always a controlling consideration." McCullough v. Railway Mail Ass'n, 225 Pa. 118, 73 
more hazardous than that under which he was classified. The general purpose of classifying occupations is to enable the company to fix the rate of the premium and protect itself from fraud or misrepresentation by preventing those whose ordinary occupation renders them more liable to accident from obtaining insurance at the same rate as those whose professions or occupations in life are usually attended with less peril and less exposure to danger.

But where the assured, in answer to the interrogatories on the application blank, states that he is.engaged in a certain occupation, and as a matter of fact he is following some other distinct pursuit, in which he is injured, the insurance company will not be liable. ${ }^{45}$

A slight discrepancy, however, between the occupation named and that actually pursued by the assured, will not invalidate the policy. ${ }^{18}$ And where the classification is

Atl. 1007, where the assured, a mail clerk, was found alone in a semiconscious condition in his car after his run, and the following day swellings were discovered on his head by the attending physicians, whose opinion it was that his condition had been caused by external violence, and not by disease.

45 Standard Life \& Accident Ins. Co. v. Ward, 65 Ark. 295, 45 S. W. 1065, where the assured gave his occupation as "ice dealer and proprietor of transportation company," and he was also engaged in the business of buying and selling cattle. Cram v. Equitable Acc. Ass'n of Binghamton, 11 N. Y. Supp. 462, 58 Hun, 11, where the occupation was given as "oil producer, supervising only," and in fact he was the lessee of oil lands, on which he personally operated severai weils. Murphey v. American Mut. Acc. Ass'n, 90 Wis. 206, $62 \mathrm{~N}$. W. 1057 , where the assured was engaged in cutting cordwood though he gave his occupation as "carpenter and millwright."

46 Ford v. United States Mut. Acc. Relief Co., 148 Mass. 153, 19 N. E. 169,1 L. R. A. 700 , where the assured, engaged as a leather cutter and merchant, described himself as a "leather merchant." To the same effect, see, also, Everson v. General Accident Fire \& Life Assur. Corp., Limited, of Perth, Scotland, 202 Mass. 169, 88 N. E. 658; Dalley v. Preferred Masonic Mut. Acc. Ass'n, 102 Mich. 289, 57 N. W. 184, 26 L. R. A. 171; Taylor v. Illinois Commercial Men's Ass'n, 84 Neb. 799, 122 N. W. 41; Brink v. Guarauty Mut. Acc. 
made by the agent of the insurer upon full information given in good faith by the assured, the company cannot claim that the policy is avoided by an incorrect classification. ${ }^{47}$ Such a policy of insurance does not amount to a contract on the part of the assured that he will not enter into or engage in any other occupation than the one in which he is classified and that he will do no act not directly connected with such an occupation. ${ }^{48}$

Ass'n, 7 N. Y. Supp. 847, 55 Hun, 606; Neafie v. Manufacturers' Acc. Indemnity Co., 8 N. Y. Supp. 202, 55 Hun, 111.

47 Pacific Mut. Life Ins. Co. v. Snowden, 58 Fed. 34z, 7 C. C. A. 264; New York Acc. Ins. Co. v. Clayton, 59 Fed. 559, 8 C. C. A. 213, where, with full knowledge that the assured was a junk dealer, the agent classified him as a "merchant," a less dangerous occupation; Carpenter v. American Acc. Co., 46 S. C. 541, 24 S. E. 500.

48 Pacific Mut. Life Ins. Co. $\nabla$. Snowden, 58 Fed. 342,7 C. C. A. 264 , where the occupation of cattle dealer covered an injury sustained while looking after cattle in transit. Provident Life Ins. Co. of Chicago v. Fennell, 49 Ill. 180. Here the assured was classified as a switchman under a general policy of accident insurance. There was a clause in the policy limiting the liability of the company in the event that the assured was injured while engaged in any other occupation. The court held that evidence tending to prove that the assured was killed while performing the duties of a brakeman was immaterial, inasmuch as the representation by the assured that he was a switchman did not amount to a contract that he would do no act not connected with such an occupation or that he would engage in no different calling. National Acc. Soc. of City of New York v. Taylor, 42 Ill. App. 97, where the court held that the occupation of "supervising farmer" covered such occasional acts as repairing a bridge on the farm, salting cattle, feeding stock, mowing lawn corners, and fixing gates, fences, and the like. Providence Life Ins. \& Inv. Co. of Chicago v. Martin, $32 \mathrm{Md}$. 310. Here the assured was classified as a locomotive engineer, and while temporarily acting as a brakeman he fell from the car and was killed; and the court declared that the assured was at the time of his application a locomotive engineer by profession or occlipation, and the conditions and warranty in this particular were fully satisfied. "Therefore it was no defense to prove that the assured at the time of his injury was engaged in any act out of line of his duties as an engineer. In policies of accident insurance, where the company inserts a clause limiting its liability only to accidents incurred in the occupation in which the assured is classified, the policy of insurance will be held to cover all risks which pertain to the occu- 
If a policy of insurance, however, so minutely and specifically describes the occupation of the insured as to exclude certain acts which may be performed by one engaged in that or a similar occupation, the company will not be liable

pation named, even though some of the duties performed or the risks incurred may be more dangerous than those ordinarily connected with the occupation specified. For example, the ordinary duties of a railroad conductor are to give instructions to the engineer, supervise the train crew, and collect tickets. On the other hand, they are required, in the very nature of their business, not only to enter tralns while they are in motion, but also to leave them before they come to a full stop at stations." 'Dailey v. Preferred Masonic Mut. Acc. Ass'n, 102 Mich. 289, 57 N. W. 184, 26 I. R. A. 171. Here the assured, classified as a conductor, met his death while attempting to allght from a train while it was in motion. The court said that this was a dangerous practice, but it is among the risks whlch the passenger conductor assumes when he enters upon such employment. Hess v. Van Auken, 11 Misc. Rep. 422, 32 N. Y. Supp. 126; also, Hess v. Preferred Masonic Mut. Acc. Ass'n of Amerlea, 112 Mich. 196, 70 N. W. 460,40 L. R. A. 444. Here the assured, the cashler of a bank, was injured while in a sawmill, where he had gone to have some lumber cut for a cabinet to be used in the bank. The court held that, while this may not have been, technically speaking, a part of his occupation as a bank cashier, yet he was within the scope of his employment. Thompson v. Loyal Protective Ass'n, 167 Mich. 31, 132 N. W. 554; Wilson v. Northwestern Mut. Acc. Ass'n, 53 Minn. 470, 55 N. W. 626 . Here the assured was classified as a stone mason, and was fatally injured by the falling of a scaffold while "pointing" the walls of a building. The court held that, whlle all masous may not customarily finish or point walls, yet the work of pointing is a part of a brick mason's trade, just as the work of shingling a roof is, properly speaking, the work of a carpenter. Jamison v. Continental Casualty Co., 104 Mo. App. $306,78 \mathrm{~S}$. W. 812 . The insured was classified as a bridge carpenter. At the time of his death he was detalled to flag trains and see that their speed was reduced before they passed over a certain bridge while repairs were being made. The court beld that his vocation exposed Lim constantly to the danger of being thus killed, and this was one of the risks insured against. Simmons v. Western Travelers' Acc. Ass'n, 79 Neb. 20, 112 N. W. 365. The policy in sult provided for a lesser llability in the event the assured should change his occupation to one more hazardous than that specified in bis application. The assured, classified as a "traveling man," lost his position, and while temporarily out of work stayed on his father's ranch, though drawing no pay. He was accidentally killed while looking for another position in his regular line of work. The court 
for injuries not reasonably included within the scope of that occupation. ${ }^{49}$

Some classifications used in policies of insurance are so broad and generic in their nature as to cover a multitude of risks which pertain to several different occupations. For example, one may be insured as "retired," or as a "capitalist," with the result that it is difficult to define exactly what risks are included under such a classification. But the general rule is that one so insured may recover for injuries sustained while engaged in any occupation not more hazardous than is ordinarily followed by men so classified, or which he might reasonably be expected to follow. ${ }^{50}$

held that he had not changed his occupation, as claimed by the insurer, to that of stock farmer or superintendent, classified as a more hazardous risk than commercial traveler. Neafie v. Manufacturers' Accident Indemnity Co., 55 Hun, 111, 8 N. Y. Supp. 202, where the occupation "proprietor of an ice company" covered also delivering ice. Price v. National Acc. Soc., 37 Pa. Super. Ct. 299. Richards v. Travelers' Ins. Co., 18 S. D. 287, 100 N. W. 428, 67 L. R. A. 175 , where the occupation "cattle dealer, or broker, visiting yards, by occupation," covered an injury sustained while in the railroad yards supervising the switching of cars containing his cattle. Denoyer v. First Nat. Acc. Co., 145 Wis. 450, 130 N. W. 475. The assured stated his occupation as that of "miller," but about the time of making the application for the policy of accident insurance he attached to his flour mill a circular saw for cutting logs into lumber. The court held that, although operating a circular saw was a prohibited occupation, the assured had not been guilty of any false representation as to his occupation.

49 See Loesch v. Union Casualty \& Surety Co., 176 Mo. 654, 75 S. W. 621. Here the assured was classified as a "stock dealer not working or tending in transit." He was fatally injured while unloading a car of cattle, which pursuit is a more hazardous employment. The company was held liable only for the lesser indemnity.

50 Bean v. Travelers' Ins. Co., 94 Cal. 581, 29 Pac. 1113. Here the assured was designated in the preferred class as a "capitalist," and the court held that he might recover, if disabled from transacting any business which a person classed as "capitalist" might ordinarily be expected to follow. Knapp v. Preferred Mut. Acc. Ass'n, 53 Hun, 84, 6 N. Y. Supp. 57. Here the assured was classified as a "retired gentleman." While operating a band saw in a wagon shop which he owned. his right hand was injured. He testified that at 
Where a policy of accident insurance is issued to a man under a certain classification, and at the same time contains conditions exempting the company from liability for certain specified risks, the company will be liable, and the insured may recover, even if, when injured, he was engaged in one of the excepted risks, providing that such risk or exposure is incident to the occupation in which he was classified. A recovery cannot be defeated on the ground of exposure to a danger which must have been contemplated by the party taking the policy of insurance, since it pertained to his business. In other words, an action cannot be defeated by the defense that the assured was killed by exposure to danger within an exception of the policy, when such an exposure is a necessary incident to his occupation. ${ }^{31}$

the time of filing his application for insurance he had no occupation and his income was derired from his investments; also that he had a shop at his house, where he spent some leisure time; that he amused himself on a steam yacht, that he himself ran, drove his own horse, and was a stockholder and director in a wagon manufacturing company; and that at times he used some of the machinery of the wagon shops for his own amusement. The court rendered a nonsuit, and declared that the work of operating a band saw was proverbially dangerous, and was not incident to the occupation or condition of a retired gentleman.

51 Wilson v. Northwestern Mut. Acc. Ass'n, 53 Minn. 470, 55 N. W. 626. Here the assured, classified as a stone mason, was fatally injured by the falling of a scaffold. The court held that a recorery could not be defeated on the ground of unnecessary exposure, within the terms of an exception to the policy, to a danger contemplated by the parties and which pertained to the business of the assured. Jamieson v. Continental Casualty Co., 104 Mo. App. 306, 78 S. W. S12. Here the assured was classified as a bridge carpenter, and was killed by being struck by an engine while stationed at a bridge to signal approaching trains. The policy contained a clause providing for a limited indemnity in the event of injuries sustained "from unnecessary exposure to danger and obvious risk of injury." These exposures to danger are a necessary part of the occupation of the assured, and to protect himself from injuries arising therefrom was his purpose in securing a policy of accident insurance. Alloway v. General Acc. Ins. Co., 35 Pa. Super. Ct. 371. Here the assured was 
Where the occupation under which the assured is classified requires physical exertion and heavy lifting, the company will not be saved liability under a condition exempting it in the event of injuries resulting from "voluntary over-exertion, unnecessary lifting," etc., providing these were performed in line of duty. ${ }^{52}$ Also the insurance company will be liable for injuries sustained by a railway conductor, who is injured while entering or leaving a moving train, despite an exception to the contrary in the policy, since this is among the ordinary duties of one engaged in that occupation. ${ }^{53}$ In many policies of insurance railway employés are excepted from the operation of this condition, and when the assured was a railroad employé at the time of the issuing of the policy he does not lose the benefit of

classified as a "clerk in a store, not doing porter's work." The store was a general store in a mining region, and one of the clerk's duties was to go to a powder house about a mile distant and deliver the powder to customers. He was killed by an explosion at the powder house while in the line of his duty, and the company was liable. Ward's Adm'r v. Preferred Acc. Ins. Co., S0 Vt. 321, 67 Atl. 821. The assured was classified as a "contractor, office and traveling." While inspecting railroad bridges in line with his work as railroad bridge contractor, he was riding upon an inspection engiue, and was killed by falling from the engine. The insurer was liable.

52 Standard Life \& Accident Ins. Co. v. Schmaltz, 66 Ark. 588, 53 S. W. 49, $74 \mathrm{Am}$. St. Rep. 112. Hele the assured was classified as 'a machinist, and was injured while lifting a heavy plece of machinery in the customary line of his employment. Rustin v. Standard Life \& Acc. Ins. Co., 5S Neb. 792, 79 N. W. 712, 46 L. R. A. 253, 76 Am. St. Rep. 136. Here the plaintiff was insured as a "capitalist," and was the owner of a pleasure resort, in which a strong man was to exhlbit his prowess. He was injured while lifting the dumb bells, which looked lighter than those advertised and contracted for by the exhibitor. The court held that the lifting was reasonable, and was performed in line with his duty.

53 Dailey v. Preferred Masonic Mut. Acc. Ass'n, 102 Mich. 289, 57 N. W. 184, 26 L. R. A. 171 . The court bere held that, in spite of the exception to the policy, this risk is so general an incident to this occupation that the insurance company must have had knowledge of it, and must have assumed such a risk when issuing the policy to one classified as a railroad conductor.

Fuller Acc.INs.-4 
this exception by subsequently engaging in another occupation, such as farming. ${ }^{54}$ And where the assured is a baggage checker of a transfer company, and his business requires him to board and leave incoming trains, he is a railway employe within the terms of that exception, although, technically speaking, working for a baggage company. ${ }^{55}$

st See Employers' Liability Assur. Corp. v. Rochelle, 13 Tex. Civ. App. 232, $35 \mathrm{~S}$. W. 869 , where the assured, formerly a railroad employé, but then a farmer, was killed while attempting to board a moving train of cars.

35 Cotten v. Fidelity \& Casualty Co. (C. C.) 41 Fed. 506, where the company under such a policy is exempted from liability by a condition prohibiting the assured "from boarding or leaving a moving train, railway employes excepted." The court held that one classitied in a less hazardous occupation, killed while attempting to board a moving train, cannot claim indemnity payable to a railroad employe, uniess that is his actual occupation. See, also, Yancy $v$. Atna Life Ins. Co., 10S Ga. 349, 33 S. E. 979, where the policy contained an exception exempting the insurance company from liability where the assured was injured "while walking or being on any railroad bridge or roadbed, railway employes excepted." The assured, a traveling salesman for a coal company, could not hold the company liable for an injury under such a clause, simply because the duties of his calling rendered it necessary for him at times to go upon the roadbed of rallroads. The court held that the proper construction of such a clause is that the insurance is suspended during the time that the assured is in the position above stated. Miller v. 'Travelers' Ins. Co., 39 Minn. 548, 40 N. W. 839, where the assured, classified as a banker, was killed while attempting to board a moving train. The court beld that the company was not liable, and that the bencficiary could not attempt to recover the indemnity specified for rallway employes. Standard Life \& Accident Ins. Co. v. Koen, 11 Tex. Civ. App. 273, 33 S. W. 133 . Here the assured was classified as an extra conductor. At the end of his run, on which he acted as a brakeman, he was sitting in a restaurant, which was blown over by a tornado, and he was killed by falling houses and flying timbers. The court held that his death was due to an accident wholly in connection with his occunation, and that the liability of the company was not altered by the fact that the assured was at the time engaged in an occupation other than that in which he was classified by the poilcy. Kinney v. Baitimore \& O. Employés' Relief Ass'n, 35 W. Va. 385, 14 S. E. 8, 15 I. R. A. 142 . Here the policy stipulated liability for accidents while in the discharge of one's duty. An employe, who a few moments before had quit work for the day, while going home from work, was kilied by a train 
Where a policy of insurance provides for a limited indemnity on the part of the company for any change in occupation to one classified as more hazardous, the company cannot avoid its original liability unless there has been an actual change. The mere fact that the assured may have been injured while performing some duty which may technically pertain to some occupation other than that in which he was classified will not relieve the company from its liability, providing the assured at the time he was injured still follows the occupation designated at the time the policy was issued. The fact that he is temporarily engaged in some act not identified with his own occupation, or has as. sumed some risk not incident thereto, will not of itself relieve the insurance company. ${ }^{56}$

while crossing railroad tracks. The court said: "Had he reached home and fallen down stairs, and been killed thereby, or had he, while yet on the railroad grounds, been murdered, or killed by a wagon, or any cause foreign to the railroad operations, he would not be within the undertaking; but he is killed while performing the indispensable act of going from his work at the day's close to his home, before yet he had gotten from the railroad tracks, and from among the cars, and out of the field of the transaction of the company's business. Was he not, while passing over the railroad tracks in going to and returning from his home, in the course of his labors, as much in the discharge of his duties and in the service of the company as wlien he had the tools with which he worked in his hands, for the purposes of the question before us? It does seem to me that to say that he was not in the discharge of his duties in the service of the company, within the spirit and meaning and purposes of this organization and its constitution, would be very technical and refined."

56 Standard Life \& Accident Ins. Co. v. Fraser, 76 Fed. 705, 22 C. C. A. 499 , where the assured, classified as "proprietor of a bar and billiard room, not tending bar," was shown to tend bar to the extent of relieving his regular bartenders occasionally at meal hours. National Acc. Soc. of City of New York v. Taylor, 42 Ill. App. 97, where the assured, classified as a "supervising farmer," was accidentally drowned while repairing a bridge on his farm. Travellers' Preferred Acc. Ass'n v. Kelsey, 46 Ill. App. 371, where one classified as an agriculture superintendent was injured while acting temporarily as a superintendent of police at a state fair. Union Mut. Acc. 
A policy may, however, contain a provision to the effect that even a temporary change of occupation will relieve the insurance company from liability. Under such a policy the company will not be liable under the occupation named in

Ass'n v. Frohard, 134 Ill. 228,25 N. E. 642,10 L. R. A. 383,23 Am. St. Rep. 664 , where the assured, classified as a merchant, was accidentally killed whlle hunting. Hess $\mathbf{v}$. Preferred Masonic Mut. Acc. Ass'n of America, 112 Mich. 196, 70 N. W. 460, 40 L. R. A. 444, where the assured, classified as a bank cashier, was injured by a saw in a planing mill, where he had gone to have some boards cut for use in building a cabinet in his bank. Johnson v. London Guarantee \& Accident Co., 115 Mich. 86, 72 N. W. 1115, 40 L. R. A. 440, $69 \mathrm{Am}$. St. Rep. 549, where the assured, classified as secretary and treasurer of a business firm, was injured while driving a bull from a pasture on his farm, which he conducted through others, and where he spent but one or two days a week. Stone's Adm'rs v. United States Casualty Co., 34 N. J. Law, 371, where a school teacher was killed by falling from a barn where he was inspecting the work being done for him by a contractor. Brink v. Guaranty Mut. Acc. Ass'n, 7 N. Y. Supp. 847, 55 Hun, 606, affirmed without opinion 130 N. Y. 675,29 N. E. 1035, where the assured, classified as "livery stable proprietor (not working)," with duties "such as were required of him in that occupation," was shown to sometimes hitch up horses himself and drire persons around. Hoffman v. Standard Life \& Accident Ins. Co., 127 N. C. 337, 37 S. E. 466, where one insured as a "freight flagman, not coupling or switching," was injured while placing a coupling pin. The court held that this single act of the assured did not vitiate the policy or change the occupation to one wore hazardous. North American Life \& Accident Ins. Co. v. Burroughs, $69 \mathrm{~Pa}$. $43,8 \mathrm{Am}$. Rep. 212 , where the assured was classified as a manufacturer. While on a visit to his grandfather, he assisted in hauling in and unloading some hay, and while handling a pitchfork it slipped through his hands, injuring him in the abdomen, as the result of which he died. . The court said: "This was not a change of his occupation or business, within the meaning of the policy. To give to the word such a construction would prerent the assured from performing any act or service outside of his usual avocation or business without rendering the policy null and void. Such a construction would be unreasonable and absurd." Standard Life \& Accident Ins. Co. v. Koen, 11 Tex. Civ. App. 273, 33 S. W. 133, where the assured, classified as an extra conductor, was killed by a cyclone while eating in a restaurant at the end of a run in which he had acted as a brakeman. Hall v. American Masonic Acc. Ass'n, 86 Wis. 518,57 N. W. 366, where one insured as a "grocer-proprietor," was 
the contract of insurance, if the assured is injured while engaged in some other occupation, even though he only be temporarily so engaged. ${ }^{57}$

The factor which controls in the adjudication of these cases is whether the act which the assured was performing at the time of his injury more properly pertained to an occupation other than that under which he was classified. The company will not be excused from liability simply because the insured happened to be engaged temporarily in a more hazardous act or occupation than that described in the policy. The question is whether the assured has actually changed his occupation, or whether at the time of his injury he was performing an act specifically pertaining to another occupation. ${ }^{58}$

Similarly, there must be an actual change of occupation, and the company will not be relieved of its liability, nor be

injured whlle delivering goods. The evidence showing that he himself only made an occasional delivery, the court held that the company was not in any way relieved from its indemnity.

See Amount of Liability Determined by Occupation of Assured, page 336.

57 Thomas v. Masons' Fraternal Acc. Ass'n, 64 App. Div. 22, 71 N. Y. Supp. 692. In this case the policy provided that the company would be liable only for a limited indemnity in the event that the assured received an injury "in any occupation, exposure, temporary or otherwise," classified as more hazardous than that for which he was insured. He was classified as a lawyer, and killed while hunting by the accidental discharge of his gun. The court held that, under the express provision of the clause contained in the policy, the company could be held liable only for the limited indemnity payable to a hunter. Brock v. Brotherhood Acc. Co., 75 Vt. 249, 54 Atl. 176, where the assured, classified as a "cattle shipper and tender in transit," under such a policy, was injured while tending horses in transit.

58 Eggenberger v. Guarantee Mut. Acc. Ass'n (C. C.) 41 Fed. 172. Here the assured, classified as a stationary engineer, was fatally injured while chopping firewood for his own use. It could hardly be contended that the insured at the time of his injury had changed his occupation from that of a stationary engineer to a wood chopper simply by chopping wood for his family use. 
liable only for a smaller indemnity, if the assured merely intends to change his occupation, though he may have taken certain steps in accordance therewith. ${ }^{59}$.

It is clear that the acts of an assured performed merely for recreation or convenience, and which pertain to the ordinary. conduct of men in all walks of life, cannot be construed as indicating a change of occupation, so as to relieve the company from the whole or a part of its indemnity in the event that the assured is injured while performing such acts. ${ }^{60}$

Hunting or fishing for recreation, although pleasures not often indulged in by the majority of people, are none the less incidents of daily life, and cannot be regarded as occupations, though, were one to hunt or fish and sell the re-

59 Atna Life Ins. Co. v. Frierson, 114 Fed. 56, 51 C. C. A. 424. Here the assured, classified as a lawyer, started for Alaska with the intention of becoming a prospecting miner. While he was on his way to the gold fields, the steamer on which he was traveling was wrecked in one of the Alaska rivers and he was drowned. The court held that the insurance company could not claim that the assured had changed his occupation to that of a prospecting miner, merely because he lost his life while on his way to Alaska, with the intention of engaging in such a pursuit, which he had not entered upon at the tlme of his death.

60 Berliner v. Travelers' Ins. Co., 121 Cal. 458, 53 Pac. 918, 41 L. R. A. 467, 66 Am. St. Rep. 49. One insured as a mining expert does not change his occupation by riding temporarily upon the locomotive of a passenger train. See, aiso, Eaton v. Atlas Acc. Ins. Co., $89 \mathrm{Me}$. 570,36 Atl. 1048, where the assured, while riding a bicycle for pleasure, was held not to have changed his occupation. In this case, howerer, the policy contained a clause limiting the indemnity in the erent that the insured be injured while engaged "for pleasure or recreation" in amateur bicycling. See Baldwin v. Fraternal Acc. Ass'n, 21 Misc. Rep. 124, 46 N. Y. Supp. 1016, affirmed without opinion 29 App. Div. 627, 52 N. Y. Supp. 1136. A man, classified as an undertaker and furniture dealer, does not become a bicyclist, merely by riding a bicycie between his place of business and his dwelling. Comstock v. Fraternal Acc. Ass'n, 116 Wis. 382, 93 N. W. 22, where one assured as the proprietor of a manufacturing industry was held not to have changed his occupation by riding a bicycle for pleasure. 
sults thereof, as an additional means of earning his living, they would then clearly be considered occupations. ${ }^{61}$

\section{Traveling Policies-Passengers-Public Conveyance.-} Many policies of accident insurance are framed merely to indemnify the assured or his beneficiary for accidents which happen to him while in the course of a journey "as a passenger in a public or private conveyance." These are known as "traveling policies." Many of the standard policies grant double indemnity to the insured, if he is injured while riding as a passenger on a public conveyance provided for that purpose. In order that the insurance company shall be liable, it is essential that the assured shall be traveling when the injury is received. ${ }^{62}$ If the assured, at the time of the accident which results in injuries or death, has left the train

61 Star Acc. Co. v. Sibley, 57 Ill. App. 315, where one classified as an engineer was killed by the accidental discharge of his gun while on a hunting trip. Union Mut. Acc. Ass'n v. Frohard, 134 Ill. 228, 25 N. E. 642,10 L. R. A. 383,23 Am. St. Rep. 664 , affirming 33 Ill. App. 178, where the assured, classified as a merchant, was accidentally shot, while hunting for recreation. Wildey Casualty Co. v. Sheppard, 61 Kan. 351, 59 Pac. 651, 47 L. R. A. 650, where one, assured as a proprietor and restaurant keeper, was accidentally shot while hunting. Kentucky Life \& Accident Ins. Co. v. Franklin, 102 Ky. 512, 43 S. W. 709, where the assured, classified as a "grocer, with desk and counter duties," was injured while hunting by the accidental discharge of his gun. Union Casualty \& Surety Co. . Goddard, 76 S. W. 832, 25 Ky. Law Rep. 1035, where the assured, classified as a druggist, was killed by the accidental discharge of his gun, which he was cleaning, while on a hunting trip. Wilkinson $\nabla$. Travelers' Ins. Co. (Tex. Civ. App.) 72 S. W. 1016. Here the policy of insurance contained a stipulation exempting the insurer from lia. bility for injuries received by the insured while hunting. While on a hunting expedition, and while helping to bring in a $\log$ to make a fire, the assured slipped and fell, injurying one of his hands under the log. The court held that, although the plaintiff was on a hunting expedition, he was not actually engaged in hunting at the time of the injury, and therefore the company was liable under the policy.

62 See Fidelity \& Casualty Co. of New York v. Teter, 136 Ind. 672, 36 N. E. 283 . Here the assured was a cattle and horse dealer. He applied for a policy which, among others, contained the clause: "Thls covers the assured only against the hazard of travel as a 
or boat at the end of his journey, the company will not be liable. But if he changes from one train to another, from a train to a boat, and walks between the different conveyances, or rides in a carry-all or a hack, he is still traveling. ${ }^{63}$ And, in the absence of any provision in the policy

passenger on a public conreyance provided by a common carrier within the United States or Canada." In response to his inquiry he was assured that the policy would insure hlm, not only while traveling, but also while tending and selling his horses. After he had reached San Antonio he fell from the hay loft in a barn in that city. The court held that the company was not liable, since this accident did not arise from the hazard of traveling.

6 3 Northrup v. Railway Pass. Assur. Co., 43 N. Y. 516, $3 \mathrm{Am}$. Rep. 724, reversing 2 Lans. (N. Y.) 166. In this case the assured was on a trip from Steuben to Madison county, both in New York state. She reached Geneva by steamer, and, following the usual custom of passengers, was walking from the steamboat landing to the railway depot, some 70 rods distant, when she fell on a slippery sidewalk, sustaining injuries which occasioned her death a few days later. Despite the fact that hacks were usually at the boat landing to carry passengers to the railroad station, they were seldom used, since the distance was comparatively short. The policy by which the assured was protected contained a provision covering accidents which shuuld happen "while traveling by public or private conveyance provided for the transportation of passengers." The court said : "Can it be said that a passenger is not traveling within the meaning of this contract by public conveyance, while passing from one train to go on board another in the actual prosecution of his journey; or, for further illustration, can this be said of a passenger from New York to Dunkirk by the Erie, while going from the ferry-boat at Jersey City, to get on board the train at that place? I think that such passenger, within the meaning of this contract, and also within the fair construction of the language, is a traveler by public conveyance all the way from New York to Dunkirk, although he may walk a short distance from the ferry-boat to the train at Jersey City, or from one train to another, when such changes are made at intermediate stations. An injury received while so necessarily walking in the actual prosecution of the journey is received while traveling by public conveyance within the meaning of the policy, as such walking is the actual and necessary accompaniment of such travel." This decision has been severely criticised, on the theory that the principle thus laid down would apply equally to a passenger who might walk across New York City on a trip from Albany to Philadelphla, as to one going from the ferry-boat at Jersey City to a train at that station. Thus a traveler pursuing his journey "by public or private conveyance" might be run over by an automobile 
to the contrary, if the assured is injured while alighting from a train, the company will be liable. ${ }^{64}$ Many policies, however, provide either that the insurance company shall not be liable, or else shall be liable only for single indemnity, if the assured is killed or suffers injuries while getting on

on Fifth avenue, or a fire engine on the Bowery, or a falling brick from a skyscraper, and yet hold the company liable on a policy which was intended to cover accidents happening only on railroads. It is clear that a person walking is exposed to many risks not incident to travel by a railroad. This case was one of the earliest of the accident insurance decisions, and we think is too broad, and is not in line with more recent and more equitable decisions. The court, in rendering the decisions, translated the clause in question to mean the whole journey as a unit. Although this decision has never been reversed or repudiated by a court of New York, yet it is viewed with suspicion by the courts in general.

'64 King v. Travelers' Ins. Co., 101 Ga. 64, 28 S. E. 661, 65 Am. St. Rep. 288. Here the assured was injured while attempting to alight from a moving street car. Under such a clause as the one under consideration the court said: "It is reasonable to hold that the insured was protected against all injuries caused by accidental means from the moment that he entered the conveyance until he had alighted therefrom. During this entire period he was riding as a passenger in the ronveyance." See the leading English case of Theobald v. Railway Passengers' Assur. Co., 26 Eng. ... \& Eq. Rep. 432. Here the plaintiff, who carried a policy insuring him against injuries arising from railway accidents while traveling, slipped while dismounting from a railway carriage on a rainy morning. The court held the insurance company liable on the policy and said: "Though at the time of the accident his journey had in one sense terminated by the carriage having stopped, he had not ceased to be connected with the carriage for he was still on it. The accident also happened * * * while doing an act which as a passenger he must necessarily have done, for a passenger must get into the carriage and get out of it when the journey is at an end, and cannot be considered as disconnected with the machinery of motion until the time he has, as it were, safely landed from the carriage and got upon the platform. The accident is attributable to his being a passenger on the railway, and it arises out of an act immediately connected with his being such passenger." Tooley v. Railway Passengers' Assur. Co., Fed. Cas. No. 14,098. Tooley took a train out of Chicago, which stopped at Kankakee. When the train stopped at this point, several persons left the cars, Tooley included. The train stood there several minutes taking on water. The conductor signaled for it to proceed. The train started, and Tooley, who was 
or off a moving car. ${ }^{65}$ If he is injured by a slippery walk or other accident while transferring at a boat landing the assured or his beneficiary will be permitted to recover. ${ }^{66}$ Similarly if the assured on an extended journey left the train temporarily while it was standing at a station, and was injured while again boarding the train as it was leav-

standing near, started forward to get aboard. Grasping the handrails of one of the cars, he was thrown between two cars, run over, and instantly killed. The policy insured against accidents received "while actually traveling in a public conveyance provided by common carriers for the transportation of passengers." The court said: "It cannot be said that the responsibility ceased whenever he stepped out of the car to alight at a station, and that it never became operative again until his foot entered the car to resume his journey. That would be giving too narrow a meaning to the clause of the policy. We think that the fair construction of the liability assumed by the defendant in this respect was that it included injurles received by Tooley while necessarily getting on or off the train as a traveler upon it." Champlin v. Railway Passengers' Assur. Co., 6 Lans. (X. Y.) 71. Here the assured attempted to jump onto an omnibus carrying passengers while it was in motion. He succeeded in landing on the steps at the rear of the vehicle, but by reason of the jarring could not maintain his hold, and fell off, receiving serious injuries. The court said: "It would be a very strained construction of a contract like this to hold that he was not traveling. If he was not traveling, it is difficult to say what he was doing. We think that, as he was actually going from one place to another, he was traveling."

65 Standard Life \& Accident Ins. Co. of Detroit, Mich., v. McNulty, 157 Fed. 224, 85 C. C. A. 22, where the assured was killed while attempting to enter a moving car. Banta v. Continental Casualty Co., 134 Mo. App. 222, 113 S. W. 1140, where the insurance company was held liable only for single indemnity when the assured, a passenger on a trolley car, was injured by jumping from a moving car when in fear of a collision.

In Kirkpatrick v. Etna Life Ins. Co., 141 Iowa, 74, 117 N. W. 1111,22 L. R. A. (N. S.) 1255 , the court held that, where one is injured while climbing over the platform of a car in a train which has blocked a street crossing, he does not come within the limitation of the policy absolving the insurer from liability for injury whlle entering or leaving a moving car, or occupying a place not provided for the use of passengers during transit; the assured not being a passenger and not trying to enter or leave a moving train.

o 8 Northrup v. Raliway Passengers' Assur. Co., 43 N. Y. 516, 3 Am. Rep. 724, supra. 
ing the station. ${ }^{67}$ But in order that the company shall be liable the assured while not actually on the train must be engaged in doing something to continue his journey as a passenger, as, for example, going into the station to purchase his tickets, or going to his residence at an intermedi-

67 Hendrick v. Employers' Liability Assur. Corp. (C. C.) 62 Fed. 893. Here the assured started from Bowling Green, Mo., to go to Chicago. He paid cash fare to Louisiana from Bowling Green, where be arrived early in the morning. He had passes for Chicago at his lodgings at Louisiana. He left the train at Louisiana, intending to get his passes and continue his journey over a connecting road some twelve hours later. After alighting on the platform he went forward to the engine to tell the engineer that he had resigned his position as fireman of a railroad, so that a mutual friend could be notified to apply for the position. The train started before he reached the engine, and in order to get back to the station he started to cross the platform of a moving car, fell therefrom, and was dragged by the cars, which passed over his arm, necessitating amputation. The company was declared not to be liable on its policy. The court said, inter alia: "Now, if he had been injured while doing anything incident to his journey from Bowling Green to Chicago, the court would instruct the jury to find a verdict in favor of the plaintiff. I will go further, and say that, if he was injured after getting off from the cars at Louisiana and going up to his boarding place to get his transportation, I would hold that to be a continuance of his journey: that is, that the accident was receired while doing something to continue his journey as a passenger. That, however, would be an extreme view of it in favor of the plaintiff. But the testimony here shows that he had gotten off the train safely, without harm to himself, and that this injury was received while doing something in no manner connected with his journey to Chicago, or in any manner connected with the condition of a passenger. * * * But even if he had done that while pursuing the idea of being a passenger, and in the relation of a passenger to the common carrier, I think the ticket would provide even for that kind of an accident. But this company had a right to llmit their liability to the relation of a passenger upon a common carrier. The view of the court is that he had clearly ceased to be a passenger when this injury occurred. He had got to the end of his journey. * * * A man is not obliged to stay upon the cars at every station. He may want to get off for various reasons incident to his passengership; but after arriving at the end of his journey, and getting off upon the platform, if he is injured in the doing of something that is not at all incident to his journey then the liability ceases." Anable v. Fidelity \& Casualty Co. of New York, 73 N. J. Law, 320, 63 
ate station to secure his transportation. But where he is injured while not on a train, and during the time that he is doing something which is not connected with his journey, the company will not be liable.

However, a man is not obliged to remain upon the cars at every station. He may desire to get off for various reasons incident to his passengership-such, for example, as to procure his meals, arrange for his baggage, procure transportation, send telegrams, etc. But if he has reached his destination, and has left the train, he ceases to be a passenger, and therefore is no longer protected by the policy. ${ }^{68}$

If the assured is insured under a policy while "traveling by public or private conveyance," and after leaving the train at his destination he takes a public conveyance, such as a hack, or carry-all, or bus, to his home or hotel, or is conveyed there in his own carriage or automobile, and during the course of this trip is injured by accidental means

Atl. 92, affirmed without opinion in 74 N. J. Law, 6S6, 65 Atl. -1117. Here the assured left his train at a station and went to a newsstand to buy a paper. He was killed while attempting to board the train as it started out. The court held that the insurer was not liable for the double indemnity payable in the event of injuries to the assured while "riding as a passenger in or on a public conveyance propelled by steam." In a well-considered opinion the court said: "It was obviously far from the intention of the parties to this contract that a passenger on a railroad train could get off the car at one station to buy a paper and then run for the moving train, could get off at another station to speak to a friend on the platform, and at still another station to buy fruit, and so repeat his exits from the car at various stations, and repeat his race for the moving train, and yet all this time remain covered by double insurance."

68 Wallace v. Employers' Liability Assur. Corp., 26 Ont. L. Rep. 10. Here the assured had alighted from a street car at the crossing near his residence. Being in danger from an approaching automobile, be attempted to again board the car, and was injured while doing so. The court held that, having alighted from the car at the end of his Journey, he was no longer "riding as a passenger in or upon a public convesance," within the meaning of a double indemnity clause of the policy. 
within the terms of the policy, the company will be liable. But this would not be true where, having reached the town where his journey ended, he set out on foot to reach home, and while walking met with such injuries. Walking is not traveling by either public or private conveyance. ${ }^{69}$

The courts have been frequently called upon to define just what is meant by a passenger. ${ }^{70}$ While the fact that the ticket of a passenger reads to a certain station may be presumptive evidence that his journey has ended there, yet his character as a passenger will not terminate when the train reaches that point, if he expects to proceed further by paying the balance of his fare in cash on the train. ${ }^{71}$ If the assured is an employé of a railroad or steamboat line, and is traveling on the business of the company, and actually engaged in the performance of his duties while

69 See Ripley v. Railway Passengers' Assur. Co., 16 Wall. (83 U. S.) 336, 21 I. Ed. 469, affirming 20 Fed. Cas. 823 . Here the assured, on his way to his home at Dalton, Mich., left the steamer at Muskegon at $11 \mathrm{p}$. m. and started to walk thence to Dalton, a distance of eight miles. After having gone about four mises, he was set upon by highwaymen, knocked unconscious, and roboed. A few days later he died from the effects of these injuries. The decision of the Supreme Court was rendered by Chief Justice Chase. He said: "That the deceased was traveling is clear enough, but was traveling on foot traveling by public or private conveyance? * * * It seems to us that walking would not naturally be presented to the mind as a means of public or private conveyance. Public conveyance naturally suggests a vessel or vehicle employed in the general conveyance of passengers. Private conveyance suggests a vehicle belonging to a private individual. If this was the sense in which the language was understood by the parties, the deceased was not, when injured, traveling within the terms of the policy."

70 Fidelity \& Casualty Co. of New York v. Morrison, 129 Ill. App. 360, where the assured, having boarded a train just as it was starting, was struck, either himself or his handbag, by a post and knocked off the car. James v. United States Casualty Co., 113 Mo. App. $622,88 \mathrm{~S}$. W. 125 , where the assured, riding on the running board of a crowded cable car, was thrown off by the sudden lurching of the car.

$7 x$ Tooley v. Railway Passengers' Assur. Co., 24 Fed. Cas. 53. 
traveling, he is not a passenger within the meaning of such a clause of an insurance policy. Strictly speaking, a passenger is one who travels in some public conveyance by virtue of paying a fare. On the other hand, an employé of a railroad may be a passenger when riding on the train while not engaged in performing his duties. ${ }^{72}$ For example,

72 Etna Life Ins. Co. v. Frierson, 114 Fed. 56, 51 C. C. A. 424. Here the assured, with others, formed an expedition to go from Seattle up the Alaska river, in Alaska, to prospect for gold. The party went by a regular steamship as passengers to the coast of Alaska, where they were transferred to a river steamer, which they were to use as a base of supplies during their explorations; the boat company to receive a percentage of the profits from the expedition. At the mouth of the Alaska river the boat was wrecked, and Frierson was drowned. The court held that he was a passenger, since it was found that, although some of the persons of the party of which Frierson was a member did constitute the crew paid to navigate the steamer by the navigation company, Frierson was not one so paid, and his relation was therefore purely that of a passenger.

Travelers' Ins. Co. v. Austin, 116 Ga. 264, 42 S. E. 522, 59 L. R. A. 107, $94 \mathrm{Am}$. St. Rep. 125. Here the assured was paymaster and cashier of a rallroad company, and his duties were to pay the salaries of the emploses, for which purpose he traveled at stated intervals over the line in a pay car. This pay car was a standard Pullman car so altered as to be available for that purpose; certain berths and seats being removed to make room for a desk, chairs, safe, guns, etc. At times the car was reconverted and used as a regular sieeping car. The train did not run on any regular schedule, but stopped at stations, or between them, as necessity demanded. On one of these trips the pay car was derailed and overturned, and a rifle hanging in the car was accidentally discharged, thereby killing the assured. The case turned upon the question as to whether the assured was a passenger riding on a rallway passenger car. 'The court held that he was not a passenger, even though he was not a part of the operating force of the train or the train crew. He was as much on duty on these trips as was the flagman. The pay car was declared by the court not to be a passenger car, any more than a bazgage or mail car could be so considered. It was not at the time used for transporting passengers. The court said: "The law throws greater protection around passengers than employes, and requires of railroad companies greater diligence in providing for their safety. Consequently the risk of insuring a passenger is not so great as that of insuring an employe. With this in vlew, the true test to be applied, to determine whether one injured in a railroad ac- 
a lawyer or official of the railroad, traveling to a certain point, where he is to perform certain duties for the company, and while so traveling not engaged in the performance of any duties, would be a passenger. But a flagman, or a conductor, or a mail clerk, on his regular run, would not be a passenger. ${ }^{73}$ This is true, even though at the particular

cident can recover from an insurance company double indemnity, is to inquire whether, presuming that a right of action exists against the railroad company, the plaintiff would be entitled to sue that company in the capacity of a passenger or an employe. In Austin's case, to ask that question is to answer it; for it is clear that the railroad company owed him no other duty than that of employer to employé, and, if liable to his widow, is only so on the ground of that relationship."

See Brown v. Railway Pass. Assur. Co., 45 Mo. 221, where the assured was a railroad engineer. The company sold two classes of tlckets-one known as the "travelers risk," and the other the "general accident"; the latter being sold at the highest price. The assured purchased a general ticket from an agent of the company, who knew that he was an engineer. The assured was killed while on his locomotive. The court said: "It is strongly contended that a locomotive or engine is not a conveyance provided for the transportation of passengers. This is certainly true, and if the ticket applies solely and exclusively to passengers or travelers, the position that the company is not liable cannot be controverted. A passenger would have no right to go upon an engine, and if he were so indıscreet as to venture on such a place, and injury ensued, he would not be protected. But this ticket was designed to include and cover something more than the ordinary risk incurred by the passenger or traveler. The locomotive is a necessary part of the conveyance. The ticket was a general accident, as contradistinguished from a mere passenger or traveling ticket."

73 Bogart v. Standard Life \& Accident Ins. Co. (C. C.) 187 Fed. 851. Here, the court held that a postal clerk, while riding in a mail car in the performance of his duties, is not a passenger within an accident policy insuring him against bodily injuries while riding as a passenger in or on any railway passenger car, propelled by mechanical power, provided by a common carrier for passenger service. The court said: "The insurance of a passenger while riding on a railway passenger car provided for passenger service is one thing; the insurance of a railway mail clerk while in the discharge of his official duties in a mail car on a moving train is an entirely different thing." See, also, Wood v. General Acc. Ius. Co. of Philadelphia (C. C.) 156 Fed. 982, affirmed by 160 Fed. 926, 88 C. C. A. 108. 
moment of the accident he may not have been actually engaged in performing any of the duties of his position.

Policies of insurance as a rule cover injuries sustained by the assured "while riding as a passenger in a passenger conveyance using steam, cable, or electricity as a motive power." And many policies provide a double indemnity for death or injuries resulting from an accident to the assured under such conditions. Under such a clause the company will not be liable for injuries received while the assured was riding on the platform of a railway car. ${ }^{74}$ Where

74 Etna Life Ins. Co. v. Vandecar, 86 Fed. 282,30 C. C. A. 48. Here the assured went out on the platform of the car when the whistle announced the approach to his station. While standing there, by the jolting of the train he was thrown off the car and suffered severe injuries. The court sald: "We think-the words used in the contract clearly indicate the intention of the parties. They evidently meant to stipulate for the double indemnity while the insured was riding in an exceptionally safe place. One who rides as a passenger in a passenger conveyance using steam occuples such a place. But one who rides on, but not in, such a conveyance, whether on the platform, or on the top of the car, or on the machinery beneath it, occupies a very dangerous place, and the parties neither. agreed by the terms of their contract, nor intended to agree, that this double indemnity should be paid to one who rode in such a position. The plain meaning of this provision is that if the plaintiff is injured while traveling as a passenger in a place in a passenger conveyance (using the motive power mentioned in the contract) assigned for passengers-in this case within the car-the defendant will pay double the amount mentioned in the policy. That the defendant had a right to so limit its liability there can be no doubt. * * The words 'In a passenger conveyance' were doubtless used advisedly, and for the express purpose of limiting the defendant's liability. The reason for so doing is at once apparent. The place specified in the contract, 'in a passenger conveyance,' is a place of little or no danger, and the risk assumed is slight, while on the platform of a conveyance using the motive power described in the contract, and especially, as in this case, on the platform of a railway car, is an exceedingly dangerous place when the train, to which the car is attached, is in motion. Riding upon the platform of rallway cars, when trains are in motion, is dangerous. * * * The fact that it is not unusual for passengers traveling by rail to go upon the platforms of cars before the trains stop at a station, as did the plaintiff in this case, cannot change or extend the contract of 
the train is a vestibuled train, and the platforms of the cars are therefore inclosed, the insurance company will be liable for death or injuries sustained by the assured as a result

the parties. If the plaintiff had remained in the car-the place assigned for passengers on the train by which he was traveling-until it arrived at the station, he could not have been injured. He chose, however, to occupy a more dangerous position on the platform of the cal-a position which, giving effect to the contract, according to the fair meaning of the words used, does not come within the provision of the policy now under consideration."

See, also, Preferred Acc. Ins. Co. of New York v. Muir, 126 Fed. 926,61 C. C. A. 456 , where the double indemnity clause stipulated that "such injury shall be received by the insured while riding as a passenger in or on a public conveyance," etc. The language here is broader than that in the Vandecar Case, since it includes the words "or on," and the beneficiary was permitted to recover when the assured was killed while out on the platform, where he was forced to go when taken suddenly sick with nausea and car sickness. The court here commented upon the restricted language of the Vandecar Case, and based its decision upon the broader terms of the policy in question.

Van Bokkelen v. Travelers' Ins. Co., 54 N. Y. Supp. 307, 34 App. Div. 399, affirmed without opinion 167 N. Y. 590, 60 N. E. 1121. Here the assured, while riding on a train, went out on the forward platform, which was not inclosed, and fell or was thrown down and in holding onto the rail was dragged for some distance. Losing his hold, he fell from a bridge over which the train was passing and was found dead. The court said: "A different meaning might be given to the clause if it provided that the passenger must be in a train. But where the liability is confined to a case where the passenger was injured when 'in a passenger conveyance,' it would seem to exclude an injury received by a person when riding otherwise than inside of a passenger conveyance. Thus it would seem that this clause would not apply if the insured was riding in a baggage car or express car attached to a passenger train, for he would not then be in a passenger conveyance. And so the clause would not apply where the insured was riding on top of a passenger car; and it would seem to exclude a person riding on the platform of a passenger car, when such platform was not a part of the car reserved for the use of passengers while being transported."

Richards v. Travelers' Ins. Co., 18 S. D. 287, 100 N. W. 428, 67 L. R. A. 175. Here the policy contained no double indemnity clause, but contained a clause stating that it would not cover accidents received while in any part of a car not provided for occupation by passengers. The policy bolder was insured as a "cattle dealer or broker visiting yards." The duties of his occupation required him

Fuller Acc.Ins. -5 
of an accident occurring to him while so riding. ${ }^{75}$ The insurance company will not be liable where the assured re-

to ride on trains of cattle cars from place to place in the freight yards. The assured was lying flat on his face on the top of a cattle car when first seen. The trainmen told him to get down, as they were making up a train. The car was still, and the assured got up and looked about for a place to get down. The railroad man pointed to a ladder and started down that himself. The assured took hold of the brake beam of the next car, and stepped across to that car, staggered, and fell. He struck the rail, was rendered unconscious, and soon died. The company was held llable, on the theory that he was insured as a cattle broker, and hence this clause of limitation could not apply. The court declared: "Modern courts very justly hold restrictions in accident policies inoperative which render the insurance nugatory and valueless by attempting to avoid liability for injurles sustained by the insured while performing necessary acts embraced in his classified occupation."

See, also, Berliner v. Travelers' Ins. Co., 121 Cal. 458, 53 Pac. 918, 41 L. R. A. 467,66 Am. St. Rep. 49 . Here the policy contained a double indemnity clause where the assured should be killed from an accident while "riding as a passenger in any passenger conveyance using steam," etc. The assured was killed as the result of a collision while riding in the $\mathrm{cab}$ of the engine upon the invitation of an official of the road. The court laid emphasis upon the fact that the assured was a passenger. Prior to the time of the accident he was riding in a passenger coach, when the superintendent of the road invited him to ride in the engine, and the court declared that by this change he did not lose the character of a passenger. The court said: "If the insured had met with an accident upon a passenger steamer, instead of a rallroad train, upon what part of the vessel must he have been at the time of the accident to be within the protection of his policy? Must he be seated in the cabin, or occupy a stateroom? The policy does not say so. It restricts him to no part of the vessel. * * * If Berliner had been riding on the train in any other capacity than that of a passenger-that is, as an employe of the railroad company, or an express or mall agent, or a tramp stealing a ride upon a brake beam-the defendant would not be llable under this clause. But he occupied no such relation to the railroad company or the train. Though upon the engine, he was a passenger. * * * That the defendant cannot import into this clause of the policy conditions as to the part of the conveyance in which the insured must be, and thus by construction work a forfeiture, need not be further discussed. All that is required is that the insured shall be 'riding as a passenger' in any passenger conveyance using steam, cable, or electricity as a motive power." The decision in this case is open to serious criticism.

75 Lilly v. Preferred Acc. Ins. Co., 83 N. Y. Supp. 585, 41 Mlsc. Rep. 8, affirmed in 87 N. Y. Supp. 1139, 92 App. Div. 614. Here the 
ceives injuries while riding on top of a car, or under the car on the machinery; nor in a baggage car, a mail car, or an express car attached to a train.

'Thus the insurance company may be liable upon its general indemnity clause, but not be liable for double indemnity, owing to the position of the assured at the time of the accident from which the death or injuries have arisen.

A train or steamboat chartered for a special occasion, such as an excursion, is none the less a public conveyance. ${ }^{7}$ And so, also, a taxicab driven by the chauffeur of the company and for rent to the general public. ${ }^{77}$

In an action for the double indemnity, the complaint should allege that the injury arose as a result of an accident to the assured while riding "as a passenger in a passenger conveyance using steam, cable, or electricity as a motive power." 78

policy contained a double indemnity clause in the sum of $\$ 12,000$ if the injury was received while riding as a passenger in a public conveyance propelled by steam, electricity, or cable, the increase conditioned on the injury not resulting from an attempt to enter or leave such conveyance. The assured was riding on a train with vestibule cars. After the train reached the eity of his destination, he was found, dying, a half mile back from the station, in the position of having fallen from the platform of one of the cars. The court held there was no evidence to show clearly how the accident and injury occurred. The court declared that he might have gone on the platform and fallen off, which would still entitle him to recover the double indemnity, but that it was improbable that he attempted to leave the moving train, since the cars were vestibuled.

76 Dunn v. New Amsterdam Casualty Co., 141 App. Div. 478, 126: N. Y. Supp. 229, reversing 67 Misc. Rep. 109, 121 N. Y. Supp. 686. Here the boat General Slocum was burned while carrying an excursion party for which it had been chartered.

77 Primrose v. Casualty Co., 232 Pa. 210, 81 Atl. 212, 37 L. R. A. (N. S.) 618. The court in an interesting decision here held that since the taxicab was operated by a chauffeur of the company, and was hired to any one who would pay the charges, it was a "public conreyance, provided for passenger service."

78 Lilly v. Preferred Acc. Ins. Co., 41 Misc. Rep. 8, 83 N. Y. Supp. อ̈85, supra. 
Time Within Which Death or Disability must Ensue After an Accident.-Policies of accident insurance usually limit the liability of the company to those injuries only which, "independently of all other causes, immediately. wholly, and continuously disable" the insured. In this clause the word "immediately" is here used to express proximity of time rather than causation, as regards the accident producing the injury on which the action is based. The purpose of this limitation is to prevent fraud by the allegation that after an accident has happened there may be no immediate bad effects, and yet some days or even weeks later disabilities become manifest. Under such a condition, fraud and deceit would be placed at a premium. The intent and purpose of the provision is to give the company an opportunity to investigate any claim for liability, to ascertain the facts and adjust a settlement before subsequent conditions may have supervened upon the injury which may cause doubt or dispute as to the liability of the company. The relation between the accident and the injury must naturally soon become obscure and difficult to trace by reason of intervening causes or events.

The word "immediately" does not mean "proximately" as the antonym of "remotely," or "directly" as opposed to "indirectly"; to so hold would be to declare that it meant the same as that other phrase of the clause quoted- "independently of all other causes."

The Supreme Court of Georgia, in the case of Williams v. Preferred Mut. Acc. Ass'n, ${ }^{79}$ has carefully and clearly

$7991 \mathrm{Ga} .698,17 \mathrm{~S}$. E. 9S2. In this case the assured was injured by being struck on the head by a restive horse which he was holding while it was being shod. The accident happened on the 24th of August. The assured was able to be at his store, giving more or less attention to his business, for thirty days, when he was forced to take to his bed. The court further said: "Where a man has received a blow on the head, which, at the time of its infliction, does not 
explained the meaning of the word in such a clause. The court said: "It would, perhaps, be going too far to say that, in a policy like the present this word means precisely the same thing as 'instantly' or 'momentarily'; but it necessarily implies that the injury must be such that the insured cannot proceed regularly and in due course with his occupation; that he cannot go on with his work or business as if he had received no injury, and then, upon becoming worse, cease the transaction of his business or labor, and hold the company responsible for the loss of his time. It seems to us there was excellent sense and reason in the employment of the words used in this policy to prevent liability on the part of the company under just such circumstances as are disclosed in this case, and we are quite sure this was deliberately intended by the draftsman. It often happens that considerable difficulty arises in determining whether or not a particular thing is the proximate or remote cause of an

appear to be serious, and for a month goes on regularly, though with some inconvenience, attending to his business, and then becomes unable for a long time to transact business at all, it is certainly not improbable, to say the least, that something else besides the original injury may have either caused, or largely contributed, to his condition." The assured here was not permitted to recover under the policy. Commercial Travelers v. Barnes, 72 Kan. 293, 80 Pac. 1020. Pepper v. Order of United Commercial Travelers of America, 113 Ky. 918, 69 S. W. 956, 24 Ky. Law Rep. 723, where the assured, a commercial traveler, was injured May 9, 1898, and was disabled and prevented from working for sixteen weeks, from June 20 to October 10, 1898. Here a demurrer on the part of the company was sustained. See Merrill v. Travelers' Ins. Co., 91 Wis. $329,64 \mathrm{~N}$. WV. 1039 . The assured, while walking on a marble floor, fell on August 18th, striking heavily on his hip and back; from that date until October 20 th he was able to be about and attend to a portion of his work for a part of the time. On that date he suffered a stroke of paralysis which completely paralyzed one side of the body. Here the assured was not permitted to recover. On the other hand, the case of Pacific Mut. Life Ins. Co. v. Branham, 34 Ind. App. 243,70 N. E. 174 , ignoring the trend of the decisions, held that "immediate" must be construed as applying to causation. This is clearly against the weight of authority in this country. 
injury and its consequences; and to avoid this difficulty, in the numerous and ever-varying cases which might arise, we think the company meant to have it understood that it would not be responsible for loss of time resulting from a physical injury, unless it was plain and manifest that the injury directly, alone and without delay, occasioned such loss of time; $* * *$ and that it would not be liable for loss of time which might result from other intervening causes taking effect after the injury was actually received."

The word "immediately" does not mean instantly, in the sense that a man shall be totally disabled from the very second of the accident which has caused the injury. A man might be unable to attend to his business from the very momert of the injury, or in another case he might not be disabled for a few minutes or a few hours after the injury. "Immediately" means presently or without any substantial interval of time elapsing. ${ }^{80}$ Thus, where the disability did not ensue until thirty days after the accident, the company was held not to be liable. ${ }^{81}$ And so where the assured performed his usual.

\section{Continental Casualty Co. v. Ogburn (Ala.) 57 South. 852.}

81 Laventhal v. Fidelity \& Casualty Co. of New York, 9 Cal. App. 275, 9S Iac. 1075. Here the assured was injured November $10 \mathrm{th}$, but went as usual to his office and attended to his duties until December 1st, when he became totally disabled and could not leave his bed for twenty-seren weeks. In an excellent opinion the court held that the assured was not immediately disabled. Williams v. Preferred Mut. Acc. Ass'n, 91 Ga. 698, 17 S. E. 982, supra. And so in Windle v. Empire State Surety Co., 151 Ill. App. 273, where after his injury the assured worked two and a half days, and did not have a physician for six weeks, the assured could not recover. Generai Accident \& Life Assur. Corp. v. Meredith, $141 \mathrm{Ky} .92,132$ S. W. 191. Here a doctor made a professional call on each of the two ensuing days after the accident in which be was injured, but was unable to go out again, and the court held that he was not immediateiy disabled. However, under a peculiar wording of this clause of the pollcy the assured, a locomotive fireman, was permitted to recover in Baumister v. Continental Casualty Co., 124 Mo. App. 38, 101 S. W. 152, where he continued to work at intervals after injuring his knee in an accldent. Letherer $\nabla$. United States Health \& Accident Ins. Co., 145 
duties for a period of five days thereafter. ${ }^{82}$ But where only a single day elapsed, or even three days elapsed, and the assured felt continuous pain, constantly becoming more and more severe, the company was liable on the ground that the disability was "immediate"; the assured being forced to take to his bed at the expiration of such time: ${ }^{33}$

Mich. 310, 108 N. W. 491. Here the assured was employed in a cider mill, running the engine and doing other work about the place. He was injured by a fall, but continued at his work there for a week. Then, leaving the cider mill, he went to work for a few days carpentering, and then digging potatoes. During all of this time he suffered pain, and at the end of about two weeks after the accident he was forced to give up all work. The policy agreed to indemnify the assured for loss of time resulting from bodily injuries which should, "immediately following the receipt thereof, wholly and continuously disable and prevent the assured from performing any and all duties pertaining to any business or occupation." The court said: "It would be in contradiction of his own testimony to say that during this time he was not only disabled from, but prevented from performing those duties. If he was able to perform all the work connected with his employment for a week, he was not immediately disabled." Continental Casualty Co. v. Wade, 101 Tex. 102, 105 S. W. 35, reversing (Tex. Civ. App.) 99 S. W. 877. Here the company was held not to be liable where the assured was disabled for fifteen minutes only, and then worked for two months, though he later died as the result of the injury.

82 Preferred Masonic Mut. Acc. Ass'n v. Jones, 60 Ill. App. 106. Here the assured, while passing through a doorway, accidentally struck his head against the door. However, he continued to transact his duties as a salesman for five days thereafter before he was wholly disabled. See Hagadorn v. Masonic Equitable Acc. Ass'n of the World, 69 N. Y. Supp. 831, 59 App. Div. 321. Here the assured, a physician, while in the discharge of the duties of his profession, was kicked in the face by one of his patients, a lunatic. Thereafter he visited many patients, but thirty-five days after the accident he suffered a stroke of paralysis, and was for a time wholly disabled. So in Vess v. United Bener. Soc., 120 Ga. 411, 47 S. E. 942, where the assured, a picture salesman, was struck on the hand by a frame, but was able to remain at work performing some of his duties for a period of twenty-four days before he was totally disabled. See, also, Merrill v. Travelers' Ins. Co., 91 Wis. 329,64 N. W. 1039, supra; and Pepper v. Order of United Commercial Travelers, $113 \mathrm{Ky} .918,69 \mathrm{~S}$. W. 956, supra.

83 Brendon $\nabla$. Traders' \& Travelers' Accident Co. of New York. 84 App. Div. 530, 82 N. Y. Supp. 860 . Here the assured, a physician, 
Accident insurance policies generally provide that, in order to render the company liable for death, the assured must die within ninety days from the happening of the accident on which the death is predicated. And under the general rule of law which governs the computation of time, the day on which the accident occurs must be included in determining the ninety-day period and whether the death of the assured occurred therein. ${ }^{84}$ And even where the insured died ninety days and nine hours after the accident the insurance company

twisted his knee by the lurching of a street car on which he was riding. He went home at once and treated the knee, which was painful and swelling badly. The next morning the pain continued, but he made a necessary visit to a patient in the immediate neighborhood, but returned to his home at once, and was then confined to his bed for three weeks. The disability was held to be "immediate," and the company liable on its policy therefor. See, also, Ritter v. Preferred Masonic Mut. Acc. Ass'n, 185 Pa. 90, 39 Atl. 1117. Here the assured, while picking cherries, pulled a wagon out from under the tree, fell backward, and struck his back, causing a serere pain. He then picked cherries for an hour or so, and for two days thereafter was able to pursue his duties as a real estate agent. On the third day he felt severe pains and was subsequently paralyzed in his lower limbs. The disability was held to be "immediate." The court in this case leclared that "immediate" meant "within a reasonable time." This decision is nore liberal than the weight of authority. See, also, Farner v. Massachusetts Mut. Acc. Ass'n, 219 Pa. 71, 67 Atl. 927, 123 Am. St. Rep. 621. Here the assured was bitten in the thumb by a dog. The hand was bandaged at once, and its use interfered with from the moment of the bite. The wound was accompanied by severe pain, which increased until the death of the assured two weeks later. The court held that he was "immediately disabled" within the meaning of the policy. In Continental Casualty Co. v. Mathis, $150 \mathrm{Ky} .477,150 \mathrm{~S}$. W. 507 , the policy provided for indemnity for total disability caused "at once and continuousiy" after the accident. The assured was wholly disabled for three days as the resuit of an accident, and then was permitted by his physician to go to work. After three days he became ill from blood poisoning, and remained so for months. The assured was permitted to recover.

84 Palmer v. Commercial Travelers' Mut. Acc. Ass'n of America, 53 Hun, 601, 6 N. Y. Supp. 870 . This provision is legal, and is not in conflict with the general clause of the policy insuring against accidents for a period of one year from date. 
was held not to be liable. ${ }^{85}$ The date of the expiration of the policy has no bearing upon the condition that the death must ensue within ninety days from the accident, provided the accident occur before the expiration of the policy. ${ }^{80}$ And thus there can be no recovery if death resulted more than ninety days after the injury happened, even though the ninety days elapsed before the expiration of the policy. Nor can the clause be construed to refer only to such injuries as should occasion death within ninety days after the twelve months. Where the assured dies within ninety days, but the policy expires before the death, the company will be liable, if the accident happened before the expiration of the policy. ${ }^{87}$

85 Perry v. Provident Life Ins. \& Inv. Co., 99 Mass. 162, and Id., 103 Mass. 242. Here the assured was the station agent on a railroad. At 9 a. m. December 11, 1866, the assured met with an accident within the meaning of the policy, and in consequence of which he died at about 9 a. m. March 12, 1867. It was held that the company was not liable, since death did not ensue within nik..y days from the date of the accident.

86 Brown v. United States Casualty Co. (C. C.) 95 Fed. 935. Here the policy extended to July 30, 1896. October 7, 1895, the assured while driving was thrown from his cart into a ravine, and as a result of the injuries sustained he died January 21, 1896. In an action to recover the face of the policy, the claim was made that although death did not ensue within ninety days after the accident, yet inasmuch as death did follow before July 30, 1896, the company was liable. The court declared that the ninety-day clause was not inconsistent with the provision by which the insurance was stated to be for twelve months. See, also, Perry v. Provident Life Ins. \& Inv. Co., supra.

American Acc. Ins. Co. v. Norment, 91 Tenn. 1, 18 S. W. 395. Where the beneficiary, in making original claim for loss of time under the policy, stated that the accident occurred March 23, 1890, she will not be estopped from showing that as a matter of fact the accident occurred on the 30th of March.

87 See Burkheiser v. Mutual Acc. Ass'n of the Northwest, 61 Fed. 816,10 C. C. A. 94,26 L. R. A. 112 . Here the policy insured its holder "against personal bodily injuries effected during the continuance of membership in this insurance association through external, violent, and accidental means," and against death resulting from such injuries within ninety days after the accident. Here the accident occurred during the membership of the assured in the association. Be- 
If death does not ensue within the ninety-day period, but does result from the accidental injury, the assured or his beneficiary can recover from the insurance company the weekly indemnity for the period between the date of the accident and the death, provided during that time the assured has been totally disabled within the terms of the policy, and provided that said period of disability has not endured longer than the period contracted for in the policy. Under such conditions he can recover as clearly as though the insured had recovcred. ${ }^{88}$ And unless the policy declares that the liability of the

fore his death the assured ceased to be a member, because of default in paying an assessment falling due after the accident. Within ninety days from the date of accidental injury the assured died. The court said: "The liability of the association became absolute upon the occurrence of the accident, the amount of indemnity and the person to whom it should be payable being contingent upon the character and result of the injury sustained; as to the plaintiff, contingent only upon the death of the assured within the stated time." After the membership ceased, the company was still liable for injuries sustained before the expiration of membership, where the results endure, as in this case, after the membership has terminated.

88 Rorick v. Railway Officials' \& Employés' Acc. Ass'n, 119 Fed. 63,55 C. C. A. 369 . The policy provided that the insurance thereunder should "extend only to physical bodily injury resulting in disability or death, * * * effected * * * by reason of and through external, violent, and accidental means, *** which shall, independently of all other causes, immediately, wholly, totally, and continuously * * * disable the insured." It further provided that there should be no liability for more than one of the losses specified, on payment for any one of which the policy should terminate, and the first loss specified was "loss of life occurring within ninety days from the date of the accident causing the fatal injury." It was held that such provision could not be construed to exempt the insurer from liability for death resulting from an accidental injury within ninety days, because such accident did not produce "immediate, total, and continuous disability."

Perry v. Provident Life Ins. \& Inv. Co., 103 Mass. 242, supra. Here the court said: "The two provisions are to be construed together, and the evident intent is that, if an injury happens within the meaning of the policy, it is insured against as coming within one class or the other. If it were otherwise construed, an injury which should not prove fatal within ninety days would furnish no 
company under one clause shall bar its liability under any other clause, the beneficiary can recover both the weekly indemnity for the period of total disability and the face of the policy for the death of the assured, if said death occurs within ninety days as provided in the policy. Otherwise, if the assured lived for more than ninety days, and then died, the company would escape all liability of every sort upon its policy. But in any event the beneficiary under an accident insurance policy cannot hold the company liable, where the policy provides for indemnity, for disability, for a period not to exceed twenty-six weeks, and the assured dies instantaneously as the result of an accident, but the policy contains no express provision for any liability in case of death. The fact that assured has been accidentally killed does not mean that he has been "totally disabled" in the sense contemplated by a policy agreeing to pay a certain sum to the. assured for

ground of action till it should be made to appear that it would never prove fatal. This would render the insurance nugatory in such cases."

Marshall v. Commercial Travelers' Mut. Acc. Ass'n, 170 N. Y. 434, 63 N. E. 446 , reversing 68 N. Y. Supp. 1143, 57 App. Div. 636 . Here the policy contained the provision that "any member of this association, who, during his membership, sustains by accident the loss of an arm or leg, or is injured by an accident, which injury shall result in the loss of an arm or leg, shall be entitled to, and shall receive as an indemnity for such loss, a sum equal to one-half the amount collected from an assessment as for one death, which sum shall not exceed $\$ 2,500$; any member of this association, who, during his membership, sustains by accident the loss of both arms or legs, or one arm and one leg, shall be entitled to, and shall receive as an indemnity for loss, a sum equal to the amount collected from an assessment as for one death, which sum shall not exceed $\$ 5,000$, provided such loss shall occur within three calendar months after the accident which causes it." The court, basing its decision entirely upon the punctuation of the provisions above quoted, declared that the limitation of three months did not apply to the loss of a single arm or leg contemplated by the first clause rendering the company liable for $\$ 2,500$, and the fact that the loss of the leg occurred more than three months after the accident did not bar the right of recovery. 
his inability to work for a specified period of time, such as twenty-six or fifty-two weeks. ${ }^{89}$ The purpose of such a policy is to indemnify the assured against loss of time and earning capacity by paying him during his lifetime the amounts provided for a specified time, and not to insure his life against death by accident for the benefit of any one else or of his estate.

Pleading and Practice.-In actions on policies of accident insurance, as well as in other cases, the pleadings must contain allegations of fact, and not conclusions of law. For example, an allegation that the insured is or will continue to be totally disabled as long as he may live is an allegation of fact. ${ }^{90}$ Where the beneficiary, in his claim for indemnity, alleges

89 Rosenberry v. Fidelity \& Casualty Co., 14 Ind. App. 625, 43 N. E. 317. Here the court said: "If we should concede that when the decedent was killed he was totally 'disabled' and was consequently prevented from following his usual occupation, the consequences claimed by counsel do not by any means necessarily follow. * * * As well might it be argued that when a beneficiary society stipulates to pay one of its members a specified sum per week as indemnlty so long as he is wholly disabled from pursuing his usual vocation, the obligation to pay continues after death. $* * *$ We think *** the conclusion is inevitable that the indemnity provided for is limited to such as accrued during the lifetime of the insured and that with his death all liability for future indemnity ceased." Hill v. Travelers' Ins. Co., 146 Iowa, 133, 124 N. W. 898, 2S L. R. A. (N. S.) 742 , where the assured died instantly, but the policy provided indemnity only for total disability. Atna Life Ins. Co. v. Bethel, 140 Ky. 609, 131 S. W. 523; Dawson v. Accident Ins. Co. of North America, 38 Mo. App. 355. Shaw v. Equitable Mut. Acc. Ass'n, 5 Neb. (Unof.) $584,99 \mathrm{~N}$. W. 672 , where the administrator of the estate of the assured brought suit to recover $\$ 10$ per week for fifty-two weeks under the clause limiting the liability of the company to that figure for fifty-two weeks for the total disability of the assured. The court held that death did not mean "total disability." Here the assured died instantly and the policy contalned no death provision. Burnett v. Railway Officials' \& Employés' Acc. Ass'n, 107 Tenn. 185, 64 S. W. 18.

90 Clark v. Brotherhood of Locomotive Firemen, 99 Mo. App. 687, 74 S. W. 412. The court held that such an allegation was not the pleading of a legal conclusion, but of a fact, though it was possibly vague and subject to correction on special demurrer or motion. 
one cause for his disability, he is not thereby precluded, in an action brought to recover on the policy, from alleging and proving other causes which were omitted from the original claim, either through ignorance or mistake. In such cases the injury or disability is the essential thing, and assigning in good faith a wrong cause will not necessarily preclude a recovery. ${ }^{91}$

When an accident policy provides that, if the assured is injured or killed in any occupation or exposure classed by the company as more hazardous than that recited in the application, the insured or his beneficiary is only to receive a reduced sum, in an action by the beneficiary on the policy for the full amount thereof, the pleading must allege that the assured was not killed while engaged in any occupation more hazardous than that stated in the application. ${ }^{92}$ Where a policy of accident insurance provides for indemnity against death resulting from bodily injuries by reason of external, violent, and accidental means, and contains an exception limiting the insurer's liability in the event of death from self-inflicted injuries, and the complaint alleges that the assured died from external, violent, and accidental means and that the injuries were not self-inflicted, and the answer sets up a general denial, and then alleges as a separate defense that the injuries were self-inflicted or inten-

91 Jarvis v. Northwestern Mut. Relief Ass'n, 102 Wis. 546, 78 N. W. 1089, 72 Am. St. Rep. 895. Here the complaint alleged paralysis as the cause of the permanent disability, and the court permitted an amendment alleging disease of the heart and nerrous system as additional causes. The court declared: "The statement of one adequate fact in the proofs did not exclude others, omitted through mistake or ignorance. The same rule applies as in case of a life or fire policy. *** The material thing was total incapacity to perform manual labor because of an incurable disability. A mistake in the real cause of the disability was by no means fatal to the claim."

92 American Acc. Co. of Louisville v. Carson, $99 \mathrm{Ky} .441,36 \mathrm{~S}$. W. 169, 34 L. R. A. 301, 59 Am. St. Rep. 473. 
tional, the burden is on the plaintiff in the first instance to make out a prima facie case by a preponderance of evidence that the insured died from external, violent, and accidental means, in order to recover the full amount of the policy. ${ }^{23}$ 'Where the policy contains a provision for a limited liability if the death of the assured results from unnecessary exposure to danger, or by his own hand, or by certain other specified means, the burden is on the insurance company to show that the assured met his death is such a way as to bring into operation the minimum indemnity clause. ${ }^{24}$ After the plaintiff has made a prima facie case showing that the injury or death comes within the terms of the policy, the defendant must show by a preponderance of the evidence that the injury or death comes within some clause or condition of the policy relieving the company from liability, or establishing a minimum liability.

Where the policy of insurance provides that the insurer will not be liable, or will be liable only for a reduced indemnity, in the event that the accident and the facts and incidents pertaining thereto are not established by the testimony of an eyewitness, the assured himself may be such

98 Whitlach v. Fidelity \& Casualty Co., 149 N. Y. 45,43 N. E. 405 , reversing 78 Hun, 262, $28 \mathrm{~N}$. Y. Supp. 951. Here the assured, a mining promoter, who was shown to have been for some time suffering from depression over his affairs, was found dead in bed in a cheap lodging house in San Francisco. He was undressed, and had a bullet wound in his head, and by his side la" a five-chamber revolver, with one chamber discharged and the others still loaded. The court said: "The burden of proof upon the whole case rests upon the plaintiff, and she must prove by a preponderance of evidence that her intestate's death was caused by external, violent, and accidental means." See, also, Preferred Acc. Ins. Co. v. Fielding, 35 Colo. 19, 83 Pac. 1013, 9 Ann. Cas. 916; Cílley v. Preferred Acc. Ins. Co., 109 App. Div. 394, 96 N. Y. Supp. 282.

24 Jamison v. Continental Casualty Co., 104 Mo. App. 306, 78 S. W. 812; North American Acc. Ins. Co. v. Gulick, 25 Ohio Cir. Ct. R. 395 . 
an eyewitness. In order to provide that the assured himself shall not alone be able to establish the injury, the company must add some such words as "other than the insured." 85

The assured is naturally a competent witness to testify in an action regarding his ability to labor, in order to prove the extent of his disability. ${ }^{96}$ And so evidence as to the suffering of the assured, and as to how much he slept during the existence of the injury, is admissible in an action upon a policy of insurance indemnifying him against the loss of the money value of his time, in so far as the discomfort may have interfered with his capacity to work, but it is not admissible as an independent element of damages. ${ }^{97}$ In an action to recover damages for a period of disability, the plaintiff need not show the value of his time, unless it is pleaded; but he cannot recover a sum exceeding that alleged in his pleadings or named in the written proof required by the insurance contract. ${ }^{98}$ And where the action is based on the allegation that the assured is totally disabled from transacting any business, the issue is not whether he received any pay or recompense for any business that he

95 National Acc. Soc. v. Ralstin, 101 Ill. App. 192. Here the assured was the only person immediately present at the time he was accidentally shot by his gun while he was attempting to shoot a cat which had been killing his chickens. He was a competent witness and satisfied the condition of the policy.

96 Lyon v. Railway Passengers' Assur. Co., 46 Iowa, 631. The court declared that the question, "What was your ability to perform labor or business of any kind for nine or ten weeks after the injury?" did not call for a conclusion and was proper.

87 Globe Acc. Ins. Co. v. Helwig, 13 Ind. App. 539, 41 N. E. 976, 55 Am. St. Rep. 247.

88 Travelers' Ins. Co. v. Thornton, 119 Ga. 455,46 S. E. 678. Where the assured claimed damages for disability for eight weeks in his proofs of loss, he was not permitted to recover for a longer period of time. 
may have transacted during the period of alleged disability, but whether he was actually transacting such business. ${ }^{90}$

The question of whether the assured is totally disabled and permanently incapacitated from performing any manual labor is for the jury to determine. ${ }^{100}$. And also whether the injury or death on which the action is based comes within any of the conditions of the policy exempting the insurance company from liability, or limiting the liability to a smaller amount, is a question for the jury. ${ }^{101}$

Rules of Evidence.-In an action upon a policy of insurance against death or bodily injuries caused by accidental means, the burden of proof is upon the claimant to show that the death or disability resulted from injuries accidentally inflicted, independently of all other causes. ${ }^{102}$ The law

99 Preferred Acc. Ins. Co. v. Gray, 123 Ala. 482, 26 South. 517. The assured, a doctor, testified that he was accidentally injured on a street car and was unable to continue his practice for three months. It was shown that he was on the streets during the three months, and that he wrote some prescriptions while confined to his room, though he did not charge for them. The court sald: "The inquiry was, not what he received or charged for the professional work he did, but whether he did it, as showing that he was not disabled to do it."

100 Grand Lodge, Brotherhood of Locomotive Firemen, v. Orrell, 109 Ill. App. 422, affirmed by 206 Ill. 208, 69 N. E. 68.

101 Fox v. Masons' Fraternal Acc. Ass'n, 96 Wis. 390, 71 N. W. 363. Here the assured, classified as a "mill owner, overseeing only," was injured while swinging an ax to cut off the tops of some trees in the way of a small portable sawmill which he owned and was superintending, while it was temporarily located in the woods for cutting logs into lumber for use in assured's planing mill. It was a question for the jury to determine whether at the time of his accident he was engaged in the more hazardous occupation of a "lumberman in the woods," so as to make the insurance company liable only for a smaller indemnity.

102 Etua Life Ins. Co. v. Vandecar, 86 Fed. 282,30 C. C. A. 48 ; National Masonic Acc. Ass'n v. Shryock, 73 Fed. 774, 20 C. C. A. 3; Preferred Acc. Ins. Co. v. Flelding, 35 Colo. 19, 83 Pac. 1013, 9 Ann. Cas. 916 ; Wilkinson v. Etna Life Ins. Co., 240 Ill. 205, 88 N. E. 550, 25 L. R. A. (N. S.) 1256, 130 Am. St. Rep. 269, affirming 144 
presumes that all men are endowed with the instinct of selfpreservation and a respect for the dictates of law and order, and therefore, when death from unexplained causes is established, the law will not presume either suicide or murder. In the event that death may have been the result of murder, suicide, or accident, the presumption raised by law is that it was caused by accident, though there may be no direct or positive testimony in support thereof. Each case must be decided according to its own facts and circumstances. ${ }^{103}$ The law, however, raises no presumption as to whether death resulted from disease or accidental causes. ${ }^{104}$

In the event of corroborative evidence, the declarations of the assured as to the incidents of the accident, made contemporaneously, or nearly so, with the event, will be admitted in evidence as forming part of the res gestæ. Though generally the declarations, to be admissible, must be contem-

Ill. App. 38; Carnes v. Iowa State Traveling Men's Ass'n, 106 Iowa, 281, 76 N. W. 683, 68 Am. St. Rep. 306; Taylor v. Pacific Mut. Life Ins. Co., 110 Iowa, 621, 82 N. W. 326; Couadeau v. American Acc. Co., 95 Ky. 280, 25 S. W. 6, 15 Ky. Law Rep. 667; Kling v. Masons' Fraternal Acc. Ass'n, 104 La. 763, 29 South. 332; Thompson v. Loyal Protective Ass'n, 167 Mich. 31, 132 N. W. 554; Landon v. Preferred Acc. Ins. Co., 60 N. Y. Supp. 188, 43 App. Div. 487.

103 Jenkin v. Pacific Mut. Life Ins. Co., 131 Cal. 121, 63 Pac. 180 ; Preferred Acc. Ins. Co. v. Fielding, 35 Colo. 19, 83 Pac. 1013, 9 Ann. Cas. 916; Wilkinson v. Atna Life Ins. Co., 240 Ill. 205, 88 N. E. 550, 25 L. R. A. (N. S.) 1256, 130 Am. St. Rep. 269, affirming 144 Ill. App. 38; Star Acc. Co. v. Sibley, 57 Ill. App. 315; Caldwell v. Iowa State Traveling Men's Ass'n (Iowa) 136 N. W. 678; Carnes v. Iowa State Traveling Men's Ass'n, 106 Iowa, 281, 76 N. W. 683, 68 Am. St. Rep. 306; Meadows v. Pacific Mut. Life Ins. Co., 129 Mo. 76, 31 S. W. 578, 50 Am. St. Rep. 427; Landon v. Preferred Acc. Ins. Co., 60 N. Y. Supp. 188, 43 App. Div. 487, affirmed without opinion in 167 N. Y. 577, 60 N. E. 1114; Stevens v. Continental Casualty Co., 12 N. D. 463,97 N. W. 862 ; Cronkhite v. Travelers' Ins. Co., 75 Wis. 116, 43 N. W. 731, 17 Am. St. Rep. 184.

104 Keefer v. Paclfic Mut. Life Ins. Co., 201 Pa. 448, 51 Atl. 347, 88 Am. St. Rep. 829 ; Taylor v. General Acc. Assur. Corp., 208 Pa. 439, 57 Atl. 830 .

Fuller Acc.Ins.-6 
poraneous with the accident, yet where there are connecting circumstances they may form a part of the whole res gestæ and be admitted, even though made some time afterward. ${ }^{105}$

105 Travelers' Ins. Co. v. Mosley, 8 Wall. (75 U. S.) 397, 19 L. Ed. 437, where the assured rose from his bed in the middle of the night and went downstairs. Upon returning, he complained to his wife and sou of having had a fall, and described his symptoms to them. North American Acc. Ass'n v. Woodson, G4 Fed. 689, 12 C. C. A. 392, where the assured fell from a ladder while repairing a gutter pipe, and stated to the witness who went to his aid that he had fallen from the ladder and struck on his neck and shoulders. Union Casualty \& Surety Co. v. Mondy, 18 Colo. App. 395, 71 Pac. 677. Patterson v. Ocean Accident \& Guarantee Corp., 25 App. D. C. 46, where the statements of an osteopath to his wife and brother-in-law within half an hour that he had accidentally strained his back and was suffering great pain were admitted. Vernon v. Iowa State Traveling Men's Ass'n (Iowa) 138 N. W. 696. Here the beneficiary claimed that the death of the assured resulted from blood poisoning due to an abrasion of the skin on one of his limbs caused by the use of a brush or other implement in the hands of a bath attendant at a health resort. The beneficiary, his wife, was permitted to testify that upon returning to their room from the bath the assured exhibited one of his limbs, disclosing the abrasion, with the remark, "I want to show you how rough that damn fool was with me in the bathroom." Fidelity \& Casualty Co. of New York 'v. Cooper, 137 Ky. 544, 126 S. W. 111; Ten Broeck v. Travelers' Ins. Co., 6 N. Y. St. Rep. 100 . Starr v. Etna Life Ins. Co., 41 Wash. 199, 83 Pac. 113, 4 L. R. A. (N. S.) 636, where statements made by the assured, explaining how the accident happened and showing that it was accidental, were admitted as part of the res gestæ, when made to the physician about an hour after the accldent, and when he was so mangled that an anputation of both arms was necessary and death resulted within thirty-six hours. Hall v. American Masonic Acc. Ass'n, 86 Wis. 518, 57 N. W. 366. An extreme case is that of Van Eman v. Fidelity \& Casualty Co., $201 \mathrm{~Pa}$. 537, 51 Atl. 177, where the assured was injured while asleep on a railroad train, and his wife was permitted to testify as to what he had said several hours later when he had reached home. The court sald: "It may be that the statement of the deceased, made to his wife several hours after he had left the train, ought not to have been recelred as part of the res gestre, and we do not understand that it was offered as such. When the husband reached his home with his aching arm, the one person for whom he first looked and to whom he would first tell the simple truth was his wife. He might have said nothing to any passenger on the train, nor to any friend or passer-by on his way home; but there he would 
Considerable latitude is shown by the courts in admitting the evidence of physicians as to what the assured said with reference to his condition, upon the strength of which he was treated. This refers, however, to the nature of his injury, the symptoms thereof, and the pain he is suffering, but does not extend to the statements of the assured as to the cause of the injury, or any narrative of events attending the mishap which would clearly be incompetent. ${ }^{100}$

tell what happened, and, first of all, to the one to whom he would naturally turn for attention and comfort. Human experience teaches us that he would speak the truth to her, and that he would tell her just what had happened to him, as he would have told it if he had spoken to those about him when he awoke in the car with his helpless arm at his side. At no time could he have told just how he had been injured, for he was asleep when his arm was knocked from under his head; but he gave a reasonable theory of how he had been hurt, as to the cause of the injury. Any statement he might have made at the instant he was hurt would have been evidence as part of the res gestre. The law presumes that having so spoken, on the instant, without premeditation, and as soon as he found he had been injured, he would speak the trnth; but whether this presumption should extend to what the deceased told his wife, and she ought to be allowed to repeat it, as part of the res gestie, we need not decide, for, even if she ought not to have been allowed to tell it, this judgment will not be reversed because she did. The defendant company, itself, by its own witness proved just what she had testified to under objection." In Hooper v. Standard Life \& Accident Ins. Co. (Mo. App.) 148 S. W. 116, the assured fell while on a street car, and was, for a brief time, apparently unconscious. He was carried to his home near by by passengers; but the court, though admitting the question to be close, declined to admit as res gestre the statement of the assured then made to his wife, though within thirty minutes after the accident.

100 Patterson v. Ocean Accident \& Guarantee Corp., 25 App. D. C. 46, supra. Here the statements of the assured, made to his physician on the day following the accident, tending to show his bodily pain, the location of the same, and the symptons of his malady, were admitted, while statements made by him to his physician, tending to show that he received a strain to which he attributed his condition, were ruled out. See, also, Omberg v. United States Mut. Acc. Ass'n, $101 \mathrm{Ky} .303,40 \mathrm{~S}$. W. 909, $72 \mathrm{Am}$. St. Rep. 413 . Here the claimant contended that the assured met his death as the result of having been stung by a venomous insect. The court said: "We are of the 
But declarations of the assured, made some time after the mishap and at a place and under circumstances disconnected with the accident, do not constitute a part of the res gestæ, and will not be admitted. ${ }^{107}$

oplnion that the declaration of the patient to his attending physician, to the effect that the injury was the result of a bite, was competent. A narrative of the events attending the mishap would not be competent, but the patient may tell what the injury is if he knows; he is suffering and is seeking relief; to get it he must tell the truth; any other course would mislead his physician and might result disastrously; he knows whether he has bruised the inflamed parts, or whether he has been bitten by an insect. Such statements are part of the description of the wound and inseparable from the patient's complaint with respect thereto." See, also, Starr v. Ftna Life Ins. Co., 41 Wash. 199, 83 Pac. 113, 4 L. R. A. (N. S.) 636, supra.

107 National Masonic Acc. Ass'n v. Shryock, 73 Fed. 774, 20 C. C. A. 3. The claimant here alleged that the death of the assured was caused by an accidental fall on the street, and offered as evidence the statements of witnesses that the deceased told them, two hours or more after the occurrence, that he had slipped and injured himself. The testimony showed that after the alleged fall the assured went about his business, and went to a hotel and to a harness . shop, and three hours after the accident, under circumstances and conditions wholly irrelevant thereto, made the declarations sought to be introduced. The court said: "They were mere narrations of a past occurrence. The result is that declarations made by a deceased person two hours after an injury from a fall in the street, and not at the scene of the accident, but while engaged in his ordinary business avocations in other places, that he had fallen, and sustained an injury from which he was suffering, are inadmissible as part of the res gestre to establish the fact of the fall, because they are mere narratives of a past transaction, which had ended before they were made." In Keefer v. Pacific Mut. Life Ins. Co., 201 Pa. 448, 51 Atl. 366, 88 Am. St. Rep. 822, it was claimed that the assured died as the result of injuries caused by a fall of which there were no direct witnesses. The plaintiff sought to introduce as evidence the statement of one to whom the assured declared half an hour thereafter that he had had a fall. The court said: "If the offer had been to prove an exclamation or a cry, uttered during the act of falling, or an explanation made immediately upon rising and before sufficient time had elapsed to permit the possibility of deliberation or design, then the offer would have been within the rule. But, as it was, every settled test excludes it. If the deceased fell while walking by himself, he got up and returned over a distance of several hundred feet, and a period of time varying from 
Many policies of accident insurance contain a provision requiring that "direct and affirmative evidence" of the injury occasioning the death must be produced as a condition precedent to the liability of the insurer. The courts uniformly hold that one cannot by a contractual agreement change the rules of evidence, and therefore that such a condition is ineffectual to prevent a recovery under the policy, where the claimant presents evidence of a circumstantial nature which establishes the injury, even though it may not be, strictly speaking, "direct and affirmative." 108

Where the evidence is so conflicting that reasonable men will differ as to whether the death or injury of the assured resulted from accident within the terms of the policy, or from

fifteen minutes to half an hour elapsed before he came walking deliberately back to the witness. This, under the circumstances, was a marked break in the continuity of events; was quite sufficient to turn any explanation then made into a narration of a past occurrence; was ample to permit of deliberation or design, and thus remove the impress of spontaneity. The deceased had gone away from the place; the act was done; the transaction was closed ; therefore a conversation at a time some fifteen minutes later, and at a place several hundred feet away, could not under the circumstances of this case be admitted as evidence. It would be no part of the occurrence and would be only his own account of the affair." See, also, Globe Acc. Ins. Co. . Gerisch, 163 Ill. 625, 45 N. E. 563, 54 Am. St. Rep. 486, where it was held error to admit statements by the assured to his physician and other persons in regard to the cause of his injury, some of which were made several hours and others several days after the alleged accident.

108 Konrad v. Union Casualty \& Surety Co., 49 La. Ann. 636, 21 South. 721. Here the assured was last seen rowing about a lake in a skiff on a foggy morning. Later in the day the skiff was found drifting empty, but the body of the assured was not discovered in the water until 15 days later. The claimant was permitted to recover on the circumstantial evidence of the accidental drowning of the assured. Reynolds v. Equitable Acc. Ass'n, 1 N. Y. Supp. 738, 49 Hun, 605, where the assured was subjected to a great strain, as a result of which he died. See, also, Standard Loan \& Accident Ins. Co. v. Thornton, 97 Tenn. 1, 40 S. W. 136, where, owing to decomposition, the body of the assured could be identified only from certain marks and by the clothing he had worn at the time of his disappearance. 
other causes, the question is one of fact, to be decided by the jury under proper instructions. ${ }^{108}$.

Contracts of insurance, like other contracts, will be given a reasonable interpretation, so as to give effect to the apparent intention of the parties. Where their terms are not clear, and are capable of more than one interpretation, they will be construed more strictly against the insurer as author of the contract and in favor of the assured. ${ }^{110}$ But they will not be given an interpretation at variance with the clear meaning of the language in which they are clothed. ${ }^{111}$

109 Stout v. Pacific Mut. Life Ins. Co., 130 Cal. 471, 62 Pac. 732, whether death resulted from disease of the heart or a blow on the head from the capsizing of a rowboat; Metropolitan Acc. Ass'n v. Tavlor, 71 Ill. App. 132, whether the assured died from brain or heart trouble or by being run over by a train; Klumb v. Iowa State Traveling Men's Ass'n, 141 Iowa, 519, 120 N. W. 81, where evidence that the death of the assured was due to a stray bullet was held insufficient to take the issue to the jury; Smith v. Aitna Life Ins. Co., 115 Iowa, 217, 88 N. W. 368, 56 L. R. A. 271, 91 Am. St. Rep. 153, whether assured fell or deliberately stepped from a moving. train ; Etna Life Ins. Co. v. Milward, 118 Ky. 716, 82 S. W. 364, 26 Ky. Law Rep. 589, 68 L. R. A. 285, 4 Ann. Cas. 1092, whether assured committed suicide or was killed by an accident; Konrad v. Union Casualty \& Surety Co., 49 La. Ann. 636, 21 South. 721, whether assured met his death by accidental drowning, or committed suicide, or died as the result of natural causes; Loesch v. Union Casualty \& Surety Co., 176 Mo. 654, 75 S. W. 621, whether death resulted from natural causes or the attack of a bull; Johnson v. Continental Casualty Co., 122 Mo. App. 369, 99 S. W. 473, whether assured died as the result of disease or from accidentally striking a plece of furniture in the dark; Landon v. Preferred Acc. Ins. Co., $60 \mathrm{~N}$. Y. Supp. 188, 43 App. Div. 487, whether finding the body of the assured in the water sereral days after his disappearance, and with no other evidence except its condition as to how he came to his death, shows that death was the result of accidental means; Taylor v. General Acc. Assur. Corp., 208 Pa. 439, 57 Atl. 830, whether an accidental fall or disease caused the death of the assured.

110 This is an elemental rule, and it is sufficient to cite Fidelity \& Casualty Co. of New York v. Hart, 142 Ky. 25, 133 S. W. 996; Porter v. Casualty Co. of America, 126 N. Y. Supp. 669, 70 Misc. Rep. 246.

111 Mady v. Switchmen's Union of North America, 116 Minn. 147, 133 N. W. 472. 


\section{CHAPTER III}

\section{EXCEPTED RISKS}

Conditions Exempting. Insurer from Certain Risks.

Excepted Risks in Accident Policies.

Suicide.

External and Visible Signs of Injury.

Violation of Law.

Intoxicants.

Taking Poison.

Inhaling Gas.

Injuries Sustained on a Railroad Bed or Bridge.

Accident Distinguished from Bodily Infirmity or Disease.

Exemption of Liability for Injuries Received While Entering or

Leaving, or Standing on the Platform of, Moving Cars.

What Constitutes Voluntary Exposure to Unnecessary Danger.

What Constitutes Due Diligence for One's Safety.

Blood Poison or Septicæmia.

Iutentional Injuries.

Beyond the Seas.

Right to Examine the Body of the Assured.

Conditions Exempting Insurer from Certain Risks.-Accident insurance policies usually contain one or more conditions relieving the insurance companies from liability for death or injuries occasioned by, or resulting from, certain designated causes, or from death or disability happening under certain contingencies. These conditions differ widely in number, character, and phraseology. In this chapter these various exceptions will be discussed separately and their meaning construed as it has been settled by the courts. There are certain general principles which govern these excepted risks, an analysis of which will make clearer the following sections. 
Among the risks most usually excepted in the standard policies of accident insurance are: Intentional injuries; injuries due to a violation of the law or the rules of corporations and employers; injuries due to violating a law; injuries resulting from diseases or bodily infirmities as distinguished from those originating in accidents; injuries due to intoxication, poison, or inhaling gas; injuries which leave no external or visible sign; injuries resulting from entering or leaving moving conveyances, or from walking on the roadbed or bridge of any railroad; and injuries occasioned by the voluntary exposure of the assured to unnecessary danger. While these embrace the usual exceptions, yet different forms of policies, particularly those issued by mutual benefit accident societies, contain other special exceptions.

The natural intent and result of these exceptions is to exclude them from those injuries occasioned "by violent and accidental means," for which the company will be liable. They specify sundry modes of violent injury and death which are excluded from the scope of the policy. However, these specific exclusions do not enlarge the scope of the principal terms of the policy. All injuries for which liability may be enforced must still fall within the principal terms of the policy and be the result of means that are accidental and violent. ${ }^{2}$

The effect of these exceptions is not varied by other clauses in the policy; as, for example, a condition providing

1 Southard v. Railway Passengers' Assur. Co., 34 Conn. 574, 22 Fed. Cas. 810. In this case the assured jumped in great haste from a train standing at a depot and ran a considerable distance to keep an engagement. A rupture developed therefrom. The action of the assured was voluntary and was not necessary to his safety. Though it was not within any of the exceptions limiting the liability of the company, the assured was not permitted to recover, because the injury was not effected by "accidental means." 
that if the assured is injured while engaged in any "occupation or exposure classified as more hazardous" than that for which he is insured, or for which a larger premium is demanded, the amount payable under the policy shall be limited to the sum which the premiums paid would actually have purchased at the rates charged for the increased risk or hazard, will not negative another condition declaring that the company will not be liable for death or injuries sustained on a railroad bed. ${ }^{2}$ The insurance is suspended during the exposure contemplated by such a clause. The words "occupation or exposure" in such a clause contemplate an occupation or exposure not inconsistent with the special exception. Under the general rule of contracts, applicable with even greater force in insurance contracts, the exceptions will be construed more strictly against the insurer than the assured. ${ }^{3}$

2 Yancy v. AEtna Life Ins. Co., 108 Ga. 349, 33 S. E. 979. Here the policy holder was insured as a traveling salesman for a coal company. A special condition of the policy provided that the insurance company would not be llable for injuries or death occurring while the assured was "walking or being on any railroad bridge or roadbed (railway employés excepted)." The assured, while walking along a railroad bed, was killed by a passing train. He had followed the roadbed as a short cut to the office of a coal company with which he had business. The court held that the fact that the duties of his occupation might at times make it necessary for him to go upon the roadbed of a railroad did not release him from this exception, and the insurer was not liable. The purpose of the clause is to suspend the insurance during the time that the assured is walking or standing on the roadbed or bridge.

3 Chatterton v. Central Acc. Ins. Co., 68 N. J. Law, 79, 52 Atl. 212. In this case a policy of accident insurance was issued to a married woman, agreeing to pay her a certain sum per week for certain specific injuries set forth in the policy, such as the loss of a leg, an arm, an eye, etc. The policy also guaranteed the payment to the husband of a fixed sum in case of the death of the assured as the result of an accident. The policy also contained the following clause: "Accidents resulting in bodily injuries not specifically named therein are not covered under the woman's policy." The assured died as a result of burns accidentally received. It was 
Amendments to the constitution and by-laws of mutual accident insurance companies, enlarging the number and scope of excepted risks, will not affect contracts already existing. ${ }^{4}$ The subsequent adoption of a by-law by a fraternal or mutual benefit society cannot change or modify the contract, without the express consent of the member whose rights are involved. Where the constitution of a mutual society does not specifically declare that amendments shall bind its members to changes in the contract subsequently made without their consent, such amendments will not affect existing certificates already issued. ${ }^{5}$ However, where one accepts membership "subject to such provisions of the constitution as are then in force or may be thereafter adopted," he will be bound by any reasonable amendment to the

maintained by the insurance company, upon an action to recover un. der the policy, that the beneficiary could not recover for death of the assured from the burning, unless it was also shown that the accidental burning caused some of the injuries mentioned in schedule $A$ of the policy, and that therefrom death ensued. The court properly held that the clause quoted referred only to certain injulies, for which the specific sum per week was to be paid for the number of weeks mentioned therein, and that it did not refer to cases of accidental death, and judgment was given for the beneficiary. See, also, Fidelity \& Casualty Co. of New York v. Hart, 142 Ky. 25, 133 S. W. 996; Porter v. Casualty Co. of America, 126 N. Y. Supp. 669, 70 Misc. Rep. 246.

4 See Starling v. Supreme Council Royal Templars of Temperance, 108 Mich. 440, 66 N. W. 340, 62 Am. St. Rep. 709. Here the assured was a leather cutter in a shoe factory. In July, 1890, he was strlcken with paralysis, which totally disabled him from work. Shortly before the suit was brought the causes of total disabllity which would render the company liable on its policy were reduced to three-loss of sight, loss of both arms or both legs, and hopeless or incurable insanity. The defendant company claimed that, inasmuch as the plaintiff had agreed to observe the rules and regulations of the order, this change of causes of total disability would prevent his recovery for a total disability growing out of paralysis. The court declared that the defense was not well taken.

5 See Carnes v. Iowa State Traveling Men's Ass'n, 106 Iowa, 281, 76 N. W. 683, 68 Am. St. Rep. 306. 
constitution subsequently made. Mutual benefit societies are self-governing bodies, and the law will not interfere to regulate amendments to their constitutions, unless they are oppressive and tend to destroy vested rights. And under such conditions amendments to the constitution or by-laws which are reasonable will be sustained. ${ }^{6}$

An insurance company will not be permitted to plead such exceptions to a contract of insurance, where the acts done or risks incurred are incident to and a natural part of the occupation for which the policy has been issued. ${ }^{7}$ In

6 Hall v. Western Travelers' Acc. Ass'n, 69 Neb. 601, 96 N. W. 170. Here the assured accepted membership in a mutual insurance company, subject to such provisions of the constitution as were then in force or might be thereafter adopted. The association subsequently, and during the life of the policy of the assured, adopted the following amendment to its constitution: "The association shall not be liable for disappearances, nor shall the association be liable for injuries occasioned, wholly or partly, directly or indirectly, by any of the following acts or causes, occurring while so engaged or affected: Disease, bodily and mental infirmity, hernia, orchitis, fits, vertigo. * * * After the adoption of this amendment the assured, in an attack of vertigo, fell and received injuries which, independently of all other causes, wholly disabled him for a period of one week. The insurance company refused to pay the claim, and the court declared the amendment to have been reasonable, and therefore binding upon the assured as a part of the contract to which he had subscribed in taking out the certificate of insurance.

7 Thus, where a man was insured as a railway conductor, and was killed while attempting to alight from a moving train, the company was not permitted to allege as a defense to a suit on the policy that it contained a clause exempting the company from liability for death or injuries due to accidents from attempting to enter or leave moving conveyances. It is a matter of common knowledge that trainmen, particularly conductors, must not only board trains while they are in motion, but that they must also leave them before they come to a stop. While these duties may be dangerous, none the less they are among the risks of the occupation for which the policy holder was seeking insurance. Therefore, unless the contrary is stipulated, the company will be liable for injuries received from risks which are incident to the occupation of the assured in spite of exceptions named in the policy. Dailey v. Preferred Masonic Mut. Acc. Ass'n, 102 Mich. 289, 57 N. W. 184, 26 L. R. A. 171. Here 
such a case the risk is a part of the obligation assumed by the company and furnishes the motive of the assured in seeking protection. What might be a voluntary exposure to unnecessary danger by a man engaged in one occupation would not constitute such an exposure by one following another pursuit. Thus it would be an unnecessary exposure to danger for a banker to climb about on the scaffolding of a building, but manifestly this would not be true of a brick mason, who was engaged in "pointing" or "facing" brick. 8

the plaintiff was insured against accidental injuries by a policy which contained a condition exempting the company from liability for injurles resulting from "unnecessary lifting." The plaintiff was the proprietor and owner of a pleasure resort, and intended to give an exhibition called "Pompeii," in which a strong man was to exhibit his skill and prowess. Rustin, the assured, had-been used to lifting weights, and noticed that the dumb bells looked lighter than those advertised and contracted for. He lifted one, said to weigh 450 pounds, but actually weighing not more than 300 pounds. His idea was to protect the company and the public from a projected fraud. While lifting the weight, a ligament in his back snapped. Although Rustin was classed as a "capitalist" in the policy, the court declared that the lifting was apparently reasonable and performed in the line of duty, and therefore the company was liable on its policy. Rustin v. Standard Life \& Accident Ins. Co., 58 Neb. 792, 79 N. W. 712,46 L. R. A. 253,76 Am. St. Rep. 136. A policy of insurance contained the stipulation that it should not "cover * * injuries * * * from overexertion, wrestling, lifting, * * * unnecessary exposure to danger." The assured was a machinist working in a railroad shop, and one of his duties was to remove cylinder heads of engines. He had frequently removed them, but upon this particular occasion the lifting of a cylinder head broke a blood vessel in his stomach, from which he died. Since the lifting was done as one of the customary duties of his employment, of which the insurance company had full notice, the insurer was held liable on the policy. Standard Life \& Accident Ins. Co. v. Schmaltz, 66 Ark. 588, 53 S. W. 49, 74 Am. St. Rep. 112.

8 See Wilson v. Northwestern Mut. Acc. Ass'n, 53 Minn. 470, 55 N. W. 626. The assured was engaged in pointing the brick walls of a building, and was working on a scaffolding suspended from the roof by means of ropes. Between the scaffold and roof there was a projection, which carried the scaffold out some distance from the building. Small guy ropes were used to draw the scaffold back to the structure. One of these ropes broke, and the scaffold swung 
Trespassing on railroad tracks over which trains were frequently running would be an unnecessary exposure in the case of a schoolteacher, but not of a brakeman whose duty it was to flag trains. ${ }^{9}$ But the fact that a man, engaged in a certain business, might occasionally be forced to assume certain risks not ordinarily a part of his business, but incident to another occupation, would not make such a risk a part of his employment, so as to warrant the application of this exception to the rule which absolves the company from liability where death or injury occurs by reason of the violation of the condition. ${ }^{10}$

away from the building, throwing the assured to the walk below and inflicting fatal injuries upon him. The court held as a matter of law that this was not such a voluntary exposure to danger as would release the company from liability. The court said: "The association was organized for the very purpose of indemnifying persons engaged in trades or occupations in which accidents were imminent and almost unavoidable, and Benson's object was to secure indemnity in case of accident. When such accident happens, and injuries result, a recovery cannot be defeated on the ground of voluntary exposure to a danger contemplated by the parties because pertaining to the business of the assured. Yet if the scaffold on which Benson was at work was insecure and unsafe, and he knew it, he would be exposing himself to danger unuecessarily, and in case of accident the defendant would not be liable. These were matters for the jury to pass upon under proper instructions. * * *"

9 See Jamison v. Continental Casualty Co., 104 Mo. App. 306, 78 S. W. 812. Here a bridge carpenter, employed by a railroad, was accustomed to flag trains and see that their speed was reduced to a certain rate before they crossed one of the company's bridges. Early one evening he was so sent out, but was not seen again until the next morning, when his body was found near the track, where it had been hurled by a passing train. That the assured was standing near the track was not of itself such an "unnecessary exposure to danger or to obvious risk of injury," by a condition in the policy, as would free the company from liability.

10 Yancy v. Atna Life Ins. Co., 108 Ga. 349, 33 S. E. 979, supra. Here the court held that the fact that an agent for a coal company might frequently be forced to cross railroad tracks did not make that a necessary incident of his occupation, so that the company would be liable for his death or injuries from an accident sustained 
In order to relieve the insurance company from liability under these conditions, the excepted risk must be the direct cause of the injury or death. The fact that the violation of such a condition is merely coincident with death will not relieve the insurance company from liability on the policy. Thus, if a man is shot while entering or leaving a passenger car, the company would not be excused from liability on the ground that the policy contained a clause exempting it from liability for injuries to the assured while entering or leaving a moving conveyance conveyed by steam, electricity, or cable. Here the fact that the man might be leaving or entering the car would not be the cause of his being shot. It would be merely an incident thereof. Similarly, if a man is insured under a policy exempting the company from liability for injuries sustained while hunting, it will not relieve the company from liability if he falls while bringing a log into camp to build a fire while on a hunting trip. There is no direct relation between the accident of falling while carrying a log to build a fire and the dangers ordinarily incident to a hunting trip. ${ }^{11}$

Causa proxima non remota spectatur.-In all these cases the excepted risk must be the immediate and effective cause of

while his presence upon the tracks was not necessary, under a policy exempting the company from liability for injuries sustained by the assured while "walking or being on any railroad bridge or roadbed."

11 Wilkinson v. Travelers' Ins. Co. (Tex. Civ. App.) 72 S. W. 1016, supra. Similarly it would seem that the company would be liable if the assured was assaulted while intoxicated, providing the assault was not the result of the intoxication, where the policy exempted the company from liability for injuries to the assured while he was intoxicated; also where a man was insured by a policy exempting the company in the case of injuries while walking on a railroad bed or bridge, the company would clearly be liable if the assured were bitten by a dog, or struck by a stone, or fell over an obstruction, since these accidents could not be occasioned by the fact of his being on a railroad bed or bridge. 
the injury, and not the remote cause. It is frequently difficult to determine what is properly the effective cause, where different forces and conditions unite in producing a resuli. The maxim "causa proxima non remota spectatur" does not mean that the cause or condition which is the nearest in point of time and space to the result is necessarily the proximate cause. It means rather that the law will not go farther back in the line of causation than to find the active, efficient, and procuring cause of which the event under consideration is a natural and probable result. The law will not concern itself with the cause of causes. It merely seeks the efficient predominant cause. ${ }^{12}$ For example, if

12 Freeman v. Mercantile Mut. Acc. Ass'n, 156 Mass. 351, 30 N. E. 1013, 17 L. R. A. 753. In this case the assured died as the result of peritonitis. Some years before he had had an attack of the same disease, which rendered him liable to a recurrent attack. Some time before the last attack the assured had a fall. It was held that if he was suffering from peritonitis at the time of the fall, and the fall aggravated and made fatal the ailment, the beneficiary could not recover. But, on the other hand, if he did not have the disease at the time but, even though he was predisposed to have a recurrence of it, if the fall brought it on, though it would not have caused. it under normal conditions, the company is liable. So in Fetter $\nabla$. Fidellty \& Casualty Co., 174 Mo. 256, 73 S. W. 592, 61 L. R. A. 459, $97 \mathrm{Am}$. St. Rep. 560. Here the assured, a man 69 years of age, attempted to close a window with a window pole. The pole slipped off the rim of the window, throwing the assured against the edge of a table near by, rupturing a kidney, and thereby producing a hemorrhage which caused his death. An autopsy revealed a cancerous condition of the kidney. The court declared that if the death resulted from the accidental rupture the company was liable. The court minimized the value of the remote predisposing cause theory that the rupture was due in the first instance to the cancerous condition of the kidney.

In Mallory v. Travelers' Ins. Co., 47 N. Y. 52, 7 Am. Rep. 410, the assured was last seen walking toward a railroad bridge over a culvert which crossed a stream. This bridge was very generaliy used by pedestrians. A few days thereafter the body of the assured was found in the pond near the bridge. His hat was broken, and there was a wound on the head. It was held that, though the wound received by the assured was accidental and of itself insufficient to cause his death, still if it did cause him to fall into the water, where 
the insured is drowned, the drowning is the proximate and sole cause of death, no matter what the cause of falling into the water may have been, unless death would have resulted without the presence of the water. ${ }^{13}$ If an excepted risk,

he was drowned, his death was accidental. The drowning was the proximate cause of the death, and upon the finding of the jury the insurance company was held liable. See, also, cases cited under Dlsease or Bodily Infirmity, page 178.

13 See Mannfacturers' Accident Indemnity Co. v. Dorgan, 58 Fed. 945, 7 C. C. A. 581, 16 U. S. App. 290,22 L. R. A. 620 . The assured with some companions went on a fishing trip some miles from home, taking along some wine, whisky, beer, and provisions. The day following their arrival in camp the members of the party spent fishing. At breakfast Dorgan spoke of having some trouble with his throat and chest. He fished in the morning, returned for lunch, and shortly thereafter went back to an island in the brook, where he was seen shortly afterwards playing a trout. A little later he was found dead, lying in the brook, face downward, submerged in six inches of water. His face was purple, and there was a little yellowish froth about the month. Evidence was introdnced by the insurance company to the effect that the assured had suffered from defective heart action. Two small stones lay on the bed of the brook, and there were two small bruises upon the forehead of the assured. An autopsy showed that the organs of the deceased were normal, and the condition of the body indicated death by drowning. The court, speaking through Taft, C. J., said: "We are of the opinion that in the legal sense, *** if the deceased suffered death by drowning, no matter what was the cause of his falling into the water, whether disease or a slipping, the drowning in such case would be the proximate and sole cause of the disability or death, unless it appeared that death would have been the result, even had there been no water at hand to fall into. The disease would be but the condition; the drowning would be the moving, sole, and proximate cause." The policy in question contained a clause exempting the company from liability for accidental injuries or death "caused directly or indirectly, wholly or in part, by or in consequence of such fits, vertigo, or disease." The conrt held that, if one of these excepted risks caused the fall into the water, then the insurance company would not be liable. See, also, Wehle v. United States Mut. Acc. Ass'n, 31 N. Y. Supp. 865, 11 Misc. Rep. 36. In this case the court said: "If immersion in water was the direct cause of death, it must be deemed the responsible one. The possibility that at some future time the deceased might have died from some other cause cannot be a defense, for, in the nature of things, all persons must die sooner or later." 
such as fits or vertigo, caused the accidental injury or death, it must be shown that the excepted risk was the cause of the death or injury, in the sense of being the proximate and immediate propelling force. This is none the less so where another cause intervenes and assists in the causation. ${ }^{14}$

If an accidental injury produces a disordered condition of certain organs, whereby these or other organs of the body fail to perform their normal functions, and death ensues, the death is naturally attributable to the original injury. That is, if death or disability ensues from the injury as its necessary consequence, and would not occur except for the injury, then the injury is the proximate or sole cause of death. However, if an independent disease or functional disorder supervenes upon the injury-one not necessarily produced by the injury-or if the injury merely brings into activity dormant diseases or disorders, and the assured dies as a result, wholly or partly, of such disease, then the injury is not the sole or proximate cause of death. ${ }^{16}$

14 Lawrence v. Accidental Ins. Co., Limited, L. R. 7 Q. B. Div. 216. Here the assured while at a railway station was seized with a fit and fell forward off the platform across the track, when a passing train ran over and killed him. It was held that the death of the assured was caused by an accident, and the insurer was held liable, although the policy excepted "all cases of death arising from fits, or any disease whatsoever. ***" The distinction between this case and the Dorgan Case, supra, lies in the fact that in the Dorgan Case the word "indirectly" appears.

15 Barry v. United States Mut. Acc. Ass'n (C. C.) 23 Fed. 712. Here the assured, in jumping from a platform, produced an internal injury which caused duodenitis, resulting in his death. Held, that the injury was the proximate cause of death. See, also, Atlanta Acc. Ass'n v. Alexander, 104 Ga. 709, 30 S. E. 939, 4z L. R. A. 18s. Here the assured, as the result of an injury, sufferea a hernia, from which death ensued. The policy exempted the company from liability for death resulting from hernia. It was held that the hernia was but a link in the chain of causation between the accident and the death, and therefore the company was liable. In Delaney $\nabla$. Modern Accident Club, 121 Iowa, 528, 97 N. W. 91, 63 L. R. A. 603, the assured accidentally cut his finger on a piece of steel. Erysipelas and Fuller Acc.Ins. - 7 
If the death of the assured is caused by a disease without any accidental means, the insurance company is naturally exempt from liability. However, if the deceased suffers an accident, but at the time of sustaining it he is already suffering from a disease or bodily infirmity, and if the accident would not cause his death if he were not affected by the disease or infirmity, but he dies because the accident aggravates the disease, or the disease aggravates the effects of the accident, the association is exempt from liability, since

blood poisoning ensued, causing his death. Held, that the company was liable, since the disease which caused the death was the natural consequence of the accident. National Benefit Ass'n of Indianapolis v. Grauman, 107 Ind. 288, 7 N. E. 233, where a fall injured the head of the assured, resulting in apoplexy, which produced death. Omberg r. United States Mut. Acc. Ass'n, $101 \mathrm{Ky} .303,40 \mathrm{~S}$. W. 909, 72 Am. St. Rep. 413, where the bite or sting of an insect caused blood polsoning, from which the assured died. A similar decision was rendered in Fetter v. Fidelity \& Casualty Co., 174 Mo. 256, 73 S. W. 592, 61 L. R. A. 459, $97 \mathrm{Am}$. St. Rep. 560, where the assured, while attempting to close a window, was thrown against a chair, causing a ruptured kiduey, which produced a bemorrhage, which in turn caused death. Martin v. Equitable Acc. Ass'n, 61 Hun, 467, 16 N. Y. Supp. 279, where an injury to a finger caused by an umbrella developed blood poisoning which resulted in death. Another suit based upon the same injury was that of Martin v. Manufacturers' Accident Indemnity Co., $151 \mathrm{~N}$. Y. 94, 45 N. E. 377. Miner v. Travelers' Ins. Co., 2 Ohio N. P. 103, 3 Ohio S. \& C. P. Dec. 289, where the assured, in running through a half-open door to catch a street car, struck against the door knob, receiving a hernia, from which he died. Travelers' Ins. Co. v. Hunter, 30 Tex. Civ. App. 489, 70 S. W. 798, where the assured was injured in a runaway, as a result of which rheumatism ensued, from which death followed. Hall v. American Masonic Acc. Ass'n, 86 Wis. 518, 57 N. W. 366, where an injury caused apoplexy, which in turn caused death. The leading case on this subject is Western Commercial Travelers' Ass'n v. Smith, 85 Fed. 401,29 C. C. A. 223,40 L. R. A. 653 , where a new shoe caused an abrasion of the skin of a toe, which developed blood poisoning, resulting in the death of the assured. Held, the blood poison was but an incident. The court said: "In such a case the disease is an effect of the accident, * * * a mere link in the chain of causation between the accident and death, and the death is attributable, not to the disease, but to the causa causans, to the accident alone." For further citations, see Disease or Bodily Infirmities, page 178. 
the death is caused partly by disease and partly by accident. $^{16}$

If, however, the assured by reason of having previously had a disease is peculiarly liable to its recurrence, and as a result of an accidental injury the disease does recur, although he was well at the time of the injury, the accident, rather than the excepted risk of disease, is the proximate cause of death. ${ }^{17}$

16 See 'Travelers' Ins. Co. v. Selden, 78 Fed. 285,24 C. C. A. 92 , where the insured was subject to such a bodily infirmity that a short run, followed by stooping, which would not have injured a healthy man, produced apoplexy. The insurance company was held to be exempt from liability, because the death was caused partly by disease and partly by accident. Commercial 'Travelers' Mut. Acc. Ass'n of America v. Fulton, 93 Fed. 621, 35 C. C. A. 493 (also Id., 79 Fed. 423 , 24 C. C. A. 654), where the assured had a defective heart. While waiting on a sidewalk, he suddenly fell, striking upon an iron water spout, which left marks on his head. He died within a half hour. The fall might have been due to a slippery sidewalk, or to the diseased condition of the heart revealed by a subsequent autopsy. If the blow was insufficient to kill one with a strong heart, but was sufficient to kill one with a diseased heart, the company would not be liable. Hubbard v. Mutual Acc. Ass'n (C. C.) 98 Fed. 930, where no recovery was permitted where the death of the assured resulted from a rupture of the heart, caused in part by its diseased condition and in part from a fall; neither cause, in itself, being sufficient to produce death. Thornton v. Traveler's' Ins. Co., 116 Ga. 121, 42 S. E. 287, $94 \mathrm{Am}$. St. Rep. 99, where the assured suffered from a reducible hernia, requiring him to wear a truss. While on a train of cars the lurching threw the assured violently against the arm of one of the seats, striking the truss, and the blow produced a strangulated hernia, requiring an operation for its relief. The court declared that if the condition of the assured, in having at the time of the accident a reducible hernia, contributed to the accident in whole or in part, the company would not be liable. "But if the existence of the hernia in the system of the insured at the time of the accident did not substantially contribute wholly or partly, directly or indirectly, in bringing about the injury, but merely aggravated the consequences of the accident, then the plaintiff would be entitled to recover. If the insured had been a perfectly sound man at the date of the accident, and it had resulted in producing a hernia, the company would be liable." For additional citations, see Disease or Bodily Infirmities, page 178.

17 Freeman v. Mercantile Mut. Acc. Ass'n, 156 Mass. 351, 30 N. E. 
The effective cause of the disability is always to be considered.

In a suit on a policy which contains first a general clause of liability, and also a separate clause which removes from the operation of the general clause certain grounds of obligation on the part of the company, the plaintiff, relying upon the general clause, may set out that clause in his pleadings, without noticing the modifying clause. The assured or his beneficiary is not compelled to set forth the exception of the policy in his pleadings, nor to disprove the same in order to establish his prima facie case. It is sufficient for the plaintiff to allege that he has met with the accident on which the suit is based, without any contributing cause or negligence on his part, and that he has fully complied with all the terms of his contract. Such an allegation in the petition negatives the idea that he has violated any condition precedent to his right of recovery under the terms of the policy or the rules" of the company or association which has issued the instrument. It is not incumbent upon the plaintiff to deny he has suffered disability by any of the means which under the policy will relieve the company from liability, since such exceptions are purely matters of defense. ${ }^{18}$

Where it is claimed that death or injury has resulted from one of the excepted causes enumerated in the policy, the defendant must plead the fact. And this plea of defeasance must be sustained by the evidence in order to relieve the company from liability. Such conditions are unavailable for defense

1013, 17 L. R. A. 753. Here the assured had some time previously suffered an attack of peritonitis, from which he had fully recovered. The attack left certain lesions, rendering him liable to a recurrence. An accident causing a recurrence of the peritonitis would be the proximate cause of ensuing death, even though under a normal state the fall would not have so resulted.

18 Voluntary Relief Department of Pennsylvania Lines West of Pittsburgh v. Spencer, 17 Ind. $\Lambda$ pp. 123, 46 N. E. 477; Crenshaw v. Pacifle Mut. Life Ins. Co., 71 Mo. App. 42 ; Employers' Liability, Assur. Corp. v. Rochelle, 13 Tex. Civ. App. 232, 35 S. W. 869. 
unless specially pleaded. ${ }^{19}$ But the company is entitled to plead and show that the disability resulted from an excepted cause, though the injury is set forth under a different name in the petition. ${ }^{20}$

After the plaintiff has shown that the death or disability of the assured is the result of bodily injuries resulting from external, violent, and accidental means, within the general terms of the policy, then prima facie the burden is on the insurance company to prove by affirmative evidence the breach of some one or more of the conditions or excepted risks avoiding the policy; as, for example, that the death was the result of disease rather than accident, that the accident was intentionally inflicted, or was the result of a voluntary exposure to unnecessary danger, etc. ${ }^{21}$

19 United States Casualty Co. v. Hanson, 20 Colo. App. 393, 79 Pac. 176, where the conditions required that the accidental injury should leave a visible mark on the body of the assured and should not have been sustained in a wild country. Vernon v. Iowa State Traveling Men's Ass'n (Iowa) 138 N. W. 696. Coburn v. Travelers' Ins. Co., 145 Mass. 226, 13 N. E. 604 (also Anthony v. Mercantile Mut. Acc. Ass'n, 162 Mass. 357, 38 N. E. 973, 26 L. R. A. 406, 44 Am. St. Rep. 367), where the defense was based upon the condition exempting the company from liability for "intentional injuries inflicted by the insured or any other person." Railway Officials' \& Employes' Acc. Ass'n v. Drummond, 56 Neb. 235, 76 N. W. 562, where in the policy the same condition was included.

20 Romayne v. Hawkeye Commercial Men's Ass'n (Iowa) 135 N. W. 735.

21 Travelers' Ins. Co. v. Wyness, 107 Ga. 584, 34 S. E. 113; Thorn. ton v. Travelers' Ins. Co., 116 Ga. 121,42 S. E. 287, 94 Am. St. Rep. 99; Fidelity \& Casualty Co. v. Sittig, 181 Ill. 111, 54 N. E. 903, 48 L. R. A. 359; Sutherland v. Standard Life \& Ace. Ins. Co., 87 Iowa, 505, 54 N. W. 453; Coburn v. Travelers' Ins. Co., 145 Mass. 226, 13 N. E. 604; Hess v. Preferred Masonic Mut. Acc. Ass'n of America, 112 Mich. 196, 70 N. W. 460, 40 I. R. A. 444 ; Meadows v. Pacific Mut. Life Ins. Co., 129 Mo. 76, 31 S. W. 578, 50 Am. St. Rep. 427; Hester v. Fidelity \& Casualty Co., 69 Mo. App. 186; Railway Officlals' \& Employés' Acc. Ass'n of Indianapolis v. Drummond, 56 Neb. 235, 76 N. W. 562; Interstate Casualty Co. v. Bird; 18 Ohio Cir. Ct. R. 488,10 O. C. D. 211. 
In its answer the defendant company may avail itself of as many defenses as it may have, provided they are not inconsistent-that is, that the proof of one shall not involve the disproof of the other. For example, the company in its answer in a suit on a policy may allege that the death of the assured was the result of a cause not covered by the policy, and that the notice required by the policy to be given the company immediately on the death of the insured was not given. And, in line with the general rule of pleading, if the insurance company pleads inconsistent defenses, neither the plaintiff nor the court can choose for the defendant which defense it will abandon. It is entitled to make that election. ${ }^{22}$

The death or accidental injury on which the suit is based may not be capable of direct and positive proof by witnesses who were present at the time thereof. Individuals will not be permitted to alter the rules of evidence, and even in cases where the policy provides that there must be direct and positive proof of the cause of death, circumstantial evidence will be admitted to prove the same, and the jury may find any act proved which "may rightfully and reasonably be inferred from the evidence." 23

When there is no controversy between the beneficiary and the insurance company as to the means by which the injury was sustained or the death of the assured was caused, it is purely a question of law for the court to determine whether it was covered by the policy. ${ }^{24}$ But where two or more causes contribute to the injury, or the facts are such that equally prudent and fair-minded persons can draw different conclu-

22 Dezell v. Fidelity \& Casualty Co., 176 Mo. 253, 75 S. W. 1102.

23 Accident Ins. Co. of North America v. Bennett, 90 Tenn. 256, 16 S. W. 723, $25 \mathrm{Am}$. St. Rep. 685. Here the assured was found dead, with a pistol shot through his heart. There was, however, no direct proof as to the manner of his death. But there were many cir. cumstances from which some theory might be drawn.

24 Dezell v. Fidelity \& Casualty Co., 176 Mo. 253, 75 S. W. 1102, supra. 
sions, the question as to which is the proximate or efficient, dominating, cause, is for the jury. ${ }^{25}$

Excepted Risks in Accident Policies.-Various exceptions are to be found in policies of accident insurance, whereby the company exempts itself from liability for death or injuries happening to the assured under certain conditions. In this chapter it is proposed to treat of the construction of the various conditions most frequently met in policies of accident insurance. They vary in different policies, both as to character and verbiage.

Some policies, for example, exempt the company from liability for injuries or death happening to the assured while "employed in the manufacture, sale, or transportation of any explosive, or handling firearms." Under such a policy the fact that the assured is injured by temporarily handling a gun on a hunting trip for pleasure does not relieve the company from liability. ${ }^{26}$ Though death from the habitual use of explosives in his regular employment would excuse the insurer, such an exception does not apply to the merely incidental handling of firearms, such as using a gun for pleasure or recreation. It refers rather to the habitual handling of firearms as a part of one's regular occupation. ${ }^{27}$

25 Continental Casualty Co. v. Lloyd, 165 Ind. 52, 73 N. E. 824; Martin v. Equitable Acc. Ass'n, 61 Hun, 467, 16 N. Y. Supp. 279; Martin v. Manufacturers' Accident Indemnity Co., 60 Hun, 535, 15 N. Y. Supp. 309 ; Thurber v. Commercial Travelers' Mut. Acc. Ass'n, 32 App. Div. 636, 52 N. X. Supp. 1071, retried 51 App. Div. 608, 64 N. Y. Supp. 174.

26 'Thomas v. Masons' Fraternal Acc. Ass'n, 64 App. Div. 22, 71 N. Y. Supp. 692 . Here the assured, while on a hunting trip during his vacation, was killed by his gun accidentally falling and being discharged, after he had rested it against a tree near which he was sitting, eating his lunch. The court held that the phrase "handling firearms" referred only to such an act done in the regular employment of the assured.

27 Wilkinson v. Travelers' Ins. Co. (Tex. Civ. App.) 72 S. W. 1016. In this policy there was a clause exempting the company from 
Insurance companies frequently specify that they will not be liable for death or injury sustained by the assured while engaged in "adventures into wild and uninhabited or uncivilized regions." The purpose of this clause naturally is to relieve the company from the greater risk incident to life in countries peopled by savages and infested by wild animals, and where, by the presence of steep mountains, deep canyons, dense woods, or limitless desert, the danger of accident or death by violent means is greatly increased and the pcssibility of securing assistance is comparatively small. A well-known and frequented bay on the çoast of Alaska is not a wild, uninhabited, or uncivilized region. ${ }^{28}$ Nor is a sawmill camp, with a population of some 300 people, thirty-five miles from a railroad, such a wild and uncivilized country as will exempt the company from liability on its policy. ${ }^{2 \theta}$

Policies of accident insurance frequently contain a condition exempting the company from liability for death or disability, "caused partly or wholly by a surgical operation or medical treatment for disease," and, under such a policy, if

liability for injuries received by the insured while handling firearms. The assured while on a hunting expedition was helping to bring a $\log$ to make a fire, when he siipped and fell, injuring one of his hands under the log. The court held that, although the as. sured was on a hunting expedition, he was not actualiy engaged in handling firearms or hunting at the time of his injury, and that therefore the company was liable under its policy.

28 Etna Life Ins. Co. v. Frierson, 114 Fed. 56, 51 C. C. A. 424. Here the assured was on his way to Alaska for the purpose of prospecting in the gold fields of that country. While a passenger on a steam ressel crossing Kuskokwim Bay, on the coast of Alaska, the vessel was wrecked and the assured was drowned. The court held that at the time of the injury the assured was not engaged in any adventure in a wild and uncivilized region, and that the company was liable.

20 United States Casualty Co. v. Hanson, 20 Colo. App. 393, 79 Pac. 176. Here the assured accidentally feli and injured himself while supervising the construction of a sawmill in a camp in which some 300 people resided, distant about thirty-five miles from a railroad. station, in the province of Ontario, Dominion of Canada. 
the assured dies as a result of inadvertently taking an overdose of medicine, the company will not be liable. ${ }^{30}$ And similarly, where the assured dies while under the influence of an anæsthetic, administered for the purpose of performing an operation for some physical disability, or sickness, the death of the assured is the result of medical or surgical treatment, for which the company will not be liable. ${ }^{31}$ But where an accident is the proximate cause of death, and the assured dies as the result of an operation necessitated by the accident, the company will be liable, despite such a condition, and the assured or his beneficiary will be entitled to recover under the policy. ${ }^{32}$

Injuries resulting from "voluntary over-exertion," as distinguished from "voluntary exposure to unnecessary danger," are generally declared excepted risks under policies of accident

30 Bayless v. Travelers' Ins. Co., 2 Fed. Cas. 1077, 14 Blatchf. 143. Here the assured inadvertently took more than the specified dose of opium to allay nervousness and restlessness. The court was of the opinion that the death was caused wholly or in part by medical treatment for disease, and was not covered by the policy, and, furthermore, that it was not an injury sustained through external, violent, and accidental means within the spirit of the policy.

31 Westmoreland v. Preferred Acc. Ins. Co. (C. C.) 75 Fed. 244. Here the assured died from the influence of chloroform administered for the purpose of performing an operation to relieve the assured from piles. The court held that death was clearly the result of medical or surgical treatment, for which the company was not liable under its policy.

32 Travelers' Ins. Co. v. Murray, 16 Colo. 296, 26 Pac. 774, 25 Am. St. Rep. 267. Here the assured was injured by an accident which produced a hernia. The assured died as the result of peritonitis, incident to an operation performed as a last hope of saving his life. The court held that the accident, and not the surgical operation, was the proximate cause of the death of the assured. See, also, Herdic v. Maryland Casualty Co. (C. C.) 146 Fed. 396, affirmed by 149 Fed. 198, 79 C. C. A. 156 . Here the policy agreed to the liability of the insurer for septicæmia resulting from an accident. The company was held not to be liable, where death ensued from septictemia, following an operation for appendicitis not caused by accidental means. 
insurance. The term "voluntary over-exertion" means an intentional over-exertion or a reckless disregard of consequences likely to ensue from great physical effort. In determining what constitutes over-exertion, the physical condition and habits of the assured must be considered. The question is not what would be an over-exertion on the part of a man of greater strength than the assured, or of a man of average strength. but what is an over-exertion on the part of the insured himself, in the condition in which he is at the time of the accident, and not whether, for a man in like condition, the exertion is extraordinary or unusual and unsuited to his physical strength. Nor will the assured be debarred from recovering on the policy if the exertion is apparently reasonable and is performed in the line of his duty. This is particularly true where the application for insurance advises the company of the nature of the occupation of the assured. ${ }^{33}$ For example, it is not a "voluntary over-exertion" for a strong man, accustomed to lifting, to raise a 300 -pound weight when in the reasonable line of his duty. ${ }^{34}$ Nor as a matter of law is riding in a bicycle race a voluntary over-exertion. ${ }^{35}$

33 Standard Life \& Acc. Ins. Co. v. Schmaltz, 66 Ark. 588, 53 S. W. $49,74 \mathrm{Am}$. St. Rep. 112. Here the assured, a railroad machinist, in the line of his duty was removing a cylinder head of an engine. On this occasion the cylinder head stuck. He picked up a steel bar to remove it, and as he did so he dropped the bar and caught the cylinder head to prevent its falling. The court held that the company would be liable for accidental injuries recelved by the assured whlle lifting in spite of this condition, for the assured was at the time of his injury engaged in the customary duties of his employment. Rose v. Commercial Mut. Acc. Co., 12 Pa. Super. Ct. 394. Here the assured died as the resuit of injuries sustained while lifting the manhole of a sewer. The court held that in this case the injuries sustained by the assured were not accidental.

84 Rustin v. Standard Life \& Acc. Ins. Co., 58 Neb. 712, 79 N. W. 712, 46 L. R. A. 253, 76 Am. St. Rep. 136.

$3 s$ Keeffe v. National Acc. Soc., 4 App. Div. 392, 38 N. Y. Supp. 854. Here the assured was injured while riding in a bicycle race. The 
In order to exempt the company from liability by this clause, it must be shown that the over-exertion is voluntary and unnecessary, and one from which injury might reasonably be expected, and which might in the exercise of reasonable care be avoided. But any undue exercise put forth in an unexpected emergency, or in the event of sudden danger, as for the purpose of saving one from impending danger, is not contemplated by this clause, and under such conditions the company will be liable. ${ }^{36}$ In all these cases, where there may be a difference of opinion as to whether the assured has been guilty of voluntary over-exertion, the question is one for the determination of the jury under proper instructions. ${ }^{37}$

Some policies exempt the insurer from liability for death or injury to the policy holder while riding on a locomotive. Under such provision a combination engine and inspection

court held that he was not as a matter of law guilty of overexertion, but that, inasmuch as it was a question on which equally intelligent men might differ in opinion, it was properly a matter to be left for the jury to determine whether the company was liable.

36 Reynolds v. Equitable Acc. Ass'n, 59 Hun, 13, 1 N. Y. Supp. 738, affirmed without opinion 121 N. Y. 649,24 N. E. 1091. Here the assured, a bridge builder, was injured while engaged in his occupation, when unexpectedly an unforeseen weight was thrown upon the tools held in the hands of his employés. The court declared that an overexertion put forth in an "emergency of danger," as, for instance, in the effort to save one's self from being crushed by a descending weight, was not within the exception of the policy.

37 McKinley v. Bankers' Acc. Ins. Co., 106 Iowa, 81, 75 N. W. 670, where the assured, a merchant, was injured while handling heavy machinery, stoves, and like articles. Metropolitan Acc. Ass'n v. Bristol, 69 Ill. App. 492. Here the assured was attempting to move the pump stock of a well, and, while so engaged, he felt a severe pain in his back, and fell to the ground helpless and cramped with pain, and later died. His daughter testified that the assured was endeavoring to move the pump stock, that she saw him fall, and later found him lying on the wet and slippery platform. The court held that the finding of the jury that the injury was not caused by lifting or undue overexertion was manifestly against the weight of evidence. 
car, used for inspecting railroad tracks and bridges, is a locomotive within the meaning of the policy. ${ }^{38}$

Most policies of accident insurance contain a clause exempting the company from liability for injuries received while violating the rules of a corporation. ${ }^{39}$ In order to bring the accident within the purview of this condition, exempting the company from liability, the rule in question must be one of which the assured has knowledge and with which a reasonably prudent man would be familiar. ${ }^{40}$

The assured is certainly not to be held responsible for the various rules of a corporation of which he is ignorant, and with which the public in general may not be familiar. Nor is he bound to examine the time-card of a railroad, or ascertain all the minutiæ connected with the management of trains, for example; he will be bound only by such rules as a general traveler might be presumed to already know. ${ }^{41}$ Obviously, to come within this condition of a policy of insurance, the rule must be one which the corporation enforces, or at least makes known to the public, or exerts a reasonable effort to enforce. But if the corporation habit-

38 Ward's Adm'r v. Preferred Acc. Ins. Co., 80 Vt. 321, 67 Atl. 821. The company was, however, held liable under another clause of the policy.

39 Burkhardt v. Columbla Relief Fund Ass'n, $35 \mathrm{~Pa}$. Super. Ct. 284. Here the policy excepted accidents resulting from the violation of any rule of an employer. The assured was a motorman, and the question arose, on conflicting evidence, whether he obeyed the rule forbidding motormen to leave their cars "without first throwing off the overhead switch and removing the controller handle."

40 Travelers' Ins. Co. v. Randolph, 78 Fed. 754, 24 C. C. A. 305; Payne v. Fraternal Acc. Ass'n of America, 119 Iowa, 342, 93 N. W. 361; Equitable Acc. Ins. Co. v. Sandifer (Super. Ct.) $12 \mathrm{Ky}$. Law Rep. 797. Here the court said: "The assured cannot be regarded as violating a rule of a corporation, within the meaning of such a provision in an accident insurance policy, unless he had knowledge of the rule."

11 Tooley v. Rallway Passengers' Assur. Co., Fed. Cas. No. 14,098. 
ually violates a rule, and permits others to violate it, then it is not a rule which the assured is bound to obey, and for the infraction of which the insurance company can properly claim exemption under such a policy. This exception is most frequently involved in cases arising from the violation of rules adopted by railroad companies for the traveling public. ${ }^{42}$

Where the rule forbidding passengers to ride on the platform of cars is generally disregarded, both by the passengers and the trainmen, to so ride is not in violation of a rule of a corporation within the meaning of this clause in a policy of accident insurance, despite a printed notice posted on the door of the car.

In the well-considered case of Marx v. 'Travelers' Ins. Co. the court said: "The insurer assumes a guardianship of its patrons in respect to the casualties of life which beset men everywhere, and as to which it is not practicable to impose limitations which shall be constantly borne in mind by the

42 Travelers' Ins. Co. $\nabla$. Randolph, 78 Fed. 754,24 C. C. A. 305. The assured was last seen while riding on the platform of a car of a railroad train, moving at a speed of 20 miles an hour. Here the court charged the jury as follows: "If the company had a rule that the passengers were not permitted to stand on the platform of the car, and that was known to him, it was his duty to obey it; and whether it was known to him or not you may determine by looking to the fact of the extent of his acquaintance with traveling, how much of that he had done; how frequently,-the fact that the rule was placarded on the doors of the car, if such was the fact, and whether or not it was a rule which a reasonable and prudent man would probably know. To constitute it a rule such as he is bound by, it must have been a rule which the company itself enforced, or used a reasonable effort to enforce. *** And if the company habitually violated or permitted it, without effort to prevent it, to be habitually violated by passengers, then it would not be a rule which he was bound to obey. If it was known to him, and was a rule which was enforced, or a reasonable effort was made to keep it enforced, it was his duty to obey it; and if he failed to do so, it would defeat his recovery." 
insured. Will any one say that on land and sea, at home and abroad, a policy holder must constantly consider whether he is within all the rules of all the corporations, public and private, which he may in any way encounter? Whatever the answer may be to any such question, it is plain enough that a rule of a corporation, within the meaning of this policy, must be one which is known to the policy holder and of force at the time of the alleged violation." 43

But where the rule is enforced, and the passengers are forbidden or are warned by the crew of the train to keep off of the platform or steps of the cars while the train is in motion, the insurance company will not be liable under its policy. And this is so, even if the assured leaves the car to stand upon the platform as the train approaches a station. ${ }^{44}$ Under such a clause it will not be a violation of the rule to pass from one car to another for proper purposes, such as going to and from the dining, smoking, or sleeping car. And the assured may recover while riding on the platform or steps of a car, if by reason of a crowd on the train there is no safer place to ride and the conductor permits him to ride there. ${ }^{45}$

4339 Fed. 321. Here the assured, while overcome by the heat of the car, and suffering from nausea, went out onto the platform of a car in motion to secure relief, and was killed by falling therefrom. Although there was a rule prohibiting passengers from riding on the platform of a train, no effort was made to enforce it.

44 Bon v. Railway Passengers' Assur. Co., 56 Iowa, 664, 10 N. W. 225, $41 \mathrm{Am}$. Rep. 127. Here the assured, in common with other passengers, went out on the platform of a car as the train approached a station. The train at tilat time was running slowly, but suddenly gave a start forward, and the assured was thrown from the car, crushing his foot. The evidence showed that the following rule was luscribed upon a metallic plate in the car: "Passengers are not allowed to stand on the platform." The plaintiff himself testified that he was aware of this rule of the company. The insurance company was exempted from liability in this case.

45 Equitable Acc. Ins. Co. v. Sandifer (Super. Ct.) $12 \mathrm{Ky}$. Law Rep. 797 . 
Of a similar nature is the rule of railroad companies forbidding the public to trespass upon their property or tracks. Where the insured is injured while crossing the tracks of a railroad at a place not dedicated to the public, the insurance company will be liable in spite of this condition, if it is shown that there existed a public custom of crossing the tracks at the point in question, if the railroad authorities are familiar with the practice and have made no effort to prevent it..6 But under an analogous exception, exempting the insurance company from liability for injuries resulting from the violation of the rules of employment, employés are held to be familiar with the regulations of their employers. ${ }^{47}$

Policies of accident insurance frequently classify steeplechase riding as an excepted risk, and, under such a clause, the company will not be liable where the insured is injured while engaged in steeplechase riding, and the knowledge of the agent that the assured frequently indulged in this sport will not affect its liability under the policy. ${ }^{48}$

46 Payne v. Fraternal Acc. Ass'n of America, 119 Iowa, 342, 93 N. W. 361. Here the assured was injured while crossing a railroad track at a point long used by the public and well recognized by the railroad company, although not a public highway. See, also, Duncan v. Preferred Mut. Acc. Ass'n of New York (Super. N. Y.) 13 N. Y. Supp. 620, affirmed without opinion 129 N. Y. 622, 29 N. E. 1029. See page 173.

47 Standard Life \& Accident Ins. Co. v. Jones, 94 Ala. 434, 10 South. 530. Here the assured, a railroad man, was injured by getting off his engine in motion in the nighttime, with his back toward the direction in which the engine was moving, contrary to the rules of the railroad. The court held that the assured must be considered familiar with the rules of his employment.

48 Smith v. Atna Life Ins. Co., 185 Mass. 74, 69 N. E. 1059, 64 L. R. A. 117, $102 \mathrm{Am}$ St. Rep. 326. Here the assured was injured while engaged in steeplechase riding, contrary to the terms of a condition in the pollcy. The court held that this form of sport inrolved a liability to accident much greater than usual sports or amusements, and the fact that the race in which the plaintiff was injured was for amateurs made no difference. 
Where the insurance company pleads the violation of the rule of a corporation as a defense, it must show that the assured has knowledge of the rule which he is alleged to have violated; but where it pleads the violation of a rule of employment, it will be assumed that the employé has knowledge thereof. But the exception must be specifically stated by the insurance company before it can be made available as a defense; and, if not pleaded, the court may exclude evidence offered to establish the rule.

A frequent condition in policies of accident insurance is one exempting the insurer from liability for death or injuries sustained by the insured while insane. This condition is legal and will be enforced. The reason for it is apparent. A sane man will instinctively protect himself from injury to which an insane man might willingly expose himself. A man who is non compos is unable to exercise the care and discretion of a sane man in protecting himself from danger. ${ }^{49}$

Suicide.-Policies insuring against death or injury from accident, like life insurance policies, usually contain a provision exempting the insurance company from liability in the event that death is caused by suicide. ${ }^{4 a \mathrm{a}}$ This provision assumes different forms in different policies. But where it provides simply that the company shall not be liable for death by suicide, the courts uniformly hold that the company will be liable in all cases except where the assured is

49 Blunt v. Fidelity \& Casualty Co., 145 Cal. 268, 78 Pac. 729, 67 L. R. A. 793, $104 \mathrm{Am}$. St. Rep. 34. Here the assured, while confined in an insane asylum, accidentally fell against a steam radiator and received injuries from which he shortly died.

$49 a$ For a further discussion of suicide as an excepted risk in insurance policies, see Cooley's Briefs on Insurance Law, vol. Iv, p. 3224 et seq. ; Elliott on Insurance, $\& 368$ et seq.; May on Insurance, vol. 1, \&307 et seq. ; Richards on Insurance Law, $\$ 509$ et seq. 
clearly sane at the time of destroying himself. The United States Supreme Court, in the leading case on this subject, holds that such a provision, not containing the words "sane or insane," does not include self-destruction by an insane person, whether his unsoundness of mind is such as to prevent him from understanding the nature and consequences of his act, or only such as to prevent him, while understanding and premeditating its physical consequences, from appreciating its normal nature and aspect. The theory, of course, is that suicide involves a mental determination, and that one who is insane is incapable of forming any mental concept. ${ }^{50}$

The prevailing American authority is that, in order to work a forfeiture under a policy of insurance on the ground of self-destruction, the insured must have had sufficient mental capacity, not only to understand that his act will destroy his life, but also to appreciate the moral element involved, and he must perform the act, not from an uncontrollable impulse resulting from insanity, but voluntarily and deliberately. In short, it must have been with evil intent. This is the doctrine which is supported by the preponderance of authority in the United States, and is both reasonable and consistent. ${ }^{51}$

50 Accident Ins. Co. $\nabla$ Crandal, 120 U. S. 527, 7 Sup. Ct. 685, 30 L. Ed. 740. Here the policy contained a provision exempting the company from liability for death caused "by suicide or self-inflicted injuries." The assured, while insane, hanged himself. The court sustained its decisions in cases of life insurance, and declared that the company was liable, and that such a policy covered self-killing by an insane person. 'The court quoted from Manhattan Life Ins. Co. . Broughton, 109 U. S. 121, at page 132, 3 Sup. Ct. 99, at page 105, 27 L. Ed. 878. Quoting the words of Justice Nelson, it said: "Self-destruction by a fellow being bereft of reason can with no more propriety be ascribed to the act of his own hand than to the deadly instrument that may have been used by him for the purpose," and "was no more his act, in the sense of the law, than if he had been impelled by irresistible physical power."

51 There are two so-called rules governing suicide clauses in inFuller Acc.Ins.- 
Sane or insane.-In order to avoid the difficulties involved in a judicial inquiry as to the exact mental condition of the assured at the time of his suicide, companies now very generally stipulate that they shall be exempt from liability in all cases of suicide, whether "sane or insane"; while others have used the words "voluntary or involuntary," or "voluntary or

surance policies. The first is the English rule, which is followed generally by the courts of New York and Massachusetts, under which the policy is void if the assured at the time of committing the act was sufficiently sane to understand its physical consequences. The other is the so-called American rule which is generally followed, and which has been succinctly set forth by the United States Supreme Court in the case of Mutual Life Ins. Co. v. Terry, 15 Wall. (82 U. S.) 580, 21 L. Ed. 236 , where the court said: "If the assured, being in the possession of his ordinary reasoning faculties, from anger, pride, jealousy, or a desire to escape from the ills of life, intentionally takes his own life, the proviso attaches, and there can be no recovery. If the death is caused by the voluntary act of the assured, he knowing and intending that his death shall be the result of his act, but when his reasoning faculties are so far impaired that he is not able to understand the moral character, the general nature, consequences, and effect of the act he is about to commit, or when he is impelled thereto by an insane impulse, which he has not the power to resist, such death is not within the contemplation of the parties to the contract, and the insurer is liable."

Blackstone v. Standard Life \& Accident Ins. Lo., 74 Mich. 592, 42 N. W. 156, 3 L. R. A. 486. Here the assured died as the result of drinking poison. The beneficiary claimed that the poison was accidentally taken, and the company set up the defense of suicide, under a provision of the policy forfelting a recovery in the case of death by suicide. See, also, Penfold v. Universal Life Ins. Co., 85 N. Y. $317,39 \mathrm{Am}$. Rep. 660, where the evidence tended to show that the assured took an excessive quantity of medicine and died from the effects thereof. Here the court said: "The taking of one's own life, not accidentally, but under the influence of insanity, has also been determined not to be a violation of the condition, but there has been difference of opinion as to the degree or character of the insanity which exempts from the operation of the condition; some authorities holding that it must be such a degree of insanity as to deprive the party of knowledge of the nature and probable consequences of the act which produced the death, others adopting the rule of the criminal law that he must have been so far deprived of his reason as to be unconscious of the moral obliquity of the act, and later cases holding that, although possessed of sufficient reason to comprehend 
otherwise." The condition so phrased has been held to cover all cases of suicide, and to exempt insurance companies from liability under a policy held by one who destroys himself. Even such a clause, however, would not cover the case of one who accidentally commits suicide, as by drinking poison which he supposes to be harmless medicine. ${ }^{52}$

the consequences of the act and the moral wrong which it involved. yet if the patient was driven to it by an insane impulse, produced by disease which disabled him from controlling his own actious, and the death resulted from that cause, the act was not voluntary and the condition was not violated. $* * *$ The clause against suicide is clearly intended to protect the insurance company against the fraudulent act of the insured, whereby he may, even at the sacrifice of his own life, secure a benefit to those whom he may desire to favor, at the expense of the insurance company. But, as has been already said, it has been held from the earliest day that a suicide committed in consequence of insanity was not within the meaning of the condition, although within its literal terms. The decisions establishing this doctrine were placed upon the ground that the death, though apparently caused by the act of the party, was not so caused in contemplation of law, because his mind did not concur in that act; his mental organs having been so diseased as to cease to control his actions or to guide them in accordance with reason."

The distinction may be briefly stated as follows: Under the New York rule the policy is void if the suicide is committed voluntarily and in pursuance of an intelligent design, with an understanding of its physical results, although the mind may be so impaired as to be unable to appreciate the moral qualities of the act. Under the socalled American rule, a suicide does not fall within the provision of the policy, no matter how intelligently the act may be committed, if at the time the assured is overcome by an uncontrollable impulse or is unable to appreciate its moral character.

52 Penfold v. Universal Life Ins. Co., 85 N. Y. 317, 39 Am. Rep. 660 , supra. Here the court said: "It would not be a fair interpretation of this clause, in either of the forms mentioned, to hold it to cover the case of a purely accidental death from poison occurring to a sane person, through mistake or ignorance, though his own hand might have been the innocent instrument by which the deadly potion was conveyed to his lips. Such an accident cannot be presumed to have entered into the minds of the contracting parties, or to have been intended to be stipulated against. The insurance was intended to cover the risk of premature death, which might result from any of the casualties to which human life is subject-self-destruction being excepted. A purely accidental act committed by a 
Some states by statutory enactment forbid insurance companies to offer suicide as a defense to a recovery on policies of life or accident insurance, unless the suicide is contemplated at the time the application is made for the policy. And under such statutes a stipulation that the company shall be liable only for a portion of the face of the policy in case of suicide is void and cannot be set up as a defense. The theory of this is that whatever tends to diminish a cause of action or to defeat a recovery in whole or in part amounts in law to

sane person, with no idea of injuring himself, cannot be regarded as an act of self-destruction within the meaning of such a contract. Suicide is the act stipulated against. The words 'voluntary or otherwise' preclude the parties claiming under the policy, if the act was one of sulcide, from setting up the condition or mind of the party committing it, and contending that it was an involuntary act of suicide. But still it must be a suicide, and who could contend that the taking of poison by mistake, or any other act which a sane person might innocently commit, though it should result in death, was what is ordinarily understood as self-destruction "or suicide? It is unreasonable to suppose that one effecting an insurance upon his life, in stipulating against death by his orn hand or act, could intend to embrace such a casualty or that the insurance company could fairly expect him so to understand."

An interesting case is presented in Cady $\mathbf{v}$. Fidelity \& Casualty Co. of New York, 134 Wis. 322, 113 N. W. 967,17 L. R. A. (N. S.) 260. Here the policy expressly exempted the insurer from liability for "suicide, sane or insane." The assured was confined in a hotel, and was apparently in a delirium from fever, though there was evidence tending to show that his death was premeditated. While his nurse was out of the room, he escaped into the hall, and plunged head first out of a window down a shaft, and died very shortly from the resulting injuries. In its syllabus of the case the court said: "The term 'death by suicide, sane or insane,' does not include death by the act of the assured without any mental purpose of self-destruction. If one, in a fit of delirium or other condition of irresponsibility, without intention to take his own life, does some act from which his death ensues, such death is by accident, not by suicide. The distinction between suicide by a sane person and suicide by an insane person, within the meaning of a policy clause 'death by suicide, sane or insane,' lies in the mental capability in the one case, and the absence of it in the other, to appreciate the moral nature and quality of the purpose." The claimant here was permitted to recover. 
a defense. ${ }^{53}$ In the absence of such statutory enactment, a limitation providing for a smaller liability in the event of suicide is valid and will be enforced. ${ }^{54}$ Some policies provide

53 Whitfield v. Etna Life Ins. Co., 205 U. S. 489, 27 Sup. Ct. 578, 51 L. Ed. 895, reversing (C. C.) 125 Fed. 269, and 144 Fed. 356, 75 C. C. A. 358. The statute of Missouri provides that suicide unless contemplated when the policy was applied for, shall be no defense to actions on policies of life and accident insurance. This statute has been sustained as a legitimate exercise of the power of the state. The Ftna Life Insurance Company issued policles which provided that in the event of the suicide of the insured it should be liable to pay only one-tenth of the principal sum. The United States Supreme Court in this case said: "Will the statute in a case of sulcide allow the company, when sued on its policy, to make a defense that will exempt it, simply because of such suicide, from liability for the principal sum? We cannot agree with the learned courts below in their interpretation of the statute. The contract between the parties, evidenced by the policy, is, we think, an evasion of the statute, and tends to defeat the objects for which it was enacted. In clear, emphatic words the statute declares that in all suits on policies of insurance on life it shall be no defense that the insured committed suicide, unless it be shown that he contemplated sulcide when applying for the policy. Whatever tends to diminish the plaintiff's cause of action, or to defeat recovery in whole or in part, amounts in law to a defense. When the company denied its liability for the whole of the principal sum, it certainly made a defense as to all of that sum, except one-tenth. If, notwithstanding the statute, an Insurance company may by contract bind itself, in case of the suicide of the insured, to pay only one-tenth of the principal sum, may it not lawfully contract for exemption as to the whole sum, or only a nominal part thereof, and, if sued, defeat any actlon in which a recovery is sought for the entire amount insured? In this way the statute could be annulled or made useless for any practical purpose. Looking at the object of the statute, and giving effect to its words, according to their ordinary, natural meaning, the legislative intent was to cut up by the roots any defense, as to the whole and every part of the sum insured, which was grounded upon the fact of suicide. The manifest purpose of the statute was to make all inquiry as to suicide wholly immaterial, except where the insured contemplated suicide at the time he applied for his policy. Any contract inconsistent with the statute must be held void." See, also, Applegate v. Travelers' Ins. Co. of Hartford, Conn., 153 Mo. App. 63, 132 S. W. 2, and Keller v. Travelers' Ins. Co., 58 Mo. App. 557.

54 Van Slooten v. Fidelity \& Casualty Co., 78 App. Div. 527, 79 
that, in the event of death or injuries received by the assured while insane, the company shall be liable only for a return of the premium. ${ }^{55}$

Presumption as to suicide.-In the absence of evidence to the contrary, courts will hold death to be the result of accidental or natural causes rather than of suicide. This presumption is based upon the love of life which exists in all sane

N. Y. Supp. 608. Here the policy provided that in the event of suicide the company should be liable for only one-twentieth of the amount otherwise payable.

55 Blunt v. Fidelity \& Casualty Co., 145 Cal. 268, 78 Pac. 729, 67 L. R. A. 793, 104 Am. St. Rep. 34. Here the policy provided that, in the event of injuries received by the assured while insane, the company would be liable only for a return of the premium. The assured, while confined in an asylum for the insane, fell against a steam radiator and received injuries from which he died. The court said: "Insurance during such insanity, except to that extent, was simply not a part of the contract, and the agreement in that contingency was that the company should be liable only for a sum equal to the premium paid. Language could not express this idea more clearly than it is expressed in the policy. The courts have always construed in favor of the assured every ambiguity and uncertainty in contracts of insurance. But where the words are clear and free from uncertainty, and the meaning plain, the contract as made by the parties is beyond the power of the courts to change by a forced construction. There was good reason for the insertion of the clause. A sane man will naturally and instinctively protect himself from injury, while if insane he might unconsciously expose himself thereto. It is to be presumed that in fixing the amount to be paid as a premium the company took into consideration its proposed exemption from full liability during such insanity, if it should occur, and reduced the premium accordingly. The assured received the benefit of this clause in the reduced amount of the premium, and hence the contract cannot be deemed inequitable or unfair. * * * The cases holding that a provision exempting an insurance company from liability, if the assured shall commit suiclde while insane, does not give exemption where the suicide is the result of insanity go upon the theory that the use of the term 'suicide,' or other similar description of the mode of death, implies a consclous and voluntary selfdestruction, and not an act impelled by the insane delusion, and in that sense involuntary. They do not apply to this policy, which makes the insane condition, and not the volition of the assured, the test of nonliability." 
persons, and the human instinct of self-preservation. This presumption goes so far as to justify the inference, upon proof of a self-inflicted death, that, in the absence of evidence to the contrary, the killing was accidental. ${ }^{56}$. Where liability for death by suicide is exempted under a policy of accident insurance, the burden rests upon the defendant to establish the defense of suicide by a preponderance of evidence. ${ }^{57}$ And where the claimant seeks to establish that death was the result of insanity, the burden rests upon him to prove such insanity, which under no condition is presumed by law. ${ }^{58}$

External and Visible Signs of Injury.-Most policies of accident insurance contain a condition specifically providing - that the company will not be liable for any bodily injury of which there shall be no "external or visible signs upon the body of the assured." This provision is obviously designed to

56 Standard Life \& Accident Ins. Co. $\nabla$. Thornton, 100 Fed. 582, 40 C. C. A. 564,49 L. R. A. 116 ; Industrial Mut. Indemnity Co. v. Watt, 95 Ark. 456, 130 S. W. 532; Jenkin v. Pacific Mut. Life Ins. Co., 131 Cal. 121, 63 Pac. 180; Star Acc. Co. v. Sibley, 57 Ill. App. 315. Here the court held that, when a person comes to his death by the discharge of a gun in his hands, the presumption of law is, in the absence of evidence to the contrary, that the act was not voluntary on his part. Klumb v. Iowa State Traveling Men's Ass'n, 141 Iowa, 519, 120 N. W. 81 ; Union Casualty \& Surety Co. v. Goddard, 76 S. W. 832, $25 \mathrm{Ky}$. Law Rep. 1035. Here the court held that, where the dead body of an insured is found under circumstances indicating death may have resulted either from accident or sulcide, the presumption is against suicide as contrary to the general conduct of mankind. Knickerbocker Casualty Ins. Co. v. Jordan, 6 Ohio Dec. 1145, 10 Am. Law Rec. 625, 7 IVkly. Law Bull. 71; Wright $\nabla$. Sun Iut. Life Ins. Co., 29 Upper Canada C. P. R. 221.

57 Standard Life \& Accident Ins. Co. v. Thornton, 100 Fed. 5\$2, 40 C. C. A. 564,49 L. R. A. 116 . Here the court said: "This presumption [against suicide] must stand in the case and be decisive of it until overcome by testimony which shall outweigh the presumption. It casts upon the defendant, who claims that the death was intentional, the burden of establishing it by a preponderance of testimony."

68 Travelers' Ins. Co. v. McConkey, 127 U. S. 661, 8 Sup. Ct. 1360, 32 I. Ed. 308. 
protect insurance companies against liability for fraudulent claims for alleged injuries of which there may be no other evidence than the word of the assured. This condition, requiring an external or visible mark, precludes recovery only for injuries which do not result fatally, and does not apply to cases where death results from accidental injury. In the event of death the body itself is an external and visible sign of the injury which has caused the death. A literal construction of the condition would work inequity, if it were applied to cases of death resulting from accidental causes. And thus where it is apparent that an accident has occurred, and it is a fair deduction from the circumstances of the case that death has ensued as the direct consequence of the accident, the company will be liable, even where no marks or contusions appear upon the body. ${ }^{59}$ Otherwise recovery would be precluded in all cases where death results from drowning, freezing, poisoning, by falling from a balloon, when death may ensue before the assured reaches the ground, by concussion, as by a blow over the heart-all causes of death likely to leave no outward mark upon the body, and yet where death is clearly the result of external or accidental means within the meaning of the policy of insurance. Similarly it would, if literally construed, prevent

59 Bernays v. United States Mut. Acc. Ass'n of New York (C. C.) 45 Fed. 455, where the assured died from erysipelas, resulting from an accidental laceration of a finger; Eggenberger v. Guarantee Mut. Acc. Ass'n (C. C.) 41 Fed. 172, where the assured died as a result of injuries sustained while chopping wood, which, however, left no visible marks upon the body; Lnion Casualty \& Surety Co. v. Mondy, 18 Colo. App. 395, 71 Pac. 677, where the assured, a sleeping car porter, was accidentally strucik on the head by a berth, as a result of which he died, there being no external or visible marks of injury on the body; Mallory v. Travelers' Ins. Co., 47 N. Y. 52, 7 Am. Rep. 758; Paul v. Travelers' Ins. Co., 112 N. Y. 472, 20 N. E. 347, 3 L. R. A. 443, 8 Am. St. Rep. 758, where the assured was accidentally asphyxiated by illuminating gas; Pickett v. Pacific Mut. Life Ins. Co., 144 Pa. 79, 22 Atl. 871, 13 L. R. A. 661, 27 Am. St. Rep. 618, where the assured was asphyxiated. 
recovery where the assured is killed and his body secreted. ${ }^{80}$ There are manifest reasons why such a condition should apply to a claimant who, if disposed to defraud the insurers, has an unusual chance for feigning an internal injury. But no such protection is required where the accident causes death. The dead body is the external and visible sign of death, as where the assured dies as the restilt of fright due to an accident. $^{61}$

Some policies provide that the insurer will not be liable for injuries or death of which there is no visible mark on the body; the body itself in case of death not being deemed such a mark. A provision of this nature will not be enforced by the courts, where it is manifest that the death has been accidentally caused and where to give literal effect to the clause would avoid the policy. ${ }^{62}$ The courts are not disposed to pay

60 Root v. London Guarantee \& Accident Co., 86 N. Y. Supp. 1055, 92 App. Div. 578, where the assured died from angina pectoris caused by an accidental fall.

61 McGlinchey v. Fidelity \& Casualty Co., 80 Me. 251, 14 Atl. 13, 6 Am. St. Rep. 190. Here the assured died as the result of fright occasioned by the horse which he was driving running away.

62 Lewis v. Brotherhood Acc. Co., 194 Mass. 1, 79 N. E. 802,17 C. R. A. (N. S.) 714. Here the assured was accidentally drowned, and the court held that, in spite of the clause in the policy that the body in case of death should not be deemed a visible mark, the claimant could recorer. The court said: "In cases of drowning, death is caused by the filling of the lungs with water, so that the air cannot get to them, and there is no reason why there should be any external mark of contusion or wound. In the ordinary case, therefore, none is to be expected. And if, while drowning, the body is bruised, there is usually no natural or necessary connection between such bruise and death. Suppose two persons, each having a policy like this, are accidentally swept overboard from a ship by the same wave. One goes clear and receives no mark, while the other is bruised and scratched by a spike, in no way disabling bim, as he goes over the rail. Both are drowned, and both bodies are recorered. Upon the body of the first is found no external mark or contusion or wound, while upon the body of the other appears the work of the spike. Is it to be said that the first case is covered by the policy, and the second is not? To bold that drowning is not 
much respect to the provisions of a policy which purport to control the laws of evidence. It is a fundamental rule that parties may contract freely in relation to conditions precedent to liability, or in relation to anything going to the remedy; but the courts will rigidly scrutinize any limitations placed on the right of recovery itself.

Nor does this condition of the policy require that the results of the accident shall be immediately visible. It is sufficient if the effect is visible soon after the accident and is shown to have been a consequence of the injury. To hold otherwise would defeat recovery in all cases of internal injuries, whose effects do not become at once apparent to the eye. ${ }^{63}$ And the

covered by the policy, unless, in addition to the flooding of the respiratory organs, there is some external mark of contusion or wound, is to base a distinction upon a circumstance which generally has nothing whatever to do with the cause of the death, and, moreover, is to eliminate practically the ordinary and usual case of drowning. An interpretation founded upon such a basis of distinction, and leading to results so unreasonable, is not to be adopted unless clearly required by unmistakable language. In view of these and other obvious considerations, the provisions of the policy relating to external marks of contusion and wounds must be held applicable to the more violent causes of injury, and not the case of death by drowning." Trone v. General Acc. Assur. Corp., 13 Ohio Dec. (N. P.) 298. Here the assured died from accidentally inhaling poisonous gas from a broken pipe in a natural gas stove. The policy contained a condition that the insurer would not be liable for injuries leaving no visible mark upon the body, the body itself in case of death not to be deemed such mark. The court held that a provision of this character would not be enforced, where the tendency would be to stifle the course of justice.

63 Pennington v. Pacific Mut. Life Ins. Co., 85 Iowa, 468, 52 N. W. 482, $39 \mathrm{Am}$. St. Rep. 306. Here the assured, a locomotive fireman, was accidentally injured by the lurching of the train, which resulted in the straining and wrenching of his back. There were no visible effects of the injury immediately following the accident. The court held that it would be sufficient if they were visible soon after the accident. The court said, inter alla: "The contract does not contemplate that there must be brulses, contusions, or lacerations on the body, or broken limbs." Thompson $\nabla$. Loyal Protective Ass'n, 167 Mich. 31, 132 N. W. 554. Here the court said: "The visi- 
company will be liable where there are visible marks of injury when the accident happens, though they may later become obliterated. It is not necessary that they should in any sense be permanent. ${ }^{64}$

The widest latitude has been given in defining what constitutes an external or visible sign of injury. In the leading case of Barry v. United States Mut. Acc. Ass'n, the United States Circuit Court has said: "Visible signs of injury are not to be confined to broken limbs or bruises on the surface of the body. There may be other external indications or evidences which are visible signs of internal injury. Complaint of pain is not a visible sign, because pain you cannot see; complaint of soreness is not such a sign, for that you cannot see; but if the injury produces, for example, a pale and sickly look in the face, if it causes vomiting and retching, or bloody or unnatural discharges from the bowels, if, in short, it sends forth, to the observation of the eye, in the struggle of nature, any signs of the injury, then those are external and visible signs, provided they are the direct results of the injury." 65

So the pallor of the assured, appearing immediately after the accident, and his subsequent emaciation and decline, are

ble marks on the body required by the policy need not become visible immediately upon the happening of the accident in order to entitle plaintiff to recover; but it is sufficient if they appear in some reasonable time thereafter. The mark visible to the eye on the body required by the policy need not be a bruise, contusion, laceration, or broken limb, but may be any visible indication of an internal injury which may appear within a reasonable time after the injury is received, such, for instance, as discoloration of the part of the body affected."

64 Bernays v. United States Mut. Acc. Ass'n of New York (C. C.) 45 Fed. 455 . Here the assured accidentally lacerated his finger, and died from resultant erysipelas, the wound having healed before death.

65 Barry v. United States Mut. Acc. Ass'n (C. C.) 23 Fed. 712. Here the assured died as a result of a strain from jumping from a low platform. 
external and visible marks within the terms of the policy. ${ }^{\text {Bs }}$ And so a pallor accompanied by perspiration on the face immediately after the accident, and a change in the color of the skin. ${ }^{67}$ So, also, a discoloration of the skin at the seat of the pain. ${ }^{68}$ Thus a nose-bleed resulting directly from the accidental injury is a visible sign within the terms of the condition in the policy. ${ }^{69}$ So a hernia, visible by its swelling or

66 Root v. London Guarantee \& Accident Co., 86 N. Y. Supp. 1055, 92 App. Dlv. 578. Here the assured from an accidental fall broke his hip and suffered internal injuries, resulting in angina pectoris, from which he died. The pallor and emaciation of the assured were held to be external and visible signs of the injury from which he died.

67 Horsfall v. Pacific Mut. Life Ins. Co., 32 Wash. 132, 72 Pac. 1028, 63 L. R. A. 425, 98 Am. St. Rep. 846. Here the assured, immediately after lifting a bar weighing 400 pounds, became sick and pale, his extremities became cold, cold perspiration stood out on his face and hands, and the next day his skin assumed a bluish gray color.

68 Union Casualty \& Surety Co. V. Mondy, 18 Colo. App. 395, 71 Pac. 677. Here the assured, a porter of a sleeping car, was struck on the head by a falling berth. He died from congestion of the brain resulting therefrom. There was a localized redness of the tissues of the brain of the deceased on the right side of the head. The court, moreover, held that the corpse of the assured was a sufficient visible and external sign of the injury to answer the terms of the condition in the policy. Sun Acc. Ass'n v. Olson, 59 Ill. App. 217. The assured fell from a lumber plle, hurting his hands and wrists, and suffering internal injuries, from which he died. Death was caused by acute peritonitis of traumatic origin, which was indicated externally by a discoloration of the skin. See, also, Thayer v. Standard Life \& Accident Ins. Co., 6S N. H. 577, 41 Atl. 182, where the assured injured his shoulder in an accidental fall, the only mark being a discoloration of the arm.

69 Whitehouse v. Travelers' Ins. Co., 29 Fed. Cas. 1038, 7 Ins. Law J. 23. Here the assured was accidentally thrown from his wagon, the seat of the wagon falling upon him. He complained later of soreness and pain in the head and side. A few days later he took to his bed and died. And the court declared that even after two or three weeks, if the bloody discharges from the bowels were a direct result of the injury, they would be regarded as a visible sign within the policy. 
otherwise, resulting from an accident, is an external sign. ${ }^{70}$ Bloody froth emanating from the mouth of the assured, who has been accidentally asphyxiated, will answer the condition requiring the existence of external and visible signs upon the body of the assured. ${ }^{71}$ And the company will be liable where, after the assured has been asphyxiated, artificial respiration expels illuminating gas from the body. ${ }^{72}$ Similarly where the assured is drowned, and, when the body is taken from the wa-

70 Summers v. Fidelity Mut. Aid Ass'n, 84 Mo. App. 605. The assured, a "hostler helper" in a railway shop, was accidentally strained while lifting a truck, and soon died as a result of heruia, plainly showing visible marks on his body.

71 United States Mut. Acc. Ass'n v. Newman, 84 Va. 52, 3 S. E. 805. Here the assured was found dead in his bed in the morning in a public hotel. The room was filled with coal gas, tending to show that the assured had been accidentally asphyxiated. Evidence showed that there was a tough ball of froth over the mouth of the assured, slightly tinged with red, some red splashes on the side of his face and on his breast, and also red spots on his body. See, also, 'Travelers' Ins. Co. v. Ayers, 119 Ill. App. 402, affirmed 217 I1l. 390, 75 N. E. 506, 2 L. R. A. (N. S.) 168.

72 Menneiley v. Employers' Liability Assur. Corp., 148 N. Y. 596, 43 N. E. 54, 31 L. R. A. 686, 51 Am. St. Rep. 716, reversing 72 Huu, 477,25 N. Y. Supp. 230 . Here the court said: "We are of the opinion that the language employed, when fairly construed, indicates that its purpose was to provide that a case of death or injury should not be regarded as within the policy, unless there was some external or visible evidence which indicated that it was accidental; in other words, that only such injury as could be shown by external and visible evidence to have been accidental should be regarded as within the policy. In this case it is admitted that the decedent's death was occasioned by his involuntarily and accidentally breathing illuminating gas, which had accidentally escaped into his room, but there was no visible mark of the accident upon the body of the deceased, but when artificial respiration was produced illuminating gas emanated therefrom to the perception of the persons producing such artificial respiration, that upon entering the room it was perceived to be full of gas, and that gas was then escaping therein, and that an inspection of the body showed life to be extinct. We think this admission furnished sufficient evidence of an external and visible character that the death of the decedent was accidental, to exclude it from this exception in the policy." 
ter, water runs from the mouth and the body seems to be filled with water. ${ }^{73}$

And to justify a recovery under such a policy the injury need not necessarily be visible to the eye. It will be sufficient if it can be ascertained by applying the hand to the exterior of the body, as where the muscles have been accidentally strained and have become knotted or have shrunk. ${ }^{74}$

Nor is it essential that the visible symptom of the injury shall be upon the outer surface of the body in order to permit a recovery. The condition of the policy will be satisfied if there are symptons or signs which would and do become visible

73 Wehle v. United States Mut. Acc. Ass'n, 31 N. Y. Supp. 865, 11 Misc. Rep. 36. Here the assured was accidentally drowned, and when his body was removed from the water there were no marks upon the body, but water ran from the mouth, and the body seemed to be filled with water, and the company was held liable.

74 Gale v. Mutual Aid \& Accident Ass'n, 66 Hun, 600, 21 N. Y. Supp. 893. The assured was injured while lifting a heavy piece of machinery, as a result of which he strained his diaphragm and rectal muscles, and was confined to his house. The testimony showed that there was no objective evidence, visible to the eye upon the body of the assured, but a manipulation of the muscles showed that they were rigid and tense. The company was held liable. The court said: "The condition of the policy as to external evidence of an injury was inserted to protect the insurer against fraudulent claims. It is a reasonable and a proper provision; but it should have a reasonable and practical construction. The evidence of the injury must be external, objective; but it must not necessarily be visible to the eye. If it can be ascertained by applying the hand upon the exterior of the body, such a test affords equal protection to the insurer against fraudulent claims based upon simulated injuries as evidence that can be seen with the eye. Information derived through the sense of feeling may be quite as satisfactory and convincing as that derived by sight." See, also, United States Casualty Co. v. Hanson, 20 Colo. App. 393, 79 Pac. 176. The assured, while supervising the construction of a mill, accidentally fell and injured his spine. The muscles of the hip and leg were shrunken, and lameness developed. Further the breaking down of the bones at the joint, which was perceptible to digital examination, answered the condition of the policy. 
upon examination, such as inspecting the interior of the body, whether that examination is made before or after death. ${ }^{75}$

Some policies limit the recovery of the beneficiary, in cases of death where there exist no external or visible marks upon the body of wounds sufficient to cause the death, to a fraction of the amount of the policy otherwise payable. And under such a provision the contusion or wound, of which there is a visible or external mark, must be sufficient to cause death in order that the company shall be liable for the face of the policy. ${ }^{78}$

The general rule as to the burden of proof in contracts containing conditions of this nature which limit the liability of insurance companies does not apply in the case of this proviso.

75 Freeman v. Mercantlle Mut. Acc. Ass'n, 156 Mass. 351, 30 N. E. 1013, 17 L. R. A. 753. Here the assured died as the result of peritonitis, localized in the region of the liver, induced by a fall. Union Casualty \& Surety Co. v. Mondy, 18 Colo. App. 395, 71 Pac. 677. Here the assured died from concussion of the brain, due to a blow on the head. There were no external marks upon the body of the assured, but an autopsy disclosed a redness of the tissues of the brain on one side, and the court declared this sufficient to comply with the terms of the condition.

76 Atna Life Ins. Co. v. Bethel, $140 \mathrm{Ky} .609,131$ S. W. 523. Here the policy provided: "In the event of death following bodily injuries of which there existed no external or visible mark upon the body of contusion or wound sufficient to cause death," the limit of liability should be one-fifth of the anount otherwise payable. The court says: "It is apparent that the policy contemplates two kinds of accidental death-one in which there are external and visible marks upon the body of contusion or wound sufficient to cause death, and the other in which there are no external or visible marks of contusion or wound upon the body. That the company had the right to thus classify the subjects of its insurance, and to provide that in one class they should receive larger indemnity than in the other, we have no doubt. * * * It provides that the contusion or wound must be 'sufficient to cause death,' and, if it is not, only one-fifth of the amount shall be payable. In other words, although the contusion or wound may have been serious, as well as external and visible, and have been produced by an accidental injury, yet unless it was sufficient to cause death the indemnity is reduced. It is only in cases where the wound or contusion is sufficient in and of itself 
It is incumbent upon the plaintiff, in order to maintain his action, to show by affirmative proof that the assured has sustained death or bodily injuries through external, violent, and accidental means, that these injuries alone caused the disability or death within the prescribed time, and, further, that there was upon his body an external and visible mark or sign of the injury which it is claimed that the assured sustained. ${ }^{77}$

Violation of a Law.-In most policies of accident insurance, as in life insurance policies, the death or injury of the insured while engaged in or resulting from the violation of any law is declared an excepted risk. The general principles which govern the construction and application of this provision are much the same in both cases. This condition in insurance policies is intended, first, to exempt the insurance company from that increased liability to death or injury which must attend acts of violence or violations of law, and, second, as a matter of public policy. ${ }^{78}$ It is axiomatic that one should not be permitted to benefit by the infraction of the law. And conditions exempting the company from liability, or limiting the amount of liability, are clearly valid and enforceable.

to cause death, independent of any other cause, that the full indemnity can be demanded."

77 Gale v. Mutual Aid \& Accident Ass'n, 66 Hun, 600, 21 N. Y. Supp. 893. But where the insurance company in the pleadings admits the death of the assured from erysipelas, ensuing upon the accidental cutting and laceration of one of his fingers, the subsequent allegation that "there was no visible mark of said alleged accidental injury upon the body of plaintiff's testator" was repugnant to the admission, and the defense was not well pleaded. Beruays $\nabla$. United States Mut. Acc. Ass'n of New York (C. C.) 45 Fed. 455.

78 Hatch v. Mutual Life Ins. Co., 120 Mass. 550, 21 Am. Rep. 541. Here the assured died as the result of an illegal operation, performed with intent to cause an abortion. The court declared: "We are of oplnion that no recovery can be had in this case, because the act on the part of the assured causing death was of such a character that public policy would preclude the defendant from insuring her against its cousequences." 
Not every act against public policy will per se relieve the company from liability unless it increases the risk assumed by the policy. It could hardly be claimed, for example, if a man should enter into an illegal conspiracy to prevent competition at a public sale, that in the event of his injury or death the contract of insurance would be void, because the act was against public policy. Similarly, if a policy holder should enter into a conspiracy to control the acts of public officials, or should enter into a marriage brokerage contract. Briefly, the rule may be stated as follows: A violation of a positive law, whether civil or criminal, avoids the policy, if the natural and reasonable consequences of the violation are such as increase the risk. But the violation of a law, either civil or criminal, does not avoid the policy, if the natural and reasonable consequences of the act are not such as increase the risk. Ordinarily the facts in each particular case must determine whether there is a causative connection between the violation of the law and the injury or death of the insured. ${ }^{78}$

79 Cluff v. Mutual Ben. Life Ins. Co., 95 Mass. (13 Allen) 308 and Id., 99 Mass. 317. Here the policy contained a clause providing that it should be void "in case the insured shall be injured or killed in the violation of any law." Cluff was the owner of a plantation in Lonisiana on which lived a family by the name of Cox. Cox was in arrears in his rent. In attempting to forcibly evict Cox, Cluff visited the plantation, where he met his tenant sitting in his wagon driving a span of horses. Cluff seized the horses by the bridle, and announced his intention of retaining them as part payment of the obligation. The testimony as to just what occurred was conflicting. It tended to establish, however, the fact that, after Cluff seized the lines, Cox, who had jumped from the wagon, started for the house, but, as he approached the rear of the wagon, he turned, drew a revolver, and shot Cluff. Cluff did not claim any right of lien or any legal title to the property which he was attempting to seize. The opinion of the Massachusetts court in this case was that, to avold the policy, there must be a violation of some criminal law, and that a mere trespass against property is an infringement of civil law, to which no criminal consequences are attached, and would not relieve the company from its obligation. The case recited did not show that Cluff was engaged in the commission of acts which

Fuluer Acc.Ins. -9 
In order to relieve the insurance company from liability, it is not necessary that the assured should realize that this criminal act will expose his life to danger. It is sufficient if such a result does ensue. The injury must be a result of a violation of the law in order to discharge the company from liability. If one should deliberately or intentionally kill another because of the violation of some civil right, such as walking across his property without permission, the case would not come within this proviso, inasmuch as the unlawful act of the deceased would be a wholly insufficient cause for shooting. But where the assured is guilty of some violation of the law, from which death or injury would be the reasonable and natural result, the insurance company would be exempt; for example, where a policy holder commits assault and battery, as the result of which he is killed. ${ }^{80}$

would constitute either robbery or larceny, since he supposed he was within his legal rights. In Bradley v. Mutual Ben. Life Ins. Co., 45 N. Y. 422,6 Am. Rep. 115, the courts of New York took issue with the Massachusetts court and declared that such a violation need not be of the criminal law alone, but that under certain circumstances the violation of a civil law would release the insurance company from its obligation. In both cases the point at issue was whether the killing of Cluff was a natural result of his attempt to forcibly seize the horses. In both states the courts agreed that the policy could not be avolded by the mere fact that at the time of his death the assured was violating a law, if death resulted from acts not involved in such a violation. The court held that the proximate and not the remote cause must be considered, and if the evidence showed that the death of Cluff was the natural, reasonable, and legitimate consequence of his acts, then the company would not be liable. The question was one of fact for the jury to determiue.

80 Bloom v. Franklin Life Ins. Co., 97 Ind. 478, 49 Am. Rep. 469. Here the assured committed assault and battery on the wife of his brother. The brother, in defense of his wife, struck the assured upon the head with an instrument, fracturing his skull, from which death ensued. The court held that the assured, in committing the assault upon the woman, had violated the law, as the proximate resuit of which he was killed. One who commits such an act must reasonably expect to meet resistance. Morris v. Travelers' Ins. Co. (Tex. Civ. App.) 43 S. W. 898. Here the assured entered the private 
In most cases the violation of the law must be a known one, and, generally speaking, the assured must be aware that he is violating the law, in order to release the insurance company. The fact that the assured may be drunk at the time of violating a law will not, however, change the effect of this condition, for a man who voluntarily makes himself drunk is, so to speak, responsible for his own irresponsibility. ${ }^{81}$

The violation of the law, most frequently cited in such a condition, releases the company from liability in case of death or injury while fighting. If both parties willingly engage in a fight, and the insured is injured as a result thereof, the insurance company is clearly exempted from its liability. The relation between the combat and the injury must, however, be clearly established. The death of one who was shot by a man whom he has attacked would clearly be within the condition of exemption. ${ }^{82}$

oftice of an acquaintance whom he cursed and abused. The man left his office to avoid him. Morris followed him into the hall, shaking his finger menacingly at him, and finally striking him. A fight ensued. Morris, drawing back, reached his hand in the direction of his 'hip pocket. His adversary then shot him through the body, killing him. The court held that there could be no recovery on the policy.

81 Bloom v. Franklin Life Ins. Co., 97 Ind. 478, 49 Am. Rep. 469, supra.

82 Murray v. New York Life Ins. Co., 96 N. Y. 614, 48 Am. Rep. 658. Here the assured, W., and his brother, S., planned an assault on B., and in pursuance of the plan S. seized B. by the arns and held him, while W. beat him with a hammer. B. succeeded in drawing a revolver and shooting W., who sought to escape. B. testified that in the struggle with $\mathrm{S}$. the pistol was accidentally discharged. The death of W., however, was clearly the result of his violation of the law, and the policy was thereby rendered void. The court here said, inter alia: "The proviso clearly exempts the company from all risks of life which attend the violation of law, and which are the natural and reasonable concomitants of the transaction. Prize fighting is prohibited by law, and is attended with some danger. Suppose in such a friendly contest by mishap one of the combatants strikes a blow which causes the death of the other. 
Where the assured is forced to fight as a matter of selfdefense, or while retreating, the insurance company will not be excused from liability under such a clause in the policy. ${ }^{83}$

Would a death under such circumstances be a death in the violation of law within the policy, although there was no intention to kill? However this might be answered, we think it is clear that there may be a death in violation of law within the meantng of the policy, although not intentionally inflicted, and although it was not occasioned by the act of another. A burglar, who, in consequence of a misstep, or to escape detection, falls or jumps from the roof of a house which he is attempting to enter, and is killed, dies in violation of law as plainly as if he had been shot by the owner in defense of his bullding. In the former as in the latter case, the death results from the criminal act, within the policy, as a natural and reasonable consequence, because, although the immediate cause of the death was the fall, yet the exposure to the danger was encountered in the prosecution of the criminal purpose. Another case may be stated, of which there may, perhaps, be more doubt. Suppose the assured in this case, instead of having been killed by the pistol, had, in the struggle with Berdell, ruptured a blood vessel, or, being predisposed to heart disease, it had been brought on by the excitement of the affray, and he had died from either of these causes in the midst of the struggle. Death from a rupture of a blood vessel, or from the disease of the heart, occurring independently of any violation of law, would be covered by the policy. The company assumes the risk of death from these causes under ordinary circumstances. But do they assume such risk when the immediate, exciting cause of the death is a struggle originating in criminal assault in which the deceased was engaged at the time? To exempt the company, must the death result from some peculiar and special risk connected with the commission of crime? It seems to us not, and that it is sufficient to bring a case within the condition, if there is such a relation between the act and the death that the latter would not have occurred at the time if the deceased had not been engaged in the violation of law." See, also, Gresham v. Equitable Acc. Ins. Co., 87 Ga. 497, 13 S. E. 752, 13 L. R. A. S38, 27 Am. St. Rep. 263. Here the assured was killed as the result of a fight in which he voluntarily engaged and which he largely provoked.

88 Robinson $\nabla$. United States Mut. Acc. Ass'n (C. C.) 68 Fed. 825. Here the assured while engaged in an altercation was shot by his adversary, who mistakenly supposed be was armed. The assured had not assaulted his adversary, nor even made any menacing gestures, at the time he was killed, but was the victim of the nervous apprehension of the other party. See United States Mutual 
And where the assured is within his legal rights in engaging in a combat, this condition of the policy will not relieve the company from its liability. For example, where the assured, classified as a bartender, as one of his duties is obliged to keep the saloon free from quarrelsome patrons, the company will be liable on its policy, even where the assured is injured while engaged in a fight necessarily encountered while ejecting a trouble-maker. ${ }^{84}$

Accident Association v. Millard, 43 Ill. App. 148, where the assured was struck as the result of a remark which he had addressed to an adversary. The court held that the company was not liable, inasmuch as the assured at the time he was injured had engaged in a fight, even though he himself was not the aggressor. Harper's Adm'r v. Phœnix Ins. Co., 19 Mo. 506. Here the assured was killed after retreating from an altercation which he commenced under circumstances which would render his adversary guilty of felonious homicide. The company was held liable under its policy.

84 Coles v. New York Casualty Co., 87 App. Div. 41, 83 N. Y. Supp. 1063. Here the policy contained a clause exempting the company from liabiltty for injuries resulting, directly or indirectly, wholly or in part, from fighting. The assured, classified as a bartender, was permitted to recover for injuries sustained by him while defending himself from an assault committed upon him by a person whom he had lawfully ordered out of the bar-room, in which he was employed, because of such person's violent and offensive language. Here it did not appear that the injuries were sustained while he was actually engaged in an attempt to forcibly eject the offending person. The court said: "The fact that the plaintiff was injured * * * while forcibly resisting the assault which he testified was made upon him, and even the fact that he was injured while pushing the aggressor from the room in the course of such resistance, does not necessarily as a matter of law operate to deprive him of all claim under the policy; for it cannot be deemed within the contemplation of the contract, in the absence of an express provision to that effect, that the assured should submit without opposition to whatever violence may be offered him. The interests of the insurance company as well as his own require that he should avail himself of such reasonable means of self-protection from unjustifiable injury as may be at his command. Nor can the mere fact that he ordered his assailant from the room, assuming that it was his duty to do so, be regarded in law under the circumstances of the case as either inviting or commencing a fight, quarrel, or altercation." 
The assured will be permitted to repel violence. In Accident Ins. Co. of North America v. Bennett, the Supreme Court of Tennessee, clearly stated the law governing the liability of the insurance company under such conditions. The court said that if the jury found the assured died from a wound brought about by a quarrel which he provoked, and from which he might reasonably expect bodily injury, then the plaintiff cannot recover. On the other hand, if he could not reasonably have expected anger to be provoked therefrom, then he can recover. Such a provision must have a reasonable construction. It cannot be held to mean that every frivolous controversy, which might in some sense be termed a quarrel, although it was not a dispute or a quarrel from which the insured might reasonably have expected anger to be provoked or injury to result, is within the meaning of the term used in the policy. ${ }^{85}$

In this line of cases the courts have required insurance companies to prove that the injury or the death of the assured was the result of a violation of the law, in order to exempt themselves from liability under this condition. It has been held, under a policy exempting the company from liability where the assured "died while violating any law," that where the assured was killed while escaping from a building which he had robbed the company will nevertheless be liable. ${ }^{86}$

The company will be liable where the assured is killed while living with a woman with whom he maintained im-

8590 Tenn. 256, 16 S. W. 723, 25 Am. St. Rep. 706.

86 Griffin v. Western Mut. Benev. Ass'n, 20 Neb. 620, 31 N. W. 122, $57 \mathrm{Am}$. Rep. 848. Here the assured went with an accomplice into the treasury department of the state of Nebraska in the daytime and demanded money belonging to the state. He was given $\$ 500$. While leaving the office he was commanded to halt by a policeman, who at the same time shot him dead. The court held 
proper relations. ${ }^{87}$ Similarly, where the insured is killed after visiting a house of ill fame; ${ }^{88}$ also, where the assured was shot by an enraged husband immediately after he had committed adultery. ${ }^{89}$ And where the assured was a de-

that, inasmuch as the assured had obtained the money and was endeavoring to escape when killed, he was not at the instant of the killing violating any law, and therefore the company was liable. This case was decided on the theory that the violation of the law had been completed before the assured was shot, and the court said: "Suppose that, instead of robbing the treasury, he had made an assault upon the treasurer in his office, ** * and had left the treasury department and nearly reached the outer door of the capitol when he was killed, it will not be contended that at the time of his death he was violating the law. So in this case the act of Griffin in obtaining money from the treasury had been completed and he was then endeavoring to make his escape." The court in this case, however, seems to have violated every rule of logic and to have given support to an absurdity. If Griftin's death did not result from his violation of the law, it is difficult to imagine from what it did result. In its effort to construe the policy favorably to the assured, the court has plainly tortured its meaning.

87 Accident Ins. Co. of North America v. Bennett, 90 Tenn. 256, $16 \mathrm{~S} . \mathrm{W} .723,25 \mathrm{Am}$. St. Rep. 706. Here the condition in the policy exempted the company from liability for injuries sustained by the insured while "engaged in, or in consequence of, some unlawful act." The assured was killed by a pistol shot through the heart while living with a woman in a state of fornication. There was no proof that such fornication was the cause of the injury, or that it constituted a violation of criminal law, and no suggestion of any causative connection between this relation and the assured's death. The court held that while this relation might be immoral, yet, if it lacked publicity and notoriety, it was not uulawful within the meaning of the clause.

88 Jones v. United States Mut. Acc. Ass'n of City of New York, 92 Iowa, 652, $61 \mathrm{~N}$. W. 4S5. Here the assured, with a companion, visited a house of ill fame. They left the house, and while on the street a quarrel ensued, and the assured was killed. The court held that the company was liable, inasmuch as no actual relation existed between his death and his visit to the house of ill fame.

89 Goetzman v. Connecticut Mut. Life Ins. Co., 3 Hun (N. Y.) 515, where the assured was caught while engaged in illicit intercourse with the wife of another. The court said: "Assuming that the act of adultery was a violation of law within the meaning of the parties to the contract of insurance, we are of opinion that the assured did 
serter from the army, and was shot and killed by an officer while seeking to avoid capture; ${ }^{90}$ where the assured was injured on Sunday while visiting a friend after hunting, although Sunday hunting was prohibited by law; ${ }^{\theta 1}$ where the assured was killed shortly after committing a misdemeanor by shooting dice; ${ }^{\boldsymbol{2}}$ where the assured at the time of the accident was intoxicated in violation of the law. ${ }^{93}$

not die in consequence of it. The undisputed facts show that he was killed not in the act of adultery, nor in the defense of person or property. The offense had been completed, and the assured was about to go away. He was not, therefore, at the time he was killed, violating any law, or even committing a trespass; for he was in the house by the license of the wife, from whom the husband had separated. * * We cau conceive of no principle upon which it could be properly treated in a court of justice as a natural or legitimate effect of the cause stated."

90 Utter v. 'Travelers' Ins. Co., 65 Mich. 545,32 N. W. 812,8 Am. St. Rep. 913. Here the assured, a deserter from the army, was shot by a deputy sheriff in a louse of ill fame, where the officer went to arrest him without a warrant. The court declared that it could not be held as a matter of law that the insured was engaged in an unlawful act within the meaning of the policy. If he had been shot in the act of deserting, the court said this claim might be made with some reason and propriety. He was neither shot because he was a deserter, nor because he was in a house of ill fame. He was shot because he did not throw up his hands when commanded to do so, and because he was in the act of drawing a pistol.

91 Prader v. National Masonic Acc. Ass'n, 95 Iowa, 149, 63 N. W. 601. Here the assured, with some companions, drove into the country for the purpose of hunting. While stopping at the home of a friend, the assured stepped into a hole, dislocating his ankle and breaking his leg. The Code prohibited hunting on Sunday. The court held that the injury was not in any way connected with the hunting.

92 Standard Life \& Accident Ins. Co. v. Fraser, 76 Fed. 705, 22 C. C. A. 499. There was no evidence to show that any quarrel had arisen as the result of the game, or that there was any causal connection between the dice game and the tragedy.

93 National Benev. Ass'n v. Bowman, 110 Ind. 355, 11 N. E. 316. Here the assured was injured by being thrown from a wagon. The evidence showed no causative connection between his intoxication in violation of the law and the injury which he sustained. The 
Most states possess more or less rigid Sunday observance laws. Where the assured is killed while violating such an ordinance or statute, the company will be liable on its policy, despite a condition exempting it where the assured is injured while violating a law, unless the causative connection between the violation of the statute and the injury which results in death or disability is clearly established. In order to relieve the insurance company, the violation of the law must increase the risk under the policy. ${ }^{94}$ Thus it

company was held liable under the policy. Conboy v. Railway officials' \& Employés' Acc. Ass'n, 17 Ind. App. 62, 46 N. E. 363,60 Am. St. Rep. 154. Here the assured at the time of his death was seining in the current of a river in which there were holes or sudden step-offs. The assured stepped into one of these holes and was drowned, as he was unable to swim. The insurance company alleged that the assured was violating a statute against seining in streams where the water was above tide water. The court here held that the company was liable, unless it appeared that the violation of the law was an act which increased the risk, and one between which and the death of the assured there was a causative connection. Collins v. Bankers' Acc. Ins. Co., 96 Iowa, 216, $64 \mathrm{~N}$. W. $778,59 \mathrm{Am}$. St. Rep. 367. Here the assured was drowned while fishing in a boat on a daris night in unfamiliar waters. The boat was upset by striking snags in the river. The insurance company claimed exemption, on the ground that the assured met his death while, or in consequence of, violating the law, which prohibited fishing with a trot line. As a matter of fact, the law did not prohibit fishing with a trot line, but merely prohibited the placing of a trot line in such a way as to obstruct the free passage of fish in the water.

84 Eaton v. Atlas Acc. Ins. Co., 89 Me. 570, 36 Atl. 1048. Here the assured attended a funeral on his bicycle, and then for exercise rode home in a roundabout way. The court held that this was not a violation of the Revised Statutes of Maine relating to the observance of the Sabbath, and hence an injury received while he was so engaged should not release the company from liability. Matthes $\mathbf{v}$. Imperial Acc. Ass'n, 110 Iowa, 222, 81 N. W. 484. Here the assured, a house painter, was injured by the breaking of a track supporting a rope scaffolding on which he was climbing to the cupola of his barn, while attempting to secure pigeons for his Sunday meal. The court held that the company was liable; the burden of proof being on the defendant to prove that the assured was not performing a 
has been held that the company will not be liable where the assured is injured while hunting on the Sabbath in violation of Sunday observance laws. ${ }^{95}$

work of necessity, which otherwise would have been a violation of the Sunday code. The court said: "We may further suggest that the violation of law mentioned in the policy is evidently intended to comprehend acts that will avoid the risk if done at any time. They must be in the nature of contributing causes, and not mere conditions of the accident. In this case the risk would have included plaintiff's acts if done on a secular day. Therefore we see no reason why it should not cover them when done on Sunday."

95 Duran v. Standard Life \& Accident Ins. Co., 63 Vt. 437, 22 Atl. 530, 13 L. R. A. 637, 25 Am. St. Rep. 773. Here the assured, whlle returning from a combined hunting and visiting expedition on Sunday, was injured by slipping and falling upon a frozen plowed field which he was crossing. The policy provided that the company should not be liable for any injury "resulting wholly or partly, directly or indirectly, from any of the following acts, causes, or conditions, or one affected by any such act, cause, or condition, or any of its influences." Among the acts specified was "the violation of any law." The court held that the assured was violating the law, both as to huntling and traveling on Sunday, and said: "At the time of the accident, the plaintiff was engaged in hunting. He had his gun with him, and was ready to shoot any game he might see, whether in the field or along the highway on his way home. He started out to secure game, wherever he might find it, and it does not appear that at the time of the accident he had abandoned this purpose. In hunting he was violating the law of the state. The traveling of the plaintiff was as much a part of his act of hunting as carrying his gun and ammunition, or shooting or capturing game when the opportunity occurred in the course of the hunt. Without walking, the plaintlff could not have engaged in his hunt. Thus the accident was caused directly by the plaintiff's violation of the law in hunting. 'The effect of the violation of the Sunday law upon a person's right to recover for injuries received in the course of such violation has generally arisen in cases in which the defendant sought to escape responsibility for his own tort to a traveler or laborer. On this question the decisions have not been uniform. Some courts have held that the immediate cause of the injury was the travel or labor on Sunday, and that the plaintiff could not recover. **** Other able courts have held that a Sunday traveler or laborer, injured by the wrongful act or neglect of another, might recover, upon the ground that the violation of the Sunday law by the injured party is in the nature of a condition rather than an immediate cause of the injury. * * If being engaged in the unlawful expedition was 
The company will not be liable where the assured is injured while engaging in horse racing in violation of the statute prohibiting racing for money. ${ }^{96}$

The courts have held that, in order to exempt the company from liability under this condition of the policy, the assured at the time of his injury must have actually been engaged in violating the law, and that the company will be liable unless the assured has passed beyond the point of making preparations or intending to violate the law. So the insurance company was held liable where the assured was injured on his way to kill prairie chickens in violation of the statute, he not having as yet actually shot any. ${ }^{97}$

not the immediate cause of his injury, it was certainly the condition causing it. * * * Every step he took in making that trip was in and of itself a riolation of law. In taking one of those steps, he slipped and was injured. We think it would saror too strongly of hair-splitting refinement to hold that the injury was not directly caused by the violation of law in traveling. * * * The liability to accident must be greatly enhanced in the case of a person who, like the plaintiff, engages in hunting or traveling about the country on Sunday, in open violation of law, as compared with one who observes the law. The defendant had a right to say that it would not assume such increased risk."

26 Travelers' Ins. Co. v. Seaver, 86 U. S. (19 Wall.) 531, 22 L. Ed. 155. Here the assured, with another man, was racing horses for money in violation of the statute. A collision ensued, and the assured jumped to the ground from his sulky, and while seizing the reins became tangled in them, fell down, and was dragged, as the result of which he was killed. The insurance company was released from liability on the policy. The court held that the jumping from the sulky, the entanglement in the reins, and the injury were immediate in their relation to the racing, and were manifestly a portion of the same transaction, so as to be a direct sequence of the violation of the law. Mr. Justice Miller, in delivering the opinion, declared it was "against this general species of danger attending nearly all infractions of the law that the company sought to protect itself by the clause in question."

o 7 Cornwell v. Fraternal Acc. Ass'n, 6 N. D. 201, 69 N. W. 191, 40 L. R. A. 437, 66 Am. St. Rep. 601. Here the assured was starting out to hunt prairie chickens at a time of the year when it was nnlawful to kill this game. While climbing a bank, his foot having slipped, 
Where an ordinance forbids passengers remaining on the platform of a street car, the company is liable where the assured was injured while attempting to board a slowly moving train; ${ }^{98}$ and leaving a train while in motion at a point other than the depot will not release the company from liability, although in violation of a statute. ${ }^{99}$ The violation of a statute forbidding the crossing of a railroad track except at a street

he caught hold of a bush and was in the act of drawing himself up by this means, when his gun was accidentally discharged; the contents lodging in his left hand, necessitating its amputation. The court beld that the company was liable, since the assured had not then committed any infraction of the law in attempting to kill prairie chickens, although he had formed the purpose to shoot them and had made preparations to accomplish that object.

98 Johanns v. National Acc. Soc., 45 N. Y. Supp. 117, 16 App. Div. 104. The court here held that such an ordinance had no application to the act at issue, since it only forbids passengers to remain on the platform of the car.

92 Smith v. Atna Life Ins. Co., 115 Iowa, 217, 88 N. W. 368, 56 L. R. A. 271, $91 \mathrm{Am}$. St. Rep. 153. Here the assured was injured while attempting to leave a moving train at a point other than the depot, in violation of a law making it a misdemeanor to get on or ofi" of railway cars while in motion. See, also, National Life \& Accident Ins. Co. $\nabla$. Lokey, 166 Ala. 174, 52 South. 45. An ordinance prohibited persons from catching hold of or swinging upon cars of a railroad company when they were in motion. The court held that alighting from a train while in motion did not constitute a violation of such ordinance. In Diddle v. Continental Casualty Co., 65 W. Va. 171,63 S. E. 962,22 L. R. A. (N. S.) 779 , the court held that a railroad employe or passenger, who jumped on or off a moving train, did not violate a section of the Code making it criminal for persons, not passengers or employés of railroads, to jump on or off of railway engines, cars, or trains. But see Flower v. Continental Casualty Co., 140 Iowa, 510, 118 N. W. 761, where the policy limited the liability of the company to $\$ 100$ if the assured came to his death while violating the law. The assured, neither an employe of the railroad nor an officer of the law, was injured while trying to get on a moving freight car, contrary to a section of the Code. The court sald: "The manifest design of the exception in the policy is to guard against liability owing to the exposure to dangers incident to the performance of unlawful acts, and to that end only the lesser liability attaches where injury is received while the insured is violating law, even though the offense is never consummated." 
does not release the company from liability, where the assured is killed while crossing a track at a point where it has been used by the public for so long as to amount to a license. ${ }^{100}$

In cases arising under a policy containing the condition under discussion, the insurance company must establish by a preponderance of evidence the fact that the assured was violating a law within the condition in order to relieve itself of liability. The assured or his beneficiary must first establish a prima facie case by showing that he has abided by the conditions of the policy and that the injury or death on which action is brought was occasioned by accidental means. But it is not necessary that he should anticipate the defense of the company, by proving that the assured did not violate any of the conditions of the policy. ${ }^{101}$ This condition, as well as all others in contracts of insurance, are construed more liberally in favor of the assured.

Intoxicants.-Most policies of accident insurance contain a clause exempting the company from liability for death or injuries which may happen to the assured "while intoxicated," or "in consequence of having been under the influence of in-

100 Lehman v. Great Eastern Casualty \& Indemnity Co., 7 App. Div. 424, 39 N. Y. Supp. 912, affirmed without opinion 158 N. Y. 689, 53 N. E. 1127. Here the assured was killed by a locomotive while crossing a railroad track at a point which the public had used for a period of years with the acquiescence of the railroad company. The court held that it would require a somewhat technical construction of the section to hold that the people avalling themselves of this privilege became ipso facto criminals. See, also, Whalen v. Peerless Casualty Co., 75 N. H. 297, 73 Atl. 642, 139 Am. St. Rep. 695, where the court held that crossing a railroad track did not constitute a violation of law, unless notices were posted according to statute where they could be seen and read by reasonable care.

101 Bloom v. Franklin Life Ins. Co., 97 Ind. 478, 49 Am. Rep. 469; Matthes v. Imperial Acc. Ass'n, 110 Iowa, 222, 81 N. W. 484; Duran v. Standard Life \& Accident Ins. Co., 63 Vt. 437, 22 Atl. 530, 13 L. R. A. 637, 25 Am. St. Rep. 773. 
toxicating liquors." The language in which this exception is framed varies widely. Some policies provide that the company shall not be liable for accidents which may occur "while the insured is intoxicated," while other policies exempt the company from liability for injuries which happen because of the assured "having been under the influence of intoxicating liquors at the time of the death or accident."

The courts have found it difficult to determine when a man is drunk. The phrase "under the influence of intoxicating liquors" does not refer to slight exhilaration resulting from a reasonable indulgence in liquor, where the passions are not visibly excited, nor the judgment or mental and physical functions impaired. It embraces rather a condition where the physical and mental faculties are so affected as to render them incapable of performing their natural functions. Insurance companies thus seek to protect themselves from liability for accidents which are likely to occur while the assured is under the influence of an intoxicant, which interferes with the full and deliberate exercise of his faculties and renders him unable to protect himself from danger. They seek, further, to absolve themselves from liability for reckless and imprudent acts induced by the use of intoxicants. While it is true that a man may to a certain extent be under the influence of intoxicating liquor after taking a single drink, yet a recovery under the policy will not be defeated where the assured retains the full control of his faculties. In order to exempt the company from liability, there must be some undue or abnormal excitement produced by intoxicants. The courts almost uniformly hold that in accident policies the phrase "under the influence of intoxicants" is synonymous with the word "intoxication." 102

102 Bakalars v. Continental Casualty Co., 141 Wis. 43, 122 N. W. 721, 25 L. R. A. (N. S.) 1241, 18 Ann. Cas. 1123. Here the policy 
Where the policy provides that the company will not be liable for injuries occurring to the assured "while under the influence of intoxicants," it is not necessary that the intoxication of the assured shall in any way contribute to his injury or death, in order to free the company from its liability. Under such a policy right to indemnity is lost if the assured is intoxicated at the time of receiving the injury, even though there may be no causal relation between the intoxication of the assured and the accident; none the less the company will be exempt only if the assured is actually intoxicated at the time of the accident. In short, the policy is suspended for

provided that the insurance company would be liable only for a reduced amount for death or injuries "where the accidental injury is sustained while the insured is insane, delirious, or under the influence of any intoxicant or narcotic." The assured, a locomotive fireman, on the day of the accident took his usual route from his home to his place of employment at the roundhouse through the railroad yards. His injuries tended to show that he had been struck and run over by a passing engine. Evidence was introduced to show that he had been drinking before the time he was thus killed. The court said: "The 'influence of intoxicants' is a very elastic term. We are told by physicians and experimenters that the most trifling quantity of alcohol has some effect, and that its effect persists for days, if not permanently, so that one is literally under the influence from a single ordinary portion. We know as a matter of common knowledge that one of the first influences may be to stimulate those very faculties of observation and alertness which would improve the capacity of the subject to shield himself from danger, or escape, and that some such degree of influence of an intoxicant would not in any respect increase the peril of injury. It is therefore a natural and almost necessary assumption that these words were not inserted in the policy for the purpose of depriving the assured of the benefit thereof in case of every and any influence of intoxicating liquors, however slight and however nonprejudicial to the insurer. The field, therefore, is open for construction to ascertain just what degree or kind of influence is referred to. As already said, we must presume that it means such and so much influence as impairs the ability of the subject to care for himself, and thus increases the probability of his suffering accidental injury. In light of such reasoning it has been decided by all courts speaking upon the subject that 'influence of intoxicants' in accident policies means the same thing as the word "intoxication." " 
the time and the policy holder receives no protection while intoxicated. ${ }^{103}$

Where the policy provides that the company will not be liable for injuries received "in consequence of having been un-

103 Mossop v. Continental Casualty Co., 137 Mo. App. 399, 118 S. W. 680 . The policy provided that the company should not be liable for disabilities arising from an accidental injury received while the assured was under the influence of any intoxicant. The assured went into a saloon, but the proprietor refused to serve him, because of his condition, and because of trouble with him on former occaslons. While leaving the saloon, he slipped off the platform and struck his knee against a post, fracturing the kneecap. The court said: "By virtue of said proviso the company was as much exempt from liability for plaintiff's loss of time, if the loss was due to an injury recelved while he was intoxicated, but not in consequence of intoxication, as if the latter brought about the injury. Counsel agree that, if the intention was to exclude liability for an injury received while plalntiff was intoxicated, regardless of a causal counection between his state and the injury, it was useless to insert the exemption, for an injury resulting from intoxication as the first proviso would embrace the latter. So it would; but we take the purpose to have been to word the contract so no doubt could arise about the nonliability of defendant in either event. Again, it is said to be unreasonable to excuse defendant merely because plaintiff was intoxicated, if the accident would have happened anyhow. An illustration is brought forward of this kind: Suppose he had been burt, while intoxicated and on a street car, in a collision of the car with another; would defendant be exempt? We answer that any insurance company has the right to refuse to insure men against accidental injury while they are intoxicated, and there are good reasons why they should refuse to do so, to wit, when a man is drunk he is less able to take care of himself, is more quarrelsome, and hence more likely to get hurt than when he is sober; and, if hurt, he may believe and testify his conduct had nothing to do with the accldent, and obtain a verdlet on that theory, when in truth intoxication led to the injury. Instances will occur where it is extremely difficult to determine what influence a state of intoxication had in bringing about an accident. We need not speculate on the reasons for the terms of this contract; suffice to say they are not against public policy, must be supported according, to thelr reasonable meaning, and there is no doubt cast on their meaning by the language used or pertinent autborities. The courts uniformly hold, in construing a policy like the one in suit, that if the insured is Injured while in an excepted state, or doing an excepted act, the company is not liable."

Standard Life \& Accident Ins. Co. v. Jones, 94 Ala. 434, 10 South. 
der the influence of intoxicants," the insurer will be exempt if the death or injury results from the intoxication of the assured, although at the time of the injury he may not be actually drunk. In order to render the condition operative, the liq-

530. Here the assured, a switchman, while under the influence of intoxicating liquors, in the nighttime, jumped from his engine in motion, with his back toward the direction in which the engine was going. The court declared that the company was not liable.

Shader v. Railway Passengers' Assur. Co., 66 N. Y. 441, 23 Am. Rep. 65, affirming 5 Thomp. \& C. (N. Y.) 643. The policy here in suit contained a similar clause, exempting the company from liability where the assured was injured while under the influence of intoxicating drink. The assured and a friend, when considerably affected by liquor, engaged in an argument over their skill at shooting. The policy holder declared that his friend could not shoot a frog, to which the friend replied that he could shoot the assured in the ear. The assured offered him the opportunity to do so for ten cents. The bullet struck the assured in the stomach, causing his death within a few days. The court held that, in view of the clause exempting the company from liability for injury or death happening to the assured while under the influence of intoxicating drink, the company was not liable, and that it was not necessary to establish any causal relation between the intoxication and the death. Furry's Adm'r v. General Acc. Ins. Co., 80 Vt. 526, 68 Atl. 655, 15 L. R. A. (N. S.) 206, 130 Am. St. Rep. 1012, 13 Ann. Cas. 515. The policy contained a clause limiting recovery to one-fifth of its face If the loss occurred "while under the influence of any intoxicant or narcotic." The night before the accident the assured was denied admittance to a fair because of his intoxicated condition. Soon after this incident he started down the railroad tracks to the rallroad yards, where he was employed. The next morning he was found sitting near a track, where a train had cut off one foot at the ankle. The court declared: "The exception under consideration is one that materially affects the risk. It is manifestly intended to require the insured to so limit his use of liquor that he will retain 'full control over his faculties of mind and body.' It is considered by no means unreasonable that the company should require that the insured be under no exciting influence that may affect his self-possession or judgment in the exercise of the faculties essential to his safety. If the plaintiff's intestate had not recovered the full use of the mental and physical powers available for his protection when in normal condition, he was still 'under the influence' of liquor within the meaning of the exception. $* * *$ If it be conceded that there may be a recovery, notwithstanding some impairment of the faculties from the immediate effect of drink, it

Fuller Acc.Ins.-10 
uor must have produced some abnormal effect-for example, where a man's nerves are so unsettled from the use of intoxicants that he loses his balance on the brink of a precipice and falls; where, as a result of their use, he does not comprehend danger, but deliberately courts it; or where his passions are so excited and his temper so aroused that he recklessly does acts dangerous in themselves, or by his insolent manner and speech invites danger from others. ${ }^{104}$

In the first condition, it is immaterial whether the intoxication is either the proximate or remote cause of the accident or death. But in the latter condition, in order to excuse the company from liability, it must be clear that the drunkenness was the proximate cause of the death or injury. The relation of cause and effect must exist between the use of liquor and the death or injury. ${ }^{105}$

In order to exempt the company from liability under this condition, it must appear that the assured has been actually intoxicated. The mere fact that he had had an opportunity to drink, and that his death occurred under circumstances suggesting that he was not in a normal physical condition at

is difficult to see upon what theory the courts can fix the limit that shall bar recovery." In Beard v. Indemnity Co., $65 \mathrm{~W}$. Va. 283, 64 S. E. 119, the court held that where an accident policy is conditioned against liability for injury happening while insured is intoxicated, and where a plea to that purport is to be successfully relied upon, the evidence must show that insured was actually intoxicated at the time the accident befell him, and said: "The mere fact that he had been drunk before does not prove that he was drunk at the time of the injury. Drunkenness at that time must be established, if it is to avail as a defense."

104 Campbell v. Fidelity \& Casualty Co. of New York, 109 Ky. 661, $60 \mathrm{~S}$. W. 492. Here the assured, a former member of the police force, became engaged in an argument with a policeman, whom he struck. Upon drawing a revolver, the policeman shot him.

105 Campbell v. Fidelity \& Casualty Co. of New York, $109 \mathrm{Ky}$. 661, 60 S. W. 492. Shader v. Railway Passengers' Assur. Co., 66 N. Y. 441, 23 Am. Rep. 65. 
the time of the accident, is not sufficient to exempt the company from liability. ${ }^{100}$

The mere fact that the assured had been drinking shortly before the accident will not exempt the company from liability, if it appears that he had been drinking but very little, acted normally, and was considered sober by those who served him. Nor will the fact that the assured is a man of intemperate habits exempt the company from liability, unless he was intoxicated at the time of the accident from which he sustained injury. ${ }^{107}$

106 Manufacturer's Acc. Indemnity Co. v. Dorgan, 58 Fed. 945, 7 C. C. A. 581, 22 L. R. A. 620 . Here it was shown that there was a supply of whisky in the fishing camp where the assured was staying. The assured was found dead in a stream where he had been fishing. The evidence showed that the party had taken wine, whis$\mathrm{ky}$, and beer with them on the trip. The court held that the mere fact that the assured had an opportunity to drink, and that death happened under circumstances suggesting some abnormal physical condition, was not sufficient to excuse the company from liability under this condition.

107 Prader v. National Masonic Acc. Ass'n, 95 Iowa, 149, $63 \mathrm{~N}$. W. 601. The evidence showed that the assured had been drinking some shortly before the accident which resulted in his death while on a hunting trip. It did not show that the deceased was injured while under the influence of liquor, and he was considered sober by those in company with him. The evidence that the assured had been intemperate at different times during the preceding year was not sufficient to prove that his death was caused by intemperance.

See, also, Couadeau v. American Acc. Co., 95 Ky. 280, 25 S. W. 6, $15 \mathrm{Ky}$. Law Rep. 667. Here the assured disappeared, and after some weeks his body was found in the river, but with no marks of violence upon it. On the evening when he was last seen the testimony showed that he had been playing cards in a saloon and was: considerably under the influence of liquor. He was last seen leaning in a helpless condition against a lamp post some distance from his. residence, and only a short distance from the river and canal, over which there was a small bridge. The court here held that the question as to whether his death was the result of intoxicants was for the jury to determine. Travelers' Ins. Co. v. Harrey, 82 Va. 949, 5 S. E. 553. Here the assured fell from a window of his home and received injuries from which he died. The evidence shored that 
The insurance company clearly will not be liable where the assured dies as a result of medical treatment administered to preserve the life of the policy holder, suffering from alcoholism. ${ }^{108}$ The intoxication of the assured after the accident upon which the claim for liability is predicated will not in any way excuse the company from its liability. ${ }^{109}$

Where the policy contains a condition providing that the company will not be liable where the assured or his beneficiary is guilty of fraud or concealment in attempting to obtain the indemnity, the company will be exempt where the assured claims not to have been under the influence of liquor at the time of his injury, and the evidence to the contrary shows him to have been notoriously drunk at that time. ${ }^{110}$

he had taken only two glasses of beer during the evening and was not to any extent under the influence of liquor.

108 Flint v. Travelers' Insurance Co. (Tex. Civ. App̄.) 43 S. W. 1079. Here the assured, a heavy drinker, went on a periodical spree, and while on such a debauch was taken to a sanitarium. for treatment for the whisky habit. As a part of the treatment, hypodermic injections of morphine were administered to him at intervals. From the immediate effect of these injections he died. The court held that the company was exempt from liability, because of the state of intoxication in which the assured was immediately preceding his death, and from the effects of which he was suffering at the timo thereof.

109 Rhodes $\nabla$. Railway Passengers' Ins. Co., 5 Lans. (N. Y.) 71. Here the evidence showed that the assured was intoxicated shortly after the accident on which the action was brought. The court in this case said: "The intemperance of the plaintiff was wholly immaterial in the case, unless it contributed in some degree to cause the injury." The condition of the policy was not set forth in the report of the case, but this obiter dictum of the court is against the weight of authority, since a lack of causal relation will exempt the company from liability only for accidents resuiting "in consequence" of intoxication.

110 Pyne v. Mutuai Accident Co., 2 Dauphin County' Rep. (Pa.) 110. Here the policy contained the following clause: "Fraud or concealment in obtaiuing membership, or attempting by like meaus to obtain indemnity, shall make this contract of insurance void." The testimony showed that the assured was drunk from Friday 
The question of drunkenness as affecting the liability of an accident insurance company is of material moment in considering a condition exempting the company from liability for injuries intentionally inflicted either by the assured himself or by a third party. While drunkenness is no excuse for crime, yet one may be so intoxicated as to be incapable of forming an intention, and thus, where the assured is assaulted by a man under the influence of liquor, the company will be liable if the evidence shows the assailant to have been so badly intoxicated as to be incapable of forming an intent to commit assault. ${ }^{111}$

Similarly, drunkenness may in itself be a violation of a law or ordinance. In a policy exempting the company from liability for accidents occurring while violating a law, unless the policy also contains a clause exempting the company for injury sustained by the assured while or in consequence of being under the influence of intoxicants, the company will not be excused unless there is established a causative relation between the violation of the law (here the drunkenness) and the injury. ${ }^{112}$ However, drunkenness is

evening until Sunday, that he had to be put to bed, that shortly therafter he arose, stumbled against a piece of furniture, and was unable to rise. He was put to bed again, and fell into a stupor. Later he was found in bed, with blood on his clothes, and evidences of disorder in the room. He claimed to have been attacked by a burglar. He died a month later as the result of the injuries he had received. He alleged in the formal proof of the injuries, submitted before his death, that he had taken only a glass of claret before retiring. The court held that the evidence showed that this was such a fraudulent concealment as would avoid the policy.

111 See Northwestern Benevolent Society v. Dudley, 27 Ind. App. 327,61 N. E. 207. Here the assured was bitten by a man who was under the influence of intoxicating liquor. The court said: "While drunkenness is no excuse for crime, the law recognizes, both in civil and criminal proceedings, that one may become so intoxicated as to be incapable of having an intention."

112 See National Benefit Ass'n v. Bowman, 110 Ind. 355, 11 N. E. 316. Here the assured was intoxicated, in violation of a criminal 
no excuse for such a violation of the law, as fighting or committing an assault. ${ }^{113}$

A condition in an accident policy providing that the insurance company shall not be liable for death resulting from intoxication is not void where the agent who receives and fills out the application knows the assured to be a man of intemperate habits, although the application states that his habits are temperate. ${ }^{114}$

In pleading on a policy of insurance containing this condition, the assured, or his beneficiary, need only allege in proper form compliance with the requirements of the policy, and that the disability or death was the result of an injury within the terms thereof. The company must first allege, and then prove, a breach of the condition under which it seeks to escape liability. ${ }^{115}$ And the burden of proof is on the insurance company to show that the assured received his injuries while intoxicated, within the intent and meaning of the condition. ${ }^{116}$

Where the insurance company in pleading fails to allege

statute, at the time of receiving his injury. The court held that the company would be liable, unless a causative connection was shown between the drunkenness and the injury sustained.

113 Bloom v. Franklin Life Ins. Co., 97 Ind. 478, 49 Am. Rep. 469. Here the assured committed an assault upon the wife of his brother. His brother, in protecting his wife, struck the assured with a jackplane, fracturing his skull, and causing his death within a few hours. The court held that the voluntary drunkenness of the assured while engaging in the violation of a law, causing his death, will not prevent a forfeiture of the policy.

114 Cook v. Standard Life \& Acc. Ins. Co., 84 Mich. 12, 47 N. W. 568. Here the evidence showed that the assured was a heavy drinker, and that the agent was aware of that fact, although the application stated that he was a man of temperate habits.

115 Jones v. United States Mut. Acc. Ass'n of City of New York, 92 Iowa, 652, 61 N. W. 485.

116 Sutherland v. Standard Life \& Acc. Ins. Co., 87 Iowa, 505, 51 N. W. 453; Hester v. Fidelity \& Casualty Co., 69 Mo. App. 186. 
the intoxication of the assured as the defense, but alleges another ground of exemption from liability, it will not be permitted to introduce evidence to show that the assured had been addicted to the use of intoxicants, since such testimony is not relevant to any issue in the case. ${ }^{117}$

Even where the exception may not be applied, it is proper for the company to show the condition of the assured at the time of receiving the injury. And it is proper to inquire of the witnesses whether they were impressed with the intoxication of the insured, and whether he seemed drunk or sober in their judgment, and was capable of taking care of himself, inasmuch as these are evidently statements of fact, indicating an appearance and not an opinion. ${ }^{118}$

But the insurance company will not be permitted to show that the assured while previously intoxicated exposed himself to a risk similar to the one causing the injury on which the action is based. ${ }^{119}$ Whether the assured is under the influence of intoxicating liquors at the time of the accident or

117 National Masonic Acc. Ass'n v. Shryock, 73 Fed. 774, 20 C. C. A. 3.

118 Cook $\nabla$. Standard Life \& Acc. Ins. Co., 84 Mich. 12, 47 N. W. 568 , supra. Here the assured was killed by falling on a slippery pavement, and it was claimed at the time of the accident that he was intoxicated. Witnesses were permitted to testify whether the assured was drunk or sober, whether he was capable of taking care of himself, and whether it was necessary for some one to accompany him as a means of protection. The court said: "A witness may state whether or not the assured had the appearance of being intoxicated, and such a statement would be a statement of a fact. Sanity, intoxication, and state of health are facts of this character."

119 Travelers' Ins. Co. v. Harvey, 82 Va. 949, 5 S. E. 553. Here the evidence tended to show that the assured fell from a window, thereby causing his death, and the insurance company set up the defense that he was intoxicated at the time. The company was not permitted to introduce evidence to show that at some previous time the assured, while under the influence of liquor, had attempted to jump from the same window under which he was found at the time of his death. 
death, and whether the death occurred as the result thereof, are questions of fact, to be submitted to the jury under proper instructions of the court. ${ }^{120}$ The finding of a trial court, based on conflicting evidence, as to whether the accident occurred by reason of intoxicating liquors, will not be disputed by the appellate court, unless a serious mistake appears to have been made in the consideration of the evidence, or an obvious error has intervened in the application of the law. ${ }^{121}$

Taking Poison.-Policies of accident insurance frequently provide that the company will not be liable for death or injury caused "by taking poison." Where the condition is so phrased, it will include death from poison taken in any way, whether intentionally or unintentionally, consciously or unconsciously. The term is generic, and thus covers all kinds of death by poison. ${ }^{122}$

120 Follis v. United States Mrut. Acc. Ass'n, 94 Iowa, 435, $62 \mathrm{~N}$. IV. 807,28 L. R. A. 78, 58 Am. St. Rep. 408. Here the assured fell from a bridge into a creek and was drowned. There was evidence tending to show that the assured was under the influence of intoxicating liquors, and in consequence of that condition walked off the railroad bridge. Couadeau v. American Accident Co., 95 Ky. 280, 25 S. W. 6, 15 Ky. Law Rep. 667, supra. De Van v. Commercial 'Travelers' Mut. Acc. Ass'n, 92 Hun, 256, 36 N. Y. Supp. 931. Here the assured was found drowned one morning in a canal. He was last seen about 2 o'clock that morning at a hotel in the vicinity. There was evidence tending to show that be was under the influence of liquor. It was a question of fact for the jury to determine whether the drowning was the result of intoxication.

121 Fidelity \& Casualty Co. v. Chambers, 93 Va. 138, 24 S. E. 896,40 L. R. A. 432 . Here the assured was last seen sitting on a bag on a rallroad track. Upon being warned of the approach of the train, he started to leave the track, but was struck by the engine. There was evidence tending to show that the assured had been drinking that morning. See Order of United Commercial Travelers of America v. McAdam, 125 Fed. 358, 61 C. C. A. 22 ; Sutherland v. Standard Life \& Acc. Ins. Co., 87 Iowa, 505, 54 N. W. 453.

122 McGlother v. Provident Mut. Acc. Co., 89 Fed. 685, 32 C. C. A. 318. Here the assured unintentionally drank poison, under the impression that it was a harmless mediclne, which he had pre- 
It must be noted, however, that the clauses which are intended to exempt the company from liability for death or injuries thus sustained differ greatly in their wording. Clearly, if a policy of accident insurance contains no such cordition, the company will be liable in all cases where the assured accidentally, and without the intent of committing suicide, takes poison mistaking it for something else, or unwittingly takes an overdose of medicine which is harmless in smaller quantities. ${ }^{\mathbf{1 2 3}}$

The company will be excused from liability under this condition where the poison was administered externally, as where a man is injured by carbolic acid thrown in his face. ${ }^{124}$ Where the condition exempts the company from

scribed for a patient. Early $\nabla$. Standard Life \& Accident Ins. Co., 113 Mich. 58, 71 N. W. 500, 67 Am. St. Rep. 445. Here an exception in the policy exempted the company from liability for death or injuries resulting directly or indirectly from poison. The assured, feeling sick, stopped at a drug store and asked for some medicine, whereupon the druggist by mistake gave him some aqua ammonia. The company was excused from liability, and the court said: "The great weight of authority is in favor of the proposition that it is not necessary that the poison be taken with intent to produce death, in order to defeat a claim." Hill v. Hartford Accident Ins. Co., 22 Hun (N. Y.) 187. Here the assured, a physician, in the course of his profession mixed poison and water in a goblet. Afterwards, mistaking it for water, he drank it, and soon died. The company was excused from liability under the policy. Pollock v. United States Mut. Accident Ass'n, 102 Pa. 230, 48'Am. Rep. 204; Id., 12 Ins. Law J. 319. Here the assured, a commercial traveler, while stopping at a store, jocosely picked up and drank a tumbler of oil of birch, mistaking it for milk of birch, which he often drank, and which it closely resembled. He shortly died from the effects of the poison. The company was excused from liability.

123 Penfold v. Universal Life Ins. Co., 85 N. Y. 317, 39 Am. Rep. 660. Here the court held that, in the absence of such a condition, the company will be liable for poison taken through error.

124 Meehan v. Traders' \& Travelers' Acc. Co., 34 Misc. Rep. 158, 68 N. Y. Supp. 821 . Here the assured was injured by a woman throwing carbolic acid in his face. The policy stipulated that it would not cover injuries resulting "directly or indirectly from or in 
liability for injury from "voluntary or involuntary" taking of poison, the clause will cover death from accidentally taking an overdose of medicine, and will excuse the insurance company from liability in such an event. ${ }^{125}$

In a leading English case, the court construed this condition as follows: "This is a clear and intelligible phrase. We are asked to insert, after the word 'poison,' 'unless accidentally taken or intentionally administered to the assured.' The only case of poison which would then be left in which the company would not be liable is that in which the assured intentionally took poison; but that is covered by the proviso as to suicide." ${ }^{120}$

In some states, as, for instance, Missouri and Illinois, it has been held that death caused by accidentally drinking poison is not within the exception exempting the company from liability in case of death by taking poison. - So, in Missouri, the beneficiary has been permitted to recover where the assured died from an overdose of morphine taken for medicinal purposes. ${ }^{127}$

any way contracted by poison in any form or manner," or "contact with poisonous substances." It was held that the assured could not recover.

125 Kennedy v. Etna Life Ins. Co., 31 Tex. Civ. App. 509, 72 S. W. 602. Here the assured accidentally took an overdose of poisonous medicine and died therefrom. The court held that the term "Involuntary," as used in the condition, did not limit it to an act forced on the assured, but included death from accidentally taking a poison. The court said: "The usual and ordinary meaning of the terms would include not one or the other, but every manner of taking poison."

126 Cole v. Insurance Co., 61 L. T. (N. S.) 227. Here the assured accidentally took poison under the impression that it was medicine which he was in the habit of taking. See, also, Batchelor v. Accident Ass'n, 34 Wkly. Law Bul. (Ohlo) 239, where the company was excused from liabllity where the assured died from an overdose of a poisonous medicine.

127 Dezell v. Fidelity \& Casualty Co., 176 Mo. 253, 75 N. W. 1102. Here the pollcy provided that it did not cover "injuries, fatal or 
Similarly, in Illinois, the company has been held liable where the assured died from mistaking a bottle of carbolic acid for peppermint. The Supreme Court of Illinois in this case said: "We are inclined to the opinion that the term 'taking poison' would, in common parlance, when used without any qualifying words, be understood to mean an intelligent and conscious act. If, in speaking of the cause of the death of another, we should say, 'He took poison,' we would most commonly be understood to mean that his act in taking poison was intentional, rather than accidental, and it would hardly be deemed necessary to say, 'He intentionally took poison,' and if it were designed to avoid such understanding we would naturally say he 'accidentally took poison,' or we would use some other qualifying words indicating that the act was accidental or its cause doubtful or unknown. It must, however, be conceded that the meaning of the term in the respect mentioned is not free from doubt. Able and learned arguments have been made on each side.

otherwise, resulting from poison or anything accidentally taken, administered, absorbed, inhaled." The assured died from an overdose of morphine taken to abate neuralgia. The court held that the exception did not preclude recovery for unintentional death caused by medicine, even though containing a poison, if it were taken or administered in good faith for the purpose of alleviating pain. The court said: "Morphine is both an opiate and a narcotic, which is so extensively and beneficially used in the modern practice of medicine and surgery, for the alleviation of pain and suffering in so many of the ills to which flesh is heir, that it would not be reasonable to suppose that any one of arerage intelligence would enter into a contract of life insurance containing a stipulation providing, in effect, that if he use this valuable remedial agent, either where prescribed for him by a physician or surgeon, or where he is suffering pain from a physical ailment, and death result therefrom, the indemnity provided shall be, in whole or in part, forfeited, unless his intention to do so is manifested by the clear and unambiguous terms of the instrument. If the insurer had intended to exempt himself from liability where death results from the use of narcotics under the conditions just referred to, it should have introduced into the exception terms clearly expressing such intention." 
of the question by counsel, and cases are cited showing that courts of high authority do not agree on the subject. It would therefore seem to be eminently proper, in such a case, to apply the well-known rule of construction applicable to such instruments, that where there is doubt or uncertainty as to the meaning of the terms employed, the language, being that of the insurer, must be liberally construed in favor of the insured, so as not to defeat, without a plain necessity, his claim to indemnity which, in making the insurance, it was his object to secure." 128

The Illinois cases seem to be based on the decision of Healey v. Mutual Acc. Ass'n of the Northwest. In this case the policy did not contain any clause exempting the company from liability for death from taking poison. The court merely held that where the assured died from poison, or disability ensued therefrom, it was within the terms of a policy, insuring for injuries received through external, violent, or accidental means. This case is therefore clearly distinguishable from the case in which death by poison is expressly excepted from the risks assumed. But the Illinois courts apparently do not so regard it. ${ }^{129}$ And so, in Illinois, the company will be liable where the assured dies from swallowing a glass of poisoned water, mistaking it for distilled water. And it has been held that the condition is not enlarged in scope by the addition of the words "in any form." 130 Thus, in Illinois and Missouri, the condition

123 Travelers' Ins. Co. v. Dunlap, 160 Ill. 642, 43 N. E. 765, 52 Am. St. Rep. 355, affirming 59 Ill. App. 515.

128133 Ill. 557, 25 N. E. 52, 9 L. R. A. 371, 23 Am. St. Rep. 637. See, also, Mutual Acc. Ass'n of the Northwest v. Tuggle, 39 Ill. App. 509. Here death ensued from an overdose of laudanum taken accidentally, and it was held to be through external, violent, or accidental means.

130 Metropolitan Acc. Ass'n v. Froiland, 161 Ill. 30, 43 N. E. 766, 52 Am. St. Rep. 359, affrming 59 Ill. App. 522. Here the assured 
will be held to exempt the company from liability only where the poison is taken with the intention of producing death. The decision in these cases is based largely upon the rule of construing a policy more favorably to the assured in all cases where there is any possible doubt, or where the policy is capable of more than one construction.

Where the policy provided that the company will not be liable for death or disability resulting from any surgical operation or from medicinal treatment for disease, the company will not be liable where the death is caused by accidentally taking an overdose of medicine. ${ }^{131}$ But where the policy provides that the company will not be liable for injuries resulting from a poison, or anything accidentally or otherwise taken, administered, absorbed, or inhaled, the company will none the less be liable where the assured accidentally eats something which wounds certain of his internal organs. ${ }^{182}$

died from accidentally drinking poisoned water, under the impression that it was distilled water. The declsion was based upon the Dunlap Case.

131 Bayless v. Travelers' Irss. Co., 14 Blatchf. 143, Fed. Cas. No. 1,138 , where a physician prescribed a dose of opium, but the assured inadvertently took more than he intended to, and died as the result thereof.

132 Miller v. Fidelity \& Casualty Co. (C. C.) 97 Fed. 836. In this case the assured ate some hard-pointed pieces of food, which perforated his intestines, causing his death. The court declared that the food had not been taken, administered, absorbed, or inhaled, in the sense contemplated by the policy. See, also, Maryland Casualty Co. v. Hudgins, 97 Tex. 124, 76 S. W. 745, 64 L. R. A. 349, 104 Am. St. Rep. 857, 1 Ann. Cas. 252, reversing (Tex. Civ. App.) 72 S. W. 1047. Here the assured, under a policy similar to that in the Miller Case, died as the result of eating oysters which had been spoiled. The court held that the word "take" does not mean to eat or swallow, and would include food or water. The Supreme Court reversed the decision of the lower court, which gave the clause a much more technical construction. The Supreme Court sald the plain meaning of this language is that the company excepts itself from liabllity 
The question frequently arises whether it is necessary that the poison be taken internally in order to bring the death within the condition under consideration. The courts have held that where the assured dies as the result of the sting of an insect, or the bite of a reptile, death is not within the terms of this exception. ${ }^{133}$

for all injuries which may arise from whatever thing of any kind or character which may be taken internally, whether poisonous or not.

133 Omberg v. United States Mut. Acc. Ass'n, 101 Ky. 303, 40 S. W. 909, 72 Am. St. Rep. 413. Here the assured died from blood poisoning, caused by the bite of a mosquito. The court held that blood poisoning thus caused was not the result of "poison in any form or manner," or, "contact with poisonous substances," within the meaning of the policy. The court declared that if death from blood poisoning, caused from the sting of the insect, would defeat a recovery, then "if blood poisoning were the immediate cause of death from an accidental gunshot the clause would prevent recovery-a conclusion wholly at war with the manifest purpose of the contract. So death from a rattlesnake bite is elearly from poison and contact with poisonous substances, but we presume no one will contend that recovery in such a death could be denied. Such causes of death as are last mentioned are not understood to be causes of death from poisoning or contact with poisonous substances in the ordinary meaning of those terms." Bacon v. United States Mut. Acc. Ass'n, 123 N. Y. 304, 25 N. E. 399, 9 L. R. A. 617, $20 \mathrm{Am}$. St. Rep. 748, reversing 44 Hun, 599. Here the assured died from blood poisoning resulting from handling the hides of animals which produced a malignant pustule. The court held that this case was not within the exception, although the case was really decided upon a different issue, namely, that the death of the assured was the result of disease, and not of accident. Preferred Mut. Acc. Ass'n v. Beidelman, 1 Monag. (Pa.) 481. Here the assured died from blood poisoning, caused by the sting of a venomous insect. The court, by way of obiter dictum, intimated that the poison should be taken internaliy in order to exempt the company from liability, but left it to the jury to determine as a question of fact whether the sting of a venomous insect was included in the exception. Kasten v. Interstate Casualty Co. of New York, 99 Wis. 73, 74 N. W. 534, 40 L. R. A. 651. Here the assured "died from biood poisoning caused by the absorption of septic poison evolved from cotton which had been inserted by a dentist in wounds caused by the removal of teeth in order to stop a hemorrhage." The policy contained a condition exempting the company from liability from "polson or anything 
The theory is that in such cases death from blood poisoning thus caused is not known in common parlance as "death from poison." But where the policy declares that the company will not be liable for death "by poison, or by contact with poisonous substance," the company can not be held where the assured, for example, is injured by the burns of an acid thrown in his face. ${ }^{134}$ Similarly, the company will not be liable where the assured is poisoned by noxious weeds. ${ }^{135}$ On the other hand, however, the company will be liable, despite the clause, where the assured is accidentally cut, and by infection sustained at the time of the injury the wound develops blood poisoning. ${ }^{136}$

taken into the system." The court held that while poison in a manner might be construed to mean liquids commonly known as poison, yet in the policy it was followed by the word "anything," evidently intending to cover everything of a poisonous nature. The court laid emphasis upon the fact that the cotton was voluntarily and intentionally placed in the mouth of the assured.

134 Meehan v. 'Traders' \& Travelers' Acc. Co., 68 N. Y. Supp. 821, 34 Misc. Rep. 158. Here a woman threw carbolic acid into the face of the assured. The company was exempted from liability; the court declaring that this condition was not confined to the taking of poison internally, but also included contact with poisonous substances.

135 Preferred Accident Ins. Co. of New York $\nabla$. Robinson, 45 Fla. 525, 33 South. 1005, 61 L. R. A. 145, 3 Ann. Cas. 931. Here the assured accidentally came in contact with poison ivy, which slightly inflamed his eye. The court held that this was the result of coming in contact with a poisonous substance, within the meaning of the condition of the policy.

136 Central Accident Ins. Co. v. Rembe, 220 Ill. 151, 77 N. E. 123, 5 L. R. A. (N. S.) 933, 110 Am. St. Rep. 235, 5 Ann. Cas. 155, aftirming 122 Ill. App. 507. Here the policy contained a clause exempting the company from liability for death caused by "contact with poisonous substance." The assured, a physician, while treating a syphilitic patient, cut his finger in removing the cork from a bottle which broke. The virus from the patient entered the wound, causing fatal blood poisoning. The court said: "The cause of the death, as we understand it, was the wound in the finger, by means of which hlood poisoning intervened. Without the accidental wounding of the 
Where opinions may differ as to whether the substance administered or taken is a poison, the matter must be left for the jury to decide as a question of fact under proper instructions from the court. ${ }^{137}$ In policies containing conditions of the nature here discussed, the burden is on the insurance company to show that the death of the insured was caused by poison within the terms of the exception, after the plaintiff shall first have established a prima facie case of liability under the general clause of the policy. ${ }^{138}$ And this fact may be shown under a simple denial of the averment that death resulted solely from accident. ${ }^{139}$

finger, blood poisoning would not have ensued, and therefore that disease was only incidental to the wound. * * * If poisonous germs entered the wound, causing blood poisoning, that wound would not be within the fair meaning of the policy, "coming in contact with poisonous substance' causing death. Even if the germs were a poisonous substance within the meaning of the pollcy, -those germs, according to the testimony, would have produced no injurious effect but for the wound in the finger. They only became poisonous when allowed to mingle with the blood." Simpkins v. Hawkeye Commercial Men's Ass'n, 148 Iowa, 543, 126 N. W. 192. Here the assured, an undertaker, accidentally punctured the palm of his hand with the point of an embalming. needle while embalming a dead body, and blood poison set in, resulting in death. The court held that death was not the result of "contact with poisonous substances," but that the death was in a legal sense the result of the wound; the infection being a mere incident to the original injury. To the same effect, see Farner v. Massachusetts Mut. Acc. Ass'n, 219 Pa. 71, 67 Atl. 927, 123 Am. St. Rep. 621, where the assured was bitten by a dog, and blood poisoning ensued, causing his death; Cary v. Preferred Accident Ins. Co. of New York, 127 Wis. 67, 106 N. W. 1055, 5 L. R. A. (N. S.) 926, 115 Am. St. Rep. 997, 7 Ann. Cas. 484, where the assured injured his leg by a fall, and blood poison developed, from which he died.

137 United States Mut. Acc. Ass'n v. Newman, 84 Va. 52, 3 S. E. 805. Here the assured was asphyxiated by coal gas escaping from a stove in the room where he was sleeping. The evidence was conflicting as to whether or not coal gas was a poison.

138 Travelers' Protective Ass'n v. Gilbert, 111 Fed. 269, 49 C. C. A. 309,55 L. R. A. 538.

13 9 Bernays v. United States Mut. Acc. Ass'n of New York (C. C.) 45 Fed. 455. 
However, where the condition contains a clause exempting certain contingencies, the burden is on the plaintiff to establish the fact that death was caused by such a contingency, as where the policy provided that it will not cover injuries resulting from poison, etc., taken, administered, absorbed, or inhaled, anæsthetics administered by a regular physician excepted, and the insured died from anæsthesia, while undergoing an operation, the burden is on the beneficiary to show that the death of the assured was caused by the anæsthetic.

Inhaling Gas.-One of the most common exceptions in policies of accident insurance is that which exempts the insurer from liability for death caused by "inhaling gas." This clause has given rise to much difficulty and some contradiction in construction: The courts seem unwilling to give effect to the literal and technical meaning of the gas clause and declare that the company will be exempt from liability only in cases of suicide by inhaling gas, or in cases where the gas is intentionally inhaled for the purpose of performing surgical operations and for like purposes, and that death resulting from purely accidental and unintentional inhaling of poisonous gas does not come within the exception.

In the leading case on this question, Paul v. Travelers' Ins. Co., the court said: "In expressing its intention not to be liable for death from 'inhaling of gas,' the company can only be understood to mean a voluntary and intelligent act by the insured, and not an involuntary and unconscious act. Read in that sense and in the light of the context, these words must be interpreted as having reference to medical or surgical treatment, in which, ex vi termini, would be included the dentist's work, or to a suicidal purpose. Of course, the deceased must have in a certain sense inhaled Fuller Acc.Ins. - 11 
gas; but, in view of the finding that the death was caused by accidental means, the proper meaning of words compels, as does the logic of the thing, the conclusion that there was not that voluntary or conscious act necessarily involved in the process of inhaling. $* * *$ To inhale gas requires an act of volition on the person's part before the danger is incurred. * * * If the exception is to cover all cases where death is caused by the presence of gas, there would be no reason for using the word 'inhale.' If the policy had said that it was not to extend to any death caused wholly or in part by gas, it would have expressed precisely what the appellant now says it meant by the present phrase, and there could have been no room for doubt or mistake. * * * To hold that the death of plaintiff's intestate was caused by the inhaling of gas, within the meaning of this policy, would be to construe its terms contrary to the usual import of language, and in fact to hold, against the finding, that the death was not accidental." ${ }^{140}$ The company will

140112 N. Y. 472,20 N. E. 347,8 Am. St. Rep. 758, 3 L. R. A. 443 , affirming $45 \mathrm{Hun}, 313$. Here the assured, a guest at a New York hotel, went to his room late one evening, and during the afternoon of the next day was found dead in bed. The room was tightly closed, and the atmosphere filled with illuminating gas. The policy declared that the company would not be liable for "any death or disability which may have been caused * * * by the taking of poison, contact with poisonous substances, or inhaling of gas, or by any surgical or medical treatment." The jury found, as a matter of fact, that the death was caused by "accidental means."

See, also, Fidelity \& Casualty Co. of New York v. Waterman, 161 Ill. 632,44 N. E. 283,32 L. R. A. 654, affirming 59 Ill. App. 297. Here the assured was asphyxiated by illuminating gas while he was asleep. The policy declared that the insurance did not cover "injuries, fatal or otherwise, resulting from poison or anything accidentally or otherwise taken, administered, absorbed, or inhaled." The court here followed the Paul Case, and held that the company was liable, and that the word "absorbed" had no application to the case at issue, since that word could have reference only to the process of absorption by sucking up or imbibing through the pores of the body. The court said: "Read in the light of the decisions, 
be exempt only where the assured voluntarily, intentionally, and consciously, though through mistake, has inhaled the gas, or where he has inhaled the gas for the purpose of

the words now in question do not mean otherwise than if they explicitly read 'poison or anything consciously and by an act of volition drawn into the system by inspiration" "-and declared that the proviso could only mean a voluntary and intelligent act, as distinguished from one that was involuntary and unconscious. The court also held that the question was res judicata, since the policy was issued several years subsequent to the decision in the Paul Case, and that the insurance company must have known, at the time of entering into the contract, what its liabilities were under that decision.

To the same effect, see Fidelity \& Casualty Co. of New York v. Lowenstein, 97 Fed. 17, 38 C. C. A. 29, 46 L. R. A. 450, affirming Lowenstein v. Fidelity \& Casualty Co. of New York (C. C.) 88 Fed. 474. Here the assured was asphyxiated by inhaling gas into his lungs while asleep. The court held that the question was res judicata, and that the court must decide the case along the lines set forth in the Paul Case, irrespective of what its view might be, were the question res integra. The court here said: "It [the insurance company] had knowledge that by reason of such adjudications its policies, if they continued to issue them in the old form, would in all probability be accepted by some, and possibly many persons, upon the understanding that the company intended to and did in fact assume the species of risk last described. *** We are unwilling to concede that an insurance company may continue to issue policies without any modification of their terms, after certain provisions thereof have been construed by several courts of the highest character and ability, and be heard to insist, in controversies between itself and the insured with respect to such subsequently issued policies, that they do not in fact cover risks which they had been judicially adjudged to cover before they were issued. While it may not be accurate to say that under such circumstances a technical estoppel arises in favor of the assured, yet the courts in such cases should rigidly enforce the rule requiring policies of insurance to be construed most strongly against the insurer, and they should not hesitate to hold that decisions construing a policy adversely to the contention of the insurer thereafter create a doubt as to its proper interpretation of sufficient gravity to be resolved in favor of the insured." The court declared that, if the insurance companies did not intend to be bound by such decisions, they should modify the language of their policies, so as to leave no doubt or speculation as to their meaning and to conform to the adjudicated cases. Travelers' Ins. Co. v. Ayers, 217 Ill: 390, 75 N. E. 506, 2 L. R. A. (N. S.) 168, affirming 119 Ill. App. 402. A provision 
committing suicide, or for the purpose of having an operation performed.

Where the policy declares that the company will be exempt from liability for death resulting from "gas or poison in any form or manner," the company will not be liable

in the policy declared that the insurance should not cover death re. sulting wholly or partly, directly or indirectly, "from any gas or vapor." The court held that this referred to those cases only where the assured consciously inhales the gas, and did not exempt the company from liability for death by asphyxiation caused by gas accidentally escaping in a hotel room and being unconsciously inhaled by the deceased, while he was asleep. The assured had apparently retired, leaving a natural gas burner lighted. During the night the gas had been turned off in the hotel, and then later turned on. The gas then was not burned, but escaped into the room.

Menneiley v. Employers' Liability Assur. Corp., 14S N. Y. 596, 43 N. E. 54, 31 L. R. A. 6s6, $51 \mathrm{Am}$. St. Rep. 716, reversing Menneiley v. Employers' Liability Assur. Corp., 25 N. Y. Supp. 230, 72 Hun, 477. Here again the assured was killed by breathing illuminating gas which had accidentally escaped into his sleeping room. The condition declared that the policy would not cover death or disablement "arising from anything accidentally taken, administered, or inhaled, contact of poisonous substances, inhaling gas, or any surgical operation, or exhaustion consequent thereon." The court held that this clause had reference to something voluntarily, intentionally, and consciously, although mistakenly, taken, administered, or inhaled, and did not exempt the insurer from liability for death caused by the involuntary and accidental breathing of illuminating gas, which has escaped into the room where the assured was sleeping. The court said: "The manifest purpose of the provision is to exempt the insurer from liability where the assured has voluntarily and consciously, but accidentally, taken or inhaled the gas, or something has been voluntarily administered which was iujurious or destructive of life. We think that the particular accidents intended to be excepted by that provision are the accidental taking or inhaling into the system of some injurious or destructive agency under the mistaken bellef that it was beneficial, or at least harmless."

Pickett v. Pacific Mut. Life Ins. Co., $144 \mathrm{~Pa}$. 79, 22 Atl. 871, 13 L. R. A. 661, $27 \mathrm{Am}$. St. Rep. 618. Here the assured, in good health, went down into a well to make repairs to a pump, and in a short time was found in the well dead from asphyxia, resulting from the inhalation of poisonous gas at the bottom of the well. The court held that the company was liable on its policy, and declared: "If that fluid had been oil, smoke, water, or molten metal, the result would have been substantialiy the same. Death, caused not so much 
where the assured is asphyxiated while sleeping. ${ }^{141}$ And where the policy by its express terms relieves the insurer from liability for death caused by the "voluntary or involuntary inhalation of any gas or any anæsthetic," there can be no recovery where the assured is asphyxiated, whether by his own mistake or the fault of another. ${ }^{142}$

by the inhalation of the fluid, as by its action in excluding life-supporting air, would have inevitably resulted."

See, however, Richardson v. 'Travelers' Ins. Co. (C. C.) 46 Fed. 843. Here the assured was asphyxiated by inhaling illuminating gas, as in the Paul Case. The court declared the reasoning in the Paul Case was unsatisfactory and repudiated it, insisting that there could be no recovery on the policy. The court said: "The language of the policy is so clear as to require no construction. The words are unequivocal that the defendant does not insure against death caused by inhaling gas. There is nothing in the terms of the policy intimating or suggesting that the inhalation of gas must be voluntary or involuntary in order to exempt defendant from liability." The decision in this case is clearly against the overwhelming weight of authority.

141 Trone v. General Accident Assur. Corp., 13 Ohio N. P. 298. Here the assured was asphyxiated while asleep by the inhalation of noxious gas caused by a stovepipe to a natural gas stove becoming unjointed and filling the room in which he was sleeping with the poisonous gas. The language in the exception here answers the distinction drawn in the Paul Case, being sufficiently broad in its scope, and the court properly held that: "Death which is the result of 'gas in any form or manner' means death caused by gas, however it may be introduced into the human system, whether by the voluntary and intelligent act of the insured or by his involuntary and unconscious act. The words 'gas in any form or manner' are not words of limitation. The language is plain and unambiguous, as much so as the English tongue can convey the idea intended."

142 Porter v. Preferred Acc. Ins. Co., 109 App. Div. 103, 95 N. Y. Supp. 682, affirmed without opinion 186 N. Y. 599,79 N. E. 1114. The assured died from the effects of gas inhaled while occupying a room in a hotel. The court in deciding the case said: "It must be conceded that an accident insurance company has the right to limit its liability in any reasonable manner-has the right to provide that in no case will it be liable if the death of the insured results from the effects of gas, inhaled voluntarily or involuntarily. We think that was the intention of the parties as indicated by the express language used in the policy in question. The meaning is no different than if the policy provided that the defendant would not be 
Where the assured dies from the effect of an anæsthetic administered for the purpose of performing a surgical operation, the insurer will be excused from liability under this condition. ${ }^{143}$ Where the evidence is conflicting whether the assured died from inhaling gas, it is a question of fact for the jury to determine. ${ }^{144}$

Injuries Sustained on a Railroad Bed or Bridge.-Policies of accident insurance usually contain a condition providing that the company shall be exempt for death or injury received by the assured while walking or being on a rail-

liable if the death of the insured resulted from the effects of dynamite, a railroad accident, or from yellow fever. The words employed in the exemption from liability clause quoted clearly indicated an intention to aroid liability where death is caused by the inhalation of gas. Concededly gas was inhaled by the deceased, and such inhalation caused his death. It was not voluntary, but nonliability for the death of the insured by the involuntary as well as the roluntary inhalation of gas was provided for. The words 'or any anæsthetic,' which follow the clause above quoted, do not in any manner enlarge the sccpe or meaning of the words 'voluntary or involuntary inhalation of gas.' The whole clause, considered together, must mean that, if the death of the insured resulted from the voluntary or involuntary inhalation of gas, no recovery could be had, and also that if death resulted from the inhalation of any anssthetic, whether roluntary or involuntary, there would be no liability on the part of the insurer." This case is to be distinguished from the Paul and the Menneiley Cases, where the policies did not provide, as in this case, against the "involuntary inhalation of gas." "

143 Westmoreland v. Preferred Acc. Ins. Co. (C. C.) 75 Fed. 244. Here the policy stipulated that the company would not be liable for death or injury resulting from anything "accidentally or otherwise taken, * * * absorbed, or inhaled." While under the influence of chloroform, administered for the purpose of performing a surgical operation, the assured died, and the company was not liable.

144 United States Mut. Acc. Ass'n v. Newman, 84 Va. 52, 3 S. E. 805. Here the assured came to his death by inhaling coal gas in his sleeping room, and the evidence as to whether or not coal gas was a poison or polsonous substance was conflicting. The question was one of fact for the jury to determine under proper instructions. 
road bridge or railroad bed. The courts have held from the very first that the purpose of this condition is not to safeguard the insurance companies against injuries arising from defective railroad beds or bridges, but rather to guard the insurer from liability for accidents which may occur to policy holders from trespassing upon railroad tracks or bridges constructed and maintained expressly for the use of trains. ${ }^{145}$ In order to release the insurance company from liability, it must be clear that the injury results from the dangers peculiarly incident to railroad traffic over the tracks and bridges. The mere fact that the insured happens to be upon a railroad track or bridge at the time of the accident will not prohibit the right of recovery, unless the accident is the logical result of his position. For example, if the assured while walking on a railroad track is hit by a stray bullet, or bitten by a dog, or struck by lightning, or killed by a highwayman, his right of recovery will not be impaired from the mere fact that he happens to be on a railroad track at the moment the accident occurs. In short, the prohibition seeks to guard against danger of injury from passing trains. The exception is intended largely to protect the company from the dangerous practice of track-walking. ${ }^{146}$

145 Beard v. Indemnity Ins. Co., 65 W. Va. 283, 64 S. E. 119. Here the court stated that the manifest intention of a clause exempting the insurance company from liability to the insured while on the roadbed or bridge of a railway is to relieve the insurer from responsibility for injury caused by collision with moving trains thereon. See, also, Osgood v. United States Health \& Accident Ins. Co. (N. H.) 84 Atl. 50.

146 Burkhard v. Travelers' Ins. Co., 102 Pa. 262, 48 Am. Rep. 205. Here the assured stepped off of a railway train when it came to a stop on a drawbridge during the night. Others also alighted from the train, but the assured fell through a concealed hole in the bridge and was killed. The court said: "The language of the exception clearly implies two thoughts: One that the insured must not be on 
Except for the danger of passing trains, the risk from being on a railroad track is no greater than anywhere else.

In considering this condition the question immediately arises: What is the roadbed of a railroad? In actions between railroad companies, or between them and their employés, or the public generally, or in reference to the construction of railroads where this question is raised, the "roadbed" means the entire right of way of the railroad, or at least that portion of the right of way which has been leveled off and prepared for the purpose of laying the railroad tracks, whether only a few feet or a hundred feet in width. But in an action between a policy holder and an insurance company involving the meaning of a contract of insurance, a more strict construction is given to this phrase. The roadbed is uniformly held to comprehend simply the width of the road; that is, the length of the ties upon which the rails are laid, generally not more than a few feet wide, and indicating the width of passing trains. ${ }^{147}$

the roadbed or bridge for any length of time; the other that the prohibition is not to guard against injury resuiting from a defective roadbed, or defective railroad bridge, but against the danger of injury from trains passing thereon. If the design was to apply the language to bridges defectively constructed, or out of repair, it would not have been restricted to railway bridges. It would have included all bridges, both foot and wagon. The purpose is not to avoid liability for injuries resulting from being on bridges unsafe in themselves. The manifest attempt is to exempt from responsibility for damages caused by collision with trains moving thereon."

147 Osgood v. United States Health \& Accident Ins. Co. (N. H.) 84 Atl. 50. Here the court said: "In this contract the phrase "the roadbed of any railway' means all that part of the right of way which may be swept by the moving rolling stock." De Loy v. Travelers' Ins. Co., 171 Pa. 1, 32 Atl. 1108, 50 Am. St. Rep. 787. Here the court held that people would generally understand by it that the roadbed is simply the road as constructed, or rather the ties upon which the rails lay, which might not be, as in this case, more than about 8 feet in width. There could be no object in an insurance company preventing a man from going upon the right of way of a rallroad company, because, if he was away from the track and 
The Supreme Court of Arkansas has defined "roadbed" as follows: "The word 'roadbed,' when used in reference to railroads, has a well-understood meaning. It is the bed or foundation on which the superstructure of the railway rests, and the superstructure is the sleepers or ties, rails, and fastenings. * * * In using it in this sense, it is presumed that the parties had reference to the manner in which railroads are usually constructed, and did not include in its meaning the ends of ties of unusual and extreme length, and extending to a place where there can be no possible collision with the cars, and where persons standing or sitting would be beyond the reach of injury by passing trains." 148

And so the space between the double tracks of a railroad, where it is of a uniform width, and where there is a level and smooth walk of cinders, is not a part of the roadbed within the meaning of this condition. ${ }^{149}$

the ties far enough not to be reached by the engine or the cars, he could be in no more danger than any place else.

148 Standard Life \& Accident Ins. Co. v. Langston, 60 Ark. 381, 30 S. W. 427. In this case the assured was invited to ride in the cab of an engine to a neighboring town, where he lived. While waiting for the engineer, the assured left the locomotive because of the heat. He crossed three or four side tracks and sat down on the edge of a tie some thirty inches longer than the ordinary cross-ties. At this point in the yards there were many side tracks, and three or four trains were passing every hour. When he sat down, the assured was conscious, but later he fell asleep, and when he awoke he realized that his arm was injured. A train of cars had passed over it in two places, indicating that his arm must have been across the rail, although his hand was not mangled. In endeavoring to arise, he jerked his arm, thinking that his coat had caught. He heard something tear, felt a stinging sensation, and discovered that he had severed his arm. The court held that the company was not exempt under the condition releasing it from liability for injuries received by the insured while on the roadbed of a railroad, but declared it a question for the jury to determine whether or not the company might not be exempted under another clause of the policy, on the ground that the assured had failed to use due care and diligence for his personal safety.

149 Meadows v. Pacific Mut. Life Ins. Co., 129 Mo. 76, 31 S. W. 578, $50 \mathrm{Am}$. St. Rep. 427. Here the distance between the main 
In order to excuse the company from liability under this condition, it must appear that the assured is voluntarily or intentionally on, or walking along, a railroad bed or bridge. The company will not be exempt if he is there involuntarily, or by accidental force, and for only a brief period of time. For example, if the assured, while approaching a railroad track, stumbles and falls against a moving train, or falls across the track and is run over by the train, it is clear that the company will not be excused from liability. ${ }^{\mathbf{1 5 0}}$

The condition in question is not construed with absolute literalness. The courts seek to ascertain the reasonable intention of the parties to the contract. It is held to be a warranty by the assured that he will not trespass on railroad tracks and on that part of the roadbed which is not also a part of the public highway or thoroughfare, and that he will not loiter

tracks was ten feet, and consisted of a well-beaten walk of the same material as the walk between a park and the main track. The evidence showed that the most prudent person would not have hesitated to walk there, since there could be no danger from passing trains. However, in McClure v. Great Western Acc. Ass'n, 133 Iowa, 224, 110 N. W. 466, 8 L. R. A. (N. S.) 970, 119 Am. St Rep. 598, 12 Ann. Cas. 41, the court held that one walking between the double tracks of a railroad used for running trains in opposite directions, the ralls of which were teu feet apart and the distance between passing engines four feet, is within the provisions of an accident policy limiting liability where the injury is received while assured is on the roadbed of any rallroad company, except while crossing at a public highway.

In Starr v. Etna Life Ins. Co., 41 Wash. 199, 83 Pac. 113, 4 L. R. A. (N. S.) 636, the court declared that the phrase "being on the right of way" meant only "on the track," or on that portion of the roadbed traversed by trains.

150 Equitable Acc. Ins. Co. v. Osborn, 90 Ala. 201, 9 South. 869, 13 L. R. A. 267 . Here the assured volunteered to get the mall for the postmaster, and ran rapidly from the post office, more than fifty yards distant, to secure the mall bag from the train, which was fast approaching, and which did not stop at that station. The assured attempted to check his speed on approaching the track, and stumbled and fell against the steam chest of the engine, receiving fatal injuries. The company was liable on the policy. The court held 
upon the railroad tracks. ${ }^{151}$ The condition will not protect the insurance company from liability where the assured is lawfully upon a railroad track. It does not include merely crossing the railroad tracks for justifiable purposes, such as reaching a station, or crossing railroad tracks in a city street. Thus the company will be liable where the assured, in taking a train at a railroad station, is obliged to cross several tracks before he reaches his own train. ${ }^{152}$

Similarly, where the assured must necessarily board or leave a train, or is called there to meet a relative or friend, or in the

that this did not constitute a voluntary being on a track, such as would excuse the insurance company.

151 Wilcox v. Central Accident Ins. Co. of Pittsburg, 234 Pa. 58, 82 Atl. 1093, where the assured was killed while crossing a railroad track at a point where there was no highway, merely to avoid a detour, and the company was held not liable.

152 De Loy v. Travelers' Ins. Co., 171 Pa. 1, 32 Atl. 1108, 50 Am. St. Rep. 787. Here the assured sought to take a train at a flag station, where there was no station agent to stop the train. The assured flagged the train, and returned with the flag to the station side of the track. He then walked up the track to take the train, but he slipped or stumbled and fell as the train approached, was struck by the engine and instantly killed. Here the court held: "It is evidently intended by this prohibition that it should not prevent the person from being lawfully upon a railroad track, unless it was in a time of danger when he voluntarily exposed himself to danger by doing it. It was certainly intended to mean that. Otherwise a person could not in safety cross a railroad track; if there were several sidings at a depot, for instance, and he had to cross one or the other to get into the train, and if an accident happened while he was getting in, they might say he could not recover, because he was on a railroad track at the time the injury happened. That construction would not be a fair one. I think it fair to assume that it was intended to cover all cases where a person is on a railroad bed when he had no business to be there. *** But when his business or other necessities call him to the railroad track or crossing, for lawful purposes, and he is injured while in the lawful pursult of his calling, or when it becomes necessary to use the roadbed for a lawful purpose, and he should be accidentally killed without any knowledge upon his part of the danger, he ought not, in such case, to be excluded from recovering if there was nothing else in the case." 
discharge of a business or social duty, the company will be liable, inasmuch as the act of the insured is lawful. ${ }^{153}$

Similarly, the condition will not apply where the assured is injured while crossing a railroad track at a well-recognized crossing, or at a public thoroughfare, as where the assured traverses a path which had long been publicly used and is recognized as a way to and from the depot. Railroad tracks are common everywhere, in rural as well as urban districts, and must frequently be crossed in the ordinary duties of life, both business and social. ${ }^{154}$

153 Meadows v. Pacific Mut. Life Ins. Co., 129 Mo. 76, 31 S. W. 578, $50 \mathrm{Am}$. St. Rep. 427, supra. Here the assured, a horse buyer, was anxious to reach home that night. The passenger trains were no longer running, but the assured knew the crew of a freight train that ran at night to his home town. He started down the yards along a well-beaten path between the tracks, and was later found dead, with his body cut in two. Although no evidence was offered as to just how he was killed, the court said: "It would be most unreasonable to hold that, merely because this space was a portion of the right of way, one seeking passage on the trains of a company, or called there on business to meet a relative or friend, on business or in the discharge of a social duty, should be charged with want of care for his welfare. There was ample space upon a well-worn and smoothly trodden path, and the court committed no error in declaring this space not a part of the roadbed." 'Traders' \& Travelers' Acc. Co. v. Wagley, 74 Fed. 457,20 C. C. A. 588, 45 U. S. App. 39. Here the assured went to the railroad station to meet his sister. He stood on a sidewalk on a higliway crossing near the station, but on the opposite side of the tracks. As the train approached, he started to cross the tracks, a distance of some twelve feet, and as he was stepping on the platform he was struck by the train and killed. The court held that the assured was crossing at a public highway, and was on the tracks for legal purposes only, and the company was not exempt under the condition.

154 Duncan $\nabla$. Preferred Mut. Acc. Ass'n of New York, 59 N. Y. Super. Ct. 145, 13 N. Y. Supp. 620. Here the assured, while attempting to drive across the railroad track, was struck by a train and killed. The policy excepted the hazard of standing or sitting on or walking on a rallroad bed or brldge. The court sald: "This does not include such a crossing of the track as the deceased made. To stand or to walk on a roadbed implies some sensible duration of the act, and does not describe a mere crossing for a justifiable purpose, 
The Supreme Court of Iowa has said: "A rule that would require a pedestrian, about to follow a well-worn and beaten path over a railroad track, to stop and satisfy himself before proceeding of his legal right to do so at the peril of forfeiting his insurance, would amount to an absurdity." 155

That such a path is not in a legal sense a regularly established highway is immaterial, where the public, by frequenting a path crossing the railroad tracks, has acquired a license through user. The fact that the assured is injured while crossing at this point will not defeat a right of recovery. ${ }^{156}$ This

such as reaching the station. Common language distinguishes between sitting or walking and crossing."

155 Payne v. Fraternal Acc. Ass'n of America, 119 Iowa, 342, 93 N. W. 361. Here the assured was killed by a freight car while crossing a track at an isolated place. The court held that the condition is a warranty by the assured that he will not enter upon that part of the roadbed which is not also a part of the highway or public thoroughfare, and that he will not loiter upon the track; but does not obligate him not to cross the railroad bed at the place provided for the public to cross it; and, if one crosses a track at a station where the public is accustomed to cross, he is not walking on a railroad bed in any such sense as will entitle the insurer to avoid the policy, irrespective of proof of such person's negligence in so crossing. Wright v. Sun Mutual Life Ins. Co., 29 Upper Canada C. P. Rep. 221. Here the court held that the use of a track to cross a street was not the mode of walking thereon to which this prohibition refers.

156 Dougherty v. Pacific Mut. Life Ins. Co., 154 Pa. 385, 25 Atl. 739. Here the assured was found early one morning lying dead near a railroad track with a wound on his temple. No one saw the deceased killed. Some two hundred feet from where the body was found was an old and well-worn path crossing the railroad, which the deceased was accustomed to use. The court here approred the charge that if the assured was crossing a railroad at a well-recognized crossing, which had long been in public use, and he used proper care under the circumstances, and was killed, the mere fact that he was crossing a rallroad track would not prevent recovery.

So, also, Lehman v. Great Eastern Casualty \& Indemnity Co., 7 App. Div. 424,39 N. Y. Supp. 912 , afhirmed 158 N. Y. 689,53 N. E. 1127. In this case the assured, while on his way to a busiuess concern located beyond the railroad tracks, followed a well-beaten path along the railroad tracks, used for a period of years to approach his destination, to which there was no other path at this point, except 
is true, even where notices are posted by the railroad company forbidding the public to cross its tracks at a given point, if no further attempt than this is made to stop the practice, and the path is used daily by large numbers of people. ${ }^{157}$ Some policies expressly provide that the company will not be liable for injuries received while on the roadbed of a railroad, "except when crossing at a public highway." Under such a condition the burden is on the insurer to show that the accident has occurred at a place not in a public highway. ${ }^{158}$

Where the assired is injured while walking on a railroad bed, even for the purpose of reaching the station, when there is a public highway across the railroad tracks, and a regular walk which he might have used, the company will be exempt; and this is true, despite the fact that many people are accus-

through a gate, which was usually locked. The assured waited for a train to pass, and while crossing the track was killed by an engine approaching from another direction. The court held that the company was not exempt from liability, and that this did not constitute being on a railroad track within the meaning of the condition of the policy.

157 Keene v. New England Mut. Acc. Ass'n, 161 Mass. 149, 36 N. E. 891; Id., 164 Mass. 170,41 N. E. 203 . Here the assured while crossing the railroad track at a point other than a public highway was struck by a detached freight car, the sight of which was cut off by his umbrella. The company forbade the use of this path, but no other attempt was made to stop the practice; the evidence showing that more than two bundred people a day crossed over this path, and that this had been done for years.

158 McClure v. Great Western Acc. Ass'n, 141 Iowa, 351, 118 N. W. 269. The policy here provided for less indemnity in case of injuries while on the roadbed of a railroad, "except when crossing at a public highway." The assured had gone to mail a letter at the post office, but, finding that the mail had already been sent to the train, he followed. a well-beaten path between the railroad tracks to the depot. Evidence tended to show that when struck, the assured was crossing the tracks at a public highway. The court held that the burden was on the insurer to show that the accident occurred at a place not in a public highway, and this burden is not shifted by simply showing that the accident occurled on a railroad track. 
tomed to use the roadbed in this manner. ${ }^{159}$ Similarly, where the assured is walking along a piece of track and is struck by a locomotive, the company will be exempt; for it is none the less the roadbed, even if it has been continuously used by the public for a period of years as a common pathway without objection on the part of the railroad. ${ }^{180}$

Where the assured uses a railroad track as a path of travel, and is struck by a train, the company is clearly not liable. ${ }^{101}$ So, also, the company will be exempt, where the assured sits down on a railroad track on which many trains pass each day, and is killed. ${ }^{162}$

159 Piper v. Mercantile Mut. Acc. Ass'n, 161 Mass. 589, 37 N. E. 759. Here the assured was walking longitudinally on the roadbed between the tracks for the purpose of reaching the station. There was a public way across the railroad, and a walk parallel with the tracks extending to the station, which he could have used. The space where he was walking was not fitted up with a path, and was purely a part of the roadbed. The court said: "That many people used it as the plaintiff's husband did is immaterial." See, also, Osgood v. United States Health \& Accident Ins. Co. (N. H.) 84 Atl. 50.

160 Weinschenk v. Etna Life Ins. Co., 183 Mass. 312, 67 N. E. 242. Here the assured, while walking along a railroad bed of his own volition, fell because his ankle gave way while he was trying to get off the track. The court very properly declared that the company was exempt, even though the piece of track along which he had been walking had been continuously and openly used for a period of thirty-five years or more by the residents of that district as a common pathway without objection from the railroad company.

161 Tuttle v. Travellers' Ins. Co., 134 Mass. 175, 45 Am. Rep. 316. Here the assured was struck by a train while running along the tracks in front of it in the nighttime for the purpose of boarding a train approaching in an opposite direction on a parallel track. The court held that this was a voluntary exposure to an obvious and unnecessary danger, within the meaning of a condition of the policy.

162 Metropolitan Acc. Ass'n v. Taylor, 71 Ill. App. 132. Here the assured, while walking upon a railroad track for some distance, sat down to rest on the rail, and was struck by a locomotive. The court in this case properly held that the limitation of this exception did not apply to walking alone, but included as well using the track for a footpath, and even stopping in the course of such use, as to tie a shoe, talk with another, or rest for a time, standing or 
Apart from not being liable where the assured has been trespassing on a railroad, the insurance company may be exempt on the ground of voluntary exposure to danger, where the assured attempts to walk across a railroad trestle. ${ }^{103}$ But where the trestle has a plank walk and a rail, and is very generally used by the public, the company will be liable.

The condition exempting the company from liability for injuries received while walking on a railroad bed frequently contains an exception rendering it inapplicable to railroad employés. In such a clause, the term "railroad employés" refers to persons employed to work on or about a railroad. This exception must of necessity render protection to that large class of men whose occupation, under which they are classified in the policy, requires them to constantly work on railroad tracks and bridges. Since they are forced to pay high premiums for their policies, and since contracts of accident insurance are presumed to cover the dangers and risks incident to the employment in which the assured are classified, and to which they are of necessity exposed, were it otherwise, the policy would fail of the very purpose for which it is secured. Naturally such an exception will apply only where the assured, when injured, is actually engaged in the duties of his occtipation as a trainman. Furthermore, it will apply only where the assured is injured while on the tracks of the company by which he is employed. On the tracks of another company he occupies the position of any other person not a railroad employé. ${ }^{164}$

sitting, but intending to pursue the journey thereon when the occasion for such suspension had passed.

163 Follis v. United States Mut. Acc. Ass'n, 94 Iowa, 435, 62 N. W. 807,28 L. R. A. 78, 58 Am. St. Rep. 408. Here the assured fell from a railroad bridge on which he was walking on a dark night and was drowned. The evidence showed that the railroad trestle had no railing and was built of ties ten feet apart.

164 Pacific Mut. Life Ins. Co. of California v. Howell, .13 Ind. App. 519, 41 N. E. 968 . Here the assured was struck by a train while 
Where the assured is returning home from work, and is still within the yards of the company by which he is employed, and is run over by a train, the insurance company will be liable, on the theory that he is killed while in the course of his labors. ${ }^{165}$

Where the assured is not a railroad employé, the mere fact that some of the duties of his occupation render it necessary for him to occasionally go on the roadbed of a railroad will not render the company liable. In such a case, under this clause, the protection afforded by the accident policy is suspended while the assured is on a railroad bed. ${ }^{166}$

After the assured or his beneficiary has established a prima facie case of liability under the terms of the policy, the burden of proof is on the insurance company to show that the accidental death or injury has resulted from a violation of the condition exempting the company from liability for injuries sustained while walking on a railroad bed or bridge. ${ }^{167}$ If

walking along the track of a railroad belonging to a company other than the one for which he worked, while returning to his home from work. The court held that he could not recover, inasmuch as at the time of the accident he was not an employe of the company on whose tracks he was injured, nor was he engaged in the discharge of the duties of his occupation.

105 Kinney v. Baltimore \& O. Employés' Rellef Ass'n, 35 W. Va. 385, 14 S. E. 8, 15 L. R. A. 142 . Here the assured, who was a car cleaner, had quit work for the day, and while on his way home, and still in the yards, was struck by a train. The court held that, while passing over the railroad tracks in coming to or returning from the yards to his home in the course of his labors, he was as much in the discharge of his duties as if he had had the tools with which he worked in his hands.

160 Yancy v. Aitna Life Ins. Co., 108 Ga. 349, 33 S. E. 979. Here the assured was a traveling salesman for a coal company. While visiting a concern in the line of his occupation, and while walking along a railroad track, he was struck by a train. The insurance company was not liable.

167 Meadows v. Pacific Mut. Life Ins. Co., 129 Mo. 76, 31 S. W. 578, $50 \mathrm{Am}$. St. Rep. 427; Starr v. Etna Life Ins. Co., 41 Wash. 199, 83 Pac. 113, 4 L. R. A. (N. S.) 636.

FUller Acc.Ins. -12 
the assured is killed or injured at a street crossing, or under other circumstances justifying his presence on the tracks, the burden then shifts, and the claimant must show that the presence of the assured on the track was for some sufficient reason excusable. ${ }^{168}$

Accident Distinguished from Bodily Infirmity or Disease. -One of the most important conditions in policies of accident insurance is that which exempts the company from liability for death resulting from "bodily infirmity or disease." These two phrases are generally used interchangeably or correlatively. It would seem that there could be little question as to whether death or injury resulted from an accident or from disease. If the policy holder dies from typhoid fever contracted by drinking germ-laden drinking water, clearly death is the result of the disease. On the other hand, if, while walking along the street, he is struck by a falling chimney, he is clearly injured by an accident. In the first case the company would be exempt under its policy, and in the other it would be liable. But between these two clearcut cases, of disease on the one hand and accident on the other, there is a wide range of infirmities where it may not be clear whether the injury or death is to be attributed to one cause or the other, and whether or not the company shall be liable on its policy.

Disease may be defined as a disorder of internal origin, while an accident, generally speaking, is a disorder arising from some external force. But an accident or external cause may, and, indeed, frequently does, produce death through the derangement of internal organs. For example, where a man is shot by a revolver, or bitten by a dog, or struck by a wagon, the accident is clearly the cause of the injury or death; but when impurities are taken into the lungs or stomach, producing

168 Correll v. National Acc. Soc., 139 Iowa, 36, 116 N. WV. 1046, 130 Am. St. Rep. 294. 
a fever or other sickness, clearly the disease is the proximate cause of death. ${ }^{169}$

The term "disease" is not applied to a mere temporary derangement of some organ of the body. ${ }^{170}$

A disease or bodily infirmity contemplates, not a mere temporary disturbance of the system, but rather functional disorders of a more prolonged nature. A temporary disorder, re-

169 Bacon v. United States Mut. Acc. Ass'n, 123 N. Y. 304, 25 N. E. 399, 9 L. R. A. 617, 20 Am. St. Rep. 748, reversing 44 Hun (N. Y.) 599. Here the policy contained a condition exempting the company from liability for death or disability caused wholly or in part by bodily infirmity or disease. It appeared that the death of the assured was caused by a malignant pustule. The assured was engaged in the business of handling wools and hides when he was infected by this disease, which is common among tanners, butchers, and herdsmen. The pustule is caused by contact with diseased or putrid animal matter, which produces at the point of contact a papula something like a flea bite, which develops into a pustule, and the disease is contracted by handling the hide or wool of animals which may be suffering therefrom, although it may be communicated by insects, such as flies or mosquitoes, which have been feeding upon carrion. It frequently becomes an acute infectious malady. The evidence tended to show that it differs somewhat from hydrophobia or other diseases in the nature of the germ by which it is communicated. The court held that the insurance company was not liable, and said: "The difference between the cause of this condition and the causes of typhoid fever, tuberculosis, smallpox, scarlet fever, and such like diseases, is that this particular condition is caused by different bacilli from the others, and they come in contact with the skin or enter into its pores, while in the other cases they are generally breathed in. But no abrasion of the skin is needed to produce the contact of the bacilli, and what follows from such contact seems to be as plainly a disease as in the case of smallpox or typhoid fever."

170 Preferred Acc. Ins. Co. of New York v. Muir, 126 Fed. 926, 61 C. C. A. 456 . Here the assured, while riding on a train, was suddenly attacked by nausea due to the heat of the cars and the motion of the train. The toilet room being locked, the assured stepped through the car door to the platform to vomit, and was accidentally thrown from the car. The court declared that the term "disease" was not intended to cover or apply to a temporary derangement of the functions of some organ, as in this case, and, moreover, the nausea was a mere coincidence, inasmuch as it was the occasion of his going on the platform, and not the actual cause of his death, within the fair meaning of this condition of the policy. 
sulting from some accidental and unexpected derangement of the system, would not be a disease within the meaning of such a policy of insurance, and would not exempt the company from its liability. Thus a fainting spell produced by indigestion or lack of proper food, or from other causes which would show a mere temporary disturbance, would not be included in the exception, nor would an anæmic murmur, indicating no structural defect of the heart, but arising simply from a temporary disability. ${ }^{171}$

So, also, death caused by insanity does not come within the condition releasing the company from liability for bodily injuries resulting from mental infirmity. As, for instance, where the assured while insane committed suicide whether by hanging or shooting himself. ${ }^{172}$

Where the policy provides that the amount of the premium paid shall be returned if an injury is sustained by the insured while insane, the company will be liable only for the amount of such premium in the event of death occurring while the insured is non compos mentis. ${ }^{173}$ Clearly where, as the result

171 See Manufacturers' Accident Indemnity Co. v. Dorgan, 58 Fed. 945, 7 C. C. A. 581, 22 L. R. A. 620 , where the assured while on a fishing trip was drowned by falling into a stream by the side of which he was fishing. He was found drowned, with his head submerged in six inches of water, and with two bruises on his forehead caused by stones in the brook.

172 Accident Insurance Co. v. Crandal, 120 U. S. 527, 7 Sup. Ct. 685, 30 L. Ed. 740, affirming Crandal v. Accident Ins. Co. (C. C.) 27 Fed. 40. Here the court said: "If insanity could be considered as coming within this clause, it would be doubtful, to say the least, whether under the rule of the law of insurance, which attributes an injury to its proximate cause only, and in vlew of the decisions in similar cases, the insanity of the insured, or anything but the act of hanging himself, could be held to be the cause of his death." See, also, Blackstone v. Standard Life \& Acc. Ins. Co., 74 Mich. 592, 42 N. W. 156, 3 L. R. A. 486, where the assured, whlle insane, committed suicide by cutting his throat.

178 Blunt v. Fidelity \& Casualty Co., 145 Cal. 268, 78 Pac. 729, 67 L. R. A. 793, 104 Am. St. Rep. 34. Here the assured, while insane 
of an accident, or the suffering incident thereto, the assured becomes insane, and inflicts death or violent injury upon himself, the company will be liable. ${ }^{174}$

Death by drowning is the result of accident, and not disease, within the meaning of this condition in a policy of insurance. ${ }^{175}$ Clearly, if a runaway horse knocks a man off a bridge into a stream, or a strong wave upsets the boat in which he is rowing and he is drowned, death is the result of an accident. Again, if the assured mistakes the depth of the water, and in diving strikes his head on a rock, it is an accident. Drowning is the result of the action of the water on the lungs and the consequent interference with respiration, in the same manner as suffocation from the smoke of a house which is on

and confined in an institution, fell against a steam radiator, sustaining injuries from which he subsequently died. In that case the court held that the company was not liable under the terms of the policy.

174 Traveleṛs' Ins. Co. v. Melick, 65 Fed. 178, 12 C. C. A. 544, 27 L. R. A. 629. Here the assured accidentally shot himself in the foot, as the result of which tetanus or lockjaw ensued. He was sul)sequently found dead, with his throat cut and a scalpel in his nand. The testimony showed that he had been suffering from tetanic spasms, which caused intense agony. The court charged the jury that if they found the shot wound caused tetanus, great pain, and delirium, and that while in that sate the assured cut his own throat, being impelled to do so by the intense agony caused by the wound, which he was unable to resist, then the shot wound might be considered the proximate cause of the injury.

175 Wehle v. United States Mut. Acc. Ass'n, 11 Misc. Rep. 36, 31 N. Y. Supp. 865. Some policies, however, expressly except death resulting wholly or partly by drowning. See Lewis v. Continental Casualty Co., 61 Wash. 154, 112 Pac. 91. Here the assured was a passenger on a vessel, which collided with another and sank some distance off the coast of California. The claimant introduced evidence to show that other passengers had been hurled against portions of the boat by the collision and lurching, and severely injured, in an effort to show that the assured had met his death by violent injuries, rather than by drowning. The court held that under the circumstances such evidence could not raise a presumption that the assured died from personal injuries thus sustained, instead of drowning. 
fire. ${ }^{176}$ So, where a man in good health is suddenly seized with cramps in the water, or is drowned as a result of exhaustion before assistance can reach him, the company will be liable on its policy, on the theory that the influx of water into the lungs is an external and accidental force. ${ }^{177}$

Where the assured is subject to epilepsy, and as the result of an epileptic fit falls into the water and is drowned, the death is accidental within the terms of the policy exempting the company from liability for death or injury resulting from bodily infirmities or disease, on the theory that the suffocation

176 See Reynolds v. Accident Insurance Co., 18 Wkly. Rep. 1141, 22 Law Times (N. S.) 820; Trew v. Railway Passengers' Assurance Company, 6 H. \& N. Rep. 838; Landon v. Preferred Acc. Ins. Co., 43 App. Div. 487, 60 N. Y. Supp. 1S8. Here the assured left his office, stating to his associates that he intended to go to a pleasure resort, and inviting them to accompany him. This was the last occasion on which he was seen alive. Some days later his body was found in the water, its condition indicating that the assured had struggled in the water and lost his iife in drowning. In such a case it is a question for the jury to determine whether the assured died from the action of the water or from natural causes. Where there is no testimony to show the exact manner of death, the law raises two presumptions in behalf of the assured-one that he did not commit sulcide, and the other that his death was not caused by the intentional act or crime of another person. These are presumptions of fact, and exist until overthrown by proof. Mallory v. Travelers' Ins. Co., 47 N. Y. 52, 7 Am. Rep. 410. Here the assured disappeared after having been last seen walking on a railroad track. A few days later his body was found, with a cut on the back of the head, in a culvert which passed under the railroad. A motion for nonsuit was overruled on the evidence that the finding of the body, the statement of his condition, coupled with the presumption raised by law, was sufficient to support an inference that the assured fell or was hurled off from the railroad track into the stream, and that he met his death by drowning.

177 See Knickerbocker Casuaity Ins. Co. v. Jordan, 6 Ohio Dec. 1145, 7 Wkly. Law Bul. 71. Here the assured, a strong man and expert swimmer, while in the water unexpectedly became disabled and cried for heip. Before assistance could reach him, he sank out of sight. His body was recovered the next day. The evidence tended to show that the assured was seized with cramps while in swimming. 
from the water, and not the epilepsy, is the proximate cause of death. ${ }^{178}$ It must be clear, in order to release the company from liability, that the death is the proximate result of a cause other than epilepsy. For example, if entering the water produces an attack of epilepsy, 'from which the assured dies, the company will not be liable. ${ }^{179}$ Where a man while standing on a railway platform is seized with an attack of epilepsy and

178 Winspear v. Accident Insurance Co., Law Rep. 6 Q. B. Div. 42, affirming 42 Law Times Rep. 900 . Here the assured while fording a stream was seized with an epileptic fit and, falling into the stream, was drowned. The policy provided that the insurance should not extend to "an injury caused by or arising from disease, although such death may have been caused by accident." The court held that the real causa causans was the influx of water into the lungs of the deceased, and although "the drowning may have been occasioned by the deceased having fallen down in the water from a fit of epilepsy and that fit may have been occasioned by a constitutional habit of body, making it dangerous for him to expose his limbs to the action of cold water * * * but for which the death, perhaps, would not have happened, but not being in the proper sense of the word the actual cause of death. **** If he had not had the fit, he probably would have crossed the stream in safety; but that does not make the fit the actual proximate cause of his death. * * * The question after all is: What was the injury of which he died? The injury was drowning, which is an injury within the precise terms of the policy, and which therefore determines the case." In passing upon the case in review, Lord Coleridge said: "Death was not caused by any natural disease or weakness, or exhaustion consequent upon disease, but by the accident of drowning. I am of opinion that those words in the proviso mean what they say, and that they point to an injury caused by natural diseases, as if, for instance, in the present case, epilepsy had really been the cause of the death. The death, however, did not arise from any such cause."

179 See 'Tennant v. Travelers' Ins. Co. (C. C.) 31 Fed. 322, where the assured, who was subject to eplleptic fits, was found dead in a bathtub in an almost standing position, firmly grasping the supply pipe; the temperature of the water being 100 degrees. There was an abrasion near his eye and a bruise on one side of the head. The testimony showed that the entrance into the water of one in his condition would likely result in an attack of epilepsy, and that the fall or blow which caused the abrasions was not sufficient to have occasioned death. 
falls onto the railroad track, where he is run over by a locomotive, the proximate cause of the injury is not the epilepsy, but the crushing by the train. ${ }^{180}$

Clearly, where the injury causes epilepsy, which in turn produces death, the death results from the injury, not from the disease. ${ }^{181}$ On the other hand, where the death of the assured is clearly the result of apoplexy, which is not occasioned or superinduced by any injury, the insurance company will not be liable. ${ }^{182}$

Dilation of the heart, caused by the shock of taking a cold bath while overheated, has been held to be the result of an accident. ${ }^{183}$

Where the condition is broader in its scope, and exempts the insurance company from liability for death occasioned "indirectly as well as directly by disease or bodily infirmity," the assured will not be permitted to recover, where-his death is the result of an accidental injury occurring by reason of an

180 See Lawrence v. United States Insurance Co., I. R. 7 Q. B. Div. 216.

181 National Benefit Ass'n of Indianapolis v. Grauman, 107 Ind. 288, 7 N. E. 233 . The court held that the fact that the injury resulting from the fall produced apoplexy did not render it any the less the cause of death.

182 Travelers' Ins. Co. v. Selden, 78 Fed. 285, 24 C. C. A. 92 . Here the assured, fifty-three years of age, while engaged in work which required him to stoop over, and shortly after running rapidly up a hill side, was attacked with pains in his head and soon died. The court directed a verdict for the insurance company. The testimony showed cleariy that the death was due solely to apoplexy, and that there was nothing in the circumstances which would have occasioned the death, unless there had been some bodily infirmity.

188 Johnson v. New Amsterdam Casualty Co., Cuyahoga County, Ohio, Common Pleas Court, Third Subdivision, Fourth District, Octobèr, 1912, not reported. In this case the assured, in perfect health, returned from a horse back ride on which he had become overheated, and at once took a cold bath, which caused dilation of the heart and his disability. The court heid that it was a question of fact for the jury, which decided that the disability resulted from an accident, and returned a verdict against the insurer. 
apoplectic stroke; as, for example, where the assured while riding in a wagon is seized by a stroke of apoplexy and falls under the wheels and is crushed to death. ${ }^{184}$

Death by sunstroke is the result of disease, and not of an accident. ${ }^{185}$ On the other hand, although sunstroke is a dis-

184 Clark v. Employers' Liability Assur. Co., 72 Vt. 458, .48 Atl. 639. The court said: "Death is caused directly and wholly by the crushing, but it is nevertheless caused indirectly by the disease. It was necessary for the plaintiff to show, not only that the injury received was the direct cause of death, but that disease did not indirectly cause the death by subjecting the insured to that injury."

185 Sinclair v. Maritime Passengers' Assurance Co., 3 Ellis \& Ellis (Q. B.) 478. Here the assured, while sailing on a ressel on the coast of Southern India, was stricken by a sunstroke as the resuit of which he died. Chief Justice Cockburn, in the opinion, said: "It is difficult to define the term 'accident,' as used in a policy of this nature, so as to draw with perfect accuracy a boundary line between injury or death from accident, and injury or death from natural causes, such as shall be of universal application. At the same time, we think we may safely assume that in the term 'accident,' as so used, some violence, casualty, or vis major is necessarily involved. We cannot think disease produced by the action of a known cause can be considered as accidental. Thus disease or death engendered by exposure to heat, coid, damp, the vicissitudes of ciimate, or atmospheric influences, cannot, we think, properly be said to be accidental, unless, at all events, the exposure is itself brought about by circumstances which may give it the character of accident. Thus (by way of illustration) if, from the effects of ordinary exposure to the eiements, such as is common in the course of navigation, a mariner should catch cold and die, such death would not be accidental; although if, being obliged by shipwreck or other disasters to quit the ship and take to the sea in an open boat, he remained exposed to wet and cold for some time, and death ensued therefrom, the death might properiy be heid to be the result of accident. It is true that in one sense disease or death, through the direct effect of a known natural cause, such as we have referred to, may be said to be accidental, inasmuch as it is uncertain beforehand whether the effect will ensue in any particular case. Exposed to the same malaria or infection, one man escapes, another succumbs. Yet diseases thus arising have always been considered, not as accidental, but as proceeding from natural causes. In the present instance, the disease called sunstroke, although the name would at first seem to imply something of external violence, is so far as we are informed an inflammatory disease of the brain, brought on by exposure to the too 
ease, many policies of accident insurance specifically enumerate it among the list of injuries for which the insurer will be liable. ${ }^{188}$

Similarly, such light ailments as heat exhaustion, death by asthma, and the like, are the result of disease. Where a policy provides that the company shall not be liable in the event that the death is caused by sunstroke while not engaged in the line of duty, or that the amount of indemnity shall be diminished in such an event, the insurer will clearly be liable where death is occasioned solely by sunstroke while the assured is engaged in the regular duties of his occupation. ${ }^{187}$

intense heat of the sun's rays. It is a disease to which persons exposing themselves to the sun in a tropical climate are more or less liable, just as persons exposed to other natural causes to which we have referred are liable to disastrous consequences therefrom. The deceased in the discharge of his ordinary duties about his ship, became thus affected and so died."

Dozier v. Fidelity \& Casualty Co. of New York (C. C.) 46 Fed. 446, 13 L. R. A. 114. Here the assured, whlle in the performance of his duties as a supervising architect, suffered from sunstroke. The court declared that sunstroke was no more an accident than cholera, small pox, yellow fever, or apoplexy. This case contains an excellent discussion of the pathological conditions of sunstroke. See, also, Hey v. Guarantors' Liability Indemnity Co., 181 Pa. 220, 37 Atl. 402, 59 Am. St. Rep. 644.

186 Continental Casualty Co. v. Johnson, 74 Kan. 129, 85 Pac. 545, 6 L. R. A. (N. S.) 609, 118 Am. St. Rep. 308, 10 Ann. Cas. 851 . Here the policy contracted liability for sunstroke occurring to the assured. The court held that the policy covered what is familiarly known as sunstroke, not only when caused by the heat of the sun, but also when caused by artificial heat. And thus the company was liable, as in this case, where the assured, a stoker, suffered an attack as a result of the heat emanating from a furnace. See, also, Bryant v. Continental Casualty Co. (Tex. Civ. App.) 145 S. W. 636. Here the court in a well-considered opinion held that death by sunstroke caused by the exposure of the assured to the sun and humid atmosphere on a hot day, while pursuing his usual avocation in his ordinary way, was not caused by sunstroke due to "external, violent, and accidental means."

187 Rallway Officials' \& Employês' Acc. Ass'n v. Johnson, $109 \mathrm{Ky}$. 261, 58 S. W. 694, 52 L. R. A. 401, 95 Am. St. Rep. 370. Here the 
Death by fright is the result of an accident, and not disease, within the meaning of such a policy. ${ }^{188}$

The effect of the exception relieving the insurance company from liability for death or injuries arising from bodily infirmity or disease is generally determined by the relation which exists between the accident and its results and the disease in question under the doctrine of proximate cause ("non remota sed proxima causa spectatur est"). The insurance company is relieved from all liability if the disease is the cause of the accident in direct and logical, sequence. Care must be exercised to distinguish cases arising under this theory from those cases where, for example, the assured was drowned, and the suffocation produced thereby is the proximate and determining cause of his death, rather than the epilepsy or spasms which have thrown the victim into the stream. Thus, for example, where the assured dies as the result of sustaining a heavy fall, occasioned by a lesion of the brain or heart. ${ }^{189}$

policy provided that the insurance company should be liable for only one-fourth the amount of the policy, where the disability or death of the insured was caused or contracted by sunstroke while not in line of his duty as a railway employé. The court held that the liability for death by sunstroke while the insured was in line of duty could not be avoided on the ground that death was by disease, if the policy expressly acknowledged the liability of the company for death thus occasioned.

188 See McGlinchey $\nabla$. Fidelity \& Casualty Co., 80 Me. 251, 14 Atl. 13, $6 \mathrm{Am}$. St. Rep. 190. Here the assured was driving upon a public street, when his horse took fright at some object and rau away, though not upsetting the carriage or colliding with anything before he was brought under control by the driver. Immediately afterwards the assured suffered severe pain, and died in about an hour. The court held that the company was liable under its policy.

180 Sharpe v. Commercial Travelers' Mut. Acc. Ass'n, 139 Ind. 92, 37 N. E. 353. Here the policy of insurance exempted the company from liabllity for any disability or death which may have been caused, "wholly or in part by bodily infirmities or disease." The assured, while engaged in his business as a traveling salesman, sustained a heavy fall, injuring the left side of his forehead while striking the floor and shortly died. The evidence showed no ex- 
So where the lungs of the assured are so diseased as to be ruptured when the assured performs so ordinary an act as closing a window. ${ }^{190}$ Or where the assured, in an enfeebled and emaciated condition, is injured while carrying a grip or other object in an ordinary manner. ${ }^{\mathbf{1 9 1}}$

The company is not liable where the assured, while delirious from a fever produced solely by sickness, is injured by falling or jumping from a window. ${ }^{192}$ And the insurer is not liable where, owing to a diseased condition of the heart or arteries,

ternal causes for the fall, but only that the assured, while standing, suddenly threw up his hands and fell to the floor. A post mortem examination developed the fact that the assured was suffering from a tumor near the base of the brain in an advanced state of fatty degeneration, and also from degeneration of the heart. It was clear that the fall and the injury was the result of this disease. Clark v. Employers' Liability Assur. Co., 72 Vt. 458, 48 Atl. 639, where the assured, as the resuit of a stroke of apoplexy, fell before a wagon and was crushed to death; the court held that the death was due "indirectly," under the terms of the policy, to disease, exempting the company from liability for death as the result of a bodily infirmity.

190 Feder v. Iowa State Traveling Men's Ass'n, 107 Iowa, 538, 78 N. W. 252,43 L. R. A. 693,70 Am. St. Rep. 212 . Here the assured was a consumptive, and, on reaching to close the window, ruptured an artery, from which he died. There was no evidence to show that anything occurred or was done in reaching for the window which the assured had not foreseen and planned, except the rupture.

191 Cobb v. Preferred Mut. Acc. Ass'n, 96 Ga. 818, 22 S. E. 976. In this case the assured was in an emaciated condition, and upon setting down a grip, which he had been carrying, he noticed a defect in the vision of one eye. He had not received any blow or injury, and the insurance company was excused from liability on its policy.

192 Carr v. Pacific Mut. Life Ins. Co., 100 Mo. App. 602, 75 S. W. 180. Here the assured, while confined in a hospital, suffering from the grippe, had a high fever and was delirious. He had to be restrained by force to prevent his doing injury to himself or others. During the temporary absence of his nurse from the room, he jumped from the window and was injured. The court held that the company was not liable under a policy exempting it for injuries resulting "directly or indirectly, wholly or in part, from any disease or bodily infirmity." The court said that in this case the question was not whether the plaintiff's sickness was the proximate 
the assured dies as the result of performing an ordinary act in the manner intended. ${ }^{193}$

Somnambulism, however, is not a disease within the meaning of the exception, and death or injury caused by an accident

or immediate cause of his injury, but whether the injury was caused dilectly or indirectly by his disease.

193 Shanberg $\dot{v}$. Fidelity \& Casualty Co. (C. C.) 143 Fed. 651, affirmed by 158 Fed. 1,85 C. C. A. 343,19 L. R. A. (N. S.) 1206 . Here the assured, while carrying a door along a street, set it down and suddenly dropped dead; an autopsy revealing that he was suffering from fatty degeneration of the heart, which caused his death. In a thorough discussion of the principles involved, the court said: "While the deceased was diseased, yet, if he met with such an accident, such an unforeseen condition of affairs or chance happening that his death was caused independently of the condition of the heart, the company may be maintained liable. For instance, suppose this man's heart was ready to burst, and in such condition that the carrying of this door would burst it, yet from the way he had lived, guarding himself from peril because of the known fact, if he had been struck by lightning, been kicked by a horse, had received some unforeseen blow, or had taken into his system a poisonous fluid, or substance, by accident, without knowledge that it was that kind of a thing, or had he inhaled poisonous and noxious gas by accident, then in such case the condition of the heart would have nothing to do with the death. On the other hand, suppose no accident happened. Suppose he walked rapidly upstairs, and death had resulted, as it might have done in the light of the diseased condition of this man's heart. * * * Suppose, being in a hurry, we should rush upstairs to see some one, or suppose we should walk rapidly up a hill, thus, of course, exciting the heart action, or suppose we should pick up a load of something and carry it, as we might do in the ordinary course of our business affairs, and everything should be done just as we intended to do it, we carried our load just as we intended, or we ran up the hill just as we intended, and the exertion ruptured the heart, and we fell dead; can we hold it to have been in contemplation of the parties in making the indemnity contract that the company should pay for the death resulting in such a case, where, as in this, the heart was badly diseased. To my mind, in such case, there can be no doubt, because there is no accident."

See, also, Hastings v. Travelers' Ins. Co. (C. C.) 190 Fed. 258. Here the assured, while raising and lowering himself by the hands and arms, suddenly sank back dead, and a post mortem examination revealed that an enlarged heart and hardened airteries were the 
received during sleep-walking will render the company liable. $^{194}$

The decisions must necessarily vary according to the different provisions or wording of this condition in the policy of insurance. So, where the company expressly provides that it will not be liable for death resulting from epilepsy, hernia, or other diseases arising within the system before, or at the time of, or following an accident, injury, etc., the company will not be liable where death is due to one of these diseases which supervenes upon an accident. For example, under such a policy, the company will not be liable where the assured accidentally cut his foot, and erysipelas followed, as the result of which he died. ${ }^{195}$

cause of death. Schmid v. Indiana Travelers' Acc. Ass'n, 42 Ind. App. 483, 85 N. E. 1032, where the assured died of heart fallure from carrying a traveling bag up a long flight of stairs in a high altitude.

An interesting case is presented in Hooper v. Standard Life \& Accident Ins. Co. (Mo. App.) 148 S. W. 116. Here the assured, a neavy and apparently robust man, when approaching his house in a street car, arose from his seat, presumably to alight, when he elther sank or fell to the floor. An autopsy revealed the fact that he was diseased in brain, heart, and arteries, and that he died from a cerebral hemorrhage. The company maintained that his death was the resuit of an apoplectic stroke without any accidental cause, while the plaintiff maintained that the lurching of the car caused his fall, rupturing a blood ressel, which caused the stroke. The court said: "Notwithstanding Hooper was fatally diseased in heart and brain, and notwithstanding his death was from apoplexy, yet if he accidentally fell in the car and ruptured a blood vessel, which caused the apoplectic stroke, his death would be accounted as accidental. For, if a man is so afficted that he will die from such affiction within a few hours, yet if, by some accidentai means, his death is caused sooner, it would be a death from accident."

104 Travelers' Ins. Co. v. Harvey, 82 Va. 949, 5 S. E. 553. Here the assured during the night fell from a window of his room and received injuries from which he died. The evidence showed that he was asleep at the time of his fall.

195 Smith ₹. Accident Insurance Co., Law Rep. 5 Exch. 209, 22) Law Times (N. S.) 861. Here the assured under such a policy acci-? 
Where the policy provides that the company will not be liable for the death or injury of the assured occurring as the result of disease, the company will none the less be liable if the assured is sick and suffers from an accident which is in no way occasioned by, or the result of, his sickness. In such a case, sickness is not the proximate or immediate cause of the injury, but merely an incident. For example, where the assured, who is deaf, is accidentally injured by a fall, the company will be liable under its policy, unless the evidence shows that the deafness contributes to the injury. ${ }^{198}$ Similarly, the company will be liable where one, while weakened from disease, is accidentally struck by a stone, or bitten by a dog, or suffers from any other accident not occasioned by his condition. ${ }^{197}$

Another phase of the condition under discussion is presented where the accident by which the assured is injured results in sickness or disease. If a disease resulting in death is the effect of an accident, so as to be a mere step or link in the chain of causation between the accident and death, then the death is attributable to the accident alone, and not to the dis-

dentally cut his foot against the broken side of an earthenware pan. Erysipelas shortly intervened, as the result of which the assured died. The company was declared not to be liable on account of the specific exemption in the policy. Except for this provision in the policy, it is clear that the company would have been liable, inasmuch as the erysipelas was caused by an accident.

196 Fidelity \& Casualty Co. v. Chambers, 93 Va. 138, 24 S. E. 896 , 40 L. R. A. 432.

197 Xtna Life Ins. Co. v. Hicks, 23 Tex. Civ. App. 74, 56 S. W. S7. Here the assured, while recovering from an attack of typhoid fever: and therefore weak and debilitated, against the advice of his physician, left for his home on a train. While the train was in motion, the assured went to the water cooler to secure a drink. While standing there drinking, the train gave a sudden lurch, which threw him against the arm of one of the seats and injured his side, as a result of which he died some days later. The evidence did not show that the typhoid fever from which he was suffering in any way caused the accident. 
ease, and the insurance company is liable on its policy. ${ }^{108}$ But if an independent disease supervenes upon the injury, or the injury merely rouses into activity an existing or slumbering disease, and the death of the assured results wholly or in part from such disease, then the accidental injury will not be the sole and proximate cause of death. The insurance company is not liable if the assured suffers an accident, but at the time of sustaining it is already suffering from a disease or bodily infirmity, and if the accident would not have caused his death

198 Etna Life Ins. Co. v. Fitzgerald, 165 Ind. 317, 75 N. E. 262, 1 L. R. A. (N. S.) 422, 112 Am. St. Rep: 232, 6 Ann. Cas. 551, where an accidental injury to the hand, compressing the tissues and blood ressels, caused perlostitis; Caldwell v. Iowa State Traveling Meu's Ass'n (Iowa) 136 N. W. 678, where an accidental wound in the cheek caused erysipelas, from which death ensued; Continental Casualty Co. V. Colvin, 77 Kan. 561, 95 Pac. 565, where the assured fell against some timber and injured his chest, which may have produced pneumonia. The court here said: "An injury may be said to be the sole producing cause of death when it stands out as the predominating factor in the production of the result. It need not be so violent and virulent as necessarily and inevitably to produce the result, regardless of all other circumstances and conditions. The active efficient cause that sets in motion a train of events, which bring about a result without the intervention of any force from a new and independent source, may be regarded as the direct and proximate cause. If the immediate cause of death is a disease produced wholly by an injury, the death must be attributable to the injury and not to the disease." Aitna Life Ins. Co. v. Bethel, $140 \mathrm{Ky} .609,131 \mathrm{~S}$. W. 523; Driskell v. United States Health \& Accident Ins. Co., 117 Mo. App. 362, 93 S. W. 880 ; MeAuley v. Casualty Co. of America, 39 Mont. 185, 102 Pac. 586, where a wound produced erysipelas from which the assured died; Rheinheimer v. Atna Life Ins. Co., 77 Ohio St. 360,83 N. E. 491,15 L. R. A. (N. S.) 245 , where the assured injured his finger and blood poisoning ensued; Armstrong $\mathrm{v}$. West Coast Life Ins. Co. (Utah) 124 Pac. 518, where the assured fell from a ladder against a showease and traumatic pneumonia developed, from which he died; French $\nabla$. Fidelity \& Casualty Co. of New York, 135 Wis. 259, 115 N. W. 869, 17 L. R. A. (N. S.) 1011, where assured struck his leg against a safe, causing an abrasion of the skin, and blood poisoning ensued. The court here said: "The contention is that the accidental injury of itself would not have resulted fatally, but that death was due to an independent intervening cause, namely, the germs which entered the system through 
unless he had been affected by the disease or infirmity, but he dies because the accident aggravates the disease, or the disease aggravates the effects of the accident. Death is caused partly by disease and partly by accident, and therefore exempts the company from liability.

The company is liable, however, where the assured as the result of an accident ruptures a blood vessel, which causes abscesses, as the result of which death ensues. ${ }^{199}$ So the company is liable where the assured dies from pneumonia resulting from a cold contracted while suffering from debility due to an

the wound. It must be apparent, however, that but for the accidental injury there would have been no cause for infection; that but for the abrasion the disease germs could not have entered and produced the fatal result. The wound produced by the accident was therefore the proximate and sole cause of death. Counsel for respondent insists that the words 'independently of all other causes' do not mean the 'sole proximate cause,' that there was an independent intervening cause, which resulted in the death of the insured, and therefore the defendant is not liable. We cannot adopt this interpretation of the language, or the conclusion sought to be drawn from the testimony."

199 McCarthy v. Travelers' Insurance Co., 15 Fed. Cas. 1254. Here the assured, while swinging Indian clubs, accidentally ruptured a blood vessel, which in turn caused inflammation in the form of abscesses and pulmonary troubles, from which he died. The court said: "If an independent disease supervened upon the injury, one not necessarily produced by the injury, or if the alleged injury merely brought into activity a then existing though slumbering disease, and the death of the deceased was caused wholly or in part by such disease, then it could not be said that the injury was the sole and proximate cause of the death. *** But, to entitle the plaintiff to recover, the injury must be the proximate cause of death. By proximate cause is meant that cause which directly precedes and produces the effect, as distinguished from the remote cause. * * And it must be remembered that whether a cause is proximate or remote does not depend alone upon the closeness in the order of time in which certain things occur. In other words, the application of the principle relating to proximate cause is not necessarily controlled by time or distance, nor by the succession of events. An efficient adequate cause being found must be deemed the true cause, unless some other cause not incidental to it, but independent of it, is shown to have intervened between it and the result."

$$
\text { Fuller Acc.Ins.-13 }
$$


accident or injury; ${ }^{200}$ or where the assured in normal health meets with an accident which produces concussion of the brain, or apoplexy, as a result of which he dies; ${ }^{201}$ or where an accidental fall produces rheumatism, resulting in heart failure, as the result of which the assured dies. ${ }^{202}$ This is true, even where the accident causes a disease from which the assured had previously suffered and been cured, however, leaving him peculiarly liable to its recurrence..$^{203}$

Probably the most frequent example of disease caused by injury is found in cases where the assured dies by blood poisoning as the result of an accidental injury. It is a settled rule that where blood poisoning results from a wound, the sting of an insect or reptile, or an accidental abrasion of the skin, the accident, and not the disease, is considered the proximate cause of the death. ${ }^{204}$ So where the assured is wearing a new pair

200 Isitt v. Railway Passengers' Assur. Co., 22 Q: B. Div. 504. 'The assured fell and dislocated his shoulder, and was confined to his room, and, suffering intense pain, became restless and unable to wear his clothes, and was reduced to a condition of general debility. He caught cold, contracted pneumonia, and die in consequence thereof.

201 Hall v. American Masonic Acc. Ass'n, 86 Wis. 518, 57 N. W. 366. Here a sudden fall produced concussion of the brain and apoplexy, as the result of which the assured died.

202 'Travelers' Ins. Co. v. Hunter, 30 Tex. Civ. App. 4S9, 70 S. W. 798. Here the assured, while alighting from a vehicle, was thrown by the starting of his horse, severely wrenching and straining his body, as a result of which rheumatism ensued, in turn producing heart trouble, causing his death. The court held that if the rheumatism whlch produced the death of the assured was caused by the accidental injury, and was but a mere link in the chain of causation between the accident and death, then the death was attributable, not to the disease, but to the accident alone.

203 Freeman v. Mercantile Mut. Acc. Ass'n, 156 Mass. 351, 30 N. E. 1013, 17 L. R. A. 753 . Here the assured, who had prevlously had peritonitis, died of peritonitis induced by an accidental fall. The insured had entirely recovered from his first attack of peritonitis, but was none the less liable to a recurrence of that disease. The court said that if, at the time of the injury, the assured was not suffering from the disease, the company would be llable on its policy.

204 Omberg v. United States Mut. Acc. Ass'n, 101 Kу. 303, 40 S. 
of shoes, which produce an abrasion of the skin, from which blood poisoning ensues. ${ }^{205}$

And where the assured accidentally cuts his hand, producing erysipelas, which causes death, the company will be liable. ${ }^{206}$

W. 909, $72 \mathrm{Am}$. St. Rep. 413. Here the assured was in good health, and was stung on the foot by an insect, which caused blood poisoning, from which he died. In Continental Casualty Co. v. Mathis, $150 \mathrm{Ky} .477,150 \mathrm{~S}$. W. 507, the assured scratched his thumb with a carpet tack, blood poison ensuing. The court said: "In accident insurance jurisprudence, blood poison resulting from accident is regarded as a part of the accident, and an injury or death from it as an accidental injury or death." Farner v. Massachusetts Mut. Acc. Ass'n, 219 Pa. 71, 67 Atl. 927, 123 Am. St. Rep. 621, where the assured was bitten by a dog and died from the effects of blood poisoning which ensued. Cary v. Preferred Accident Ins. Co., 127 Wis. 67, 106 N. W. 1055,5 L. R. A. (N. S.) 926, 115 Am. St. Rep. 997, 7 Ann. Cas. 484, where the assured fell and sustained an abrasion of the skin on one leg, in which blood poisoning developed, from which he died. In an excellent opinion the court sustained the verdict against the insurer.

205 Western Commercial Travelers' Ass'n v. Smith, 85 Fed. 401, 29 C. C. A. 223,40 L. R. A. 653 . Here the assured, who was a strong, healthy man, wore a new pair of shoes, which produced an abrasion of the skin on one of his toes. Blood poisoning ensued, as a result of which he died. The court held that the disease was, a mere step between the abrasion which produced it and the death which it in turn produced.

206 Delaney v. Modern Accident Club, 121 Iowa, 528, 97 N. W. 91, 63 L. R. A. 603 . Here the assured accidentally cut his finger on the point of a steel eraser; inflammation set in, which developed into. erysipelas, and blood poisoning ensued, causing his death. In its decision the court said: "The simple question is whether the deatly of Delaney resulted through natural causes, without the interposition of a new and independent cause, from the cut on his finger. Dlsease brought about as the result of a wound, even though not the necessary or probable result, yet if it is the natural result of the wound, and not of an independent cause, is properly attributed to the wound; and death resulting from the disease is a death resulting from the wound, even though the wound was not in its nature mortal, or even dangerous. Even though the wound results in disease and death through the negligence of the injured person in failing to take ordinary and reasonable precautions to avoid the possible consequences, the death is the result of the wound." This case will be 
Hernia is usually declared an excepted risk for which the company will not be liable. ${ }^{207}$ This condition, however, does not relieve the insurance company if the hernia is produced by an accident, as distinguished from a rupture produced by natural causes. ${ }^{208}$ So the company will be liable where the accident produces hernia, necessitating an operation in order to prevent death, and the assured dies as the result of the operation. The accident, and not the operation, or the hernia, is the proximate cause of death. ${ }^{209}$

distinguished from the Bacon Case (Bacon v. United States Mut. Acc. Ass'n, 44 Hun, 599; Id., 123 N. Y. 304, 25 N. E. 399, 9 L. R. A. 617, $20 \mathrm{Am}$. St. Rep. 748, supra), where the erysipelas and consequent death was due to bacilli absorbed into the skin through the pores, there being no accidental abrasion or wound, as in the Delaney Case. See, also, Martin v. Equitable Acc. Ass'n, 61 Hun, 467, 16 N. Y. Supp. 279; Martin v. Manufacturers' Accident Indemnity Co., 151 N. Y. 94, $45 \mathrm{~N}$. E. 377. Here the assured accidentally injured the thumb of his hand, which was lanced and continued to suppurate up to the time of a second injury to the other hand, and there was evidence to show that blood poisoning was communicated from the first to the second injury.

207 Kelsey v. Continental Casualty Co., 131 Iowa, 207, 108 N. W. 221, 8 L. R. A. (N. S.) 1014.

208 Atlanta Acc. Ass'n v. Alexander, 104 Ga. 709, 30 S. E. 939, 42 L. R. A. 188. Here the assured, a blacksmith in good health, was injured while using a heavy sledgehammer, which resulted in a hernia, later producing death. Summers v. Fidelity Mut. Aid Ass'n, 84 Mo. App. 605. Here the assured, employed in a rallway shop, received a rupture from lifting a heavy truck. The court said: "In accident insurance, where a person is insured against bodily injuries which are effected by external, violent, and accidental means, and an accident produces the hernia, causing death, the insurer wili be liable; for the insurance is against accidents, and if hernia result from an accident, it will no more exempt the insurer than if it has not been named as a cause of exemption." Miner v. Travelers' Ins. Co., 3 Ohio S. \& C. P. Dec. 289, 2 Ohio N. P. 103, where the assured, in running through a half-open door, struck against the doorknob, producing a hernia, from which he died.

209 Travelers' Ins. Co. v. Murray, 16 Colo. 296, 26 Pac. 774, 25 $\Delta \mathrm{m}$. St. Rep. 267. Here the assured, a railway fireman, as the result of falling against some machinery, received an injury causing $u$ rupture and inguinal hernia. The testimony showed that death was 
But where the hernia already exists at the time of the accident, and is the contributing cause of death, and the assured would not have died except for the existence of the hernia, the company will not be liable. But in such a case it is incumbent upon the insurance company, after it has been shown prima facie that an injury to the assured resulted from an accident within the meaning of the terms of the policy, to show that the existence of the hernia was a substantial contributing cause, which wholly or partly produced the death of the assured. The liability under the policy will not be defeated by showing simply that the hernia merely aggravated the consequence of the accident. ${ }^{210}$

unaroidable without a surgical operation. The court held that the accident was the proximate cause of the death of the insured, and that the company was liable.

210 'Thornton v. Travelers' Ins. Co., 116 Ga. 121, 42 S. E. 287, 94 Am. St. Rep. 99. Here the assured had for years been suffering from a so-called reducible hernia, for which be was obliged to wear a truss. While traveling upon a train, and walking in the aisle of a car for the purpose of obtaining a drink of water, the assured was thrown violently to one side by a sudden lurch of the train, and the truss which he was wearing struck one of the seats, producing a strangulated hernia. An operation was necessary, and the assured was totally disabled for a period of time. The court said: "It seems to us that the true test to be applied, in order to determine whether there is a liability under the contract, is whether the condition of the insured, in having, at the time of the accident, a reducible hernia, contributed to the accident in whole or in part, directly or indirectly. If it did so contribute, the company would not be liable. But if the existence of the bernia in the system of the insured at the time of the accident did not substantially contribute wholly or partly, directly or indirectly, in bringing about the injury, but merely aggravated the consequences of the accident, then the plaintiff would be entitled to recover." Sec, also, Fitton $\nabla$. Accidental Death Insurance Co., 17 C. B. (N. S.) 122,112 E. C. L. 122. In this leading English case, the policy expressly provided that it did "not insure against death or disability arising from gout, rheumatism, hernia, erysipelas, or any other disease or cause arising within the system of the insured before, or at the time of, or following, such accidental injury, whether causing death or disability directly or jointly with such accidental 
The mere fact that the insured is suffering from a disease at the time of the accident will not exempt the company from liability, if the accident in itself is a sufficient cause of the death or injury. But if the assured is suffering from a disease, but for which death would not result from the accident, the company will not be liable, even if the accident aggravated the disease. In Commercial Travelers' Mut. Acc. Ass'n of America v. Fulton, the United States Circuit Court of Appeals tersely states the law as follows: "When the accident, such as a fall, which causes the death, was itself caused by some disease, or when an existing disease co-operates with the accidental injuries to cause the death, or when the accidental injuries are of such a character that they would not cause the death of a person in normal health, but do kill the insured, because an existing disease, unknown, perhaps, to the insured, has put him into such an abnormal condition that he is unable to resist the effects of the injuries as he would if in normal health, then in none of these cases is the insurer liable." ${ }^{211}$ So where

injury." It was held that death from hernia caused solely and directly by external violence followed by a surgical operation performed for the purpose of relieving the patient was not within such exception. In that case, said Williams, J.: "Looking at the language, and taking the first condition altogether, upon the best interpretation I can put npon it, I am of opinion that it means to exempt the company from liability only where the heruia arises within the system." Any other construction the court declared would make the policy misleading to the insured, and would result in a most illusory contract.

21179 Fed. 423,24 C. C. A. $654 ; 93$ Fed. 621,35 C. C. A. 493. Here the assured, weighing 190 pounds, while waiting on a sidewalk for a street car, suddenly fell. There was some evidence to show that his fall was caused by accidentally slipping on the ice. In falling he struck upon an iron water spout, which projected a few inches above the sidewalk, and which left external, visible marks upon his head and face. He died a few minutes later. An autopsyperformed some time later showed a badly diseased condition of the heart and arteries. See, also, National Masonic Acc. Ass'n v. 
the assured, suffering from a diseased condition of the arteries, falls while taking a bath. ${ }^{212}$ So where death results

Shryock, 73 Fed. 774,20 C. C. A. 3, where the evidence tended to show that the assured was injured by a fall, but that his death was caused, not alone by the fall, but by heart disease. Stanton $\mathrm{v}$. Travelers' Ins. Co., 83 Conn. 708, 78 Atl. 317. Here the assured, while suffering from a diseased and abnormal appendix, strained that portion of his body, and thereby brought on another attack of appendicitis, from which he died. The insurer was held not liable. Hooper v. Standard Life \& Accident Ins. Co. (Mo. App.) 148 S. W. 116, supra; White v. Standard Life \& Accident Ins. Co., 95 Minn. 77, 103 N. W. 735, 884, 5 Ann. Cas. 83, affirmed without opinion in $100 \mathrm{Mrinn}$. $541,110 \mathrm{~N}$. W. 1134. Here the assured was suffering from diabetes when he accidentally injured his thumb. The evidence showed that the diabetes co-operated with the injury to cause his death. The company was discharged from liability. The court said: "Similar policies have been before both the state and federal courts, and the consensus of judicial opinion is that, subject to the exemptions contained in the policy, if the injury be the proximate cause of death, the company is liable; but if an injury and existing bodily disease or infirmity concur and co-operate to the end, no liability exists. If, however, the injury be the cause of his infirmity or disease-if the disease results and springs from the injury-the company is liable, though both co-operate in causing death. The distinction made in this particular is found in that class of cases where the infirmity or disease existed in the insured at the time of the injury, and, on the other hand, that class of cases where the disease was caused and brought about by the injury. And even in cases where the Insured is aflicted at the time of the accident with some bodily disease, if the accidental injury be of such a nature as to cause death solely and independently of the disease, liability exists." Ward $\nabla$. Etna Life Ins. Co., 82 Neb. 499, 118 N. W. 70. Here the assured, after recorering from an accident, died from a disease which would not hare been fatal, but for his lowered vitality. The court held that the disease, and not the accident, caused his death, and there could,

212 Binder v. National Masonic Acc. Ass'n, 127 Iowa, 25, $102 \mathrm{~N}$. W. 190. Here the assured went into the bathroom to take his usual bath, and half an hour later was found in the tub in a semiconscious condition. There were bruises on his head and body, and his right leg and arm. The right side of his tongue and face were paralyzed, and he was unable to speak. He died some time later, never having recovered from his paralyzed and semiconscious condition. The evidence tended to show that he was suffering from a diseased condition of the arteries known as arteriosclerosis, and that his disability may have been caused partly or wholly therefrom. 
from rupture of the heart, caused partly by its diseased condition and partly from a fall, neither cause being in itself

therefore, be no recovery. Penn v. Standard Life \& Accident Ins. Co., 158 N. C. 29,73 S. E. 99 . Here the assured was suffering from a cataract on one eye which would have resulted eventually in destroying it. He fell from a car and sustained an injury, which was soon followed by the loss of sight. The court held that if the condition of the plaintiff's eye at that time was such that, independent of the injury, he would have ultimately lost his sight, which falling from the car merely hastened, he could not recover, and said: "If the jury had found that the injury was caused by the sum of two causes-that is, that the accident and the pre-existing cataract and diseased condition of the eye were together responsible for the subsequent blindness-the plaintiff could not have recovered, as the injury must have resulted from the accident, independently of all other causes." In a rehearing of this case in (N. C.) 76 S. E. 262, the court said: "Under policy contracts, such as the one under consideration, three rules may be stated: (1) When an accident caused a diseased condition, which together with the accident resulted in the injury or death complained of, the accident alone is to be considered the cause of the injury or death. (2) When at the time of the accident the insured was suffering from some disease, but the disease had no causal connection with the injury or death resulting from the accident, the accident is to be considered as the sole cause. (3) When at the time of the accident there was an existing disease, which, co-operating with the accident, resulted in the injury or death, the accident cannot be considered as the sole cause or as the cause independent of all other causes. * * * It should be understood that in the case of an accident resulting in injury or death, if there was an existing disease having also a causal connection therewith, it is not necessary that the disease should itself have been one which would ultimately have proved fatal, or that it should be of itself sufficient to have caused the injury or death. Under the rule that, where the injury or death has been caused by the sum of two causes, it is sufficient to prevent a recovery on the policy if any ordinary disease, not itself necessarily fatal, should contribute with the accident to cause the death; that is, if without the presence of the disease the accident itself would not have been sufficient to have caused the injury or the death. And so in this case it would have been sufficient to have shown a diseased condition of the eye, which, together with the alleged accident, resulted in blindness. It is not necessary in such a case to show that the disease of the eye was such that it would ultimately have resulted in blindness." Continental Casualty Co. v. Peitier, 104 Va. 222, 51 S. E. 209. Here the assured died from typhoid fever three weeks after receiving an injury. Two weeks before the fever dereloped, 
sufficient to cause death $;^{213}$ and also where an accidental strain ruptures a vital organ, which was in a diseased condition. ${ }^{214}$

If the assured dies while undergoing a surgical operation, if the anæsthetic alone causes his death, the company will be liable; but if the anæsthetic merely aggravates the effect of the disease, or the disease aggravates the effect of the drug, the company will not be liable. ${ }^{215}$ But a mere

he had so far recovered as to be able to take a trip, and expected in a few days to return to work. The company was held not liable; the testimony showing that there was no natural or necessary connection between the injury and the fever.

213 Hubbard v. Mutual Acc. Ass'n (C. C.) 98 Fed. 930. Here the assured died from a rupture of the heart, caused in part by a diseased condition of that organ and in part by falling on a slippery pavement. The court held that the plaintiff could not recover if the disease entered into the cause of death; in other words, if the fall would not have produced death but for the disease. It was contended that the fall would not have killed him if his heart had been sound, and also that the diseased heart would not have killed him at that time if the accident had not occurred.

214 Atna Life Ins. Co. of Hartford, Conn., v. Dorney, 68 Ohio St. $151,67 \mathrm{~N}$. E. 254 . Here the assured, while cleaning his yard, assisted in lifting a heavy stone, and in so doing ruptured his stomach. He shortly afterwards died. A post mortem revealed the fact that the assured was suffering from an ulcer of the stomach, which resulted in the complete perforation of that organ. The evidence tended to establish that the perforation of the stomach was present as a contributing, and even a primary, cause of death, and therefore the company was not liable.

216 Maryland Casualty Co. v. Glass, 29 Tex. Civ. App. 159, 67 S. W. 1062. Here the assured died while undergoing a surgical operation for appendicitis, when under the influence of chloroform. The court declared that the burden was on the beneficiary to show that the chloroform was the proximate and sole cause of death. It was maintained that the insurer would not be liable, if the chloroform would not have caused the death of the assured, if it had not been for the appendicitis. The evidence showed that the assured was extremely weak, and suffering from a gangrenous condition, and that the operation promised the only possible chance for recovery. Some policies provide for the nonliability of the insurance company in case of death or disability resulting from medical or sur- 
weakness resulting from a disease, which may render the assured more susceptible to accident, does not, of itself, release the company from liability. So if accidents that persons of ordinary strength would withstand should kill a weak person, or a person of otherwise ordinary strength because of a weak organ, the accident is the cause of the death, and not the weakness. ${ }^{216}$ If the disease follows the

gical treatment. The courts construe this phrase to cover only cases of accident growing out of medical or surgical treatment, and not to apply to such treatment when necessary for the purpose of relieving the insured from the results of accidental injury. See Vernon v. Iowa State Traveling Men's Ass'n (Iowa) 138 N. W. 696. Here the court declared that this condition "was undoubtedly enacted to cover cases of accident growing out of medical or surgical treatment, and should not be held to apply to such treatment which was necessitated because of an accidental injury."

216 Miller v. Fidelity \& Casualty Co. (C. C.) 97 Fed. 836. Here the assured died as the result of swallowing hard pieces of food, which by reason of the weakened condition of his intestines, caused by an illness from which he had otherwise recovered, perforated the intestinal canal, so as to cause death. The court said that the weakness, although left by disease, could not be said to have killed him, but rather the accident. Ludwig v. Preferred Acc. Ins. Co. of New York, 113 Minn. 510, 130 N. W. 5. Here the assured, a ball player, was injured while stealing a base by sliding into the bag. Two days later he was operated on for appendicitis, from which he died. The appendix was found to be gangrenous and badly inflamed, and the testimony showed that he had previously suffered from appendicitis, though he had not been operated on therefor. The court charged the jury in part as follows: "If you find that Ludwig had at some previous time suffered from an attack of appendicitis, and he had fully recovered therefrom, so that immediately before the external injury at the ball game * * * there was then no appendicitis present, but because of such previous attacks Ludwig was more susceptible to the disease, and such an injury started it, there may be a recovery, although the external, accidental injury would not have produced the appendicitls, if the appendix had never been previously impaired by disease. In other words, if Mr. Ludwig recovered from his former attack of appendicitis, if he had it, so that such disease no longer existed in his body, and there was only a susceptibility to have it in case a proper exciting cause should arise, and if this fall on the cement slab on the base is by you found by a fair preponderance of the evidence to be such 
injury as its necessary consequence, and would not have occurred except for the injury, then the injury becomes the

exciting cause, and to be an external, violent, and accidental injury, the amount of the policy would become payable, upon proper notice and proof being made. But if, because of the former attack, there was not merely a susceptibility to a further attack, but the actual disease itself existed, liable to be rendered active and virulent by an injury such as that suffered by Mr. Ludwig, in that event the active disease which resulted in death would not be regarded as the result of the fall alone, but as the joint result of the fall and the latent disease, and there can be no recovery." Fetter v. Fidelity \& Casualty Co., 174 Mo. 256, 73 S. W. 592, 61 L. R. A. 459, 97 Am. St. Rep. 560. Here the assured, in attempting to close a window, lost his equilibrium and fell against a chair, rupturing a kidney, which caused his death. An autopsy revealed a cancerous condition of the kidney, and it was left for the jury to decide whether the cancerous condition resulted from the rupture, or whether the rupture resulted from the cancerous condition, and whether the assured would have died had this condition not existed. Driskell v. United States Health \& Accident Ins. Co., 117 Mo. App. 362, 93 S. W. 8S0. Here the plaintiff alleged that the assured met death as the result of scalding water from a locomotive about which he was working falling into his ear, while the company claimed that death resulted from disease. The court in an excellent opinion said: "The important question that may arise under certain possible phases of proof is this: What is meant by the term, 'If death should result solely from such injuries?' We think the only reasonable interpretation to be placed upon this clause is to say that the injury must stand out as the predominant factor in the production of the result, and not that it must have been so virulent in character as necessarily and inevitably to have produced that result, regardless of all other conditions and circumstances. People differ so widely in health, vitality, and ability to resist disease and injury that what may mean death to one man would be comparatively harmless to another, and therefore the fact that a given injury may not be generally lethal does not prevent it from becoming so under certain conditions; and 1f, under the peculiar temperament or condition of health of an individual upon whom it is inflicted, such injury appears as the active, efficient cause that sets in motion agencies that result in death, without the intervention of any other independent force, then it should be regarded as the sole and proximate cause of death. The fact that the physical infirmity of the victim may be a necessary condition to the result does not deprive the injury of its distinction as the sole producing cause. In such case disease or low vitality do not arise to the dignity of concurring causes, but, in having deprived nature of her normal power 
proximate and sole cause of death within the meaning of such a policy of insurance. ${ }^{217}$

Many policies of insurance limit the liability of the company for death or disability caused by disease to a speci-

of resistance to attack, appear rather as the passive allies of the agencies set in motion by the injury."

217 Barry v. United States Mut. Acc. Ass'n (C. C.) 23 Fed. 712. Here the court clearly states the rule as to what will be considered the proximate cause of death. The court said: "To entitle the plaintiff to recover sou must be satisfied that the alleged injury was the proximate cause of death. Whetber a cause is proximate or remote does not depend alone upon the closeness in the order of time in which certain things occur. An efficient adequate cause, being found, must be deemed the true cause, unless some other cause not incidental to it, but independent of it, is shown to have interrened between it and the result. If, for example, the deceased sustained injury to an internal organ, and that necessarily produced inflammation, and that produced a disordered condition of the injured part, whereby other organs of the body could not perform their natural and usual functions, and in consequence the injured person died, the death could properly be attributed to the original injury. In other words, if these results followed the injury as its necessary consequence, and would not have taken place, had it not been for the injury, then I think the injury could be said to be the proximate and sole cause of death; but if an independent disease or disorder supervened upon the injury, if there was an injury-I mean a disease or derangement of parts not necessarily produced by the injury-or if the alleged injury merely brought into activity a then existing, but dormant, disorder or disease, and the death of the deceased resulted wholly or in part from such disease, then it could not be said that the injury was the sole or proximate cause of death."

Generai Accident, Fire \& Life Assur. Corp., Limited, of Perth, Scotland, v. Homely, 109 Md. 93, 71 Atl. 524, where the assured was struck in the back by a bale of hay and later died of acute nephritis, claimed to have been caused by the accidental blow.

Sullivan v. Modern Brotherhood of America, 133 N. W. 486,167 Mich. 524, where the assured, while washing clothes, splashed water into her eye, causing an infection which resulted in the loss of sight. An interesting case is presented in Atna Life Ins. Co. of Hartford, Conn., v. Griffin (Tex. Civ. App.) 123 S. W. 432 . Here the assured was struck in the right eye by a splinter of iron, which flew from some rails which he was unloading. The eye was severely injured, and the left eye in sympathy became affected, as the result of which the assured lost his sight. The court properly held that 
fied amount less than for death or disability resulting solely from accidental causes. ${ }^{218}$

Where two or more causes contribute to the injury, and the effects are such that equally competent persons arrive at different conclusions, the question as to which of the causes is the efficient and dominating cause of the injury is for the jury to determine. ${ }^{210}$

the loss of sight was the result of accident, independently of all other causes and not of disease.

218 Kenny v. Bankers' Accident Ins. Co. of Des Moines, 136 Iowa, $140,113 \mathrm{~N}$. W. 566. Here the testimony tended to show that the traumatic neuritis from which the assured was suffering was caused by an injury. It was left to the jury to determine whether it was such a disease as was contemplated by the policy for which only a smaller liability was contracted. See, also, General Accident, Fire \& Life Assur. Corp., Limited, of Perth, Scotland, v. Homely, 109 Md. 93, 71 Atl. 524.

210 Manufacturers' Accident Indemnity Co. $\nabla$. Dorgan, 56 Fed. 945, 7 C. C. A. 581, 22 L. R. A. 620 , as to whether the assured died as the result of an accidental fall or disease; New Amsterdam Casualty Co. v. Shields, 155 Fed. 54, 85 C. C. A. 122, whether assured died from accident or appendicitis; McCormack v. Illinois Commercial Men's Ass'n, 159 Fed. 114, 86 C. C. A. 304, whether death resulted from disease or from being accidentally thrown from a buggy; Railway Officials' \& Employés' Acc. Ass'n $\mathbf{v}$ Coady, 80 Ill. App. 563, as to whether the assured died from a fall or from a diseased condition of the lungs. Continental Casualty Co. v. Lloyd, 165 Ind. 52, 73 N. E. 824. Here the question was whether the insured died as the result of a fall or a disorder of the brain; Etna Life Ins. Co. v. Fitzgerald, 165 Ind. 317, 75 N. E. 262, 1 L. R. A. (N. S.) 422, 112 Am. St. Rep. 232, 6 Ann. Cas. 551, supra, whether accident or disease caused death through periostitis; Meyer v. Fidelity \& Casualty Co., 96 Iowa, 378, 65 N. W. 328, 59 Am. St. Rep. 374 , as to whether the insured died as the result of an accidental fall or an attack of vertigo; Caldwell v. Iowa State Traveling Men's Ass'n (Iowa) 136 N. W. 678, whether erysipelas resulted from accidental wound or disease; Atna Life Ins. Co. v. Bethel, 140 Ky. 609, 131 S. W. 523, whether the assured died from a fall or from auto-intoxication; Continental Casualty Co. v. Semple (Ky.) 112 S. W. 1122 ; General Accident \& Life Assur. Corp. v. Meredith, 141 Ky. 92, 132 S. W. 191, where evidence tended to show that assured died of intussusception, or the slipping of the bowels. Travelers' Ins. Co. v. McInerney (Ky.) 119 S. W. 171. Here the assured, while 
But, in the event of an admitted state of facts, or where the evidence is so clear and convincing that all reasonable men must fairly reach the same conclusion, the question of whether death is the result of an accident or of disease is

going to the rear of his house after dark, ran against the open door of a coalhouse, and struck his left eye on a piece of the iron hinge, and subsequently became blind in this eye. The insurer claimed that the eye was already diseased, and that that caused the loss of sight. Travelers' Ins. Co. v. Bingham, $105 \mathrm{~S}$. W. 894, $32 \mathrm{Ky}$. Law Rep. 233. Here the assured, a locomotive fireman, was accidentally struck a severe blow on the head, as a result of which it was claimed that he became insane and died. The insurer introduced evidence to show that he was deranged at the time of the accident. Maryland Casualty Co. v. Burns, 149 Ky. 550, 149 S. W. 867, whether death resulted from disease or a fall; General Accident Fire \& Life Assur. Corp., Limited, of Perth, Scotland, v. Homely, 109 IId. 93, 71 Atl. 524; Traiser v. Commercial Travelers' Eastern Acc. Ass'n, 202 Mass. 292, 88 N. E. 901; Thompson v. Loyal Protective Ass'u, 167 Mich. 31, 132 N. W. 554; Ludwig v. Preferred Acc. Ins. Co. of New York, 113 Minn. 510, 130 N. W. 5, supra, whether the accident caused appendicitis or merely aggravated the lurking disease; Baehr v. Union Casualty \& Surety Co., 133 Mo. App. 541, 113 S. W. 689; Crotty v. Continental Casualty Co., 163 Mo. App. 628, 146 S. W. 833, whether accident or malaria produced paralysis, which caused death; Driskell v. United States Health \& Accident Ins. Co., 117 Mo. App. 362, 93 S. W. 880, supra ; Johnson v. Continental Casualty Co., 122 Mo. App. 369, 99 S. W. 473, whether pneumonia, causing death, resulted from accident or independent cause; Larkin v. Interstate Casualty Co., 43 App. Div. 365, 60 N. Y. Supp. 205, where the assured, after complaining of feeling sick, was found dead in his room, with his head resting upon the fender, there being a bruise on the neck, and blood about his face and the fender. Here the company claimed that death was the result of vertigo. Peck v. Equitable Acc. Ass'n, 52 Hun, 255, 5 N. Y. Supp. 215, as to whether the assured died from a thrombus, as the direct result of a broken arm, or from pneumonia; 'Thurber v. Commercial Travelers' Mut. Acc. Ass'n, 51 App. Div. 608, 61 N. Y. Supp. 174, as to whether the assured died as the result of pneumonia or an accidental blow in a vital part of the body; Rheinheimer v. Astna Life Ins. Co., 77 Ohio St. 360,83 N. E. 491,15 L. R. A. (N. S.) 245, supra, whether blood poisoning was due to accidental wound or disease; McCullough v. Railway Mail Ass'n, $225 \mathrm{~Pa} .118,73 \mathrm{Atl}$. 1007, whether accident produced cerebral hemorrhage, or whether it resulted from a previous illness; Armstrong v. West Coast Life Ins. Co. (Utah) 124 Pac. 518, whether pneumonia resulted from an accident. 
one of law for the court to determine. ${ }^{220}$ If the death of the assured may have resulted from either disease or accident, there is no presumption of law as to the cause of death. ${ }^{21}$

The burden of proof is on the insurance company to show that the death of the assured is caused by the disease, and not by an accident, within the terms of the condition on which it relies to excuse itself from liability. ${ }^{222}$ In determining whether the assured came to his death as the result of an accident or disease, the usual rules of evidence apply. Expert witnesses, such as doctors and professional nurses, may testify whether the assured had suffered from a certain

220 Travelers' Ins. Co. v. Melick, 65 Fed. 178, 12 C. C. A. 544, 27 L. R. A. 629 ; Continental Casualty Co. v. Lloyd, 165 Ind. 52, 73 N. E. S24; Standard Life \& Accident Ins. Co. v. Thomas (Super. Ct.) $12 \mathrm{Ky}$. Law Rep. 715 ; s. c., $17 \mathrm{~S}$. W. $275,13 \mathrm{Ky}$. Law Rep. 593; Stull v. United States Health \& Accident Ins. Co. (Ky.) 115 S. W. 234. Here the assured, while working in a stone quarry, fell against a heavy piece of iron, injuring his chest and leaving a discoloration. He died a few days later, but his physician could not say that the pneumonia of which he died was the result of the accident. The court held that he could not recover. Thomas v. Fidelity \& Casualty Co. of New York, 106 Md. 299, 67 Atl. 259. The assured, sixty-four years of age, fell on an icy street, breaking one of the bones of an ankle. Some six weeks later, and after the fracture had entirely healed, he died of congestion of the lungs and meningitis. The claimant was properly nonsuited. Modern Woodmen Acc. Ass'n v. Shryock, 54 Neb. 250, 74 N. W. 607, 39 L. R. A. 826.

221 Taylor v. General Acc. Assur. Corp., 208 Pa. 439, 57 Atl. 830. Here the evidence was conflicting as to whether the assured died as the result of an accidental fall or disease.

222 Fetter v. Fidelity \& Casualty Co., 174 Mo. 256, 73 S. W. 592, 61 L. R. A. 459, $97 \mathrm{Am}$. St. Rep. 560. Here the court held that, where the plaintiff has made out a prima facie case showing that the assured's death resulted from accident, the burden is on the company to show that it was the result of natural causes. Vernon v. Iowa State Traveling Men's Ass'n (Iowa) 138 N. W. 696 ; Interstate Casualty Co. v. Bird, 10 O. C. D. 211, where it was claimed that the deceased died from an attack of vertigo. See, also, McCarthy v. Travelers' Ins. Co., 15 Fed. Cas. 1254. 
disease, since they bring to the stand expert knowledge derived from study and experience. ${ }^{223}$. Lay witnesses may testify concerning the symptoms manifested by the patient from day to day as one of ordinary observation could detect them, but they will not be permitted to give their opinion from these symptoms as to the disease from which the assured may have been suffering. ${ }^{24}$

On this issue evidence will be admitted to show the health of the assured from infancy as tending to prove or disprove the existence of a disease. ${ }^{225}$ Evidence is also admissible showing that the assured has been constantly employed prior to the accident to establish the question as to whether he is suffering from a disease. ${ }^{226}$ Declarations of the assured, so closely connected with the accident as to be fairly a part of the res gestæ, are admissible. ${ }^{227}$

So a statement made by the deceased to his physician,

223 Standard Life \& Accident Ins. Co. v. Thomas, 17 S. W. 275, 13 Ky. Law Rep. 593.

224 American Acc. Co. v. Fidler's Adm'x, 35 S. W. 905, 18 Ky. Law Rep. 161.

225 McCarthy v. Travelers' Ins. Co., 15 Fed. Cas. 1254.

226 'Travelers' Ins. Co. v. Murray, 16 Colo. 296, 26 Pac. 774, 25 Am. St. Rep. 267. Here the evidence showed that the insured, a locomotive fireman, had for years been afflicted with chronic hernia. The testimony of the assured was admitted to show that he had been continuously employed prior to the accident.

227 Travelers' Ins. Co. v. Mosley, 8 Wall. 397, 19 L. Ed. 437; North American Acc. Ass'n v. Woodson, 64 Fed. 689, 12 C. C. A. 392 ; Union Casualty \& Surety Co. v. Mondy, 18 Colo. App. 395, 71 Pac. 677; Patterson v. Ocean Accident \& Guarantee Corp., 25 App. D. C. 46; Vernon v. Iowa State 'Traveling Men's Ass'n (Iowa) 138 N. W. 696; Fidelity \& Casualty Co. of New York v. Cooper, 137 Ky. 544, 126 S. IV. 111; Hooper v. Standard Life \& Accident Ins. Co. (Mo. App.) 148 S. W. 116 ; Ten Broeck v. Travelers' Ins. Co., 6 N. Y. St. Rep. 100; Van Eman v. Fidelity \& Casualty Co., 201 Pa. 537, 51 Atl. 177 ; Starr v. Atna Life Ins. Co., 41 Wash. 199, 83 Pac. 113, 4 L. R. A. (N. S.) 636; Hall v. American Masonic Acc. Ass'n, 86 Wis. 51S, 57 N. W. 366. 
upon which the physician forms his opinion and prepares a prescription, is competent evidence to prove what was actually the cause of his illness and death. ${ }^{228}$

Exemption of Liability for Injuries Received While Entering or Leaving, or Standing on the Platform of, Moving Cars.-Policies of accident insurance usually contain a clause stipulating that the company will not be liable for death or injury received while entering, leaving, or standing on the platform of a conveyance while in motion, such conveyance using steam, electricity, or cable as a motive power. Such a condition is valid, and its violation will relieve the insurer from liability for injuries thus sustained. ${ }^{29}$

228 Dabbert v. Travelers' Ins. Co., 2 Cin. R. 98, 13 Ohio Dec. 792. Here the court, through Judge Taft, said: "I am satisfied that there is a tendency in the decisions of the present time to enlarge the range of testimony, especially where it is necessary to avoid a failure of justice. A more complete failure of justice could not be imagined than that of a man holding a policy of insurance against accident, and meeting with an accident when alone, which injured him internally and fatally, and yet causing symptoms such as might be produced by natural disease, if his statements, even to his physician, cannot be taken. It seems to me reasonable to hold that the declarations of the deceased, made to his physician, who prescribes for him, and on which the opinion of the physician is in part founded, are competent evidence. * * * The statements of the history of his case, made to his physician by a patient, who is seeking relief from pain and severe sickness, are entitled to credit. To state untruly to his doctor the cause of his sickness would be directly against his most vital interest in saving his health and life. In such a case, the absence of a statement by the patient of such a cause of his sickness would be an important element in forming the physician's opinion; for, if the patient did not refer to such an accident as the cause of his sickness, the doctor would necessarily conclude that the symptoms did not come from such a cause." See, also, Patterson v. Ocean Accident \& Guarantee Corp., 25 App. D. C. 46; Omberg v. United States Mut. Acc. Ass'n, 101 Ky. 303, 40 S. WV. 909, 72 Am. St. Rep. 413; Starr v. Atna Life Ins. Co., 41 Wash. 199, 83 Pac. 113, 4 L. R. A. (N. S.) 636.

229 Standard Life \& Accident Ins. Co. of Detroit, Mich., v. McNulty, 157 Fed. 224, 85 C. C. A. 22 ; Miller v. Travelers' Ins. Co., 39 Fuller Acc.Ins.-14 
It is not a valid defense to such a condition that, under the circumstances of the case, a prudent or cautious man would attempt to board or leave the moving train. Nor is it a question of negligence, or voluntary exposure to danger. Insurance is purely a contractual relation. ${ }^{230}$ This is a specific class of injuries, against which the company does not insure, and for which it will not be liable. Similarly, it cannot be shown that the assured was accustomed to jumping on trains or cars while in motion, as a defense to the condition. ${ }^{231}$ Nor is it an answer to the defense that the assured slipped and fell on an icy pavement as he was about to board a moving train, even though he may not have taken hold of the railing or handle of the platform of the car. ${ }^{232}$

It is a common custom of travelers to temporarily alight from a train when it stops at an intermediate station. The insurance company will not be liable for the. injuries sus-

Minn. 548, 40 N. W. 839. Here the assured, a banker, was killed while attempting to board a moving train. 'Travelers' Ins. Co. v. Snowden, 45 Neb. 249, 63 N. W. 392. Here the assured, a cattle dealer, alighted from a train on which he was traveling to examine his stock. While engaged in attending to some cattle, the signal was given to start the train, and the assured attempted to jump on one of the stock cars as it passed. The company was exempt from liability.

230 Banta v. Continental Casualty Co., 134 Mo. App. 222, 113 S. W. 1140.

231 Mulville v. Pacific Mut. Life Ins. Co., 19 Mont. 95, 47 Pac. 650. In this case the court held that it was no defense to show that the assured as a prudent man was justified under the circumstances in attempting to board a moving train, and that he was accustomed to jump on trains while in motion.

232 Huston v. Travelers' Ins. Co., 66 Ohio St. 246, 64 N. E. 123. Here the assured was walking along a rallroad track, the ground being slippery and icy, when a freight train going slowly orertook him, and it occurred to him to step on the caboose and ride. As he was about to do so, and before he had touched the car, he slipped and fell, and one foot was crushed by the wheels of the car. The court held that the company was not liable, on the ground that in the effort to step upon the caboose he was within the exception, as 
tained by the assured while thus attempting to board the train after it again starts. ${ }^{233}$ But, where the assured attempts to board a train which is standing still, and in so doing grasps the handrails, and is injured by the train suddenly starting, the company will be liable, on the ground that the train was not moving when the assured began attempting to board it. ${ }^{234}$ The courts have held that where the assured inadvertently steps from a train, so that leaving the cars in motion is not the result of design, the company will be liable. ${ }^{235}$

a matter of fact, whether he had actually taken hold of the car or not.

233 Standard Life \& Accident Ins. Co. of Detroit, Mich., จ. McNulty, 157 Fed. 224, 85 C. C. A. 22 ; Travelers' Ins. Co. . Brookover, 71 Ark. 123,71 S. W. 246 . Here the assured started to board a train, which started suddenly without warning. The court held that the company was not liable for the injuries thus sustained. See the excellent opinion in Anable v. Fidelity \& Casualty Co. of New York, 73 N. J. Law, 320, 63 Atl. 92, affirmed without opinion 74 N. J. Law, 686, 65 Atl. 1117.

234 'Terwilliger v. National Masonic Acc. Ass'n, 197 Ill. 9, 63 N. k. 1034, reversing National Masonic Acc. Ass'n v. Terwilliger, $98 \mathrm{Ill}$. App. 237. Here the assured took hold of the handrail of a car to raise himself, and at the same time the car started. Instinctively holding the rail, he continued his efforts to board the car, and was dragged some distance. At length, releasing his hold, he fell to the track and was instantly killed. The court very properly declared that, since the train was standing still when the assured attempted to board the car, the case was not within the exception, and the insurance company was liable on its policy. See, also, Kirkpatrick v. Atna Life Ins. Co., 141 Iowa, 74, 117 N. W. 1111, 22 I. R. A. (N. S.) 1255. Here a stationary train had blocked a street crossing. The assured started to cross the platform of one of the cars, when the sudden jerking of the train in starting threw him to the ground, and his arm was crushed by the car wheels. The insurer was held liable.

235 Smith v. Atna Life Ins. Co., 115 Iowa, 217,88 N. W. 368, 56 L. R. A. 271, $91 \mathrm{Am}$. St. Rep. 153. Here the assured stood on the steps of a moving car, holding the rail. The evidence tended to show that he accidentally stepped from the car. The court held that if the jury found that the assured had inadvertently stepped from the train, so that his injury was the result of an erent which 
Of a similar type is the condition exempting the insurance company from liability for injuries received while riding or being on the platform of a moving car. Where the policy expressly declares that the insurance will not cover injuries sustained while entering or trying to enter or leave a moving conveyance using steam as a motive power, but does not mention in such a clause "riding on the platform" of such a conveyance, this latter phrase will not be implied from the former, so as to relieve the company from liability for injuries sustained while riding on the platform of a car. ${ }^{236}$

The phrase, "standing, riding, or being upon the platform of a moving train," does not include passing from one car to another, since the condition does not mean a mere transitory occupation of the platform, but rather contemplates at least its temporary occupancy. ${ }^{237}$ In such cases the insur-

took place without his foresight and expectation, a verdict for the assured would be sustained. See, also, Travelers' Preferred Acc. Ass'n v. Stone, 50 Ill. App. 222, where a policy of insurance provided that the company would not be liable for injuries sustained "where the death or disability was caused * * * by jumping on or off of moving cars, engines, or vehicles, unless claimant $* * *$ could establish by positive proof that the said death or accident was caused by external, violent, and accidental means, not the result of design of the member or any other person." The court declared, where the assured was injured while crossing from the platform of one car to that of another, that through the obvious misarrangement of or omission of words the effect was absurd, yet they must construe the policy as actually framed, and the assured might recover, since it was not shown that the accident was one of design.

236 Travelers' Ins. Co. v. Randolph, 78 Fed. 754,24 C. C. A. 305. Here the assured was last seen standing on the platform of a moving car, and the court held that unless the assured had been guilty of voluntary exposure to danger, or violating one of the rules of a corporation, he was not within the condition of the policy, and the company would be liable.

237 Sawtelle v. Railway Passengers' Assur. Co., 21 Fed. Cas. 555, 15 Blatchf. 216, where the assured was killed by falling at night, from the platform of a train, while in full motion. The court held 
ance company will be liable, as the condition does not forbid such temporary, transitory, or necessary occupancy of the platforms of a moving train as a traveler may risk for convenience in the course of his journey, as, for example, in visiting the dining car. The clause rather contemplates the occupancy of the platform or steps of a car for the purpose of riding, as one would occupy a seat or stand in the aisles of a car. A temporary occupation of the platform by a traveler for any necessary or reasonably convenient purpose does not violate the condition. Thus the company will be liable if the assured is killed or injured while standing on the platform waiting to enter another car, while the crowd before him is entering and being seated, as in the case of a rush for the dining car, although in a literal sense he is riding on a platform. ${ }^{238}$ Similarly, where the assured goes to the platform of a car for the purpose of securing relief from sickness, he will not be violating this condition. ${ }^{239}$

But where the assured goes out on the platform of a moving car as the train approaches a station, for the purpose of

that the company would not be liable if the assured was at the time riding on the platform, but that it would be liable if he were merely passing from car to car at the time of the accident.

238 Standard Life \& Accident Ins. Co. v. Thornton, 100 Fed. 582, 40 C. C. A. 564, 49 L. R. A. 116 . Here the assured disappeared from a train, and his body was later found lying near the track over which the train had passed. The cause of death was conjectural, but, from the evidence, he might have been standing on the platform of one of the cars, which did not have a vestibule attachment. The court held that a passenger who was on the platform of a car for a temporary, but necessary, purpose is not riding there within the meaning of this condition in a policy of accident insurance.

239 Marx v. Travelers' Ins. Co. (C. C.) 39 Fed. 321. Here the assured, overcome by the heat of the car and suffering from nausea, thought it necessary to go upon the platform to obtain relief. When last seen the assured was sitting on the platform of the car. Preferred Acc. Ins. Co. of New York v. Muir, 126 Fed. 926, 61 C. C. A. 456. Here the assured, suffering from nausea, went on the platform of a car to get fresh air, and the company was held liable. 
getting off the train before it finally stops, the company will not be liable for an injury thus sustained. ${ }^{240}$

Even where the policy does not contain such a condition as we are now discussing, the insurance company will frequently be exempted from liability where the insured stands on the platform of a moving train, under a condition excusing the company from liability for injuries received as the result of voluntary exposure to unnecessary danger. ${ }^{241}$ But the company will be liable in spite of this condition where the assured goes on the platform prompted by some sudden emergency or necessity. ${ }^{242}$

Where the policy does not contain the exception under consideration, but provides that the insurer will not be liable for injuries sustained while violating the rule of a corporation, and it is the rule of a railroad company that passengers shall not ride on the platform of a car, but the rule is universally ignored, by both the trainmen and the traveling public, then riding on a platform is not such a violation of a rule of a corporation as will release the company from liability. ${ }^{243}$ Nor is

240 Hull v. Equitable Acc. Ass'n, 41 Minn. 231, 42 N. W. 936. Here the assured, while standing on the platform of a train from which he intended to alight when it stopped, was thrown off and killed. The court held that the company was not liable.

241 Overbeck v. Travelers' Ins. Co., 94 Mo. App. 453, 68 S. W. 236. Here the assured was injured while standing on the platform of a car as the train was slowing up, approaching a station. The company was exempted from liability on the ground of voluntary exposure to an unnecessary danger. See cases cited under Voiuntary Exposure to Unnecessary Danger, page 220.

242 Banta v. Continental Casualty Co., 134 Mo. App. 222, 113 S. W. 1140. Here the policy provided double indemnity for injuries sustained while riding on a car, but single indennity for injuries happening as a result of getting on or off a moving car. The assured, in unwarranted fear of a wreck, jumped from a car in motion and was injured. The insurer was liable only for singie indemnity.

243 Marx v. Travelers' Ins. Co. (C. C.) 39 Fed. 321. Here the evidence showed that the rule against riding on the piatform of a car was universally ignored by both the trainmen and the public. 
the assured violating the rule of a corporation while riding upon the platform of a moving car, if by reason of the crowd on the train there is no other place where he may ride, and the conductor permits him to do so. ${ }^{244}$

This condition varies frequently in its form, and in some policies stipulates against liability for death or injury resulting from being in or on any conveyance not provided for the transportation of passengers. Under such a policy, the company has been held liable where the assured, a passenger, temporarily riding on a locomotive, was killed as the result of a wreck, on the theory that a locomotive is a portion of a passenger train, and is therefore a conveyance for the transportation of passengers. The Supreme Court of California comments upon this condition as follows: "The term 'conveyance' applies as well to the means of transporting freight as of passengers, and in the clause exempting the insurance company from liability for accidents occurring in 'entering or trying to enter or leave a moving conveyance using steam as a motive power' is so applied; while the clause here under consideration distinguishes a 'conveyance provided for the transportation of passengers' from those used for the transportation of freight. Neither clause specifies railroad trains, and each includes as clearly vessels propelled by steam. If the insured had met with an accident upon a passenger steamer, instead of a railroad train, upon what part of the vessel must he have been at the time of the accident to be within the protection of his policy? Must he be seated in the cabin, or occupy a stateroom? The policy does not say so. It restricts him to no part of the vessel, and therefore, if the insurance company sought to escape liability by showing that at the

214 Equitable Acc. Ins. Co. v. Sandifer (Super. Ct.) $12 \mathrm{Ky}$. Law Rep. 797. See, also, Badenfeld v. Massachusetts Mut. Acc. Ass'n, 154 Mass. 77,27 N. E. 769,13 L. R. A. 263. 
time of the accident he was not in the cabin or a stateroom, it must import into the contract a qualification or provision which is not expressed or even implied." 245

Where a policy provides that the insurance company will not be liable for injuries sustained while "entering or trying to enter or leaving a moving conveyance using steam for a motive power" (except cable and electric street cars), but in another clause provides for double indemnity for injuries sustained while "riding as a passenger in any conveyance using steam, cable, or electricity as a motive power," the company will be liable for the double indemnity if the assured is injured while attempting to alight from an electric car in motion. The assured is a passenger until he has completely disconnected himself therefrom. ${ }^{246}$

It is a clearly established rule of accident insurance that where the company contracts to insure an applicant under a

245 Berliner v. 'Travelers' Ins. Co., 121 Cal. 458, 53 Pac. 918, 41 L. R. A. 467, 66 Am. St. Rep. 49. The assured in this case, at the request of an officer of the road, was riding on the locomotive attached to a passenger train. The court held that a person thus riding on the locomotive did not thereby lose his character as a passenger. This policy also contained a clause providing for doubie insurance for injuries, causing death, sustained while riding as a passenger in any passenger conveyance using steam as a motive power, but excepting accident or death arising wholly or partly from being in or on such conveyance not provided for the transportation of passengers. The insurer was held liable for double indemnity. This is, however, an extreme case.

246 King v. Travelers' Ins. Co., 101 Ga. 64, 28 S. E. 661, 65 Am. St. Rep. 288. Here the assured was injured while attempting to alight from a moving electric street car. The policy provided for double indemnity for injuries sustained while riding as a passenger in any conveyance using steam, electricity, or cable for a motive power. The court held that a person is a passenger from the moment of entering the conveyance until he has alighted and disconnected himself therefrom. See, also, Northrup v. Railway Passengers' Assur. Co., 43 N. Y. 516, 3 Am. Rep. 724, reversing 2 Lans. (N. Y.) 166. Here the court held that one is stili a passenger while passing from one train to another, while engaged in the prosecution of his journey. 
given occupation, whose duties require exposures to risks that are matters of common knowledge, the policy will be construed to cover all risks or exposures incident to the occupation of the assured, regardless of exceptions contained in the policy. So, where a policy containing a clause exempting the company from liability for injuries received while attempting to enter or leave a moving train or conveyance is issued to one who gives his occupation as a conductor, the exception will not apply. It is a matter of common knowledge that it is the duty and one of the risks of employment of a conductor to enter trains while in motion and to leave them before they come to a full stop. ${ }^{247}$

Frequently railroad employés are especially excepted by the policy from the operation of this condition. In such a case there can be no question as to the liability of the company, and within the meaning of such a provision a man employed as a baggage checker for a transfer company, who meets and boards passenger trains to check baggage to other trains, and to hotels and residences, is a railway employé. ${ }^{248}$ In order,

247 Dailey . Preferred Masonic Mut. Acc. Ass'n, 102 Mich. 289, 57 N. W. 184,26 L. R. A. 171 . Here the assured, classified as a railway conductor, was killed while attempting to alight from his train while in motion. The court held that it was a matter of common knowledge that conductors of passengers trains must, in the very nature of their business, not only enter trains while in motion, but leare them before they come to a full stop. They give the signal to start, and after the train starts they get on board. They also alight from the train while it is slowing down upon reaching a station. The company must have had knowledge of these risks at the time of issuing the policy, and therefore, since it assured against these risks of occupation, such a condition in the policies would not exempt the company from liability.

248 Cotten v. Fidelity \& Casualty Co. (C. C.) 41 Fed. 506. Here the assured was a baggage checker for a transfer company, and was accustomed to board trains as they approached stations to check the baggage of passengers at the terminus of the run. The court held that, under the provisions of the policy, the assured was a railroad employe within the meaning of the policy, and that the company 
however, to render the insurer liable under such a clause, it must be shown that the assured was injured while actually engaged in the performance of the duties of his occupation. ${ }^{249}$

Where the policy excuses railroad employés from the condition, the exception is based partly upon the fact that the policy holder is insured from the dangers incident to his occupation and partly because of the judgment and experience which enables him to board and leave moving trains with much less danger than one who is not constantly thus engaged. But where a policy contains a clause such as that under consideration, and a further clause limiting the liability of the company to a less sum than that named for any occupation or exposure classified as more hazardous than that specified, a law-

was liable where the assured was injured while undertaking to board a moving train when engaged in the prosecution of his duties.

249 Hull v. Fquitable Acc. Ass'n, 41 Minn. 231, 42 N. W. 936. Here the policy contained a clause providing that the company would be liable for injuries happening to "railway employes, while on the platform of moving trains in the course of their duty." The assured, a rallway employe, was being carried from his shop at the close of his day's work upon one of the trains of the company. He went out upon the platform of the train while it was in motion, intending to get off when it stopped. He was thrown off and killed. The company was exempt from liability here, because the act of the assured, in going out on the platform, was in no sense a part of his duty as a rallway employe, but a voluntary act suggested by his own convenience, and not prompted by any sudden emergency or necessity. On the other hand, see Employers' Liability Assur. Corp. v. Rochelle, 13 Tex. Civ. App. 232, 35 S. W. 869. Here the assured was classified as a railroad employe in the policy, and paid the premium for the risk of that occupation. He was killed while attempting to board a moving train. Although he had left the employ of the rallroad company, and was a farmer at the time of the accident, the company was beld liable. The difference between this case and the Hull Case is to be found in the verbiage of the policies. In the Rochelle Case, the exception was declared in the policy to refer to railroad employes as a class. In the Hull case, it did not apply to railroad employes except in the course of their duties. Had the words "in the course of duty" been used in the policy issued in the Rochelle Case, the judgment must have been in favor of the insurance company. 
yer or a business man, injured while attempting to enter a moving train, cannot seek the benefit of this latter clause, so as to recover the indemnity payable to a railroad employé. ${ }^{250}$

If the assured has established a prima facie case of accident or injury within the terms of the policy, the burden of proof is on the insurance company to show that the assured was killed or injured by being on the platform of a moving train, or entering or leaving a moving train, within the exception of the policy. But whether the death or injury is the result of an excepted risk is a question of fact for the jury to determine. ${ }^{251}$ Thus the burden of proof is on the insurance company to show that the assured at the time of the accident was trying to leave a moving train, and that he did not

250 Miller v. Tra velers' Ins. Co., 39 Minn. 548, 40 N. W. 839. Here the assured, a banker, was killed while attempting to board a moving train. The policy contained a clause exempting the company from liability for injuries received while entering or leaving a moving train, railway employés excepted. Another clause of the policy provided that, where the assured was injured while engaged in an exposure or occupation more hazardous than that in which he was classified, the assured could recover only the lesser indemnity provided for such an occupation. The court very properly held that the banker could not recover, under the policy, the indemnity payable to a railroad employe, simply because the injury was sustained in an exposure incident to the occupation of a railroad emploýé.

251 Myler v. Standard Life \& Accident Ins. Co., 92 Fed. 861, 35 C. C. A. 55. Here the evidence tended to show that the assured was killed while attempting to board a freight train. On the other hand, evidence was offered to show that the insured intended to take a train going in the opposite direction, and therefore that it was impossible for him to have boarded a freight train. Anthony $\nabla$. Mercantile Mut. Acc. Ass'n, 162 Mass. 354, 38 N. E. 973, 26 L. R. A. 406, $44 \mathrm{Am}$. St. Rep. 367. Here the assured was last seen on one of the cars of a train, late in the evening; just before it reached a station. He had a ticket for a station some distance further on. The train started slowly, and when it had gone but a few feet the assured was discovered on the ground near the track, with his legs crushed by the wheels of the train. See, also, Badenfeld v. Massachusetts Mut. Acc. Ass'n, 154 Mass. 77, 27 N. E. 769, 13 L. R. A. 263, supra; Travelers' Ins. Co. v. Snowden, 45 Neb. 249, 63 N. W. 392, supra. 
inadvertently or accidentally slip and fall from the steps of the car. ${ }^{252}$

What Constitutes Voluntary Exposure to Unnecessary Danger.-Most policies of accident insurance contain a clause specifically exempting the company from liability for death or injury happening as a result of the assured voluntarily exposing himself to unnecessary danger.

Such a condition is valid, since it is in no way repugnant to the general contract of indemnity. The insurance company may except any class of injuries, however general they may be, provided they are capable of being distinguished from those injuries for which the insurer is liable. ${ }^{253}$

Voluntary exposure to unnecessary danger in insurance contracts is not synonymous with contributory negligence. $^{254}$ This clause has no reference to the general principles of the law of negligence, since the relation of assured and insurer is purely contractual. Manifestly a contract to indemnify one against accidents is to be construed more liberally than the rules of common law, where one seeks to put the responsibility for an injury upon another. In securing a policy of insurance against accidents, one naturally understands that he is to be indemnified against accidents resulting either in whole or in part from his own inadvertence or carelessness.

It is manifest that a great majority of the events which are generally called accidents occur through some contributory carelessness or negligence of the party injured.

$2 \approx 2$ Smith v. Xtna Ins. Co., 115 Iowa, 217, 88 N. W. 368, 56 L. R. A. 271, 91 Am. St. Rep. 153, supra.

253 Metropolitan Acc. Ass'n v. Taylor, 71 Ill. App. 132.

254 'Travelers' Ins. Co. v. Randolph, 78 Fed. 754, 24 C. C. 4.305 ; Hunt v. United States Acc. Ass'n, 146 Mich. 521, 109 N. W. 1042, 7 L. R. A. (N. S.) 938, 117 Am. St. Rep. 655, 10 Ann. Cas. 449; Kephart v. Continental Casualty Co., 17 N. D. 3s0, 116 N. W. 349. 
Men are daily injured by the careless use of firearms, of explosives, of machinery, careless walking on slippery pavements, careless driving of vehicles, and in countless ways which readily occur to the mind, where it can easily be seen in retrospect that a little greater caution or care on their part would have prevented the disaster. ${ }^{255}$

Naturally consciousness of danger must precede a voluntary exposure to unnecessary danger. To excuse the insurer, the exposure or negligence of the assured must be

255 Keene v. New England Mut. Acc. Ass'n, 164 Mass. 170, 41 N. E. 203 ; Lelıman v. Great Eastern Casualty \& Indemnity Co., 7 App. Div. 424, 39 N. Y. Supp. 912, affirmed without opinion in $158 \mathrm{~N}$. Y. 689, 53 N. E. 1127. In these cases the courts hold clearly that "exposure to unnecessary danger" is not synonymous with "negligence." See, also, Schneider v. Provident Life Ins. Co., 24 Wis. 28, $1 \mathrm{Am}$. Rep. 157, where the clause provided for the discharge of the insurance company from liability in case of accident happening from "willful and wanton exposure." This is undoubtedly the correct law, although earlier cases held that "negligence" and "exposure to unnecessary danger" are equivalent terms. See Sawtelle v. Railway Passengers' Assur. Co., 15 Blatchf. 216, Fed. Cas. No. 12,392, where the common-law rules of negligence were applied to the construction of the policy. This is against the undoubted weight of authority and has been thoroughly repudiated. See, also, Hoffman v. 'Travelers' Ins. Co., N. Y. Supreme Court, 1871, not officially reported, but discussed in $7 \mathrm{Am}$. Law Rev. 594 .

An interesting case is that of Morel v. Mississippi Valley Life Ins. Co., 4 Bush (Ky.) 535, decided in 1868, where the plaintiff was insured against personal injury by any accident within the meaning of the policy. There was no clause in the contract requiring the assured to exercise diligent care. In traveling from Chattanooga to Nashville he inadvertently put his arm out of the car window, as a result of which it was injured. The insurance company demurred to the petition of the assured, and the court sustained the demurrer, holding that the injury, being caused by the carelessness of the assured, gave him no right to compensation. The court rested its decision solely on the ground that the injury was produced wholly by the carelessness of the assured, and the court apparently assumed that the plaintiff was bound to show that he had exercised due care before he could recover, although the contract was generally against any accident and contained no stipulation as to care. The decision is clearly against the weight of authority, and is supported neither by logic nor precedent. 
accompanied by knowledge on his part of the existence of danger, or knowledge that injury is likely to result from his act. Unless the assured is conscious of the danger to which he is subjecting himself, and, knowing or realizing it, purposely assumes the risk, the case does not fall within the exception. A mere inadvertent and unintentional exposure to danger is not voluntary, but rather involuntary. ${ }^{250}$ In order to forfeit the policy, the company must show that the assured realized that his act was dangerous and likely to result in injury to him, and yet that he voluntarily assumed the risk. ${ }^{257}$ Both the act and the exposure must be voluntary.

256 Dillon v. Continental Casualty Co., 130 Mo. App. 502, 109 S. W. 89. Here the assured, a car repairer, was riding through the railroad yards on a step on the side of a car and hanging onto a handhold, when he was struck by a car on the adjoining track, knocked off, and killed. The court said: "When we state that one voluntarily exposed himself to unnecessary danger, it is the same as to say that he knew there was danger to which it was unnecessary for him to expose himself." Whalen v. Peerless Casualty Co., 75 N. H. 297,73 Atl. 642, 139 Am. St. Rep. 695, where the court said: "A voluntary exposure to unnecessary danger or obvious risk * * is a conscious or intentional exposure to a known risk and not a merely inadvertent or accidental one." Continental Casualty Co. v. Deeg (Tex. Civ. App.) 125 S. W. 353, where the assured, a railroad employe, traveling as a passenger, alighted from a slowly moving train. Beard v. Indemnity Ins. Co., 65 W. Va. 283, 64 S. E. 119 , where the court held that this condition referred only to danger of a real, substantial character, which the insured recognized, but to which he nevertheless purposely and consciously exposed himself, intending at the time to assume all the risks of the situation. Bakalars v. Continental Casualty Co., 141 Wis. 43, 122 N. W. 721, 25 L. R. A. (N. S.) 241,18 Ann. Cas. 1123, where the assured, a locomotive fireman, was killed while making his way through the railroad tracks to his home after returning to the roundhouse from his run.

257 Where the assured was suffocated or burned to death by the ignition of a bucket of tar pitch which he was heating inside a tank for calking purposes, it was held to be a question for the jury to determine whether the deceased was conscious of the danger, and if he was not aware of the risk then the insurance company would be 
It is not sufficient for the insurance company to show knowledge on the part of the assured of the generally dangerous character of the acts or the locality, but it must show that the assured appreciated the special danger incurred. $^{258}$ In order to relieve the insurer it is not necessary to

liable. Ashenfelter v. Employers' Liability Assur. Corp. of London, Eng., 87 Fed. 682, 31 C. C. A. 193.

National Life \& Accident Ins. Co. v. Lokey, 166 Ala. 174, 52 South. 45 , where the court held that "the negligence of the assured, to bring his acts within an exception of voluntary exposure to danger, must be accompanied with knowledge of the existence of danger or knowledge that injury is likely to result from his acts."

In Commercial Travelers' Mut. Acc. Ass'n v. Springsteen, 23 Ind. App. 657,55 N. E. 973 , the plaintiff was riding his bicycle against a heavy wind, with his head down over the handle bars, when he collided with a wagon whose approach he did not observe. The jury here found that the assured had no knowledge of the danger which confronted him, and therefore the insurer was liable.

In Thomas v. Masons' Fraternal Acc. Ass'n, 71 N. Y. Supp. 692, 64 App. Div. 22, the assured, an attorney, while out hunting, sat down at the foot of a tree to eat his lunch. His gun, which he had rested against the tree, fell from its position, and exploded in such a way as to send the charge through his heart. The court held that the assured was not voluntarily exposing himself to an unnecessary danger. "The voluntary exposure in such cases," declared the court, "is not mere carelessness and recklessness, but implies that the person accused has knowingly and without reason put himself in the way of some danger from which injury is likely. $*^{*} *$ While there is no doubt that the way in which Thomas managed his gun was improper, careless, and reckless, there is nothing to show that he had any idea that he was exposing himself to danger by his act."

258 Where the assured went out in a boat on a river to fish on a dark night, without knowing of the existence of snags in the water, and, by reason of colliding with a partially submerged tree, was thrown out of the boat and drowned, the insurance company was liable. The court said: "Before he could voluntarily expose himself to a danger, he must know of the danger, and it does not appear that he had such knowledge." Collins v. Bankers' Acc. Ins. Co., 96 Iowa, 216, 64 N. W. 778,59 Am. St. Rep. 367.

In Travelers' Ins. Co. v. Clark, $109 \mathrm{Ky} .350,59 \mathrm{~S} . \mathrm{W} .7,22 \mathrm{Ky}$. Law Rep. 902, 95 Am. St. Rep. 374, the assured, a deckhand on a boat, was detected by the officers on top of the boilers, and was warned of the danger of his position. After his work the assured on a cool evening went to sleep near the boilers to keep warm, and 
show that the assured realized that injury was certain to result. But he must be shown to have either known, or have had notice of, such facts as would cause an ordinary man of reasonable prudence and caution to apprehend or suspect danger. 259

was killed by the steam escaping from the safety valve near where he lay. The court declared that it was not a voluntary exposure to unnecessary danger, unless the assured was conscious of the danger from escaping steam; it not being sufficient to show that he was warned that it was dangerous to be on top of the boilers.

259 In Fidelity \& Casualty Co. v. Sittig, 181 Ill. 111, 54 N. E. 903, 48 L. R. A. 359, affirming 79 Ill. App. 245, the assured, a traveling man, reached the railroad station just as his train was pulling out. Running after it, he threw his valise on the platform of the car, seized the railing, and attempted to climb on; the train at the time running at from five to ten miles an hour. He either lost his hold and fell, or was knocked off and killed by striking against a small building used as a ticket office, which stood ncar the track and a short distance from the station. It did not appear from the eridence that the assured knew of the ticket office building or its proximity to the track, or that he had any reason to suppose he was exposing himself to the danger from this source. In this case the beneficiary was permitted to recover. And the court went so far as to say: "It would be an unreasonable rule to adopt, as a legai proposition, that a traveler who steps upon the platform or steps of a moving car of a railway train voluntarily exposes himself to unnecessary danger, though it may be conceded he is guilty of negligence in so doing."

In Matthes v. Imperial Acc. Ass'n, 110 Iowa, 222, 81 N. W 484, the assured, a bouse painter, was injured while using a rope sling thirty feet above his barn floor, by the breaking of a truck supporting it. The evidence showed that he had used the apparatus before, and on this occasion examined it carefully, and was accustomed to working at great heights on church spires. It was held that the danger was not obvious to the assured

In Campbell v. Fidelity \& Casualty Co. of New York, 109 Ky. 661, $60 \mathrm{~S}$. W. 492, $22 \mathrm{Ky}$. Law Rep. 1295, the assured, a retired policeman, who had been drinking some, got into an argument with an active member of the police force. After some words the assured drew his revoiver, but was fired upon and killed by his adversary. The court declared that in order to discharge the insurance company from liability the jury must believe that the assured realized the danger to which he exposed himself in making the assault.

The assured was at a rallroad station after dark, intending to 
The danger must be so apparent that a man of ordinary intelligence would, under the circumstances, necessarily have known it and avoided it. One may voluntarily expose himself to some danger which he does not apprehend and which is not obvious. In such a case he manifestly has not

take a local train which stood on a track distant from the depot, and on a nearer track approached an express train which did not stop at the station. When warned of his danger, he replied that he knew his business. After the train passed his body was found lying near the local train. The court held that the insurance company, in order to relieve itself of liability, must show that the insured was intentionally negligent in consciously exposing himself to a known danger. North American Acc. Ins. Co. v. Gulick, 25 Ohio Cir. Ct. R. 395. In this case the policy provided against liability for death resulting "directly or indirectly from unnecessary or negligent exposure to obvious danger."

The assured was a passenger on a train which stopped on a railroad bridge crossing a river, because of an open draw, and he, in common with other passengers, got out of the coach. No notice of danger was given to the passengers, and the bridge on which they alighted was apparently sound and well protected, and the brakeman and many passengers were standing about; but the assured stepped off the coach and through a hole, falling into the river. Neither word nor sight gave him any notice of danger. This was declared not to be a voluntary exposure to danger. Burkhard $\nabla$. Travelers' Ins. Co., $102 \mathrm{~Pa}$. 262, $48 \mathrm{Am}$. Rep. 205, reversing Burkhard v. Travelers' Ins. Co. of Hartford, 39 Leg. Int. (Pa.) 420.

In Carpenter v. American Acc. Co., 46 S. C. 541, 24 S. E. 500, the assured, the proprietor of a livery stable, died as the result of being kicked in the head by a mule in his stables. It appeared that after dark, while standing near her hind feet, the assured slapped the mule on the rump, whereupon the mule then kicked him. The court, in charging the jury, said: "The question is not whether Jude, the mule, was a kicking mule; but the question is: Did Carpenter know it?" The Supreme Court of the state, in reviewing the case, upheld the lower court and continued: "We do not mean to say * * * that actual knowledge of the danger is always essential to constitute a voluntary exposure to unnecessary danger. Reckless, wanton conduct, short of actual knowledge of danger, might, under certaln circumstances, be characterized as a voluntary exposure to unnecessary danger. If the unnecessary danger be such as a reasonably prudent man ought to have known it, and he voluntarily goes into it, it would be a voluntary exposure to unnecessary danger. The unnecessary danger must be known or obvious, such as a prudent man

Fuller Acc.Ins. -15 
voluntarily exposed himself to danger, for, if he is not cognizant of the danger, he certainly cannot voluntarily assume it. It must be remembered that there is a distinction between a voluntary act and a voluntary exposure to danger. A hidden danger may exist, but the exposure thereto, without any appreciation of the danger, does not constitute a voluntary exposure to it. The approach to an unknown and unexpected danger does not of itself constitute a voluntary exposure. Nor does the result of an act necessarily determine the motive which prompts it. The act may be voluntary and the exposure involuntary, and, the danger being unknown, the injury is therefore accidental. Moreover, in order to excuse the insurance company, it does not suffice that the danger should be one that the assured might have appreciated by the exercise of ordinary care. It must be one that he actually knows to exist. The insurer is not excused from liability for accidents happening through mere inadvertence or mistake.

On the other hand, the assured must not wantonly and willfully assume the risk of a known danger, nor subject himself to dangers that are evident and manifest. If the assured acts as a man of ordinary prudence would act under like circumstances, then the injuries resulting therefrom cannot be said to be due to a voluntary exposure to unnecessary danger, or to an unnecessary exposure to obvious risk. To make the assured guilty of a voluntary exposure to danger, he must intentionally perform some act which reasonable and ordinary prudence would pronounce dangerous. ${ }^{260}$ Thus an act cannot be said to be voluntary un-

should know. It would be very hard to prove to a jury what a dead man once actually knew; but it would not be so difficult to prove circumstances from which a jury might infer that he knew or ought to have known."

200 The assured, in crossing railroad tracks near a station, was 
less it results from some deliberation, even though the deliberation be brief. As a corollary to this, it follows that an act cannot be considered a voluntary act or exposure when done at a moment's notice and under the belief that the party is already in imminent danger of losing his life. Mere

suddenly warned and shouted to from different directions; but these warnings were indefinite, and he was not told to stop. Under the impulse he hurried forward and was killed by an unseen train approaching on the track upon which he stepped. The jury was requested by the court to consider the effect upon a prudent man under the circumstances of such shouts and calls, and whether he would stop where he was, or proceed at a more rapid rate to reach a point of apparent safety. The court said: "In common apprehension, in respect to the ordinary transactions of life, if the external circumstances would have such a controlling inflnence upon a man of ordinary prudence and intelligence that he would take a certain course, that course would not be considered voluntary on his part. His course would not be freely taken. It would be controlled by external circumstances." Duncan v. Preferred Mut. Acc. Ass'n (Super. N. Y.) 13 N. Y. Supp. 620, affirmed 129 N. Y. 622, 29 N. E. 1029. See Burklard v. Travelers' Ins. Co., 102 Pa. 262, $4 \mathrm{~S}$ Am. Rep. 205, supra.

In Travelers' Protective Ass'n of America v. Small, 115 Ga. 455, $41 \mathrm{~S}$. E. 62S, the assured was injured while attempting to board a moving train. In this case the court said: "Whether one who attempts to board a moving train is engaged in an act which is dangerous in its nature, or is an obvious risk of injury, depends upon the circumstances under which the act is attempted to be performed, the place at which the train is, the speed at which it is moving, the position of the party, his age and activity, and all other circumstances which would be considered in determining whether an ordinarily prudent person would, under such circumstances, attempt at such a time and in such a place to board a train moving at such rate of speed. It is not necessarily what would be done by a particular individual under the circumstances stated, but what wonld be done ordinarily by a man in the exercise of due care and caution. If a man of ordinary prudence would have attempted, under the circumstances, to board the train, then the attempt would not be negligence. *** If the plaintiff in the present case attempted to board the train under such circumstances that an ordinarily prudent person would not have made the attempt, and was injured in making such attempt, his injuries were the result of an exposure to danger and to an obvious risk of injury."

See, also, Price v. Standard Life \& Accident Ins. Co., 92 Minn. 
thoughtlessness of the assured will not excuse the company. ${ }^{201}$

In determining the question of what constitutes a voluntary exposure to danger, the jury must consider what would be the conduct of a man of ordinary caution and prudence, and not the peculiar or local attitude of some particular section of the country, or of some class of people. ${ }^{202}$ Where different and equally intelligent and unbiased men may fairly differ in opinion as to whether a risk of injury was voluntarily or unnecessarily incurred, then it cannot be said as a matter of law that such an act constitutes a voluntary exposure to unnecessary danger. ${ }^{263}$

As a matter of law, to amount to a voluntary exposure to unnecessary danger, the conduct of the assured must be grossly and wantonly negligent and imprudent. This does not mean such exposure as men usually take; and such as are incident to the ordinary habits and customs of life. It must be rather a wanton piece of gross carelessness or reck-

$238,99 \mathrm{~N}$. W. 887 , where the insured died as a result of burns recelved while starting a fire in a stove with the assistance of kerosene.

261 As where the assured, a mason, was working on a scaffold supported by horses, in laying brick, and where one horse had been removed, apparently without his knowledge, so that when he stepped to that end of the scaffold he was precipitated to the ground and killed, there was no evidence of negligence. Irwin v. Phœnix Accident \& Sick Benefit Ass'n, 127 Mich. 630, 86 N. W. 1036.

262 In Travelers' Ins. Co. v. Seaver, 19 Wall. (86 U. S.) 531, 22 L. Ed. 155, the Supreme Court declared it error for the trial court to instruct the jury that in determining this question they should consider "how ordinary people in the part of the country where the insured resided, in view of the state of things then existing, the frequency of such (horse) races, and the way in which such matters are usually regulated, would naturally understand such language."

263 It becomes, then, entirely a question for the jury. See Keeffe v. National Acc. Soc., 4 App. Div. 392, 38 N. Y. Supp. 854, where the assured was injured while engaged in bicycle racing. 
lessness in order to relieve the insurance company from liability. ${ }^{264}$ And the exposure is none the less voluntary, and

264 See Manufacturers' Accident Indemnity Co. v. Dorgan, 58 Fed. 945,7 C. C. A. 581,16 U. S. App. 290,22 L. R. A. 620 , where the assured, in a somewhat weakened physical condition, was found drowned in a brook where he had been fishing.

The owner of a farm does not necessarily expose himself to unnecessary danger by attempting to drive a bull from a calf pasture into which it has broken, if he does not believe and has no reason to believe that there is any danger to himself in so doing. The court here charged the jury: "If the assured in this case believed, or had good reason to believe, that he was endangering his safety by attempting to drive this bull from this inclosure, then I charge you that he cannot recover. If, on the other hand, he did not believe, or had no reason to believe, that there was any danger to himself in that attempt, then I charge you that it was not a voluntary exposure to unnecessary danger." Johnson v. London Guarantee \& Accident Co., 115 Mich. 86, 72 N. W. 1115, 40 L. R. A. 440, 69 Am. St. Rep. 549. Where the assured, in going from his place of business to the railroad station after dark, instead of taking a safe and longer route, chose, as had been his custom, a shorter one through railroad yards, where there were ten or more tracks, and numerous semaphores, signal posts, and switch stands, and numerous trains were constantly passing and repassing, and, finding his way blocked by a slowly moving freight train going in the direction in which he was, he climbed aboard with the idea of riding a short distance and then jumping off, but as he was ready to dismount he was struck by a semaphore and injured, the court declared: "A recital of such facts is sufficient to convict him of guilt of an act of gross negligence in the minds of all reasonable persons, and such action was not excused by his daily exposure, by his habit of reaching the station over such dangerous path during the many previous years, * * * but made his conduct rather more reckless of consequences from the continuous knowledge of the danger incurred and the manifest perils of such daily trips." Alter v. Union Casualty \& Surety Co., 108 Mo. App. 169, 83 S. W. 276.

Biehl v. General Accident Assur. Corp., 38 Pa. Super. Ct. 110. The assured here was seated on the rear seat or the back platform of an open street car, which was crowded both in the seats and on the running board. The assured stepped across the platform to signal the conductor to stop the car, when he fell or was thrown off and killed. The court said: "The exception upon which the defendant relies is that of "unnecessary exposure to obvious risk of injury or obvious danger.' The very language of the exception implies that there may be a necessary exposure to obvious danger. Is this neces- 
the negligence none the less wanton and reckless, by reason of the fact that the assured may have performed the same

sity to be construed as an imperative one, which would permit only the incurring of such risks as cannot possibly be avoided? If so, the burden would be upon the assured to guard himself against the ordinary dangers which beset every prudent man in everyday life. The man who could by any possibility aroid entering upon the busy streets of a city would be compelled to shun all such localities. The clause should have a reasonable construction, such as will permit an assured to pursue his business or pleasure in a reasonably convenient manner. When an assured voluntarily undertakes to do some dangerous act, in which the peril is imminent and extreme, such exposure to peril must be held to be within the exception of a contract of the character with which we are now dealing. * * * The exception means a wanton or grossly imprudent exposure. It is not such exposure as men usually are going to take, such as is incident to the ordinary habits and customs of life. Such an exposure does not come within the range of a defense. An exposure, in order to have been a contributing cause, and so defeat the plaintiff's right to recover, must be something beyond the ordinary, or a wanton piece of gross carelessness, as we would term such in our designation of conduct in the usual walks of life."

Diddle v. Continental Casualty Co., 65 W. Va. 171, 63 S. E. 964, 22 L. R. A. (N. S.) 779, where the court held that voluntary exposure consisted of "either reckless or deliberate encountering of known danger, or danger so obrious that a reasonably prudent man would have observed and avoided it." Here the assured, a railroad employe, was killed while swinging on a train by striking a water tower, of whose existence he was aware, since he had passed and repassed it frequently.

In Schneider v. Provident Life Ins. Co., 24 Wis. 28, 1 Am. Rep. 157, the assured, while attempting to board a slowly moving train of cars, fell under them and was killed. The policy contained a clause exempting the insurance company from liability for injuries happening by reason of the assured "willfully and wantonly exposing himself to any unnecessary danger or peril." The assured was permitted to recover. In Shevlin v. American Mut. Acc. Ass'n, 94 Wis. $180,68 \mathrm{~N}$. W. 866,36 L. R. A. 52, the assured, with a companion, was riding on the top of a freight train without permission. They proposed to get off at a certain station. It was agreed between the two that if the train did not stop there they would jump off. Instead of slowing up as it approached the station, the train increased its speed. The assured jumped, and was found lying unconscious beside the track. The policy upon which sult was brought excluded liability for "any injury resulting in whole or in part from exposure to unnecessary danger." The court declared that 
acts or assumed the same risks daily, or at frequent intervals, without having incurred any injury therefrom. ${ }^{265}$

It must be understood, for a proper appreciation of this subject, that it does not follow that, because an act is voluntary, the exposure is voluntary. The mere fact that a man of his own volition performs an act which places him in danger does not necessarily mean that he voluntarily subjects himself to and assumes the risk or peril. The danger itself may be wholly unexpected, or suddenly encountered, or it may be hidden. ${ }^{266}$ The test is rather whether

this exception prevented a recovery, unless the insured exercised ordinary care within the general principles of the law of negligence. This case is distinguished from Schneider v. Provident Life Ins. Co., supra, where the words "willfully and wantonly" appeared in the policy; and it is to be distinguished from the Keene and Dorgan Cases by the omission of the word "voluntary." In the Shevlin Case the court very properly characterized the conduct of the assured as "an act consistent only with a conscious disregard of personal safety, measuring such conduct by the standard of that of a reasonably prudent person."

205 Alter v. Uuion Casualty \& Surety Co., 108 Mo. App. 169, 83 S. W. 276.

266 Where the assured, running rapidly from the post office to get the mail from a train fast approaching, but not scheduled to stop at that station, attempted to check his speed, but stumbled and fiell against the steam chest of the engine, receiving fatal injuries, there was no voluutary exposure to unnecessary danger. Equitable Acc. Ins. Co. v. Osborn, 90 Ala. 201, 9 South. 869, 13 L. R. A. 267. As where the assured, not knowing how to swim, was seining in the swift current of a river, which contained holes or "step-offs," of which he was ignorant. The fact that he stepped into one of these holes and was drowned, no knowledge of the danger having been proved, does not constitute a voluntary exposure. Couboy v. Railway Officials' \& Employés' Acc. Ass'n, 17 Ind. App. 62, 46 N. E. 363, 60 Am. St. Rep. 154.

Where the assured, carrying weapons, visited a disorderly house, and later went out into the street, where he and his companion became involved in an argument, during which he was shot, there was no voluntary exposure to danger. There was no obvious danger, nor would a man of reasonable prudence anticipate death as the result of such conduct, even though it was reprehensible. Jones v. United States Mut. Acc. Ass'n of City of New York, 92 Iowa, 652, 61 N. W. 
the assured appreciates at the time the fact that by doing a certain thing he is putting his life or limb at hazard. So the approach to an unknown and unexpected danger does not make the act a voluntary exposure thereto. Nor does the result of the act necessarily determine the motive which prompted it.

The circumstances under which the assured may expose himself to danger and the motives which likely inspire him thereto frequently determine the question of liability on policies containing this exemption clause. The law is always slow to impute negligence to one who has exposed himself to danger for the purpose of saving life. Similarly it is evident that the assured will not be guilty of a voluntary exposure to unnecessary danger, if the danger is incurred for the purpose of rescuing relatives, or even strangers, from situations of peril. ${ }^{267}$

485. Standing on the step of a moving railway passenger car, holding on the railings with both hands, does not constitute a voluntary exposure to unnecessary danger as a matter of law, even though the assured fell and was killed as a result thereof. Smith v. Atna Life Ins. Co., 115 Iowa, 217, 88 N. W. 368, 56 L. R. A. 271, 91 Am. St. Rep. 153.

267 Da Rin v. Casualty Co. of America, 41 Mont. 175, $10 \mathrm{~S}$ Pac. 649,27 L. R. A. (N. S.) 1164, 137 Am. St. Rep. 709. Here the assured, a miner, while attempting to rescue fellow miners caught in a mine explosion, was overcome by gas, as a result of which he died. The court said: "The general rule on this subject is that the law has so high a regard for human life that it will not impute negligence to one who attempts to sare it, unless the attempt be made under such circumstances as to constitute it rashness in the estimation of prudent persons. Thus stated, the rule is broad enough to cover, not only an attempt to save life under spontaneous impulse, aroused by sudden and uuexpected perception of the perll, and without thought or calculation of the chances of injury or loss of life to him who makes the attempt, but also an attempt which is made after such calculation as the circumstances permit, the rescuer acting upon the conclusion that he can save the life without the loss of his own. In the latter case the exposure is voluntary in a sense, yet if, under the same circumstances, a prudent man would 
A surgeon or physician, hurrying to reach the bedside of a patient dangerously ill and in immediate need of professional services, could hardly be held to expose himself to unnecessary danger if he knowingly assumes reasonable risks in his efforts to reach his patient. The same would equally apply to a lawyer or barrister seeking to reach the bedside of a dying client in time to clothe in legal form his wishes as to the disposition of his property. The necessity of keeping a business engagement of pressing and unusual importance would also excuse an exposure to a reasonable risk, though it is

obey the impulse to save a life, the exposure ought not to be held to be voluntary, within the meaning of the contract. At any rate, the danger is not, under the circumstances, unnecessary. This rule, we think, is fairly deducible from the adjudicated cases. * * * The rule which applies to this provision of the policy is analogous to that which governs the defense of contributory negligence. The engineer, who stands at his throttle in the presence of imminent danger of collision or the derailment of his train by an obstruction on the track, in an effort to save his passengers, and is killed or injured, cannot be said, as a matter of law, to be guilty of contributory negligence. He voluntarily exposes himself to the peril, but not unnecessarily so. The circumstances demand that he do his duty, and he does so in obedience to those higher impulses which must govern the conduct of the arerage prudent man. He may use his best judgment as to whether he can save his passengers by assuming the risk, and it is for the jury to say whether in doing so he is guilty of contributory negligence. So, also, in other practical affairs of life. Emergencies often arise calling for immediate action. In all such cases, though action may be accompanied by danger, yet while the exposure to it is voluntary, the danger cannot in any sense of the term be said to be unnecessary. On this subject the court in Fidelity \& Casualty Co. v. Sittig, 181 Ill. 111, 54 N. E. 903, 48 L. R. A. 359, said: 'For one to leap into a turbulent stream, rush into a burning building, or do any other hazardous thing, to save human life, would be a voluntary exposure to danger, but not to unnecessary danger. So, too, many emergencies in the lives of men occur where the most urgent necessity requires their presence at some particular place, at some particular time, and where to miss a train would involve serious consequences. In such a case a voluntary exposure to danger might not be unnecessary. The presence of a physician or surgeon at some critical period in the illness or injury of a human being might be necessary to save life, and it might 
doubtful if the insurance company would be liable where the assured assumed wanton risks in any of these hypothetical cases.

The assured, however, will not be permitted to hold the company liable where he voluntarily assumes risks or exposes himself to danger for such trivial reasons as matters of temporary convenience, or to avoid the delay occasioned by missing a train, or to obviate the task of walking a somewhat longer and safer distance to reach some destination. ${ }^{268}$

be necessary for him to expose himself to danger to reach his patient, or in some other respect to perform his professional duty. The necessity implied in the provision of the policy does not mean only that which is unavoidable or inevitable, but also any object or purpose which men of moral responsibility and prudence would regard as of such serious importance in the performance of duty as to demand or justify the incurring of risk of danger to accomplish it." "

Where the assured saw two drunken men on a railroad track exposed to the danger of being killed by an approaching train, and in the humane desire to save them he stepped on the track, slipped, fell, and was run over, this was held not to be a voluntary exposure to unnecessary danger. Williams v. United States Mut. Acc. Ass'n, S2 Hun, 268, 31 N. Y. Supp. 343, affirmed without opinion 147 N. Y. 693,42 N. E. 726.

Where the assured was a farmer living on the shore of Lake Ontario, and a schooner was driven aground in a storm and exhibited a flag of distress, and the assured, who lived in the neighborhood, went with his neighbors to the rescue of the crew, and was drowned in the capsizing of his boat, the court held that this did not constitute a voluntary exposure to unnecessary danger, but that it was his duty to aid in rescuing the distressed crew. Tucker v. Mutual Ben. Life Ins. Co., 50 Hun, 50, 4 N. Y. Supp. 505, affirmed without opinion Tucker v. Mutual Ben. Life Ins. Co., 121 N. Y. 718, 24 N. E. 1102.

268 Wilcox v. Central Acc. Ins. Co. of Pittsburg, 234 Pa. 58, 82 Atl. 1093. Here the assured, living by the side of a double railroad track, started to pay a call on a neighbor living across the tracks. Though there was a regular street crossing some 300 feet away, he started to cross the tracks, which were slightly depressed, merely to avoid the detour. He went down the embankment, and while crossing behind a train standing at that point was killed by another train approaching on the other track. The court said: "Neither any business pursuit nor necessity of the occasion called him to make the crossing at that point. * * * But conceding that the 
By the phrase "voluntary exposure to unnecessary danger" the policy contemplates only dangers of a real, substantial character which the assured recognizes, but to which he, none the less, purposely and consciously exposes himself, intending at the time to assume all the risks of the situation. Mere thoughtlessness or negligence or inattention does not constitute an exposure to danger within the meaning of the policy. The contract does not contemplate the release of the insurance company from liability by reason of a merely inadvertent exposure to danger. One who purchases a policy of accident insurance expects and understands that he is to be indemnified against accidents which result either wholly or partially from his own inadvertence. The contract means that the assured shall not unnecessarily expose himself to a danger of which he is conscious. It does not even contemplate dangers of which the assured might have known by the exercise of ordinary care, but it refers rather to the wanton and willful assumption of the risks of a known danger.

But it is frequently impossible, and generally very difficult, to establish a man's intentions by positive evidence. They must generally be deduced from his acts and conduct. If a man, therefore, conducts himself so recklessly and carelessly that he exhibits an utter contempt for and disregard of known dangers, then the law will translate his conduct into a voluntary exposure to danger. The standard of judgment in these cases is the rational conduct of a prudent man. Thus, if the risk of danger is so obvious and manifest that a man of ordinary care, exercising reasonable foresight, would not have done the act, the assured may safely be said to have voluntarily exposed himself to danger. ${ }^{26 \theta}$

insured had a lawful right to cross the tracks at that point, yet we are of opinion that his death was caused by an unnecessary exposure to danger."

269 In Union Casualty \& Surety Co. v. Harroll, 98 Tenn. 591, 40 S. W. 1080, $60 \mathrm{Am}$. St. Rep. 873 , the assured became involved in 
The words "voluntary exposure to unnecessary danger" in an accident policy do not include such an exposure as is incident to the ordinary habits and customs of life of the assured.

a quarrel, during which he grew abusive, and, despite a warning, advanced in a threatening manner upon his adversary, who drew a gun and fired, killing him. The court declared that the death did not result from a voluntary exposure to unnecessary danger, although the assured was shot while advancing toward his slayer with angry and threatening demonstrations, after the latter had warned him not to approach, unless he knew or had sufficient reason to believe that his adversary was armed, and, on his continued admence, would shoot to kill. In reviewing the case the Supreme Court of Tennessee said on the question of voluntary exposure: "A voluntary act is an intentional one-one which the actor of his own will, with the power of choice, determines to do or perform. So this condition is to be read as the equivalent of one exempting the insurer from liability where death results from an intentional exposure of one's self to unnecessary danger. Both terms imply some degree of knowledge or apprehension of the danger incurred and a purpose to take the risk. If the danger he concealed and unknown to the party, who ultimately suffers from it, then it cannot be said he has voluntarily exposed himself to it."

In De Loy v. 'Travelers' Ins. Co., 171 Pa. 1, 32 Atl. 1108, 50 Am. St. Rep. 787, the court instructed the jury that, unless the assured "did it intentionally, you cannot find that he exposed himself to danger within the terms of this exemption." This charge the court, however, modified by declaring that a risk of danger might be so obvious, and the exposure so wanton and reckless, as to amount to a voluntary exposure. In this case the assured desired to take a train at a small station, where there was no ticket agent, but merely a flag, with which prospective passengers hailed the trains. The assured on the occasion of the accident flagged an approaching train, returned the flag to its proper place, and walked a few steps up the side of the track to take the train, when he stumbled and fell towards the track as the train approached. He was struck in the breast by the engine and instantly killed. The insurance company in this case was held liable.

In Travelers' Ins. Co. v. Randolph, 78 Fed. 754, 24 C. C. A. 305, the assured was seen by the porter of the train riding on the steps and platform of a train traveling at the rate of 15 to 30 miles an hour, holding onto the handrails in the position of one about to alight. No one saw him fall from the car, but he was killed. The court instructed the jury: "If you find that standing on the platform, under all circumstances of this case, taking into account his position on the train, the speed of the train, the track, and everything else that makes up the situation where the accldent occurred, 
The death of the assured, caused by an accident incurred while he is engaged in the usual discharge of his regular duties, is not the result of such a voluntary exposure to unneces-

if you find that that was dangerous, and that, being conscious of that danger, he took a position that exposed him to it, and death resulted, your verdict showld be for the defendant; otherwise for the plaintiff, as to that issue." The insurance company was held liable in the lower court, and the judgment was affirmed. This seems an extreme case, since from the report there was no apparent reason for the assured riding in the position which he occupied at the time of his injury, and it is difficult to suppose that a prudent man would assume such a risk.

Where the assured on a dark and rainy night, with two packages in his hands, other and safer ways of travel being open to him, by choice tried to cross a railroad trestle which he knew to be dangerous, and by reason of a misstep fell through and seriously hurt himself, the insurance company was not liable. And this was so despite the fact that the assured made this his usual route home, had been going that way for ten years, and many others went the same way. Travelers' Ins. Co. v. Jones, 80 Ga. 541, 7 S. E. 83, 12 Am. St. Rep. 270 .

In Keene v. New England Mut. Acc. Ass'n, 161 Mass. 149, $36 \mathrm{~N}$. E. 891, the insurance company was liable where the assured was killed, while crossing railroad tracks at an accustomed place, by being struck by a detached car, which had been kicked along, and the sight of which was cut off by his umbrella. See, also, Ashenfelter $\nabla$. Employers' Liability Assur. Corp. of London, England, 87 Fed. 682, 31 C. C. A. 193, supra, and North American Acc. Ins. Co. v. Gulick, 25 Ohio Cir. Ct. R. 395.

But where the assured was injured by jumping from a passenger train after it had left a station and was running at from one to six miles an hour, he having at the time a satchel weighing from forty to fifty pounds in each hand, and there being no necessity for his jumping from the train, a verdict was directed for the insurance company, since the accident was the result of "voluntary or unnecessary exposure to danger or obvious risk of injury." Smith v. Preferred Mut. Acc. Ass'n, 104 Mich. 634, 62 N. W. 990.

In Bateman v. Travelers' Ins. Co., 110 Mo. App. 443, 85 S. W. 128 , the assured was a railroad porter. His train having stopped during the night, he was sent back, in line with his duty, to flag any train that might approach from the rear. He sat down on the track, and apparently went to sleep, and while in that position an approaching train struck and killed him. The court held that as a matter of law the assured had not voluntarily exposed himself to unnecessary danger. There was no evidence to show that he had voluntarily gone to sleep. If the assured had lain down, or other- 
sary danger as will relieve the insurance company, but is rather an accident for which the contracting parties intended the policy should render the company liable. ${ }^{270}$

wise placed himself, for the purpose of going to sleep, on a railroad track, then undoubtedly the insurance company would be exempt. See, too, Jamison v. Continental Casualty Co., 104 Mo. App. 306,78 S. W. 812.

One of the best-considered cases involving the question of voluntary exposure to unnecessary danger is that of United States Mut. Acc. Ass'n v. Hubbell, 56 Ohio St. 516, 47 N. E. 544, 40 L. R. A. 453. The assured received his policy of accident insurance as a traveling salesman. While traveling in the course of his employment on a road over which he had passed twice a year for thirteen years, he came to a slough in the highway occasioned by the heavy rains and floods of the season. He made inquiry of men living in the immediate vicinity as to the danger of driving through the water, and received varying opinions; some expressing a fear of danger, and others advising him that the way was safe. Acting upon his deliberative judgment, formed from these opinions, the appearance of the road, and his previous knowledge, in apparent good faith he concluded that there was no danger to his "life in crossing. The court held that this was not a "voluntary exposure to unnecessary danger," within the meaning of the policy. In its decision the court declared that the company would not be liable where the assured "recklessly and in a foolhardy way rushed into probable danger, even though he was at the time pursuing his legitimate calling. But where different men, having substantially equal means of judging, would differ in opinion as to the safety of an act, it cannot be said to be foolhardy. * * It is a recognized rule that, where one is confronted with a sudden emergency, the failure on his part to exercise the best judgment possible does not establish lack of care. We think that Hubbell's previous acquaintance with this ford and the landmarks thereabouts, and the information from others at the time, justified him in exercising his own judgment, and if he did so in good faith, and in the belief that there was no danger to his life in crossing, however erroneously he judged, his act in attempting to cross was not a voluntary exposure to unnecessary danger. Nor was the warning of others nore than a circumstance to be considered. Such warning was but the expression of an opinion, and he had received opinions to the contrary. It was a part of the circumstances; it did not of itself forbid the exercise of personal judgment. The question, therefore, of whether the attempted crossing was or was not a voluntary exposure to unnecessary danger, was for the jury, and not * * * solely a question of law to be determined by the court."

270 See Cotten v. Fidelity \& Casualty Co. (C. C.) 41 Fed. 506, where the assured, a mail clerk, in the discharge of his duties, board- 
Accident insurance companies were organized largely for the purpose of indemnifying persons engaged in trades or occupations in which accidents are imminent and almost unavoidable, and it is the object of the assured to secure indemnity in case of such accidents. Thus, when such accidents do happen, and injuries result, recovery cannot be defeated on the ground of

ed a slowly moving train. Richards v. Travelers' Ins. Co., 18 S. D. 287,100 N. W. 428,67 L. R. A. 175 , where the assured, a cattle dealer and broker, whose occupation required him to ride on trains of cattle cars from place to place in the freight yards, was killed by falling from moving cars on which he was riding. "Modern courts very justly hold restrictions in accident policies inoperative which render the insurance nugatory and valueless by attempting to avoid liability for injuries sustained by the insured while performing necessary acts embraced in his classified occupation."

In Pacific Mut. Life Ins. Co. $v$ Snowden, 58 Fed. 342, 7 C. C. A. 264. the assured, a cattle dealer, went to one of the forward cars to look after his steers when the train stopped. Finding one of the steers down, he endeavored to get it to its feet, when the train started. He was thrown from one of the cars onto which he had climbed, and was injured by the jar of the "helping" engine. The insurance company was held liable, on the ground that the assured was acting within the limits of common practice and usual custom of his business. Where the assured, described in his policy as a "cattle dealer, or broker and shipper, not tender or driver," was riding on a train, and went forward to inspect his steers when the train stopped, and was thrown while climbing on the cattle car after the train suddenly started, held, that the company was not liable. Travelers' Ins. Co. v. Snowden, 45 Neb. 249, 63 N. W. 392. This case is different from the preceding case, in that here the question was whether the injuries were contracted within the regular occupation of the assured. The form of policies also differed.

In Providence Life Ins. \& Inv. Co. of Chicago v. Martin, 32 Md. 310 , the assured, a locomotive engineer, while backing his engine on a downgrade with a car in advance, as a precaution to check the speed, directed the fireman to run the locomotive, while he went: on and over the tender to reach the car and set the brakes. In so doing he slipped and fell between the car and tender, and was instantly killed. The insurance company was held liable, since this was a risk reasonably attending the duties of his occupation.

A mason, who worked upon a swinging scaffold in painting the walls of an eight-story brick building, the scaffold being suspended from the roof by means of ropes which passed over a projection in the building and was drawn toward the building, so as to bring 
voluntary exposure to a danger contemplated by the parties, because pertaining to the business of the assured. Yet, if the assured purposely and unnecessarily works in places and with tools which he knows to be dangerous and unsafe, the company will not be liable in the event of injury arising therefrom. ${ }^{271}$

it into position, by guy ropes, one of which broke, throwing him to the street below, did not thereby unnecessarily expose himself to danger withln the meaning of a condition in an accident insurance policy against liability for injury caused by such exposure, as it was contemplated by both partles when the policy was issued that he would be exposed to the dangers incident to his occupation. Wilson v. Northwestern Mut. Acc. Ass'n, 53 Minn. 470, 55 N. W. 626.

Where the assured in line of his duty was stationed at a bridge to flag approaching trains, and went to his station one night, and the next morning his dead body was found a short distance from the track, with no clear evidence as to how he met death, it was left to the jury to determine whether or not he had been exposing himself to unnecessary danger. Jamison v. Continental Casualty Co., 104 Mo. App. 306, 78 S. W. 812. In the Bateman Case, supra, the assured was, under somewhat similar circumstances, in a dangerous position in line with his duties. Alloway v. General Acc. Ins. Co., $35 \mathrm{~Pa}$. Super. Ct. 371, where the assured was a clerk in a general store in a mining town and one of his duties was to sell gunpowder. He was killed by an explosion of the powder, and the court held that this was not an "unnecessary exposure to risk," since it was one of the duties of the occupation under which he was insured. The court sald: "If the insured had gone to the powder house with a lighted cigar or pipe, or was in the company of one who had a lighted cigar or pipe, then in that case he would have exposed himself to an 'obvious risk of injury or obvious danger,' and that risk would have been unnecessary exposure, and under such circumstances the plaintiff could not recover; but there is no eridence that these circumstances caused the accident."

See, also, National Ben. Ass'n r. Jackson, 114 Ill, 533, 2 N. E. 414.

271 Where the assured, a railroad switchman, got off an engine in motion in the nighttime with his back in the direction in which the engine was going, which was an unsafe and dangerous way to alight, the court declared that the accident did not result from the ordinary discharge of the duties of the assured, but that it resulted from his negligence or want of due care in the performance of his duties, and the Insurance company was not liable on a policy exempting it, where injuries were occasioned by want of due care or negligence. Standard Life \& Accident Ins. Co. v. Jones, 94 Ala. 434, 10 South. 530. 
It is well settled that the plaintiff may introduce evidence in such cases to establish the common practice among men engaged in the same occupation or profession as the assured, for the purpose of showing that the assured acted in the same way as men similarly engaged under like circumstances and conditions, and that the risks which he has taken were no greater than those habitually assumed in his business by men of reasonable care and prudence. ${ }^{272}$

To relieve the insurance company of liability for injuries or death under this clause, the insurer must show that the excepted risk was the proximate cause of the accident. Unless the injury or death was the result of the unnecessary exposure, the company will be liable. ${ }^{273}$ The mere fact that the

272 Pacific Mut. Life Ins. Co. v. Snowden, 58 Fed. 342, 7 C. C. A. 264; Garcelon v. Commercial Travelers' Eastern Acc. Ass'n, 195 Mass. 531,81 N. E. 201,10 L. R. A. (N. S.) 961 . Here the assured, a commercial traveler, was thrown from a moving freight train which he had started to board in order to reach a neighboring town in the pursuit of his business. He claimed that this was the custom of commercial travelers in that part of the country, and that he himself had done this same thing on an average of once a week for eight years. The court held that he could not recover, and the fact that he had done the same thing repeatedly before, or that it was the custom of commercial travelers to do so, did not relieve him from the consequences of his act.

273 Where the assured was suffering from a disease, and against the advice of his physician was making a trip by train, and while on the train went to the water cooler to get a drink, and by the lurching of the train was thrown against a seat, thereby injuring his back, as the result of which he died, there was clearly no proper defense that the injury was the proximate result of his exposure in taking the trip in his enfeebled condition. The accident might have happened with equally fatal results to one in normal health. Atna Life Ins. Co. v. Hicks, 23 Tex. Civ. App. 74, 56 S. W. 87.

And so similarly where the assured was preparing to walk to a neighboring city after dark, and the trip was apparently one of danger, from the likelihood of assault, and his wife begged him not to go because of the danger, and he took with him a razor as a weapon of defense, and on the trip he fell in a hole at the end of a bridge which he was crossing, by reason of which he was rendered unconscious and suffocated to death, the insurance company was

Fuller ACC.INS.-16 
assured was voluntarily exposing himself to unnecessary danger, when he met with an accident which was in no way related to or the result of such exposure, will not relieve the company. It is not enough to defeat liability under this clause that the assured violated the conditions of the policy with respect to exposing himself to unnecessary danger, but the company must also show that his act was the efficient cause of the injury.

Engaging in common sports or pastimes outside of one's occupation or employment, when done simply as a diversion, does not constitute a voluntary exposure to unnecessary danger, even though the sport may involve certain risks, providing the assured exercises the care and precaution of a man of reasonable prudence under similar conditions. ${ }^{274}$

held liable, since his injury was not the result of the dangers which he had anticipated. Employers' Liability Assur. Corp. v. Anderson, 5 Kau. App. 18, 47 Pac. 331.

274 Hunt v. United States Acc. Ass'n, 146 Mich. 521, 109 N. W. 1042, 7 L. R. A. (N. S.) 938, 117 Am. St. Rep 655, 10 Ann. Cas. 449. Here the assured was playing indoor baseball on a smooth, slippery gymnasium floor. After batting, he ran to first base, but with such momentum that he overran the bag and put his foot and hand out against the wall, a few feet beyond, in order to stop himself, as was the custom with the players. In striking the wall his ankle was broken. The court said: "That negligence which would defeat a plaintiff in an action for damages on account of the negligence of a defendant finds no place as a defense in the law of insurance against accidents. Such contracts must be shorn of much of their value, if ordinary contributory negligence could be interposed as a defense. Thoughtless and inconsiderate acts are some of the very things which these policies are designed to cover. One might easily ascertain whether his gun was loaded before he undertook to clean it. The hunter, in golng through the brush, or getting over a fence, or rowing his boat, should be careful to handle his gun so as to prevent accident. One climbing a ladder should see that the rounds were sound and securely fastened. Ordinary prudence would require these precautions, but hundreds of accidents happen because they are not taken. 'The term 'voluntary exposure to danger' means a realization that an accident will in all probability result and an injury follow from the action about to be taken. The danger of injury must be obvious.

* * The plaintiff did not anticipate 
Accidents of this nature happen frequently while the assured is engaged in a hunting trip for pleasure and result from handling firearms. ${ }^{275}$ The ordinary use of a gun while hunting is not as a matter of law a voluntary exposure to danger. ${ }^{27 e}$ Scaling a bank with a loaded gun is not a voluntary exposure to danger, though to go through a dense thicket - with the hammer of one's gun raised and the muzzle pointed toward one is such an exposure. So to drag a gun, loaded and cocked, through a fence toward one, would generally amount to an unnecessary exposure to danger. ${ }^{277}$

injury from doing what he had done before and what others have repeatedly done. There was no obvious danger of injury. Granting that he might have stopped, we cannot say that there would not have been as much danger in trying to stop upon a slippery floor as in running against the wall. A jury would be justified in finding that the plaintiff had no anticipation of an accident, and did not realize that there was any danger. Eren if he were careless, and might have aroided running against the wall, but, in doing so, dir not realize any danger, he was entitled to recover."

275 Cornwell v. Fraternal Acc. Ass'n, 6 N. D. 201, 69 N. W. 191, 40 L. R. A. 437,66 Am. St. Rep. 601 . In this case the assured, while hunting for pleasure, was climbing a bank, whell, his foot luaving slipped, he caught hold of a limb, and was in the act of drawing himself up by means thereof, when in some way his gun was discharged. He received the charge in his hand, shattering it so badly that amputation was necessary. The court declared that the assured was not guilty of a voluntary exposure to unnecessary danger.

276 See Wildey Casualty Co. จ. Sheppard, 61 Kan. 351, 59 Pac. 651, 47 I. R. A. 650.

277 Sargent $\nabla$. Central Acc. Ins. Co., 112 Wis. 29, 87 N. W. 796, $88 \mathrm{Am}$. St. Rep. 946. Here the assured, after climbing a fence, placed his wrist in front of the muzzle of his gun, which was loaded and cocked, and started to drag it towards him through the fence, when it exploded, shattering his hand and wrist. This was held to be a voluntary exposure to unnecessary danger. 'The court suggested, however, that even such conduct might be excused in circumstances of great excitement, imminent peril, or extreme haste, so engrossing as to divert the attention of the assured from this danger.

See, also, Holiday v. American Mut. Acc. Ass'n, 103 Iowa, 178, 72 N. W. 448, $64 \mathrm{Am}$. St. Rep. 170, where the assured, while on a pleasure hunting trip, in going to his wagon in the highway, had 
Cleaning a gun, not known to be loaded, will not relieve the insurance company, on the theory that a degree of consciousness of danger is necessary before there can be a voluntary exposure. ${ }^{278}$

Certain sports are of such an inherently dangerous nature that to participate in them at all constitutes a voluntary exposure to unnecessary danger, and must relieve the insurance company from liability for injuries resulting from a participation therein. Such, for example, are steeplechase riding and undoubtedly bull fighting and sports of a similar nature. ${ }^{279}$ Ordinary horseback riding, if the assured exercised the care of a prudent man, and did not ride a vicious horse, or subject the horse to danger or fright, would not be such an exposure. ${ }^{280}$ Even horse racing under proper conditions will not

to cross a wire fence, there being no gate. He put the gun on the other side, and in climbing through himself he fell in such a manner as to strike the gun, release the safety catch, and discharge it. The charge so badly lacerated his foot that amputation was necessary. The court held that as a matter of law this did not constitute a voluntary exposure.

278 Union Casualty \& Surety Co. v. Goddard, 76 S. W. 832, 25 Ky. Law Rep. 1035. Here the assured, having completed a hunting trip, went upstairs, the night before his return to the city, to pack his clothes and clean his gun. The evidence, largely circumstantial, tended to show that he was cleaning the gun, supposing it to be unloaded, when it exploded, killing him. The jury found against the insurance company, and their verdict was sustained on appeal.

See Miller v. American Mut. Acc. Ins. Co., 92 Tenn. 167, 21 S. W. 39, 20 L. R. A. 765, where the assured was cleaning a gun in the usual manner, believing it to be unloaded, but which, being loaded, was discharged unintentionally by reason of an unknown defect in its lock which caused the hammer to be thrown when the butt struck the floor.

279 In Smith v. Aetna Life Ins. Co., 185 Mass. 74, 69 N. E. 1059, 64 I. R. A. 117, $102 \mathrm{Am}$. St. Rep. 326, the assured was injured while riding in an amateur steeplechase, and the court held this to be such a voluntary exposure to unnecessary danger as would relieve the insurance company of liability.

280 Putnam v. Phœnix Preferred Acc. Ins. Co., 155 Mich. 134, 118 N. W. 922, where the evidence differed as to whether the horse was 
relieve the insurance company from liability for injuries received therefrom. Bicycle riding is not an exposure to danger; nor is riding in a bicycle race of itself, when unaccompanied by peculiar and obvious danger, as a matter of law, such an exposure. ${ }^{281}$

Engaging in a fight is not of itself a voluntary exposure to unnecessary danger, particularly where the assured does not realize or have occasion to suspect that he is exposing himself to danger in making the assault. ${ }^{282}$ This is true, even where the assured himself provoked the assault, provided he did not anticipate nor have reason to expect such a result. ${ }^{283}$ But if the assured has good reason to believe that an attack by him will result in injury to himself, then it would constitute such a voluntary exposure to danger as will relieve the insurance company.

vicious and unmanageable, or gentle and tractable, and it was held to be a question for the jury. The court held admissible evidence of witnesses to show the disposition and temperament of the horse, which it was claimed ran away with the assured twice on the day of the accident.

281 Keeffe v. National Ace. Soc., 4 App. D1v. 392, 38 N. Y. Supp. 854. Here the assured was injured as a result of riding in a bicycle race, and the court, refusing a nonsuit, submitted the question to the jury as to whether he was voluntarily or unnecessarily exposing himself to danger or the obvious risk of injury, on the ground that different and equally intelligent and unbiased men might fairly differ in opinion as to whether by taking part in such a race any risk of injury was necessarily incurred. The jury found for the assured.

282 See Campbell v. Fidelity \& Casualty Co. of New York, 109 Ky. 661, 60 S. W. 492, $22 \mathrm{Ky}$. Law Rep. 1295, where the assured, after drinking heavily, provoked a fight witk a pollarman, who shot him in supposed self-defense. See, also, Yale v. Travtlers' Ins. Co., 2 Thomp. \& C. (N. Y.) 221, where the assured was killed in a fight over the possession of certain premises, the title to which was in dispute between him and another. Here threats made against the assured by the other party to the fight were properly admitted in evidence on the question of whether the death resulted from such exposure.

283 Where the assured was stopped by a policeman for fast driving, and an altercation resulted, during which he was shot by the 
Where the assured in such a case must have realized the danger, or where a man of ordinary prudence would have appreciated the risk, the insurance company will not be liable. ${ }^{284}$

Attempting to board or leave a moving train is not of itself necessarily a voluntary exposure to unnecessary danger, nor is it a willful and wanton exposure to peril. ${ }^{285}$ In

policeman, and the evidence was conflicting as to whether the assured first threatened the officer and drew a gun on him, the question was properly for the jury. De Greayer v. Fidelity \& Casualty Co., 126 Cal. xvii, 58 Pac. 390.

See Collins v. Fidelity \& Casualty Co., 63 Mo. App. 253. Where the evidence is conflicting as to the realization of the danger by the assured, the question is for the jury. See, also, Hester v. Fidelity \& Casualty Co., 69 Mo. App. 186.

284 See Shaffer v. Travelers' Ins. Co., 31 Ill. App. 112; Id. (Ill.) 22 N. E. 589. Here the assured, whom the police were pursuing, made his way to the room of a woman. The police demanded admittance, which was refused, while the assured prepared to escape from the second-story window. Using a piece of selvage some six inches wide that was lying on the floor, he first tried its strength over his knee with both hands, then tied it to the leg of a sewing machine standing near, and, holding to the strip, started out of the window to let himself down to the brick sidewalk, about fifteen feet below. He had descended but a foot or two, when the strip of bedticking broke and he fell to the walk in such a way as to receive fatal injuries. The court instructed the jury to find for the insurance company.

285 National Life \& Accident Ins. Co. v. Lokey, 166 Ala. 174, 52 South. 45, where the court held that the stepping from a moving train, irrespective of the speed thereof, was not as a matter of law an obvious danger.

Schnelder v. Provident Life Ins. Co., 24 Wis. 28, 1 Am. Rep. 157. The assured, in this case, was walking back and forth on the platform of the station waiting for the train, which had backed so that the cars stood at some little distance from it. As the train came along, moving at a slow rate, about as fast as a man would waik, it did not stop, and the assured attempted to get aboard. In some way he fell under or by the side of the cars and was crushed to death. The court said: "The act may have been imprudent. It may have been such negligence as would have prevented a recovery in an action based upon the negligence of the [railroad] company, if there had been any. But it does not seem to have contained those 
Travelers' Protective Ass'n of America v. Small, the Supreme Court of Georgia outlined the criterion by which to judge such cases, as follows: "Whether one who attempts to board a moving train is engaged in an act which is dangerous in its nature, or takes an obvious risk of injury, depends upon the circumstances under which the act is attempted to be performed, the place at which the train is, the speed at which it is moving, the position of the party, his age and activity, and all other circumstances that would be considered in determining whether an ordinarily prudent person would, under such circumstances, attempt at such a time and in such a place to board a train moving at such rate of speed. It is not necessarily what would be done by a particular individual under the circumstances stated, but what would be done ordinarily by a man in the exercise of due care and caution. If a man of ordinary prudence would have attempted, under the circumstances, to board the train, then the attempt would not be negligence. If, on the other hand, a man of ordinary prudence would not have made the attempt, it would be negligence, and a person engaged in such an act would be exposing himself to danger, or to obvious risk of injury, within the meaning of such terms when used in a policy of accident insurance. * * * If at the time he made this attempt, there was no pressing emergency upon him requiring him to make this attempt, either in behalf of his own safety or welfare, which was imperiled at the moment, or in behalf of the safety or welfare of some one else,

elements which could be justly characterized as willful or wanton. The deceased was in the regular prosecution of his business. He desired and expected to leave on that train. Finding that he would be left unless he got on while it was in motion, it was natural enough for him to make the attempt. * * * The railroad employés were getting on at about the same time. Imprudent though it is, it is a common practice for others to get on and off in the same manner." 
who was likewise imperiled at the moment, but merely for the purpose of avoiding the delay incident to missing a given train, and the attempt was made by the plaintiff freely and voluntarily, then the attempt to board the train would be a voluntary and unnecessary exposure to danger or to obvious risk of injury, $* * *$ and the plaintiff would not be entitled to recover." 288

$286115 \mathrm{Ga} .455,41 \mathrm{~S}$. E. 62S. See same case on retrial Small v. Travelers' Protective Ass'n, 118 Ga. 900, 45 S. E. 706, 63 L. R. A. 510. Here the assured, a traveling man, left his grips on the car and started across the street to attend to some business. On his return, and just as his train was starting, a freight came along. He ran down the track some seventy yards to catch the train, which was now running at the rate of eight or ten miles an hour. The place was smooth and he was an expert at boarding moving trains, as he was almost daily accustomed to do so. He stood in the correct position, and caught the rail of the car, swung himself forward, and got one foot on the step, when he slipped and fell off, suffering severe injuries. The court held that the insurance company was not liable. See Fidelity \& Casualty Co. v. Sittig, 181 IIl. 111, 54 N. E. 903,48 L. R. A. 359, supra, where the assured, in boarding a slowly moving train, was brushed off the steps of the car by a small ticket office, which he did not notice, standing near the track. The jury held against the insurance company. It is not of itself a voluntary exposure to unnecessary danger to attempt to board a train moving at the rate of two miles an hour. Travelers' Preferred Acc. Ass'n v. Stone, 50 Ill. App. 222 ; Anthony v. Mercantile Mut. Acc. Ass'n, 162 Mass. 354, 38 N. E. 973, 26 L. R. A. 406, 44 Am. St. Rep. 367 ; Rebman v. General Acc. Ins. Co., $217 \mathrm{~Pa}$. 518, 66 Atl. 859,10 L. R. A. (N. S.) 957, where the court held that an attempt by a man 66 years of age, weighing 184 pounds, with an umbrella under his arm, to get upon a train running at the rate of six or eight mlles an hour, was a "voluntary exposure to unnecessary danger." The court said: "His act was not the less roluntary because it may have been on a sudden impulse, without reflection. He intended to do what he did, and the words of the policy admit of no distinction between premeditated acts and impulsive acts springing from a fully formed intention. The danger cannot be considered as not obvious, because he may not at the moment fully have understood and appreciated it. He could have seen it, and would have seen it and comprehended it, if he had given to what he was doing the reasonable attention that ordinary prudence required." 
As a legal proposition, a passenger stepping aboard a moving car of a railway train is undoubtedly guilty of negligence; but it could not be said that in all cases it would amount to a voluntary exposure to unnecessary danger. All reasonable men will agree that it is obviously dangerous for one to attempt to climb upon a railway train going at fuil speed, or at a high rate of speed, and in such case the jury should be so instructed. But where a train is moving slowly the question is one of fact, to be determined by the jury under proper instructions to consider all the various circumstances of the particular case. The same rules apply to any attempt to board a moving street car. ${ }^{287}$

Naturally the same rules which apply to an attempt to board a moving car control an attempt to leave a car while in motion. The speed of the car, the age and condition of the assured, his habits of life, the circumstances under which the attempt is made, all go to form the equation from which the court or jury must determine whether his act constitutes a voluntary exposure to unnecessary danger. ${ }^{288}$

Standing on the platform of a moving car is not of itself and as a matter of law a voluntary exposure to unnecessary danger. It is rather a question of fact for the jury to deter-

287 Unless the act was obviously or wantonly dangerous, "an attempt to board a moving street car is not, as a matter of law, 'voluntary or unnecessary exposure to danger' 'within the meaning of an accident policy." In this case the assured, while attempting to board a car on an electric street railroad, fell, and one of the wheels passed over his foot, necessitating amputation. Johanns v. National Acc. Soc., 45 N. Y. Supp. 117, 16 App. Div. 104.

288 Where the assured purposely and knowingly jumped off the top of a car of a freight train traveling at a high rate of speed, it was gross negligence, and the court should direct a verdict for the insurance company. Shevlin v. American Mut. Acc. Ass'n, 94 Wis. 180, 68 N. W. \$66, 36 L. R. A. 52, supra. See, also, Badenfeld ₹. Massachusetts Mut. Acc. Ass'n, 154 Mass. 77, 27 N. E. 769, 13 L. R. A. 263. 
mine from the circumstances of the case. There can be little doubt that to voluntarily ride on the platform of a car, after dark, when there are no guard rails or closed vestibules, and the train is moving at a rapid speed over rough and uneven track, would be such an exposure to danger as would warrant a court in instructing the jury to return a verdict for the insurance company on this form of a policy. ${ }^{289}$ But to ride upon a platform of a car protected by rails, or inclosed by vestibules, is not such an exposure. So, also, to ride upon the platform of an observation car, such as are common on many trains, is not of itself a voluntary exposure to danger. ${ }^{200}$

It has been held to be a voluntary exposure to unnecessary danger for one to leave the car and voluntarily go out on the

280 Where the assured, either while riding upon the platform of a car or while passing from one car to another, on a train running at full speed late at night, without any apparent necessity was thrown off and killed, the insurance company was not liable on its policy. Sawtelle v. Railway Passengers' Assur. Co., 15 Blatchf. 216, Fed. Cas. No. 12,392.

290 See Travelers' Ins. Co. $\nabla$. Randolph; 7S Fed. 754, 24 C. C. A. 305 , which is the leading case on this point. Here the assured, when last seen before the accident, was riding on the lower step of a car, holding onto the rails, while the train was moving at a rate of from fifteen to twenty-five miles an hour. His position was that of a man about to jump off, and he was seen to suddenly release his hold and fall back. The track was straight and level. Mr. Justice Harlan, in reviewing the case, declared that the evidence did not clearly establish an intentional or voluntary exposure to danger, and that the question was properly left to the determination of the jury. See, also, Smith v. Etna Iife Ins. Co., 115 Iowa, 217, 88 N. W. 368, 56 L. R. A. 271, 91 Am. St. Rep. 153, where the assured, intending to leave the train at a certain crossing, went out on the platform and stood on the lower step, holding onto the ratling with both hands and facing inwards. In falling, the assured was dragged some distance. The accident happened after dark, and one of the witnesses, a brakeman, declared that the assured acted as though he was going to step down another step, under the impression that there was another step there. The jury here found against the insurance company. 
platform preparatory to leaving the train when it reached the station. ${ }^{201}$ This was so held despite the fact that many travelers of ordinary care and prudence are accustomed to go on the platform of a car while the train is approaching the station of their destination.

It is not a voluntary exposure to unnecessary danger to ride upon a platform of a moving train, or upon the steps of a platform, if by reason of the crowd on the train there is no safer place to ride. This is particularly true where this is done with the permission of the conductor. ${ }^{292}$ Nor is it, as a matter of law, a voluntary exposure to unnecessary danger for the assured to ride upon a platform of a moving train, when by reason of illness he is forced to leave the interior of the car. ${ }^{293}$ The nature of the emergency or exigency which induces the man to resort to the use of the platform must be considered in determining the question of exposure to danger. ${ }^{204}$

291 See Overbeck v. Travelers' Ins. Co., 94 Mo. App. 453, 68 S. W. 236. The court declared: "Lvery persọn of ordinary intelligence knows that it is dangerous to so ride." This seems to be the only adjudicated case directly on this point. It is difficult to reconcile this case with the reasoning in the Randolph Case.

282 Equitable Acc. Ins. Co. v. Sandifer, $12 \mathrm{Ky}$. Law Rep. 797.

293 Marx v. Travelers' Ins. Co. (C. C.) 39 Fed. 321, where the assured went out on a platform of a moving train to secure relief, because he was overcome by the heat of the car and was suffering from nausea. The verdict of the jury, holding the insurance company liable, was sustained on appeal.

Preferred Acc. Ins. Co. of New York v. Muir, 126 Fed. 926, 61 C. C. A. 456. In this case the assured, while riding on the train, was seized with a severe attack of car sickness. Finding the closet door locked, he went out on the platform for the purpose of vomiting. The train was traveling at from 50 to 60 miles an hour, and he was thrown off, receiving injuries from which be died. The jury found that this did not constitute an "unnecessary or negligent exposure to obvious danger," within the meaning of the insurance policy.

204 Where the assured fell asleep on a moving train, and while in a dazed and unconscious condition of mind walked to the rear platform of the car and fell off, it was not a voluntary exposure. 
It is not, as a matter of law, a voluntary exposure for one to cross a track in front of an approaching train, when it appears to a man of ordinary prudence that the crossing may be made in safety before the arrival of the train. Where one has sufficient time, or thinks he has, to cross a track in front of an approaching train, and in crossing falls and is run over, there is not, as a legal proposition, such a voluntary exposure as will release the insurance company from its liability on the policy. The question is one for the jury to determine. ${ }^{295}$ For one to cross such tracks at a regular crossing is clearly not such an exposure, unless the act is accompanied by some elements of gross negligence or wanton risk to an apparent danger. Nor is it such an exposure when one crosses at a place where the public in general is not supposed to cross, provided no attempt is made to stop the practice, and if the place has been so used daily by large numbers of people for a considerable period of time. ${ }^{296}$

Scheiderer $\nabla$. Travelers' Ins. Co., 58 Wis. 13, 16 N. W. 47, 46 Am. Rep. 618.

295 Columbian Acc. Co. v. Sanford, 50 Ill. App. 424; Williams v. United States Mut. Acc. Ass'n, 82 Hun, 268, 31 N. Y. Supp. 343, supra.

296 Keene v. New England Mnt. Acc. Ass'n, 161 Mass. 149, 36 N. E. 891. Here the assured was crossing rallroad tracks at a point that was not considered a public crossing. In fact, notices were posted forbidding the public to cross at this point. But no other attempt was made to stop the practice, and from one thousand to two thousand persons crossed there each day, and the crossing had been so used for years. The assured was struck by a detached car, which was being kicked along, the sight of which was cut off by his umbrella. The question was left for the jury to determine.

See Badenfeld v. Massachusetts Mut. Acc. Ass'n, 154 Mass. 77, 27 N. E. 769,13 L. R. A. 263 , supra, where the assured was struck by a train while walking about the platform of a station, and the manner of the injury was in doubt.

Where the assured, a horse trader, wanted to get home at night, and passenger trains were not running, but he knew the crew on a freight train that ran out at night to his home, and he started down the track to the yards for the purpose of boarding this 
But to cross the tracks at any point before a rapidly approaching train, or to make one's way after dark over a network of tracks used by constantly passing trains in an unaccustomed and unfrequented place, constitutes a voluntary exposure to unnecessary danger. ${ }^{207}$

freight, and was later found dead, with no evidence to establish just how he was killed, the question was left to the jury to decide whether there was a voluntary exposure to unnecessary danger. They found against the insurance company. Meadows $\nabla$. Pacific Mut. Life Ins. Co., 129 Mo. 76, 31 S. W. 578, 50 Am. St. Rep. 427.

Where the assured, in order to reach a depot, crossed certain railroad tracks behind a train, and as he continued was called to and warned from various directions, though the shouts were unintelligible; in apparent confusion he hurried to reach the platform of the depot, and was struck by an approaching train which he had not seen, owing to the obstruction of the train behind which he was passing; held that this was not, as a matter of law, a voluntary exposure to unnecessary danger. The verdict of the jury, holding the insurance company liable on its contract, was sustained by the reviewing court. Duncan v. Preferred Mut. Acc. Ass'n, supra (Super. N. Y.) 13 N. Y. Supp. 620 , affirmed without opinion 129 N. Y. 622 , 29 N. E. 1029.

See Lehman v. Great Eastern Casualty \& Indemnity Co. of New York, 7 App. Div. 424, 39 N. Y. Supp. 912, affirmed without opinion 158 N. Y. 689,53 N. E. 1127. Here the assured, on his way to a business house located near the railroad, walked along a path on the side of the west track until nearly opposite his destination. Observing a train approaching, he waited for it to pass, and then turned to cross the other track in the direction of the house where he was bound, when he was struck by a train whose approach he had not seen. The use of the crossing which he had taken had long been acquiesced in by the railroad company. Held, that the assured was not, as a matter of law, guilty of a voluntary exposure to unnecessary danger. See, also, Payne v. Fraternal Acc. Ass'n of America, 119 Iowa, 342, 93 N. W. 361; Traders' \& Travelers' Acc. Co. v. Wagley, 74 Fed. 457, 20 C. C. A. 588.

297 Where the policy contained a condition that the insured should use "due care for his personal safety," and the insured, being invited late at night to ride with the engineer in his locomotive, and while waiting for the train to start, got down from the cab and sat on the end of a railroad tie, where there were many side tracks, with trains constantly passing, and was killed, held, the insurance company was not liable. Standard Life \& Accident Ins. Co. v. Langston, 60 Ark. 381, 30 S. W. 427. 
It is such an exposure as will relieve the insurance company if the assured walks along the track, or loiters upon it, without some sufficient reason or necessity. ${ }^{298}$ Where the assured, in a spirit of boasting or bravado, stood on a railroad track before an approaching train, and, as it drew nearer, in that same spirit, bent down before the train, there was such voluntary exposure to unnecessary danger as would relieve the insurance company from liability. ${ }^{290}$

But where one is on a railroad track by reason of the duties incident to his regular occupation or employment, a different rule will naturally apply. The ordinary duties of a brakeman, a switchman, a track-walker, or of several classes of railway employés, require them to constantly cross and recross railway tracks, often in close proximity to moving trains and under circumstances that may seem peculiarly dangerous and full of hazard to a layman. Yet if, in the discharge of their duties, they employ the same measure of care and caution that is customarily exhibited by men of ordinary prudence in that same employment, they cannot be said, in the event of injury, to have voluntarily exposed themselves to unnecessary danger. The risks that they assume are incident to and a portion of their occupation, and those risks the insurance company assumes by issuing policies of insurance to men following that business. Thus, where a brakeman, or a switchman, stationed at a point to manipulate the switches or flag approaching trains, is injured by reason of being where his duties have placed him the insurance company will be liable upon its pol-

298 See Lovell v. Accident Ins. Co., 3 Ins. L. J. (Q. B.) 877, where the court held that walking on a rallroad track on a dark and rainy night, at a time when deceased knew that trains were frequently passing both ways, constitutes an "obvious risk."

200 See Wiliams v. United States Mut. Acc. Ass'n of New York, 133 N. Y. 366,31 N. E. 222 , supra. 
icy, unless the assured has exposed himself to dangers or assumed risks not usual among railway employés. ${ }^{300}$

300 In Metropolitan Acc. Ass'n v. Taylor, 71 Ill. App. 132, as in the Chambers Case, the assured was not a railroad employé. In this case the assured, with some companions, was walking along the railroad tracks. His companions left him to visit a neighboring house in quest of food. While awaiting them he sat down on one of the ties, close to the track of a railroad in active operation. Here he apparently fell asleep, with his body sprawling across the track, or suffered some brain attack, and was killed by being struck by a train. The court held that the assured had voluntarily exposed himself to unnecessary danger, and the insurance company, therefore, was not liable on its policy. Where an employé was sent to shovel snow from a crossing, and was killed by an approaching train, it was declared that he was rightfully upon the railroad track under his employment, and the insurance company was held liable on its policy. Freeman v. Travelers' Ins. Co., 144 Mass. 572, $12 \mathrm{~N}$. E. 372 .

The insurance company was held liable where the assured, a bridge carpenter, working for a railroad, was stationed at a particular bridge to flag approaching tralus, and was killed by being run upon by a train. The evidence as to the exact manner in which he met death was limited and contradictory. There was a suggestion that he had fallen asleep at his post. Jamison v. Continental Casualty Co., 104 Mo. App. 306, 78 S. W. 812, supra. See, also, Bateman v. Travelers' Ins. Co., 110 Mo. App. 443, 85 S. W. 128, supra, where the assured, being sent back to flag any approaching trains, sat down on the track, and apparently fell asleep, and was killed by a train. The court declared that it was not necessarily a voluntary exposure to danger for a railload employe to sit down on a railroad track while waiting to flag a train, since it is constantly done by railway employés of known caution and discretion. But if he sat there, and voluntarily and purposely went to sleep, the insurance company would not be liable. On the other hand, if he unconsciously fell asleep, this would not as a matter of law constitute a voluntary exposure to unnecessary danger.

Kephart v. Continental Casualty Co., 17 N. D. 380,116 N. W. 349. Here the assured, employed as a brakeman on a freight train, was sent to close a switch of the track on which his train was standing, and while at that post he was killed by another train.

In Fidelity \& Casualty Co. v. Chambers, 93 Va. 138, 24 S. E. 896 , 40 L. R. A. 432 , the assured was sitting on a bag on a railroad track, with his back to a train coming around a curve. Upon being warned of his danger by shouts, he started off and was clear of the 
But for the assured to cross railroad tracks merely for the purpose of convenience, or to save time, when another and safer way offers, is a voluntary exposure. ${ }^{301}$

To cross a railroad trestle or bridge, particularly at night, where only ties offer a footing, and there is no railing, or to run before an approaching train merely for the sake of reaching another train, constitute voluntary exposure to danger.$^{302}$ Clearly there can be no recovery where the assured attempts to cross a railway track between the cars of a train, either standing or in motion, by climbing over the drawheads and

track, but, reaching for his bag, was struck by the engine and killed. The court held that, as a matter of law, he was not guilty of roluntary exposure to unnecessary danger. There was no evidence to show that the assured, who was rather deaf, knew that a train was due, and he got off the track immediately upon being warned of his danger. In calculating that he could get his bag off the railroad track, he was mistaken, and this mistake cost his life.

801 The assured was struck by a train while crossing the tracks in a railroad yard in a city for the purpose of boarding a suburban train standing on one of the tracks, preparatory to being mored up to the station, some distance away. The assured, with some others, was in the habit of boarding the train at this point merely for the sake of convenience, and to save a walk to the station, to which there was a safe passage. Held, that the assured had been guilty of a voluntary exposure to unnecessary danger, and the right to recover on the policy was thereby defeated. Glass v. Masons' Fraternal Acc. Ass'n of America of New York (C. C.) 112 Fed. 495. See, also, Wilcox v. Central Acc. Ins. Co. of Pittsburg, $234 \mathrm{~Pa}$. 58, 82 Atl. 1093, supra.

302 Where the assured, after dark, attempted to walk across a railroad trestle, without any railing and built of ties ten inches apart, the insurance company was not liable on its policy. But to cross a trestle on a plank walk protected by a guard rail, which was generally used, would not of itself constitute such an exposure as would relleve an insurance company of liability. Follis v. United States Mut. Acc. Ass'n, 94 Iowa, 435, 62 N. W. 807,28 L. R. A. 78, 58 Am. St. Rep. 408.

The plaintiff was not permitted to recover on an accident policy where the assured was struck by a train, while running along the tracks in front of it in the nighttime, for the purpose of gettiug on a train approaching in an opposite direction on a parallel track. Tuttle v. Travelers' Ins. Co., 134 Mass. 175, 45 Am. Rep. 316. 
couplings, or across the platforms, or by crawling under the cars. ${ }^{303}$

In suits brought under this form of a contract the petition must state a cause of action within the general terms of the policy. The plaintiff need not allege or prove that the death or injury on which the action is based was not within the special exception exempting the insurance company. The insurance company in its answer, where the defense is that the assured voluntarily exposed himself to unnecessary danger, must state the facts upon which its contention is based. And an answer alleging facts which on their face suggest a voluntary exposure within the terms of the policy is sufficient. ${ }^{304}$ The answer must state facts, and not conclusions. An answer

303 In Willard v. Masonic Equitable Acc. Ass'n, 169 Mass. 288, 47 N. E. $1006,61 \mathrm{Am}$. St. Rep. 285 , a freight train standing still blocked the street. Although the train was in readiness to move, and the assured saw the engineer and brakeman in their accustomed places, he attempted to cross between the cars and was killed. The court declared that he had voluntarily exposed himself to unnecessary danger. See, also, Bean v. Employers' Liability Assur. Corp., 50 Mo. App. 459. In this case the assured, on his way to work, after waiting ten or fifteen minutes, undertook to pass between the cars of a freight train standing at a crossing, though he could have gone around. He made no effort to ascertain whether or not the engine was attached. The train started suddenly, and his foot was caught between the drawheads or couplings of two cars and crushed. Held, that no recovery could be had on the policy.

304 But an answer which alleges that the assured at the time of his death was in a daugerous place and engaged in a dangerous act, but which fails to allege that the assured knew of the dangers and voluntarily exposed himself thereto, is not sufficient on demurrer. Conboy v. Railway Officials' \& Employés' Acc. Ass'n, 17 Ind. App. 62,46 N. E. 363,60 Am. St. Rep. 154.

The answer must state facts, and not conclusions, else it is demurrable, as where an answer filed by a relief association alleged that the accident on which the suit was brought did not occur to the assured whlle in the performance of the duties of his employment, as required by the rules of the association, but resulted from his voluntarily and unnecessarily exposing himself to danger when off duty, and while seeking his own pleasure. To this answer a demurrer should be sustained. Voluntary Rellef Department of the

Fuller Acc.I Ns.-17 
which merely gives conclusions, but does not set forth the facts from which these conclusions are drawn, is demurrable. A defense, under the exemption clause in a policy containing a provision excusing the insurance company from liability for injuries resulting from a voluntary exposure to unnecessary danger, involves the entire right of recovery. An offer to confess judgment for a smaller sum than that demanded, or any offer, except by way of compromise, and saving the rights of parties, waives this defense. ${ }^{305}$

Following the general rule, where one who relies in defense upon an exception in the contract to relieve him of liability, the burden of proving that the death or injury was due to a voluntary exposure to unnecessary danger is on the insurance company. ${ }^{306}$

We have seen that what constitutes a voluntary exposure to unnecessary danger is largely a question of fact,-and as such should be left to the decision of the jury under the conditions

Pennsylvania Lines West of Pittsburg v. Spencer, 17 Ind. App. 123, 46 N. E. 477.

305 See Holiday v. American Mut. Acc. Ass'n of Oshkosh, 103 Iowa, 178, 72 N. W. 448,64 Am. St. Rep. 170, where it was held that an offer by the insurance company to confess judgment for a smaller sum, on the ground that insured's occupation was more hazardous at the time of the accident than that under which he was insured, operates as a waiver of a defense that the injury resulted from exposure to unnecessary danger. See, also, Wildey Casualty Co. v. Sheppard, 61 Kan. 351, 59 Pac. 651, 47 L. R. A. 650.

306 De Greayer v. Fidelity \& Casualty Co. of New York, 58 Pac. 390, 126 Cal. xvil, supra; Fidelity \& Casualty Co. v. Sittig, 181 Ill. 111, 54 N. E. 903,48 L. R. A. 359, supra; Follis v. United States Mut. Acc. Ass'n, 94 Iowa, 435, 62 N. W. 807, 28 L. R. A. 78, 58 Am. St. Rep. 408, supra; Garcelon v. Commercial Travelers' Eastern Acc. Ass'n, 195 Mass. 531, 81 N. E. 201, 10 L. R. A. (N. S.) 961; Badenfeld v. Massachusetts Mut. Acc. Ass'n, 154 Mass. 77, 27 N. E. 769, 13 L. R. A. 263, supra; Meadows v. Pacific Mut. Life Ins. Co., 129 Mo. 76, 31 S. W. 578, 50 Am. St. Rep. 427, supra; Hester v. Fidelity \& Casualty Co., 69 Mo. App. 186, supra; Jamison v. Continental Casualty Co., 104 Mo. App. 306, 78 S. W. 812 ; Price v. National Acc. Soc., 37 Pa. Super. Ct. 299 ; Bakalars v. Continental Cas- 
of each case. Where all men of unprejudiced and intelligent mind must agree from the evidence that a certain act constitutes such an exposure, or where the facts are not in dispute, then it becomes a question of law for the court. ${ }^{307}$

But where a number of men, without passion or prejudice and of equal intelligence, may differ, the question must be referred to the jury for their decision under proper instructions. $^{30 s}$ The assured has the further advantage, in an action

ualty Co., 141 Wis. 43,122 N. W. 721, 25 L. R. A. (N. S.) 1241, 18 Ann. Cas. 1123.

307 Morse v. Commercial Travelers' Eastern Acc. Ass'n, 212 Mass. $140,98 \mathrm{~N}$. E. 599. Here the assured, despite the warning of experienced guides and the fact that no others were out in boats, rentured out in a canoe, which was upset by a squall, and he was drowned. The court held that this constituted a voluntary exposure as a matter of law, and the beneficiary could not recover.

308 'Traders' \& Travelers' Acc. Co. v. Wagley, 74 Fed. '457, 20 C. C. A. 588, 45 U. S. App. 39, supra; Ashenfelter v. Employers' Liability Assur. Corp. of London, England, 87 Fed. 682, 31 C. C. A. 193, supra; National Life \& Accident Ins. Co. v. Lokey, 166 Ala. 174, 52 South. 45; Columbian Acc. Co. v. Sanford, 50 Ill. 'App. 424, supra; Payne v. Fraternal Acc. Ass'n of America, 119 Iowa, 342, 93 N. W. 361, supra; Powell v. Travelers' Protective Ass'n of America, 160 Mo. App. 571, 140 S. W. 939; Travelers' Ins. Co. v. Snowden, 45 Neb. 249, 63 N. W. 392; Pacific Mut. Life'Ins. Co. v. Adams, 27 Okl. 496, 112 Pac. 1026; Bakalars v. Continental Casualty Co., 141 Wis. 43, 122 N. W. 721, 25 L. R. A. (N. S.) 1241, 18 Ann. Cas. 1123.

See, also, Taylor v. Metropolitan Acc. Ass'n, 172 Ill. 511, 50 N. E. 115 , supra. Here the court held that where the policy insures against death or injuries produced by accidental means, but exempts the company from liability for death or injuries happening in consequence of disease or bodily infirmity, or as a result of voluntary exposure to unnecessary danger, an alternative finding of fact that the assured met his death in consequence of bodily infirmity or disease, or as a result of voluntary exposure to danger, is sufficient. to support a judgment for the insurance company.

Where on such a policy as herein discussed, in answer to interrogatories, the jury found that the insured was injured, while riding a bicycle against a heavy wind, by running into a wagon which he might have avoided if he had been looking ahead, and further found that he was unconscious of danger and did not knowingly or 'purposely assume the risk of striking the wagon, and that he did not 
on such a policy, in the presumption of law that he has used proper care for his safety. ${ }^{809}$

What Constitutes Due Diligence for One's Safety.-Policies of accident insurance frequently provide that the insurance company will not be liable for death or injuries resulting from the failure of the assured to use due diligence for his personal safety or protection. This clause, however, does not require the assured to use more than ordinary care, and imposes upon him no higher degree of diligence than prudent persons are accustomed habitually to use. Due diligence for safety is not inconsistent with mere inadvertence, or with assuming such risks as those to which prudent and cautious persons are in the habit of exposing themselves. The question upon which the issue turns is whether a man of ordinary prudence would have done the same thing under similar circumstances. ${ }^{310}$

voluntarily expose himself to unnecessary danger, the court held that these findings, as a whole, were not in irreconcilable conflict with the general verdict in the plaintiff's favor. Commercial Travelers' Mut. Acc. Ass'n v. Springsteen, 23 Ind. App. 657, 55 N. E. 973. Continental Casualty Co. v. Jennings, 45 Tex. Civ. App. 14, 99 S. W. 423, where it was for the jury to determine whether a death by falling from a tree while gathering pecans was the result of voluntary exposure to unnecessary and obvious danger.

300 See Meadows v. Pacific Mut. Life Ins. Co., 129 Mo. 76, 31 S. W. 578, 50 Am. St. Rep. 427, supra, where the court said: "The law presumes, in the absence of evidence to the contrary, that the deceased was in the exercise of due care."

310 Where the assured, in crossing rallroad tracks, became confused by the cries of warning from different directions and walked in front of a 'train, the court held that it was not, as a matter of law, a failure to use due diligence. Duncan v. Preferred Mut. Acc. Ass'n (Super. N. Y.) 13 N. Y. Supp. 620. Nor is boarding a train, which suddenly started from the depot, while it was moving slowly, a fallure to use due diligence, if men of ordinary prudence would have done the same thing under the circumstances. Tooley $\nabla$. Rallway Passenger's' Assur. Co., led. Cas. No. 14,098. So, where the assured, 'while hunting, sat down on a rail fence with a double-barreled shotgun in his hands, with one or both hammers cocked, when 
Grave danger or a sudden emergency would excuse an act which might otherwise amount to a failure to use due diligence. But assuming a risk, such as crossing a railroad track before an approaching train, merely to avoid the inconvenience of delay or possible injury to business resulting therefrom, will not excuse an act which is in itself a failure to use due diligence, and in such a case the insurance company will not be liable. Under such a policy it is proper to consider the circumstances under which the act is performed, the place where it occurs, the position of the party, his age, his activity, his experience, and all other circumstances which would be considered in determining whether an ordinarily prudent person would, under similar circumstances, attempt the same thing. ${ }^{311}$

If the occupation of the assured is one involving danger and exposure to particular hazards, he is required to exercise only such care as is customarily exercised among reasonably prudent and careful persons engaged in the same calling. He has a right to incur all the risk and danger incident to his employment in the manner customary among generally prudent men employed in the same line of work, and such risks, no matter how great they are, do not constitute a violation of the provision of the policy requiring the assured to use due diligence for his personal safety and protection. ${ }^{312}$

a rail turned and he fell off, and the gun was discharged, injuring him, the question was for the jury to determine whether a prudent and cautious person would have carried his gun and acted as did the assured. Kentucky Life \& Accident Ins. Co. v. Franklin, 102 Ky. 512, $43 \cdot$ S. W. 709.

311 Travelers' Protective Ass'n v. Small, 115 Ga. 455, 41 S. E. 628.

312 Pacific Mut. Life Ins. Co. v. Snowden, 58 Fed. 342, 7 C. C. A. 264. Here the assured was a cattle dealer, tending cattle in transit. The train stopping, he went forward from the caboose to raise one of his steers, which had fallen, when the engineer suddenly gave 
The general rule of law undoubtedly is that a party is not entitled to compensation for an injury to which his own negligence or want of proper care has been a contributing cause. The contract of insurance, however, forms a distinct exception to this rule. A policy of insurance is expressly a contract of indemnity, and the manifest object which the assured has in view in effecting an insurance is protection against casualties arising from his own inadvertence and lack of care. In personal injury cases, where the foundation of the action is an injury caused by the negligence of the defendant, to show contributing negligence on the part of the plaintiff is a proper defense. But in insurance liability is created by a contract, one of the chief objects of which is to protect the assured against his own carelessness or negligence. Therefore, in the absence of an express condition excepting the insurance company from liability for injuries due to voluntary exposure to danger, or to failure to use due diligence, even extreme negligence or carelessness on the part of the assured will not defeat a recovery for injuries received in consequence thereof. A large. percentage of the events which are universally called accidents in fact happen through some carelessness of the party injured which contributes to produce them. ${ }^{313}$

the signals, "Off brakes!" and the assured climbed up on one of the cattle cars, but was thrown off and injured by the bumping of a "helping engine." It was a question for the jury to determine whether the assured acted as would a reasonably prudent cattle dealer under like circumstances, and the plaintiff may show what the common practice is among cattle dealers. In Standard Life \& Accident Ins. Co. v. Jones, 94 Ala. 434, 10 South. 530, where the assured was a switchman, the insurance company pleaded a failure to use due diligence, in that he contributed directly to his own injury by getting off an engine in motion in the nighttime with his back toward the direction in which it was golng.

318 Providence Life Ins. \& Inv. Co. of Chicago v. Martin, 32 Md. 310 , where the assured, a railroad engineer, while running down a 
Therefore rules defining contributory negligence, which will defeat a recovery for personal injuries caused by the negligence of the claimant, have no application to actions upon accident insurance policies. The liability upon such policies depends upon the contractual relation, and the negligence of the assured is no defense, unless it is expressly made so. ${ }^{314}$

As in the case of most exceptions to the liability of the insurance company, the burden is on the insurer to show that the assured did not use due diligence for his personal

grade, climbed over the tender to set the brakes on a car, and, slipping, fell and was killed. The court said: "The observance of due care and diligence on the part of the assured is no element of the contract on his part, and can in no way affect the right of action thereon." In Wilson v. Northwestern Mut. Acc. Ass'n, 53 Minn. 470 , $55 \mathrm{~N}$. W. 626 , the assured, a mason, was engaged in pointing walls, and was working on a scaftold suspended on an eight-story building, when one of the supporting ropes broke, throwing the assured to the ground. The court declared that it was not a good defense that the accident might have been caused by the mere carelessness or negligence of the assured. And so the company is liable where the assured attempted to jump on a moving omnibus, but was thrown from the step by the jarring of the vehicle. Champlin v. Railway Passengers' Assur. Co., 6 Lans. (N. Y.) 71. See, also, North American Acc. Ins. Co. v. Gulick, 25 Ohio Cir. Ct. R. 395, where the court said: "The guaranty against injuries or death by the insurance company by its policy must mean more than indemnity against accidents other than those occasioned by the want of ordinary care upon the part of the assured, or there would be no use for such policies." In Aitna Life Ins. Co. v. Hiclis, 23 Tex. Civ. App. 74, 56 S. W. 87, the assured, while sick, was traveling against the orders of his doctor; but the accident was in no way a result of his exposure, but was one which might have happened to any one, even in good health. Schneider $\nabla$. Provident Life Ins. Co., 24 Wis. 28, 1 Am. Rep. 157, where the assured was killed while attempting to board a slowly moving train. This question is treated more at length under the condition exempting the company from liability for injuries resulting from Voluntary Exposure to Unnecessary Danger, page 220.

314 Riding upon the platform of a rapidly moving railroad car, though there may be no necessity therefor, is not in itself, and as a matter of law, a failure to use due diligence, but presents a ques- 
safety, as required by the policy. ${ }^{315}$ Whether the assured exercised due care for his own safety and protection, as required by the policy, is for the jury to determine, and the law presumes, in the absence of evidence to the contrary, that the deceased was in the exercise of proper care. ${ }^{\mathbf{1 1 6}}$

tion of fact, to be determined by the jury under all the evidence. Travelers' Ins. Co. v. Randolph, 78 Fed. 754, 24 C. C. A. 305.

315 Badenfeld $\nabla$. Massachusetts Mut. Acc. Ass'n, 154 Mass. 77, 27 N. E. 769,13 L. R. A. 263 ; Freeman v. Travelers' Ins. Co., 144 Mass. 572, 12 N. E. 372 ; Meadows v. Pacific Mut. Life Ins. Co., 129 Mo. 76, 31 S. W. 578, 50 Am. St. Rep. 427; Mulville v. Pacific Mut. Life Ins. Co., 19 Mont. 95, 47 Pac. 650.

316 Standard Life \& Accident Ins. Co. v. Langston, 60 Ark. 381, $30 \mathrm{~S}$. W. 427 , where the assured sat down on the end of a railroad tie dangerously near one of the other tracks and fell asleep, and his arm was crushed by a passing train. United States Casualty Co. v. Hanson, 20 Colo. App. 393, 79 Pac. 176, where the court held that failure to exercise due care was not shown as a matter of law where the assured, after having been advised of his condition bj one physician, failed to follow the treatment suggested, but was examined and followed the treatment of other physicians of presumed standing and ability. Tinsman v. Illinois Commercial Men's Ass'n, 255 Ill. 635, 85 N. E. 913, affirming Illinois Commercial Men's Ass'n v. Tinsman, 139 Ill. App. 307. Here the assured was camping by a river near Reno, Nev. When too high to be forded, the river was crossed by a troiley ferry, attached to a suspended cable. The river on the day in question was rising rapidly and was at flood stage, though some boys had crossed in safety a few hours before, despite the swift current. The assured, with others, started to cross on the ferry; but when it reached midstream the car was struck by the swift current and dashed to pieces, the policy hoider and his companions being drowned. The court said: "The measure of prudence is not necessarily what an ordinarily prudent person would do. That cannot always be told. Different persons may adopt different courses of action under like circumstances, and yet all act with due diligence for their self-protection. Whatever a person in the exercise of reasonable care might do is within the limits of due diligence." Payne v. Fraternal Acc. Ass'n of America, 119 Iowa, 342, 93 N. W. 361 , where the assured was killed by a train while crossing a rallroad track at a regular crossing. Sutherland v. Standard Life \& Accident Ins. Co., 87 Iowa, 505, 54 N. W. 453, where the assured at the time of the accident was riding on the platform of a moving street car. Where the assured carelessly put his arm out of the window of a car while the train was moving with its usual speed, 
Blood Poison or Septicæmia.-Many companies have of late inserted in their policies of accident insurance a condition exempting themselves from liability for death or disability resulting from "blood poison or septicæmia." The rule adopted by the courts in construing this exception is

without the slightest necessity for doing so, and his hand was badly injured by striking a post near the track, there was a failure to use due diligence, and the company was not liable. Morel v. Mississippi Valley Life Ins. Co., 4 Bush. (Ky.) 535.

Kentucky Life \& Accident Ins. Co. v. Franklin, $102 \mathrm{Ky} .512,43$ S. W. 709. Badenfeld v. Massachusetts Mut. Acc. Ass'n, 154 Mass. 77, 27 N. E. 769,13 L. R. A. 263 , where the assured apparently was killed while waiting for a train and casually examining the girders and other structure of the depot. Freeman v. Travelers' Ins. Co., 144 Mass. 572,12 N. E. 372, where the assured was killed while cleaning snow from a railroad track in the course of his employment. Keene v. New England Mut. Acc. Ass'n, 161 Mass. 149, 36 N. E. 891 , where insured, carrying an umbrella which obstructed his view, crossed a railroad track and was killed by a freight car, which was being shunted along a track by a switch engine. Tuttle v. Travellers' Ins. Co., 134 Mass. 175, 45 Am. Rep. 316, where no recovery could be had for the death of the assured, which was caused by his being struck by a railroad train while running along the track in front of it, in the nighttime, for the purpose of boarding a train approaching in an opposite direction on a parallel track.

Robinson v. United States Benev. Soc., 132 Mich. 695, 94 N. W. 211. $102 \mathrm{Am}$. St. Rep. 436. Here the assured, a passenger on a vestibuled train, whlle passing from his sleeping car to the diner, was thrown from the train while it was running at full speed; it being shown that the night was extremely warm and dark and that the vestibuled doors were left open. Meadows v. Pacific Mut. Life Ins. Co., 129 Mo. 76, 31 S. W. 578, 50 Am. St. Rep. 427. The presumption that due care has been used is not rebutted by the unexplained fact, for instance, that the assured was found injured on a railroad track. The assured, being a horse buyer, and wishing to get home, late at night had started down the railroad yards to board a freight. His body was later found cut in two, and there was no direct evidence to show how he was killed.

Stone's Adm'rs v. United States Casuaity Co., 34 N. J. Law; 371, where the assured, classified as a teacher, while inspecting a house which he was having constructed, trod upon a joist, which broke from a hidden defect, and he was killed in falling to the ground. Duncan v. Preferred Mut. Acc. Ass'n (Super. N. Y.) 13 N. Y. Supp. 620 , judgment affirmed in 129 N. Y. 622, 29 N. E. 1029. North Ameri- 
that if the septicæmia is the effect of the accident, so as to be a mere link in the chain of causation between the accident and death, then the death must be attributed to the accident alone, and not to the septicæmia, and the company will not be exempt. ${ }^{317}$ But the company will not be liable under this exception for death caused by septicæmia which

can Life \& Accident Ins. Co. v. Burroughs, 69 Pa. 43, 8 Am. Rep. 212, where it was held that the death of the assured as the result of an accidental injury or strain, by being struck by the handle of a pitchfork while throwing hay, did not show unreasonable imprudence or a failure to use due care.

317 Central Acc. Ins. Co. v. Rembe, 220 Ill. 151, 77 N. E. 123, 5 L. R. A. (N. S.) 933,110 Am. St. Rep. 235,5 Ann. Cas. 155 , affirming 122 Ill. App. 507, where the assured, a physician, in treating a patient suffering from virulent blood poisoning, cut his finger on a bottle and blood poison ensued. The company was held liable. United States Health \& Accident Ins. Co. v. Harvey, 129 Ill. App. 104. Here the assured accidentally punctured his hand with a piece of wire and acute septicrmia developed. The court said: "The puncture by the wire or nail was within the terms of the policy, and blood poisoning, resulting from and being caused by the accident, was a disease caused by the accidental wound, and is within the policy." Garvey v. Phœnix Preferred Acc. Ins. Co., 123 App. Div. 106,108 N. Y. Supp. 186. Here the contract limited the liability of the insurer to one-tenth of the face of the policy for injuries or disabilities resulting directly or indirectly from poison or infection. The court held that this limitation did not apply to a case where blood poisoning developed in a wound accidentally received, and said: "The original disability was within the terms of the policy, and whatever, naturally and in the ordinary course of events, followed the injury was fairly within the scope of the policy. The injury * * * or disability' referred to in the clause quoted relate to the time of the accident. They did not 'result' from the poison or infection, if such existed, but the latter resulted from the injuries. The company was not expecting by this provision to be exempted from liability for what might occur in the progress toward recovering from the wound, or what might normally arrest its improvement. Conditions which inevitably or ordinarily are the effect of a disability covered by the policy are also within its compass; otherwise, the contract is a sham." Rheinheimer v. Etna Life Ins. Co., 77 Ohio St. 360,83 N. E. 491,15 L. R. A. (N. S.) 245 , where the assured injured his finger and died from blood poisoning, which ensued. Farner v. Massachusetts Mut. Acc. Ass'n, 219 Pa. 71, 67 Atl. 927, 123 Am. St. Rep. 621, where the assured died from blood poisoning 
develops in a wound caused by an operation for a disease, since the wound is not of accidental origin. ${ }^{318}$

Many of these policies expressly impose upon the insurer a liability for blood poison introduced into the system through "wounds" suffered by surgeons or doctors in their professional operations. ${ }^{319}$ Under this clause, however, it

which developed in a wound caused by the bite of a dog. The court said: "Suppose the insured had been accidentally shot, and, as a result of the accident, suffered with blood poisoning from the bullet recelved into his body and died. It would hardly be said to be a case of contact with poison, or with a poisonous or infectious substance, in the ordinary acceptation of the term. We can see no real distinction between such a case and the one at bar." Jones v. Pennsylvania Casualty Co., 140 N. C. 262, 52 S. E. 578, 5 L. R. A. (N. S.) 932, 111 Am. St. Rep. 843, where assured scratched his hand and blood poisoning developed. A peculiar case is presented in Schumacher v. Great Eastern Casualty \& Indemnity Co., 197 N. Y. Rep. 58, 90 N. E. 353,27 L. R. A. (N. S.) 480, affirming 132 App. Div. 929 , where under the phraseology of the policy the insurance company was held liable for septicæmia, though it did not result in any way from external, violent, or accidental means. See, also, Vernon v. Iowa State Traveling Men's Ass'n (Iowa) 138 N. W. 696; Continental Casualty Co. v. Mathis, $150 \mathrm{Ky} .477,150$ S. W. 507.

318 Herdic v. Maryland Casualty Co. (C. C.) 146 Fed. 396, affirmed by 149 Fed. 198,79 C. C. A. 156. Here the policy was so worded as to include liability for septicæmia resulting from an accident. The assured died of septicæmia after a surgical operation for appendicitis, and the court held there was no liability on the part of the insurer.

319 Central Acc. Ins. Co. v. Rembe, 220 Ill. 151, 77 N. E. 123, 5 L. R. A. (N. S.) 933, 110 Am. St. Rep. 235, 5 Ann. Cas 155, affirming 122 Ill. App. 507, supra, where the assured, a doctor, cut his finger on a bottle while treating a syphilitic patient, and blood poison developed. The policy extended the insurance to "septic wounds, caused by accident while performing any operation pertaining to the business of the assured, the poison matter being injected into the wound at the time of the accident." The court said: "Suppose the insured had cut his finger by accident while preparing instruments with which to perform a surgical operation, or if, after the operation, in disinfecting the instruments used, he had accidentally wounded himself, and blood poisoning had in either case intervened; would it be claimed there was no right of recovery under the conditions of this policy? We hardly think it would be seriously 
is essential to a recovery that the infection be introduced into the system through a wound, and the insurer will not be liable where the infection enters the system through the mucous membrane, as of the mouth, throat, nose, or eye. ${ }^{320}$

Intentional Injuries.-In the absence of any provision to the contrary in a policy insuring against death or injury effected through "external, violent, and accidental means," an injury inflicted intentionally by another upon the assured, but without the foreknowledge or connivance of the assured, is within the terms of the policy rendering the company liable. If the injury is not brought about by the agency of the assured, and if it is not anticipated by him, it is none the less accidental as far as he is concerned, although it may be inflicted with malice and premeditation by the other party. While,

contended. The clause is 'caused by accident while-performing any operation pertaining to the business of the assured.' His business was both that of surgeon and physician. His treatment of the patient was a continuing service, and should not be limited to any particular act in such treatment. The preparation of medicine to be taken intexnally at the very time the patient was in his office, or subsequently, according to the directions, was, we think, administering treatment pertaining to the business of the insured within the meaning of this clause of the policy."

320 Fidelity \& Casualty Co. of New York v. Thompson, 154 Fed. 484, 83 C. C. A. 324, 11 L. R. A. (N. S.) 1069, 12 Ann. Cas. 181 . Here the assured was an operating dentist, and was working on a patient, who suddenly coughed, and particles of septic matter from his mouth were thrown against the mucous membrane of plaintiff's eye. Without abrading or penetrating the membrane, the septic matter infected the eye and caused blood poisoning. The court said: "Without doubt, it is essential to a right of recovery under the provision relating to blood polsoning that the septic matter should have been introduced into the system through a wound. * * * So far as is disclosed by the evidence, the immediate mechanical effect of the particles blown into the plaintiff's eye was not different from what it would have been if they had consisted of so much pure ralnwater; they did not wound it, but infected it from the exterior, operating in like manner as do some other species of infecting matter, when they come in contact with the unbroken skin or mucous membranes of other parts of the body." 
strictly speaking, an intentional killing may appear not to be a death by accidental means, yet the death is clearly accidental as far as the assured is concerned, for it happens without his design or procurement. ${ }^{\mathbf{2 1}}$

To absolve themselves from liability for death or injuries inflicted intentionally-such, for example, as assaults, murders, attacks by robbers, etc.-a clause is frequently inserted in policies of accident insurance, specifying that the policy shall not cover death or disability due to injuries intentionally inflicted by the assured or other persons. This condition, however, may be waived by the insurance company either personally or through general agents, who have authority to receive and pass upon applications for insurance and complete contracts without referring them to the company. ${ }^{\mathbf{2 2}}$

But where a policy contracts to indemnify the insured

821 Accident Ins. Co. v. Bennett, 90 Tenn. 256, 16 S. W. 723, 25 Am. St. Rep. 685 ; Campbell v. Fidelity \& Casualty Co. of New York, 109 Ky. 661, 60 S. W. 492 ; Hutchcraft's Ex'r v. Travelers' Ins. Co., 87 Ky. 300, 8 S. W. 570, 10 Ky. Law Rep. 260, 12 Am. St. Rep. 484. An interesting case is that of Fidelity \& Casuaity Co. v. Johnson, 72 Miss. 333, 17 South. 2, 30 L. R. A. 206, where the assured was hanged by a mob. The court held that he met his death through "external, violent, and accidental means," and that the insurance company was liable, in the absence of a clause exempting it in the event of injuries intentionally inflicted upon the policy holder by others."

322 One $H$. applied to the general agents of an insurance company for a policy, informing them that he was in danger of being attacked and killed, and desired a policy which would protect his family in that event. The agents assured him that the policy would be good in such a case. The policy issued, which was received and accepted by $H$. without reading, contained a condition to the effect that it would not be good if the assured came to his death by intentional injuries inflicted by another person. No fraudulent intent was shown on the part of the agent. On a suit to reform the policy, it was held that the condition as to death by intentional injury was not waived, the assured having had ample opportunity to examine the contract offered before accepting it, and no fraud being proven. Travelers' Ins. Co. v. Henderson, 69 Fed. 762, 16 C. C. A. 390, reversing Henderson v. Travelers' Ins. Co. (C. C.) 65 Fed. 438. 
against death or injury by external means leaving a visible mark on the body, and a later and wholly independent paragraph contracts to pay a certain lesser sum for an injury causing death, which shall result from the intentional acts of others than the assured, the exception as to intentional injuries applies only to such injuries as leave no visible mark, but does not include injuries leaving visible marks. ${ }^{328}$ Here the principle of "noscitur a sociis" is adhered to. Similarly, where a policy insures against death or injury by external, violent, and accidental means, and also contains a provision that it shall not "extend to or cover intentional injuries inflicted by the insured or any other person," the exception as to intentional injuries refers only to those which are non-fatal. The omission of the word "death" in this exception, where in all other conditions of the policy the phrase "injury or death" is used, explains this ruling. ${ }^{324}$

Where the assured is engaged in a hazardous occupation, the dangers of which are matters of public knowledge, and as a result of which he pays a higher rate of premium, the fact that by reason of his occupation he is peculiarly liable to intentional injuries does not avoid the condition or render the company liable upon such a policy. ${ }^{32 r}$

323 Stephens v. Railway Officials' \& Employés' Acc. Ass'n, 75 Miss. 84, 21 South. 710.

324 American Acc. Co. of Louisville v. Carson, $99 \mathrm{Ky} .441,36 \mathrm{~S}$. W. 169, 34 L. R. A. 301, 59 Am. St. Rep. 473.

325 Where the deceased was a policeman, and was intentionally shot by a person whom he was attempting to arrest in the performance of his duty, even though his occupation was cleariy stated on the face of the application and policy, and he paid a higher rate of premium by virtue of such occupation, in the absence of fraud, the company is not liable. Grimes v. Fidelity \& Casualty Co., 33 Tex. Civ. App. 275, $76 \mathrm{~S}$. W. 811 . And where the plaintiff was insured as a constable and paid a higher rate therefor, the company was not liable for injuries received when he was assaulted by a person on whom he was serving a writ. Miiler v. Interstate Casualty Co. of New York, 17 Pa. Super. Ct. 360. 
Injuries inflicted by the assured on himself, when done intentionally, are clearly within the exception relieving the company from liability. To determine whether an injury is inflicted intentionally by the assured or otherwise, it is proper to show his financial condition, the circumstances under which the policy was applied for and issued, together with the declarations, acts, and conduct of the assured prior thereto, as tending to establish, at least circumstantially, the motive. ${ }^{328}$

Any evidence tending to show that the injury was intentional, or which constitutes a link in the chain of proof necessary to establish that fact, is admissible. ${ }^{327}$

326 In Long v. Travelers' Ins. Co., 113 Iowa, 259, 85 N. W. 24, the assured, while on a hunting trip, injured his foot by the explosion of his gun. The court permitted the introduction of evidence tending to show that the assured had been talking about this seemingly unimportant hunting trip for weeks previous to the injury; that he only went two miles into the country; that he had spoken frequently of the indemnity procurable from accident insurance in the erent of the loss of a hand or foot in hunting and had suggested "smoothness" on the part of others injured and indemnified; that he had mentioned a presentiment that something was going to happen to him on this trip, and that he had dreamed of the loss of his foot; that he had declared his intention of loading up on that day with insurance as a convenient thing to fall back upon; and that in obtaining some of the policies he had inquired as to what portion of the foot must be removed in order to entitle him to indemnity. And to establish motive it was held proper to introduce evidence tending to show his situation in life, and not only his insolvency, but that his creditors were demanding a liquidation of their claims; that the premium notes were forged as to their suretyship to secure the payment of the premium on a policy of $\$ 10,000$, and that within an hour before starting on his trip he procured eight insurance tickets of $\$ 3,000$, all of which either contained, or he supposed them to contain, clauses providing heavy indemnity for the loss of a foot. All of these facts were of value in assisting the jury to determine whether the injury was self-inflicted or not.

327 It is proper to show that the assured at the time of securing the policy was financially embarrassed; that in conversation with a friend he remarked, "I have been damned hard up, but I am going to make a stake;" that, upon being asked, "How?" he repled, "What did I take out three insurance policies for?" that the witness then asked, "You are not going to have an accident, are you?" 
A voluntary approach to an unknown danger, or the intentional performance of some act which causes an injury, where the result of the act is unpremeditated and unforeseen, does not constitute an intentional injury within the meaning of this clause in a policy of accident insurance..$^{328}$

to which the assured replied, "You just wait and see; I have been hard up long enough, and I am going to get in a position shortly where I will have what money I need." Where the injury consisted of his hand being crushed so as to require amputation by being run over by a train, it was proper to show that the assured had conferred with a doctor regarding injuries to the hand and foot; that he had inquired how and where to ligate to stop the flow of blood in case a hand or foot was crushed in being run over; that the assured had inquired as to the percentage of mortality from such injuries; and that he had manifested a close interest in the replies of the doctor to these and similar questions. Etna Life Ins. Co. v. Vandecar, 86 Fed. 282,30 C. C. A. 48 . On a demurrer the allegation that the assured fell asleep from weariness and the motion of the cars, and while in a dazed and unconscious condition of mind, and not knowing or realizing what he was doing, involuntarily arose from his seat and walked unconsciously to the platform of the car, and, without fault on his part, fell therefrom to the ground and was thereby injured, sufficiently negatires the condition that the injury was inflicted by design. Scheiderer $\nabla$. Travelers' Ins. Co., 58 Wis. 13, 16 N. W. 47, 46 Am. Rep. 618.

328 Where one approaches a moving train on a legitimate errand, stumbles and falls, and is thereby thrown agalnst the steam chest of the engine and injured, such injury is clearly not intentional. Equitable Acc. Ins. Co. v. Osborn, 90 Ala. 201, 9 South. 869, 13 L. R. A. 267. Where one jumped on a train, and while the train was moving slowly attempted to pass from one car to another, and was thrown from the train and injured, the accident or injury was not one of design. Travelers' Preferred Acc. Ass'n v. Stone, 50 Ill. App. 222. The case of Pollock v. United States Mut. Accident Ass'n, $102 \mathrm{~Pa}$. 230, $48 \mathrm{Am}$. Rep. 204, however, holds that, if the act which caused the injury was intentional, it would fall within the exception, although the result of the act was unforeseen. Here the assured intentionally drank a glass of poisonous liquid, mistaking it for a harmless beverage. The case, however, really turned on the question of drinking poison; the policy not containing a clause exempting the company for injuries intentionally inflicted. The Pollock Case in this respect is against the clear weight of authority, and has been expressly repudiated in several well considered decisions. 
It is clearly established by the overwhelming weight of authority that an injury intentionally inflicted upon the assured by another is accidental, if it is unintentional on the part of the assured..$^{228}$ Where the exempting clause in a policy merely provides that the company will not be liable for "intentional injuries," the word "intentional" refers to the insured alone. And in such a case the company will be liable for injuries inflicted upon the assured by a third party, no matter how wanton and deliberate the assault may be, provided the injuries were not produced or hastened or invited with the intention and consent of the assured. ${ }^{330}$

Where a policy expressly provides that the company will not be liable for injuries intentionally inflicted either by the insured or any other person, it is not necessary that the insured should participate in the intent of such third persons, in order to render the exception operative and relieve the company from its liability. And this is true in spite of the fact that the injury may be wholly accidental as to the assured; that is, may be wholly unexpected by him. ${ }^{831}$

329 Cooke, Life Ins. \& 50. See, also, Fidelity \& Casualty Co. v. Johnson, 72 Miss. 333, 17 South. 2, 30 L. R. A. 206, supra.

330 Under such a clause the insurance company will be liable where an unknown party deliberately shoots the assured. Button v. American Mut. Acc. Ass'n, 92 Wis. 83, 65 N. W. 861, 53 Am. St. Rep. 900.

331 Where the assured, in the night and without intent or provocation on his part, was feloniously assaulted and robbed in his store, and the robbers beat him and cut off one of his hands, it was held that the insurance company was not liable, on a policy exempting it in the case of "intentional injuries inflicted by the insured or any other person." De Graw v. National Acc. Soc., 51 Hun, 142, 4 N. Y. Supp. 912 ; Orr v. Travelers' Ins. Co., 120 Ala. 647, 24 South. 997; Travelers' Ins. Co. v. McCarthy, 15 Colo. 351, 25 Pac. 713, 11 L. R. A. 297, 22 Am. St. Rep. 410; Fischer v. Travelers' Ins. Co., 77 Cal. 246, 19 Pac. 425, 1 L. R. A. 572; Butero v. Travelers' Acc. Ins. Co., 96 Wis. 536, 71 N. W. 811, 65 Am. St. Rep. 61.

See, also, Washington v. Union Casualty \& Surety Co., 115 Mo. App. 627,91 S. W. 988 . Here the assured became engaged in an

Fuller Acc.Ins. -18 
The policy becomes, not a contract of general indemnity, but one of limited indemnity, insuring only against a specified class of accidental injuries, from which an injury intentionally inflicted by the insured or any other person is excluded. Naturally under such a clause the insurance company is exempted from liability where the assured is murdered, regardless of the motive which may have inspired the murder. And it makes no difference whether the assured is shot during a brawl in which he intentionally engages, or whether the murder is entirely without provocation. ${ }^{332}$

altercation, in which the other party threw a brick, injuring him on the arm. The company was not held liable.

332 Where the assured had been placed under arrest by officers of the law and disarmed, and while in custody of the officers he was shot and killed by third persons, the case comes within this exception. And the proximate cause of his death was the shot fired by the third parties, and not the alleged negligence of the officers in failing to protect him. Jarnagin v. Travelers' Protective Ass'n. of America, 133 Fed. 892,66 C. C. A. 622 , 68 L. R. A. 499 . Where, as a result of a conspiracy, H. secured B. to shoot the assured while she was riding in a buggy, in order that $\mathrm{H}$. might secure the insurance on the life of the assured, and in line with the plot B. shot the assured from behind while she was riding in a buggy, and then threw her out upon the frozen ground, it was clearly a deliberate assassination; for which the insurance company is not liable. Ging v. Travelers' Ins. Co., 74 Minn. 505, 77 N. W. 291.

In another case the assured came home late at night, knocked at his door, and called to his wife, who was in the room, for admittance. One S., who was in the room with the wife, drew his pistol when the assured knocked, boited the door, and threatened to shoot the woman if she opened it. Assured, after failing to gain admittance, went out into the yard near a window of the room, when $S$. fired through the window, jumped from it, and ran off, the shot killing the assured. Here the company was not liable, since from the evidence S. had, to all appearances, intentionally and dellberately shot the assured. Orr v. Travelers' Ins. Co., 120 Ala. 647, 24 South. 997. Where the assured was lured to a different city, and then into a meeting. where he was attacked, as the result of a concerted arrangement to assassinate $\mathrm{hlm}$, the insurance company was not liable for injuries which he thus received. Phelan v. Travelers' Ins. Co., $38 \mathrm{Mo}$. App. 640. So where the assured, while on a drunken spree with a woman in a house of prostitution, insults a man, who in turn 
Some policies provide that, where death or injuries result from the intentional act of the assured or any other person, the amount payable shall be less than that for which the company shall be otherwise liable under the policy. ${ }^{333}$

But an exception in an accident policy of "intentional injuries inflicted by the insured or any other person" does not include injuries inflicted by an insane person without capacity to form an intention to inflict injuries or to understand the nature and quality of his acts. The term "intentional" implies consciousness and volition, the exercise of the reasoning faculties. But when a man's mental faculties are so far impaired that he is unable to understand the moral character or the general nature and consequences of his act, or is incapable of distinguishing between right and wrong, or of form-

deliberately shoots him, the beneficiary cannot recover on the policy. Railway Officials' \& Employés' Acc. Ass'n v. McCabe, 61 Ill. App. 565. See, also, Travelers' Ins. Co. v. McConkey, 127 U. S. 661, 8 Sup. Ct. 1360, 32 L. Ed. 308; Brown v. United States Casualty Co. (C. C.) 88 Fed. 38; 'Travelers' Protective Ass'n of America v. Langholz, 86 Fed. 60, 29 C. C. A. 628; Fischer v. Travelers' Ins. Co., 77 Cal. 246, 19 Pac. 425, 1 L. R. A. 572 ; Travelers' Ins. Co. V. McCarthy, 15 Colo. 351, 25 Pac. 713, 11 L. R. A. 297, 22 Am. St. Rep. 410; Hutchcraft's Ex'r v. Travelers' Ins. Co., 87 Ky. 300, 8 S. W. 570, $10 \mathrm{Ky}$. Law Rep. 260, 12 Am. St. Rep. 484; Johnson v. Travelers' Ins. Co., 15 Tex. Civ. App. 314, 39 S. W. 972 ; Butero v. Travelers' Acc. Ins. Co., 96 Wis. 536, 71 N. W. 811, 65 Am. St. Rep. 61.

33 Continental Casualty Co. v. Morris, 46 Tex. Civ. App. 394, 102 S. W. 773 , where the policy provided that, where the injury to the assured results from his own intentional act or that of any other person, the amount payable should be but one-tenth of that otherwise payable under the policy. The assured was wantonly and deliberately shot and killed by another man without provocation. The beneficiary was permitted to recover only one-tenth of the face of the policy. Weidner v. Standard Life \& Accident Ins. Co., 132 Wis. $624,113 \mathrm{~N}$. W. 50. Here the policy provided that an accidental loss. should be limited to one-tenth of the face of the policy in the event the injurles were intentionally inflicted on the assured by another, except in case of assault for the purpose of robbery. The court held that the word "robbery" should be construed in its ordinary sense. 
ing a rational intent, his acts cannot be said to be "intentional." 834 But the insanity which will render the act unintentional, and stamp it as accidental within the terms of such a policy, must be such a mental derangement as deprives the person committing the act of sufficient mental capacity to understand its nature and the consequences which will logically follow from it. A mere temporary burst of anger, or an irresistible impulse, is not such a mental impairment as will remove the death or injury from the operation of this clause.

Of a similar nature are acts committed by a man while intoxicated or under the influence of liquor. While intoxication is not an excuse for a crime in the eyes of the law, still it may so far control the question of intent as to constitute a material element in the determination of a crime. But the drunkenness of a person inflicting an injury upon another will not render the exception inoperative, unless he is so intoxicated as to not appreciate the nature and consequences of his act, or not to be capable mentally of forming a rational intention. The question of whether the person inflicting the injury is so drunk as to be incapable of forming such a rational intent is a matter of fact for the jury to determine. And the burden of proof of such drunkenness is on the claimant, after the defendant company shall have offered the defense that the injury sued upon was intentionally inflicted. ${ }^{\mathbf{3 3 5}}$

884 Berger v. Pacific Mut. Life Ins. Co. of California (C. C.) 88 Fed. 241; Corley v. Travelers' Protective Ass'n, 105 Fed. 854, 46 C. C. A. 278; Marceau v. Travelers' Ins. Co., 101 Cal. 338, 35 Pac. 856, rehearing denied 36 Pac. 813.

836 Travelers' Ins. Co. v. Houston, 3 Willson, Civ. Cas. Ot. App. (Tex.) $\& 429$, where the person who committed the assault is shown by the evidence to have known what he was doing up until the time he committed the assault, and it is also shown that immediately thereafter he washed the blood from his face and remarked that he did not want it known how the blood got there, he is clearly so rational that the act could not have been unintentional within the meaning of the pollcy. Northwestern Benev. Soc. v. Dudley, 27 Ind. App. 327. 61 N. E. 207. 
In order to exempt the insurance company from liability, it must be shown that the injury inflicted is actually intended by the assailant, or that it is the logical result of a deliberate act committed by the assailant.

In the leading case of Utter v. Travelers' Ins. Co., the court said: "If a person should draw a pistol in a crowded street, and deliberately fire the same, with the intent of killing some one, or with a reckless disregard of human life, and a person was killed or wounded, would such killing or wounding be an accident, or would it be by the design referred to therein? There would undoubtedly be a design to kill or wound some one, but no design to kill or wound the particular person injured. Suppose that, for the purpose of plunder, persons arrange to throw a passenger train off a railroad track, knowing that such act is liable to kill or injure some one, but having no malice against any individual thereon, or any design to kill any particular person, and the train is derailed, and the insured killed; can it be said that his death was not accidental, under this policy, but by the design of some person? The argument may be carried further. Suppose one fires a pistol in the air. The shot strikes the insured and kills him. The act which causes the death-the shooting of the pistol-is designed, and therefore not accidental; but the killing is certainly accidental, and not designed. If the pistol is fired at one man, and hits another, is it any less accidental, as far as the person hit is concerned, or the mind of the person who does the shooting? And, if the shot is fired at the insured in the belief that he is another man, is not the character of the act the same? If one designedly roll a stone down a mountain side, with no intent to injure any one, and in its course it crush a man, it is an accident. If it were purposely rolled down to crush one man, and it is deflected from the course 
intended, and kills another, is it not equally an accident? The design or purpose was not to kill the one injured, because it was intended to kill another, and not him. The criminal intent of the one putting the stone in motion may render him guilty, and responsible for the actual result, though not intended; yet the death of the person thus killed must be considered, as far as he is concerned, an accident, as his death was not intended by any one. It seems to me that the design intended by the terms of this policy must be the design that intended the actual result accomplished, and not the design of the act itself, which act resulted in the killing of one contrary to the design of the act. If, when $B$. fired this shot, he did not know the man fired at was U., and did not intend to kill U., it cannot be said that U. lost his life by the design of B." 330

And death at the hands of another may be purely accidental, as where one is accidentally shot by a robber, who waylays him. ${ }^{337}$ Where the act is intentional, is directed against the assured, and some injury to him is intended, the insurance company will be released from liability even if the injury sustained is not precisely that intended by the perpetrator, either in its nature or in the results which accrue from

83665 Mich. 545, 32 N. W. 812, 8 Am. St. Rep. 913. In this case U. was a deserter from the army. B., a deputy sheriff, learning where he was, went to the house at night to apprehend him. U., with a companion, shut the door. $U$. then opened the door and drew a pistol, and B., not being able to see, and not knowing who was at the door, but intending to kill whoever it was, drew his pistol and fired, killing $U$. It was held that the evidence did not necessarily establish a deliberate design to kill $\mathbf{U}$.

837 Where the assured was held up by robbers, and it appeared that the gun of the robber may have gone off accidentally and killed the assured, it was not an intentional injury which would excuse the Insurance company from liability. Rallway Officials' \& Employes' Acc. Ass'n of Indianapolis v. Drummond, 56 Neb. 235, 76 N. W. 562. 
it. $^{338}$ These policies frequently contain a provision excluding injuries intentionally inflicted by burglars and robbers from the scope of the exception.

A presumption of intent to kill or inflict injury will arise, within the exception, where a weapon is used in a manner naturally calculated to inflict injury or cause death. Circumstances, however, may show that the use of the weapon was not intentional, but accidental..$^{339}$

338 Where, for example, the assured was violently assaulted by another person, who attempted to strike him upon the head with a stick, and the assured to protect himself put up his arm and received the blow thereon. Matson v. Travellers' Ins. Co., 93 Me. 469, 45 Atl. 518, 74 Am. St. Rep. 368. See, also, Fidelity \& Casualty Co. of New York v. Smith, 31 Tex. Civ. App. 111, 71 S. W. 391, where the assailant to protect himself purposely struck the insured, though not intending to inflict severe injury. Travelers' Protective Ass'n of America v. Weil, 40 Tex. Civ. App. 629, 91 S. W. 886. 'The assured and his wife lived apart; the assured called on his wife, who was staying with another woman, and a quarrel ensued in which both his wife and the other woman became involved. The wife of the assured called for help, and the husband of the other woman, thinking it was his wife's voice, rushed in and struck the assured in the face." As a result of the blow the assured lost one eye. Finding that it was not his wife who was in danger, the other man apologized to the assured and declared that he had no intention of injuring him. The court held the company was not liable on the policy and said: "We think the injury to the eye falls clearly within the general purpose to injure, and that it did not devolve on the defendant to show that Innis had a specific intention to inflict the particular character of injury which might flow from the assault."

339 Travelers' Ins. Co. v. Wyness, 107 Ga. 584, 34 S. E. 113. Contrary to the accepted rule and the general weight of authority is the case of Richards v. Travelers' Ins. Co., 89 Cal. 170, 26 Pac. 762, $23 \mathrm{Am}$. St. Rep. 455, in which it was held that where the policy provided that the Insurance should not extend to any cause of death, unless the claimant should show by positive proof that the death was not the result of design on the part of the insured or any other person, and it appeared that the insured died from the effect of a blow struck by a third party, the exemption would not apply if the person inflicting the blow did not mean to kill the insured. Here the assured was apparently struck on the head by a person who was attempting to blackmail him, but had no intention of killing him, though apparently planning to stun or wound him. 
To be available to the insurance company, the defense that the death or disability of the assured was caused by injuries intentionally inflicted by him or some other person must be specially pleaded. ${ }^{340}$

Where the question involved is whether the injury, from which the death or disability arises, is purely accidental or intentional, the presumption is that it was accidental, in the absence of evidence to the contrary. ${ }^{341}$ The law will not presume, in the absence of evidence to that effect, that an injury is self-inflicted, nor that it is intentionally inflicted by another person, nor that it is illegally inflicted. ${ }^{342}$

The burden of proof is on the insurance company to show that the injury on which the suit is brought was the result of an intentional act. The company must satisfy the jury by a fair preponderance of evidence that the condition of the policy was broken. ${ }^{343}$

340 Coburn v. Travelers' Ins. Co., 145 Mass. 226, 13 N. E. 604; Stevens v. Continental Casualty Co., 12 N. D. 463,97 N. W. 862.

341 Caldwell v. Iowa State Traveling Men's Ass'n (Iowa) 136 N. W. 678. Here the assured died from erysipelas, which developed from a slight wound, of unknown origin, in the cheek. The court said: "It has been repeatedly beld that, in the absence of direct evidence upon the subject, a presumption arises that the wound was not intentionally inflicted, either by the assured or by another. This presumption is almost the equivalent of a presumption that the wound was inflicted through accidental means. The authorities, however, stop short of announcing the presumption in this latter form. They do hold, however, that the presumption first stated is available to the plaintiff as affirmative evidence, and that an inference may be drawn therefrom by the triers of fact that the wound was caused by accidental means as the only other alternative."

842 Preferred Acc. Ins. Co. v. Flelding, 35 Colo. 19, 83 Pac. 1013, 9 Ann. Cas. 916; Kirkpatrick v. Etna Life Ins. Co., 141 Iowa 74, 117 N. W. 1111, 22 L. R. A. (N. S.) 1255; Peck v. Equitable Acc. Ass'n, 52 IIun, 255, 5 N. Y. Supp. 215; Stevens v. Continental Casualty Co., 12 N. D. 463,97 N. W. 862 ; Butero v. Travelers' Acc. Ins. Co., 96 Wis. 536, 71 N. W. 811, 65 Am. St. Rep. 61.

843 Lampkin v. Travelers' Ins. Co., 11 Colo. App. 249, 52 Pac. 1040; Travelers' Ins. Co. v. Wyness, 107 Ga. 584, 34 S. E. 113; 
And on an issue as to whether the insured was killed intentionally or otherwise, it is proper to introduce evidence tending to show a quarrel between the assured and his assailant, and also an admission made by the assailant that he had killed the assured. But it is not proper to admit as evidence the indictment of the assailant for the alleged crime, nor the record of a pardon granted him. ${ }^{344}$

Threats made by the assailant against the assured are admissible as tending to show an intent. ${ }^{345}$

It is necessary only that the evidence of intentional injury or killing should preponderate against the presumption of accident, and it is not necessary, as in a criminal prosecution, to establish the fact of an intentional killing beyond a reasonable doubt. It is sufficient to satisfy the jury of the truth of this defense with reasonable certainty. ${ }^{348}$ While primary proofs of death are ordinarily admissible on the trial as prima facie evidence of the facts stated in them, as against the assured and in favor of the insurance company, such statements are not conclusive. ${ }^{347}$

Kirkpatrick v. Atna Life Ins. Co., 141 Iowa, 74, 117 N. W. 1111, 22 L. R. A. (N. S.) 1255 ; Stevens v. Continental Casualty Co., 12 N. D. 463, 97 N. W. 862; Guldenkirch ₹. United States Mutual Accident Ass'n (City Ct. N. Y.) 5 N. Y. Supp. 428. 684 .

344 Masons' Fraternal Acc. Ass'n v. Riley, 65 Ark. 261, 45 S. W.

345 Standard Life \& Accident Ins. Co. v. Askew, 11 Tex. Civ. App. 59,32 S. W. 31.

346 Butero v. Travelers' Acc. Ins. Co., 96 Wis. 536, 71 N. W. 811, 65 Am. St. Rep. 61.

347 And where the preliminary proofs were made by a guardian of the infant beneficiaries under the policy, and the statements made by him as to the cause of the death were based entirely upon hearsay, such statements could not be considered competent evidence of matters therein recited as against the infant plaintiffs, so as to relieve the insurance company from the necessity of proving such facts. The statements were admissions of the guardian alone, and a guardian has no authority to make admissions against the inter- 
Evidence is admissible to show the assured's financial embarrassment, as tending to establish his intention to injure himself, so as to recover on the policy, and refute the claim that the injuries were accidentally received. ${ }^{\mathbf{3 4}}$

Where the evidence is so conflicting that reasonable men of intelligence may fairly differ in their conclusions, the question whether the injury is intentional or accidental is for the determination of the jury. ${ }^{340}$

Beyond the Seas.-Where the policy contains no limitations as to the place or country in which the accidental injury shall occur for which the company is to be liable, the fact that the assured at the time of the accident may be beyond the confines of the United States will in no wise affect the ability of the beneficiary to recover on the certificate. Some policies, however, contain a condition limiting their liability to an injury or death occurring only within the United States. Although no such accident policy has received judicial interpretation, it would be construed most strongly against the company, and under certain conditions might include an injury or death in our insular and outlying possessions, such as Alaska, Porto Rico, the Canal Zone, Hawaii, or the Philippine Islands. This would occur where a policy was issued to the assured when it was known to the officials of the insurance company that he lived in some one of these possessions, or was contemplating a trip thereto, and was securing the policy purely for the purpose of protecting himself for that time, and it was clearly understood between the parties that it would cover this risk.

ests of his wards. Stevens v. Continental Casuaity Co., 12 N. D. 463,97 N. W. 862.

348 Everson v. Casuaity Co. of America, 208 Mass. 214, 94 N. E. 459 ; Cornellus v. Central Acc. Ins. Co., 218 Pa. 532, 67 Atl. 840.

349 Guldenkirch v. United States Mutual Accident Ass'n (City Ct. N. Y.) 5 N. Y. Supp. 428; Northwestern Benev. Soc. v. Dudley, 27 Ind. App. 327,61 N. E. 207. 
Certain policies expressly cover only such injuries as are received within the United States, "not including its parts beyond the seas." Such a policy will cover only injuries or death inflicted accidentally within the continental portion of the United States-that is, as bounded by the Atlantic and Pacific and Canada and Mexico. ${ }^{350}$

Right to Examine the Body of the Assured.-Frequently policies of accident insurance contain a provision giving to the insurance company or its representative the right to "examine" the body of the assured as a condition to the right of recovery in cases where death ensues from an accidental cause for which the company would be liable. This clause guarantees to the insurer an opportunity to examine the body, in the sense of viewing it or inspecting it under reasonable conditions. The word "examine" will be construed in its popular sense, and will not be held to give the company the right to exhume the body, or to dissect it, or to perform an autopsy. The courts have uniformly held that, if the company intended that it should have any further rights, the clause should plainly use the word "autopsy" or "dissect," so that there could be no misunderstanding on this point by the parties to the contract. ${ }^{351}$

850 Currie v. Continental Casualty Co., 147 Iowa, 281, 126 N. W. 164, $140 \mathrm{Am}$. St. Rep. 300. The policy in question contained the following clause: "This policy covers only injuries received within the United States (not including its parts beyond the seas), Mexico, and Canada." The assured, a resident of Iowa, during the life of the policy went to the Panama Canal Zone as a locomotive engineer and was killed in a collision. The court held that, apart from the question of whether or not the Canal Zone was in any sense a part of the United States, it was without question "beyond the seas" within the meaning of the policy, and therefore the company was not liable for the death of the assured.

381 Patterson v. Ocean Accident \& Guarantee Corporation, 25 App. D. C. 46. A clause in the policy in suit declared that there could be no recovery if the right to "examine" the person or body of the insured is refused the company. The evidence showed that the doctors representing the insurance company called at the house a few 
The examination of the body of the assured, in the absence of circumstances excusing delay, must be made as soon as possible after receipt of the notice of death. The insurer cannot wait indefinitely, or for an unreasonable length of time.

minutes before the funeral and said they were there to perform an autopsy to determine the cause of death. The relatives refused permission for this, but offered them the chance to step inside and look at the body, which was declined. After burial the company demanded that the body be exhumed for examination, and this request was refused, whereupon parment on the policy was refused. The court sald: "We cannot agree with the general contention of the appellee that this right to examine the body includes also the right of autopsy, or dissection, much less exhumation for that purpose. * * * Whatever meaning the word 'examine,' in relation to the body of a deceased person, might convey to medical experts, we think it clear that, in popular understanding, it does not include the right of dissection. The prejudice, if it may be so called, which so generally prevails, and especially among the relations and friends of a deceased person, against the submission of the body to dissection, would doubtless prevent many persons from accepting insurance containing an express condition extending that right to the insurer, if considered material for his protection. It would seem, from the evidence before recited, that the purpose of the insurer was not to view or examine the appearance of the body merely, but to dissect the same. If the question be raised upon another trial, it will be the duty of the court to instruct the jury in accordance with this view of the effect of the clause under consideration, and to submit to them the single question whether, upon demand reasonably made therefor, the plaintiff, or those acting for her, refused to permit the medical advisers of the insurer to examine the body in the sense of that word as here given. A failure to extend that permission, upon demand made at a reasonable time and place before burial, would. bar recovery upon the policy." Sudduth v. Travelers' Ins. Co. (C. C.) 106 Fed. 822. Here it was averred that the company had no notice or knowledge of the death of the insured until after his burial, and that within a few days after the interment of the body the defendant demanded of the plaintiff the privilege of exhuming and examining the body, but that this demand was refused. The court said: "The court does not think that any ordinary person, in agreeing to the stipulation for an examination of the insured before or after death, would suppose he was agreeing to what would have been much more clearly expressed by the word 'autopsy' or by the word 'dissect.' I do not think that one would ordinarily suppose that the word 'examine,' as applied to the human body, either living or dead, would, ex vi termini, include, or by an insured, at least, 
Inasmuch as interment invariably is made within a few days after death, the examination should be made immediately upon notification to the company of the death of the assured. ${ }^{352}$

would be supposed to inciude, the idea of cutting it up. * * * Can it reasonably be supposed that it was in the contemplation of both of the parties to these contracts at the time they were made that the meaning of the word 'examine' in its context was to be so expanded as to include either the idea of an autopsy or the idea of a dissection? * * * If the company desired or expected the insured to agree to a condition such as either of these words would have ciearly indicated, there is no obvious reason why it should not have been expressed in plain terms. * * * It may be that the right to dissect a body, even after burial, is or would be an important right to the company; but that would make it all the more necessary for it to express it in language in no way ambiguous or doubtiul, or which, in order to effect the company's purpose, would have to be extended beyond its ordinary import."

See, also, Ewing v. Commercial Travelers' Mut. Acc. Ass'n, 55 App. Div. $241,66 \mathrm{~N}$. Y. Supp. 1056, affirmed without opinion $170 \mathrm{~N}$. Y. 590,63 N. E. 1116. Here it was claimed that the death of the assured was caused by an overdose of morphine accidentaily taken. An autopsy was performed by the coroner immediately after death, and a report thereon was made two weeks thereafter, and notice was at once given the company. Nearly a month after burial the company requested opportunity to make an examination. The organs affected had been removed from the body and not subsequently repiaced. Permission was refused. The court said: "If the right to 'examine the person of a member' in respect to any 'cause of death' is extended for a reasonabie time after death and so long as the body is unburied, or not finally disposed of, I think the utmost limit of the privilege stipulated for would be reached. * * * In any case, I think a party who alleges a contract right to invade the tomb, or the graves of the buried dead, should be sure of the language of his written agreement. It should at least be unmistakably clear. The purpose should be apparent, and the terms so plain that inference or conjecture need not be resorted to, to discover the true intent of the contracting parties. If the policy in question in plain terms stated to an applicant for membership that by accepting membershlp the applicant bartered to the insurer the right at any time to dig up and examine or dissect his dead body, it is quite conceivable that there would be few applicants for membership."

352 Wehle v. United States Mut. Acc. Ass'n, 153 N. Y. 116, 47 N. E. 35, 60 Am. St. Rep. 598, affg. 11 Misc. Rep. 36, 31 N. Y. Supp. 865. Here the assured met death by drowning September $4 \mathrm{th}$, and 
Moreover, power to comply with the request for an examination frequently passes from the beneficiary upon the burial of the body, and therefore, if such a condition is insisted upon, right to recovery would frequently be defeated by the company, by simply delaying formal demand for an examination until after interment. ${ }^{353}$

On the other hand, an exhumation of the body will be ordered where it is evident that a fraud is likely to be accomplished, and where the insurance company has exhausted every other legal means to expose the conspiracy. ${ }^{354}$

immedlate notice thereof was given to the insurance company. September 9th the body was interred. Ten days later the company requested permission to examine the body, which was refused. Held, that the company could not advance this as a defense to payment on the policy. See, also, American Employers' Liability Ins. Co. v. Barr, 68 Fed. 873,16 C. C. A. 51, where no request was made for an examination until several weeks after the burial of the insured. Root v. London Guarantee \& Accident Co., 86 N. Y. Supp. 1055, 92 App. Div. 578, where, though the company knew of the death of the assured on the day following his demise, it did not ask for an autopsy until the day after the burial, which was three days after death. The delay was deemed unreasonable. Ewing v. Commercial Travelers' Mut. Acc. Ass'n, 55 App. Div. 241, 66 N. Y. Supp. 1056, affirmed without opinion 170 N. Y. 590, 63 N. E. 1116, supra, where the request was not made until a month after burial. So, also, Union Cent. Life Ins. Co. v. Hollowell, 14 Ind. App. 611, 43 N. E. 277, where a demand was made for an examination of the body nine months after death, four months after beginning the action, and two days before the trial, though no effort had been made to secure an autopsy before burial. Here the company had been notified of the death of the assured on the day of his demise.

353 See Ewing v. Commercial Travelers' Mut. Acc. Ass'n, 55 App. Div. 241, 66 N. Y. Supp. 1056, affirmed without opinion 170 N. Y. $590,63 \mathrm{~N}$. E. 1116 , supra, where the request was not made until a month after burial, and was refused by the widow of the assured, and the beneficiary had no control over the matter. The same conditions existed in American Employers' Liability Ins. Co. v. Barr, 68 Fed. 873, 16 C. C. A. 51. See Root v. London Guarantee \& Accident Co., 92 App. Div. 578, 86 N. Y. Supp. 1055, supra, where it was intimated that, where it is not within the province of the beneficiary to grant the privilege of exhumation, application should be made to the relatives of the decedent who have control of the body.

354 Grangers' Life Ins. Co. v. Brown, 57 Miss. 308, 34 Am. Rep. 
Although in no adjudicated case has a recovery been defeated because of a refusal to comply with the demand of the company for permission to examine the body after burial, yet if it should appear that, after interment, facts uncovered by the insurer warranted a reasonable belief that death had been occasioned by causes specifically excepted from the insurance contract, a reasonable construction of the clause under consideration would authorize the company to insist upon an exhumation and dissection of the body, and a refusal to pay the amount of the policy if that were denied..35

Policies frequently contain a proviso to the effect that in case an autopsy is held the company shall have notice thereof, and an opportunity shall be given for its medical representative to participate. A notice given to the agent of the company of a proposed autopsy will answer the requirements of this condition, even where the company refuses to take any part in the examination of the body. ${ }^{350}$

446. Here the company claimed that, though the assured stated in his application he had never received any serious injury, as a matter of fact he had in boyhood fractured his skull, which had been trephined. Upon the trial, which occurred two years after the death of the assured. the company asked for an order to have the body exhumed in order to ascertain the facts as to the alleged fracture; it being claimed that it was impossible to produce witnesses living in the jurisdiction of the court who were familiar with the boyhood of the assured. The court denied the order in this instance, but said: "We are not prepared to say that in a proper case the court, in the interests of justice, should not compel the exhuming and examination of a dead body which is under the control of the plaintiff, if there is strong reason to believe that without such examination a fraud is likely to be accomplished, and the defendant has exhausted every other method known to the law of exposing it. * * * It would be a proceeding repugnant to the best feelings of our nature, and likely to be in many cases so abhorrent to the sensibilities of the surviving relatives that they would prefer an abandonment of the suit to a compliance with the order."

355 Wehle v. United States Mut. Acc. Ass'n, 153 N. Y. 116, 47 N. E. 35, 60 Am. St. Rep. 598, affg. 11 Misc. Rep. 36, 31 N. Y. Supp. 865 , supra.

356 Legnard จ. Standard Life \& Accident Ins. Co., 81 N. Y. Supp. 
A clause giving the insurer the right to perform an autopsy on the body of the assured does not confer an exclusive right to perform an autopsy, and an autopsy performed by a representative of the assured without notice to the company, under such a policy, will not bar a recovery. ${ }^{357}$

516, 81 App. Div. 320. Three weeks after death an autopsy was held by the beneficiary, notice of which was given the insurer by the physician in charge, but the company declined to have anything to do with it. In this case recovery was defeated on another pointfailure to comply with the conditions of the policy as to notice and proof of death. In Loesch v. Union Casualty \& Surety Co., 176 Mo. $654,75 \mathrm{~S}$. W. 621 , the policy provided that, "if the post mortem be held without notifying the company in time to have its medical examiner present, then all claims under this policy shall be forfeited." The assured's physician, the day following death, informed the mother of the assured that he wished to hold a post mortem, to which she made no objection. After the post mortem the mother showed the physician the policy, and, discovering the clause here yuoted, he went immediately to the office of the company, notified the company's officers, and on behalf of the beneficiary offered to hold another post mortem with their medical adviser. The company expressed no desire for this, and the following day the body was buried. The mother testified that she did not know what the physician meant by a post mortem, and neither assented nor dissented, and did not know what was done until after it was over. The court held that the holding of a post mortem under these circumstances, without notice to the company, did not forfeit the policy, and that, if the examination was had without the knowledge or consent ' of the beneficiary, it would be no defense to a suit on the policy.

357 Crotty v. Continental Casualty Co. (Mo. App.) 146 S. W. 833. The policy here merely provided that the insurance company should have the right and opportunity to perform an autopsy as it might require, but did not give the company the exclusive right to perform the autopsy, nor did it require the claimant to give notice of ber intention to have one performed. The plaintiff had an autopsy, and, though she gave no notice beforehand, yet immediately thereafter she informed the defendant of what had been done. The insurer at no time requested an opportunity to perform an autopsy. In the action the defendant resisted recovery on the ground that one of the surgeons removed the left kidney of the assured for examination, and also remored a piece of the spinal cord, which he lost, thereby rendering an autopsy useless. The court held that the defense was entirely without merit under the provisions of the policy in issue. 


\section{CHAPTER IV}

\section{AMOUNT OF LIABILITY}

Death distinguished from disability.

Total disability.

What is permanent or continuing disability.

Confinement to the house and bed.

General principles determining anount of liability of insurer.

Double liability and amount of indemnity determined by the cause of injury or death-Passengers-Public conveyance.

Amount of liability determined by the occupation of the assured.

Injuries inflicted by robbers.

Liability for particular injuries.

The loss of an eye.

Broken leg or arm.

Accidents in elevators.

Burning building.

Public highway.

Pleading and evidence.

Death Distinguished from Disability.-Accident insurance policies are predicated upon three general kinds of losses - partial disability, total disability, and death by accident. All accident policies, however, do not render the insurance company liable for death as the result of accident. Where the policy by its terms merely promises to indemnify the assured in case of disability resulting from accident, but contains no express provision for liability in the event of death, then the death of the assured, even though it be the direct and immediate result of an accident, is not a loss under the policy such as will render the company liable. ${ }^{1}$

1 Dawson v. Accident Ins. Co. of North America, 38 Mo. App. 355. Here the assured, a railway switchman, had taken out an accident insurance policy providing that he should be indemnified in the sum of ten dollars per week during the period of his disability to work,

Fúler Acc.Ins.-19 
"Disability" has reference to the ability of the insured to perform the duties incident to the usual vocation or trade in which he is engaged. Death is not a "total disability" within the meaning of such a policy of insurance, and a claim for indemnity in the event of death cannot be maintained under a policy which agrees to pay the insured a principal sum in the event that he is "totally disabled" by an accident. ${ }^{2}$ These are policies of indemnity, which undertake merely to make good any loss to the assured of time and earning capacity as a result of accident, by the payment of the amounts provided in the contracts. Payments are made to the assured, and the policy does not undertake to insure his life against death by

for not exceeding twenty-six consecutive weeks. While engaged in his usual occupation he was instantly killed as the result of an accident. Action was brought by the administrator of the estate to secure judgment against the insurance company for the sum of $\$ 260$, on the theory that, having been killed outright, the insured was totally disabled, and the company liable for such total disability during the maximum twenty-six weeks contemplated in the policy. The court said: "We cannot take hold of any mode of reasoning by which the language of the policy can be construed into a contract to indemnify the deceased for the loss of his time in case of his immediate death, nor can we understand how a man can be indemnified for the loss of his time, or for the loss of ability to labor, or for anything else, after he is dead. The policy is, on its face, not a death policy, but a mere indemnity policy, and where the assured is immediately killed, there is nothing upon which it can operate." See, also, Burnett v. Railway Officials' \& Employés' Acc. Ins. Co., 107 Tenn. 185, 64 S. W. 18 . In this case the policy contained the clause: "The death of the insured shall immediately terminate all liability under this policy, and in no case shall the insured be entitled to recover for more than 104 weeks hereunder." The insured, a railway brakeman, was accidentally thrown from a car, run over by the wheels, and killed. The company was held not to be liable.

2 Hali v. American Employers' Liability Ins. Co., 96 Ga. 413, 23 S. E. 310 ; Rosenberry v. Fidelity \& Casualty Co., 14 Ind. App. 625, 43 N. E. 317 ; Atna Life Ins. Co. v. Bethel, $140 \mathrm{Ky} .609,131$ S. W. 523; Dawson v. Accident Ins. Co. of North America, 38 Mo. App. 355, supra ; Burnett v. Raiiway Officials' \& Employés' Acc. Ins. Co., 107 Tenn. 185, 64 S. W. 18, supra. See, also, Permanent or Continuing Disability, page 306. 
accident, for the benefit of another. ${ }^{3}$ Whatever indemnity might accrue up to the time of the death of the assured, where an accident was not immediately fatal, may be claimed by his personal representatives, the same as any other amount due his estate. It has become a debt due to the decedent in his lifetime, which inures to the benefit of the estate as a portion of the personal assets thereof. ${ }^{4}$

Even where the accident indemnity policy contains blank spaces for insuring the principal in case of death, the company is not liable for his accidental death, unless the blanks were filled in and the intent of the company to pay a death benefit thus clearly manifested. ${ }^{5}$

Total Disability.-Policies of accident insurance usually contain a clause expressly providing the degree or amount of injury which must be sustained by the assured to render the company liable. Generally the assured must be "totally disabled" by an accident within the scope of the policy. Analogous to policies of accident insurance are policies insuring against sickness.

3 Shaw v. Equitable MIut. Acc. $A s s ' n, 5$ Neb. (Unof.) 584,99 N. W. 672.

4 Rosenberry v. Fidelity \& Casualty Co., 14 Ind. App. 625, 43 N. E. 317, supra.

5 Hall v. American Employers' Liability Ins. Co., 96 Ga. 413, 23 S. E. 310, supra; Rosenberry v. Fidelity \& Casualty Co., 14 Ind. App. 625,43 N. E. 317 , supra.

So, where the blank proofs forwarded to the assured upon the occasion of a previous accident under the policy had a blank space for the amount claimed in the event of death, these facts were held irrelevant in an attempt to hold the insurance company liable for a principal sum upon the accidental death of the assured, where the filled-in portions of the policy provided for a weekly indemnity, payable to the insured during the period of his disability from accident for a period of not longer than 104 weeks, and further declared that in case of death the liability of the company at once terminated. Burnett v. Railway Officials' \& Employes' Acc. Ins. Co., 107 Tenn. 185,64 S. W. 18 , supra. 
In the absence of any limitation, so long as the cause of the disability is included within the risks covered by the policy, the nature of the disability does not affect the liability of the company. It may be either mental or physical. And a lunatic is totally disabled, provided the insanity is due to any one of the risks enumerated or not exempted. ${ }^{6}$ No general definition has been given by the courts to the words "total disability," and what does or does not constitute a total disability depends largely upon the circumstances of each case and the verbiage of the policy upon which the action is instituted.

In order to constitute a total disability, it is not necessary that the assured should be absolutely helpless. If he is incapacitated for work, he is disabled, although he may be able to be "up and around" the house, and even go out of doors and away from his house.

The clause in different accident policies defining this disability is by no means uniform. In some policies the pro-

- McMahon v. Supreme Council, Order of Chosen Friends, 54 Mo. App. 468. See, also, McCullough v. Expressmen's Mut. Ben. Ass'n, 133 Pa. 142, 19 Atl. 355, 7 L. R. A. 210.

7 Where the assured was incapacitated for work or business, though he was occasionally able to leave the house and take the car to the office of his doctor, he was held to be "totally disabled" within the terms of the policy, and the company therefore liable. Mutual Ben. Ass'n v. Nancarrow, 18 Colo. App. 274, 71 Pac. 423. Where the policy insured the plaintiff against the loss of time from injuries "wholly and continuously disabling him from transacting any and every kind of business pertaining to his occupation as merchant," it is not necessary that the disability should amount to an absolute physical inability to transact any kind of business pertaining to his occupation; but it is sufficient if his injuries were such that common care and prudence required him to desist from transacting any such business in order to effectuate a cure. In this case the assured was accidentally thrown from his bicycle, landing on his face, dislocating the thumb of one hand, breaking loose some of his teeth, and so injuring and jarring his head and neck as to affect his spine and nerves, and produce severe nervous prostration, which required 
vision as to total disability declares that the assured must be disabled "from prosecuting his usual employment," or "from prosecuting any and every kind of business pertaining to his occupation." Under either one of these conditions, naturally, one who is unable to do any work pertaining to his occupation is totally disabled. ${ }^{8}$

The extent of the disability depends, of course, upon the

constant and absolute rest and quiet for its successful treatment. Lobdill v. Laboring Men's Mut. Aid Ass'n, 69 Minn. 14, 71 N. W. 696, 38 L. R. A. 537, 65 Am. St. Rep. 542.

8 Where the assured was a tenant farmer, keeping a dairy and operating a portable sawmill a portion of each year, and while so running the saw he was accidentally drawn thereon in such a manner as to nearly serer his right arm, and permanently destroy the use of his right hand, ultimately obliging him to give up farming and milling altogether, the assured was "totally disabled." In this case the court said: "It is somewhat difficult to conceive of a case where a party could be so severely injured as to be entirely disabled from directing the conduct of some kind of business. A brakeman on a railroad might lose both arms, and in consequence be unable to perform the kind of labor he had always followed; but he could doubtless direct some one else to do it if permitted by his employer, and he might possibly earn a living as a track walker, provided he could obtain such employment; but in these circumstances would it be seriously contended that the language of the contract should be so construed as to relieve it [the insurance company] from all liability? Again, a farmer who has been so injured that he cannot hold a plow, or swing a scythe, or drive his horses, or milk his cows, might, nevertheless, hire some other person to perform these several duties, or he might direct how they should be performed, or he might leave his farm and find himself able to perform the duties of a flagman at a railroad crossing, and by so doing earn a livelihood, or at least sufficient to keep the wolf from the door. * * * We are of the opinion * * * that the language above quoted means simply that, if a party whose occupation is that of directing others in the performance of their duty is so injured that he can no longer follow that occupation, or if any member shall be so far disabled as to be unfitted for the performance of his ordinary occupation or for following any other means of livelihood requiring substantially the same physical and mental ability as that in which he is usually engaged, he shall be deemed entitled to disability benefits." Beach v. Supreme Tent of Knights of Maccabees of the World, $177 \mathrm{~N}$. Y. 100, 69 N. E. 281; Id., 74 App. Div. 527, 77 N. Y. Supp. 770. See, 
ability of the assured to perform the labor or to conduct the business he has usually followed and by which alone he can earn a livelihood. Therefore the matter of disability is largely a relative question, depending upon the attainments and habitual occupation of the person disabled. Thus a physical ailment which would render an illiterate laboring man totally unfit to earn a livelihood might not prevent a lawyer from practicing his profession, or take away from him all other chances of earning a living in some other avocation. Therefore, in determining the liability of the

also, Crotty v. Continental Casualty Co., 163 Mo. App. 627, 146 S. W. 833. Here the assured, after being disabled as a blacksmith, went to work for a few days, but could do no work, and his fellow employes performed his duties for him, so that he drew his pay for that time. He was forced to give up entirely, and died shortly thereafter. The court held that the jury was justified in finding him unable "to engage in any labor or occupation." Industrial Mut. Indemnity Co. v. Hawkins, 94 Ark. 417, 127 S. W. 457, 29 L. R. A. (N. S.) 635, 21 Ann. Cas. 1029. Here assured, a day laborer, as the result of an accident so injured his knee that he could do no manual labor. The court said: "Total disability is necessarily a relative matter, and must depend chiefly on the peculiar circumstances of each case. It must depend largely upon the occupation and employment and capabilities of the person injured. * * * In the case at bar the total disability occurred when the insured was prevented by the injury 'from the prosecution of any and every kind of business.' The use of the word 'prosecution' indicates that the parties intended to mean that the insured was wholly disabled from doing that business which he had the capabilities to prosecute. Otherwise he could not recover, unless he sustained an injury that rendered him absolutely helpless, both mentally and physically. The plaintiff was an uneducated day laborer. He had no ability to do any business of any kind, except that of manual work. He could not practice law, or medicine, or perform the duties of a banker or bookkeeper. He did not have the ability to follow these lines of business, and yet he was not so totally disabled that he could not follow these arocations if he had possessed the ability to do so. * * * It was manifestly the intention of the parties that he should recelve indemnity when he was so injured that he was wholly and totally disabled and prevented from the prosecution of any business which, without the injury, he was able to do or capable to engage in." 
insurance company, the courts must consider both the mental and physical capabilities of the assured. ${ }^{\circ}$

Some policies define what injuries shall be held to constitute a total disability, as, for example, the loss of an arm, or limb, or other member. ${ }^{10}$

Where the contract imposes a liability upon the insurance company in the event that the assured should become "totally incapacitated to perform manual labor," the total incapacity refers to inability to perform sustained manual labor, so as to enable him to earn or assist in earning a livelihood. ${ }^{11}$ The test of liability under such a policy is the extent to which the earning power of the assured is impaired. If he is earning substantially the same amount after the injury as before, clearly his disability is not total. ${ }^{12}$

a Ordinarily the loss of the fingers of the hand does not constitute total disability for the performance of any kind of labor or business, although it may totally disable one who is a switchman upon a railroad from performing his usual duties, or following that particular employment longer. Hutchinson v. Supreme Tent of Knights of Maccabees of the World, 68 Hun, 355, 22 N. Y. Supp. 801. An accident to an illiterate middle-aged laborer, which prevents him from earning his living by manual labor, is a total disability. McMahon v. Supreme Council, Order of Chosen Friends, 54 Mo. App. 468.

10 Mady $\nabla$. Switchmen's Union of North America, 116 Minn. 147, $133 \mathrm{~N}$. W. 472 . Here the certificate defined total disability as the "physical separation of four fingers of one hand at or above the third jotnt, * * * provided the above amputations occur." The assured lost three fingers of the hand above the third joint by amputation, and suffered an injury to the other finger which impaired its usefulness to the extent of 50 per cent., but did not occasion or warrant its amputation. In a very clear opinion the court held that the assured could not recover for a total disability, and sustained the lower court in directing a verdict for the insurer.

11 Fidelity \& Casualty Co. of New York v. Hart, $142 \mathrm{Ky.} \mathrm{25,} 133$ S. W. 996.

12 Where one has become incapacitated through consumption, so that he is unable to perform any sustained labor from which he can receive earnings, he is "totally incapacitated from performing manual labor." The clause does not mean a condition of absolute and complete incapacity to perform any manual labor, but an inability to perform manual labor to an extent necessary to entitle him to 
The courts are a unit in declaring that this clause must be given a practical and rational construction. It is not often that a man is so completely disabled as to prevent his

receive pay therefor. Grand Lodge, Brotherhood of Locomotive Firemen, v. Orlell, 206 Ill, 208, 69 N. E. 68, affirming 109 Ill. App. 422. Where the petition alleged an injury whereby the hand and forearm were lacerated and crushed, so that they had to be amputated below the elbow, resulting in partial paralysis of the left side, of a progressive character, resulting in total disability, it states a sufficient cause of action under a policy allowing indemnity for total disability by accident or disease, or from both, producing a local lesion amounting to total disability. Faulkner v. Grand Legion of Select Knights, 63 Kan. 400, 65 Pac. 653. In the case of Monahan v. Supreme Lodge of the Order of Columbian Knights, 88 Minn. $224,92 \mathrm{~N}$. W. 972 , the policy contracted to pay a certain indemnity when the assured should become "totally and permanently disabled, by reason of accident or disease, from following any occupation whatever." At the time of the injury the assured was a strong, robust, and vigorous man. The injury resulted in partial and progressive paralysis, by which he lost permanently the use of one leg, and could get about only by the use of a crutch, and then only with the greatest difficulty and pain. By what labor he could perform the assured was barely able to pay his board, and the court held this to be a total disability within the meaning and spirit of the policy. The court declared that it was not necessary that the assured, in order to recover, must be incapacitated to the extent that he has not sufficient physical power and strength to follow any occupation whatsoever, or perform some slight and infrequent labor. "The words 'following any occupation' mean something more than the doing of one or more acts pertaining thereto. They involve the idea of continuity, and involve, also, the doing of all those things which are essentially a part of the work or business in which a party is engaged." Where the assured was a brakeman on a railroad and was accidentally hurt, the mere fact that he made two runs as a brakeman after the accident, but was unable to do any of the work himself, and was compelled to call a substitute on those runs, or the fact that he did trivial work on his farm during the time for which he made claim, which was not shown to have added to his income, and was nothing more than he would have done while remaining in his employment as brakeman, would not defeat his right to recover on the policy. The court in this case declared: "The test of liability of the insurer is whether the loss of earning power on the part of the insured " * * was total." Wall v. Continental Casualty Co., 111 Mo. App. 504, 86 S. W. 491 . Under a policy of accident insurance issued for one day, by which the insurer agreed to be liabie for loss of time from an accident and injury which totally disabled and prevented the assured from per- 
engaging in any kind of occupation. ${ }^{13}$ However, to hold the insurance company liable on its policy, it is not sufficient that the disability impairs the effectiveness and earning power of the assured in a general and superficial way. Nor is it sufficient that the injury resulting from the accident renders him unable to perform all the duties of his profession or occupation. ${ }^{14} \mathrm{He}$ must be unable to perform them with substantial and reasonable effectiveness in order to recover on his policy. To entitle the assured to indemnity, it is not essential that his injury should disable him to such an extent that he lacks the physical ability to do anything in the prosecution of his business. It is sufficient, according to the undoubted weight of authority, even under the clause providing for indemnity for injuries which shall "wholly disable and prevent him from the prosecution of any and every kind of business pertaining to the occupation

forming all kinds of business, it was shown that after an accident on the day named the assured was able to work for a time, but that he became totally disabled some days later on receiving additional injuries which aggravated the injury originally received; and it did not appear that the original injury would have produced total disability to labor. Held, that the insurance company was not liable. Rhodes v. Railway Passengers' Ins. Co., 5 Lans. (N. Y.) 71. Where the assured was a trainman, and suffered injury to a hand, by which he lost its use, but was able to earn a substantial salary in yard service. Gahagan v. Morrisey et al., 19 Pa. Co. Ct. R. 238, 6 Pa. Dist. R. 135.

See, also, Maryland Casualty Co. v. Chew, 92 Ark. 276, 122 S. W. 642 , where the court held that damages were not recoverable on account of an extension of the injury occasioned by the assured's failure to observe the directions of his physician.

13 Fidelity \& Casualty Co. of New York v. Getzendanner, 93 Tex. 487, 56 S. W. 326 , reversing 53 S. W. 838 , and 55 S. W. 179 , where the assured was so injured mentally that, though able to do some work, his condition prevented the successful performance of the duties of his occupation.

14 Where the policy provided that the company would be liable for accidental injuries which should "wholly disable and prevent him from the prosecution of any and every kind of business pertaining to his occupation," and the assured was injured in the foot, 
under which he is insured," that his injury be of such a character and so severe that he is unable to do all the substantial acts necessary to be done in the prosecution of his business. ${ }^{15}$

Where the assured, as a result of an injury accidentally received, is able to do personally only minor and trivial things not requiring much time or physical effort, and through others, acting under his direction, to do the heavier things demanding physical exertion, and which in the ordinary and proper performance of his duties he does personally, he is totally disabled, provided the things he is unable personally to do constitute substantially all of his occupation. $^{16}$ And so the mere ability to go to one's place

and wholly disabled and confined to the house for a week, but was later able, with great exertion, to get in his buggy and superintend a small part of his business, the insurance company was not liable for such time as he was able to get about as stated. Saveland $\nabla$. Fidelity \& Casualty Co., 67 Wis. 174, 30 N. W. 237, 58 Am. Rep. 863.

15 Thus, where the plaintiff was insured as a billiard saloon keeper, and could perform only some small part of his duties, or where a barber might injure his right hand, but could perform trivial acts with his left. Young v. Travelers' Ins. Co., 80 Me. 244, 13 Atl. 896. And where the assured, a physician, by reason of injuries was confined to his bed for a period of several weeks, and as a result of such injury was unable to go about his business, enter his office, or make calls upon his patients, but was able to exercise his mind on occasional applications to him for advice, and issue certain instructions, he was totally disabled. The court said: "Total disability must of the necessity of the case be a relative matter, and must depend largely upon the occupation and employment in which the party insured is engaged. One can readily understand how a person who labors with his hands would be totally disabled only when he cannot labor at all. But the same rule would not apply to the case of a professional man, whose duties require the activity of the brain, and which is not necessarlly impaired by serious physical injury." Wolcott v. United Life \& Accident Ins. Co., 55 Hun, 98, 8 N. Y. Supp. 263.

16 Where the assured was the manager of a clothing firm, and as such was called upon to handle heavy garments and packing cases, but as a result of his injuries could perform practically none of the 
of business each day does not relieve the insurance company of liability, if the assured is unable to do any work there. ${ }^{17}$

Where the assured usually performs manual labor, and as a result of an accident is so injured that he cannot work any himself, the mere fact that he can exercise some supervision of the work, and give general directions to persons who take

important and material things necessary to his occupation, he was totally disabled. Commercial Travelers' Mut. Acc. Ass'n v. Springsteen, 23 Ind. App. 657, 55 N. E. 973. James v. United States Casualty Co., 113 Mo. App. 622, 88 S. W. 125. Here the assured fell from a street car, and his knee was severely injured. He was confined to his bed a portion of the time, and was forced to use crutches for a long while. He was able to be at his office almost daily, where he dictated letters, signed checks, and attended to such matters. But he could not get about the store or wholesale house, and was compelled to sit in his office in a crippled condition; nor could he look after customers, supervise his employés, or sell goods, as was his custom. The court said: "We hold the contract to mean, not that the assured was rendered absolutely and literally unable to perform any part of his occupation, but that he was disabled from performing substantially the occupation stated in the policy. * * It cannot be that the parties intended that, before an assured could recover on the policy, he should lie the full period of his injury in a state of coma. *** We therefore find ourselves driven back to the position taken by the authorities on the construction of the first part of the clause, viz., that the disability meant is a disability as to the performance of any substantial part of the business."

17 Where the plaintiff, insured as a real estate broker, fell and dislocated his shoulder, for ten weeks was unable to do any business, but hired a man to attend to his affairs for him, and, though he went to his office for a short time each day, could do no kind of work. Turner v. Fidelity \& Casualty Co., 112 Mich. 425, 70 N. W. 898,38 L. R. A. 529, 67 Am. St. Rep. 428. Where the assured, a shoe dealer, injured his shoulder and, though able to go to his store two or three times a week, could not attend to any business. Thaver v. Standard Life \& Accident Ins. Co., 68 N. H. 577, 41 Atl. 182. Where the assured, a furniture dealer, suffered a broken hip, and for a year was unable to perform any manual labor, though after a time he went to his store daily on crutches, and kept certain books that were brought to his house for that purpose, he was wholly disabled. Baldwin v. Fraternal Acc. Ass'n, 21 Misc. Rep. 124, 46 N. Y. Supp. 
his place, does not make his disability any less than total.is There is a reasonable and logical limitation to this rule. If an employé who has been performing manual labor is disabled from an accident, but thereafter and during the period of his injury is employed as a superintendent or overseer at substantially the same wages, he is not totally disabled. ${ }^{19}$ And so where his duties are of a general nature, he is not totally disabled if he can still perform those duties, though, by reason of the injury, he is unable to attend to every detail of the work, as he had been accustomed to do prior to the injury which he suffered. ${ }^{20}$ But if, as a result of the injury, the assured is forced to employ another to conduct his business, and can give his personal attention to only a few of the details, such as conducting a portion of the correspondence, his dis-

1016, affirmed without opinion 29 App. Div. 627, 52 N. Y. Supp. 1136, and in 159 N. Y. 561,54 N. E. 1089.

18 Where the assured was an ice man, and by reason of the injury could do no work himself, but could give personal directions to those who took his place during his disability. Neafie v. Manufacturers' Acc. Indemnity Co., 55 Hum, 111, 8 N. Y. Supp. 202. See, also, Beach v. Supreme Tent of the Knights of the Maccabees of the World, 77 N. Y. Supp. 770, 74 App. Div. 527.

10 Where the assured, a bumper in a grantte yard, injured his thumb so badly that he could not do that particular kind of work, but as overseer of the yard received 90 per cent. of his former wages. Bylow v. Union Casualty \& Surety Co., 72 Vt. 325, 47 Atl. 1066. See, also, Rayburn v. Pennsylvania Casualty Co., 141 N. C. 425, 54 S. E. 283. Here assured was the foreman of a railroad construction gang. The evidence showed that for a portion of the time for which he claimed indemnity he performed the same services as before his injury and at the same salary. The court held that he could not recover for such time.

20 Where the assured was superintendent of a furniture and funeral supply manufacturing house, carrfed on the correspondence, and exercised a general oversight and management of the concern, a sprained knee required him to use canes and interfered somewhat with his getting about the plant; but as he was able to conduct the correspondence, and go to the plant nearly every day, and issue orders through the foreman, he was not totally disabled. Spicer v. Sommercial Mut. Acc. Co., 4 Pa. Dist. R. 271, 16 Pa. Co. Ct. R. 163. 
ability is total. ${ }^{21}$ And so it is a total disability where the assured, though he is able to perform the usual duties and labors of his occupation, suffers great pain and bodily discomfort. ${ }^{22}$

But if he is able to work, and merely suffers some inconvenience or some pain as a result of his injury, it is not a total disability such as will render the insurance company liable. ${ }^{23}$ Where as a result of an injury he is forced to wear a harness or an appliance which endangers his life or subjects him to intolerable discomfort, the mere fact that he can thus pursue some occupation does not lessen the character of his disability. ${ }^{24}$

21 Where the assured was employed as superintendent in constructing a mill, and as a result of the injury was forced to employ an experienced man in his place, and devoted practically all his time to securing relief from his injury, though he could conduct a portion of the correspondence, he was totally disabled. United States Casualty Co. v. Hanson, 20 Colo. App. 393, 79 Pac. 176.

22 Where the assured, a barber, was injured, but was able for a time to do certain portions of his work at his shop, but suffered additional severe pain and much bodily discomfort, and became so weak that he was forced in a short time to sit down, and after a few days of such attempts was forced to remain at home for several weeks, the company is liable for a total disability. Hohn v. Interstate Casualty Co., 115 Mich. 79, 72 N. W. 1105.

23 Where the assured suffered from hernia due to an accident, but by wearing a truss properly adjusted he could go about and attend to his business, he was not totally disabled. Potter v. Accident Ins. Co. of Columbus, 29 Ind. 210. See, also, Etna Life Ins. Co. v. Lasseter, 153 Ala. 630, 45 South. 166, 15 L. R. A. (N. S.) 252. Here the assured, law and stock agent for a railroad, was ruptured as the result of an accident. He was not permitted to recover, where the evidence showed that he had not on account of his injury been prevented from performing the duties of his business, but that in fact he had been attending to them ever since the injury.

2* The assured, a day laborer, was injured, and operated on three times for hernia without securing relief. He was unable to work, and the rupture was so large that a truss could not be worn without great danger of serious injury, and even then he could not perform labor requiring much exertion. The court held that he was totally disabled. McIIahon $\nabla$. Supreme Council, Order of Chosen Friends, 54 Mo. App. 468. 
But the inability of the assured to perform certain portions of the work pertaining to his occupation does not constitute a total disability within the meaning of the policy, provided he is able to transact such features and branches of his business as form the substantial and material portion of his occupation. ${ }^{25}$

A disability which merely prevents the assured from doing sume part of a whole day's work, or from doing as much in a day's work as before, is not total, though an injury that entirely prevents his doing certain material portions of his accustomed work is total, even when there are other portions that he is able to do. This statement applies even where the policy insures against injuries which shall totally disable the assured from prosecuting his usual employment. ${ }^{28}$ The disability is not total merely because the performance of these duties may occasion some pain' or inconvenience. ${ }^{27}$

25 Maryland Casualty Co. v. Chew, 92 Ark. 276, 122 S. W. 642, where the assured was classified as a "cotton factor," but only one of his duties was to sample cotton. He was not totally disabled merely because of his inability to sample cotton.

26 Where a farmer was so injured that he could do no heavy work, could not carry a pail of milk or water, or take care of his cattle, or pitch hay, or hold a plow, or mow for more than a half hour, but could milk a little, could drive a horse, and with care and difficulty could do light work about the farm, the company was liable. Sawyer. v. United States Casualty Co., 8 Am. Law Reg. (N. S.) 233.

27 Where the assured, a lawyer, suffered such injury that he was unable to use one hand, but was, during his office hours, at his office or in court engaged in the practice of his profession, he is not wholly disabled from attending to his business. United States Mut. Acc. Ass'n v. Millard, 43 Iil. App. 148. Where the assured, a druggist, was accidentally shot in the left arm, and it was amputated at the shoulder joint, but no other injury was sustained, though it was admitted that the injury might inconvenience the plaintiff, and still he could perform most of the duties connected with his business substantially as before, it was held that he was not totally disabled. In this case the court declared that, where the occupation of the assured is well understood and a matter of common knowledge, the court must take notice of the requirements of the buslness. Smith v. Supreme Lodge of the Order of Select Friends, 62 
The theory upon which this clause in insurance contracts is construed is that the policy does not undertake to indemnify the assured against pain, or inconvenience, but against the loss of time in the prosecution of his business. Where one is insured in a specific occupation, a provision for indemnity for the "total loss of such business time as may result from his injuries" refers to the loss of time of the assured in the

Kan. 75, 61 Pac. 416. Where the plaintiff was insured as a "leather cutter and merchant," to entitle him to recover on a policy for a total disability from pursuing "any kind and every kind of business pertaining to his occupation," he must show a disability both as a leather cutter and as a merchant. Ford v. United States Mut. Acc. Relief Co., 148 Mass. 153, 19 N. E. 169, 1 L. R. A. 700. Lobdill v. Laboring Men's Mut. Aid Ass'n, 69 Minn. 14, 71 N. W. 696, 38 L. R. A. 537, 65 Am. St. Rep. 542, supra. Where the assured, a capitalist, accidentally cut the tendon of the first finger of his right hand, but he was able to go to his office every day, direct the management of his business, dictate his correspondence, attend meetings of the directorate of his bank, and was able to visit out of town, but suffered considerable pain and was unable to button his collar, tie his shoes, or divide his food at meals, he was not wholly disabled "from transacting any and every kind of business pertaining to his occupation." Coad v. Travelers' Ins. Co., 61 Neb. $563,85 \mathrm{~N}$. W. 558. Where the plaintiff, described in the policy as a "retired gentleman," and having no further occupation than his own amusement, injured himself while operating a buzz saw at a wagon shop of which he was a director, and in consequence was obliged to carry his arm in a sling and was deprived of its use to a greater or less extent for a period of some months, he was not entitled to recover under a policy requiring him to be "totally disabled and prevented from the prosecution of any and every kind of business pertaining to his occupation." Here the plaintiff could still look after his investments, collect, disburse, or reinvest his income, attend the meetings of various boards of directors, and superintend the general conduct of his affairs. Knapp v. Preferred Mut. Acc. Ass'n, 6 N. Y. Supp. 57, 53 Hun, 84. But where the assured was a lawyer or solicitor and registrar, and as the result of a severely sprained ankle he was confined to his bedroom for several weeks, was prevented from passing his accounts as registrar, and from attending at various places at which he was required to complete purchases for his clients, he was "wholly disabled from following his usual business, occupations, or pursuits." Hooper v. Accidental Death Ins. Co., 5 H. \& N. (Exch.) 546. 
business of his particular occupation, and does not require that he should be disabled from doing any kind of business. ${ }^{28}$ The provision more frequently defines the total disability as an inability to carry on any and all kinds of business, and under such a clause the assured must be so injured as to be unable to perform, not only the duties of his usual occupation, but the duties of any other occupation in which he is qualified to engage and earn a living. ${ }^{20}$

Where the contract of insurance provides indemnity for an assured "permanently disabled from following his usual or other occupation," one who, though unable to follow his own trade or occupation, is able to work at another business, though totally dissimilar, cannot recover. ${ }^{30}$

28 Where the assured, a locomotive fireman, was so injured that he was disabled from in any way continuing his occupation, but he could, however, do other things, the company was held liable. Pennington v. Pacific Mut. Life Ins. Co., 85 Iowa, 468, 52.N. W. 482, 39 Am. St. Rep. 306.

29 The assured, a carpenter, was disabled so that he could not go on a four-story building to put on the roof, but he could do every thing else pertaining to his trade. Held he was not "totally disabled." In this case the court sald: "If the plaintiff is skilled in but one business, and can pursue but one employment, and is disabled from pursuing that, he may recover; but if he has greater skill, and can turn his attention to other pursuits, he cannot recover unless he is disabled from engaging in any employment for which he is qualified." Lyon v. Rallway Passengers' Assur. Co., 46 Iowa, 631. See Supreme Tent of the Knights of Maccabees of the World $\nabla$. Cox, 25 Tex. Civ. App. 366, 60 S. W. 971, wnere the court held it was not error to submit the issue as being whether the plaintiff had become disabled to perform and direct any and all kinds of labor. To same effect, see Supreme Tent of the Knights of Maccabees of the World v. King, $79 \mathrm{Ill}$. App. 145, where the assured while working at a machine lost the fingers of his hand; the thumb not being injured. "Total disability naturally means being totally disabled from all kinds of business, unless by the contract the disability is to be only from the usual occupation of the assured."

30 Where the assured was so disabled that he could not follow his trade as a barber, but was able to engage in other occupations, and had run a restaurant and bad also clerked in a boot and shoe store since his disabllity, he cannot recover. Albert 7 . Order of Chosen Friends (C. C.) 34 Fed. 721. 
But in order to relieve the insurance company the assured must be able to perform work belonging to some recognized trade, occupation, or profession, and it is not sufficient that he can occasionally perform light and inconsequential duties not connected with any occupation. And this is a question for the determination of the jury. ${ }^{31}$

And it is also a question for the jury to determine whether an assured party is "totally disabled" in all cases where from the evidence there might be an honest difference of opinion among fair-minded men. ${ }^{82}$

31 See Starling v. Su,leme Council Royal Templars of Temperance, 108 Mich. 440,66 N. W. 340, 62 Am. St. Rep. 709. Here the court said: "The fact that a man may carry a bucket of coal, or" may carry a stick of wood, or perhaps may run a lawn mower over a lawn, will not in itself necessarily show that he is competent to follow some avocation. The fact that a man may work for a few moments, even though, perhaps, he may work for a few months, * * * is not conclusive evidence that he can follow some avocation. But if you find that he can perform some kind of employment, if you find, as suggested by the counsel in this case, that he can keep a newspaper stand or a peanut stand or could do any work, or follow any line of employment, why, then, under those circumstances, he would not be entitled to recover." In this case the policy contracted to pay indemnity for injurles which should produce absolute disability to follow any avocation. But where the policy agreed to pay indemnity where the assured shall be totally disabled from following his "usual or some other occupation," it was held that the company was liable unless the assured could follow some occupation "requiring substantially the same physical and mental ability as that in which he was usually engaged." The court affirmed a judgment for the plaintiff, who as a railroad brakeman was so badly injured that he could not follow that work, but was able to watch a milk car at much lower wages. Neill v. Order of United Friends, 149 N. Y. 430,44 N. E. 145,52 Am. St. Rep. 738, affirming 78 Hun, 255, 28 N. Y. Supp. 928.

32 The assured, a physician, was injured, and as a result thereof the evidence showed he was unable to continue the practice of his profession for a period of three months, and lost weight from 220 to 147 pounds, and was obliged to go away to recuperate; on the other hand it was shown by evidence that he had been seen on the street during the three months in question, and the insurance company introduced in evidence some fifty prescriptions shown to have been made by the assured during the time he was alleged to have

Fuller Acc.Ins. - 20 
What is Permanent or Continuing Disability.-Where the policy of accident insurance provides as a condition precedent to recovery that the injury must be of a permanent or continuing character, the company will not be liable where the disability is merely temporary in its nature. Under such a policy the assured will be permitted to recover for such time only as he is continuously and permanently disabled from conducting his business. ${ }^{33}$ The company will not be liable for any portion of the time, when he is able to perform any of the work pertaining to his occupation; and this is so, although he is able to perform only a small part of his regular duties. ${ }^{34}$

The disability of the assured must be continuous during. any

been "wholly and continuously disabled from transacting any and every kind of business pertaining to his occupation." The court held that it was error to admit testimony to the effect that the assured did not charge his patients for these prescriptions. The court declared: "The inquiry was, not what he received or charged for the professional work he did, but whether he did it, as showing that he was not disabled to do it." Preferred Acc. Ins. Co. v. Gray, 123 Ala. 482, 26 South. 517.

33 Gordon v. United States Casualty Co. (Tenn. Ch. App.) 54 S. W. 98. Here the plaintiff had his arm broken, and by reason of the injury and his ill health therefrom he suffered such total disability that he was unable to carry on his business from the time of the injury to the time of bringing the action, several months later, and it appeared from the evidence that the disability was likely to continue, the court held that he could recover under a policy indemnifying against loss from injuries which are immediately, continuously, and wholly disabling. See, also, Jennings v. Brotherbood Accident Co., 44 Colo. 68. Here the assured was so disabled that he was unable to perform any labor or pursue his usual calling during any period of his disability, though for a portion of that time, on the advice of his physician, he was out of doors nearly every pleasant day.

34 McKinley v. Bankers' Acc. Ins. Co., 106 Iowa, 81, 75 N. W. 670. Here the assured, a hardware merchant, severely injured one of his hands. At the end of four weeks, during which he was totally and continuously disabled, he was able to perform certain of the lighter work about the store, but was unable to handle the heavier articles, such as stoves, machinery, etc. Held, he could not recover beyond the four weeks. 
period of time for which he may recover. If the assured suffers a loss of business time, and afterwards his injuries improve so that he suffers no loss of time, he cannot recover for any period thereafter, although he may subsequently again suffer a total loss of time by reason of the accident. The loss of business time must be continuous, and after the loss of that time once ceases there can be no recovery, although there may be a recurrence of his disability. ${ }^{35}$ In this connection the word "permanent" means continuing without a break or interruption. ${ }^{36}$

The clause requiring that the assured must be "immediately, continuously, and totally disabled" does not refer to a case where the assured dies, and an action is brought to recover the full amount of the policy, but has reference only to losses growing out of disability to labor. ${ }^{37}$

35 Pacific Mut. Life Ins. Co. v. Branhạm, 34 Ind. App. 243, 70 N. E. 174. Here the assured was injured, and some days later underwent an operation which confined him in bed for four weeks, at the end of which time he was able to go to his office and perform a portion of his labor, which he did for nearly a month. He then again discontinued labor and was treated for his injuries for over two months, when he was able to move about on crutches with his injured limb in a plaster cast. But at the end of the month he was compelled to remove this and take treatment for two months and a half, and after another period, during which he was able to use crutches and a cane, he took treatment steadily for several months and was again operated upon. It was held that his disability was continuous within the meaning of the policy. Continental Casualty Co. v. Wade, 101 Tex. 102, 105 S. W. 35, reversing (Tex. Civ. App.) 99 S. W. 877. Here the company was not liable where as a result of an accident insured was totally disabled for fifteen minutes only following the accident, after which the assured resumed his labor and continued it for two months, though he then died in consequence thereof.

36 Grand Lodge, Brotherhood of Locomotive Firemen, v. Orrell, 206 Ill. 208 , 69 N. E. 68, affirming 109 Ill. App. 422. Here the court declared that the definition of the word "permanent" as meaning an injury that "will exist throughout all time" was unobjectionable, though it was intimated that the definition was probably too favorable to the insurance company.

37 Atna Life Ins. Co. v. Bethel, 140 Ky. 609, 131 S. .W. 523. 
The question of whether or not an injury produces continuous or permanent disability is one of fact, to be determined by the jury under proper instructions from the court. ${ }^{\mathbf{8 8}}$ Some policies of insurance cover partial permanent as well as total permanent disabilities, and under such policies the company will not be liable for injuries resulting only in temporary disability. ${ }^{39}$

Confinement to the House and Bed.-Policies of accident insurance differ in their requirement as to the degree of the disability for which they will be liable for the indemnity specified in the contract. Some policies require that the assured must be so disabled as to be incapable of earning a livelihood

88 Beach v. Supreme Tent of Maccabee, 77 N. Y. Supp. 770, 74 App. Div. 527. Here the assured was a tenant farmer, who kept a dairy and also ran a portable sawmill. While operating the saw, his right arm was injured and nearly severed. The evidence that this injury permanently destroyed the use of the right hand, and ultimately compelled him to abandon farming and milling altogether, was sufficient to sustain a finding that the disability was total, as well as permanent. In this case the policy contracted indemnity for total "or" permanent disability. The court held that it would not be affected by a subsequent amendment of the by-laws of the insurance company or society requiring the disability to be total "and" permanent.

39 Hollobaugh v. People's Ins. Ass'n, 138 Pa. 595, 22 Atl. 29. The certificate here stipulated for the payment of a weekly relief in the event of accidental injuries permanently disabling the assured either totally or partially. There was no provision in the certificate for the payment of any benefits for an injury which resulted in partial disablement, unless it was also of a permanent character. The court held that the liabllity of the company was not enlarged, so as to embrace cases of partial disablement of a temporary character only, by an indorsement on the certificate providing that if the assured shall sustain bodily injuries, whether partially or totally disabling, "by means as provided for in this certificate," the payment of the weekly relief should relieve the company from all further liabllity. The court held, properly, that the injuries referred to in the indorsement must be limited to the same classes, those permanent in their results, as are mentioned in the body of the certificate of insurance. Therefore no liability existed for a disability which was but temporary. 
or following his usual or any other occupation, while others demand that in order to recover the assured must be confined to his house or bed as a result of the injury. The clause differs in different policies of insurance, and its construction will naturally depend upon its verbiage. The condition is binding upon the assured, and is a condition precedent to his right of recovery. Under such a condition the injury upon which the action is brought must not only totally disable the assured, but must also confine him to the house. ${ }^{40} \mathrm{~A}$ much stricter rule is applied in the construction of health policies, insuring against disability resulting from sickness, than in the case of accident policies. ${ }^{41}$

40 Bishop v. United States Casualty Co., 99 App. Div. 530, 91 N. Y. Supp. 176. Here the policy required that the slckness or injury must not only render the assured wholly unable to transact his business, but must "necessitate continuous confinement indoors and treatment by a regularly qualified physician." The court held that the assured could not recover unless his disabllity was such "as reasonably to necessitate continuous confinement to his house and medical treatment." In Dunning v. Massachusetts Mut. Acc. Ass'n, 99 Me. 390, 59 Atl. 535, the pollcy made "absolute and necessary confinement to the house" an indispensable measure of the disability which will entitle the assured to indemnity. The assured suffered from an attack of iritis, a disease of the eyes, which totally disabled him from attending to his business, but did not make necessary his confinement to the house. After a short time he was able to go out by wearing dark glasses as a protection to his eyes. The court held that "absolute and necessary confinement to the house" was under the policy a condition precedent to recovery, and therefore the company was not liable.

41 Cooper v. Phœnix Accident \& Sick Ben. Ass'n, 141 Mich. 478, 104 N. W. 734. Here a sick benefit policy undertook to indemnify the assured for such time as he should be "necessarily, entirely and continuously" confined to the house. The assured suffered from a bone felon on a finger which was twice amputated. The evidence showed that he was not confined continuously to the house, and that he frequently visited the doctor's office, the drug store, post office, and other places. The court held that there could be no recovery where the assured was not entirely confined to the house, but went out for an airing, even under his physician's orders. Lieberman v. Columbia Nat. Life Ins. Co., 47 Pa. Super. Ct. 276. Here the policy provided for indemnity when illness "necessarily confines 
The more reasonable rule, and one more in line with accepted authority, particularly with regard to accident policies, is that which holds the confinement to the house to be a fact merely evidentiary of the total disability of the assured to follow his occupation. And the fact that the assured, while totally disabled, may go from his house to an outbuilding for some necessary purpose, or under the advice of a physician and for the purpose of promoting his recovery may sit in a chair or recline in a hammock on the porch, or even stroll about the yard, will not prevent a recovery. The assured is to all intents and purposes confined to the house. ${ }^{42}$ And the

the insured to the house and prevents the insured from performing any and every kind of duty pertaining to his occupation." The assured, suffering with an attack of bronchitis, visited the doctor's office every day, and under the physician's orders spent an hour each day in the open air, and, though occasionally visiting his office, was incapable of performing any duty pertaining to his occupation. The court held that he could not recover under the policy. See, however, Ramsey $\nabla$. General Accident, Fire \& Life Ins. Co., 160 Mo. App. 236, 142 S. W. 763 , where a more liberal rule was followed, and though the policy denied liability, except where the assured was "continuously confined within the house," he was permitted to recover where he was unable to attend to his business, and was confined to the house a large portion of the time, but went out frequently, and even visited another city to consult specialists and receive treatment.

42 In Metropolitan Plate Glass \& Casualty Ins. Co. v. Hawes' Ex'x, $150 \mathrm{Ky} .52,149 \mathrm{~S}$. W. 1110, the policy provided an indemnity "for the period of such disablement during which he shall be continuously and necessarily confined to the house and during which he shall be continuously under the care of and regularly treated by a legally authorized and licensed physician." The assured, suffering from tuberculosis, was directed by his physician to take fresh air, and in obedience thereto in warm weather sat out on the porch. The court sald: "In our opinion the purpose of the clause copied above was to. allow a weekly indemnity to the assured whenerer he became so sick as to be continuously and wholly unable to perform any and every kind of duty pertaining to his occupation. Evidently, this was the intention of the parties to the contract, and, If he was actually and continuously so sick that he was not able to perform any kind of labor for a period of twenty weeks, he is entitled to the weekly indemnity. The other part of the clause, which says that he must be confined to the house and regularly 
assured is still confined to the house where, under his doctor's orders and while incapacitated for work, he occasionally leaves

treated by a licensed physician, was intended only to give the company evidence of his sickness and inability to labor, so that it would not be compelled to pay claims of mere malingerers, which was a reasonable requirement. Appellant makes no claim that [assured] was not treated by a physician as required in the policy, but claims that he was not actually confined in the house all the time, as it claims the policy required. Appellee's deceased was affected with tuberculosis, and it is of common knowledge that a person in that condition requires fresh air and as much as possible, and he testified that while he was actually sick, and would have felt much better in the house and in bed, his physician ordered him to get out in the open as much as possible, and he did so. He sat on the porch at times as the weather was warm. In addition to this, the policy does not, in terms, require the assured to be necessarily and continuously confined in the house. It says 'to the house,' and we are of the opinion that the confinement of the insured in this case, as described in the evidence, was a full compliance with the terms of the contract. It would be unreasonable to hold that the language of the policy required him to be necessarily and continuously confined in the house at all times, when the testimony shows conclusively that he was actually sick as provided in the contract, and the taking of fresh air was directed by his physician for his benefit, and when his staying out of doors would have a tendency to shorten the duration of his sickness and thus lessen the amount of appellant's liability." To the same effect, see National Life \& Accdent Ins. Co. v. King (Miss.) 59 South. 807. Scales v. Masonic Protective Ass'n, 70 N. H. 490, 48 Atl. 1084. Here the assured was seriously sick and totally incapacitated for labor during a period of sixty-seven days. He remained in the house the first five days, and after that, under the direction of his physician to keep in the open air all he conld and stir around as much as his strength would allow, he was in his dooryard a portion of the time, sitting in a chair or lying in a hammock. The court here said: "It is unreasonable to suppose that the defendants understood and intended that if the insured, although totally disabled from labor by sickness, should go from bls house to an outbuilding for a necessary purpose, or should by the advice of his physician and for the purpose of recovery sit in a chair or lie in a hammock on the piazza of his house or his dooryard, this departure from the strictly literal meaning of the words used to describe the evidentiary fact (if it be a departure) should defeat the object of the contract. Such supposition cannot be entertained without an accompanying inference that the defendants intended to deceive the insured." 
the house and goes to the doctor's office for treatment. ${ }^{43}$ The courts have even held that where the assured, under orders from his physician, goes to another city for medical treatment, he is still confined to the house under the terms of such a condition in a policy of insurance. ${ }^{44}$

43 Mutuai Ben. Ass'n v. Nancarrow, 18 Colo. App. 274, 71 Pac. 423. Here the court said: 'The words 'totally disabled,' as well as the words 'confined to the house,' must receive a reasonable interpretation. The purpose of the policy was to indemnify the plaintiff against loss occasioned by inability to attend to his work or business. * * * The plaintiff might have been able to walk, he might have been able to ride on the cars to his physician's office, and still have been entirely incapacitated for work or business. * * Nor do we think that the words 'confined to the house' were intended to mean a constant restraint within doors. One may be sick, and still be able to move about, and, on occasion, temporarily to pass to the outside. A complete and enforced withdrawal from business or work was undoubtedly necessary, under the policy; but exceptional and temporary absences from the house are not inconsistent with the idea of a general confinement within it. The complaint says that the plaintiff was confined to the house, except at interrals, when he rode on the cars from his house to his physician's office; and we think a sufficient confinement is alleged to answer the requirements of the policy." Dulany v. Fidelity \& Casualty Co., 106 Md. 17, 66 Atl. 614. Here the assured was suffering from tuberculosis, and the policy of health insurance contracted to pay indemnity for such time as he might be "confined to the house." Under the advice of his physician the assured went to a sanatorium in the Adirondacks for treatment, and spent his time almost entirely upon the porches of a house, leaving it only occasionally for the purpose of visiting his physician. The court declared that the phrase "confined to the house" should be construed to mean "confined to any part of the house, either inside of the doors or upon the porches or verandas attached to it on the outside."

44 Hoffman v. Michigan Home \& Hospital Ass'n, 128 Mich. 323, $87 \mathrm{~N}$. W. 265,54 L. R. A. 746 . The court charged the jury, inter alia: "To constitute a compliance with this provision, it is not necessary that the plaintiff should remain in the house continuously during the entire time of disability; that to step out of doors now and then, or to occasionally go to the office of his physician, would not be a violation of this clause or defeat plaintiff's right of recovery. It may be that an occasional airing is essential to a speedy recovery. A rule which wouid make nugatory a contract having for its special object indemnity on account of sickness, because the insured took an occasional airing, would be unreasonable. Was the 
But the company will not be liable where the assured, although confined to the house for the larger portion of the time, is none the less able to visit frequently his place of business. ${ }^{45}$

Where the policy of insurance provides that the company will not be liable, except where the assured is actually confined to his bed, no indemnity will be recoverable, except for the time actually and necessarily spent in bed. ${ }^{46}$ Policies of accident or health insurance frequently stipulate that the company will not be liable for any period of injury and confinement of less than a week's duration, nor where the assured has not had the regular and periodical services of a physician. ${ }^{47}$

General Principles Determining Amount of Liability of Insurer.-Where an accident insurance policy contains a clause stipulating a weekly indemnity for disabilities arising

plaintiff * * * continuously confined to his house on account of such sickness, to the extent that he was necessarily and in good faith there the larger portion of the time, and only went forth from necessity for consultation with, or by direction of, the physician in whose charge and care he was? An answer to this question will determine this branch of the case."

45 Shirts v. Phœnix Accident \& Sick Benefit Ass'n, 135 Mich. 439, $97 \mathrm{~N}$. W. 966. Here the assured was able to visit his place of business each day and sit there a couple of hours superintending matters.

46 Gainor v. St. Lawrence Life Ass'n, 46 N. Y. Supp. 965, 21 Misc. Rep. 27. Here the court declared that there could be no recovery where, although the assured suffered from malaria for several weeks, he was confined to the bed for only one day, and the policy stated that disability must be evidenced by actual confinement in bed, that seven full days shall contribute a week's sickness, and that no indemnity will be paid for a less period.

47 Liston v. New York Casualty Co., 58 N. Y. Supp. 1090, 28 Misc. Rep. 240. Here the policy provided that no disability should constitute a claim where claimant should be able to leave his bed, nor during any period of convalescence, nor where a physician should not be required every second day. It was held that the insured could not recover for twenty-two weeks' sickness, where he was confined to his bed for only about ten weeks, and after that occasionally returned to bed, and at times went out for air and recreation, and made a visit out of town for his health, all within the 
from an accident, the beneficiary cannot recover anything where the insured is instantly killed by an accident, unless the policy also expressly provides for the payment of a principal sum in such event. Death is not a total disability within the meaning of an accident insurance policy. Such a policy is merely a contract to indemnify the assured against loss of time and earning capacity resulting from an accident by the payment of the specified amounts, and does not contemplate insuring against death by accident for the benefit of another or for the benefit of his estate. The contract to pay a weekly indemnity for disabilities is an agreement entirely separate and distinct from any undertaking to pay a principal sum for death. ${ }^{48}$

But if death does not ensue immediately after the accident, the beneficiary or the estate of the assured can recover the weekly indemnity only for that period of his disability which elapsed prior to the date of his death. ${ }^{49}$

twenty-two weeks, and where a physician attended him but once. See, also, Schneps v. Fidelity \& Casualty Co. of New York (Sup.) 101 N. Y. Supp. 106. Here the policy provided that the company would pay a specified sum per week for the period of disability during which the assured should be "necessarily confined to the house." The court said: "It does not appear that it was on account of disability alone that the weekly payment was to be made. It was conditloned on dlsability and necessary confinement to the house for a week."

48 Hall v. American Employers' Liability Ins. Co., 96 Ga. 413, 23 S. E. 310. In this case the clause providing for the payment of a principal sum in the event of the death of the assured was left blank. The assured was instantly killed in a rallroad accident, and his widow brought suit to recover the weekly indemnity for the period of fifty-two weeks specified in the policy as for total disability. She was not permitted to recover. See, also, Shaw v. Equitable Mut. Acc. Ass'n, 5 Neb. (Unof.) 584, 99 N. W. 672.

49 Rosenberry v. Fidelity \& Casualty Co., 14 Ind. App. 625, 43 N. E. 317. Here the court said: "Whatever indemnity had accrued up to the time of the death of the insured could be collected by such personal representatives * * because it is a debt which was due to the decedent in his lifetime." 
The liability of an insurance company for injuries becomes fixed at the time of the accident, and the amount of the indemnity and the person to whom it shall be payable are both contingent upon the character and result of the injury which is sustained. It is not, however, contingent upon the continuation of the life of the policy after the date of the accident. And if the accident occurs before the expiration of the policy, it will not relieve the company of liability that the policy expires before the death of the assured, or that the total disability continues after the date on which the policy expires. For example, if a policy of accident insurance expires on June 25 th, and the assured is injured on June 15 th by an accident which totally disables him for a period of thirty weeks, the company will be liable for the weekly indemnity for that period, although it runs considerably past June 25 th, the date of the expiration of the policy. Similarly, if a policy provides a principal sum for the death of the assured, which shall result within ninety days of the date of the injury, and in the same hypothetical case the assured meets with an accident on June 15th, from which he dies on August 1st, the company will be liable for this principal sum, although the policy expired on June 25th. The liability of the company is not contingent upon the continuation of the policy after the date of the accident. There is no obligation resting upon the assured to continue the policy after his accident, nor will his failure to continue the policy result in forfeiting any indemnity for injuries theretofore received, or in discharging the insurer from liability theretofore incurred.

While the membership ceases, the legal liability of the company for previous accidental injury remains. Cessation of membership, whether voluntary or involuntary, operates prospectively, and not in derogation of acquired rights, or in release of antecedent liability. Liability attaches immediately 
upon the occurrence of the injury. ${ }^{50}$ However, the claim for death does not accrue until the death of the assured actually occurs. Similarly, a claim for the loss of a limb or the loss of time by reason of disability does not accrue until the limb or the time, as the case may be, has actually been lost. ${ }^{51}$ In the case of an accidental death, a vested interest accrues to the beneficiary, not when the accident happens, but at the time that death occurs in consequence thereof. ${ }^{52}$ Of course, the expiration of the policy relieves the company from any claim for damages or indemnity resulting from an accidental injury occurring thereafter.

Where a policy insures in a certain sum against loss of life from accidental injuries occasioning death within ninety days from the accident, and in a lesser sum per week for a certain

50 Burkheiser v. Mutual Acc. Ass'n of the Northwest, 61 Fed. 816, 10 C. C. A. 94,26 L. R. A. 112 . Here a policy in a mutual benefit association insured against death resulting from accidental injuries within ninety days after the accident. After the accident, but before the death of the assured, who died within ninety days of the accident, the assured ceased to be a member of the association because of default in paying an assessment falling due after the accident. The court said that the failure of the assured to pay the assessment did not relieve the company of liability, since the accident happened before the assessment was due, and the liability of the company became fixed at the time of the accident.

51 Knowiton v. Equitable Acc. Ins. Ass'n, 175 Mass. 196, 55 N. E. 890 , and Knowlton v. Bay State Beneficial Ass'n, 171 Mass. 455, 50 N. E. 929. The assured held a policy in an assessment insurance company against loss of time by reason of accidental injuries, and also for a stated sum in case of death resulting within ninety days after the injuries. He was injured June 28th and died August 31st. In the interim, on August 12th, a receiver was appointed for the company on a bill filed August 9th. The Revised Statutes of Massachusetts provide that in case of insolvency any unexpended portion of the emergency fund is to be first applied to the payment of "accrued claims." The court held that the claim for death was not an accrued claim, and that claims for disabllity were divisible, and had accrued only to the time of the filing of the bill for a receiver.

52 Woodmen Accident Ass'n v. Hamilton, 70 Neb. 24, 96 N. W. 989; Id., 70 Neb. 30,97 N. W. 1017. Here the insurance company settled with the assured for all claims which be "had or might 
period of weeks against personal injuries "for any single, accident by which the assured shall sustain any personal injury which shall not be fatal," the weekly sum is due for injury by an accident which does not occasion death within ninety days, although it is finally fatal. ${ }^{.3}$

Under a policy providing for the payment of a weekly indemnity for total disability, the assured is entitled to weekly payments after making satisfactory proofs of the injury, and is not required to wait before beginning action for the loss of time until the disability ceases, or until the number of weeks for which the company assumes liability have terminated, unless the policy expressly states that no action shall be brought until a specified time. ${ }^{54}$ In such an action the assured can recover only the amount which has accrued in his favor at the time of bringing the suit. The policy may provide that no benefits shall be due until disability ceases or the right to the benefit has terminated. Naturally such a provision would not apply in case the assured is permanently totally disabled; otherwise, a recovery would be prohibited

have" against the company. But the settlement made no express reference to the beneficiary, nor to future accruing claims. The court held that this referred only to the then accrued claims for disability, and not to the subsequent death of the insured, and hence was no defense to the death claim.

53 Perry v. Provident Life Ins. \& Inv. Co., 99 Mass. 162; Id., 103 Mass. 242. The assured had his arm crushed by an accident December 11, 1866, and continued to be absolutely and totally disabled from the prosecution of his usual employment until March 12, 1867, when he died from the effects of the accident. The policy provided for the payment of a principal sum of $\$ 2,000$ in the event of the accidental death of the assured within ninety days after the accident, and, for injuries which should not be fatal, the sum of $\$ 10$ per week for a period not exceeding altogether twenty-six weeks. It was held that the beneficiary could recover $\$ 10$ per week for the time between the date of the accident and the death of the assured.

54 Kentucky Life \& Accident Ins. Co. v. Franklin, $102 \mathrm{Ky} .512,43$ S. W. 709 . 
until after the death of the assured.55 Nor will such a provision terminate the right of the assured to weekly indemnity on a policy where, after an accident resulting in complete disability, he prematurely goes out and thereby prolongs his disability. ${ }^{56}$

A provision in a policy that it must be in effect twelve months prior to the death of the assured, before the insurer will be liable, does not relieve the insurance company from liability for an accidental injury resulting in death, where the premium for the year has been paid and accepted by the company. ${ }^{\text {st }}$

A policy may provide that, where the assured has become totally and permanently disabled by reason of accident from following any occupation whatever, he may be paid onehalf the amount of the principal sum of the policy at his option. And in a mutual benefit society, with such a bylaw, where the certificate or policy contains no reference to such a provision, the by-law is none the less a part of the insurance contract, and the holder of the certificate is 190.

58 Binder v. National Masonic Acc. Ass'n, 127 Iowa, 25, 102 N. W.

56 Maryland Casualty Co. v. Gehrmann, 96 Md. 634, 54 Atl. 678. On March 22d the assured fell, seriously injuring his knee, resulting in his complete disability within the terms of the policy. On May 11th he prematurely left the house, thereby bringing on a hemorrhage of the knee. The prayer of the company that the recovery be limited to the day he left the house was denied.

${ }^{7}$ Summers v. Fidelity Mut. Aid Ass'n, 84 Mo. App. 605. A policy was issued January 4th, and the assured died as a result of accidental injuries on November 27 th following. The policy provided that it must be in force twelve months prior to death before the insurance company would be liable. The court held that the acceptance of a premium for one year rendered the insurer liable, despite this provision, and the fact that the policy provided for other insurance than death makes no difference, since the premium was not apportioned. 
entitled to exercise that option. ${ }^{58}$ In mutual benefit associations the constitution and by-laws may be consulted in order to ascertain the amount of the benefits to which the assured is entitled, since they are in effect a part of the certificate of insurance. ${ }^{59}$ And an association cannot, by amendments to its by-laws, reducing the amount of its liability in the event of accidents to the insured, prejudice the rights of a member whose certificate was issued prior to the passage of such amendments. ${ }^{00}$

Where a policy provides for the payment of weekly indemnity for permanent disability and for temporary total disability, and also stipulates that such payments shall be made only during the time that the assured is under the care of a physician or surgeon, or in case of amputations only until they have healed, such limitations upon the amount to be paid will apply only when the disability is temporary. ${ }^{61}$

58 Monahan v. Supreme Lodge of the Order of Columbian Knights, 88 Minn. 224, 92 N. W. 972.

59 Corley v. Travelers' Protective Ass'n, 105 Fed. 854, 46 C. C. A. 278. This is particularly true where a statute requires a copy of any portion of the constitution and by-laws referred to in the certificate to be attached thereto.

80 Beach v. Supreme Tent, Knights of Maccabees, 177 N. Y. 100, 69 N. E. 281.

81 Cook v. Benefit League of Minnesota, 76 Minn. 382, 79 N. W. 320. Here the assured, a stereotyper, met with an accident necessitating the amputation of the fingers of both hands, by which he was permanently and totally disabled from performing the duties of his occupation, within the terms of the policy. The policy provided for the payment of a certain sum per week for such total permanent disability for a period not exceeding fifty-two weeks, and also provided for indemnity at the same rate for loss of time by temporary total disability or by sickness caused by disease. The application and by-laws provided that benefits would be allowed only while the assured was under the care of a physician or surgeon, or, in the case of amputation, until the wounds were healed. The court held that these provisions did not apply to such a case as the one in action, but only to cases of temporary total disability and to cases of 
In a policy providing for a fixed weekly indemnity of a certain sum in the event of total disability of the assured, he will be able to recover that amount during the entire period of such disability. And where the policy provides that the assured shall be entitled to a certain sum per week as indemnity for total disability, provided that the assured shall not be entitled to indemnity in excess of his salary or the money value of his time, the amount of his salary will determine the maximum amount of the weekly indemnity which he may recover. But where there is nothing to show what salary the assured receives, or what the money value of his time actually is, he can recover the amount per week specified in the policy. ${ }^{62}$ And so where the policy provides that the amount of weekly indemnity to which the assured shall be entitled shall be in the same ratio that his weekly

sickness or disease, and that the assured was entitled to recover for the whole fifty-two weeks, even though the amputations healed before the end of that time. He was under the care of a physician only two months, and the wounds caused by the amputation of his fingers healed in somewhat less than nine weeks after the injury. The court admitted that the language was ambiguous, and, in accordance with the law, construed it most strongly against the insurer and in favor of the assured. A distinction was suggested to the effect that if the toes of the assured had been amputated the injury would have resulted only in total temporary disability, and when the wounds healed over he would cease to be disabled and the indemnity would terminate.

See, also, Chicago, B. \& Q. R. Co. v. Olson, 70 Neb. 559, 97 N. W. 831. Here the relief department of a railroad company in its policy contracted with an employe for the "payment for each day of disability by reason of accident." The regulations governing the issuance of these policies provided that the word "disability" should be beld to mean physical inability to work. The court deciared that the decision of the medical examiner that the plaintiff, who had suffered amputation of a leg as the result of bis injury, was "able to work," would not be construed to mean that the assured had recovered from his disability, when the evidence showed that the examiner at the same time declared plaintiff "able to do light work at present, * * but he is still disabled."

62 Crenshaw v. Pacific Mut. Life Ins. Co., 71 Mo. App. 42. 
income bears to the amount of indemnity for which he is insured, the assured can recover only that amount. This is true, although the assured by the payment of larger premiums has been placed in a higher class. ${ }^{63}$ And where the recovery is limited to the amount of the weekly salary of the assured, reference is had to those who receive a weekly salary and does not limit the right of recovery of those who are insured without occupation in the preferred class. ${ }^{64}$

These clauses or conditions are inserted in insurance policies so as to discourage fraud and secure the company against claims inspired by a desire to make money by pretended injuries. To make injury profitable would be to put a premium upon defrauding insurance companies. But where the policy provides for the payment of a certain weekly indemnity, with the proviso that the assured shall be permitted to "recover no more than the money value of his time," the indemnity covers the loss sustained by the assured by virtue of the injury, and also the value of the time of the assured outside of his regular occupation. And the assured may recover the amount of the fixed weekly indemnity, provided he recover no more than the money value of his time. In this connection it may not be necessary for the assured to prove the value of his time in the occupation

63 Howe v. Provident Fund Soc., 7 Ind. App. 586, 34 N. E. 830. In such a case, while the assured can recover only the smaller weekly indemnity, he can, however, recover back the excessive premiums which he has paid.

64 Denison v. Masons' Fraternal Acc. Ass'n, 59 App. Div. 294, 69 N. Y. Supp. 291. In this case the policy contained the provision that "in no case shall the weekly indennity exceed the weekly salary of the insured," and also the clause that "this certificate does not cover accidents or injuries to persons who have ceased to follow any regular occupation, except such persons as are insured as preferred." It was held that the former clause referred only to those persons receiving a weekly salary, and did not limit a recovery by one insured in the preferred class, as a farmer who bad retired.

Fuller Acc.Ins.-21 
under which he is assured, since his time may also be of value outside of his regular employment. ${ }^{65}$

And where the policy provides a weekly indemnity against the loss of the money value of the time of the assured, he may recover for the time actually lost, within the amount of the weekly indemnity specified, even though his pay continue during the period of the disability in question. ${ }^{66}$

And the policy may provide that in the event of total disability the company may at its option pay one-half of the principal sum named in the policy for death in complete discharge of the contract. This corresponds to those contracts where the assured may, upon proof of his total dis-

65 Bean v. Travelers' Ins. Co., 94 Cal. 581, 29 Pac. 1113. Here the assured was insured in the sum of $\$ 50$ per week against loss of time, provided he recover nothing in excess of the money value of his time. He was insured as a capitalist, and the court declared that it was not essential that he prove the money value of his time in the occupation named in the policy, but that he might recover for the money value of such time at a rate not exceeding $\$ 50$ per week.

See, also, Travelers' Ins. Co. of Hartford v. Ebert (Ky.) 47 S. W. 865. Here the policy provided that "this ticket insures females against death only." It was issued to a woman in the hurry of travel by an agent of the company in response to her request and an oral contract to Insure her against loss of time by accident, and she paid the premium charged by the company for tickets insuring persons against loss of time as well as death. The court declared the company must pay the indemnity provided for loss of time where she was disabled by an accident, and held that the company was thus bound by the representations and contracts of insurance made by an agent authorized to make any contract of insurance.

6 6 Globe Acc. Ins. Co. v. Helwig, 13 Ind. App. 539, 41 N. E. 976 , $55 \mathrm{Am}$. St. Rep. 247. Here the assured was insured "against the loss of the money value of his time, not exceeding $\$ 25$ per week." His pay was continued by his employer during the period of his disability. The court said: "If by reason of an injury insured against, appellee actually lost the time from his business, he was entitled to recover the money value thereof up to $\$ 25$ per week, even though his pay was continued during his disability. We can see no more reason in holding such payment to inure to appellant's benefit than there would be for refusing to one wrongfully injured by another the right to recover the value of medical services and nursing, because gratuitously rendered." 
ability, demand the payment of one-half of the face of the policy. This is merely an option, to be exercised in the discretion of the party in whom it is vested by the contract. ${ }^{6:}$;

The fact that the assured has received a sum in settlement of one accident in no way affects his right to recover for injuries sustained by a subsequent injury within the terms of the policy. Unless the policy provides that upon the settlement for one injury the policy must be surrendered, it will indemnify the assured against loss by successive injuries within its terms. ${ }^{68}$ And the assured may claim co-ordinate indemnities where the policy provides for separate and different indemnities for different disabilities, as, for example, the loss of eyesight and total disability. Here the different claims for indemnity arise under separate clauses or provisions of the policy, and in the absence of any agreement to the contrary the discharge of one indemnity will not operate as a bar to the enforcement of the liability of the company on the other. This is particularly true where a specific disability results from an accident after the claim for temporary or total disability has been made, and the existence of the specific disability was at the time unknown. ${ }^{69}$ However, many policies of insurance prevent

67 See Worthen v. Massachusetts Ben. Life Ass'n, 53 N. Y. Supp. 685, 24 Misc. Rep. 437; Knowlton v. Bay State Beneficiary Ass'n, 171 Mass. 455,50 N. E. 929 ; Monahan v. Supreme Lodge of Order of Columbian Knights, 88 Minn. 224, 92 N. W. 972.

68 Martin v. Equitable Acc. Ass'n, 16 N. Y. Sup. Ct. 279, 61 Hun, 467, and Martin v. Manufacturers' Acc. Indemnity Co., $60 \mathrm{Hun}, 535$, $15 \mathrm{~N}$. Y. Supp. 309. Here the assured was injured by an accident on April 8th, and on April 13th he executed a receipt for $\$ 25$ in full satisfaction and final settlement of all claims by reason of the injuries received on that day. On April 27 th he received another injury, from which he died on May 10th. The beneficiary was permitted to recover for the death of the assured.

69 Cunninghain v. Union Casualty \& Surety Co., 82 Mo. App. 607. The assured fell from a tree on June 26th, sustaining severe bruises and cuts. July 25th he presented a claim for loss of time from his 
such double liability by expressly providing that the liability of the company under one clause of the policy will discharge its liability under any and all other clauses thereof. And unless the policy contains a definite provision to the contrary, the assured can recover for more than one specific loss or liability, as where he loses an arm or a leg together with his eyesight, or where he loses such a member of the body and is also totally disabled from following his occupation within the terms of the policy.

Where the policy provides that not more than one amount shall be payable for one or more operations performed as the result of one accident, the insurer will not be liable for a reamputation, where such becomes necessary owing to the failure of the original amputation..$^{70}$

occupation by reason of these disabilities. This claim, amounting to $\$ 51.78$, the insurance company paid on July 28 th, and he returned a signed voucher reciting that in consideration of said amount he discharged and released the company from all claims under the policy for indemnity resulting from said accident. August 4th the assured gave notice to the company of the loss of the "entire sight" of his left eye, a specific disability within the terms of the policy. The court held that the payment was indemnity for disability mentioned under one provision of the schedule, and there was no consideration for the release of the company from liability under other provisions of the schedule, and that at the time of that payment the specific disability was not in the minds of the parties, since the assured did not at that time know that he would loose the sight of the eye. Hastings v. Bankers' Acc. Ins. Co., 140 Iowa, 626, 119 N. W. 79. Here a provision in the policy forbade the assured to recover for more than one injury under one clause; but he was also permitted to recover for separate injuries under another clause where they resulted from the same accident, but were not mere complications of the other injury, as where he suffered broken ribs, and also a broken sternum. See, also, Anderson v. Aitna Life Ins. Co., 75 N. H. 375, 74 Atl. 1051.

70 Anderson v. Atna Life Ins. Co., 75 N. H. 375, 74 Atl. 1051, where a reamputation of the arm was necessary. But the court expressly stated that the company was not thereby released from liability for amputations of different members of the body which might be necessitated from a single accident. 
And where the assured has received two injuries at different times, and would not have died but for the last injury, the company is liable, though that injury would not have proved fatal but for the first. ${ }^{71}$

And where the assured has made claim for a period of total disability, and the claim has been paid, and a receipt given in full for all claims and demands resulting from the injury, and he has resumed his occupation, he cannot recover any further indemnity, where he is subsequently disabled and such disability is merely a continuance or recurrence of the original disability for which settlement has been made. ${ }^{72}$

71 Baehr v. Union Casualty \& Surety Co., 133 Mo. App. 541, 113 S. W. 689. Here the court said: "If one insured is injured, and then afterwards is again injured, and then dies within the time limited by the policy, and would not have died but for the last injury, he may recover, even though the last injury would not have been fatal but for the first. Otherwise one weakened by disease or injury, so as to become less able to withstand a succeeding injury, which is the immediate cause of the death, would be unprotected."

72 Wood v. Massachusetts Mut. Acc. Ass'n, 174 Mass. 217, $54 \mathrm{~N}$. E. 541. Here the assured was insured against bodily injury by a weekly indemnity and in a principal sum for death resulting from such injuries alone within ninety days. August 4th Wood, while bathing at the seashore, sprained his ankle. He at once went home and had a doctor, who attended him until September 10th. September 17th he signed an application for indemnity at the weekly rate from August 4th to September 17th, and signed a release receipt reading, "which, when paid, shall be in full discharge of all claims which I have or may have on account of the personal injuries aforesald." A check was sent him for the amount. The check was not cashed. After September 17th the assured twice went to his factory out of town, went to his office, and took an extended business trip. He returned home September 28th, when he was much worse. His leg was badly swollen, and he was in bed practically all the time between September 28th and October 17th, when he died. He had no medical attendance between September 12th and the 28th of that month. An autopsy showed that an embolism had formed, which had gone through the heart and caused death, all of which was the result of the injury of August 4th. The court held that, in the absence of any fraud on the part of the company, the assured had by 
Naturally where the assured signs a receipt for indemnity for disability resulting from an accident to the date thereof, he may recover indemnity for such period of disability as may ensue after that date. ${ }^{73}$ This is particularly so where the payment for which the receipt is given is by way of indemnity for disability under the weekly indemnity clause, and the policy also nominates a principal sum to be paid in the event of death to a beneficiary, and the assured dies after the payment of the weekly indemnity. ${ }^{74}$ After the period

his receipt released the defendant from all claims under the certificate for the injury.

Clanton v. Travelers' Protective Ass'n, 101 Mo. App. 312, 74 S. W. 510 , where the assured, after receiving weekly indemnity for a period of disability and recovering sufficiently to resume his usual occupation, became subsequently disabled as a result of the same injury, by reason of an abrasion of the wound, at the time about healed, and filed a claim for the subsequent period of disability. The court held that the first payment in full was a bar to any further recovery of indemnity on account of the injury.

See, also, 'Travelers' Ins. Co. v. Thornton, 119 Ga. 455, 46 S. E. 678; Continental Casualty Co. v. Wade, 101 Tex. 102, 105 S. W. 35, reversing (Tex. Civ. App.) 99 S. W. 877; Blckford v. Travelers' Ins. Co., 67 Vt. 418, 32 Atl. 230.

73 See Pacific Mut. Life Ins. Co. v. Branham, 34 Ind. App. 243, 70 N. E. 174. Here the assured fell and injured his knee while bowling. The knee swelled badly, and an operation was necessary, whlch confined him in bed for four weeks, at the end of which time he was able to go to his office and perform a part of his labor, which he did for nearly a month. At that time he discontinued labor and was again treated for his injuries for several months. The court held that his disabllity was continuous, and that where the assured made proof of his disability and loss of time to a certuin date, under the advice of a physican that he would soon get well, he was not thereby precluded, in an action on the policy, from claiming the amount due for disability continuing after that date. It is to be noted in this case, however, that at no time in the interim had the assured really recorered from the disability, but was able to perform only a part of hls work at the time he was able to go to his office. The court sald: "After the loss of business time once ceases, there can be no recovery after that time, although there may be a recurrence of the loss of time."

74 Woodmen Acc. Ass'n v. Hamilton, 70 Neb. 24, 96 N. W. 989, supra. See, also, Lord $\nabla$. American Mut. Acc. Ass'n, S9 Wis. 19, 
of disability once ceases, and the assured returns to his occupation, there can be no further recovery, although there may be a recurrence of the loss of time as a result of the injury.

Where the insurance policy provides for indemnity only while the assured is under the care of a physician or surgeon, he will not be permitted to recover for any time before he actually receives the attention of the physician or after the physician has been dismissed. Where he is under such care for only a portion of his disability, he will be permitted to recover only for the time that he was actually under such treatment. ${ }^{75}$

Double Liability and Amount of Indemnity Determined by the Cause of Injury or Death-Passengers-Public Conveyance.-Liability on policies of accident insurance varies frequently with the nature of the injury, the circumstances

61 N. W. 293,26 L. R. A. 741, 46 Am. St. Rep. 815 . In this case, on the claim of the assured for indemnity for the loss of a hand, the insurance company alleged a full settlement, and produced proofs of loss signed by the plaintiff with his mark, in which he claimed a weekly indemnity for an injury to his hand, and stated that, when paid, it should be in full discharge of all claims. The plaintiff was allowed to show by parol evidence that he could neither read nor write English, and that he signed such proofs of loss without knowing that they contained the statement as to a discharge in full, and that upon receiving the amount of the weekly indemnity he refused to sign a receipt in full.

75 Hayes v. Continental Casualty Co., 9S Mo. App. 410, 72 S. W. 135. The policy in this case provided for a weekly indemnity for such period only as the assured was under the care of a physician. The assured was injured while in Texas, as he claimed, by jumping from a freight train under apprehension of a wreck. He landed in a ditch and was injured about the breast and ankle. He claimed not to know where he was, and that he was taken to a farm house by a stranger, and that he remained there for some six weeks, when he came to his senses and wished to be removed to his home in Missouri. Upon arriving there he went to bed, but claimed still not to know where he was. He had no physician at any time until he arrived in Missouri from Texas. The court held that he could not be permitted to recover for the loss of time during which he had no surgeon. 
under which it occurs, and the occupation of the assured at the time of the accident from which the disability ensues. The policy may contain conditions exempting the company from certain risks of the nature already discussed. It may also contain a provision that in the event of disability or death resulting from certain injuries, or from injuries received under certain conditions, the amount of the weekly indemnity or principal sum shall be either limited to a smaller amount or increased to a larger figure than that nominated in the face of the policy. For example, the policy may provide that, if the injury which produces the death or disability occurs while the assured is walking on the roadbed or bridge of any railway, the beneficiary shall be entitled only to the indemnity or death loss provided in the classification for railway employés insured to cover such risks. ${ }^{76}$ Also a clause may provide that the liability of the insurance company shall be limited to the amount of the premiums paid in the event that the assured is intentionally injured by another person. ${ }^{77}$ Or where the injury which causes the death

76 Keene v. New England Mut. Acc. Ass'n, 164 Mass. 170, 41 N. E. 203. Here the assured left a train on the side nearest a station, passed in front of the engine, attached to the train, to a platform. As he stepped from the platform upon another track in order to reach the street, he was struck by a moving freight car and killed. His beneficiary was permitted to recover only the amount named in the policy under the classification for railway employés. This was true, even though the assured at the time was crossing the tracks near a rallroad station, where, by the consent of the railroad company, they were commonly used as a thoroughfare by the general public.

77 Grimes v. Fidelity \& Casualty Co., 33 Tex. Civ. App. 275, 76 S. W. 811. In this case the assured was a policeman, and was insured under such a classification. While attempting to arrest a man in the discharge of his duty, the person whom he was arresting intentionally shot him. In spite of the fact that he had been insured as a policeman, the beneficiary was permitted, under the clause limiting the liability of the company for injuries intentionally inflicted upon the assured, to recover only an amount equal to the premiums paid. 
of the assured must leave a visible mark, or the company will be liable only for a reduced indemnity. ${ }^{78}$

Policies of accident insurance commonly limit the amount of indemnity to be paid in the event that the assured commits suicide. ${ }^{78}$ In some states, however, the insurance companies are forbidden to limit their liability in the event of the suicide of the assured, or to make such suicide, a defense to the policy. ${ }^{80}$

78 Stephens v. Railway Officials' \& Employés' Acc. Ass'n, 75 Miss. 84, 21 South. 710. In this policy the assured was indemnified against death or injury leaving a visible mark on the body. In an independent clause the indemnity was limited to one-tenth of the face of the policy, if the injury causing the death left no visible mark, or was the result of the intentional act of another person. The assured came to his death by the intentional act of another, which left its visible, external mark; the head of the assured having been split open. Construing the independent clause by the principle of "noscitur a sociis," the beneficiary was permitted to recover the full amount of the policy.

79 Van Slooten v. Fidelity \& Casualty Co., 79 N. Y. Supp. 608, 78 App. Div. 527. In this case the policy provided for the payment to the beneficiary of the sum of $\$ 5,000$ in case of the accidental death of the assured, or $\$ 10,000$ if the fatal injuries should be received under certain specified circumstances-while the assured was a passenger in a railroad car or as the result of the burning of a building. It further provided that, in the event of the suicide of the assured, the company would be liable for only one-twentieth of the "amount otherwise payable." The assured committed suicide by shooting himself at his home while temporarily insane. The court properly held that the "amount otherwise payable" referred to the amount generally payable in the event the death was accidental, without reference to the clause relating to the burning building and the railroad car, and the beneficiary was entitled to recover one-twentieth of $\$ 5,000$.

80 In Missouri a statute provides that upon policies of insurance suicide shall constitute no defense to the liability of the company, in the absence of proof that the assured contemplated suicide at the time of making application for the policy. In Keller v. Travelers' Ins. Co., 58 Mo. App. 557, the policy provided that instead of the face of the policy, in this case $\$ 2,500$, in the event the assured should commit suicide, the beneficiary should receive only the then full net value of the policy according to the mortality table plus 4 per cent. The assured committed suicide. The court held that the suicide 
Accident insurance policies generally contain a stipulation providing for the payment of double indemnity to the beneficiary in the event of death resulting from an injury received by the assured while riding as a passenger in a conveyance intended for the transportation of passengers. An engineer, brakeman, flagman, mail clerk, or other official of a railroad is not a passenger, if at the time he is riding on the train he is engaged in the performance of his duties. For example, a flagman or brakeman is not a passenger, even if at the time of the accident he is sitting in a passenger coach and for the moment is not engaged in the active discharge of some one of his duties as flagman or brakeman, etc. On the other hand, if he were riding in a passenger coach, but was not a member of the crew of the train on which he was riding, but was traveling on the train to reach a station where he was to become one of the crew of a train, he was a passenger in the sense of such a provision in a policy of insurance. ${ }^{81}$ A conveyance intended for the trans-

was in reality a defense to the extent of the reduction, and therefore the limitation was contrary to the statute and void. See, also, Whitfield ex rel. Hadley v. Ttna Life Ins. Co., 205 U. S. 489, 27 Sup. Ct. 578, 51 I. Ed. 895, reversing (C. C.) 125 Fed. 269, and 144 Fed. 356,75 C. C. A. 358 , where the court held that such a clause, limiting the liability of the company to one-fifth of the face of the policy in the event of suicide, was contrary to the statute and could not be enforced. The beneficiary was permitted to recover the fuil amount of the policy.

81 Atna Life Ins. Co. v. Frierson, 114 Fed. 56, 51 C. C. A. 424. Here the assured was one of a party formed in the United States for the purpose of going up the Alaska river in Alaska with the intent of hunting gold in that region. They contracted for the use of a steamer to take them up this river from the Alaskan coast, and agreed in return for the use of the steamer to pay a share of the profits of the expedition. The assured did no work on the steamer, aithough certain members of the party were so engaged. The steamer was wrecked, and the assured was drowned. It was held that the assured was a passenger, and the insurance company was liabie on its policy. Travelers' Ins. Co. v. Austin, 116 Ga. 264, 42 S. E. 522, 59 L. R. A. 107,94 Am. St. Rep. 125 . Here the assured 
portation of passengers refers to such cars as the ordinary day coach of a train, or a Pullman car, or a chair car, and would not include an express car, a baggage car, or a mail car. ${ }^{82}$

The phrase "while riding as a passenger" is liberally construed to include one who is attempting to board or alight from a car. And in the absence of a stipulation that the injury shall not result from an attempt to enter or leave a passenger car, the company will be liable under such a

was the paymaster of a railroad company. Being killed by an accident while trareling in that capacity and being on duty, the court held that he was not a passenger within the meaning of such a clause in an accident insurance policy.

82 Bogart $\nabla$. Standard Iife \& Accident Ins. Co. (C. C.) 187 Fed. 851. Here the policy undertook to insure against injuries to one while riding as a "passenger in or on any railway passenger car propelled by mechanical power, provided by a common carrier for passenger service." The assured, a postal clerk, was lilled while riding in a mail car in the performance of his usual duties. The court said: "It seems manifest that a postal clerk does not ride on a train as a passenger, within the common and ordinary meaning and acceptation of that term, and that a mail car is not a railway passenger car provided by a common carrier for passenger service. * * The fact that the insurance company knew that the insured was a railway postal clerk at the time of the issuance of the policy is not material. It might well be argued from that fact that the policy was intentionally thus framed to exclude the insured from its protection while thus employed. It may be that a mail clerk or an express messenger is a passenger for some purposes as between himself and the carrier; but it does not follow from this that he is a passenger for all purposes, or a passenger within the meaning of a contract of insurance. The insurance of a passenger while riding on a railway car provided for passenger service is one thing; the insurance of a railway mail clerk while in the discharge of his olficial duties in a mail car on a moving train is an entirely different thing." See, also, Wood v. General Accident Ins. Co. of Philadelphia (C. C.) 156 Fed. 982, affirmed by 160 Fed. 926, 88 C. C. A. 108 where the court said: "Now to us it is clear that the words 'actualiy riding as a passenger' and 'actually riding as a passenger in or on any regular passenger conveyance' meant the indemnity should apply to the case of a passenger in the ordinary, common, everyday use of that word, and to an injury received while such person was in or on a regular passenger conveyance." 
clause, where the assured was killed or suffered an accidental injury while boarding or alighting from a car. ${ }^{83}$ But one who has alighted from a car and severed his connection

83 King v. Travelers' Ins. Co., 101 Ga. 64, 28 S. E. 661, 65 Am. St. Rep. 288. Here the assured was injured while attempting to alight from a moving electric street car. The court sald: "A person may be said to be traveling in a carriage whlle alighting therefrom, until he has completely disconnected himself and alighted. ** * It is reasonable to hold the insured was protected against all injuries caused by accidental means from the moment he entered the conveyance until he had alighted therefrom. During this entire period he was riding as a passenger in the conveyance." The assured was permitted to recover under the double indemnity clause. Fidelity \& Casualty Co. of New York v. Morrison, 129 Ill. App. 360. Here the assured, whlle starting to leave the city on a trip, waited on the station platform for the train to discharge its passengers, when he apparently stepped aboard just as it was moving off. He was carrying a satchel, and as the train pulled out either he or his satchel was struck by an iron post and he was thrown off the train. The court held that from the evidence the jury was justified in finding the insurance company liable for the double indemnity contracted for in case the assured was killed while riding in a public conveyance propelled by steam. The court said: "The material question is whether he was a passenger on the train." "In Klrkpatrick v. Atna Life Ins. Co., 141 Iowa, 74, 117 N. W. 1111, 22 L. R. A. (N. S.) 1255 , the policy exempted the company from liability for injuries received by the assured "while attempting or trying to enter, or leaving, a moving car." A train, standing still, blocked a street crossing, and the assured, not a passenger, attempted to pass over a platform and through the train, when a sudden jerk threw him to the ground, when the wheels ran over one of his arms. The court held that the assured did not come within this exception, and the company was liable on its policy. James v. United States Casualty Co., 113 Mo. App. 622, 88 S. W. 125, where the assured boarded a crowded street car, and while, owing to the crowd, standing on the running board of the car, was thrown off by the sudden lurching of the car. The court sustained the verdict of the jury in favor of the assured.

Where the policy expressly excepts liability for injuries resulting from an attempt to enter or leave such a conveyance, it must be alleged and proved that the injury was not so suffered in order that the company may be held liable under its double indemnity clause. See Standard Life \& Accident Ins. Co. of Detroit v. McNulty, 157 Fed. 224, 85 C. C. A. 22 ; Lilly v. Preferred Accident Ins. Co., 83 N. Y. Supp. 585, 41 Misc. Rep. 8, affirmed in 87 N. Y. Supp. 1139, 92 App. Div. 614. 
therewith is no longer a passenger, even though he may be again attempting to board the car-as where he leaves it at a station. ${ }^{84}$

And where the clause provides for double liability in cases where the assured meets death or injury while riding as a passenger "in any passenger conveyance," the company will not be liable for such increased indemnity where the as-

84 Wheeler v. Fidelity \& Casualty Co. of New York, 129 Ga. 237, 58 S. E. 709. 'The policy insured against injuries happening to the assured while a passenger on a car. The assured, while walking up the steps to her house was killed by a bullet from the pistol of a street car conductor, who became engaged in an altercation with a passenger, whom he attempted to shoot. Held, that the insurance company was not liable under the policy. Anable v. Fidelity \& Casualty Co. of New York, 73 N. J. Law, 320, 63 Atl. 92. Here the policy provided a double indemnity in the event of death from injuries received while riding as a passenger in or on a public conveyance propelled by steam. The assured left the train on which he was traveling. went to a news stand, bought a paper, stood for a moment on the platform, and as the train started ran toward it and grasped the handrail of one car, but was thrown under the car wheels. The court held that the company was liable only for single indemnity, and said: "A passenger in a public conveyance, who keeps himself within a car, or on a steamboat, is regarded as subjected to the slightest risk, while the act of getting on or off moving trains involves a considerable degree of peril. It was, therefore, obviously far from the intention of the parties to this contract that a passenger on a railroad train could get off the car at one station to buy a paper and then run for the moving train, could get off at another station to speak to a friend on the platform, and at still another station to buy fruit, and so repeat his exits from the car at various stations, and repeat his race for the moving train, and yet all this time remain covered by the double insurance."

Tallace v. Employers' Liability Assur. Corp., 26 Ont. L. Rep. 10. This policy provided for double indemnity for injuries sustained while "riding as a passenger in or upon a public conveyance." The assured had alighted from a street car at the corner near his home, when an automobile approached, and he tried to save himself from being struck by jumping on the car again, but was injured in so doing. The court said: "In the present case the plaintiff was not in fact either in or on the car when he received the injury. * * * It is common knowledge that the vast majority of street car accidents occur in connection with entering or leaving the car; injuries to those in or on the cars being limited to the rarer cases of colli- 
sured is injured while riding on the platform of the car. ${ }^{85}$ The theory of this clause is that the interior of a passenger car is a place of exceptional safety, and in view of the slight risk to one seated there the insurance company can contract to pay a double indemnity in the event of injury or death. On the other hand, one riding on the exterior of a car, whether on the roof, or under the car on the trucks, or on

sions or the car running off the track. * * I am further of opinion that the plaintiff was not even a 'passenger' within the meaning of the policy at the time he received the injury. He had fully completed the journey for which he had entered the car and paid his fare. The car had stopped at his request at the very spot at which he desired to alight, and with which he was very familiar, as it was almost at his own door. He had completely separated himself from the car and was securely landed on the roadway. His subsequent attempt to lay hold of the car and get upon its steps was not for the purpose of resuming his journey, or again becoming a passenger on the car, and was in no way connected with his having been a passenger a short time preriously. His position was the same as that of any foot passenger on the street, who might find himself in the same peril, and might try to take refuge from the deadly automobile."

85 Etna Life Ins. Co. v. Vandecar, 86 Fed. 282,30 C. C. A. 48. Here the assured went out on the platform of the car of a train in motion as he was approaching the city of his destination, and was thrown off when the jerking of the car threw another passenger against him. The car ran over his wrist, necessitating the amputation of his arm at that polnt. In Banta v. Continental Casualty Co., 134 Mo. App. 222, 113 S. W. 1140, the policy provided for double indemnity against accidents to the assured while riding as a passenger upon certain vehicles, but a single indemnity only while "getting on or off." The assured, while riding on a trolley car, anticipated a collision, and jumped and broke his leg. The court beld he could recover only the single indemnity. Van Bokkelen v. Travelers' Ins. Co., 34 App. Div. 399, 54 N. Y. Supp. 307. Here, also, the assured was thrown from the platform of a car and killed. In neither this nor the Vandecar Case was the company held liable under the double indemnity clause.

The case of Berliner v. 'Travelers' Ins. Co., $121 \mathrm{Cal}$. 458, $53 \mathrm{Pac}$. 918, 41 L. R. A. 467, 66 Am. St. Rep. 49, seems to hold that the principal point is that the assured shall be a passenger traveling in good faith. In this case the assured, while riding in a passenger coach was invited by an official of the railroad to go forward with him and ride in the cab of the engine. As a result of a wreck the as- 
the platform, is exposed to the various dangers for which the company cannot assume an enlarged liability. But if the clause provides for such double indemnity in the event of injury while riding as a passenger in or on a public conveyance, the assured or his beneficiary will be permitted to recover where death or disability ensues from an accident received while riding on the platform of a car, and recovery would not be limited to those cases wherein the accident happens to the assured inside a railway car. ${ }^{86}$

A steamboat is a public conveyance, even though it may be chartered for a special purpose, as to carry an excursion party. ${ }^{87}$ And a taxicab, rented to the public generally and

sured was killed while riding there. The beneficiary was permitted to recover under the double llability clause. The court compared the train as a whole to a steamboat, and declared that the assured would not be compelled to remain upon any certain part of the boat under the clause under consideration. This decision is much broader than the weight of authority will warrant.

86 Preferred Acc. Ins. Co. of New York v. Muir, 126 Fed. 926, 61 C. C. A. 456. Here the policy contained a clause providing for a double indemnity for death or disability resulting from injuries happening to the assured while riding as a passenger in or on a public conveyance. The assured being taken sick in a railroad car, and the toilet room being locked, he went out on the platform of the car for relief, and was thrown off and killed. The beneficiary was permitted to recover the double indemnity. See, also, Gordon v. United States Casualty Co. (Tenn. Ch. App.) 54 S. W. 98. Here the assured injured his arm slightly while driving. Two weeks later, while boarding a street car, he received a violent jerk, producing an additional injury. A doctor declared that the arm, judging from its condition, must have been broken by the second injury. Before the second injury the arm was unbandaged, but thereafter it was helpless. The court held that the accident on the street car was the cause of the injuries of the assured, and he was permitted to recover the double indemnity allowed for injuries received while a passenger on a public conveyance.

87 Dunn v. New Amsterdam Casualty Co., 141 App. Div. 478, 126 N. Y. Supp. 229, reversing 67 Misc. Rep. 109, 121 N. Y. Supp. 686. Here the assured lost his life in the burning of the steamer General Slocum, which had been chartered to carry an excursion party. The policy insured against injuries received while "actually riding as 
driven by a chauffeur of the company, is a public conveyance provided for passenger service. ${ }^{88}$

\section{Amount of Liability Determined by the Occupation of the} Assured.-In most policies of accident insurance, the amount of the liability of the insurance company is dependent upon the occupation of the insured. The risks which are insured against are classified according to the employment, or occupation, and various rates or premiums are charged, according as the employment is more or less dangerous. Most policies provide that certain forbidden hazards shall render the policy void, as well as that the amount of the insurance shall be diminished in proportion to the increase of other hazards. The contract of insurance depends primarily and essentially upon an equitable adjustment of the premiums and the risks assumed. Under these policies of insurance the various occupations of life are divided into several classes, depending upon the degree of risk or hazard which they involve. Manifestly, one engaged in the sedentary pur-

a passenger in a place regularly provided for the transportation of passengers, within a surface or elevated railroad car, steamboat, or other public conveyance provided by a common carrier for passenger service only." At the time of the disaster the General Slocum had been chartered for the day by a church society. The steamboat company received a lump sum for the use of the boat and for managing and manning the boat with captain, officers, and crew. The court said: "The steamboat company is a common carrier. True, this steamboat was specially chartered by an excursion party; but it was regularly provided for the transportation of passengers. It was not a freight boat, and it was regularly in the business of taking similar parties to either of the two specified pleasure resorts."

88 Primrose v. Casualty Co., 232 Pa. 210, 81 Atl. 212, 37 L. R. A. (N. S.) 618 . In a well-considered orinion, the court said: "The occupants were as much passengers in them as they would have been if ridiug in a specially chartered car of a railroad company from which all but themselves were excluded, the only difference being that, as automobiles do not run on rails, the occupants could select their own traveling route; and it is not to be pretended that the double Indemnity clause does not include passengers riding on a specially chartered railroad car." 
suits of life is less liable to accident or accidental death than one engaged in the more dangerous pursuits, such as railroading, mining, sailing, and the like. The clause which provides for the reduced indemnity is regarded by the courts as a special contract, contemplating a future change of occupation by the assured. Such a change of occupation does not avoid the policy. It simply limits the amount of indemnity so as to accord with the increased hazard. ${ }^{89}$

Nor does this stipulation contemplate the inhibition of acts whose performance is necessarily implied from the vocation named in the policy. ${ }^{90}$

89 Standard Life \& Accident Ins. Co. v. Carroll, 86 Fed. 567, 30 C. C. A. 253,41 L. R. A. 194 . Here the assured was classified as a passenger conductor, but at the time of receiving the injuries which resulted in his death he was conductor of a mixed railway train composed of freight cars with a combination baggage car and passenger car attached. This occupation was included in a more hazardous class. The court held that the change of occupation simply altered the amount of indemnity, so as to accord with the increase of hazard. National Masonic Acc. Ass'n v. Seed, 95 Ill. App. 43. In this case the insured described his occupation as proprietor of a meat shop, with office and counter work, under clause 3 . The proofs showed that he not only did this, but also as a part of his duties he went into the country for live stock and assisted in driving it home and slaughtering it. These dutles would bring him under class 5 at a higher risk. On one of his trips into the country for the purpose mentioned, his horse took fright and ran away, throwing him from the cart and killiug him. The court held: "The certificate was not void because of the more hazardous occupation, but if the actual occupation was classed as more hazardous, the beneficiary was mereiy restricted to the recovery of the lower indemnity provided for the more hazardous occupation." See, also, Thompson v. Loyal Protective Ass'n, 167 Mich. 31, 132 N. W. 554.

90 Thorne $\nabla$. Casualty Co.. of America, 106 Me. 274, 76 Atl. 1106. The assured was classified as manager of a beef company-"office duties and traveling only." He was injured while in one of the company's refrigerators, directing the transfer of carcasses and illustrating the method of doing this work. The court said: "The clause did not contemplate the inhibition of these acts, the performance of which would be necessarily implied from the vocation named in the policy." See, also, Ward's Adm'r v. Preferred Acc. Ins. Co., $80 \mathrm{Vt}$. 321, 67 Atl. 821 . Here the policy declared that it did not cov-

Fuller Acc.Ins.-22 
These conditions in accident policies generally provide that, in the event the assured is injured while engaged in any occupation more hazardous than that under which he is classified in the policy, he shall be indemnified at that rate only which is provided for the class in which he is injured, or that the indemnity shall be limited to such an amount as the premiums paid by him will purchase at the rate designated for the increased hazard which he has incurred. Whether the risk has been increased, or whether there has been any change of occupation on the part of the assured, will, depend entirely upon the original classification in which he was placed. These classifications are fixed by the company. The company is thereupon bound by them, even though the original classification may be erroneous. ${ }^{\theta 1}$ Where the insurance company places the assured in a certain class, and the occupation in which he is engaged when injured differs from that in which he was insured, but is not

er injury or death "while or in consequence of riding in or on any locomotive," etc. The assured was classified as a "contractor, office and traveling." The evidence showed that the assured was killed by accidentally falling from an inspection car while traveling in that conveyance in pursuance of his occupation of contractor, under which he was insured. An inspection car consisted of a locomotive with an observation room built over the boiler in front of the engineer's cab. The court held that the company was liable under its policy, since this was a risk incident to the occupation of the assured.

91 See Schmidt v. American Mut. Acc. Ass'n, 96 Wis. 304, 71 N. W. 601. Here the assured stated that he was a "bakery and confectionery proprietor, supervising," and that he worked for himself. A certlficate was issued to him, insuring him as a "bakery and confectionery proprietor," under class AA. The insurance company had another classification, known as ciass $\mathrm{C}$, which included "bakerworking in the shop, or driving the wagon." In an action to recover on the pollcy, the court held that the insurance company made its classification with sufficient knowiedge of the facts, and that there had been no substantial change of occupation on the part of the insured. Hoffman v. Standard Life \& Accident Ins. Co., $127 \mathrm{~N}$. C. 337,37 S. E. 466 . 
classified as more hazardous, the insurance company cannot, after the injury, thus classify the risk. ${ }^{92}$ Nor can the insurer reclassify a risk, so as to reduce the amount of the policy, without the consent of the assured. ${ }^{93}$ If upon correct answers by the applicant the agent incorrectly classifies him, the company will be liable only for the amount provided for the occupation in which the policy holder is actually engaged, and not for the amount specified for the risk in which he has been incorrectly included. ${ }^{94}$

92 Bushaw v. Women's Mut. Ins. \& Acc. Co., 8 N. Y. Supp. 423. 55 Hun, 607. Here the plaintiff was insured as a jobber and contractor, but was injured while employed as a farm hand. The policy provided that, if the assured was injured while engaged in a more hazardous occupation than that of jobber or contractor, he would be indemnified only at the rate provided for the class in which he received the injury. Accident risks were divided into five classes by this company. The occupation of jobber and contractor was in the' second class, but none of the by-laws showed that the occupation of farm hand, in which he was injured, was graded in the third class. The insurance company, with the knowledge that plaintiff was sometimes a farm hand, classified him as a jobber and contractor. The court held that, after the injury to the insured, the insurance company could not classify the occupation in which he was injured as in the third class.

93 See Morse v. Fraternal Acc. Ass'n, 190 Mass. 417, 77 N. E. 491, $112 \mathrm{Am}$. St. Rep. 337. The assured was classified as a passenger brakeman in the policy. Later he became a stage driver, and so notified the company, whereupon he was advised that the premium was the same for the latter as for the former occupation. The court held that the company could not subsequently make stage driving a more hazardous risk without the consent of the assured, unless the policy gave that power.

94 Bothell v. National Casualty Co., 59 Wash. 209, 109 Pac. 590. Here the assured gave his occupation as that of a logger, but the agent incorrectly stated his occupation in the policy as that of logging contractor. The court held that the company was liable only for the amount of the policy fixed for the actual and more hazardous occupation. The court said: "The policy automatically adjusts itself to the occupation of the insured, and gives him such indemnity as the premium paid by him will purchase in the occupation in which he is engaged when injured. This is fair and equitable to both the insurer and insured. True, it does not give the beneficiary 
On the other hand, if the risk is not classified by the insurance company in the policy, it is a question for the jury to determine whether the risk has been changed, and, if so, whether it has been increased, so as to reduce the amount of the liability of the company upon its policy. ${ }^{95}$

However, such a clause in a policy providing for a smaller amount of indemnity in the event of an increase of hazard will not entitle the assured or his beneficiary to recover from the insurance company in the event that the increased hazard is a risk excepted by the terms of the policy. As, for example, if the policy of insurance contains a clause exempting the company from liability where the assured is walking on a railroad bridge or bed at the time he receives the injuries, the company will not be liable by reason of another clause providing for a smaller indemnity in the event of death through any hazard greater than that in which the occupation of the insured is classified. ${ }^{\text {ob }}$

all that the solicitor promised; but it does give him all that the premium would have purchased, had the application truthfully stated the occupation. By the automatic provisions of the policy the insured is guaranteed protection, and the company is protected against the overzeal and dishonesty of its agents."

95 Standard Life \& Accident Ins. Co. v. Martin, 133 Ind. 376, 33 N. E. 105. Here the principal was insured as a brakeman running on passenger trains. After the policy was issued, he changed his occupation to that of brakeman on a construction train, an occupation much more hazardous. He remained in that occupation until the time of the injury which resulted in his death. The court held that. If the policy itself does not designate the increased hazard, the question of increased hazard and the degree thereof shall be determined by the jury. Ford v. United States Mut. Acc. Relief Co., 148 Mass. 153,19 N. E. 169,1 L. R. A. 700. Here the principal was insured as a leather cutter and merchant, and the risk of his occupation was classified as "medium." The court held that this classification would control the company, although the occupation was not so listed in the general classification of risks indorsed on the back of the policy.

96 Yancy v. Etna Life Ins. Co., 108 Ga. 349, 33 S. E. 979. In this case the assured was a traveling salesman for a coal company. The 
In policies of accident insurance containing this provision, the important questions are, first, whether or not the insured has changed his occupation since the policy was issued; and, second, whether the insured was actually engaged in any other business or occupation when injured, although he has not actually changed his profession or occupation. Manifestly, if the insured has actually changed his occupation from that specifically described in the policy, and is injured while engaged in the performance of some act or duty in no wise connected with the occupation in which he was first classified, the insurance company will be liable only for the lesser indemnity specified in the policy as a discharge for the increased hazard..$^{97}$

policy of insurance contained a clause exempting the company from any liability for injuries resulting from walking or being on any rallway roadbed-railway employes being excepted. The policy also contained a clause providing that, if the assured was injured in any occupation classed as more hazardous than that named in the policy, the amount of indemnity should be limited to that purchasable by the premium paid at the rate specified for the increased hazard. In this case the assured, while engaged in the duties of a coal salesman, was struck by a train while traversing a rallroad track to the oflices of a prospective customer. The plaintiff contended that, inasmuch as the assured was at the time of the accident engaged in his regular occupation, the company was liable under the policy. The court, howerer, declared that, inasmuch as he was not a railway employe, the company was exempt, and that the policy of insurance was suspended during the time that the insured was on the railway roadbed.

97 In Employers' Liability Assur. Corp. v. Back, 102 Fed. 229, 42 C. C. A. 286 , the insured was described in the pollcy as an "importer and dealer in Chinese merchandise, and contractor for Chinese labor." At the time of the injury which caused his death he was engaged as a foreman of Chinese laborers in a fish-canning company, his death being caused by the breaking of certain machinery used in the cannery. This occupation was so much more hazardous than that of the class for which he was insured that the beneficiary was permitted to recover only for the greater risk. In Railway Officials' \& Employés' Acc. 'Ass'n v. Bradley, 97 Ill. App. 355, the assured was insured as a passenger conductor, and was killed while serving as a conductor on a mixed train and engaged in the work of coupling and 
Where the occupation in which the assured is classified is of so general a nature that the act of the assured wherein he was injured comes fairly within that occupation, or is

switching the cars on this train: The occupation of a conductor of a mixed train was classified as more hazardous than that of a conductor for a passenger train, and the court held that the beneficiary could recover only the amount of indemnity rated according to the classification of the occupation in which he was engaged at the time of his injury. In Metropolitan Acc. Ass'n v. Hilton, 61 Ill. App. 100, the plaintiff was classed as a "proprietor of a livery stable," with office duties. Under this occupation he was placed in class A. He was injured while driving one of his own cabs. A cabman came under class $\mathrm{C}$. The court held that driving a cab was not merely incidental to his general occupation, but was in fact a part of it; that he was engaged for hire and profit in line with his business as a livery proprietor. In Aldrich v. Mercantile Mut. Acc. Ass'n, 149 Mass. 457,21 N. E. 873 , the assured was described in the policy as a "spare conductor," and was killed while acting as a brakeman. The beneficlary was permitted to recover only the amount of indemnity provided for brakemen. The court manifestly considered in this case the fact that the insurance company had no notice that the duties of a spare conductor included those of a brakeman. In Loesch v. Union Casualty \& Surety Co., 176 Mo. 654, 75 S. W. 621, the insured was classified as a "stock dealer, visiting yards, not working or tending in transit," which was known as a preferred risk. The occupation of stock dealer tending in transit was classified as extrahazardous. The assured, while attempting to get a steer out of a car, was tossed by the animal, as a result of which he was severely injured and death ensued. The beneficiary was permitted to recover only the indemnity for the extrahazardous risk. In Standard Life \& Accident Ins. Co. v. Taylor, 12 Tex. Civ. App. 386, 34 S. W. 781, the lusured was classified as a "blacksmith." The evidence showed that the insured also acted regularly as a switchman and car coupler, occupations classified as much more hazardous than that of a blacksmith. The assured was killed while coupling cars, and the court held that the beneficiary could recover only according to the increased hazard. In Standard Life \& Accident Ins. Co. v. Koen, 11 Tex. Civ. App. 273, 23 S. W. 133, assured was classified as an extra conductor. The testimony showed that in the railway service an extra conductor performs any other service required of him, such as braking. The assured, on the day of the injury which resulted in his death, had been acting as brakeman on a train. At the end of his run, while seated in a restaurant, a cyclone blew over the structure, and he was killed by falling timbers. The court held that the beneficiary could recover the amount of indem- 
not excluded by the description, there will be no reduction in the amount of indemnity. ${ }^{98}$

Frequently policies of insurance classify "occupations," and not "acts" or "exposures." In such cases, a particular exposure, though not in pursuit of or actually pertaining to the business or occupation mentioned in the certificate, does not affect the liability of the insured. ${ }^{99}$ The question largely depends upon the definition of the word "occupation." Primarily an occupation is one's business or calling

nity specified by the clause for an extra conductor. In Frink's Adm'r v. Brotherhood Acc. Co., 75 Vt. 249, 54 Atl. 176, the assured's occupation was classified as that of a "cattle shlpper and tender in transit," and the deceased was killed while traveling in a box car in charge of a horse. The court held that the word "cattle" did not include "horses," and the beneficiary could recover only for the increased.hazard.

98 See Neafie v. Manufacturers' Accident Indemnity Co., 55 Hun, 111,8 N. Y. Supp. 202. Here the assured was classified as "an ice man-proprietor." At the time of his injury he was personaliy engaged in delivering ice. The court held that the classification used in the policy covered not merely a proprietor who conducted a general ice business from his offices, but also a man who might be a deliverer of ice and at the same time be the owner and proprietor of such a business.

99 Berliner v. Travelers' Ins. Co., 121 Cal. 458, 53 Pac. 918, 41 L. R. A. 467, 66 Am. St. Rep. 49. Here the assured was classified under the occupation of "mining expert," and was injured while riding on a locomotive. The policy provided for diminished insurance in case of injury in an occupation or exposure more hazardous than that named in the policy. The court declared that this referred only to the extrahazardous employment or business, and could not be construed as referring to inevitable acts of hazardous exposure. See, also, Fox v. Masons' Fraternal Acc. Ass'n, 96 Wis. 390, $71 \mathrm{~N}$. W. 363. Here the assured was classified as "mill owneroverseeing only." At the time of his injury he was superintending a small portable sawmill temporarily located in the woods for the purpose of cutting logs into lumber to be used in a planing mill owned by him. While so doing, he took an ax to cut away a tree top which interfered in reaching certain logs, and in doing so cut his foot, from the effects of which he subsequently died. The court held that this did not place him in the classification including the more hazardous occupation of a lumberman in the woods. 
in life, by means of which he earns a livelihood. Nearly every man, whatever his occupation, occasionally performs an act, or does something in connection with his usual vocation, which might also belong to some other occupation. Engaging in an occupation does not mean a casual engagement, such as most men may indulge in during intervals of time when they are not occupied in their usual employment; rather, it means following such an employment as a usual business.

In Hess v. Preferred Masonic Mut. Acc. Ass'n, the court said: "The man insured in this company as a bank cashier might, while engaged in chopping his own firewood, accidentally cut his foot with an ax, and still it would not necessarily follow that he had changed his occupation from a bank cashier to a wood chopper. This chopping of his own wood could be an incident to his occupation as a bank cashier, although it might be an incident to the occupation of a wood chopper." ${ }^{100}$ Similarly, a lawyer, insured as such, might be accidentally drowned while rowing a boat during a fishing trip, and yet his occupation would not thereby be changed, either to that of a sailor or a fisherman. Similarly, a professional man might be injured while on a brief hunting trip, and yet his occupation would not be changed to that of a hunter.

A man's occupation is the profession or vocation in which he engages for profit. It has no reference to any acts or duties which are simply incidental to the daily life of men in any and all occupations. ${ }^{101}$

100112 Mich. 196, 70 N. W. 460, 40 L. R. A. 444.

101 Travelers' Preferred Acc. Ass'n v. Kelsey, 46 Ill. App. 371. The assured was classified as an "agriculture superintendent." While acting temporarily as a superintendent of police at a state fair, he was accidentally shot by a "cowboy," who was shooting glass balls with bird shot. Here the court declared that there had been no change of occupation. In National Acc. Soc. of City of New 
This clause in a policy of accident insurance, providing that the insurance company shall be exempt from liability, or shall be liable only for the lesser indemnity, in the event that the insured is killed or injured while engaged in a more hazardous occupation than that in which he was classified, does not preclude him from performing those acts which form a usual part of the daily life of men in any and all occupations, or from enjoying ordinary acts of exercise, diversion, or recreation. In Union Mut. Acc. Ass'n v. Frohard the court said: "It would be unreasonable and absurd to hold that a merchant, who at one time meas-

York v. Taylor, 42 Ill. App. 97, the assured was classified as a "supervising farmer." The evidence showed that most of the work was done on the farm under his direction, but that he occasionally did such jobs as berding cattle, feeding stock, fixing gates and fences, etc. The assured, while repairing a private bridge on his farm, by driving posts into the bed of the creek with a sledgehammer, met his death by accidental drowning. The court declared that the assured had not gone into the bridge business, and that there had been no change of occupation or business while he was thus engaged. Hess v. Preferred Masonic Mut. Acc. Ass'n of America, 112 Mich. 196, 70 N. W. 460,40 L. R. A. 444 . Here the plaintiff was insured as a banker, and visited a sawmill to have certain boards sawed for use in the bank. Slipping on a small piece of wood, he fell against a hand saw and received injuries which resulted in the loss of his hand. The court held that there had been no change of occupation, and stated that any change, in order to diminish the liability of an insurance company, must be a permanent change, rather than of an incidental nature. The court said: "It does not apply to temporary employments during leisure hours, to acts done outside of one's usual and ordinary business, or to casual employment in a different business." Hoffman v. Standard Life \& Accident Ins. Co., 127 N. C. 337,37 S. E. 466 , where the assured was classified as "freight flagman"-not coupling or switching. Here the court held that the fact that the insured was killed while placing a slack pin between two cars did not change the occupation of the assured to one more hazardous. The court declared that the policy referred to occupations or employments, and not to isolated or individual acts. Stone's Adm'rs v. United States Casualty Co., 34 N. J. Law (5 Vroom) 371. The assured was classified as a "teacher by occupation." At the time of the injury he was having a small barn built. He had gone up to the second story to inspect the work, and while treading on a 
ured a few bushels of grain, at another time hung a few rolls of wall paper upon his own premises, at another drove a teami of horses in a carriage or wagon, and at still another rowed a skiff for exercise or recreation, became $* * *$ at these several times, a grain measurer, a paper hanger, a teamster, and a boatman respectively." 102

joist it broke, and he fell to the ground and was killed. The court declared that the fact that he was having a barn or some houses built by contract did not in any sense mean a change of employment or occupation. See Hall v. American Masonic Acc. Ass'n, 86 Wis. $518,57 \mathrm{~N}$. W. 366 . Here the court held that a grocer, who occasionally delivers goods to his customers, most deliveries being made by others, is not thereby "a grocer delirering goods by occupation," so as to diminish the liability of the insurance company.

102134 Ill. 228, 25 N. E. 642, 10 L. R. A. 3S3, 23 Am. St. Rep. 664, affirming 33 Ill. App. 178. In this case the assured was classifled as a "merchant." He was killed from an accidental shot while hunting for recreation. The court said that the word " 'occupation' must be held to have reference to the vocation or profession, trade, or calling which the assured is engaged in for hire or for profit." I'acific Mut. Life Ins. Co. v. Van Fleet, 47 Colo. 401, 107 Pac. 1087. The assured was classified as a railroad brakeman. A condition in the policy aroided it, in the event the insured was "injured or killed while following any occupation or in any exposure or performing acts of any occupation classed by this company as more hazardous." The assured was killed while making a balloon ascension. The court sustained the claimant in the contention that recovery ought to be allowed. In Star Acc. Co. v. Sibles, 57 Ill. App. 315, the assured was classified as an "engineer." While on a trip West, and by himself, he went hunting. He was subsequently found dead, with a bullet hole through his head. The court held that there had been no change of occupation, and said: "While hunting is a thing which the average laborer, mechanic, clerk, or small tradesman rare$l y$, if ever, engages in, it is not an act so extraordinary as to excite attention as a departure from what an individual might be expected to do. * * * Accidents happening from doing such acts as are incident to the life of a considerabie portion of mankind are not such as are excepted from insurance by such a provision of the policy." Kenny v. Bankers' Accident Ins. Co. of Des Moines, 136 Iowa, 140, $113 \mathrm{~N}$. W. 566. The assured, classified as the manager and owner of a flour mill, was injured whlle mowing hay while on a vacation at his brother's farm. The court held that the assured was not engaged in farming, and said: "The word 'occupation' has reference to a rocation, trade, or calling, and not to the performance of acts of 
Most policies of accident insurance contain the provision that the insured shall notify the company of any change of occupation, and such a notification, if accepted by the com-

exercise, diversion, or recreation." Kentucky Life \& Accident Ins. Co. v. Franklin, $102 \mathrm{Ky}$. 512, 43 S. W. 709, where the insured, classified as a "grocer with desk and counter duties," was injured by the accidental explosion of his shotgun while hunting. The court said that, so far as this clause went, a merchant, lawyer, physician, etc., might go fishing, and, if drowned, there might still be a recovery under the policy. Union Casualty \& Surety Co. v. Goddard, $25 \mathrm{Ky}$. Law Rep. 1035, 76 S. W. S32. Here the assured, classitied as a druggist, was killed by the accidental discharge of his gun, which he was cleaning, while on a pleasure trip, hunting. The court held that the insurance company was liable for the indemnity provided for druggists. In Wildey Casualty Co. v. Sheppard, 61 Kan. 351, 59 Pac. 651, 47 L. R. A. 650, Sheppard was insured as a "barber and restaurant keeper." $\mathrm{He}$ was accidentally injured while hunting rabbits. The court held that this was merely an incident to his daily life, and was not a change of occupation. In Holiday v. American Mut. Acc. Ass'n, 103 Iowa, 178, 72 N. W. 448, 64 Am. St. Rep. 170, the assured was classified as a "bookkeeper." He was accidentally shot by the discharge of a gun while hunting for recreation. The court held that he was not engaged in an act pertaining to the occupation of hunting, and therefore the company was liable for the greater indemnity. 'The court made the following observation: "If a minister, must the accident occur while doing the distinguishing duties of a minister; or, if a lawyer, while doing his professional work; or, if an artist, while doing the work of an artist-with perhaps, in each case, the essential duties of home, of society, and of citizenship? Or does the association intend, and should such a person understand, that the classification is based on the decreased risk, because of the effect of such callings lessening the hazard, in view of the usual experiences of such men, not professionally, but as a whole? It seems to us that reason and authority sustain the latter rule." On the other hand, see Lane v. General Accident Ins. Co. (Tex. Civ. App.) 113 S. W. 324, where under the same condition the assured, classified as a sheep farmer, was killed while deer hunting for recreation. The court here expressly disarowed the ruling in the Holiday Case as in the very teeth of plain and simple language, and held that the insurer was liable only for the amount of indemnity provided for the occupation of hunting, since the assured had been killed "while performing an act pertaining to" that occupation. See Thomas v. Masons' Fraternal Acc. Ass'n, 71 N. Y. Supp. 692, 64 App. Div. 22. Here the policy contained a clause providing that if the insured received an injury in any occupation or exposure, temporary, or otherwise, classified as more hazardous than that for 
pany, operates as effectually to modify the contract as if the change had been indorsed upon the certificate. ${ }^{103}$

Where there is room for an honest difference of opinion, the question of whether the assured has changed his oc-

which he was insured, the beneficiary should receive a reduced indemnity. The assured, classified as a lawyer, was injured while hunting for pleasure, by the accidental explosion of his gun. The court held that the beneficiary could recover only for the more hazardous occupation of hunting. This case is differentiated from others cited because of the fact that the limitation in the policy is more specific in its provisions. In Doody v. National Masonic Accident Ass'n, 66 Neb. 493,92 N. W. 613, 60 L. R. A. 424, the pollcy provided for a smaller indemnity if the injury was received while "handling or in any way using firearms, or hunting." Here the assured was classified as a "proprietor of a boarding house." While removing a gun belonging to a boarder from one room of the house to another, it was accidentally discharged, killing the assured. Under the wording of the clause of limitation, the insurance company was liable only for the limited indemnity.

In Baldwin v. Fraternal Acc. Ass'n, 46 N. Y. Supp. 1016, 21 Misc. Rep. 124, the assured was classified as an undertaker and furniture dealer. While riding a bicycle from his place of business to his home, he was injured by being accidentally thrown from his wheel. The policy contained a clause providing that one insured in a higher classification, injured while engaged in polo, baseball games, or "bicycling," shall receive only the indemnity provided for such games. The court held that this clause did not prevent a full recovery on the part of the assured, for the reason that the provisions of the policy must be construed to refer only to a professional "bicyclist." In Comstock v. Fraternal Accident Ass'n, 116 Wis. 382, 93 N. W. 22, the insured, classified as a "proprietor of a factory," was injured while riding a bicycle for recreation. The court held that riding a wheel occasionally for pleasure did not constltute a change of occupation, so as to reduce the indemnity of the insurance company. Eaton v. Atlas Acc. Ins. Co., 89 Me. 570, 36 Atl. 1048. Here the policy provided for a lesser indemnity if the insured be injured whlle engaged for pleasure or recreation in amateur bicycling. The assured, while returning from a funeral by a circuitous route, was injured by falling from his wheel. The court held that, by taking the longer route home, the assured was engaged in amateur bicycling for pleasure or recreation, and therefore the company was liable only for the smaller indemnity. See, also, Price v. National Accident Society, 37 Pa. Super. Ct. 299.

103 Sce Fox v. Masons' Fraternal Acc. $\Delta s s^{\prime n}, 96$ Wis. 390, $71 \mathrm{~N}$. W. 363 . 
cupation to one more hazardous than that in which he was classified by the policy is for the jury to determine under proper instructions by the court. ${ }^{104}$ Evidence tending to show that the assured at the time of the injury had actually changed his occupation is clearly admissible. ${ }^{105}$ The burden is on the insurance company to prove that the assured has changed his occupation from that designated in the policy, and also that he was given a wrong classification when the policy was issued. ${ }^{106}$

Injuries Inflicted by Robbers.-A condition in many policies provides that the company shall be liable for but onehalf of the indemnity in the event of death or injuries inflicted by robbers. Such a condition is valid, and will limit the recovery of the beneficiary. Frequently the question arises whether the motive of the assailant is robbery. This is a matter of fact, and, like similar questions, is for the jury to determine. ${ }^{10 i}$

Liability for Particular Injuries.-Accident insurance companies may extend the scope of their policies indefinitely under the general clause of indemnity, or they may restrict their liability by defining and particularizing the injuries for which they will agree to indemnify the assured or his beneficiary. Thus, the company may agree to pay a specific or principal sum for the death of the assured occasioned by

104 Everson v. General Accident Fire \& Life Assur. Corp., Limited, of Perth, Scotland, 202 Mass. 169, 88 N. E. 658.

105 Maryland Casualty Co. v. Chew, 92 Ark. 276, 122 S. W. 642. Here the assured was classified as a "cotton factor," while evidence tended to show that at the time of the accident he was in fact en. gaged in the occupation of "supervising farmer."

106 Roseberry v. American Benev. Ass'n, 142 Mo. App. 552, 121 S. W. 785.

107 Bader v. New Amsterdam Casualty Co., 102 Minn. 186, 112 N. W. 1065, 120 Am. St. Rep. 613. This policy contained a clause 
accidental injuries, and another or different sum for the disability, partial or total, of the assured by reason of injuries sustained by accidental means; and the company may by still another clause or series of clauses contract to pay to the beneficiary a certain specified sum for particular injuries, such as the fracture of a certain bone, or the loss of a limb or some organ of the body.

Where the policy provides that the company shall indemnify the assured "for the loss of" a limb or limbs, it is not necessary that they should actually be amputated in order to render the company liable on its contract. If by some injury the assured has been deprived of the use of his arms or his feet, he has "lost" them as certainly as though they had actually been amputated. ${ }^{108}$ Thus a man may be deprived of the use of his feet by their complete paralysis as entirely as if there had been an actual physical loss.of his limbs. But the loss of the use of the feet must be complete.

limiting the liability of the company to one-half of its face in case of loss by accident due to shooting. The assured died after having been shot by a burglar, and the court held that the beneficiary could recover but half of the indemnity named in the policy. See, also, Weidner v. Standard Life \& Accident Ins. Co., 130 Wis. 10, $110 \mathrm{~N}$. W. 246. In this case the policy contained a clause limiting the loss to one-tenth of the amount otherwise payable in the event of death due to injuries intentionally inflicted upon the insured by any other person, except assault committed for the sole purpose of burglary or robbery. 'The assailant took certain boots from the assured, having inflicted upon him blows from which death ensued. The boots were without question the property of the assured, and were taken without his consent. The court declared that the question of whether the acts of the assailant were for the sole purpose of robbery was one of fact for the jury.

108 See Sheanon v. Pacific Mut. Life Ins. Co., 77 Wis. 618, $46 \mathrm{~N}$. W. 799, 9 L. R. A. 685, 20 Am. St. Rep. 151; Id̀., 83 Wis. 507, 53 N. W. 878. Here the assured was accidentally shot in the spine, as the result of which both legs were permanently paralyzed. The insurance company was held liable on a policy which insured the beneficiary, among other things, agalnst "the loss of two entire feet." 
If their use can be restored by employing artificial appliances, such as braces, the company will not be liable. ${ }^{109}$

Whether the loss of a limb is the result of an accident or its diseased condition is a question for the jury. ${ }^{110}$

"Loss of a hand" does not necessarily imply amputation. An injury to the hand which renders it useless for the purposes to which it is normally susceptible of application is sufficient to render the company liable. ${ }^{111}$ To constitute the loss of a hand, it is not necessary that it be actually severed from the arm. It is lost if it is so badly injured that it cannot perform the functions for which it is intended by nature. ${ }^{112}$

109 See Stevers v. People's Mut. Acc. Ins. Ass'n, 150 Pa. 132, 24 Atl. 662, 16 L. R. A. 446. Here the assured was injured while riding in a wagon, and as a result of an accident sustained a concussion of the spine. The paralysis of certain spinal nerves rendered one leg and foot helpless. Howerer, by means of a plaster jacket the foot could be used constantly. Soon after commencing the use of this appliance, the condition of the assured improved, so that he was finally enabled to resume the practice of his profession and go about visiting his patients, riding in his carriage, or on the street cars, or even occasionally walking a little. It was held that as a matter of law the assured had not actually lost the use of his feet and the company was not liable.

110 Atna Life Ins. Co. v. Crabtree, $146 \mathrm{Ky} .368,142$ S. W. 690. Here it was claimed by the plaintiff, a railroad conductor, that his limb was so injured, as the result of a fall while extinguishing a fire in a railroad coach, that amputation was necessary. The company claimed that the amputation was necessitated by the diseased condition of the leg, due to an injury sustained in boyhood.

111 Lord v. American Mut. Acc. Ass'n, 89 Wis. 19, 61 N. W. 293, 26 L. R. A. $741,46 \mathrm{Am}$. St. Rep. 815 . Where by an accident three fingers were wholly torn off, as well as a portion of the other, and the hand cut and the joint of the thumb was destroyed, the question of whether there was the "loss of a hand" was properly left to the jury. Sisson v. Supreme Court of Honor, 104 Mo. App. 54, 78 S. W. 297. Here the assured caught his hand in a brick press, and it was sererely lacerated, and two fingers were amputated at the knuckle joint, and another at the second joint, and the action of the remaining fingers was impaired by the injury to the leaders.

112 Supreme Court of Honor v. Turner, 99 Ill. App. 310. Here a 
Where the policy, instead of insuring against the "loss of a hand," agrees to indemnify the assured for "loss by severance of one entire hand," it is not necessary that the entire hand, anatomically speaking, shall be removed. ${ }^{113}$ If a large portion of the hand be severed, and the remainder be absolutely useless, the company may be liable. Or where it is provided in the policy that "the loss" of an arm or leg shall mean actual amputation, it is not necessary, in order to render the company liable, that the entire arm or leg shall be severed. It will suffice if so much of the limbs are severed as to leave the balance useless for all practical purposes to which it might be put by the assured. ${ }^{114}$ So, where the policies read "the loss of feet or hands by severance thereof," this refers to the manner, rather than to the exact

gun load of shot passed through the palm of the hand of the assured, tearing the muscles, leaders, and nerves, and paralyzing three fingers, so that the hand was useless for laboring purposes.

113 See Sneck v. 'Travelers' Ins. Co., 88 Hun, 94, 34 N. Y. Supp. 545, reversing 81 Hun, 331, 30 N. Y. Supp. 881. Here about one-half of the hand of the assured was cut off by a planer, and there was testimony to the effect that the rest of the hand was absolutely useless. The court said: "The compensation to be paid is not merely for the physical pain of its amputation, but principally for the deprivation of its use as a member of the body. It would seem to be an extremely narrow and technical construction of this contract to say that only a physical removal of every particle of that portion of the human anatomy known as the hand would entitle the insured to recover under the clause of the pollcy now under consideration. Is it not more reasonable and logical to conclude that in the use of the language above referred to the 'entire hand,' as a part of the human structure, is considered in connection with the use to which it is adapted and the injury which the loss of such use would entail?"

114 Garcelon v. Commercial Travelers' Eastern Acc. Ass'n, 184 Mass. 8, 67 N. E. 868,100 Am. St. Rep. 540. Here it was held that the amputation of an arm four inches below the elbow was the loss of the arm; the word "loss" having been agreed to mean actual amputation. Gabagau v. Morrisey, 19 Pa. Co. Ct. R. 238, 6 Pa. Dist. R. 135. Here the policy provided that for the "loss of a hand at and above the wrist joint" the insured "shall be considered totally disabled." It was held that the loss of the use of the hand was 
physical amount, of the injury. The effect of the injury, as well as its extent, is to be considered.

The parties to a policy of insurance have the right to limit their contract, provided it be clear that there was a meeting of the minds. And if the contract or policy specifically states that the company will be liable for an injury which shall "cause amputation of a limb (whole hand or foot)," the assured will not be able to recover where only a part of the foot is amputated, even though the balance is thereby rendered useless for the performance of its natural and ordinary functions. ${ }^{115}$

covered by the policy, and a recovery was allowed, although the assured was afterwards employed by the company in another capacity as a yard switchman.

115 See Fuller v. Locomotive Engineers' Mut. Life \& Accident Ins. Ass'n, 122 Mich. 548, 81 N. W. 326, 48 L. R. A. 86, 80 Am. St. Rep. 598. Here the policy provided that the accidental injury must "cause amputation of a limb (whole hand or foot)." The assured lost about one-third of the foot from the toe, and some two-thirds of the foot was left. This left all of the heel, substantially all of the hollow of the foot, and possibly a part of the ball of the foot. It was held that the company was not liable. See, also, Mady $v$. Switchmen's Union of North America, 116 Minn. 147, 133 N. W. 472. Here the policy contracted to insure the policy holder against total disability, which it defined as "suffering by means of a physical separation of the loss of four fingers of one hand at or above the third joint, * * * provided the above amputations occur." The assured lost three fingers by amputation, and the fourth finger, though not amputated, was so badly injured as to be only fifty per cent. useful. The court held that, inasmuch as the fourth finger was not physically separated, the injury did not come within the purview of the above clause.

In Chevaliers v. Shearer, 27 Ohio Cir. Ct. R. 509, the certificate of accident insurance was issued subject to the provisions and bylaws of the order. The constitution defined the "loss of a hand" as "amputation at or above the wrist." By an accident the assured was injured, and his right arm permanently disabled, and the use thereof practically destroyed, though neither the arm nor hand was amputated. He was not permitted to recover therefor, though the certificate of insurance provided for an indemnity if he should "by accident lose one hand."

FULler Acc.INs. - 23 
And where the policy provides that there must be the loss of "one entire hand and one entire foot, or two entire hands or two entire feet," the insurance company will not be liable unless the assured has lost two entire limbs within the terms of the contract. ${ }^{116}$

Where there is no separate clause providing for a specific liability on the part of the insurance company where the assured has lost an arm, or a foot, or any other member of the body, the question of the liability of the insurer for an injury will depend upon whether the assured has been disabled from following his ordinary vocation or employment under the general liability clause of the policy. So where, in the policies which fix a total loss for the severance of a foot by amputation, if the foot is not so lost as to come within the terms of this clause, the assured may yet recover the weekly indemnity stipulated for any accidental injury. ${ }^{117}$

116 Gentry v. Standard Life \& Accident Ins. Co., 6 Ohio S. \&. C. P. Dec. 114. The court said: "It may not be morally creditable to so write the policy without a corresponding fixed total loss for a single hand, or foot, or eye, but the legal right exists to thus contract."

117 See Neill v. Order of United Friends, 78 Hun, 255, 28 N. Y. Supp. 928, and 149 N. Y. 430, 44 N. E. 145, 52 Am. St. Rep. 738. Here the assured was by occupation a railroad brakeman. While in the discharge of his duties as such, he was pushed from a car by a tramp, and was so severely injured that it was necessary to amputate one of his legs. He could no longer act as a brakeman, but the railroad company gave him a position as watchman of a milk car at a small station, with much lower wages. The policy insured the plaintiff for such injury as might disable him to follow his "usual or some other occupation." The company was held liable. In Smith v. Supreme Lodge of Order of Select Friends, 62 Kan. 75, 61 Pac. 416 , where a pharmacist was accidentally shot in the left arm, and amputation was necessary, the company was held not to be liable, since this did not constitute a total disability. Hess v. Preferred Masonic Mut. Acc. Ass'n of America, 112 Mich. 196, 70 N. W. 460, 40 L. R. A. 444, where a banker, while in a sawmill, fell against a saw and lost a hand. Travelers' Ins. Co. v. Snowden, 45 Neb. 249, 63 N. W. 392, where a cattle broker lost a band while attempting to board a moving freight train. Hutchinson $\nabla$. Supreme Tent of 
An insurance company may define what constitutes a specific injury, as, for example, that a broken leg, for which it contracts a specific liability, shall consist of "the breaking of the shaft of the thigh bone between the hip and knee joints, or the breaking of the shafts of both bones between the knee and ankle joints." Such a definition will preclude the liability of the company for a so-called "Pott"s fracture," which is the breaking of one of the bones between the knee and the ankle and the dislocation of the other. If, however, the injury is not so defined, the company will be liable for a "broken leg" if the assured has sustained a "Pott's fracture." 118

In the absence of any specific provision to the contrary, the weekly. indemnity for the loss of time and, the indemnity

Knights of Maccabees of the World, 68 Hun, 355, 22 N. Y. Supp. S01, where a brakeman lost all of the fingers of one hand.

118 Peterson v. Modern Brotherhood of America, 125 Iowa, 562, 101 N. W. 289,67 L. R. A. 631 . Here the court said: "In the instant case, had there been no attempt at definition of what was meant by the breaking of a leg, there would be no doubt that the plaintlff's injury was covered by his certificate; but here there is a definition given which is clear and unambiguous, and there is no reason why the parties may not define any term they see fit to use in their engagements one with the other. *** The defendant company had the right to narrow its liability, to define the terms used in its certificates, to remove from the field of debate the character of a particular injury, or, in other words, to make its own contract. Having made its contract, it is not within the province of a court of justice to change its terms." Ross v. Modern Brotherhood of America, 120 Iowa, 692, 95 N. W. 207. Here the plaintiff was insured under a certificate which bound him by the by-laws of the company "now in force, or which may be hereafter adopted." Under the policy a broken leg was not defined. After the assured had taken out this policy, but before he was injured, a by-law was adopted defining a broken leg as stated in the text. Here, although it was conceded that, except for the adoption of the by-law, the insurance company would have been liable to the assured, who had sustained a "Pott's fracture," the company was now declared exempt from liability, since the shafts of both bones between the knee and ankle joints were not broken. 
for a specific loss, such as a hand or foot, provided in a policy, may both be recovered, although they are the result of the same accident, provided the total indemnity under the two does not exceed the limit fixed by the terms of the contract. ${ }^{119}$

The Loss of an Eye.-The loss of an eye is the loss of the sight of the eye, under the terms of a policy providing for specific indemnities in accident insurance. ${ }^{120}$

And in the absence of fraud, where the company contracts to pay a certain indemnity for the loss of the sight of both eyes, and at the time the policy is issued the assured is blind in one eye, then the company will be liable none the less for the total loss of eyesight, where the assured afterwards loses the sight of the remaining eye. ${ }^{121}$ And where no specific liability or indemnity is promised for the loss of eyesight, yet such loss of sight may constitute permanent and total disability under the general terms of a

119 See Hart v. National Masonic Acc. Ass'n, 105 Iowa, 717, 75 N. W. 508. The assured was run over by a street car, which severed one foot and seriously injured the other. The assured brought suit for the specific indemnity for the loss of his foot and the weekly benefits for the disability arising from the loss. The court held that he could recover both under the terms of the policy.

120 Sullivan v. Modern Brotherhood of America, 167 Mich. 524, $133 \mathrm{~N}$. W. 486, where the assured lost the sight of one eye as the result of gonorrheal infection caused by accidentally splashing water into it while washing clothes.

But where the policy provides liabllity for injury resulting from accidental means "directly and independently of all other causes," the insurer was not liable where the assured suffered the loss of one eye by falling from a train; it having been shown that at the time of the injury he was suffering from a cataract on that eye which would have ultimately resulted in its loss and contributed to that end. Penn v. Standard Life \& Accidental Ins. Co., 158 N. C. 29, 73 S. E. 99 ; Penn v. Standard Life Ins. Co. (N. C.) 76 S. E. 262.

121 Bawden v. London E. \& G. Assur. Co., [1892] 2 Q. B. 534. In this case the policy detined "permanent total disability" as "complete and irrevocable loss of sight in both eyes," and "permanent partial disability" as "a complete and irrevocable loss of sight in 
policy of insurance. ${ }^{122}$ And where the policy undertakes to indemnify the assured for the "total and permanent loss of eyesight," he can recover where he has totally and permanently lost the sight of one eye by an accidental injury. ${ }^{123}$

one eye." The assured had only one eye at the time of taking, out the policy, which fact was known to the agent of the company. He afterwards lost the sight of the remaining eye, and this was held to be "a complete and irrevocable loss of sight in both eyes," and thus a total disability. So in Humphreys v. National Ben. Ass'n, 139 Pa. 214, 20 Atl. 1047, 11 L. R. A. 564. Here the certificate provided that, in case of the total and permanent loss of the sight of both eyes, the company would pay the whole of the principal sum of the policy. Before the assured took out the pollcy he had lost the sight of one eye, a fact which, while not stated in his application, was known to the agent of the company. He was held to be entitled to recover the full amount of the policy, upon subsequently losing the sight of the other eye. The court declared that the assured had no doubt taken the policy under the belief that the words "total and permanent loss of the sight of both eyes" meant the loss of eyesight.

122 See Mogé v. Societe de Bienfaisance St. Jean Baptiste, 167 Mass. 298, 45 N. E. 749,35 L. R. A. 736. Here it was held that the clause providing for indemnifying the assured when he should find himself "incapable of working by reason of sickness or accident" applied to total blindness resulting from an accident to one eye, which gradually extended to the other eye, ruining them both.

123 See Maynard v. Locomotive Engineers' Mut. Life \& Accident Ins. Ass'n, 14 Utah, 458, 47 Pac. 1030, and 16 Utah, 145, 51 Pac. 259, $67 \mathrm{Am}$. St. Rep. 602. Here the assured, a locomotive engineer, while engaged in his employment, accidentally fell into a pit and received an injury about the head, which resulted in the loss of one eye, which disabled him from pursuing his accustomed occupation. The court said: "The by-law does not provide that the insured will not receive the amount of his policy unless the injuries are such as to cause the loss of the sight of both eyes. There is no express provision * * * limiting the insurance to a total and permanent loss of the sight of both eyes. * * Where in a case like this the total and permanent loss of one eye disables * * * the insured from pursuing his usual and accustomed occupation, it would be a rigid construction that would limit a recovery to cases of total blindness in both eyes, and thus effectuate by implication what the association failed to provide for in express terms. No such result is a necessary sequence to the language employed; for where a person has become permanently blind in one eye, he may, with strict propriety, be said to have sustained 'total and permanent loss of 
Where the policy provides for an indemnity for the accidental loss of both eyes, the assured cannot recover for the loss of but one eye. The loss of an eye refers not alone to the physical loss of the eye itself, but to the loss of the sight of the eye. ${ }^{124}$

Broken Leg or Arm.-Many policies of accident insurance contain a clause providing for the payment of a special or liquidated indemnity for a "broken leg or arm." The words "leg" and "arm" are construed in their broadest sense, and recovery under such a clause will not be limited to cases where the assured has suffered a fracture of the middle section of those limbs. Although in an anatomical sense the leg does mean merely that portion of the limb between the knee and ankle joint, including the patella, the tibia, and the fibula, yet in a policy of accident insurance it will be held to include as well that portion between the knee and the thigh and the bones of the foot. In common parlance the legs and arms are considered to include both feet and hands. - Therefore, under such a clause, the assured will be permitted to recover where he has fractured bones of the entire limbs, whether they be in the hands or feet or in the upper or central divisions of the limbs. ${ }^{125}$

eyesight.' The terms of the by-law in question must be interpreted liberally and reasonably."

124 Phillipy v. The Homesteaders, 140 Iowa, 562, 118 N. W. 880. Here the policy contained a clause providing, an Indemnity for the "loss of the sight of both eyes." The assured claimed that it was his understanding that he was to be indemnified for the loss of one eye; but the court held that the language of the certificate was explicit, and would not admit of any construction which would entitle the plaintiff to a benefit for the loss of one eje. The court declared: "The loss of the sight of both eyes' necessarily excludes as a ground for benefit the loss of one eye only."

125 Rogers v. Modern Brotherhood of America, 131 Mo. App. 353, $111 \mathrm{~S}$. W. 518. Here the policy of accident insurance agreed to indemnify the plaintiff in case he should "accidentally break his leg or arm." He fractured his heel bone. The court said: "It is too 
Accidents in Elevators.-Many policies contain clauses limiting or increasing the liability of the insurance company for accidental injuries or death suffered by the assured in a passenger elevator. The main point to be considered is the relation of the elevator to the injury. Clearly the company will be liable for an injury which occurs to the assured when actually riding within the elevator. Also the clause will apply when the assured is injured or killed either in entering or leaving the elevator, as, for instance, where the assured in entering the car stumbles, falls, and is crushed between the elevator and the walls of the building. ${ }^{120}$

absurd for serious consideration to think that, in speaking generally of an arm and leg, the contracting parties intended to provide indemnity for a fracture of no other bones in the leg than those comprised in the middle section. *** When one thinks of arms and legs as of limbs, it is manifest that hands and feet must be included. * * * A fracture of the heel was covered by the certificate, and the court should have so instructed the jury." See, also, Peterson v. Modern Brotherhood of America, 125 Iowa, 562, 101 N. W. 289, 67 L. R. A. 631; Ross v. Modern Brotherhood of America, 120 Iowa, 692, 95 N. W. 207.

128 Depue v. Travelers' Ins. Co. (C. C.) 166 Fed. 183 . Here the elevator was standing at the first floor of a building, with the door, which extended to the roof of the elevator, wide open; the conductor or operator being elsewhere at the time. The car was operated by a lever on the side wall. No one saw the accident. But the assured was found hanging head downward into the elevator, her body caught between the roof of the elevator and the floor of the building. One limb, which had been caught at the thigh, was projecting over the floor. When the elevator was released, assured fell in on the floor. From the evidence there were two or three theories as to the manner of the accident-that she fell as she entered the elevator, and, plunging forward, grasped the lever to catch herself, thus starting the car; that while in the car she accidentally started the car by leaning against the lever, and, being scared, tried to jump out, and was caught and crushed; or in getting into the elevator she may have grasped the lever, and thus started the car. Whichever of these theories was accepted, the court declared the assured ought fairly to be considered as "in the elevator."

And so in Etna Life Ins. Co. v. Davis, 191 Fed. 343, 112 C. C. A. 87 , the court held that the assured was riding as a passenger in an elevator, if at the time of the injury he had so far entered the ele- 
Burning Building.-Frequently policies of accident insurance contain a clause providing for double indemnity if the assured is injured as the result of the burning of a building. The purpose of the assured in purchasing such a policy is to secure indemnity against an accident from fire while he is in a burning building, and not merely from the burning of a building. The beneficiary will, therefore, be entitled to recover under such a double indemnity clause, where the assured receives fatal injuries from a fire in the contents of a building, even though the fire may not have burned the building in its more literal sense. In short, for the purposes of such a policy, the burning of the contents of a room in a building is to be construed as the burning of the building, so that the insurance company will be liable where the assured is fatally injured under such circumstances. ${ }^{127}$

vator as to be within it in common parlance, although some part of his body; as his foot, may have protruded. See, also, Scarritt Estate Co. v. Casualty Co. of America, 166 Mo. App. 567, 149 S. W. 1049 , where the policy indemnified against injuries to persons "while in the car of any elevator." The court held that this corered an injury to a boy who inserted his head into the elevator shaft far enough to have it struck by a car.

127 Wilkinson v. Atna Life Ins. Co., 240 Ill. 205, 88 N. E. 550, 25 L. R. A. (N. S.) 1256, 130 Am. St. Rep. 269, affirming 144 Ill. App. 38. The assured owned a barn two stories high in the rear of his house. In the loft of the barn he was accustomed to construct large straw targets for use in archery, and for this purpose considerable straw was stored in the loft for use. The assured, an inveterate smoker, was last seen golng to the barn with a lighted cigar in his mouth. Shortly thereafter the loft burst out in flames, and the assured was found by the firemen lying on the floor, unconscious and badly burned about different parts of his body. The floor and roof of the loft were more or less burned. The policy provided for double indemnity if the insured recelved fatal injuries "in consequęnce of the burning of a bullding in which the insured shall be at the commencement of the fire." It did not here appear that the building, as distinguished from its contents, was on fire. The court, applying the well-accepted rule that an ambiguity in the policy should be favorably construed on behalf of the assured, declared: "Still, 
Public Highway.-Many policies of accident insurance contract for a double liability on the part of the insurer, where the assured is injured or killed while walking on a public highway. This expression is general in its scope, and will include any walk or way where the public are accustomed to travel. And the platform of a railroad station may be a public highway to those who have legitimate business necessitating its use. ${ }^{128}$

as the contents of the loft were on fire, we think the appellant should be held liable, under the terms of said policy, for the double indemnity. The word 'building' should be held, we think, to include the contents of said loft. *** The insured in this case was contracting for indemnity against an accident from fire while he was in a building, and not alone from the burning of a building."

Contra, see Houlihan v. Preferred Acc. Ins. Co. of New York, 196 N. Y. 337,89 N. E. 927,25 L. R. A. (N. S.) 1261, reversing 127 App. Div. 630, 111 N. Y. Supp. 1048. This policy insured the beneficiary against the effect of external, violent, and accidental injury, "if caused by the burning of a building while the said person is therein." The policy holder was burned to death while alone in her room by a fire the origin of which was unknown. Other occupants of the building, attracted by her cries, on reaching her room found the clothing which she wore almost burned off her, and the bedclothes and bedding on her bed on fire. A quantity of her wearing apparel, hanging on the door, was also burned. The door was scorched, but no portion of the building was actually burned, and the fire was speedily extinguished. The court held that the burning of a building is not the same thing as the burning of articles in a building, and therefore, under the language of the policy, the beneficiary could not recover. A strong dissenting opinion in support of the lower court was filed, declaring that the burning of the contents of a room in a building should be fairly construed to mean that it was caused by the burning of a building. Beyond doubt the dissenting opinion is more consonant with reason, and more in line with the rules of construing insurance policies, and should be accepted as the law.

128 Rudd v. Great Eastern Casualty \& Indemnity Co., 114 Minn. 512, 131 N. W. 633, Ann. Cas. 1912C, 606. Here the court said: "The platform * * * was not a legally laid out or dedicated public highway, but it was a public highway in a limited sense. It was open to the public, not for general use, but for the use of those having business transactions with the company, or having occasion to pass that way. One going to a station to mail a letter is not a 
Pleading and Evidence.-In an action on an insurance policy which provides for the payment of a specific amount in the event that the death or injuries result from external, violent, and accidental means, the complaint must allege that the injuries were accidentally received, ${ }^{129}$ and that they were the result of external violence. ${ }^{130}$ In the petition it is not necessary to state all the details and circumstances of the injury on which the actionlis based, it being sufficient in an action on an express contract to state the substance of the material facts and their legal effect. ${ }^{131}$ For example,

trespasser. * * A person is not a trespasser who goes upon depot grounds for the purpose of holding a business consultation with another, who was expected to be there to take a train. * * * Those who go to depots to meet passengers are not trespassers: * * * Besides, the public had acquired the privilege of using the platform as a short-cut way to another street. The term employed in the policy is very general. It is not expressly limited to legally laid out or dedicated public highways, which are open to the general public without any restrictions. It may reasonably refer to any walk or way where the public are accustomed to travel for certain purposes. When there is any fair doubt as to the meaning of terms used in such contracts, they must be construed most strongly against the party selecting the language."

129 Newman v. Railway Officials' \& Employés' Accident Ass'n, 15 Ind. App. 29, 42 N. E. 650. The undertaking of the insurance company is to insure the life of the assured against accidental injuries. It therefore devolves upon the beneficiary to allege and prove that the death is the result of injuries accidentally received, and for the want of such facts the complaint is insufficient. Cilley $\nabla$. Preferred Acc. Ins. Co., 109 App. Div. 394, 96 N. Y. Supp. 282. Most of the questions involved in pleading are discussed under the different sections relating to particular clauses in the insurance policy.

130 Hastings v. Travelers' Ins. Co. (C. C.) 190 Fed. 258; Hester v. Fidelity \& Casualty Co., 69 Mo. App. 186.

131 McElfresh v. Odd Fellows Acc. Co., 21 Ind. App. 557, 52 N. E. 819. Here the complaint alleged that the plaintiff fell, injuring, lacerating, and tearing the muscles and flesh of the palm of his right hand from the fingers back to the wrist, bruising and jarring his right shoulder, straining the muscles and leaders thereof, causing the swelling of the same and stiffening the joint, and stating the existence of the disabllity in the language of the policy. The court heid that, while the disability might without impropriety have been 
an allegation in the petition that the death of the assured resulted solely from physical bodily injuries proceeding from and inflicted by external, violent, and accidental means producing immediate death is sufficient to show an accidental death. ${ }^{132}$ And it is not necessary that the complaint should specifically state that the injury was accidental, provided the circumstances attending the injury are so described as to render necessary the conclusion that it was accidental within the terms of the policy. ${ }^{133}$ Frequently the exact circumstances causing an injury or attending an accidental death may not be known. In such a case the complaint should state that the assured sustained bodily injuries through external, violent, and accidental means, resulting in death or disability, following this with a brief description of the manner and cause of the injury so far as it may be known. ${ }^{134}$ Occasionally the answer of the insurer

more particularly described, it was not necessary, or indeed proper, to state facts merely evidentiary. See, also, Richards v. 'Travelers' Ins. Co., 89 Cal. 170, 26 Pac. 762, 23 Am. St. Rep. 455; Phœnix Accident \& Sick Ben. Ass'n v. Stiver, 42 Ind. App. 636, 84 N. E. 772; Railway Officials' \& Employés' Ass'n v. Beddow, 112 Ky. 184, 65 S. W. 362, 23 Ky. Law Rep.' 1438.

132 Railway Officials' Acc. Ass'n v. Armstrong, 22 Ind. App. 406, 53 N. E. 1037 ; Maynard v. Locomotive Engineers' Mut. Life \& Accdent Ins. Ass'n, 16 Utah, 145, 51 Pac. 259, 67 Am. St. Rep. 602. Here the court held that, where a complaint states a cause of action in general terms, objections that the allegations are indefinite or uncertain or ambiguous must be taken advantage of before judgment, by proper pleading, or they will be waived. See same case in 14 Utah, 458, 47 Pac. 1030.

133 Richards v. Travelers' Ins. Co., 18 S. D. 287, 100 N. W. 428, 67 L. R. A. 175.

134 Jamison v. Continental Casualty Co., 104 Mo. App. 306, 78 S. W. 812 . Here the assured, a bridge carpenter, was found dead the next morning after he had been stationed at a railroad bridge to flag approaching trains. He had a large wound on his head, but the exact circumstances of the injury were unknown, though while in a semiconscious condition he stated that he had been struck by a train. The complaint alleged that he sustained bodily injuries 
will cure a defect which might otherwise be fatal in the complaint of the assured. ${ }^{\mathbf{1 3 5}}$

The proof must show that the injuries were sustained by the assured in substantially the manner alleged in the pleadings. And the beneficiary will not be permitted to recover on proof that the death or injuries of the assured resulted from an accident substantially different from that set forth in the petition. ${ }^{136}$ But where the petition alleges the specific effect of the injuries sustained, and the proof shows that, while the effect upon the assured was different from that alleged, yet the disability or death of the assured did result from the injuries alleged, the variance is immaterial,

through external, violent, and purely accidental causes, resulting in death, in that while he was employed as a bridgeman for a railway company he "was struck upon the head with some hard substance, Inflicting a mortal wound." The court held that the language was full and precise enough to constitute a good averment, though it was followed by the allegation: "A more particular description of the circumstances of said accident cannot be here given, because they are to the plaintiff unknown." See, also, Pervangher v. Union Casualty \& Surety Co., 85 Miss. 31, 37 South. 461. Here the court held sufficient an allegation that the death of the assured was caused from bodily injuries to his lungs or stomach, or the rupture of some blood vessel caused by being strained in lifting or handling some heavy substance, and the said substance while being so handled or lifted fell or struck assured, causing said injury. In Dezell v. Fidelity \& Casualty Co., $176 \mathrm{Mo} .253,75 \mathrm{~S}$. W. 1102, an answer alleging that the assured "did not die of any bodily injuries sustained through external, violent, or accidental means, but, on the contrary, died from the result of a medicine commonly called morphine, intentionally and knowingly taken by said deceased, without expecting or intending the same should produce death," states a mere conclusion, and is bad.

185 Summers v. Fidelity MIut. Aid Ass'n, 84 Mo. App. 605. Here the petition falled to allege that the death of the assured was caused by external, violent, and accidental means; the insurance company in its answer alleged that the death did not occur by such means, which put it in issue, and thereby cured the defect in the petition.

186 Clark v. Employers' Liability Assur. Co., 72 Vt. 458, 48 Atl. 639. The court here sald: "It was sufficient for the plaintiff to allege that the insured's death resulted solely from bodily injuries, 
and will not prevent a recovery in the action. ${ }^{137}$ Where the policy does not require the preliminary proofs of death or disability to show in detail the manner in which the injury was sustained, it is immaterial if the proof on the trial of the action presents a variance from the statement in the preliminary proofs. ${ }^{138}$

The cause of the death or injury of the assured under these policies of accident insurance is a question for the

sustained through external, violent, and accidental means, without setting out the particulars of the accident which caused his fatal injuries. But those particulars, although not necessary to be alleged, were material to the inquiry; and if particulars thus material are unnecessarily alleged, they must be proved substantially as stated. It is only when the matter unnecessarily stated is wholly foreign and irrelevant to the case, or is repugnant to what goes before, that it can be rejected as surplusage. The pleader cannot relieve himself from the necessity of proving unnecessary allegations of relevant matter by putting them under a videlicet."

137 Actna Life Ins. Co. v. Hicks, 23 Tex. Civ. App. 74, 56 S. W. 87. Here the petition averred that the death of the assured was caused from his having wrenched and hurt his back, ruptured his stomacl, and dislocated one of his kidneys; and the evidence showed that the death was caused by injury either to his stomach proper, or to the pyloric orlfice connecting the stomach with the intestines, with such effects as must have resulted from a rupture of the membrane. The court beld that there was not such variance as to warrant the rejection of the evidence. Mercier v. Travelers' Ins. Co., 24 Wash. 147, 64 Pac. 158. Where the complaint alleged that the assured fell and bruised his left side directly over the heart, and died as a result of such injury, and a bill of particulars filed in connection therewith alleged that the death of the assured was caused by the injuries to his side, and the character of the injuries causing his death were described as being a bruise upon the side directly over the heart, causing a malignant growth of the spleen and fatty degeneration of the heart, the ultimate fact alleged is that the death was caused by the injury to the side, and the pleader's conclusion that the injury produced a malignant growth of spleen and fatty degeneration of the heart, while the evidence showed that the injury produced inflammation of the pericardium instead, would constitute but an immaterial variance, which could not have misled the defendant to its prejudice.

138 North American Life \& Accident Ins. Co. v. Burroughs, $69 \mathrm{~Pa}$. 43, $8 \mathrm{Am}$. Rep. 212. See under Proofs of Death or Injury, page 406. 
jury, where the facts are such that equally intelligent and fair-minded men may differ in their conclusions. But where the facts are admitted by both parties to the suit, or the evidence so strongly supports one contention that all honest and impartial men must agree, it then becomes a question of law for the court to determine. ${ }^{130}$ Thus, the jury may be called upon, for example, to determine whether the death or injury resulted from voluntary exposure to unnecessary ,danger, was accidental as distinguished from intentional, was the result of a disease rather than an accident, or whether the assured used due diligence for his personal safety. ${ }^{140}$

139 It is sufficient merely to cite Barry v. United States Mut. Acc. Ass'n (C. C.) 23 Fed. 712; Duncan v. Preferred Mut. Acc. Ass'n of New York, 13 N. Y. Supp. 620, affirmed by 129 N. Y. 622, 29 N. E. 1029; Wehle v. United States Mut. Acc. Ass'n, 153 N. Y. 116, 47 N. E. 35, $60 \mathrm{Am}$. St. Rep. 598. An able discussion is found in National Ass'n of Railway Postal Clerks v. Scott, 155 Fed. 92, 83 C. C. A. 652. Here the court stated that, in order to warrant a recovery on an accident policy, the plaintiff must establish two fundamental propositions: First, that there was an accidental injury; and, second, that it alone caused death. The court held that in such an action the plaintiff could not recover, where the sole evidence of any accidental injury sustained by the deceased was testimony showing that some three months prior to his death thexe was a discolored spot on one of his shins several inches in extent, which might have been caused by a bruise or an abrasion.

140 For citations, see footnotes under these and kindred subjects. 


\section{CHAPTER V}

\section{NOTICE AND PROOFS OF ACCIDENT OR DEATH}

Notice and Proofs of Loss.

When Notice and Proofs Must be Furnished.

Immediate Notice.

Impossibility of Giving Notice Within Specified 'Time.

Method of Computing Time.

Who may Furnish Proofs.

Proper Service of Notice and Proofs of Loss.

What Constitutes Sufficient Proof.

Amount of Proof Required.

Pleading and Practice.

Proofs of Loss as Evidence.

Waiver of Notice and Proofs of Death or Injury.

Neglect or Refusal to Furnish Blank Forms.

Walver by Request for Further Information.

Acceptance of Subsequent Premiums.

Failure to Object to Defects in Notice or Proofs of Death or Injury.

Waiver by Denial of Liability.

Pleading and Evidence.

Notice and Proofs of Loss.-Where a policy of accident insurance does not require notice of the death or injury of the assured to be given to the insurance company, there is nothing in the nature of the contract requiring such notice or demand before bringing suit. And in the absence of such a provision in the policy, the failure of the insured to give notice of disability will not work a forfeiture of his right of action. ${ }^{1}$ However, standard policies of accident

1 Windle v. Empire State Surety Co., 151 Ill. App. 273. Here the court held that, in the absence of a provision in a policy so declaring, the failure of the insured to give notice of disability does not work a forfeiture of his right of action. Railway Passengers' Assur. Co. of Hartford v. Burwell, 44 Ind. 460. Here the policy contained the following ciause: "Provided, always, that no claim shall be made under this policy by the said insured in respect to any injury 
insurance generally require notice and proof of the death or injury on which liability is predicated. The purpose of this is to permit the insurance company, by its own agent, surgeon, or otherwise, to examine into the facts surrounding the accident, and to determine whether it is real or simulated. The effect of this condition varies according to the language in which it is phrased in different policies. Although in their general character these are conditions subsequent, since they effect a right under a policy which has already accrued, they are in reality conditions precedent. And where the policy states that no claim shall be paid thereunder until the necessary notice and proofs have been furnished, the giving of such notice constitutes an essential condition precedent to the liability of the insurer. ${ }^{2}$ Some policies contain a provision that the loss thereunder shall be payable at a certain period after proofs of death or injury shall have been furnished to the company. This naturally makes the production of such proofs a condition precedent to any liability on the part of the company. ${ }^{3}$

The requirement that notice of injury and proofs of loss shall be made to the company is for evidentiary purposes, and does not constitute, strictly speaking, a condition of liability, inasmuch as the loss contemplated by the policy has already occurred in the shape of the injury or death. The

unless the same shall be caused by some outward or visible means, of which proof satisfactory can be furnished." The court held that this provision did not require that proofs be made and presented to the company as an act precedent to a right of recovery.

2 Lyon v. Railway Passenger Assur. Co., 46 Iowa, 631; Correll v. National Acc. Soc., 139 Iowa, 36, 116 N. W. 1046, 130 Am. St. Rep. 294; McCord v. Masonic Casualty Co., 201 Mass. 473, 88 N. E. 6; Clanton v. Travelers' Protective Ass'n, 101 Mo. App. 312, 74 S. W. 510 ; Crotty v. Continental Casualty Co., 163 Mo. App. 628, 146 S. W. 833 .

3 National Ben. Ass'n of Indianapolis v. Grauman, 107 Ind. 28s, 7 N. E. 233. 
courts have held it equitable, however, that the insurance company should in this manner reserve to itself a right of protection, by requiring the assured to promptly furnish preliminary evidence of his injury, and by imposing a penalty for failure to do so. Such a provision is in its effect a condition subsequent, in the nature of a forfeiture, by defeating a right which has already accrued. For this reason the courts are disinclined to construe this condition strictly against the assured, unless the case arouses the suspicion of fraud. The law will not lend itself to an effort to defeat a right already vested, unless the parties to the contract clearly express their intention to provide for a forferture.

However, in cases where the policy provided only that a claim should be invalidated or a right of action forfeited by failure on the part of the assured to give notice, the courts have held that furnishing the required proofs was none the less a condition precedent to a recovery. ${ }^{4}$

4 Fidelity \& Casualty Co. v. Brown, 4 Ind. T. 397, 69 S. W. 915. Here the court held that a complaint alleging no notice of accident until immediately after death was sufficient, where the policy required immediate notice to be given of any accident to which a claim should be made. Thornton v. Traveler's' Ins. Co., $116 \mathrm{Ga} .121,42$ S. E. 287, 94 Am. St. Rep. 99, and Tŕavelers' Ins. Co. v. Thornton, 119 Ga. 455,46 S. E. 678 . Here the court held that under the terms of the policy the plaintiff forfeited to the insurance company any sum for which proof of loss was not made in the stipulated time. The policy required the assured to furnish notice of injury and duration of the disability within thirteen months from the accident; otherwise, all claims thereon "were forfeited to the company." However, in Massachusetts the courts have declared that a provision forfeiting claims for failure to furnish proofs constitutes merely a matter of defense, and is not a condition precedent to a right of recovery. Coburn v. Travelers' Ins. Co., 145 Mass. 226, 13 N. E. 604. And in Utah the courts have held that a provision forfeiting clatms under the certificate for failure to give the required notice is a condition subsequent, and must therefore receive a reasonable and liberal construction in favor of the beneficiary. The court in the case of Brown v. Fraternal Acc. Ass'n of America, 18 Utah, 265. 55 Pac. 63, held as follows: "Doubtless the purpose of such conditions in a

Fuller Acc.INs. - 24 
When Notice and Proofs Must be Furnished.-Where the policy of insurance expressly provides that notice of the accident and proofs of death or injury must be furnished the company within a specified time, a compliance therewith is an essential condition precedent to recovery. ${ }^{5}$ It has been held that where the policy stipulates that notice shall be given within a certain time, but does not contain a clause of forfeiture, the claimant will not be barred from recovery for failure to give the notice demanded. ${ }^{6}$ In any event the provision will be construed more liberally in favor of the claimant, and in line with the principle of law which tends to discourage the forfeiture of rights of action which have accrued. ${ }^{\top}$

policy is to afford the insurer an opportunity, within a reasonable time after the occurrence, to inquire into the cause of the accident, and ascertain the surrounding facts and circumstances while fresh in the memory of witnesses, so as to determine whether or not liability under the contract exists. The condition in the policy requiring notice to be given within a specified time, with full particulars of the accident, operates upon the contract of insurance only after the fact of the accident. It is a condition subsequent, and must, therefore, receive a reasonable and liberal construction in favor of the beneficiary under the contract. Niblack, Ben. Soc. \& Acc. Ins. 417. And this is in harmony with the doctrine that forfeitures are not favored in law, which applies to life and accident insurance, as well as to any other kind of forfeitures."

5 United Benev. Soc. v. Freeman, 111 Ga. 355, 36 S. E. 764; McCord v. Masonic Casuaity Co., 201 Mass. 473, 88 N. E. 6 ; Clanton v. Traveler's' Protective Ass'n, 101 Mo. App. 312, 74 S. W. 510; Lyon v. Railway Passenger Assur. Co., 46 Iowa, 631.

6 Hurt v. Employers' Liability Assur. Corp. (C. C.) 122 Fed. 828. Here the policy provided that written notice within thirty days was a condition precedent to recovery. The notice was not given within thirty days, and the court declared that in the absence of an express provision in the contract forfeiting the policy for failure to furnish proofs within the required time, insured would not be estopped from recovery. Windle v. Empire State Surety Co., 151 Iil. App. 273.

7 Woodmen Acc. Ass'n v. Pratt, 62 Neb. 673, 87 N. W. 546, 55 L. R. A. 291, $89 \mathrm{Am}$. St. Rep. 777. Here the court said: "The risk assumed by the insurer has not been increased or in any wise jeop- 
It is not necessary, however, that the provision shall be specifically designated in the policy as a condition precedent. It will suffice if the language in effect states that, unless the notice and proofs of injury or death are furnished within the prescribed time, all claims under the contract shall be forfeited. ${ }^{8}$

In many states insurance companies are forbidden by law to limit the time within which notice of accident or proof of death or injury must be furnished by the claimant, or establish a minimum period of time within which the company may compel the claimant to furnish such notice or

arded by the failure of the insured to comply literally with the provisions for notice of the accident and the injury flowing therefrom. The insurer has received the stipulated consideration for the indemnity contracted for, and which the insured should not be deprived of after he receives an injury, save for his violation of the letter and spirit of the contract in respect of subsequent conditions to be performed as contemplated and intended by the parties thereto under well recognized and established rules of construction of contracts of the kind under consideration. A company of this character, organized for the purpose of providing indemnity to those suffering injury and loss from accident, should, and we assume does, have a higher mission than merely the collection of revenues. If the provision quoted must, under all circumstances and regardless of conditions, be absolutely and strictly complied with according to the letter thereof, then the contract can only be regarded as a snare and pitfall, sure to entrap the unwary and deprive them of the protection and indemnity contracted for on their part in the best of faith and honesty of purpose."

8 Thornton v. Travelers' Ins. Co., 116 Ga. 121, 42 S. E. 287,94 Am. St. Rep. 99 ; Traveler's' Ins. Co. v. Thornton, 119 Ga. 455, $46 \mathrm{~S}$. E. 678; Heywood v. Maine Mut. Acc. Ass'n, 85 Me. 289, 27 Atl. 154; Martin v. Equitable Acc. Ass'n, 61 Hun, 467, 16 N. Y. Supp. 279. Meech v. National Acc. Soc., 63 N. Y. Supp. 1008, 50 App. Div. 144. Here the court said: "The law does not favor forfeiture. The provision of the policy should be reasonably, not rigidly, construed, and the insurer should not be relieved of liability upon technical grounds. But, in the absence of express waiver of the performance of conditions precedent, some element of estoppel must exist." Foster v. Fidelity \& Casualty Co. of New York, 99 Wis. 447,75 N. W. 69, 40 L. R. A. 833 . 
proof as a condition precedent to recovery. ${ }^{\circ}$ Such a statute cannot affect a contract entered into prior to the date of its enactment, on the principle that no legislative act can make invalid a provision in an existing contract otherwise valid. ${ }^{10}$

Immediate Notice.-Many policies of accident insurance require the claimant to give immediate written notice of any accident or injury for which a claim of damages is to be made. The word "immediate" will not be literally construed, but will be given a common-sense interpretation, and will not be held to require the insured to do something that is impossible or unreasonable. Whether this provision has been complied with will depend upon the facts and circumstances of each case, and is therefore a question for the jury to decide. The requirement will be answered if the claimant uses due diligence to send the notice with reasonable

- Maryland Casualty Co. v. Hudgins (Tex. Civ. App.) 72 S. W. 1047. The Texas statute (Rev. St. 1S95, art. 3379) declares that no stipulation requiring notice to be given of any claim for damages thereon as a condition precedent to the right to sue thereon shall ever be valid unless such stipulation is reasonable; and any stipulation fixing the time within which such notice shall be given at a less period than ninety days shall be void. The court here declared: "It is insisted that the statute fixes ninety days as a reasonable time, and if the policy fixes a shorter period it renders that stipulation void, and substitutes therefor the said period of ninety days as to the time of notice. We cannot concur in this contention. The statute clearly expresses the intention of the lawmakers. It leaves it to parties to fix a time for the giving of notice, provided it is not less than ninety days, and where a less period is fixed it declares it void; and there is no intimation that ninety days shall be substituted for the less period named in the contract. * * *" See, also, General Acc. Fire \& Life Assur. Co. v. Walker, 99 Miss. 401, 55 South. 51, where under the Mississippi statute the court held that a limitation of liability to one-fifth of the face of the policy unless notice be given within ten days thereafter of an accident was not enforceable. 102

10 Kimball v. Masons' Fraternal Acc. Ass'n, 90 Me. 183, 38 Atl. 
promptness. ${ }^{11}$ Delay may be so great that the court may rule on it as a matter of law. ${ }^{12}$ The purpose of prompt notice is to give the company full opportunity by its representatives, medical or otherwise, to examine into the facts surrounding the accident and determine whether they are

11 'Traveiers' Ins. Co. v. Nax, 142 Fed. 653, 73 C. C. A. 649, reversing Nax v. Travelers' Ins. Co. (C. C.) 130 Fed. 985. Here the court said: "It is, of course, admitted that the words "immediate notice' must have a common-sense interpretation, and cannot be held to require of the insured anything that is impossible or unreasonable. Whether the stipulation for immediate notice has been complied with must depend upon the facts and circumstances of the concrete case. * * * of course, as we have already said, the requirement of immediate notice will be construed with reference to the circumstances of the case, and if there were no reasonable opportunity for the giving of such notice prior to the death, a notice within reasonable time thereafter would be held to comply with the requirement."

See, also, Preferred Acc. Ins. Co. v. Fielding, 35 Colo. 19, 83 Pac. 1013, 9 Ann. Cas. 916; Sun Acc. Ass'n v. Olson, 59 Ill. App. 217; Fidelity \& Casualty Co. v. Weise, 80 Ill. App. 499; Etna Life Ins. Co. v. Fitzgerald, 165 Ind. 317,75 N. F. 262, 1 L. R. A. (N. S.) 422 , 12 Am. St. Rep. 232, 6 Ann. Cas. 551; Railway Passenger Assur. Co. of Hartford v. Burwell, 44 Ind. 460; Lyon v. Railway Passenger Assur. Co., 46 Iowa, 631; Atna Life Ins. Co. v. Bethel, 140 Ky. 609, 131 S. W. 523, where the court held that the word "immediate" should be construed to mean that a notice must be furnished within a reasonable time, and "in such time as the beneficiary can reasonably obtain information upon whlch to base it"; Konrad $\nabla$. Union Casualty \& Surety Co. of St. Louls, Mo., 49 La. Ann. 636, 21 South. 721; McFarland v. United States Mut. Acc. Ass'n, 124 Mo. 204, 27 S. W. 436; Gilles v. United States Casualty Co. (Sup.) 114 N. Y. Supp. 54 ; Ewing v. Commercial Travelers' Mut. Acc. Ass'n, 55 App. Div. 241,66 N. Y. Supp. 1056, affirmed without opinion 170 N. Y. 590, 63 N. E. 1116; Hughes v. Central Acc. Ins. Co., $222 \mathrm{~Pa}$. 462, 71 Atl. 923; Crane v. Standard Life \& Acc. Ins. Co., 6 Ohio Dec. 118, 3 Ohio N. P. 309; Manufacturers' Acc. Indemn. Co. v. Fletcher, 5 Ohio Cir. Ct. R. 633; Horsfall v. Pacific Mut. Life Ins. Co., 32 Wash. 132, 72 Pac. 1028, 63 L. R. A. 425, 98 Am. St. Rep. 846; Foster v. Fidelity \& Casualty Co. of New York, 99 Wis. 447, $75 \mathrm{~N}$. W. 69,40 L. R. A. 833 ; Wood on Insurance, p. 695, § 414.

12 People's Acc. Ass'n v. Smith, 126 Pa. 317, 17 Atl. 605, 12 Am. St. Rep. 870. Here the court said: "The word 'immediate' in the contract must be construed to mean within a reasonable time there- 
real or pretended, and also to enable them to gather such evidence from witnesses and in other ways as will enable them to present a defense to the claim.

Inasmuch as the question of whether immediate notice has been given is left to the construction of the jury, and must depend upon the circumstances of each case, no fixed period of time can be stated, applicable to all cases, within which the notice must be served. A mere delay of ten days will not defeat a recovery; ${ }^{13}$ and a delay of twelve days after death will not estop the claimant from recovering under the policy. ${ }^{14}$ However, an unexcused delay in giving notice of one hundred and thirty-nine days will defeat a recovery under the policy; ${ }^{15}$ so, also, will a delay of four months. ${ }^{16}$ And likewise a delay of twenty-nine days has

after, under all the facts and circumstances of the caşe, and what is a reasonable time must be decided by the jury, unless the delay has been so great that the court may rule upon it as a question of law."

13 McFarland v. United States Mut. Acc. Ass'n, 124 Mo. 204, 27 S. W. 436. Here the court said: "The word 'immediate' cannot be construed literally without in many cases causing a forfeiture. It is frequently impossible under the circumstances of the accident or death to give inmediate notice. This condition consequently must be liberally construed in favor of the beneficiary. So it has been uniformly held that this, and similar words, should be construed to mean within a reasonable time. So, though the time within which the notice shall be given is fixed under the contract, if the circumstances of the accident are such as to make it impossible to comply with the condition, giving the notice within a reasonable time after it becomes possible has been held sufficient."

14 Horsfall v. Pacific Mut. Life Ins. Co., 32 Wash. 132, 72 Pac. 1028, 63 L. R. A. 425, 98 Am. St. Rep. 846.

15 'Travelers' Ins. Co. v. Nax, 142 Fed. 653, 73 C. 'C. A. 649. Here no notice was given until 139 days after the accident which resulted in the death of the insured, during 72 days of which the insured lived and was in full possession of his faculties. The court held that, without any excuse therefor appearing, the delay as a matter of law defeated any right the beneficiary would otherwise have had to recover on the policy for the death of the assured.

16 Dunshee v. Travelers' Ins. Co. of Hartford, 25 Pa. Super. Ct. 563. And in Myers v. Maryland Casuaity Co., 123 Mo. App. 682, 101 
prevented a recovery. ${ }^{17}$ And so even a delay of six days. ${ }^{18}$ Courts have even held that whether a delay of fifty days is reasonable is a question for the jury. ${ }^{19}$ Policies frequently specify that the notice or proof of death or injury shall be given "as soon as possible." 'The courts have held this phrase to be synonymous with the word "immediate," and to mean within a reasonable time. ${ }^{20}$

Naturally, where the serious nature of an accident does not become at once apparent, it will suffice if the claimant furnishes notice to the company within a reasonable time

S. W. 124, the court declared that a notice given after a delay of six weeks did not constitute "immediate notice," which must be given within a reasonable time.

17 Foster v. Fidelity \& Casualty Co., 99 Wis. 447,75 N. W. 69,40 L. R. A. 833. Here the alleged accident occurred August 31st, and death ensued on September 5th. The beneficiary had satisfied herself of the facts of the case as early as September 17th, but notice was not given until October 17th. The court said that this notice would not be held to satisfy the condition of the policy. See, also, Etna Life Ins. Co. v. Fitzgerald, 165 Ind. 317, 75 N. E. 262, 1 I. R. A. (N. S.) 422, 112 Am. St. Rep. 232, 6 Ann. Cas. 551.

18 Railway Passenger Assur. Co. of Hartford $\nabla$. Burwell, 44 Ind. 460. June 19,1867 , the assured, while making repairs in a church, slipped from a ladder and fell, seriously injuring his spine. He was totally disabled for a space of thirty weeks. On the 25th day of June he gave notice of his injury. The court said: "It is of the highest importance that immediate notice of an alleged accident, within the terms of the policy, should be given to the company. The company can then, by its own surgeon or otherwise, examine into the facts relating to the accident, and determine whether it is simulated or real. As there are no circumstances of excuse for the apparent delay stated in the complaint, and as it is not alleged that immediate notice was given, but only that notice was given on the 25 th of the month, we have only to decide whether or not this is sufficient. What is 'immediate notice,' or 'notice forthwith,' in such cases, is held to depend on the particular circumstances of each case."

10 Atna Life Ins. Co. v. Fitzgerald, 165 Ind. 317,75 N. E. 262, 1 L. R. A. (N. S.) 422, 112 Am. St. Rep. 232, 6 Ann. Cas. 551.

20 Provident Life Ins. \& Inv. Co. $\nabla$. Baum, 29 Ind. 236. Here the court held that a notice at the end of eight or ten days complied 
after the extent of the injury fully develops. ${ }^{21}$ And the same rule applies where the cause of death is not determined until the performance of an autopsy some time there-

with the requirement of the policy. The court declared that if the claimant has not been guilty of unnecessary procrastination or delay, but has used due diligence, recovery will not be defeated, owing to a failure to give immediate notice. See, also, Everson v. General Accident Fire \& Life Assur. Corp., Limited, of Perth, Scotland, 202 Mass. 169,88 N. E. 658 . Here the assured, while in a lonely camp, far from home, was accidentally burned about the hands. On the fourth day thereafter he sent a notice in writing to the company. A jury held that this was a compliance with the condition of the policy requiring that notice be given as soon as possible.

21 People's Acc. Ass'n v. Smith, 126 Pa. 317, 17 Atl. 605, 12 Am. St. Rep. 870. Here the assured, a physician, while riding in his buggy, was accidentally struck in the eye by the lash of his whip. This occurred September 4, 1887. The injury was not at first thought to be dangerous, and for some days the assured treated the eye himself. Soon, however, he was confined to his room, and other medical assistance was summoned. Not until October 15th did he become convinced that he would lose the use of his eye, but on October 1st he gave formal notice in writing to the company of the accident and claim for his loss. The court said: "It is our duty to give the policy in question a fair, businesslike, common-sense interpretation. It is in such a sense that the parties to the contract probably understood 1t. * * His clalm, however, was for the loss of his eye, and it is difficult to see how he could with any propriety make such a claim until be had actually lost it, or it had become clear that he would lose it. How could he have truthfully made such a claim on the 5th of September? * * It is true the delay in such cases may be so great as to justify the court in ruling it as a question of law. There was no such delay in the case at hand, however. The word 'immediate' in the contract must be construed to mean within a reasonable time thereafter under all the facts and circum. stances of the case, and what is a reasonable time must be decided by the jury, unless, as before observed, the delay has been so great that the court may rule it as a question of law. A person might be so injured as to be physically unable to give notice for weeks. Hence it is that such questions are referred to the jury, to say whether under all the circumstances there has been an unreasonable delay in giving notice. * * * I see no reason which requires notice to be given of the loss of an eye until the eye is destroyed any more than that in a life policy a man should give notice of his death before he dies." 
after. ${ }^{22}$ Where, however, there is reasonable ground to believe that the injury may have been caused by accidental means as a result of which the company would be liable, the claimant should give immediate notice, and a failure to do so would be at the risk of the claimant. ${ }^{23}$ Or where the assured disappears, and there is no way of establishing his death until the finding of the body some months later, it is manifestly impossible for the claimant to furnish notice un-

22 Ewing v. Commercial Travelers' Mut. Acc. Ass'n, 66 N. Y. Supp. 1056, 55 App. Div. 241, affirmed without opinion 170 N. Y. 590,63 N. E. 1116. Here the policy required the claimant to furnish immediate notice, with full particulars of the death of the assured. This notice was not forwarded until two weeks after death, because of the necessity of performing an autopsy and conducting a medical examination, in order to determine whether the insured met his death by accidental means and under circumstances covered by the policy.

23 See Coldham v. Pacific Mut. Life Ins. Co., 2 Ohio S. \& C. P. Dec. 314. Here the assured during the life of the policy fell upon an icy sidewalk, and two days later died as a result of his injuries. At once the claimant made every effort to find witnesses who saw the accident, but was unsuccessful. She did not discover that the fall was accidental unfil some thirteen months later, when she at once gave written notice to the company, with full particulars of the accident and cause of death. The claimant was not permitted to recover. The court declared that the claimant knew of the death at the time of its occurrence, and knew that it was the result of a fall, though she did not know that the fall was the result of an accident. The court said: "If the plaintiff had communicated to the company what she did know, and even only the bare possibility that the fall might have been the result of an accident, the company could have examined into the facts by its medical adviser as provided in the policy. Of this privilege it was deprived by the delay in giving the notice. No fault of any kind can be imputed to the company to excuse the delay. The plaintiff alleges that immediately after the accident she began to make efforts to find the persons who witnessed it. There was nothing to prevent her from communicating that fact to the company. It is not a case where it was impossible to give any kind of notice. If she only surmised that it was an accident, she was in fault in not communicating such surmise to the company. And if she was making the efforts alleged, not for the purpose of discovering whether or not the injury was accidental, but for some other purpose not disclosed, and if she discovered the 
til the demise of the assured has been established. ${ }^{24}$ In many cases the existence of a policy is unknown to the beneficiary at the time of the death of the assured. And where a delay in forwarding notice to the company is occasioned by such ignorance, if the beneficiary uses due diligence, the insurance company will not be exempted from liability. ${ }^{25}$

fact of the accident merely by accident, then it cannot be said that the notice was given in a reasonable time. Otherwise, there is no limit to the time, and a notice given at any time, no matter how many years after the accident, would be in a reasonable time." Moreover, the policy in this case limited the beneficiary to a perlod of one year within which action on the policy might be brought.

24 Kentzler v. American Mut. Acc. Ass'n, 88 Wis. 589, 60 N. W. 1002, 43 Am. St. Rep. 934. The policy here in suit did not cover disappearance. The insured, a tugboat engineer, disappeared November 9,1892 . Shortly thereafter the water in which the boat lay was frozen over, and the body was not discovered until the rce melted on April 19th of the following year. Search was made for the beneficiary under the policy, who lived, in a distant city. She did not learn of her father's death until May 24th, when she at once gave notice to the company. The court held that the requirements of the policy had been sufficiently complied with, and that the word "immediate" should be construed to mean such time as was reasonably requisite for giving the notice after the discovery of death.

25 Nax v. Travelers' Ins. Co. (C. C.) 130 Fed. 9S5. Here the beneficiary, an aged woman, had no knowledge of the existence of the policy. After the death of her husband she was taken to the home of a daughter, where she remained some two months. On her return the policy was found among the papers of the deceased, and notice was at once given to the insurer. The court held that whether the circumstances excused the delay in giving the notice was a question for the jury. However, the assured lived seventy-tivo days after the accident, and on appeal the court held that the failure to give notice within that time excused the company from its liability. The decision on appeal thus turned on a different point. Konrad v. Union Casualty \& Surety Co. of St. Lonis, Mo., 49 La. Ann. 636, 21 South. 721. Here the body of the assured was found in a lake some fifteen days after his death. The beneficiary did not find or know of the existence of the policy until some two months after death. But when the policy was found she immediately notified the company. American Acc. Co. v. Card, 13 Ohio Cir. Ct. R. 154. Here the fact of the existence of a policy of accident insurance was unknown to the beneficiaries thereof until it came to their knowledge by accident, some four months after the death of the insured, when 
At the same time the failure of the beneficiary to examine the effects of the deceased policy holder will be admitted as evidence to show a lack of due diligence on his part, though he is not bound to make an immediate search.

Where the assured is totally disabled as a result of the accident, and is therefore unable to either personally attend to his affairs or request others to do so, a failure to give immediate notice will not prevent a recovery under the policy. ${ }^{26}$

proper notice was given to the company. The court held that the condition of the policy for immediate notice of the accident was thus complied with. Pacific Mut. Life Ins. Co. v. Adams, 27 Okl. 496, 112 Pac. 1026. Here the assured died August 5, 1903. The beneficiary, who lired several hundred miles away, first learned of the policy January 8,1904 , but not of its terms or the name of the company by which it was issued. He did not obtain the policy until January 23, 1904, on which date he sent written notice to the insurer of the accident and demanded payment, and on February 5th furnished proof of death. The court held that the notice and proof of death were furnished within a reasonable time under the circumstances of the case, and that the failure to furnish this proof within two months after the death of the insured, as required by the policy, was no defense to the suit. See, also, Provident Life Ins. \& Inv. Co. v. Baum, 29 Ind. 236. Here, although it did not appear that the claimant was ignorant of the existence of the policy, it was shown that he had never seen the policy and was not familial with its contents. The court held that these facts might be considered by the jury in determining whether a notice within eight days indicated an exercise of due diligence.

26 Lyon v. Railway Passenger Ins. Co., 46 Iowa, 631. Here the jury was permitted to decide whether immediate notice had been given in a case where a delay of four weeks had been occasioned by the medical treatment to. which the assured was subjected. Roseberry v. American Benev. Ass'n, 142 Mo. App. 552, 121 S. W. 785. Here the assured was required under the policy to deliver notice of any disability within ten days from the beginning thereof. However, as a result of his injuries and the administration of opiates in the treatment thereof, the assured was unconscious for a period of three weeks. The court held that a notice given within a reasonable time after the assured became conscious was sufficient. Guy v. United States Casualty Co., 151 N. C. 465, 66 S. E. 437, where the court held that, where the assured's mental condition or physical suffering is such that he cannot give the company notice of an 
Inasmuch as the beneficiary has no title, and therefore cannot give notice of an accident, until after the death of the assured, a failure to give such notice during the life of the policy holder will not prejudice his claim under the contract. ${ }^{27}$

Impossibility of Giving Notice Within Specified Time.Even though the policy may expressly declare that all claims thereunder shall be forfeited unless notice of death or injury be given within a specified time, a failure to comply with this condition, due to circumstances over which the claimant has no control, wiil not excuse the company from liability. 'As already stated, in some states any clause compelling notice of injury to be given within ninety days thereafter is void, and in such states notice shall be given only within a reasonable time. ${ }^{\dot{2}}$ But in the absence of such

accident for which he subsequently claims benefit, as required, by the policy, his failure to do so will not prevent a recovery. Manufacturers' Acc. Indemn. Co. v. Fletcher, 5 Ohio Cir. Ct. R. 633 . Here the policy required notice to be given within ten days of the accident. For a period of some two months after the accident the pollcy holder was delirious, and was kept under the influence of oplates, and was incapable of attending to any business. The court said: "It will be seen that what is due diligence in view of all the circumstances is a question of fact, to be determined by the jury in each particular case. In the case before us, taking into consideration the condition of Mr. Fletcher, both physically and mentally, we cannot say that the jury were not justified in finding that immedlate notice of the accident was given."

But where his condition is such that, though he cannot personally give notice, he can still 'direct another to do so for him, the company will not be liable in the event of a failure to give the required notice. Whiteside v. North American Acc. Ins. Co., 200 N. Y. 320, 93 N. E. 948, 35 L. R. A. (N. S.) 696, reversing 104 N. Y. Supp. 1150, 119 App. Div. 915.

27 Horsfall v. Pacific Mut. Life Ins. Co., 32 Wash. 132, 72 Pac. 1028, 63 L. R. A. 425,98 Am. St. Rep. 846.

28 This is true in Texas. See Maryland Casualty Co. $\nabla$. Hudgins (Tex. Civ. App.) 72 S. W. 1047, and, also, Kimball v. Masons' Fraternal Acc. Ass'n, 90 Me. 183, 38 Atl. 102. 
statutory enactment, or of conditions rendering a compliance with the clause impossible, the condition may be enforced. ${ }^{29}$

Delay in furnishing notice to the company is generally the result of injuries which so disable the assured as to render it impossible for him to comply therewith. The law discourages forfeitures, and the courts have held that it was not in the contemplation of the parties to a policy of insurance that, if an accident for which indemnity is provided should render the insured incapable of giving notice, thereby the company would escape liability under its contract. Moreover, the law does not compel the performance of an impossible task. ${ }^{30}$

29 Hatch v. United States Casualty Co., 197 Mass. 101, S3 N. E. 398, 14 L. R. A. (N. S.) 503, 125 Am. St. Rep. 332, 14 Ann. Cas. 290. Here the policy contained a clause requiring that written notice of the injury, whether fatal or non-fatal, be giren by the insured or the beneficiary to the company within ten days of the event causing injury. July 7 th the assured met with an accident which was within the terms of the policy, but which he did not consider at all serious. From August 7 th he was confined to his bed until his death on August 11th. Within four days after his death the claimant gave notice of the injury. The court sustained a demurrer and declared: "The promise to insure is not absolute but conditional. The covdition is that the notice, whatever it may be and by whomsoerer or whenever giren, shall be given. It is a condition precedent to the creation of liability or to the life of the promise; or to put it, perhaps, in a better way, the giving of the notice is one of the essentials of the cause of action. It is further to be observed that we are not dealing with a case where it was impossible to give notice, as where death is contemporaneous with the accident, and the fact of death is not known nor can be known until more than ten days after the accident."

30 In Continental Casualty Co. v. Mathis, $150 \mathrm{Ky} .477,150 \mathrm{~S}$. W. 507 , the policy required written notice of the injury within fifteen days from the date of the accident. The insured accidentally pricked his thumb with a carpet tack. Blood poisoning dereloped, and from the sixth day after the accident the assured was delirious. The insurance company maintained that, inasmuch as be was rational some part of the fifteen days, the failure to give the required notice within the stipulated time should defeat a recovery. The court refused this construction and said: "The company's con- 
Where the policy provides that notice of injury shall be given within a stated time, either by the assured or somebody acting for him, the policy holder will not be excused

struction would require the contract to read that the insured must anticipate his coming delirium, and give the notice at a time far short of the contract period of fifteen dars, a construction which would demand the impossible." Hayes v. Continental Casualty Co., 98 Io. App. 410, 72 S. W. 135. Here the assured was injured by jumping from a train in anticipation of collision. He was taken to a neighboring house, where he lay unconscious for several weeks. Notice was not given until he was taken to his home in a distant city, though the policy required that the company be notified within ten days after the happening of the accident. Roseberry $\nabla$. American Bener. Ass'n, 142 Mo. App. 552, 121 S. W. 785. Here the assured was severely injured by the ignition of gasoline on his trousers, as a result of which his limbs were burned from the ankles to the knees and the flesh and muscles partly roasted. The assured became unconscious, and was under the influence of opiates for approximately three weeks. The court held that "he was excused from complying with the condition of the policy requiring written notice of injury to be given within ten days, and a notice given within a reasonable time after the insured became conscious was sufficient." Woodmen Acc. Ass'n v. Pratt, 62 Neb. 673, 87 N. W. 546, 55 L. R. A. 291, S9 Am. St. Rep. 777. Here the assured suftered a fall by reason of an accident. This resulted in concussion of the brain and dementia for more than four months thereafter. The injury happened October 17th. November 25th his wife,- in looking over some papers, came across the policy of insurance and forthwith sent a notice in writing to the company. The court said: "The risk assumed by the insurer has not been increased or in any wise jeoparded by the failure of the insured to comply literally with the provisions for notice of the accident and the injury fiowing therefrom. The insurer has received the stipulated consideration for the indemnity contracted for, and which the insured should not be deprived of after he receives an injury, sare for his violation of the letter and spirit of the contract in respect of subsequent conditions to be performed as contemplated and intended by the parties thereto under well recognized and established rules of construction of contracts of the kind under consideration. A company of this character, organized for the purpose of providing indemnity to those suffering injury and loss from accident, should, and we assume does, have a higher mission than merely the collection of revenues. If the provision quoted must under all circumstances and regardless of conditions be absolutely and strictly complied with according to the letter thereof, then the contract can only be regarded as a snare and pitfall, sure to entrap the unwary and 
for failure to comply with this condition if, though not able to personally give notice, he is yet able to direct another

deprive then of the protection and indemnity contracted for on their part in the best of faith and honesty of purpose. If the contract is legally incapable of any other construction than that contended for, requiring a literal and exact compliance as a condition precedent to be performed in the time mentioned, then if for eleven dars the insured is irrational and deranged in his mind as a result of the accident, as he appears to have been, and therefore incapable of complying with this provision, he would be altogether debarred from relief, and the failure would, on legal principles, be as fatal as would be the case if the time were forty-four days, as in the present instance. Such a construction would be shocking to our sense of justice, unconscionable, and unreasonable. * * * It is well to note here that we are not considering a question of complying with conditions before loss or injurs, such as the payments of assessments and dues at the time stipulated, observing requirements affecting the nature and desirability of the risk in order to continue a policy of insurance in force and effect. Such stipulations are and should be regarded as of the very essence of the contract, and on their compliance depends the life and success of the company. For is it to be questioned seriously that the terms of a contract of the nature of those under consideration have a substantial basis and ralid cause for their existence, in all respects reasonable in character, and to be enforced, with proper qualifications and exceptions under certain circumstances, in all instances where the enforcement of the terms of the contract is inroked by one of the parties thereto. The reason for the notice required is made manifest by a reading of the provisions of the policy requiring the same to be giren. It is for the purpose of advising the insurer of the accident and the injury resulting therefrom, for which claim to indemnity is made, with full particulars as to time, place, and cause of accident, and the nature of the injury. With this information the company is better enabled to protect itself from fraud, imposition, and demands unjust in character, and for which no legal liability exists. This is not only reasonable and proper, but also commendable. It indicates good business judgment, prudence, and foresight. But if this is the reason and object to be accomplished by the notice. as we apprehend will be cheerfully conceded, then it must have been the intention of the parties that the notice is not to be given until some person with knowledge of its requirements and mental capacity to act thereon is in a position to comply with its terms. It is not the notice of the accident alone that is the important information desired, but the particulars and circumstances surrounding the incident, which is regarded and contracted for as of equal importance. How, then, ought this provision of the contract be construed? Must it be by a hard 
to do so for him. ${ }^{31}$ But if the insured is incapacitated from requesting another to perform the condition, his claim will not be forfeited by reason of the failure to give the notice within the required time..$^{32}$

and fast rule, which admits of no deviation or qualification, and for a failure to gire the required notice during the time stated the policy is ipso facto forfeited, or can there be a legal excuse for failure to comply literally and with exactness with its terms, which the law recognizes as valid and allows a recovery, notwithstanding the failure of the insured to give the notice in the time stipulated? * * *

"In respect of the rule of construing provisions in a contract of insurance for notice of accident and injury or loss or damage, and proof of the same to be given 'forthwith' or 'immediately' or within a stipulated time, the authorities are not entirely harmonious, and yet, from the examination we have been able to make in the limited time at our command, the great weight of authority is to the effect that the exercise of due diligence and reasonable effort on the part of the insured to meet the requirements thus imposed, to be determined under all the circumstances as disclosed in each individual case, is deemed a compliance with such provisions, although not within the time according to the strict letter of the terms used in defining the same." Guy v. United States Casualty Co., 151 N. C. 465, 66 S. E. 437.

Manufacturer's' Acc. Indemn. Co. $\nabla$. Fletcher, 5 Ohio Cir. Ct. R. 633. Here the assured was delirious and kept under the influence of opiates for approximately two months after the injury, when notice thereof was given to the company. The court said: "We hold that the condition of Mr. Fletcher's mind within ten days from the date of the accident was such that he was excused from that condition of the policy" requiring notice to be given within ten days.

See, also, Comstock v. Fraternal Acc. Ass'n, 116 Wis. 3s2, $93 \mathrm{~N}$. W. 22, where the court held that the assured would not forfeit his insurance if he complied with the stipulation for notice within a reasonable time after mental capacity to do so shall have been restored to him.

31 United Benev. Soc. v. Freeman, 111 Ga. 355, 36 S. E. 764. Here the policy required notice within ten days after the date of iujury. On the day of the injury the insured requested the local agent of the company to notify the main office. This the local agent forgot to do until more than ten days had elapsed since the injury. The court held that this fallure excused the company from liability. See, also, Whiteside v. North American Acc. Ins. Co., 200 N. Y. 320,93 N. E. 948,35 I. R. A. (N. S.) 696, reversing 104 N. Y. Supp. 1150, 119 App. Div. 915.

32 Manufacturers' Acc. Indem. Co. v. Fletcher, 5 Ohio Cir. Ct. R. 
Similarly where the claimant has no knowledge of the existence of the policy until after the time has elapsed within which he was required under the terms thereof to furnish proof of death, the clause requiring such proof within a certain time, under penalty of forfeiting the policy, will not be enforced. ${ }^{33}$

633,3 O. C. D. 308 . In this policy the company required either the insured or his physician to send notice of injury within ten days. For several weeks following the injury the assured was delirious and under the influence of opiates, and was unable either to notify the company himself or to request his physician to do so. The court held that these facts excused the assured from that condition of the policy.

33 Maryland Casualty Co. v. Burns, 149 Ky. 550, 149 S. W. 867. The assured died as the result of an accidental injury on December 17, 1910. Not until some time after the 1st of the following month did his wife ascertain that he had an accident insurance policy. Upon learning of this she gave written notice of the accident to the company-on January 10, 1911. The company resisted payment because notice had not been given within the ten days required by the policy. The court said: "Our conclusion is that, under a policy like the one in question, the insured himself, if he survives the accident, should give the contract notice, unless his faculties be so impaired, or he be so circumstanced, that the giving of such notice is impossible. But, in case of the death of the insured, the beneficiary named in the policy has ten days after acquiring knowledge of the existence of the contract to give the notice; or, if the right of action devolve upon a personal representative, he shall have ten days after his qualification, and after acquiring such knowledge, to give the notice. To require the giving of the notice before it is possible to give it would work a hardship, which would be contrary to public policy, and which cannot be sustained upon any theory of right." Munz v. Standard Life \& Accident Ins. Co., 26 Utah, 69, 72 Pac. 182, 62 L. R. A. 485, 99 Am. St. Rep. 830. Here the deceased died June 29, 1900, leaving no friends or relatives surviving him, except the beneficiary, who lived some 234 miles distant. The claimant first learned of the death of the assured October 1st, but did not know of nor obtain the policy until February 15, 1901. On February $23 d$ she gave notice of death to the company and was refused payment. As soon as she could procure legal advice, on Mas 1, 1901, she submitted proofs of death. The policy required that proofs of death be submitted within two months after the demise of the assured. The court said: "Being thus ignorant of these things; how could she comply literally with the terms of the policy as to notice Fuller Acc.Ins. - 25 
And where at the time of the death it is not certain whether it is the result of natural causes or accidental injuries within the terms of the policy, and the cause of death

and proof? How could she give 'full particulars' of an accident, the occurrence of which was not within her knowledge, or the 'full name and address of the insured,' when she knew nothing of the insurance? We cannot assume that the parties to the insurance contract intended such absurdities. The contracting parties doubtless intended that notice and proof should be furnished at the earliest practicable time after the happening of an accident and injury for which liability would be claimed, so that the real facts of the case could be ascertained by the insurer before time had effaced them from the memory of witnesses. 'The word 'immediate,' under such circumstances as are disclosed in this record, cannot be construed as excluding all intervening time between the occurrence of the death and the giving of notice. It does not, by any fair construction of the policy, mean instantly; but 'immediate notice' means notice within a reasonable time, under all the circumstances of each particular case, and no doubt, ordinarily, unless there are circunstances excusing delay, the notice should be given at once. It would, however, be both an unreasonable and unfair interpretation to hold that, as used in the policy, the word 'immediate' required the doing of a thing impossible for the benefictary to do. Such provisions must receive reasonable construction in favor of the beneficiary. May, in his work on Insurance (volume $2, \S 462$ ), says: "If the notice be required to be "forthwith," or "as soon as possible," or "immediately," it will meet the requirement if given with due diligence under the circumstances of the case, and without unnecessary and unreasonable delay, of which the jury are ordinarily to be the judges. To give the word a literal interpretation would in most cases strip the insured of all hope of indemnity, and policies of insurance would become practically engines of fraud.' * * * In this case there is no question that all the conditions of the policy were complied with by the deceased up to the time of his death. Those were conditions precedent for the purpose of continuing the policy in force and effect, and to them a more strict rule of construction is applicable. But where precedent conditions were all performed, courts are not inclined, by a very harsh and technical construction, to deprive the beneficiary of the benefit of a llability, because of a fallure to do an impossible tbing, which was never in the minds or contemplation of the contracting parties. Forfeitures are not favored in law, and will not be aided by interpretation. Such a defense as the one hereln is purely technical. The risk of the insurer was nelther increased nor in any way jeopardized by the failure of the beneficlary to comply literally with the conditions of 
is not established until after the expiration of the period within which notice or proof of death is required, a failure to furnish such notice or proof, resulting from ignorance as

which she had no knowledge. The defendant received the consideration for the indemnity as provided in the contract, and it has no cause to complain if the harsh and technical meaning which it now seeks to place upon the conditions as to notice and proof of loss be rejected. The construction thus put upon the conditions in question secures to the defendant every advantage and benefit to which it is entitled, and which was intended by the provisions of the policy. In such a case, and under such circumstances, the beneficiary is not required to do what amounts to an impossibility, but must perform the conditions subsequent within a reasonable time after obtaining knowledge of the existence of the policy, or after such knowledge could, by the exercise of due diligence have been obtained. Up to the time of the knowledge of the accident and discovery of the policy, such a beneficiary is not in default, and if after that he gives notice of the accident and proof of the death within a reasonable time, or within the time limited in the policy, it will be a compliance with the intention and requirements of his contract. Before that time it is impossible for him to furnish proof of the particulars and circumstances surrounding the accident, required by the policy, and to hold that, because of the failure to do so, his rights under the contract were forfeited, would be alike unfair and unjust. * * * That the beneficiary in this case acted with due diligence after the discovery of the policy, we think, is clear from the facts alleged in the complaint, which, for the purposes of this decision, must be assumed to have been admitted to be true by the filing of the demurrer. The notice of the accident and proof of death, with the particulars required, appear to have been given and furnished within a reasonable time after she obtained the policy and learned that she was entitled to the benefit. As the policy, in the event of death, was payable to the insured's estate, executors, or administrators, it became necessary for her to be appointed administratrix before she could proceed in a lawful manner, and this necessarily caused some delay. Considering the facts and circumstances, however, we cannot say that, under our laws, she was guilty of laches in securing her appointment as administratrix, or in furnishing the company the necessary proofs, or in instituting this suit. Where such a policy contains an agreement on the part of the insurer that, in the event of the death of the insured, the indemnity shall be paid to his legal representatives, the conditions subsequent as to notice and proof within a certain time must not, in the absence of express: language to that effect, be beld to apply to them."

See page 378, supra, and also Nax v. Travelers' Ins. Co. (C. C.) 
to the cause of death, will not defeat a recovery. ${ }^{34}$ However, the beneficiary, in order to recover under the policy, must exercise due diligence in ascertaining whether death

130 Fed. 985; Konrad v. United States Casualty \& Surety Co., 49 La. Ann. 636, 21 South. 721; American Acc. Co. v. Card, 13 Ohio Cir. Ct. R. 154; Pacific Mut. Life Ins. Co. v. Adams, 27 Okl. 496, 112 Pac. 1026; Continental Casualty Co. v. Lindsay, 111 Va. 389, 69 S. E. 344. In Globe Acc. Ins. Co. v. Gerisch, 163 Ill. 625,45 N. E. $563,54 \mathrm{Am}$. St. Rep. 486 , the court held that a condition requiring notice within a given period of time must apply only to the assured, and not to his legal representatives, inasmuch as there could be no claimant until letters of administration had been issued upon his estate.

34 United States Casualty Co. v. Hanson, 20 Colo. App. 393, 79 Pac. 176. Here the assured was injured June 7, 1897, while in a sawmill camp, while supervising the construction of a mill. Neither he nor his physicians discovered that the accident was the cause of his injuries until February 4, 1898; his condition having been diagnosed as rheumatism. The policy required that notice of injury should be given within ten days after the event causing the injury. The court held that this delay in giving notice would not release the company from liability, inasmuch as notice had been given in good faith as soon as the cause of the injuries was apparent.

Peele v. Provident Fund Soc., 147 Ind. 543, 44 N. E. 661, 46 N. E. 990. Here the assured met his death while taking a bath. He was found unconscious in the water and shortly after died. This was on December 17th. The coroner was summoned and made an investigation, and the funeral was held on December 19th at a distance of seventy-five miles. The beneficiary did not return home until December 24th, and in the meantime had no knowledge of the report of the coroner, nor did she learn thereof until she visited the county seat December 28th. She then investigated the facts and notified the company on January 2d next. The court held that the notice given was reasonably sufficient and within the terms contemplated by the parties when the contract was entered into.

Ewing v. Commercial Travelers' Mut. Acc. Ass'n, 66 N. Y. Supp. 1056, 55 App. Div. 241, affirming without opinion 170 N. Y. 590, 63 N. E. 1116, supra. Here the claimant did not know the cause of death until it had been established some two weeks later by an autopsy. Trippe v. Provident Fund Soc., 140 N. Y. 23, 35 N. E. 316, 22 L. R. A. 432, 37 Am. St. Rep. 529, affirming 3 Misc. Rep. 445, 23 N. Y. Supp. 173. Here the place of business of the insured was in a building in New York City, which collapsed and crushed to death many of the occupants, among whom was the insured. Apparentiy the assured was killed on the day of the accident, August 22, 1893, 
was actually caused by accidental means, and a failure to do so will defeat his claim. ${ }^{35}$ Where the policy requires that notice of the accident shall be given within ten days thereof by the beneficiary, and the policy holder fails to give such notice within the prescribed time, and subsequently dies, such a limitation will not defeat the right of the beneficiary

but the fact was not known until August 25th, when the body was found among the ruins and identified. Here the court said: "It is quite conceivable that in many cases of death by accident the fact cannot be and is not known until days, or even weeks, after it has occurred. Such conditions in a policy of insurance must be considered as inserted for some reasonable and practical purpose, and not with a view of defeating a recovery in case of loss by requiring the parties iuterested to do something manifestly impossible. The object of the not"re was to enable the defendant, within a reasonable time after the death or injury, to inquire into all the facts and circumstances while they were fresh in the memory of witnesses, in order to determine whether it was liable or not upon its contract. The full particulars of the death which the condition requires cannot ordinarily be furnished until the fact of death and the manner in which it occurred are ascertained. * * * The parties having contracted that the notice of death should be accompanied by full particulars of the manner in which it occurred and the attendant circumstances, they evidently intended that it should be given only when the fact and manner of death became known to the parties who were required to act. The fair and reasonable construction of this condition, therefore, is that the ten days within which the notice is to be given did not begin to run from the date of the accident, or the disappearance of the insured, but from the time when the body was found, and the important fact of death, with the circumstinces and particulars under which it occurred, ascertained. This construction secures to the defendant every benefit and advantage that was intended by this provision of the policy, and it cannot, therefore, complain if the very harsh and technical meaning which it now seeks to put upon a condition subsequent is rejected. * * To hold that the plaintiff was bound to give notice of the death of her husband, with full particulars, before she had any knowledge of the facts, would be to require ber, by a technical and literal coustruction, to do an impossible thing, which was not within the intention of the parties when the contract was made." See, also, Rorick v. Railway Officials' \& Employés' Acc. Ass'n, 119 Fed. 63,55 C. C. A. 369.

35 Legnard v. Standard Life \& Accident Ins. Co., 81 N. Y. Supp. 516, 81 App. Div. 320. 
to recover under the contract of insurance, since until the death of the assured he has no recognized rights under the policy. ${ }^{36}$

It is impossible to reconcile the various decisions with reference to the time within which notice of accident or proof of death must be sent to the company after the claimant discovers the policy and is advised as to the cause of injury. Some decisions hold that the time within which notice must be given under the policy does not begin to run until the day the claimant is able to furnish the required proof. ${ }^{37}$ Other decisions hold that the provision of the policy will be complied with if the claimant furnishes notice of accident or proof of death within a reasonable time after the removal of the obstacles which prevent immediate notice. ${ }^{38}$ The better law seems to be, however, that the claimant will be permitted to recover under the policy if he exercises due diligence in notifying the company as soon as he can ascertain the facts upon which to base the required proofs.

36 Hoffman v. Manufacturers' Acc. Indem. Co., 56 Mo. App. 301. Here the policy required that, "in the event of an accident for which any claim may be made, notice shall be given, signed, in case of death, by the physician," and that such notice should be given within ten days of the happening of the accident. The assured gave no such notice of the injury, and died forty days after the accident. The court held that the beneficiary in an accident policy until the death of the assured has at most an inchoate and contingent interest only, and would not bave been recognized by the company as having an interest in the contract, and therefore it was impossible and unreasonable to require the beneficiary to give notice within ten days after the accident.

37 Ioffman v. Manufacturers' Acc. Indem. Co., 56 Mo. App. 301; Trippe v. Provident Fund Soc., 140 N. Y. 23, 35 N. E. 316, 22 L. R. A. 432, 37 Am. St. Rep. 529, affirming 3 Misc. Rep. 445, 23 N. Y. Supp. 173; Kentzler v. American Mut. Acc. Ass'n, 88 Wis. 589, 60 N. W. 1002, 43 Am. St. Rep. 934.

38 Woodmen Acc. Ass'n v. Pratt, 62 Neb. 673, 87 N. W. 546, 55 L. R. A. 291, $89 \mathrm{Am}$. St. Rep. 777; Munz v. Standard Life \& Accident Ins. Co., 26 Utah, 69, 72 Pac. 182, 62 L. R. A. 485, 99 Am. St. Rep. 830. 
Method of Computing Time.-Policies of accident insurance frequently are so worded that it is difficult to tell whether the notice and proof of death shall be given within a certain time after the accident, or whether the time shall be computed from the date of death or disability which results therefrom. Some policies specifically declare that the time shall be computed from the date of death, or the beginning of the disability, rather than from the date of the accident. This is particularly true in cases where the death or disability does not immediately ensue upon the accident. To hold otherwise would practically nullify the contract in all cases where the assured does not become disabled until some time after the date of the accident.*

* Baumister v. Continental Casualty Co., 124 Mo. App. 38, 101 S. W. 152. Here the policy required that notice be given within fifteen days as a condition precedent to recovery. The court said: "The injury to plaintiff for which the defendant was to indemnify him was loss of time. The loss of time for which be claims did not begin until more than the number of days after the accident which were limited for notice had expired. Defendant's contention that the notice must be given within fifteen days after the accident practically would nullify the policy in all those cases where loss of time did not begin until after the time for notice had expired. The true meaning of the clause as to notice is that it must be given within fifteen dass after the loss of time began."

Rorick v. Railway Officials \& Employés Acc. Ass'n, 119 Fed. 63, 55 C. C. A. 369 . Here the policy required that notice of the accident causing the disability or death shall be given in writing within fifteen days from the date of the accident causing the disability or death. The insured, a railroad conductor, accidentally struck his head on a bolt in a railroad car. The injury showed no outward signs and was supposed to be trivial. He continued for six days to perform his duty, though suffering severe pains in the head. This increased in violence until the day of his death, which occurred some fifteen days later. The autopsy first revealed the fact that his death was the result of the injury. The court beld that a notice given four days after his death and within ten days after the beginning of his disability answered the requirements of the policy, and said: "It must be remembered that it was not every accident that was insured against, but only such as should result in the disability or death of the assured. Until one or the other of those things happened as a result of the striking of the head 
Many policies of insurance are so worded as to require two classes of notice-the one to be given by the assured within a certain time after the accident which merely produces disability; the other to be given by the beneficiary within a certain time after death where the accident results fatally. $\dagger$

Who may Furnish Proofs.-Where the policy contains no express stipulation as to who shall furnish the proof of

of the deceased, there was no accident to him within the terms of the policy in suit, and therefore nothing for which the insurer was required to be notified. Within fifteen days of the disability of the deceased resulting from the striking of his head, and within four days after the autopsy upon his body disclosed the cause of his death, the plaintiff ** * gave the notice specified in the poilicy. The accident covered by the policy was not complete until the hurt resuited in the disabiiity or death of the insured; and according to the averments of the complaint, both his disability and death occurred less than fifteen days prior to the giving of the notice."

See, also, Wiidey Casualty Co. v. Sheppard, 61 Kan. 351, 59 Pac. 651, 47 L. R. A. 650; Grant v. North American Casualty Co., 88 Minn. 397, 93 N. W. 312 . In this latter case the court sets forth a similar rule to be applied in policies of health insurance.

$\dagger$ Western Commercial 'Travelers' Ass'n v. Smitb, 85 Fed. 401, 29 C. C. A. 223,40 L. R. A. 653 . Here the policy provided that "in case of any accident or injury for which any claim shall be made under this certificate, or in case of death resulting therefrom, immediate notice shall be given in writing," with full particulars of the accident, and that failure to give such notice would invalidate the claim. The court here heid that two classes of notices were intended-one an immediate notice of the accident or injury when not resulting in death, and the other an immediate notice of death resulting from an accident or injury, the latter to be given by the beneficiary. And the court further held that a notice so given in the latter case was sufficient, though no notice of the injury had been given before death. See, also, McFariand v. United States Mut. Acc. Ass'n, 124 Mo. 204, 27 S. W. 436. Here the policy provided that in case of an injury totally disabling the insured from carrying on his work notice of the accident should immediately be given the company, and in case such injuries caused the death of the insured notice should be given in like manner, and that proof be made within six months after the accident. The court held that it was not necessary, where the injuries caused death, but did not totaliy disable the insured at the time from working, to give notice of the accident at the time it occurred, and that proof of death from injuries which did not cause disability, though they subsequently caused death, need not be given untii six months after the death. 
death or injury, the notice may be furnished by the assured or the beneficiary, or any other party acting in behalf of the assured or in behalf of the claimant. It is not necessary that the person who furnishes the proof shall be a beneficiary of the policy, either directly or indirectly, or, indeed, that he shall have been requested to furnish proof by the beneficiary. ${ }^{39}$ Where the assured is injured in an accident from which he subsequently dies, his failure to give notice of the accident within the required time will not prevent a

39 Brown v. Fraternal Acc. Ass'n of America, 18 Utah, 265, 55 Pac. 63. This policy required written notice to be given to the company, without designating any one to perform that function. The local agent was notified of the accident on the day it occurred. He stated that he immediately notified the association by letter. The receipt of the letter was denied by the company. The company, in defending an action to recover, raised the point that the notice was not on behalf of the assured. The court said: "Whether or not the insured or beneficiary personally requested the agent to send the notice is immaterial under the terms of the policy, which simply required written notice to be given, without designating by whom. As we have seen, the object of the notice is to enable the insurer to inquire into the facts and circumstances surrounding the accident, while they are fresh in the memory of witnesses in order to determine whether or not there is liability under the policy. Such object is accomplished, whether notice be sent by the insured himself or at the instance of some one in his behalf." Van Eman 5 . Fidelity \& Casualty Co., $201 \mathrm{~Pa} .537,51$ Atl. 177. Here the policy provided that immediate written notice must be given of an accident, and affirmative proof of death furnished within two months from the date of death. Nine days after the accident the general agent of the company sent an accident blank to the company's main office. On the day after the death of the assured, one month later, the agent telegraphed the fact to the company. The court beld that it was sufficient proof under the terms of the policy, and that the local agent, even on his own initiative, might furnish proof which would be sufficient to comply with the terms of the contract. Mellen v. United States Health \& Accident Ins. Co., 83 Vt. 242, 75 Atl. 273. Here the policy required that written notice be given the insurer within 20 days from the date of the injury. The court held that the notice could be given by another, even the company's agent, as well as by the assured, and a letter written by the doctor of the assured, informing the insurance company of the injury, constituted a proper and sufficient notice. 
recovery on the part of the beneficiary, whose claim arises from the death of the assured, and therefore the condition in such a case would be invalid. ${ }^{40}$ It is not essential that the notice of the accident should be given directly by the claimant to the main office of the company. The claimant may give verbal notice to the local agent, who in turn may notify the home office by letter. It is sufficient if the main office receives written notice within the time prescribed by the policy. ${ }^{41}$

On the other hand, however, where the assured undertakes to notify the company through a third party, he does so entirely at his own risk. And where the third party failed to deliver the notice, the beneficiary would be accountable for the omission, since it is the act of his agent. ${ }^{\mathbf{2}}$

40 Hoffman v. Manufacturers' Acc. Indemn. Co., 56 Mo. App. 301. IIere the policy required the beneficiary to give notice of the death within 10 days of the happening of the accident, under penalty of forfeiting the policy. Forty days after the accident the assured died, without having given any notice. The court held that the condition was invalid, as being impossible of performance, and therefore unreasonable, since, even if the notice had been given within ten days after the happening of the accident, it would not have availed the beneficiary.

41 American Acc. Ins. Co. v. Norment, 91 Tenn. 1, 18 S. W. 395. Here the policy required "immediate written notice of an accidental injury or death" to be given the insurance company at its home office. The assured gave verbal notice of the accident to the local agent, who promptly communicated the notice to the home office by mail, and thereafter the insurance company made an examination of the facts of the case, both before and after the death of the assured.

42 Railway Passengers' Assur. Co. of Hartford v. Burwell, 44 Ind. 460. Here the assured after an injury sent notice thereof by his son to one Dresser, the agent of another company, in which he had another policy. Dresser called upon him, and the assured requested Dresser to notify the agent of the defendant company of the accident. For some reason Dresser failed to notify the company in accordance with the request of the assured. The court said: "When the plaintiff requested Dresser to carry the notice to the agent of the defendant, he made him his agent for that purpose, and must 
Where the policy provides for notice of the injury within a specified time, and the amount of the policy is payable to the assured or his estate, and the assured dies as a result of the injury, the clause in question will not apply to the claim made for the indemnity by an administrator inasmuch as until the appointment of the administrator there can be no claimant. $^{43}$

Proper Service of Notice and Proofs of Loss.-Most policies of accident insurance provide that the notice and proofs of death or injury shall be delivered to the main office of the company; but where the company, either directly or by inference, vests the local agent with authority to receive proofs, delivery to him will fulfill the terms of the contract. Most policies require the notice to be in writing; otherwise, mere oral notice would be sufficient. However, the mere knowledge of the death or injury of the assured which the local agent may happen to possess does not constitute giving notice within the terms of the policy. ${ }^{44}$ And notice

be accountable for his omission, just as if it had been his own omission. The failure of Dresser to give the notice cannot make the act of the plaintiff a bona fide endeavor to give the notice, nor shield him from the consequences of want of notice."

43 Globe Acc. Ins. Co. v. Gerisch, 163 Ill. 625, 45 N. E. 563, 54 Am. St. Rep. 486. In this case the policy requiled notice of the injury to be given by the claimant within seven days thereafter. The assured died on the seventh day after the accident. The court held that this condition did not apply to the case of a claim by the administrator, since there could be no claimant within the specified time of seven days. The court also held that the grant of letters of administration related back, so that the administrator became the claimant from the time of furnishing the proofs. See, also, Maryland Casualty Co. v. Burns, $149 \mathrm{Ky} .550,149$ S. W. 867.

44 American Acc. Co. v. Card, 13 Ohio Cir. Ct. R. 154. Here the policy provided that immediate written notice of the accident must be given to the company's secretary and that failure to give such notice would invalidate all claims under the policy. The wife of the assured had no knowledge of the existence of the policy, and did not find it until four months from the date of the death of the assured, when the required notice was given. The evidence tended to 
of an accident given to the surgeon employed by the insurance company does not comply with the condition.

The notice and proofs of injury are generally transmitted by mail, and need not be delivered in person or by messenger. This is particularly true where the home office or the official to be notified resides in a distant city. Testimony that a letter was properly addressed, stamped, and mailed constitutes prima facie evidence of its receipt, and presents a question for the jury to determine as to whether or not it reached the insurance company. ${ }^{45}$

show that the local agent of the company had heard of the accidental death of the assured. The court held, however, that this did not constitute such notice to the company as was contemplated by the policy.

45 McFarland v. United States Mut. Acc. Ass'n, 124 Mo. 204, 27 S. W. 436. Here the plaintiff testified that a few days after the death of her husband she wrote a letter properly addressed to the home oftice of the insurance company. This she stamped and deposited in the post office. This letter contained a notice of the death of her husband and a request for information as to the proper method of further procedure. No answer being received, she wrote a second letter, with similar results. The court held that it was for the jury to determine whether the company had actually receired notice. McAuley v. Casualty Co. of America, 39 Mont. 185, 102 Pac. 586. Here the court declared that, where proof of death was mailed to the home office of the insurance company by registered letter, the presumption obtains that it was received in due course of mail. Brown v. Fraternal Acc. Ass'n of America, 18 Utah, 265, 55 Pac. 63. Here the local agent, having been advised of the injury to the assured, testified that he sent the usual notice thereof promptly to the home office. The secretary testified that no such notice had been received. This raised a conflict of evidence and presented a question for the jury to determine. The court said: "In construing the conditions of an insurance contract, the evident purpose and intent of the parties must be considered, and, in a case like the one at bar, where the insurer is located at a great distance from the insured, it cannot be reasonably supposed or inferred, in the absence of express stipulation in the contract as to how the notice shall be given, that the parties did not intend that the notice should be given by letter sent through the mail, which has become the principal medium through which the commercial business of the country is being transacted. Service of 
A provision in the policy stating that the amount thereof shall be payable at the home office does not by inference re-

notice in person or by agent was clearly not intended. While the mere mailing of the notice may not be a full compliance with the conditions of the policy, still, if it be mailed by the insured and received by the insurer, it becomes so. A different rule of construction would give undue effect and force to technical, arbitrary conditions, and would too seriously jeopardize the interests of the insured. In this case there is no question made that the notice was not properly addressed, stamped, and mailed; but the appellant, by deposition of its secretary read in evidence, denied that it received the letter, in which the notice was sent, and it is maintained that this testimony the court and jury were bound to accept as conclusive that the insurer was not notified, and consequently conclusive against any liability under the policy. We think not. * * * In the case of an insurance contract, requiring notice of an accident to be given at the place of the insurer, when the insured is at such a distance as to render the sending of a notice by messenger within the time specified inconvenient or practically impossible, and where the contract is silent as to the manner of service, the necessity would seem equally great for holding that, where notice is properly sent by mail, it raises at least a prima facie presumption that the notice was received. This presumption is not as conclusive, it is true, as that respecting negotiable paper; but still, until disproved, it is effective. Because of the peculiar and widely extended business of insurance, the fact that policies and other papers relating to insurance and loss are usually sent by mail, the evident intent and understanding of the parties as to service of notice in the absence of any specified mode, the well-known usage respecting service when the insurer lives at a distance and in a different place from the insured, with which usage the parties must be presumed to have been familiar when the contract was entered into, the reason for adopting the presumption, in the case of an insurance policy, is quite as strong as for adopting the one in the case of a bill or note. In the case of an insurance policy like the one in question, therefore, this presumption, so arising, while not conclusive of the fact that the notice was received, is an inference of fact, founded on the usual course of business, and the probability that the officers of the postal system will do their duty and is prima facie evidence of service."

See, also, Western 'Travelers' Acc. Ass'n v. Holbrook, 65 Neb. 469, $91 \mathrm{~N}$. W. $276,94 \mathrm{~N}$. W. 816 . January 8,1898 , the plaintiff accidentally broke both of his legs, totally disabling him until some time in February, 1899. The contract required notice of the accident to be given within fifteen days. This condition was complied with. It also required the assured to furnish proofs of the duration of the disability and its nature within thirty days after the total disabil- 
quire that notice and proofs of the injury shall be sent to that office. ${ }^{46}$

What Constitutes Sufficient Proof.-Where the policy merely requires that the insurance company be furnished with "proof of death," it is sufficient if the claimant notifies the company of the decease of the assured and furnishes statements or affidavits setting forth his death. He is not required to detail fully the causes of the assured's death. ${ }^{47}$ Where the policy requires that notice be given of an injury,

ity ceased. In January, 1898, the company sent to the plaintiff printed forms for final proofs. These were filled ont and mailed so as to reach the company January 30,1899 , some days before the disability ceased, and twelve days after the fifty-two weeks' term of indemnity had expired. The company, however, demanded further proofs. The plaintiff complied with this demand, but on account of unavoldable delays in the mail these proofs did not reach the company until some time in February, more than thirty days from the expiration of the term of indemnity, but within thirty days from the cessation of the disability. The court said: "The beneficiary will not be held to a strict and literal compliance with the provisions of an accident insurance policy with reference to final proofs of the extent and duration of the injury, where a short delay in supplying such proofs has been occasioned by circumstances not attributable to his own laches or bad faith, and particularly where the insurer could easily have enabled the claimant to obviate its objections to the sufticiency of the proofs."

In Scheiderer v. Travelers' Ins. Co., 58 Wis. 13,16 N. W. 47, 46 Am. Rep. 618 , the court held that a clause requiring that notice of the injury be given in writing to the company at Hartford did not require that proof of the injury be sent to Hartford, uuless it was so specifically stated in the policy.

46 Pennington v. Pacific Mut. Life Ins. Co., 85 Iowa, 468, 52 N. W. 482, 39 Am. St. Rep. 306.

47 Van Eman v. Fidelity \& Casualty Co., 201 Pa. 537, 51 Atl. 177. Here the policy provided that immediate written notice should be given of the accident, and affirmative proof of death furnished within two months from the time of death. Nine days after the accident the general agent of the company filled out and mailed to the company's main office the regulation accident blank. When the insured died, a month later, the agent on the following day telegraphed the company of that fact. The company thereupon instructed its surgeon to attend the autopsy, and fifteen days later the 
it is not sufficient to merely describe the nature of the injury, but the cause thereof must be set forth. ${ }^{48}$

Where more than one injury happens during the life of a policy, a new notice must be given for each injury, whether it be an independent injury, or one which merely aggravates an injury previously. received. ${ }^{49}$ And similarly additional proof must be furnished where a further claim is presented as the result of a continuation of an initial disability for which proof has already been made. ${ }^{50}$ However, where the claim is based merely upon a continuation of the original disability, without any intervening and contributing accident, and the proofs first furnished by the insured showed

attorney for the claimant notified the company of the death and circumstances under which it occurred. The court here held that this constituted sufficient proof of death.

48 Simons v. Iowa State Traveling Men's Ass'n, 102 Iowa, 267, 71 N. W. 254. Here the assured notified the association that he had badly sprained his right foot as a result of favoring his left foot, which had been previously injured. The court held that this did not constitute sufficient notice of an accident to the right foot, caused by stepping from a street car. The court said: "The accident of which notice was to be given is not the injury alone, but the cause of it." See, also, Standard Life \& Accident Ins. Co. v. Strong, 13 Ind. App. 315, 41 N. E. 604, where the court held that under this policy mere notice of the injury or death was not sufficient, and that the requirement for full particulars could not be ignored.

49 Spicer v. Commercial Mut. Acc. Co., 4 Pa. Dist. R. 271, 16 Pa. Co. Ct. R. 163. Here the assured accidentally sprained his knee, which required him to use a cane in walking. While thus crippled, he suffered another injury from a misstep. The court held that a provision in the policy that "immediate notice of any accidental injury or death, for which claim may be made under this certificate, shall be given in writing, with full particulars of the accident and injury, and failure to give such immediate written notice shall inralidate all claims under this Insurance," requires for each new injury a new notice and a new proof, without which there can be no recovery.

50 Clanton v. 'Travelers' Protective Ass'n, 101 Mo. App. 312, 74 S. W. 510. Here the assured furnished proofs of loss for a disability which occurred March 13, 1900. On the payment of the amount of the policy therefor, he executed a release and discharge of the de. 
his injury and disability, it is sufficient for him in furnishing further proof to show merely the continuation of his total disability during the balance of the life of the policy. ${ }^{51} \mathrm{Un}$ der the general form of policies of accident insurance, it is not necessary, in making proof of death or injury, to enter minutely into the details of the accident. The proof need not consist of depositions or sworn statements of eyewitnesses. It will suffice if the evidence be sufficiently substantial and trustworthy to enable the insurance company to form an intelligent opinion as to its rights and liabilities under the contract. ${ }^{52}$

fendant from all liability on account of said injury. Subsequently to that date he became totally disabled as a result of the injury of March 13th. The subsequent injury was the result of an injury to the old wound. He made no proofs of loss after the date of executing the release, and the court held this a bar to any further recovery of indemnity on account of the injury.

51 Woodall v. Pacific Mut. Life Ins. Co. of San Francisco (Tex. Civ. App.) 79 S. W. 1090. Here the assured on November 17, 1901, fractured his hip as a result of a fall, which disabled him from engaging in any work for more than fifty-two weeks from the date of the policy. Subsequently he furnished notice and proofs of disability for a period of thirteen weeks and two days, but did not state that he had recovered sufficiently to return to work. The insurance company forwarded a draft of payment of its liability for that period. Subsequently he made additional proofs of disability for a further period. The court held that it was necessary for him to furnish proof only of the continuation of the total disability duriug the remaining life of the policy.

52 Simpkins v. Hawkeye Commercial Men's Ass'n, 148 Iowa, 543, $126 \mathrm{~N}$. W. 192. Here the court held that a declaration in the proof of death under an accident policy, that death was caused by poisoning introduced by a needle, sufficient!y states the cause of death, where the assured, an embalmer, accidentally punctured the palm of his hand with the point of an embalming needle while embalming a dead body, and death resulted from blood poisoning.

Da Rin v. Casualty Co. of America, 41 Mont. 175, 108 Pac. 649, 27 L. R. A. (N. S.) 1164, 137 Am. St. Rep. 709. Here the court held that the proof of death, required to be made by the terms of a policy of accident insurance, need not consist of formal depositions or sworn statements of eyewitnesses; but evidence in any form, when substantial and trustworthy enough to enable the insurer to form 
Where, however, the policy requires that the notice shall give full particulars of the accident, this provision must be complied with. ${ }^{53}$

The provision requiring the notice to give full particulars of an injury is not violated where, through ignorance of the exact nature of the injuries received, the claimant fails to include all of them in his notice. ${ }^{54}$ A false statement by the claimant as to the manner and cause of the death of the assured will not discharge the company from liability under

an intelligent estimate of his rights and liabilities under his contract, is sufficient.

American Acc. Co. v. Card, 13 Ohio Cir. Ct. R. 154. Here the beneficiary filed with the company an affidavit which gave no details other than that the assured died by falling from a window of his hotel. In reply to the clain of the company that the proof of death was too indefinite, the court said: "We think that their understanding of what was the accident was sufficient; that it was not necessary to enter Into every detail-whether in falling he struck his head upon the coping of some window underneath, or whether he struck his head upon a stone when he fell upon the ground, or the like."

53 Standard Life \& Accident Ins. Co. v. Strong, 13 Ind. App. 315, 41 N. E. 604. Here the policy required that notice be given of any accident or injury for which a claim is made, with full particulars thereof. The court held that the notice must give a detailed account of the injury. See, also, McFarland $\nabla$. United States Mut. Acc. Ass'n, 124 Mo. 204, 27 S. W. 436. 'The policy here provided that, in case of an injury totally disabling the assured, notice of the accident, with full particulars, should immediately be given the company, and in case the injuries caused the death of the assured notice "in like manner" should be given. The court held that, where the injuries caused the death of the assured without having totally disabled him, it was not necessary to give notice of the accident at the time of its occurrence.

54 Root v. London Guarantee \& Accident Co., 86 N. Y. Supp. 1055, 92 App. Div. 578. Here the policy required that the notice contain "full particulars of the accident." On the day following the accident the claimant notified the company and described the injury as a broken hip. Through internal injuries not then known, death resulted from angina pectoris. The court held that the requirement of the policy was satisfied. See, also, Rhodes v. Railway Pass. Ins. Co., 5 Lans. (N. Y.) 71. Here the policy provided, upon condition of forfeiting all claim, that full particulars of the accident and injury Fuller Acc.Ins.-26 
the policy, if it is responsible under the true facts. ${ }^{s s}$ And in the absence of fraud a misstatement of the date of the accident will not defeat the rights of the claimant. ${ }^{56}$

Amount of Proof Required.-As a general proposition, it may be stated that no better proof is required of the injury or death than would be necessary to establish a cause of action upon a trial. In any event, the insurance company will not be permitted to establish its own standard of proof. That is a matter for the jury to determine. Nor is it necessary that it be in the shape of affidavits by eyewitnesses. Circumstantial evidence, from which the nature of the injury may be determined, is sufficient. ${ }^{57}$ And where the insurer has received a notice of 'death, and through its representative has taken part in a post mortem examination or

should be furnished to the insurer, without suppression of any material fact. The court held that a failure to disciose injuries happening subsequent to the accident, by which the original injury was aggravated, was not the suppression of a fact within the meaning of the contract.

$5 s$ Continental Casuaity Co. v. Jennings, 45 Tex. Civ. App. 14, 99 S. W. 423.

56 Young v. Travelers' Ins. Co., So Me. 244, 13 Atl. 896. Here it was ciaimed that the original notice and proof of disability did not reach the company. The accident happened on the $2 d$ day of May, 1885. In the second notice the date of the accident was stated to be June 25, 1885. The court held that a misstatement of the date of the accident, with no improper motive, did not render the notice insufficient.

57 Preferred Acc. Ins. Co. v. Barker, 93 Fed. 158, 35 C. C. A. 250. Here the assuped went duck hunting, and was last seen alive eariy in the morning. That evening he was found standing in mud and water up to his hips, leaning across his boat, but a short distance from the shore. The proofs furnished to the company inciuded, among other things, a sworn statement by the man who had found the body, detailing the circumstances thereof, and from the coroner as to the cause of death, etc. The policy required the claimant to furnish direct and positive proof that death resuited soleiy from accidental causes. The court held that the testimony of eyewitnesses to the death of the assured would not be required, where there were no such witnesses, but that the furnishing of such circumstantial ev- 
an inquest, the company cannot allege upon trial the insufficiency of the proofs submitted. ${ }^{58}$

These policies frequently stipulate that the claimant shall furnish the insurance company with specific proof of the death of the assured. Under such policies satisfactory proof will be construed to mean reasonable proof, and the company will not be permitted to defeat a claim by arbitrarily rejecting the proofs of the claimant as unsatisfactory. ${ }^{59}$

Policies of accident insurance frequently contain a stipulation requiring the claimant to furnish, as a part of the proof

idence as was afterwards sufficient to satisfy the jury that death resulted from one of the causes insured against must be deemed a suflicient compliance with the requirement.

In Travelers' Ins. Co. v. Sheppard, 85 Ga. 751, 12 S. E. 18, the court declared that "any proof that ought to be satisfactory will suffice, although it may involve inference of the main fact from other facts, and therefore be properly termed circumstantial rather than direct evidence."

In Atna Life Ins. Co. v. Milward, $115 \mathrm{Ky} .716,82$ S. W. 364, 26 Ky. Law Rep. 589, 68 L. R. A. 2S5, 4 Ann. Cas. 1092, the assured was found dead from a pistol shot wound in the head; his body, partially disrobed, lying in a small entry in the rear of his house. The court held that it was not necessary for the claimant to produce proof from one who had seen the death of the assured, but that it was sufficient if the claimant alleged circumstances from which it would naturally be inferred that the assured met his death by violent and accidental means.

58 Van Eman v. Fidelity \& Casualty Co., 201 Pa. 537, 51 Atl. 177. Here the company was notified by telegraph on the day following the death of the assured, previous notice of the accident having been given. The company thereupon instructed its surgeon to attend the autopsy.

59 Supreme Council of the Order of Chosen Friends v. Forsinger, 125 Ind. 52, 25 N. E. 129, 9 L. R. A. 501, 21 Am. St. Rep. 196. Here the court declared: "The certificate issued to the appellee is a contract of insurance, and his right to recover upon it does not depend upon the action of the officers of the society; for if he has performed his part of the contract, and is totally disabled by disease or accident, he has a complete cause of action. A refusal by the officers of the society to allow the claim will not defeat a recovery. * * * But while it was necessary for the appellee to comply with the requirement of the valid by-laws of the association, 
of death or injury, the affidavit of an attending physician; but, in the absence of such an express stipulation, the claimant is under no obligation to furnish such an affidavit, even though a blank certificate therefor may be furnished by the company. ${ }^{60}$ But where this stipulation does occur, the affidavit must be signed by an attending physician in active practice. ${ }^{61}$

Pleading and Practice.-Where the policy requires the claimant to furnish notice and proofs of the injury or death as a condition precedent to a recovery under the contract, the petition must aver that this condition has been complied with. ${ }^{62}$ In many states the question of pleadings is made a

it was not in the power of the officers to defeat his claim by arbitrarlly rejecting his proofs as unsatisfactory, or by wrongfully declaring that he had not done what his contract and the by-laws of the association required of him."

6o Sun Acc. Ass'n v. Olson, 59 Ili. App. 217. Here the policy required the claimant to furnish sufficient proof of the death of the assured, together with the cause thereof. Among the blank proofs furnished by the company was a form of certificate to be filled out by the attending physician, the physician to sign the certificate. The court held, inasmuch as the policy did not expressly state that such a certificate was essential, a failure to furnish it would not invalidate the claim of the beneficiary.

e1 Gibson v. American Mut. Life Ins. Co., 37 N. Y. 580. Here the assured, while hunting, fell and was mortally wounded by the accidental discharge of his gun. The assured was brought to his home, where he lived but twenty-four hours. Among others who called at the house as a matter of friendship was a doctor, who, though formerly a practicing physician, had not been in actual practice for some years previous. A messenger had been dispatched to secure the famlly physician. Meanwhile the condition of the assured became so serious that upon request the physician present examined the wound and gave the wounded man morphine to relieve his pain. Upon his arrival, the family doctor took charge of the case. From the evidence it appeared that the first doctor acted only in a friendiy capacity and that his service was purely voluntary. The court held that his affidavit could not be required, inasmuch as he was not an attending physician within the meaning of the policy.

62 National Ben. Ass'n of Indianapolis v. Grauman, 107 Ind. 288, 7 N. E. 233. 
subject of statutory regulation, by which it is generally sufficient to merely allege that all of the conditions of the contract of insurance have been complied with, and it is not necessary to specifically aver that notice and proof of death or injury have been furnished the company. ${ }^{63}$ Where the policy provides that it shall be forfeited in the event that the claimant fails to furnish notice and proofs of death or injury in accordance with the terms thereof, it is essential that the defendant should so aver in its answer to the petition of the plaintiff. ${ }^{64}$

The claimant may introduce copies of the proofs of loss during trial to show a compliance with the requirement of the policy. Their insufficiency is a matter for the determination of the court, and not for the jury. ${ }^{65}$ The testimony of the claimant that notice and proof of death have been sent to the company within the prescribed time establishes a prima facie case of notice. The mere fact that the plaintiff is unable to remember what was contained in the proofs does not of itself warrant a conclusion that they were insufficient. ${ }^{\text {Be }}$

63 This is true in California (see Richards v. Travelers' Ins. Co., 89 Cal. 170, 26 Pac. 762, 23 Am. St. Rep. 455), in Iowa (see Hart v. National Masonic Acc. Ass'n, 105 Iowa, 717, 75 N. W. 508), and in Wisconsin (see Scheiderer v. Travelers' Ins. Co., 58 Wis. 13, 16 N. W. 47, 46 Am. Rep. 618).

64 Coburn v. Travelers' Ins. Co., 145 Mass. 226, 13 N. E. 604. See, also, Mutual Ben. Ass'n v. Nancarrow, 18 Colo. App. 274, 71 Pac. 423. Here the court held that where on the face of the complaint a liability exists in favor of the plaintiff, but there is no averment as to the condition prescribing that notice shall be given the insurer, the defendant, to avoid the policy, must plead this condition and allege the insured's failure to comply therewith.

65 See Cook v. Standard Life \& Accident Ins. Co., 84 Mich. 12, 47 N. W. 568. Here the court held that whether proofs of death comply with the requirements of an insurance policy is a question for the court, and these are matters in which the jury are in no. way concerned.

6 в Lampkin v. Travelers' Ins. Co., 11 Colo. App. 249, 52 Pac. 1040. 
Proofs of Loss as Evidence.-Proofs of death or injury are merely ex parte affidavits and statements, and as against the insurance company are not competent evidence to determine the truth of the allegations they contain. In the event that the insurance company contests the proofs offered, on the ground that they do not comply with the requirements of the policy, they may be put in evidence, and may even be read to the court, but not to the jury, since it is for the court, and not for the jury, to decide whether they are sufficient. At most, the proofs of death, if admissible at all as evidence, are admissible only to show that the requirements of the policy in that respect have been complied with. ${ }^{6 r}$

Some policies contain a condition, which has been upheld by the courts, declaring that the statements contained in the proofs of death shall be evidence thereof as against the claimant, but not as against the insurer.

o7 Cook v. Standard Life \& Accident Ins. Co., 84 Mich. 12, $47 \mathrm{~N}$. W. 568. In the lower court the plaintiff, without objection, had been permitted to read in full to the jury the proofs of death which the policy required the plaintiff to furnish, under the claim that it was for the purpose of showing that they were received by the company, the date on which they were received, etc. As a part of the proofs there was an affidavit by an eyewitness, the statement of the physician, and the coroner's certificate. The court on appeal held: "There was no contention on the part of the defendant but that the preliminary proofs had been furnished in full compliance with the terms of the policy, and it was error to allow them to be read in full in the presence of the jury. These were ex parte affidavits and statements, and they may have had their influence upon the jury, and have been taken by them as proof of the facts therein contained. There can be no doubt that, had the proofs been contested by the defendant on the ground that they were not in full compliance with the requirements of the policy as preliminary proofs of cleath, counsel would have had the right, not only to put them in evidence, but to have read them to the court; but they were matters in which the jury were in no way concerned. Whether they compled with the requirements of the pollcy was for the court, and not for the jury." See, also, Foster v. Fidelity \& Casualty Co., 99 Wis. 447,75 N. W. 69,40 L. R. A. 833. 
The same rule prevails in accident insurance as in life insurance, that statements made by the beneficiary in proofs of death or injury are admissible in evidence against him, on the theory that they are admissions against interest. This is particularly true where the statements are made by the beneficiary himself, as distinguished from the statements or affidavits of eyewitnesses, physicians, or others, though the application of the rule is not limited to the statements of the beneficiary alone. If the proofs are furnished by others than the beneficiary, he may show that fact; and clearly a guardian cannot prejudice his minor wards by his admissions against their interest.

Although the statements may be considered admissions against interest, the claimant will not be estopped from introducing evidence to show that they are untrue or are hearsay, provided it appears that the insurance company has not been misled to its prejudice by relying on the statements contained in the proofs. ${ }^{68}$ In short, the proofs of death are not conclusive as against the assured, as to their truth or falsity, provided the insurance company be given reasonable notice of their inaccuracy. ${ }^{69}$ In any event, there can

68 Employers' Liability Assur. Corp. v. Anderson, 5 Kan. App. 18, 47 Pac. 331. In the proofs of death the claimant alleged that the assured was choled to death by highwaymen. The petition in the action alleged that he stumbled and fell into a hole near a bridge, and died as a result of a blow on the head resulting from his fall. The court held that misstatements in the proofs are conclusive of the facts stated, as against the claimant, only where the insurance company has been prejudiced in its defense by relying on the statements thus made. Evidence showed that the claimant relied on the verdict of the coroner's inquest in making proofs of death, and not on her personal knowledge, and, further, that the insurance company was represented at the inquest and had thoroughly investigated the circumstances of the death of the policy holder, and thus was not prejudiced by the statements contained in the proofs.

69 Travelers' Ins. Co. v. Melick, 65 Fed. 178, 12 C. C. A. 544, 27 L. R. A. 629 . Here the assured, a physician, accidentally sustained 
be no question but what the beneficiary will be permitted in an action to show the actual facts, where, in the absence

a gunshot wound in the foot. Tetanus, or lockjaw, developed. This disease causes the most frightful suffering, together with violent spasms or convulsions. The assured was found dead in his bed some three weeks after the accident, with a scalpel in his right hand and his trachea and jugular veins cut. Either the tetanus or the wound in the throat was sufficient to cause death. The administrator, who was not a physician, in the proofs of death asserted that the assured "took a knife and cut his throat; all evidence tends to show that the condition of his mind and his physical condition that prompted the suicide was caused by the shot wound." The attending doctor testified that tetanus was the only cause to which he would attribute the death. The lower court instructed the jury that they were at liberty to consider the statement of the administrator, the defendant, in error, but that it was not in any manner conclusive upon him; that whatever cause of death might have been alleged in the proof of death, he was at liberty, on the trial, to show that the death resulted from some other or different cause. The higher court declared: "The better rule upon this subject is that statements of this nature in proofs of loss are-binding upon the party who makes them until, by pleading or otherwise, he gives the insurance company reasonable notice that he was mistaken in his statement, and that he will endeavor to show that the death was the resuit of a different cause from that stated in his proofs. After the insurance company has received due notice of this fact, the proofs have the probative force of solemn admissions under oath against interest, but they are not conclusive. There was nothing in the charge of the court in conflict with this rule. Ample notice of the claim of the defendant in error that the death was not caused by suicide was given in the pleadings, and the proof itself disclosed the claim that the cutting was an effect of the accidental shot wound. * * * The real complaint of the counsel is that the court did not also charge the jury that the weight which they should give to the statement was that of a solemn admission under oath against interest. Undoubtedly the court wouid have so charged, if its attention had been called to it, and it had been requested so to do."

Young v. Travelers' Ins. Co., 80 Me. 244, 13 Atl. 896. Here the agent of the insurance company, upon receiving notice of a claim for indemnity, made out the proof of loss, and therein misstated the date of the accident. The assured signed the proof of injury by the advice of the agent and without any improper motive. The court held that the company could not take advantage of the misstatement, and said: "We do not think the date of the accident so material that an honest misstatement of it in the notice is fatal. 
of fraud, from any reason inaccuracies may have crept into the proofs of death or injury. ${ }^{70}$

Where statements furnished by the claimant are not required under the policy as a part of the proofs of death or injury, the tendency of modern decisions is not to consider them as evidence against the claimant upon trial.

It follows that, though the statements in the proofs of death are not conclusive as against the claimant, yet if they set forth facts under which no recovery could be had under the policy, unless they are explained upon trial, the court must enter a nonsuit or direct a verdict.

Waiver of Notice and Proofs of Death or Injury.-Compliance with the condition of the policy requiring the claimant to furnish notice and proofs of death or injury, as well as any defects in the notice or proofs, may be waived by the insurance company. Inasmuch as these provisions of the policy are inserted for the benefit of the company, it is

The policy does not in terms require a statement of the date. It is not of the essence of the contract. A misstatement of it in the declaration in the plaintiff's writ would not prevent him from proving the true date. The defendant was in no way misled or prejudiced by it."

See, also, Bowen v. Preferred Acc. Ins. Co., 82 App. Div. 458, 81 N. Y. Supp. 840. Here a certificate accompanying the proofs of death, made by an officer in another state, where the assured was killed, stated that the deceased was of a certain age at the time of his death. The court held that this was not conclusive upon the plaintiff, where it appeared that, while she verified certain affidavits accompanying the proofs of death, she did not verify or expressly adopt the statements of this official; and similarly that a statement as to the age of the assured made and verified by the plaintiff in the proofs of death would not be conclusive upon her.

70 Wildey Casualty Co. v. Sheppard, 61 Kan. 351, 59 Pac. 651, 47 L. R. A. 650 . Here the assured lost his left hand by the discharge of a gun while hunting rabbits. The doctor, who attended Sheppard and made the claim for him, stated that Sheppard placed the gun on the ground, butt down, and that it was discharged, taking effect in his left wrist. The testimony showed that Sheppard stepped into a hollow place in the ground, causing the gun to slip through 
optional with it to claim a forfeiture for their breach. ${ }^{71}$ No separate valuable consideration is required to support such a waiver, since, in theory at least, its validity depends upon the doctrine of estoppel. The same general rules apply in accident as in life insurance policies.

Requirements of the policy, inserted for the benefit and protection of the insurer, may be waived by any agent of the company having general authority to represent it in negotiations with the assured for settling his claim. ${ }^{72}$ It is expressly true that any agent having authority to accept notice and proofs of death or injury has the power to waive them, or to waive any defects in them. But in the absence of statutory provisions to the contrary, a local agent or representative, whose powers are curtailed, generally by a provision in the policy itself, cannot bind the company by a waiver either express or implied. In many states statutes provide that any agent authorized to solicit and draw contracts of insurance is deemed the agent of the company for all purposes, and therefore any waiver by such agent will be binding upon the company. ${ }^{73}$ Such statutory enactment

his hands, so that it struck the ground and was discharged. There was testimony to the effect that the assured called the attention of the doctor to the fact that the proof made out was incorrect in that particular, and that the doctor agreed to correct it, but by some orersight failed to do so. The court sald: "The inaccuracy seems to us to be rather immaterial; but, in any event, it having been made by mistake, the insured is not prevented from showing the actual facts."

71 Hurt v. Employers' Liability Assur. Corp. (C. C.) 122 Fed. 828; Preferred Acc. Ins. Co. v. Fielding, 35 Colo. 19, 83 Pac. 1013, 9 Ann. Cas. 916; Fidelity \& Casualty Co. of New York v. Cooper, $137 \mathrm{Ky}$. 544, $126 \mathrm{~S}$. W. 111; Da Rin v. Casualty Co. of America, 41 Mont. 175, 108 Pac. 649, 27 L. R. A. (N. S.) 1164, 137 Am. St. Rep. 709.

72 Fidelity \& Casualty Co. of New York v. Cooper, $137 \mathrm{Ky}$. 544, $126 \mathrm{~S}$. W. 111. Here the court held that the agent who takes the application, and is the only person with whom the parties deal, has authority to waive verification of the proofs.

78 See statutes in Maine, Massachusetts, Minnesota, and Wisconsin. 
will set aside the clause contained in the standard policies of accident insurance issued in most states, providing that "no officer, agent, or other representative shall have power to waive any provision or condition of this policy $* * *$ unless such waiver, if any, shall be written upon or attached thereto."

Compliance with the condition requiring notice and proofs of death or injury may be waived in several ways, the most important of which are by direct statement, by acts of the company or its agent inconsistent with the purpose of enforcing a compliance, or by denial on the part of the company of liability under the policy.

Generally speaking, the power of any one to bind the company by waiver is a question of agency. If a general agent informs the claimant that proof or notice will not be required, or need not be furnished within the time specified in the policy, the company will be bound, and the requirements of the policy in this regard will be deemed waived. ${ }^{74}$

74 Continental Casualty Co. v. Ogburn (Ala.) 57 South. 852, where the court held that defects in preliminary proofs of loss were waived by insurer's fallure to object on that ground, or by a refusal to pay the amount of the policy for any other reason than defects in the proofs. Correll v. National Acc. Soc., 139 Iowa, 36, 116 N. W. 1046, 130 Am. St. Rep. 294; American Acc. Co. v. Fidler's Adm'x, 35 S. W. $905,36 \mathrm{~S}$. W. 528, $18 \mathrm{Ky}$. Law Rep. 161. Here evidence was introduced to the effect that the agent advised the widow of the assured that she had twelve months in which to make the required proofs and give notice, although the policy required "immediate notice of the accident or death." The court said: "Such a notice may be waived by the company or its general agent, as well as the necessity of proof of loss, which seems to have been done in this case." Ramsey v. General Accident, Fire \& Life Ins. Co., 160 Mo. App. 236. 142 S. W. 763. Reynolds v. Equitable Acc. Ass'n, 49 Hun, 605, 1 N. Y. Supp. 738. Here the policy required that notice of the happening of the accident should be given to the company. The evidence showed that the agent of the company visited the widow, who was the beneficiary, and advised her that a failure to give notice would make no difference. Other officials of the company addressed letters to a person acting in behalf of the widow, stating that she had no claim 
Where the claimant is advised that the proofs of injury submitted are sufficient, or where the company fails to call attention to any defects in the proofs which are submitted, the company will be estopped from insisting upon any additional proofs, no matter how inadequate the proofs received may be, and will also be estopped from setting up the defense of defective proofs in a suit brought to enforce liability on the policy. ${ }^{75}$ And similarly, where the company requests the beneficiary to submit certain proofs, with the declaration that they will comply with the terms of the policy, it will be estopped from insisting upon any further proofs.

Where the company accepts the proofs which are submitted and declares them sufficient, or where it asks for further information after receiving them, it is estopped from

by reason of the manner in which the injury was received. The court sustained the jury in finding that these acts constituted a waiver.

75 Hurt v. Employers' Liability Assur. Corp. (C. C.) 122 Fed. 828. Here the court said: "It is a very well settled rule, where defective proofs are furnished within the prescribed time, if an insurance company receive and retain them, and make no objection, a waiver of all objections thereto is inferred; and a sinilar result may follow if there is any additional act 'required' by the company and performed by the insured after the first proofs are furnished after the time fixed in the policy." McClure v. Great Western Acc. Ass'n, 141 Iowa, 350, 118 N. W. 269; National Masonic Acc. Ass'n v. Seed, 95 Ill. App. 43 . Here the court held that where a notice of death is defective in form, and the insurer, upon receiving it, makes no objection to it, such want of objection is to be regarded as a waiver of a sufficient notice; and where a defective notice of a death loss is given, if the insurer points out the defects, the assured can supply them, but, if he fails to do so, the objections may be regarded as waived. Fidelity \& Casualty Co. of New York, v. Cooper, $137 \mathrm{Ky}$. 544,126 S. W. 111 . Where the accident policy did not require the proofs of death to be sworn to, and the resident agent who procured the policy informed the plaintiffs that the proofs furnished were all that were necessary, the court held that the insurer could not dispute the claim because sworn proofs were not furnished, under the rule that the agent who takes the application, and is the only person 
later setting up any defects therein. ${ }^{78}$ And any conduct on the part of the insurer which prevents the claimant from performing the conditions of the policy relating to furnishing notice and proofs of death or injury will constitute a waiver of any failure thus induced. ${ }^{77}$ For example, it is unnecessary for the assured to show that he has furnished

with whom the parties deal, has authority to waive verification of the proofs. McFarland v. United States Mut. Acc. Ass'n, 124 Mo. 204, 27 S. W. 436. See, also, Da Rin v. Casualty Co. of America, 41 Mont. 175, 10 S Pac. 649, 27 L. R. A. (N. S.) 1164, 137 Am. St. Rep. 709. When notice of a casualty and proof of resulting death are incorporated in the same communication to the insurer, and the proof of the cause of death, with the attendant facts, meets all the requirements of the policy, except that the statement is not as full as it might be, the court held that the failure of the insurer to demand more explicit proof is a waiver of his right to thereafter object to its sutticiency.

76 Commerclal Travelers' Mut. Acc. Ass'n v. Springsteen, 23 Ind. App. 657, 55 N. E. 973. Here the policy provided that written notice of the injury should be given the secretary of the association within ten days. Oral notice was given to that official within the required time by the assured. Hohn v. Interstate Casualty Co., 115 Mich. 79,72 N. W. 1105 . Here the court held that the failure of the assured to give notice of an injury within the time required by an accident policy was waived by the insurance company's asking for further information after receiving notice, without suggesting that the notice came too late. However, see Standard Life \& Accident Ins. Co. v. Strong, 13 Ind. App. 315, 41 N. E. 604, where the court held that, if the proofs were furnished too late, the mere fact that they were retained does not revive the company's liability.

Brink v. Guaranty Mut. Acc. Ass'n, 55 Hun, 606, 7 N. Y. Supp. 847 , affirmed without opinion 130 N. Y. 675,29 N. E. 1035. The policy required written notice of the injury within ten days after the accident. A month after the injury plaintiff addressed a notice thereof to the defendant, who receired it and kept it, and later defendant's secretary stated to the agent of the plaintiff that the notice was sufficient. The court held that this constituted a waiver of the failure to comply with the terms of the policy.

77 See Railway Officials' Acc. Ass'n v. Armstrong, 22 Ind. App. $406,53 \mathrm{~N}$. E. 1037, where the court held that a continued denial of liability by an accident insurance company, beginning at the time of the death of the insured, dispenses with any formal proof of death required by the policy. 
proofs of loss to the company, where it contends that it has fully discharged its liability and refuses to accept the proofs, or where it is shown that it would have ignored them, had they been received. ${ }^{78}$

Neglect or Refusal to Furnish Blank Forms.-The beneficiary will be excused from furnishing proofs of death where, upon notice to the insurer requesting blank forms, the company either refuses to provide the necessary blanks or delays sending them until after the time has elapsed within which, under the policy, the final proofs must be made. $^{79}$ Where the policy stipulates that blank forms for

78 Woodall v. Pacific Mut. Life Ins. Co. of San Francisco (Tex. Civ. App.) 79 S. W. 1090 . Here the assured was severely injured in an accident. At the end of thirteen weeks he furnished notice and proofs of injury to the company, as provided by the policy, of his total and continuous disability. In these proofs no "statement was made that he had sufficiently recovered to return to work. The company forwarded its draft for the amount of the policy for this time. The assured, an illiterate, signed the receipt in ignorance of its contents, under the impression that it was merely a receipt for the amount of the draft, and without intending to relinquish the company from further liability for his disability. Later the assured attempted to make out additional proofs of his total disability, but the company's physician refused to sign them. The court said: "If it should appear from the evidence * * * that the defendant, upon the contention that it had fully discharged its liability, falled or refused to accept proof of the continuation of plaintiff's total disability, or would have wholly ignored such proofs had they been recelved, it would be unnecessary for plaintiff to show that such proofs had been made out or furnished the company."

79 Standard Life \& Accident Ins. Co. v. Schmaltz, 66 Ark. 588, 53 S. W. 49, 74 Am. St. Rep. 112. Here the evidence showed that the company knew the beneficiary relied upon it to furnish the customary blanks for proof of death by accident, and willfully encouraged her to rely upon it to furnish such blanks until the time for making the proof had explred, and then falled to furnish them. The court held the evidence sufficient to support a finding that the company had waived the proofs of death. Union Casualty \& Surety Co. v. Mondy, 18 Colo. App. 395, 71 Pac. 677. The policy required immediate written notice of injury, and that affirmative written proof of death must be furnished the company within two months from the time 
final proof of death will be furnished the assured upon request, a refusal to furnish the blanks will serve as a waiver of the requirement to furnish proofs of death or injury. ${ }^{80}$

of death. The representative of the deceased called upon the agent several times for proper blanks for making out proofs of death. The agent requested him to delay the matter, assuring him that the rights of the beneficiaries would not be prejudiced. After two months had elapsed the company furnished the proper blanks, and no objection was made that proofs of death had been furnished too late, until the company filed its answer to the suit on the policy. The court held that the company had waived objection to the failure to furnish proofs within the prescribed time. Metropolitan Casualty Ins. Co. v. McAuley, 134 Ga. App. 165, 67 S. E. 393 . Here the court held that where a brief delay in furnishing the proofs of the death of the assured is caused, not by the laches of the beneficlary, but by the failure of the insurer to furnish the proper blanks with reasonable promptness, the beneficiary will not be held to a strict compliance with the stipulation of the policy relative to the time within which final proofs of death should be submitted. National Masonic Acc. Ass'n v. McBride, 162 Ind. 379, 70 N. E. 483. The court here said: "The condition that, in default of the delivery of the proofs required within ninety days after the accident, the right to claim the sum promised to be paid by the association should be forfeited, was entirely for the benefit of the insurer. But the ap. pellant had the right to waive strict compliance with it, and in such cases very slight circumstances have been held sufficient evidence of the intention of the insurer not to take advantage of the breach or to insist upon the forfeiture." Hoffman v. Manufacturers' Acc. Indemn. Co., 56 Mo. App. 301. Here, after the death of the assured, the beneficiary gave timely notice and asked for blanks to make proofs upon, as required by the policy. The insurer refused the blanks, upon the ground that the notice was not given in time. The court held that the proofs of loss were waived. See, also, Western Travelers' Acc. Ass'n v. Holbrook, 65 Neb. 475, 94 N. W. 816, affirming 65 Neb. 469,91 N. W. 276. To the contrary, see Standard Life \& Accident Ins. Co. v. Strong, 13 Ind. App. 315, 41 N. E. 604. Here the court held that the mere fact that the insurance company failed to furnish blanks to enable the beneficiary to make proofs of loss does not constitute a waiver of such proofs.

80 Phoenix Accident \& Sick Ben. Ass'n v. Stiver, 42 Ind. App. 636, 84 N. E. 772. Here the beneficiary, within the ten days provided by the policy, notified the company of the death of the assured and requested blanks for final proof of death; the policy stipulating that they would be furnished on request. The company having refused to supply the blanks, the court held that the requirement of 
Waiver by Request for Further Information.-Where the initial proofs are for any reason defective, or even where the notice or proofs are not furnished within the time prescribed by the policy, this defense will be waived by any act of the company which induces the claimant to take further steps to satisfy the insurance company with reference to the loss. ${ }^{81}$ This waiver is frequently accomplished on

proofs of death was waived. See, also, Manufacturers' Acc. Indemnity Co. v. Fletcher, 5 Ohio Cir. Ct. Rep. 633, where the court said: "As to the formal proofs of loss after the disability had terminated, the condition of the policy provided that the company would furnish blanks for that purpose. This the company refused to do. By so doing this condition of the policy was waived by the company." Evarts v. United States Mut. Acc. Ass'n, 61 Hun, 624, 16 N. Y. Supp. 27, where the court held that failure to furnish proof of death cannot be relied on as a defense in an action on a policy, where the company, by letter acknowledging recelpt of the notlfication of the death of the assured, refuses to furnish blanks for giving formal, positive proof thereof.

81 Hurt v. Employers' Liability Assur. Corp. (C. C.) 122 Fed. 828. Here the court held it to be a well-settled rule that a waiver is inferred if any additional act is required by the company and performed by the insured after the first proofs are furnished after the time fixed in the policy. Pacific Mut. Life Ins. Co. v. Branham, 34 Ind. App. 243,70 N. E. 174 . The policy required immediate notice of injury, and the company, on receiving notice some time after the injury, sent assured blanks on which to furnish proofs of injury and loss of time, giving particular instructions, and stating that when the proofs had been made and insured was ready to resume his duties the ciaim would be adjusted without unnecessary delay. The court held this constituted compliance with the requirement of immediate notice. Standard Life \& Accident Ins. Co. v. Davis, 59 Kan. 521, 53 Pac. 856, where the court held a condition requiring notice to the insurance company within a specified time would be deemed waived, where notice of the injury or death was subsequentiy given, together with proofs of loss, and the company retained them without objection, and subsequently calied for and received additional information and proof respecting the injury and death of the assured. The court said: "Instead of returning the proofs because not furnished in accordance with the terms of the policy, they retained them and demanded additional proofs. The insured was therefore put to the expense and trouble of furnishing the additional proofs, and, having done so at the instance of the company, 
the part of the insurance company by having its physician examine the assured, or by securing statements from the assured or others. ${ }^{82}$ In short, any act on the part of the

the defense with respect to notice must be deemed to have been waired." To the same effect, and based on this case, is Wildey Casualty Co. v. Sheppard, 61 Kan. 351, 59 Pac. 651, 47 L R. A. 650. In Peabody $\nabla$. Fraternal Acc. Ass'n, 89 Me. 96, 35 Atl. 1020, the court said: "When an insurance company accepts or assists in preparing second proofs of loss, it thereby waives any defects in the first proofs." Hohn v. Interstate Casualty Co., 115 Mich. 79, 72 N. W. 1105, where the court held that the failure of the assured to give notice of an injury within the time required by the policy was waived by the company's asking for further information after receiving notice, without suggesting that the notice came too late. Trippe v. Provident Fund Soc., 140 N. Y. 23, 35 N. E. 316, 22 L. R. A. 432, $37 \mathrm{Am}$. St. Rep. 529. Here notice of the death of the assured was retained by the assured without objection. Forty days thereafter, upon written application, defendant furnished the necessary blanks for proofs of loss, which were made and forwarded to the company, and retained by it without objection. More than five months thereafter defendant called for further information. The court said: "It is well settled that such defenses [a literal compliance with the condition regarding notice and proofs of death or injury] are waived when the company, with knowledge of all the facts, requires the assured by virtue of the contract to do some act or incur some expense or trouble inconsistent with the claim that the contract had become inoperative in consequence of a breach of some of the conditions." See, also, Moore v. Wildey Casualty Co., 176 Mass. 418,57 N. E. 673.

82 Fidelity \& Casualty Co. v. Brown, 4 Ind. T. 397, 69 S. W. 915. Here the assured did not notify the company of the accident, but the company heard of the accident from other sources, and had its physician examine the assured and secure statements. The court held that it had waived the furnishing of proofs in accordance with the terms of the policy. Contra, see Heywood v. Maine Mut. Ace. Ass'n, 85 Me. 289, 27 Atl. 154, where the court declared that, though at the request of the company the assured submitted to an examination by the company's physician, there was no waiver of the prompt notice required by the policy. In Fidelity \& Casualty Co. of New York v. Cooper, $157 \mathrm{Ky}$. 544, 126 S. W. 111, the court held that, where the insurance company investigated the claim under an accident policy on unverified proofs of death and denied liability, the beneficiaries were not required to furnish other or further proofs.

Peabody v. Fraternal Acc. Ass'n, 89 Me. 96, 35 Atl. 1020. October 19, 1893, the assured met with a painful accident. A provision of

Fuller Acc.Ins.-27 
insurer which justifies the assured in believing that a forfeiture of the policy will not be insisted upon, and which in-

the policy required written notice to be given the company within ten days after the occurrence of the accident. November $2 d$ plaintiff sent a written notice, which was not received by the defendants until after the ten days had expired. Upon receipt of the notice, the company sent assured a printed blank containing a schedule of inquiries to be answered, as a first proof of loss, and to be returned to the company. Subsequently a second blank form was sent to the assured, to be filled out as a final proof of loss. The first blank, but not the second, reserved to the company its right to object to any failure to comply with the conditions of the policy. March 27th next an officer of the company, together with a medical expert, called at the home of the assured and with his permission subjected hin to a personal examination. Subsequently the company rejected the claim, and later set up as a defense the failure to receive the original notice of the accident within the prescribed ten days. The court said: "The sending of the second blank (form No. 5) unconditionally, and the fact of the bodily examination made by the agents of the company and submitted to by the plaintiff, taken in connection with the confession that the company finally abandons its charges of fraud as a defense to the action, relying upon the want of a strict compliance with the contract in the matter of notice, all these facts, aided by the other conduct of the company as before considered, certainly establish a waiver of any technical forfeiture that might have been created by the lateness of the notice." Crenshaw v. Pacific Mut. Life Ins. Co., 63 Mo. App. 678. The policy called for immediate written notice of any injury. The assured directed his wife to notify the company, and on the day of the injury she sent a note to the company's physician by a lad. The physician examined the assured. The court held that this did not constitute notice to the company. But some three months later the assured called on the general agent of the company and requested and received from him blank forms for final proof of injury, which were furnished to him. 'The court said: "If the jury believed that such action, in view of all the circumstances of the case, was reasonably calculated to lead plaintiff, as a reasonable man, into the belief that no formal notice was required, and he, in consequence thereof, went to the trouble and expense of getting up proofs, then defendant would be held to have waived the notice. Waiver is something in the nature of an estoppel, and if defendant thus led plaintiff into additional trouble and expense, it would not be permitted afterward to interpose a want of notice." In a subsequent review of the case, 71 Mo. App. 42, the court held: "It is too plain for argument that, if the defendant furuished plaintiff blanks to make out his proofs of disability, this would constitute a wairer of proof of notice of the accident. If the defendant intended to insist upon a forfeiture upon 
duces him to assume the expense and labor of preparing proofs of loss, will constitute a waiver. ${ }^{83}$

But where, either by notice on the part of the company or by the terms of the policy, the assured is put on his information, at the time blank forms for proof are sent or the request is made for further information, that the company will insist upon a compliance with the terms of the policy, and that furnishing the blanks or requesting the information is not to be deemed a waiver of any conditions, no waiver will arise. ${ }^{84}$ And similarly where the company at the time of making the additional request is ignorant of the facts which have constituted the waiver, since to be effectual a waiver must not only be made intentionally, but with knowl-

that ground, why furnish plaintiff with such blanks, and thus lead him to believe that, if he went to the expense and trouble of making such proofs, the same would be receired? If the defendant intended to insist on a forfeiture on any such ground, common fairness would have required that it so advise the latter when he applied for the blanks to make proof of disability. But, instead of doing this, it furnished the blanks without objection or reservation. This was sufficient to justify any reasonable man in concluding that the defendant did not intend to insist upon a forfeiture, but intended to waive compliance with this condition." Myers v. Maryland Casualty Co., 123 Mo. App. 682, 101 S. W. 124.

83 Ramsey v. General Accilent, Fire \& Life Ins. Co., 160 Mo. App. 236, 142 S. W. 763.

84 McCord v. Masonic Casualty Co., 201 Mass. 473, s8 N. E. 6, where the court held that there had been no waiver of the requirement for notice, when the insurance company, in furnishing the proper blank forms, stated that such action must not be construed as an admission of any claim or a waiver of any rights set forth in the policy. Loesch v. Union Casualty \& Surety Co., 176 Mo. 654, 75 S. W. 621. Here the company stamped on the blank form for proof of loss that it did not, by furnishing the same, waive any right to forfeit the policy for a breach of its conditions, and also sent to the beneficiary a letter to the same effect along with the blank. The court held that this furnished positive proof that the company did not waive any of the conditions of forfeiture. See, also, Meech v. National Acc. Soc., 50 App. Div. 144, 63 N. Y. Supp. 1008. Here the claimant neglected to give notice of the injury within the ten days required by the policy. In sending him a blank form to make proof of injury, the company inclosed a letter expressly reserving its rights 
edge of the circumstances. ${ }^{85}$ Waiver under the conditions here contemplated generally occurs where by the expiration of the time specified all possibility of complying with the terms of the policy has ceased. ${ }^{86}$

arising by virtue of the failure to give the required notice. The court said: "In the absence of express waiver of the performance of conditions precedent, some element of estoppel must exist. It must be aftirmatively shown by the insured that he has been misled to his prejudice by some act of the insurer, or that the latter, after knowledge of the facts constituting the forfeiture, has done or required something, or exercised a right which could only be done, exercised, or required, by virtue of the policy. Such estoppel or waiver cannot be inferred from mere silence on the part of the insurance company, nor from its suggesting the forwarding of proofs of loss or corrections therein, expressly reserving its right to declare the forfeiture." The court here held that there had been no waiver. To the same effect, Hagadorn v. Masonic Equitable Acc. Ass'n of the World, 69 N. Y. Supp. 831, 59 App. Div. 321.

85 United Benev. Soc. v. Freeman, 111 Ga. 355, 36 S. E. 764. Here the policy required a written notice within ten days. The assured on the day of the injury visited a physician and verbally requested the local agent of the company to notify the main office of the accident. This the agent neglected to do until after the expiration of the ten days, when he wrote them a letter, but neglected, among other things, to state the date of the accident. The company thereupon sent the assured blank forms for proofs of injury, without knowing that more than ten days had elapsed since the injury. The court said: "There is undoubtedly much excellent authority for holding that if the society, with full knowledge of the facts, required the beneficiary under the contract of insurance to do some act or incur some expense or trouble which was inconsistent with the claim that the contract had become inoperative in consequence of a breach of the condition as to the time within which the notice should be given, then it impliedly waived this defense. But certainly no one can be held to have impliedly waived a defense of the existence of which he had no knowledge at the time he did the act which is relied upon as a waiver thereof. One cannot be held to have waived something of which he was ignorant." Whalen v. Equitable Acc. Co., 99 Me. 231, 58 Atl. 1057, where in a health policy undel somewhat similar circumstances the court said: "Waiver is a matter of intention. One cannot be said to waive that which he does not know." See, also, Berman v. Fraternities Health \& Accident Ass'n, 107 Me. 368, 78 Atl. 462; Hagadorn v. Masonic Equitable Acc. Ass'n of the World, 69 N. Y. Supp. 831, 59 App. Div, 321.

86 Hurt v. Employers' Liability Assur. Corp. (C. C.) 122 Fed. 828. IIere walver was found after the thirty days for furnishing notice 
Acceptance of Subsequent Premiums.-The policy of insurance does not become void by the failure of the assured to give the required notice of an accident or proof of injury, but his claim for indemnity because of that particular accident is merely forfeited. Therefore the acceptance by the company of premiums which subsequently become due under the policy, or the sending to the assured of a notice of subsequent assessments, do not constitute a waiver of any failure on the part of the assured to comply with the condition relating to notice and proofs. ${ }^{87}$

\section{Failure to Object to Defects in Notice or Proofs of Death} or Injury.-Where the insurance company receives notice or proofs of death or injury, and fails to object to any defect therein, or to call the attention of the claimant to errors which they contain, it is held to waive all such objection. ${ }^{88}$

to the company had expired. Pacific Mut. Life Ins. Co. v. Branham, 34 Ind. App. 243, 70 N. E. 174. Although the policy required immediate written notice, twenty-two days elapsed after the injury before notice was given to the company. To the same effect, see Standard Life \& Accident Ins. Co. v. Davis, 59 Kan. 521, 53 Pac. 856; Peabody v. Fraternal Acc. Ass'n, 89 Me. 96, 35 Atl. 1020; Moore v. Wildey Casualty Co., 176 Mass. 418, 57 N. E. 673; Hohn v. Inter-State Casualty Co., 115 Mich. 79, 72 N. W. 1105; Crenshaw v. Pacific Mut. Life Ins. Co., 63 Mo. App. 678; Id., 71 Mo. App. 42; Trippe v. Provident Fund Soc., 140 N. Y. 23, 35 N. E. 316, 22 L. R. A. 432, 37 Am. St. Rep. 529.

87 Hagadorn v. Masonic Equitable Acc. Ass'n of the World, 59 App. Div. 321, 69 N. Y. Supp. 831. Here the assured failed to give notice of his injury within the time required by the policy, and the company later sent him a notice of assessments which subsequently fell due. The court said: "The policy was in force, notwithstanding the accident and the claim made on account of it. The plaintiff had a right to continue it by paying such assessments as should be lawfully levied, and continue it as a protection against future accidents; and the sending to the assured notice of such assessment subsequent to the accident had no bearing whatever on the claim made, or the defense to the claim as made." See, also, Meech $\nabla$. National Acc. Soc., 50 App. Div. 144, 63 N. Y. Supp. 1008.

88 Grand Lodge Brotherhood of Locomotive Firemen v. Orrell, 206 IIl. 208, 69 N. E. 68, affirming 97 Ill. App. 246. Here the court held 
The logic of this rule is that, if the insurer for any reason is not satisfied with the proofs submitted, it is only reasonable that he should notify the assured, so that any defects may be supplied or errors corrected. Forfeitures are repugnant to the law, and it will not encourage them. It will not lend itself to the forfeiture of contracts by reason of purely formal defects, when the information desired by one party can be secured by merely calling attention to defects which must be apparent to it. ${ }^{89}$ Where the evidence shows

that, where a claim for indemnity was presented by a member of a benefit society in a manner satisfactory to the subordinate lodge, which certified the same to the grand or supreme lodge, if the latter acts upon the claim as having been properly presented, it cannot complain as to the manner of such presentation when an action is brought to recover the indemnity. United States Health \& Accident Ins. Co. v. Clark, 41 Ind. App. 345, 83 N. E. 760. See, also, Railway Officials' \& Employés' Ass'n v. Beddow, 112 Ky. 184, 65 S. W. 362, $23 \mathrm{Ky}$. Law Rep. 1438. Here the policy requirèd the claimant to furnish verified affirmative proof in writing as to the particulars of the injury. The company accepted the affirmative proof furnished, without objecting to the lack of verification. The court held the company was estopped from defending on that ground, and said: "When proofs are furnished in time, and are objectionable in form or deficient in matter, the insurer should, without unreasonable delay, inform the claimant in what particulars the proof is unsatisfactory. Falling to do so, he will be estopped from showing that the proofs were insufficient on the trial of the case, should suit be brought to recover on the policy. When proofs are defective in more than one particular, the objections returned by the company should state definitely each point respecting which further information is desired; otherwise, it will be presumed that the proofs are satisfactory in regard to all matters that are not essentially pointed out." Anderson v. Ftna Life Ins. Co., 75 N. H. 375, 74 Atl. 1051; Hughes v. Central Acc. Ins. Co., 222 Pa. 462, 71 Atl. 923; Continental Casualty Co. v. Lindsay, 111 Va. 389, 69 S. E. 344; Mellen v. United States Health \& Accident Ins. Co., 83 Vt. 242, 75 Atl. 273.

89 Martln v. Manufacturers' Acc. Indemn. Co., 151 N. Y. 94, 45 N. E. 377. Here the court said: "It would be a very harsh and unreasonable construction to apply this clause [of forfeiture for failure to give immediate notice within ten days] to every imperfection In a notice, which, although promptly given, 'omitted to state some particular embraced among those enumerated in the prior clause. * * The company could have demanded further particulars; 
that the notice or proofs have been accepted and retained by the insurer, all defects are waived. This is particularly true where the policy merely calls for "satisfactory" proofs, without specifying what facts must be set forth therein. ${ }^{90}$ Moreover, objections must be made by the insurer promptly, or at most within a reasonable time.

Where the insurer notifies the claimant of certain defects in the notice or proofs, but fails to call attention to other defects, the defects not objected to will be waived, since by inference, at least, the beneficiary is given to understand that the proofs are satisfactory, except as to the matters to which attention is directed. ${ }^{01}$ This does not apply, how-

but, having omitted to do so, it waived any objection to the form or contents of the notice." In Peacock v. New York Life Ins. Co., 14 N. Y. Super. Ct. 33s, the court said: "When what are in good faith presented to them as preliminary proofs are in any respect defective, common fairness requires that such defect be suggested, and that it be not held in reserve, to be used afterwards to obtain further delay of payment, or to defeat a suit brought for the money." See, also, De Van v. Commercial Travelers' Mut. Acc. Ass'n, 36 N. Y. Supp. 931,92 Hun, 256.

90 Bushaw v. Women's Mut. Ins. \& Acc. Co., 8 N. Y. Supp. 423, 55 Hun, 607. Here the policy called for "proof satisfactory to the company." It received an informal statement in writing of the injury and disability, and made no objection to its form or substance, and made no demand for anything further. The court held that this constituted a waiver of all objections thereto. Railway Officials' Acc. Ass'n v. Armstrong, 22 Ind. App. 406, 53 N. E. 1037. The court here said: "While it is no part of a company's duty to make out a claim for a beneficiary, yet it is well settled that the company must throw 110 obstacle in the way of furnishing proofs. The company has seen fit to insert a clause requiring satisfactory proof within a given time, without providing in the policy what that proof shall be. When the company has been notified of the death of a policy loolder, it then becomes its duty, upon request under the policy, to indicate what further proofs are required."

91 Braymer v. Conmercial Mut. Acc. Co., 199 Pa. 259, 48 Atl. 972, where the court said: "If for any reason purely technical the company deemed the proofs insufficient, they should have notified the plaintiff and given her an opportunity to amend them." See, also, Railway Officials' \& Employés' Ass'n v. Beddow, $112 \mathrm{Ky} .184,65 \mathrm{~S}$. W. 362, 23 Ky. Law Rep. 1438, supra. 
ever, to a general objection to the proofs, coupled with a declaration by the company that it will insist upon a compliance with the conditions of the policy. In Illinois, Indiana, Missouri, and Pennsylvania the failure to furnish original proofs within the time required by the policy will not be waived by mere silence on the part of the insurer, though in other jurisdictions a delay in furnishing the proofs will be waived by failure to object, the same as any other defect. ${ }^{92}$

Waiver by Denial of Liability.-Denial of liability by the insurance company on grounds other than a failure to furnish proper notice or proofs of death or injury within the prescribed time, or its denial of liability without assigning reasons therefor, waives the necessity of furnishing such notice or proofs. ${ }^{93}$ This denial of liability may be based on any

92 Standard Life \& Accident Ins. Co. v. Strong, 13 Ind. App. 315, $41 \mathrm{~N}$. E. 604. Here the court said: "The mere fact that the appellant 'accepted and retained' the proofs of death, or failed to furnish blanks to enable the appellee to make proof, does not constitute a waiver of such proof. The contract does not provide that the company will furnish blanks for that purpose. If the proofs were furnished too late, $* * *$ the mere fact that they were retained does not revive the company's liability."

93 Depue v. Travelers' Ins. Co. (C. C.) 166 Fed. 183 . Here a provision that no action should be brought within three months after receipt of proofs of death by the company was waived by its denial of liability. Lampkin v. Travelers' Ins. Co., 11 Colo. App. 249, 52 Pac. 1040, where the company refused to pay the amount of the policy on the ground of misrepresentation in the application; Fidelity \& Casualty Co. of New York v. Waterman, 161 Ill. 632, 44 N. E. 283, 32 L. R. A. 654, affirming 59 Ill. App. 297; Metropolitan Acc. Ass'n v. Froiland, 161 Ill. 30, 43 N. E. 766, 52 Am. St. Rep. 359, affirming 59 1ll. App. 522, where the company denied liability on the ground that the death was caused by poison, and was not therefore covered by the policy; United States Health \& Accident Ins. Co. v. Clark, 41 Ind. App. 345, 83 N. E. 760; Fidelity \& Casualty Co. of New York v. Hart, 142 Ky. 25, 133 S. W. 996; Standard Life \& Accident Ins. Co. v. Thomas, 17 S. W. 275, 13 Ky. Law Rep. 593, where the company refused to pay the ciaim, alleging that the assured died of sickness, and not as the result of an accidental injury; 
one of several grounds, as, for example, that the application was fraudulent by reason of misrepresentation; ${ }^{94}$ that the death of the assured was the result of causes not covered by the policy; ${ }^{95}$ that the company has already discharged its liability; ${ }^{96}$ or liability may be denied without assigning any reason therefor. ${ }^{97}$ The denial of liability and refusal to pay the amount of the policy by an insurance company, in order to amount to a waiver of the notice or proofs required by the policy, must be made within, and not after, the time in which proof of the accident and injury can be made. In short, to amount to an estoppel, the company must deny its liability before the expiration of the time within which it is possible for the claimant to comply with the conditions prescribed by the policy. ${ }^{98}$ Manifestly, if

Continental Casualty Co. v. Mathis, 150 Ky. 477, 150 S. W. 507; Hoffman v. Michigan Home \& Hospital Ass'n, 128 Mich. 323,87 N. W. 265, 54 L. R. A. 746; Anderson v. Atna Life Ins. Co., 75 N. H. 375, 74 Atl. 1051; Cornell v. Travelers' Ins. Co. of Hartford, 104 N. Y. Supp. 999, 120 App. Div. 459; Hughes v. Central Acc. Ins. Co., 222 Pa. 462, 71 Atl. 923; Standard Loan \& Accident Ins. Co. v. Thornton, 97 Tenn. 1, 40 S. W. 136; Woodall v. Pacific Mut. Life Ins. Co. (Tex. Civ. App.) 79 S. W. 1090; Continental Casualty Co. v. Lindsay, 111 Va. 389, 69 S. E. 344 ; 'Travelers' Ins. Co. v. Harvey, 82 Va. 949,5 S. E. 553; Mellen v. United States Health \& Accident Ins. Co., 83 Vt. 242, 75 Atl. 273.

94 Lampkin v. Travelers' Ins. Co., 11 Colo. App. 249, 52 Pac. 1040, supra.

95 Metropolitan Acc. Ass'n v. Froiland, 161 Ill. 30, 43 N. E. 766, 52 Am. St. Rep. 359, affirming 59 Ill. App. 522, supra; Standard Life \& Accident Ins. Co. v. Thomas, 17 S. W. 275, 13 Ky. Law Rep. 593, supra.

96 Woodall v. Pacific Mut. Life Ins. Co. of San Francisco (Tex. Civ. App.) 79 S. W. 1090, supra.

97 Standard Loan \& Accident Ins. Co. v. Thornton, 97 Tenn. 1, 40 S. W. 136, supra.

98 Railway Officlals' Acc. Ass'n v. Armstrong, 22 Ind. App. 406, 53 N. E. 1037, where the court held that the pleadings must show the waiver to have become effective before the pollcy was forfeited through failure to perform its conditions. Also, by inference, Hohn v. Interstate Casualty Co., 115 Mich. 79, 72 N. W. 1105: Coldham 
the denial is made before the expiration of the time specified in the policy for furnishing the notice and proofs, it is logical to suppose that, but for the action of the company, the proper proofs might still be supplied. To amount to a waiver, it must appear that the assured knew of the denial of liability, and was induced by it not to furnish notice or proofs. ${ }^{99}$ Some cases, however, hold that a denial of liability, on grounds other than of failure to furnish notice or proofs, may amount to a waiver, even after the expiration of the time for furnishing these documents; but in all of these cases other questions are involved, as, for example, that the proofs had been otherwise waived, or that there first existed other grounds of estoppel. ${ }^{100}$ The better law is that

v. Pacific Mut. Life Ins. Co., 2 Ohio S. \& C. P. Dec. 314 . Here the court sald: "This case is not within the rule, nor the reason of the rule, that a refusal to pay on the ground that there is no liability is a waiver. That rule does not cover a case where the refusal to pay is put upon the ground that no proofs have been filed, and that the time for filing proofs is past. In such a case, the insured understands that the failure to file the proofs will be insisted upon, and hence there is no waiver. It is only when the insurer refuses to pay, without assigning reasons, or when the refusal to pay is put distinctly upon some ground other than the failure to furnish proof, that there is a waiver." Western Travelers' Acc. Ass'n . Tomson, 72 Neb. 661, 101 N. W. 341, rehearing 72 Neb. 674, 103 N. W. 695, 105 N. W. 293. Here the court held that, where no notice of the accident was given within the time limited by the by-laws of the association, a denial of liability for the reason that no accident occurred, made after the time had expired, is not a waiver of the provision specifying that no claim for injuries shall be valid unless written notice of the accident shall have been given within fifteen days from the happening thereof. In Employers' Liability Assur. Corp. v. Rochelle, 13 Tex. Civ. App. 232, 35 S. W. 869, the court said: "Its denial of liability and refusal to pay its policy by an insuring company, to amount to a waiver of the notice required by the policy, must be made within the time in which proof of the accident and injury can be made."

๑ Employers' Liability Assur. Corp. v. Rochelle, 13 Tex. Civ. App. 232,35 S. W. 869 , supra.

100 Union Casualty \& Surety Co. v. Mondy, 18 Colo. App. 395, 71 Pac. 677, where the agent of the company had induced the repre- 
a denial of liability on other grounds, made after the time has elapsed for furnishing notice or proofs of loss, will not amount to a waiver of the requirement that they must have been furnished.

By pleading that the death of the assured resulted from a cause not covered by the policy, and a consequent denial of liability, the insurance company does not waive the defense that the claimant has failed to give proper notice or proofs of death or injury. ${ }^{101}$

sentative of the assured to delay filing proof of death until the time had elapsed, and then denied liability on other grounds; Unthank $r$. Travelers' Ins. Co., 28 Fed. Cas. 824; Crenshaw v. Pacific Mut. Life Ins. Co., 71 Mo. App. 42, where the insurer furnished the assured blanks to make out his proofs of disability without any demand or notice; Reynolds $\nabla$. Equitable Acc. Ass'n, 1 N. Y. Supp. 738, 59 Hun, 13, where the agent of the insurer told the claimant that failure to give notice would not prejudice her claim.

101 Dezell v. Fidelity \& Casualty Co., 176 Mo. 253, 75 S. W. 1102. Here the court said: "But to create an estoppel there must have been conduct on the part of the insurer which induced, or might have induced, the holder of the policy to refrain from furnishing the proof of loss, and to create a waiver there must have been an intention to waive. If we should now go a step farther than auy court has yet gone, and say that an insurer has no right to make a defense under this clause, although he may have done nothing to induce the insurer to refrain from making his proof of loss, or nothing to indicate an intention to waive his right, we would have to invent some other reason to sustain that doctrine. * * * No negotiations, no correspondence, no discussion passed between the parties relative to the matter (until suit was filed three and a half years after the death of the assured). When the defendant was called into court to answer the suit, it answered, and said that the death was from a cause not covered by the policy, and, besides, no notice of the death was given as required. Appellant asks us now to say that the answer means that the defendant. waives the notlce. No greater violence could be done to the letter and spirit of the answer than to give it that meaning. No case cited by appellant would justify such an interpretation. There is no necessity for looking into the cases which hold that when an insurance company informs the holder of the policy, before the period prescribed for making the proof of loss has expired, that it has resolved not to pay the insurance, the policy holder is excused from the duty of furnishing such proof to the company. The justice and sound logic of those deci- 
Pleading and Evidence.-Where the assured relies upon a waiver of the required notice or proofs of death or injury, he must so allege in his petition. ${ }^{102}$ Some cases hold that a waiver of the condition as to the time within which proofs are to be furnished may be proved on the trial under the general allegations of performance, though not specifically pleaded. These, of course, are based upon the theory of estoppel, by which the company is prevented from disputing their sufficiency. ${ }^{103}$

The question of waiver is usually one of fact, and therefore whether the assured shall be excused for a failure to furnish proper notice and proofs of death or injury is for the jury to determine under proper instructions from the court. ${ }^{104}$ It is, however, for the court to decide whether the evidence of waiver is sufficient to warrant the question be-

sions are not questioned. And no one will dispnte the proposition that the company may, if it so wills, waive its right to notice and proof of loss, after as well as before the expiration of the period for furnishing the same. But waiver, unconnected with estoppel, is an act of the will and the result of an intention."

102 Meech v. National Acc. Soc., 50 App. Div. 144, 63 N. Y. Supp. 1008. Here the court said: "Giving notice of the accident and furnishing proofs of the extent of the injury within the time specified in the contract are conditions precedent to a right to indemnity under the policy; and it is incumbent on the plaintiff to allege and prove compliance in this regard if he expects to recover on the theory of performance, or to allege and prove facts showing absolute denial of liability or other waiver or estoppel, or sufficlent excuse to authorize a recovery notwithstanding his noncompliance. This is a general rule of pleading." See, also, Etna Life Ins. Co. v. Bethel, 140 Kу. 609, 131 S. W. 523.

103 See Foster v. Fidelity \& Casualty Co. of New York, 99 Wis. 447,75 N. W. 69,40 L. R. A. 833.

104 Nax v. Travelers' Ins. Co. (C. C.) 130 Fed. 985; Continental Casualty Co. v. Ogburn (Ala.) 57 South. 852; Currie v. Continental Casualty Co., 147 Iowa, 281; American Acc. Co. v. Fidler's Adm'x, 35 S. W. 905,36 S. W. 528, $18 \mathrm{Ky}$. Law Rep. 161; Shelden v. National Masonic Acc. Ass'n, 122 Mich. 403, 81 N. W. 266; Reynolds v. Equitable Acc. Ass'n, 1 N. Y. Supp. 738, 59 Hun, 13. 
Ch.5) - notice and proofs of accident or death

ing submitted to the jury; and where there is no conflict of evidence it becomes a question of law for the decision of the court. ${ }^{105}$

105 Martin v. Equitable Acc. Ass'n, 61 Hun, 467, 16 N. Y. Supp. 279. 


\section{CHAPTER VI}

\section{LIABILITY-PAYMENT-DISCHARGE}

Arbitration of Liability and Submission to Fraternal Tribunals. Beneficiaries and Right to Proceeds.

Payment of Policies.

Suits on Accident Insurance Policies.

\section{Arbitration of Liability and Submission to Fraternal Tri-} bunals.-Where a contract of insurance agrees to pay a certain sum upon the death or disability of the assured, a further provision that claims under the policy shall be determined by arbitration and that no action shall be maintained on the contract is invalid, and does not constitute a legal bar to an action, and is not a condition precedent thereto. This is in harmony with the general rule of law that courts will not enforce contracts which serve to oust them from jurisdiction and the ability to provide relief for suppliants. ${ }^{1}$

1 Prader v. National Masonic Acc. Ass'n, 95 Iowa, 149, 63 N. W. 601. Here the court said: "As a general rule, the parties to an agreement may stipulate for the determination of specified questions which may arise between them by a third person or by arbitrators. Thus, a provision that the amount of money which shall be paid for materials to be furnished or services to be performed, or the time of payment, shall be determined in a specified manner, or by a person or body named, is valid and will be enforced. * * * It is equally well settled that a general provision by which the parties to an agreement in terms bind themselves to submit to arbitration all matters of dispute which may thereafter arise, and making the arbitration final, will not deprive the courts of their appropriate jurisdiction, nor be enforced by then.."

Badenfeld v. Massachusetts Mut. Acc. Ass'n, 154 Mass. 77, 27 N. E. 769, 13 L. R. A. 263; Whitney v. National Masonic Acc. Ass'n, 52 Minn. 378, 54 N. W. 184; National Masonic Acc. Ass'n v. Burr, 44 Neb. 256, 62 N. W. 466; Baldwin v. Fraternal Accident Ass'n, 46 N. Y. Supp. 1016, 21 Misc. Rep. 124; Keeffe v. National Acc. Soc., 38 N. Y. Supp. 854,4 App. Div. 392 ; Kinney v. Baltimore \& O. Employés' Relief Ass'n, 35 W. Va. 385, 14 S. E. 8, 15 L. R. A. 142 . In 
Such contracts are deemed oppressive and against public policy. This condition is, however, to be distinguished from those contracts where the agreement provides only for the determination by arbitration of some particular fact or facts, as well as from those cases where the contract expresses no obligation to pay any definite sum or to do any particular thing, but only to pay such sum or to do such thing as may be determined by the arbitrators.

At the same time the courts have uniformly upheld insurance contracts framed by fraternal organizations making reasonable rules requiring those claiming benefits to submit their claims to designated officials or tribunals for investigation and allowance before they are made the subject of litigation in the courts. ${ }^{2}$ A requirement of this nature, however, does not abridge the right of members to resort to the courts when their claims have been submitted to and finally rejected by such designated officials and tribunals.

And a condition in such a policy is valid which requires

Fox v. Masons' Fraternal Acc. Ass'n, 96 Wis. 390, 71 N. W. 363, the court said: "The contract was clearly so worded as to require all questions between the association and the assured to be, at its option, settled by arbitration, and to thereby wholly oust the court of jurisdiction over every part of the subject of liability and the amount thereof as well. On grounds of public policy, all agreements between parties to submit the whole subject-matter of their differences to arbitration, wholly stipulating away the rights of each or either party to resort to the tribunals created by the law of the land for a determination of such differences, are void, and have been uniformly so held." In Smith v. Preferred Masonic Mut. Acc. Ass'n (C. C.) 51 Fed. 520, the court held that, while it did not constitute a condition precedent to a suit on the policy, a clause providing for the arbitration of any claim, which contemplated simply referring to arbitration the question of the amount of the loss or damage, might be held valid.

2 Supreme Lodge, Order of Select Friends, v. Raymond, 57 Kan. 647,47 Pac. 533, 49 L. R. A. 373, where the claim of the assured was rejected by the various officials and tribunals of the order, after which suit was brought thereon. 
the claimant to follow a prescribed mode of procedure demanding the presentation of claims to subordinate officers, and in case of an adverse decision an appeal to the governing body of the society, though a by-law undertaking to make the decision of the subordinate officers final and conclusive is void; and the failure of the assured to appeal to the governing body before bringing an action in the courts constitutes a valid defense. ${ }^{3}$ The tendency of the courts, however, is to construe strictly and literally all such provisions in accident policies, and, unless they are clear and specific in their terms, the courts will excuse claimants for ignoring them."

3 Supreme Councll, Order of Chosen Friends, v. Forsinger, 125 Ind. 52, 25 N. E. 129, 9 L. R. A. 501, 21 Am. St. Rep. 196. Here the court said: "Requiring claims for benefits to be presented to the ofticers of the association is not, in any just sense, an invasion of the property rights of the member, nor is a by-law requiring their presentation unreasonable. The authorities are well agreed upon this question. * * * It is not unreasonable to provide that the member claiming benefits shall appeal to the governing body of the association. The member voluntarily enters the association with knowledge of its by-laws, and agrees to be bound by such as are not in violation of law, and certainly no principle of law is violated in making provision for the submission of claims of a member to the highest body of the association with which he voluntarily unites himself. It is but just to the association that its chief officers should have an opportunity to investigate the claim asserted by the member before it is harassed by litigation; and, indeed, the provision is presumptively for the benefit of the member, for the fair inference is that the governing officers will do their duty and allow all rightful claims. At all events there is no principle of law violated by a by-law requiring an appeal to the governing body. By-laws similar to that under consideration have often been upheld. There is, indeed, no contrariety of opinion upon the question. We have no doubt that a by-law requiring the presentation of claims to subordinate officers, and requiring, in case of a decision adverse to the claimant, an appeal to the gorerning body of the society is reasonable and valid." See, also, McMahon v. Supreme Couucll, Order of Chosen Friends, 54 Mo. App. 468.

4 Supreme Council, Order of Chosen Friends, v. Garrigus, 104 Ind. 133, 3 N. E. 818, 54 Am. Rep. 298. 
The decisions are not in complete accord as to the force of a condition in the policy that the decision of the appointed tribunal shall be conclusive. The majority of the courts, however, hold that while the assured must, as a condition precedent, exhaust all the remedies in the association specified in the policy, none the less, after he has done this, no provision in the contract, however decisive, can deprive him of his constitutional right to appeal to the courts for review and judgment. ${ }^{5}$

However, the insurer may waive a compliance with the requirement for arbitration or for a decision on the case by the tribunals named in the contract. A waiver may be effected by various methods, the most frequent of which is a denial of liability under the policy; ${ }^{6}$ or waiver may be effected by any other act of the company which prevents the assured from pressing his claim in the prescribed manner. ${ }^{7}$

5 Supreme Council, Order of Chosen Friends, v. Forsinger, 125 Ind. 52, 25 N. E. 129, 9 L. R. A. 501, 21 Am. St. Rep. 196 . Here the court said: "The authorities are agreed upon the proposition that mutual benefit societies may require an appeal to the governing bodies as a condition precedent to a right of action, so that upon that question there can be no doubt; indeed, the only doubt is whether they may not go further, and make the decisions of the officers designated in the contracts with their members final and conclusive. * * * Until the claimant has done what his coutract requires, or has shown some valid excuse for not doing it, he can not have any standing in court." See, also, Albert v. Order of Chosen Friends (C. C.) 34 Fed. 721 ; Supreme Council, Order of Chosen Friends, v. Garrigus, 104 Ind. 133,3 N. E. 818, 54 Am. Rep. 298; Supreme Lodge, Order of Select Friends; v. Raymond, 57 Kan. 647, 47 Pac. 533, 49 L. R. A. 373.

6 Baldwin v. Fraternal Acc. Ass'n, 46 N. Y. Supp. 1016, 21 Misc. Rep. 124.

7 See Brotherhood of Railroad Trainmen $\nabla$. Newton, 79 Ill. App. 500 , where the by-laws provided that claims must be submitted to a subordinate board, and appeal then prosecuted to the grand lodge, and the subordinate board deferred action until it was too late to take an appeal and commence suit within the time allowed by the by-laws; McMahon v. Supreme Councll, Order of Chosen Friends, FULLER Acc.Ins.-28 
Beneficiaries and Right to Proceeds.-The same general rules of law which govern the naming of beneficiaries and the distribution of the proceeds of policies of life insurance apply to contracts of accident insurance. They are so completely and so minutely set.forth in standard works on Life Insurance that it is not desirable here to do more than merely enumerate certain general principles which control questions particularly likely to arise. Where one, having an insurable interest in the life of another, for his own benefit takes out a valid policy on that life against death resulting from accident and pays the premiums thereon, the policy manifestly is his own property, and the proceeds thereof are immune from the claims of others. So, also, where the assured in purchasing a policy upon his own life designates a beneficiary, generally his wife or children, or others dependent upon him, the courts strive to give effect to his intent, and the proceeds are payable directly to those designated, and are not subject to the claims of the creditors of the assured. In fact, they constitute no part of his estate. The party designated acquires a vested right in the policy, except in cases where a right to revoke or change the beneficiary is reserved. Where the policy is made payable to the heirs or estate of the assured, the proceeds thereof become a part of his estate, and are subject to administration and the rights of creditors, in the absence of any statutory provision to the contrary. The laws of the state where the assured resides govern the distribution of the proceeds of the policy, on the theory that the policy or contract is there consummated.

54 Mo. App. 468, where, on motion of one of its members, the supreme council having reviewed the rulings of the subordinate offcers, and affimed their rejection of the claim, the association waived its right to require such an appeal specified in the policy. 
The proceeds of a policy in which the wife or children of the assured or other designated parties are named as beneficiaries do not become funds in the hands of the administrator. In most instances, where the wife is designated as the beneficiary, she is entitled to the proceeds of the policy, although she may have obtained a divorce before the death of the assured, and thus in law not be his wife in fact at that time.

In the absence of any provision in the policy to the contrary, or of any statutory enactment limiting that right, where the contract does not name a beneficiary, the proceeds thereof may be disposed of by the assured by will.

Where the policy does not in terms permit the assured to change beneficiaries, it is necessary to secure the consent of the beneficiary designated in order to substitute another. But where the contract reserves to the assured the right to make such a change, the consent of the beneficiary is neither essential nor necessary. Most policies prescribe the method by which this is to be done, though in the absence of frand the courts are liberal in giving effect to the apparent wishes of the assured, and do not require a literal compliance with the terms of the policy, if to do so will work an inequity. In the event that the beneficiary dies before the assured, and no alternative beneficiary is named in the policy, the proceeds of the policy will go to the representatives of the beneficiary named in the instrument, and do not revert to the: estate of the assured.

Payment of Policies.-Most policies of life and accident: insurance provide that the insurer shall pay the amount thereof within a specified time, generally sixty or ninetv days, after the presentation of the required proofs of death or injury. The company is not bound to wait until the expiration of the time specified before making payment. The 
policy generally provides that no suit thereon for the amount of the policy shall be brought within a specified time, usually six months, after the receipt of the required proofs. ${ }^{8}$ The beneficiary need not wait the specified time, where the insurer denies liability, but may commence action at once. ${ }^{8}$ In general, a demand for payment is necessary before interest will commence to run.

Payment to the wrong person does not discharge the liability of the insurance company. In the absence of a dispute or disagreement in good faith, the payment of a smaller amount than the face of the policy, without consideration, will not discharge the company, and a surrender of the policy and release thus secured are void. This is true, even where the beneficiary gives a receipt in full therefor. ${ }^{10}$ And a receipt procured by fraud is invalid, though a compromise of a disputed claim made in good faith will be sustained. And conversely a payment of the amount of the policy by the insurance company induced by fraud, or made under a mistaken impression of the facts, can be recovered by the insurer.

8 See Maynard $\nabla$. United States Health \& Accident Ins. Co., 76 N. H. 275, 81 Atl. 1077, where the court upheld the provision limiting the time within which suit must be brought upon the policy. In Fitzpatrick v. North American Acc. Ins. Co., 18 Cal. App. 264, 123 Pac. 209, a provision requiring actions to be brought within one year after the accident held to bar an action brought thirteen months after an accident causing death.

9 Depue v. Travelers' Ins. Co. (C. C.) 166 Fed. 183; Jennings $\nabla$. Brotherhood Acc. Co., 44 Colo. 68, 96 Pac. 982, 18 L. R. A. (N. S.) 109, 130 Am. St. Rep. 109, 16 Ann. Cas. 787; Continental Casualty Co. v. Mathis, 150 Ky. 477, 150 S. W. 507; Miles v. Casualty Co. of Amerlca, 136 App. Div. 908, 120 N. Y. Supp. 1135, affirming (Sup.) 115 N. Y. Supp. 1.

10 Goodson v. National Masonic Acc. Ass'n, 91 Mo. App. 339; Jones $\nabla$. Commercial Travelers' Mut. Acc. Ass'n of America, 131 App. Div. 936, 118 N. Y. Supp. 1116, affirming (Sup.) 114 N. Y. Supp. 589. 
Suits on Accident Insurance Policies.-Here the same general principles prevail as in actions on policies of life insurance. In the absence of statutory enactment, suit may be brought against the insurance company wherever service can be secured. Most states have enacted statutes requiring insurance companies to maintain agents within the state on whom process may be served, as a condition precedent to the right of doing business in the state. As a general rule, conditions in a policy limiting the place where actions may be brought are void as against public policy. In the absence of any statute to the contrary, a condition in the policy declaring that no recovery may be had unless suit is brought thereon within a specified time is generally held valid. ${ }^{11}$ This provision may, however, be waived by the insurer, either expressly or by implication. The time is generally construed to begin to run from the date on which the amount of the policy becomes due and payable, rather than from the date of the death or disability of the assured.

11 General Acc., Fire \& Life Assur. Co. $\nabla$. Walker, 99 Miss. 404, 55 South. 51. Under a Mississippi statute companies are prohibited from limiting to less than one year after loss the time within which suit may be commenced. A provision in the policy in suit limited the insurer's liability to one-fifth of the amount of insurance, unless notice of the accident should be given within tell days. The provision was held invalid, and the court said: "The clause referred to in this policy is nothing but a limitation that no suit shall be entertained to recover the full amount of the policy, unless preliminary steps looking to the suit be commenced within ten days from the accident, whereas the statute provides that there shall be no limit for less than a year. It is true that the condition excludes, not all, but four-fifths of the amount; but the principle is just the same as if it provided that no suit should be begun to recover any part of the policy, unless written notice should be given within ten days. Any contract of insurance which undertakes to relieve the insurance company from the full respousibility on its contract, by requiring any kind of notice for less than the time required by the statute, is in conflict with section 2575 , Code of 1906 , and void." 


\section{CHAPTER VII}

\section{EMPLOYERS' LIABILITY INSURANCE}

Employers' Liability Insurance.

Violation of Law.

Death or Bodily Injuries.

Contingent Liability.

When Insurance Company Liable Under Its Policy.

Policies of Indemnity Against Loss Sustained.

What Constitutes Payment of Loss.

Insolvency of the Assured.

Right of Injured Employe to Recover from the Insurance Company. Assignment of Causes of Action.

Notice of Injury and Action for Damages.

Notice of Ciaim for Damages.

Waiver of Notice.

Limitation of Time for Bringing Suit.

Agreement to Defend Suit.

liefusal of the Insurance Company to Defend.

Limit of Liability of Insurer.

Immediate Surgical Relief.

Liability for Costs.

Failure to Pay Premium.

Employers' Liability Insurance.-Employers' liability insurance is a contract by which an insurance company agrees to assume the liability and make compensation for loss resulting to an employer by reason of the injury or death of a servant or other employé which may happen in the usual course of employment and for which the employer is liable. 'This liability of the employer against which he is thus insured may be imposed by the common law or by statutory enactment. Although these policies have been criticised as being contrary to public policy, since they tend to diminish the penalty of negligence on the part of employers toward 
their servants, the courts have refused to sanction this view, and they have in all cases been upheld. ${ }^{1}$ Manifestly a contract made to protect one against a willful or intentional violation of law, or the deliberate commission of some future wrong, is contra bonos mores, and thus void. But a contract of indemnity against the results of possible, but unintended, future acts of negligence, clearly cannot be open to this objection. The motives which might induce one to secure indemnity against unintentional negligence differ radically from those which would induce him to seek protection against the consequences of an intended offense against the law. ${ }^{2}$

In a general sense employers' liability insurance is a branch of accident insurance. The policies cover accidents to others than the assured, and cover only accidents re-

1 American Casualty Ins. Co.'s Case, 82 Md. 535, 34 Atl. 778, 38 L. R. A. 97.

2 Royle Mining Co. v. Fidelity \& Casualty Co. of New York, 126 IIo. App. 104, 103 S. W. 1098. Here the policy undertook to indemnify the mining company against loss from common-law or statutory liability. The court here said: "But it is argued by defendant that the liability of plaintiff could not be made the subject of a contract of indemnity, for the reason that the agreement to insure a person against the consequences of a violation of law is against public policy, and such agreement cannot be enforced. It is true that a contract made to protect a person against a willful or intentional riolation of law, or against a willful or intentional commission of any future wrong, is contra bonos mores, and therefore void. But contracts of indemnity against the consequences of possible, but unintended, future negligent acts, have been sustained, and we perceive no distinction in principle between the negligent omis:on of a statutory duty and a similar breach of common-law duty. Both are sins of omission, since they result from the fallure of the actor to observe the degree of care imposed on him by the rules of law. The motive which prompts a person to purchase indemnity against acts of this character cannot be said to include an intent to violate the law, and in this respect differs from that which would impel a person to contract for protection against the consequences of an intended future offense against the law." 
sulting in bodily injury or death, and the victim of the accident must be one for whose injury or death the assured is legally liable. ${ }^{3}$

The contract may be broad or narrow in its scope according to the terms and limitations of the individual policy. Primarily the loss for which the insurance company agrees to indemnify the assured must arise from an injury for which he is legally chargeable with liability, and, further, it must be within the risks covered by the provisions of the policy. The assured cannot recover under such a contract for any and all liability which a master may incur. The policies issued by different companies, as well as the various forms written by the same company, show a wide divergence.

The most common form of policies contract to indemnify the assured only for those injuries which may happen to employés. ${ }^{4}$ These policies generally contain the additional

8 Employers' Liability Assur. Corp. v. Merrill, 155 Mass. 404, 29 N. E. 529. This case arose upou the question whether a license to a foreign insurance company to write policies of accident insurance in the state of Massachusetts empowered it to write policies of employers' liability insurance. The court held in the affirmative and said: "In one sense, there can be no doubt that an employers' liability policy is accident insurance. Such policies corer accidents to others than the assured, but the assured must stand in such a relation to the person accidentally injured or killed as to be legally liable for the result of the accident, and it is only an accident causing bodily injury or death which creates a right to the insurance."

4 Travelers' Ins. Co. v. Bright, 24 Ohio Cir. Ct. R. 441 . Here the court held that one employed as a laborer by a contracting carpenter in constructing a building is a laborer in the employ of the contractor within the meaning of the policy, although he is engaged on a holsting apparatus leased and operated jointly by the contracting carpenter and another contractor, where it is shown that he receives his wages from his employer only, and that the apparatus is a necessary part of the work of the contracting carpenter. See, also, Anoka Lumber Co. r. Fidelity \& Casualty Co., 63 Minn. 286, 65 N. W. 353,30 L. R. A. 689. 
limitation that the employé must be on duty at the time of the accident in an occupation described in the policy or at the place mentioned in the application. ${ }^{5}$ These policies frequently contain a limitation agreeing to indemnify the assured for losses sustained as a result of injuries to those

5 Home Mixture Guano Co. v. Oceall Accident \& Guarantee Corp.. Limited, of London, Eng. (C. C.) 176 Fed. 600. Here the policy was drawn to cover "ordinary repairs" when made on the premises by employes carried on the company's pay roll. "Construction, demolition, or extraordinary repairs" were not covered. A large part of the assured's factory had been destroyed and was being rebuilt. In connection with this it was rebuilding an acid chamber, and an employé while unrolling lead in this work fell from a scaffold and received injuries for which he recovered from the assured. The court held that the work on which the injured employe was kllled was not "ordinary repairs" within the meaning of the policy. People's Ice Co. v. Employers' Liability Assur. Corp., 161 Mass. 122, 36 N. E. 754. The policy here undertook to indemnify the assured for injuries to employes engaged in "operations connected with the business of ice dealers." The employe was injured by the fall of an icehouse which was being constructed by the assured during the season in which ice was not being cut. The court held that the insurance company was not liable on its policy. Fuller Bros. Toll Lumber \& Box Co. v. Fidelity \& Casualty Co., 94 Mo. App. 490, 68 S. W. 222. The assured operated a wooden box manufactory, and an employé while performing his duties was hurt by the fall of an elevator, and recovered judgment against the lumber company. Wollman $\nabla$. Fidelity \& Casualty Co. of New York, 87 Mo. App. 677. The business of the assured was described in the policy as that of wholesaling dry goods and general merchandise. After the policy had been issued, the assured installed machinery for polishing rusted cutlery and engaged an adept polisher, who was injured in running the machinery and recovered therefor from the plaintiff. The policy especially exempted liability for any loss caused by the prosecution on the premises of any business not therein mentioned, and the assured was not permitted to recover. Travelers' Ins. Co. v. Bright, 24 Ohio Cir. Ct. R. 441, supra. Fidelity \& Casualty Co. v. Lone Oak Cotton Oil \& Gin.Co., 35 Tex. Civ. App. 260, 80 S. W. 541. The business of the assured was detailed as manufacturing cotton seed oil, etc. The policy excluded additions or alterations in any building, but permitted ordinary repairs. The deceased employe had been employed in the construction of the plant and installing machinery which had been completed. A few days before his death the employe had been placed on the wage list of the assured as a carpenter, his services 
employés only whose wages are included in its pay roll. ${ }^{6}$ Under such policies the premium is invariably based on the total amount of the pay roll for the year. By an agreement in the policy it will cover loss resulting from an injury to those on the pay roll of a subcontractor as well as a principal employer. ${ }^{7}$ In order to render the insurance company

being necessary in the operation of the plant. While removing some scaffolding in the water tower, which was a part of the plant, the water tank crushed through and killed him. The court held that the deceased at the time of his death was pursuing an operation or business covered by the policy. Hoven v. Employers' Liability Assur. Corp., 93 Wis. 201, 67 N. W. 46, 32 L. R. A. 388 . The pollcy agreed to indemnify the assured agaiust loss for injuries to employes in "all operations connected with the business of iron and steel works." The court held that an injury to an employe caused by the fall of a girder which was being raised by an independent crew engaged in building an addition to the works was within the terms of the policy. Cashman v. London Guarantee \& Accident Co., 187 Mass. 188, 72 N. E. 957. A firm of stevedores had contracted with a coal company, which owned a certain runway and dock, to keep them in repair so long as they conducted the business of unloading coal at that place. One of the employes of the assured stevedores was injured and killed as the result of a defective post on the runway, and the stevedores were permitted to recover from the insurance company the amount of indemnity covered by the policy insuring against liability for accidents to employes.

${ }^{6}$ Fidelity \& Casuaity Co. of New York v. Phœnix Mfg. Co., 100 Fed. 604, 40 C. C. A. 614. The policy here agreed to indemnify the assured, a manufacturer and erector of machinery, office fixtures, and general woodwork, against liability on account of injuries to employés whose wages were included on its pay roll. Certain carpenters, whose wages were included on its general pay roll, were injured while tearing down an old building preparatory to the erection of a new structure. The assured was permitted to recover from the insurance company. Fidelity \& Casualty Co. v. Lone Oak Cotton Oil \& Gin Co., 35 Tex. Civ. App. 260, 80 S. W. 541, supra, where the employe had been transferred from another pay roll to the operating list but a few days before the accident, and where his wages were "included in the estimated wages" set forth in the policy. See, also, London Guarantee \& Accident Co. v. Ogeisby, 231 Pa. 186, 80 Atl. 57.

7 Dives v. Fidelity \& Casualty Co., 206 Pa. 199, 55 Atl. 950, where the injured employe was working for a subcontractor, but was with. in the terms of the policy in suit. 
liable, the injury of the employé must have been sustained while engaged in the work of the assured, and must have resulted from the negligence of the assured, or one for whose negligence the assured is responsible. ${ }^{8}$

The scope of this class of policies of liability insurance may be limited by any conditions which they contain. Among the more common conditions is a warranty against the use of explosives by the assured or his employés; ${ }^{\theta}$ a condition that the policy shall not cover liability for loss

${ }^{8}$ Kelley v. London Guarantee \& Accident Co., 97 Mo. App. 623, 71 S. W. 711. Here the assured was a partnership. One of the mem. bers of the firm and the employe were engaged in experimenting with a machine belonging to the firm whell the injury occurred. The employe sued the partnership on the ground of negligence, but recovered only against the individual partner with whom he was working. The court said: "We are of the opinion that, where the contract of indemnity is to indemnify for loss occasioned by accidents to employés of a partnership for negligence of the partnership, in order to render the insurer liable the accident must happen to the employe while engaged in work for the partnership and by reason of the negligence of the partnership, and that this must be made to appear by the judgment of the proper court. A partnership is a separate legal entity from the individual members composing it. And when one agrees to indemnify a partnership for damages resulting to it on account of its negligence, he does not become liable for loss to an individual for his individual negligence, as such, as distinguished from such negligence as would render the partnership liable as such. * * * In order to render liable an indemnitor like this defendant, it must be made to appear that the negligent act of the individual member was such an act as made it the act of the partnership."

• B. Roth Tool Co. v. New Amsterdam Casualty Co., 161 Fed. 709, 88 C. C. A. 569 . The policy contained a warranty that assured would not permit the use of explosives on the premises. A large metal tube, filled with various materials of an explosive and dangerous nature, was exposed to the heat of a furnace on the premises of the assured. The tube exploded and injured an employe, who recovered a judgment against the assured. The court held that the insurance company was not liable, and that the question whether the metal tube was an explosive was res judicata as between the insurance company and the assured upon the finding for the injured employe. 
arising from an injury to an employé in buildings before their completion and occupancy; ${ }^{\mathbf{1 0}}$ or for loss due to injuries sustained by any person engaged in making additions to or alterations in the building covered by the insurance. ${ }^{11}$ Some policies contract to indemnify only against loss from liability to one employe from injuries suffered by the negligent act of a fellow servant; in many instances this is confined to injuries suffered by one employé by the negligence of a fellow servant on the pay roll of the assured. ${ }^{12}$

10 Andrus v. Maryland Casuaity Co., 91 Minn. 358, 98 N. W. 200. An old building was being replaced by the assured with a new structure. After the new building had been neariy completed, one-half being occupied by-tenants, assured applied to the company for a policy of insurance to indemnify him against liability for accidental injuries suffered by persons within the premises or on adjacent sidewalks. The fact that the building was not completed was known to the insurer, but the policy was dated from December 17, 1900, to December 17, 1901. Later an employe in the building while operating an elevator was injured and recovered damages from the assured. The insurance company was held liabie on the ground that its agents knew of the unfinished condition of the building at the time of issuing the policy, and therefore the condition that the policy should not be effective until the building was fully ready for occupancy was waived. See, also, Scarritt Estate Co. v. Casuaity Co. of America, 166 Mo. App. 567, 149 S. W. 1049.

11 Andrus v. Maryland Casualty Co., 91 Minn. 358, 98 N. W. 200, supra. The court held that replacing an ordinary four-story brick structure with a new building ten stories high was not included in the meaning of the words "making additions to or alterations in the building."

12 East Caroiina R. Co. v. Maryland Casuaity Co., 145 N. C. 114, $58 \mathrm{~S}$. E. 906 . The contract provided that the assured should not be indemnified for any loss arising to one of its servants who was injured, and who was not on the pay roll or within the list of est1mated wages, or who was injured by a fellow servant not within the same category. The exception was clearly inclusive of both classes. The court said: "Stated differently, the piaintiff, in order to recover, must have shown that both of the servants, the injurer and the injured, were on the pay roll, and not within the descriptive words of the exception from liabllity. This is not an unreasonable view of the matter, as the basis of calculating the premium to be paid is just this very stipulation and requirement. If we should hold the 
Nor is liability under these policies of employers' indemnity insurance confined to those cases alone where the assured is forced to pay damages to employés because of accidents in the strictly literal sense of that term. They will also cover cases where an employé has contracted a disease under conditions such as to render the employer liable for negligence, as where an employé contracts kidney disease from handling infected paper or rags in the course of his employment, ${ }^{13}$ and where an employer negligently and without warning puts an employé at work in stalls and among horses suffering with glanders, as a result of which he becomes infected with the disease. ${ }^{14}$

plaintiff entitled to recover, he would clearly receive a benefit and indemnity for which he had never paid the defendant."

13 Columbia Paper Stock Co. v. Fidelity \& Casualty Co., 104 Mo. App. 157, 78 S. W. 320. The court here said: "Appellant further" puts forward the contention that a disease produced by a known cause cannot be accidental, and therefore such a disease as acute kidney disease or dropsy, produced by the absorption of poison consequent on handling infected paper or rags in the course of employment, is not covered by the policy, and the legal question is thus sharply presented whether the injuries consequent on such illness resulted from a cause agaiust which the insurance was issued. In the construction of such contracts it is well established that not only should they be given a fair and reasonable construction, so as to give effect to the objects intended by the parties thereto, but any obscurity in the language employed is to be resolved against the insurer, and to receive a broad and liberal interpretation in faror of the assured. * * * If, for example, in lieu of producing the more gradual and protracted infirmities of acute kidney disease or dropsical affection, the infected material submitted to defendant's workwoman bad emitted poisonous gases or fumes, producing her iustantaneous death, or resulting in immediate and violent convulsions, under numberless authorities the occurrence would, in legal contemplation and within the interpretation of policies insuring against accidents, be confidently pronounced accidental, yet such consequences would be disease produced by known causes."

14 H. P. Hood \& Sons v. Maryland Casualty Co., 206 Mass. 223, 92 N. E. 329,30 L. R. A. (N. S.) 1192, 138 Am. St. Rep. 379 . The employe here had the care of horses which were found to have been suffering from glanders and,were killed, though no notice had been 
Another class of policies of employers' liability insurance agrees to indemnify the assured against liability for injuries to all persons except employés. ${ }^{15}$ Other policies undertake to indemnify the assured for liability for damages sustained by any person, without any limitation as to his relationship

giren to him of that fact. The court in an interesting discussion of the case said: "The question is whether the amount which the plaintiff was compelled to pay Barry was paid 'for damages on account of bodily injuries accidentally suffered' by him within the meaning of the policy. It is plain that Barry suffered bodily injury in consequence of becoming infected with glanders, as much so as if he had had a leg or an arm broken by a kick from a vicious horse. Indeed, it is possible that the bodily injury caused by glanders was greater and more lasting than that caused by a broken leg or arm would have been. * * Was the injury brought about accidentally within the fair scope and meaning of the policy, or was it the result of disease contracted while in the employ of the plaintiff, but for which the defendant is not liable? It is clear, we think, that the infection which caused the disease from which Barry suffered was due to accident. It was in the nature of an accident that he was set to work upon or cleaning up after horses that had glanders, and it was in the nature of an accident that he became infected with the disease. * * * If the disease was the result of an accident, then we do not see why it does not follow that the bodily injury which Barry suffered as the result of the disease was not accidentally suffered, nor why the case does not come within the terms of the policy. The language is 'bodily injuries accidentally suffered.' It hardly could be broader. The intention is to afford full protection and indemnity to the assured. Any accident that causes bodily injury in any way is included. Bodily injury is more commonly associated with physical force of some sort, but in the absence of anything in the policy limiting it to that we do not see how or why it can or should be so restricted. A liability growing out of an accident which results in infecting the workman with a loathsome and dangerous disease, and thereby causes him great and perhaps lasting physical injury, would seem to be as much within the spirit and intent of the contract as if the injury had been caused by a blow or some other equally obvious manifestation of force."

15 Employers' Liability Assur. Corp. v. Merrill, 155 Mass. 404, 29 N. E. 529; Gray v. Standard Life \& Accident Ins. Co., 170 Mass. 558,49 N. E. 921 . Here the policy agreed to insure the beneficiary against liability for bodily injuries to the public caused by the horses or vehicles of the assured enumerated in the application and 
to the beneficiary. ${ }^{10}$ These are in the nature of general or omnibus policies of liability insurance.

Violation of Law.-These policies of insurance frequently
contain conditions especially exempting the insurance com-

used in his business. The court held here that the use of a buggy by the assured in coming to his store from his home or in going from his store to the bank necessarily involved its use in his business. Phillipsburg Horse Car Co. v. Fidelity \& Casualty Co., 160 Pa. 350, 28 Atl. 823. The policy undertook to insure the street rallway company from liability for damages on account of injuries resulting from any accident caused by its horses, cars, maclinery, etc. This policy was held not to cover liabiilty for injuries caused by omnibus sleighs used by the company for transporting passengers when the car tracks were obstructed by snow and ice. Camden \& Atlantic 'Tel. Co. v. United States Casualty Co., $227 \mathrm{~Pa} .242,75$ AtI. 1077. The policy indemnified a telephone company against damages for bodily injuries to any person not employed by the assured, arising from the operation of the plant or construction and maintenance of lines. IIeld to cover liability for damages to a stranger accidentally killed while employés of the company were trimning trees to run its wires. Victorian Stevedoring \& General Contracting Co., Ltd., v. Australian Accident Insurance \& General Guarantee Co., Ltd., 19 Victorian (Australia) 139. This was a policy insuring an employer of workmen against damages that might be recovered in an action brought against him by any person not being in his employ for injury caused to him by reason of any defect in the state of the works, machinery, etc., used in the, employer's business, or caused by the negligence of any of his workmen. American Employers' Liability Ins. Co. v. Fordyce, 62 Ark. 562, 36 S. W. 1051, 54 Am. St. Rep. 305. By the policy here in suit the insurance company agreed to indemnify a street lailway company for damages resulting from injuries to its passengers for which it was liable. See, also, Fidelity \& Casualty Co. v. Fordyce, 64 Ark. 174, 41 S. W. 420.

16 'Trarelers' Ins. Co. v. Wild River Lumber Co., 83 Fed. 977, 28 C. C. A. 127. Here a lumber company procured a policy insuring it against loss from liability to any persons to whom by reason of injuries it might be liable either under the common law or by statute. The assured in connection with its business conducted a short railway connecting its camp with a nearby settlement for the transportation of supplies, workmen, and people having business at its mills and stores. Two commercial travelers who had come to take orders for the company's store were taken back over its road on an engine, paying fare for the transportation. The locomotive was orerturned, and the lumber company held liable for the injuries sustained by 
pany from liability for injuries sustained by employés hired in contravention of any statute, ${ }^{\mathbf{1 7}}$ or for injuries resulting from the violation by the assured of any law regulating the

the traveling men. The insurance company was held liable, since the injuries occurred within the scope of the company's "own lumbering purposes," as indicated by the application. American Casualty Ins. Co.'s Case, 82 Md. 535, 34 Atl. 778, 38 L. R. A. 97; Ross v. American Employers' Liability Ins. Co., 56 N. J. Eq. 41, 38 Ati. 22, where a policy insuring employers and rallroad companies against accidents to employés and persons and property transported was under adjudication. Creem v. Fidelity \& Casualty Co. of New York, 141 App. Div. 493, 126 N. Y. Supp. 555, affirming 132 App. Div. 241, 116 N. Y. Supp. 1042, where the policy corered liability for injuries to employés and injuries to the general public caused by employés. See, also, Lewinthan v. Travelers' Ins. Co., of Hartford, Conn., 61 Misc. Rep. 621, 113 N. Y. Supp. 1031.

17 Frank Unnewehr Co. v. Standard Life \& Accident Ins. Co., 176 Fed. 16, 99 C. C. A. 490 . A statute of Ohio expressly forbids the employment of any child under sixteen in any occupation whereby its life or limb is endangered. The assured here eimployed a child under sixteen as an off-bearer from a circular veneer saw in a mill. The saw was sixty-eight inches in diameter, welghed 1,000 pounds, and extended some forty-five inches above the floor. 'Though it was no part of the child's duty, to start or stop the saw, he frequently attempted to do so, and on one occasion one of his arms was seriously injured by the teeth of the saw. It was held that the child was employed in violation of the statute, and the assured could not recover on a policy exempting the company from liability for injuries suffered by any person employed in violation of law as to age. Fairbanks Canning Co. v. London Guaranty \& Accident Co., 154 Mo. App. 228, 133 S. W. 664, where an injured chlld was employed when under the age of fourteen years in contravention of the Missouri statute, but the insurer was estopped from setting up such defense through having undertaken the control of the action without reserving its rights. Mason-Henry Press v. Etna Life Ins. Co., 146 App. Div. 181, 130 N. Y. Supp. 961, where the injured employe was under sixteen years of age and was employed in violation of the labor law. Here the insurance company defended the action for the assured, having first reserved the right to rely upon the exceptions in the policy, and the judgment rendered in the initial action was held conclusive as to the employment in violation of law as between the assured and the insurance company. Buffalo Steel Co. r. Atna Life Ins. Co. (Sup.) 136 N. Y. Supp. 977. Here the court held that the judgment in the action agalnst the insured was conclusive against it in its action on the policy, and the insurer, hav- 
safeguarding of machinery. ${ }^{18}$ In many states insurance companies are forbidden to contract to indemnify an employer against any loss arising in consequence of any injury to any employé caused either by (a) the willful act of the assured, or any of the assured's officers or agents; or (b) the failure of the assured, or any of the assured's officers or agents, to comply with any municipal ordinance or law-

ing reserved its "policy rights," was not liable. The court, moreover, held that under an employers' indemnity policy excepting the insurer from liability for injury to an employe "employed in violation of law" it is immaterlal whether the accident to one so employed was due to or caused by violation of the law. Goodwillie v. London Guarantee \& Accident Co., 108 Wis. 207, 84 N. W. 164. Here the policy declared that, "if any child is illegally employed on the work of the assured, the company will not be liable for any injuries which may thereby be sustained or occasioned." The court held that no recovery could be had under this clause for an injury to a child under twelve employed in violation of a Wisconsin statute, eren though the injury was not the proximate result of the illegal employment.

18 Chicago-Coulterville Coal Co. v. Fidelity \& Casualty Co. of New York (C. C.) 130 Fed. 957. An Illinois statute required a passageway to be constructed fourteen feet wide around the bottom of the shaft of a mine. As a result of a cave-in the passage had become obstructed, so that one could get through the passageway only by crawling over the debris and then by squeezing through a narrow passage. This condition existed for some six weeks before the injury, though it might have been repaired within three days. The assured was not permitted to recover on the liability policy. London Guarantee \& Accident Co. v. Morris, 156 Ill. App. 533, where the question arose as to whether there had not been a violation of the Missourt statute forbidding the employment of a minor about machinery in motion. Sargent Mfg. Co. v. Travelers' Ins. Co., 165 Mich. 87,130 N. W. 211,34 L. R. A. (N. S.) 491 , where it appeared that the injured employe, a child of fifteen, was employed about a dangerous piece of machinery in violation of the Michigan statute, and where the insurer, though defending the action for the assured, reserved its rights under the policy. Royle Min. Co. v. Fidelity \& Casualty Co. of New York, 161 Mo. App. 185, 142 S. W. 438, where an injured employé recovered judgment against the assured mining company for its failure to observe the "prop" statute, but the insurer was held liable therefor because it assumed charge of the litigation without any notice to the assured of an intention to reserve its rights under the policy.

Fuller Acc.Ins.-29 
ful order of any duly authorized officer, or any statute for the protection of the life or safety of employés. In these states such policies are held to be void on the theory that they are against public policy. ${ }^{10}$

Death or Bodily Injuries.-A policy which undertakes to indemnify the assured for liability to any person accidentally suffering bodily injuries does not cover the case of a person who dies instantly and without conscious suffering. ${ }^{20}$

Contingent Liability.-There is no such thing as a loss from common-law or statutory liability arising from a contingent liability on the part of the assured, and a policy thus worded imposes no liability on the insurance company issuing it. ${ }^{21}$

19 See opinion of Attorney General of Ohio, April 4, 1912, on the Ohio Workmen's Compensation Law.

20 Worcester \& S. St. R. Co. v. Travelers' Ins. Co., 180 Mass. 263, 62 N. E. 364, 57 I. R. A. 629,91 Am. St. Rep. 275 . By the terms of the policy here at issue the insurance company agreed to insure the street railway company against loss from liability to any person who might accidentally sustain bodily injuries through the fault of the railway "under circuinstances which shall impose upon the insured a common-law or statutory llability for such injuries." A traveler on the road died instantly and without conscious suffering as the result of an accident for which the assured was responsible. The court held: "By the terms of the policy the plaintiff is insured against loss from liability to every person who may accidentally sustain bodily injuries under circumstances which impose upon the assured a common-law or statutory liability for such injuries. The liability is to a person who sustains bodily injuries, and such person must have a right of action therefor either at common law or by statute. The policy cannot include the case of death, for which the person never had a right of action."

21 Sroka v. Frankfort American Ins. Co., 47 Misc. Rep. 607, $94 \mathrm{~N}$ : Y. Supp. 501. Here the policy agreed to insure the owner of a building in process of erection against loss from common-law or statutory liability arising from the contingent liability of the assured, as owner, for damages on account of injuries accidentally suffered by any person in connection with and during the construction of the building for an act or negligence of any contractor or subcontractor. The court said: "The action is upon a policy of insurance purporting, 
When Insurance Company Liable Under Its Policy.-One of the most important questions to be determined is whether the policy is one of insurance against the liability of the assured, or is one of indemnity against loss actually sustained. In short, when does the liability of the insurance company actually attach? Manifestly it must attach at one of three points-upon the occurrence of the accident, when the injured party recovers judgment, or when the assured finally pays the claim or judgment of the injured person. The cases are not entirely in harmony on these points, though many apparent inconsistencies are explained by the varying provisions of the different policies at issue.

The earlier policies were based on the theory that they were to insure against the liability of the beneficiary. Under them the liability of the insurance company was contingent until the happening of the accident or event which establishes the responsibility of the assured, whereupon the contingent liability of the insurance company to reimburse the assured became a fixed liability. But the amount of the liability remained contingent until the extent of the claim of the assured was established by a judgment of the courts. These cases held that the contingency which existed as to the amount of the liability did not alter the fact that a liability for some amount had actually arisen. ${ }^{22}$

unless carefully read, to insure the owner of premises against accidents happening during the erection of a building, but which, in fact, is so skillfully worded as to insure him only against claims for which he would in no event be liable. *** The insurance is. against 'contingent liability' for the act or negligence of a contractor or subcontractor. There is no such liability known to the law. The owner may be liable in a given case for the result of an accldent; but the liability in such a case will be original, and not contingent. * * * It seems to us entirely clear that the defendant took plaintiff's money, and gave him in return a document purporting to be a policy of insurance, which in fact insured him against nothing."

22 American Casualty Ins. Co.'s Case, 82 Md. 535, 34 Atl. 778, 38. 
The difference between a contract of indemnity against loss and one to pay legal liabilities is that upon the former an action cannot be brought and a recovery had until the liability is actually discharged, whereas upon the latter the

L. R. A. 97. Here the court said: "The amount actually paid by the assured to the person injured, or to the representatives of the person killed, or to the owners of the property damaged or destroyed, settled and measured, within the limits specified in the policy, the extent of the insurer's liability. And whilst the mere liability of the assured to pay unascertained damages for any of the causes set forth in the contract of indemnity did not determine the precise amount which the insurer was bound to pay to reimburse the assured, it nevertheless fixed the insurer's liability to the assured under the contract. The happening of the event which subjected the insured to a claim for damages established the period when the correlative obligation of the insurer became complete and ceased to be contingent, except as to the amount to be paid. The liability of the insurer was thereby fixed, though the extent of that liability might, and in most cases must necessarily, have been unascertained until a subsequent period. * * * It is not solely because the insured has actually paid damages that the liability of the insurer to him is fixed; but it is because an accident or casualty or occurrence has happened for which he is responsible, and against the loss arising from which he has been indemnitied, that the obligation of the insurer to reimburse him arises, though the precise amount to be paid by the insurer may depend for its ascertainment upon events happen: ing after the insolvency. In other words, the contingent liability of the insurer to reimburse the insured becomes a fixed liability the moment an event happens which fastens a responsibility on the insured, if that event be within the terms of the policy; but the amount of the liability continues to be contingent till the precise extent of the demand against the insured is established and paid. This contingency as to amount in no manner derogates from the fact that a liability for some amount has arisen and become fixed." Ross v. American Employers' Liability Ins. Co., 56 N. J. Eq. 41, 38 Atl. 22. The court in this case expressed itself in favor of the view that the policy was one of insurance against liability in the followlng language: "The recovery of the judgment against the insured by the injured party is not the injury against which the insurer insures him; but it is the liability for the consequences of the accident against which he is insured, and of which liabllity the judgment is a mere test or mode of proof. In fact, the recovery of the judgment is a mere mode by which the insured proves to the insurer that the intrinsic character of the accident was such that he was liable for the consequences of it. In this respect the judgment re- 
cause of action is complete when the liability attaches, though the amount of indemnity is not fixed until judgment is rendered. ${ }^{23}$

sembles the proof of loss to be furnished to an ordinary insurer against fire or shipwreck before action brought, or proof of death in case of life insurance. * * * And in the case of a judgment against the party insured under one of these policies for damages for the result of an accident, the liability, though legally fixed at the time, relates back to the accident itself. In contemplation of law, the insured either was or was not, from the first, liable for the consequences of the accident; and the presumption is that the result of an investigation of the facts was never doubtful from the first, and always sure to result according to the actual fact. So that the recovery of the judgment cannot be held or treated in the law as a contingency which may or may not happen, but a mere judicial ascertainment of the intrinsic character of the occurrence which determined the liability of the insured. Again, another office of the judgment is to ascertain, by the only legal mode, the extent of the damages, precisely as the extent of the damages in case of a fire or shipwreck is to be ascertained by an inquiry undertaken before payment." See, also, Fenton v. Fidelity \& Casualty Co., 36 Or. 283, 56 Pac. 1096, 48 L. R. A. 770. The court, ruling on the policy here in suit, said: "There is a distinction made by the authorities between a contract of indemnity against liability for damages and a simple contract of indemnity against damages. In the former case it has very generally been held that an action may be brought, and a recovery had, as soon as the liability is legally imposed, while in the latter there is no cause of action until there is actual damage. If, therefore, the policy upon which this action is based is a mere contract of indemnity, the payment by the mill company of the liability incurred by it for the injuries of the plaintiff is a condition precedent to the right of recovery. If, on the other hand, the contract is one of indemnity against liability, a cause of action accrued thereunder as soon as the liability of the mill company to the plaintiff attached. Upon this question the policy must speak for itself; and its several provisions, in our opinion, indicate quite clearly that it is not merely an agreement to indemnify the mill company against such damage as it may suffer on account of injury to its employes, but that, in case of an accident to an employe whereby a cause of action arises against it, the insurance company will assume the liability on account thereof. By the express terms of the contract, it agrees to indemnify the mill company, not only against actual damage, but against liability for such damage."

23 American Employers' Liability Ins. Co. v. Fordyce, 62 Ark. 562, 36 S. W. 1051, $54 \mathrm{Am}$. St. Rep. 305. The policy here in sult con- 
Under policies drawn to indemnify employers against liability for injuries to others, a contract exists to indemnify, not merely against loss, but also against liability; and the liability of the insurer is definite and fixed upon final judgment rendered against the insured, though the judgment itself may not as yet have been paid. ${ }^{24}$ This is especially true in those policies wherein the insurance company reserves to itself the conduct of all legal proceedings on behalf of the insured in defense of the action of an injured employé, and wherein the insured is expressly forbidden to settle any claim without the company's consent. ${ }^{25}$

tracted to pay "all damages with which the insured might be legally charged or required to pay, or for which it might become legally liable." The court held this to be plainly a contract to pay liabilities.

24 Fidelity \& Casualty Co. v. Fordyce, 64 Ark. 174, 41 S. W. 420 ; Campbell v. Maryland Casualty Co. (Ind. App.) 97 N. E. 1026.

25 Anoka Lumber Co. v. Fidelity \& Casualty Co., 63 Minn. 286, 65 N. W. 353,30 L. R. A. 689 . Here the court said: "If the plaintiff is forbidden to settle a claim for an accident of this kind, we fail to see how it is imperative upon him to pay a judgment rendered against him upon such claim as a condition precedent to his right of recovery. The insurance company, by the terms of its own policy, has taken into its own hands the whole machinery for settling such a claim, and will not allow the employer to do it." Fenton v. Fidelity \& Casualty Co., 36 Or. 283, 56 Pac. 1096, 48 L. R. A. 770, supra; Pickett r. Fidelity \& Casualty Co., 60 S. C. 477,38 S. E. 160 . Of the policy in litigation, the court here said: "It is expressly indemnity against liability. This liability attaches when the amount of the employe's damage is agreed upon by the parties, with the insurer's consent, or when there is a final judgment fixing the liability of the insured employer to the injured employé. In this case there was a final judgment for the injured employe for more than the amount of the insurance, and the suit was defended by the company as provided for in the policy. One of the objects of the provision authorizing defense of any suit for damages to be made by the insurer, and taking from the insured all right of interference, was to enable the insurer, if possible, to prevent any liability against the insured employer, and this liability, which by the policy the insurer was to contest, was the liability against which the policy was issued. If the insurer meant to stipulate that payment of the judgment rendered in 
The amount of the liability, and therefore the liability itself, of the insurance company, is fixed by the final judgment of the courts against the insured. Therefore the amount of the liability of the insurer does not become definite so long as an appeal to a higher court is pending from a judgment of a lower court. The liability of the insurance company is thus measured and settled only upon the rendition of judgment by the highest court to which an appeal is or may be taken. ${ }^{26}$

Policies of Indemnity Against Loss Sustained.-As a result of the wide latitude of liability assessed against insurance companies by the determination of the courts that

the suit for damages was a condition precedent to recovery on the policy, it was easy to say so." Hoven v. Employers' Liability Assur. Corp., 93 Wis. 201, 67 N. W. 46, 32 L. R. A. 388. Here a policy agreeing to pay an employer all sums for which he "shall become liable to his employés" on account of personal injuries is held to be a contract of indemnity against liability, so that payment by the employer of a personal injury claim is not a condition precedent to his right of recovery against the insurer.

26 Fidelity \& Casualty Co. v. Fordyce, 64 Ark. 174, 41 S. W. 420. The court held that the amount of the liability of the insurer is not determined so long as an action therefor is pending in court against the assured or an appeal from a judgment therefor is pending in the supreme court. The court said, inter alia: "So long as the latter [the insurance company, for the assured] resisted in the courts the enforcement of such claims, no right of action accrued upon its policy; for, until the termination of the litigation, both parties to the policy denied the liability of the assured, and the existence and extent thereof remained undetermined according to the methods by which the parties in effect agreed it should be ascertained and fixed." Stephens v. Pennsylvania Casualty Co., 135 Mich. 189, 97 N. W. 686, 3 Ann. Cas. 478. In this case the action against the assured was appealed to the Supreme Court of Michigan, and it was held that the indemnity did not become due and payable until the determination of the case by that court. Rosenbloom v. Maryland Casualty Co., 153 App. Div. 23, 137 N. Y. Supp. 1064. Here the court said that an indemnity insurer, who had control of the defense of an action against the insured and had neglected to appeal from a judgment, could not defeat an action on the policy on the ground that there had been no adjudication by a court of last resort. 
these policies were of indemnity, not alone against loss, but against liability as well, the underwriters began to adopt a modified form of policy intended to limit the liability of the insurance company to losses actually suffered by the assured by reason of damages paid to employés and others for injuries sustained under conditions imposing a common-law or statutory liability upon the assured. These policies as now issued contain a clause specifically providing that no action shall lie against the insurance company for any loss unless brought "by the assured to reimburse him for a loss actually sustained and paid in satisfaction of a judgment after trial of the issue."

Under such policies there is no right of action against the insurance company until the assured sustains a loss by the payment of a liability or judgment. Inasmuch as these policies are contracts of indemnity against loss resulting from liability, and not contracts of insurance against liability, the company will not be liable under its policy until a loss has actually been sustained. Manifestly there can be no reimbursement where there has been no loss. The difference between a contract of indemnity, strictly speaking, and one to pay legal liabilities, is that upon the former an action cannot be brought and a recovery had until the liability is discharged, whereas upon the latter the cause of action is complete when the liability attaches. ${ }^{27}$ Therefore, even if the liability of the assured be established by a judgment in the courts, unless this liability has been satisfied by payment of the judgment rendered, no action will lie against the insurance company under these policies. They are issued, not for the benefit of injured employés and others, but to reimburse employers for such sums as they may be

27 American Employers' Liability Ins. Co. 7 . Fordyce, 62 Ark. 562, 36 S. W. 1051, 54 Am. St. Rep. 305. 
obliged to pay and have paid on account of injuries sustained by an employé, either through their negligence or through the negligence of others for whom they are responsible. ${ }^{28}$

Even if the liability policy is by agreement made to specifically cover a certain loss, the insurance company is not

28 Cushman v. Carbondale Fuel Co., 122 Iowa, 656, 98 N. W. 509. Here the court said: "The only obligation of the guarantee company was to indemnify the fuel company against a 'loss actually sustained and paid in satisfaction of a judgment after trial of the issue.' This covenant is as explicit and certain as language could well make it, and, as between the parties to the contract, no recovery could be had against the guarantee company, because the judgment against the fueT company was not paid and consequently the covenant was not broken." Carter v. Atna Life Ins. Co., 76 Kan. 275, 91 Pac. 178, 11 L. R. A. (N. S.) 1155. The court in construing the policy here in suit said: "The liability of the insurance company under the policy must be measured by its terms. * * * In its general features it provided for making good the loss suffered by the assured, or rather for reimbursing it to the extent of its loss. Until the assured had met with a loss there was no occasion to pay indemnity -no reason to reimburse until something had been paid by the assured. Aside from the fact that in its general characteristics the contract was one of indemnity, it contained the specific provision that no recovery could be had against the insurance company under the policy unless the action was brought by the bridge company itself to reimburse it for the loss actually sustained and paid in satisfaction of a judgment. This provision leaves no doubt of the intention of the parties, which was that the insurance company was not required to pay anything because of the policy until losses had been paid by the assured in satisfaction of a judgment."

See also Allen v. Ftna Life Ins. Co., 145 Fed. 881, 76 C. C. A. 265, 7 L. R. A. (N. S.) 958, affirming Allen v. Gilman, McNeil \& Co. (C. C.) 137 Fed. 136; Frye v. Bath Gas \& Electric Co., 97 Me. 241, 54 Atl. 395, 59 L. R. A. 444, 94 Am. St. Rep. 500 ; Connolly v. Bolster, 187 Mass. 266, 72 N. E. 981; Nesson v. United States Casualty Co., 201 Mass. 71, 87 N. E. 191, 131 Am. St. Rep. 390; Kelly v. Maryland Casualty Co., 89 Minn. 337, 94 N. W. 889 ; Kénnedy v. Fidelity \& Casualty Co., 100 Minn. 1, 110 N. W. 97,9 L. R. A. (N. S.) 478, 117 An. St. Rep. 658, 10 Ann. Cas. 673; Conqueror Zinc \& Lead Co. v. Atna Life Ins. Co., 152 Mo. App. 332, 133 S. W. 156; Travelers' Ins. Co. v. Moses, 63 N. J. Eq. 260, 49 Atl. 720, 92 Am. St. Rep. 663 ; Beacon Lamp Co. v. Travelers' Ins. Co., 61 N. J. Eq. 59, 47 Atl. 579; Beyer v. International Aluminum Co., 115 App. Div. 853, 101 N. Y. Supp. 83 ; Burke v. London Guarantee \& Accident Co., 47 Misc. Rep. 171, 93 N. Y. Supp. 652, affirmed without opinion 126 
precluded from refusing to pay the amount of indemnity before the assured has paid the judgment in the action for bodily injuries, if the policy makes this a condition precedent to liability. ${ }^{29}$

What Constitutes Payment of Loss.-The provision in the policy requiring the satisfaction of a judgment by the

App. Dir. 933, 110 N. Y. Supp. 1124; Cornell r. Trarelers' Ins. Co., 175 N. Y. 239,67 N. E. 57S, rerersing 66 App. Dir. 559, 73 N. Y. Supp. 341; Creem r. Fidelity \& Casualty Co., 141 App. Dir. 493, 126 N. Y. Supp. 555, affirming 132 App. Dir. 241, 116 N. Y. Supp. 1042 ; Appel v. People's Surety Co. of New York, 148 App. Dir. 70. 132 N. Y. Supp. 200; Lawrence r. General Acc. Assur. Corp., 124 App. Div. 545, 105 N. Y. Supp. 939, affirmed without opinion 192 N. Y. 56S, 85 N. E. 1112 ; Clark r. Bonsal \& Co., 157 N. C. 270,72 S. E. 954 ; - Edgefield Mfg. Co. v. Maryland Casualty Co., 7S S. C. 73, 5 S S. E. 969; Finley r. United States Casualty Co., 113 Tenn. 592, 83 S. W. 2, 3 Ann. Cas. 962; Puget Sound Imp. Co. r. Frankfort Marine, Accident \& Plate Glass Ins. Co., 52 Wash. 124. 100 Pac. 190; Seattle \& S. F. R. \& Nar. Co. r. Maryland Casualty Co., 50 Wash. 44, 96 Pac. 509, 18 I. R. A. (N. S.) 121; Ford r. Etna Life Ins. Co. of Hartford, Conn. (Wash.) 126 Pac. 69; Stenbom r. Brown-Corliss Engine Co, 137 Wis. 564, 119 N. W. 308, 20 L. R. A. (N. S.) 956.

See Lewinthan v. Trarelers' Ins. Co. of Hartford, Conn., 61 Misc. Rep. 621, 113 N. F. Supp. 1031. Here the policy limited the liability of the insurance company to loss actually sustained and paid in money in satisfaction of a judgment after trial. On trial the insurance company admitted recorery of a judgment by a third party against the plaintiff in an action for personal injuries, but neglected to introduce in evidence the policy setting forth the clause limiting liability to loss actually sustained and paid. The assured was permitted to recorer after establishing the judgment rendered against it in faror of the injured third party.

$290^{\circ}$ Connell r. New York, N. H. \& H. R. Co., 187 Mass. 272, 72 N. E. 979. By an agreement between the parties in interest it was understood that the insurance company would indemnify the assured against a certain loss. The court held that this agreement would in no way constitute a waiver of a prorision in the policy which made the payment by the assured of the judgment in the artion for bodily injuries a conditlon precedent to the liability of the insurance company. Appel v. People's Surety Co. of New York, 148 App. Div. 70, $132 \mathrm{~N}$. Y. Supp. 200 , where the court held that a repudiation of liability by the insurance company did not waire the necessity for the actual pasment of a loss fixed by a judgment as a condition precedent to its liability. 
assured as a condition precedent to the liability of the insurance company means merely that the judgment must be paid and liquidated by the beneficiary, and that when the judgment is thus satisfied the loss is actually sustained and action may be brought upon the policy of liability insurance. It is not essential to the liability of the insurer under these policies that the assured shall discharge the judgment by an actual cash payment into court or to the judgment creditor. The judgment may be satisfied by a conveyance of property or by the execution of promissory notes, if delivered in good faith and so accepted by the plaintiff in the action. ${ }^{30}$

30 Kennedy r. Fidelity \& Casualty Co., 100 Minn. 1, 110 X. W. 97. 9 L. R. A. (N. S.) 478, 117 Am. St. Rep. 658, 10 Ann. Cas. 673. One of the emplorés of the assured was injured during the term of the policy and recorered a judgment, in full parment of which the assured delivered to the judgment creditor certain promissors notes, bearing interest and indorsed by a guarantor. No cash, property, or other consideration than the execution and delivery of the notes passed from the assured to the judgment creditor in satisfaction of the judgment. The insurance compans resisted pasment under the policy on the ground that there had been no compliance with the following clause of the polics: "No action shall lie against the company as respects any loss under this policy unless it shall be brought by the assured himself to reimburse him for loss actually sustained and paid by him in satisfaction of a judgment within sixty dars from the date of such judgment and after trial of the issue." In construing the polics the court said: "The contract contemplates that an actual loss shall be sustained and paid before the company becomes liable, and appellant submits that by the fair and reasonable meaning of the language the assured cannot accomplish payment or satisfaction of the judgment in ans other way than by actually parting with the cash. It is admitted that the debt and judgment was paid and satisfied by the execution of the promissory notes, if giren in good faith. But the whole argument of appellant rests upon the claim that the mere giving of the notes did not amount to a loss actually sustained, for the reason that the maker of the notes and the guarantor might nerer be called upon to make parment, might become insolvent, that there is no certainty they will erer be paid, and, if not paid, there is no loss actually sustained. This means that the party assured, no matter what his financial condition might be, would be compelled to raise the actual 
Whatever consideration passes between the assured and the judgment creditor must amount to a bona fide settle-

cash within sixty days and pay it to the judgment creditor, or be foreclosed from enforcing the indemnity against the company. If the position is sound, the money could not be raised by borrowing at a bank, or at any other place, upon promissory notes secured either by a signer or by property, because, before the notes became due, the property might be worthless, deteriorate in value, or the parties might become insolvent, and no actual payment ever be made; hence no loss. Fairly construed, the language means simply that the judgment must be paid and satisfied within sixty days from date of its entry, and, when such judgment is paid or satisfied, the loss is actually sustained. Of what consequence is it to the company whether respondent has on band immediate cash to pay the judgment, or whether the judgment debtor is compelled to borrow that amount on the most favorable terms, or whether he makes the payment and secures the satisfaction by the execution of promissory notes running direct to the judgment creditor? Logically there is no difference in the method, and in either case it amounts to a payment and satisfaction of the judgment. If the assured accomplished the satisfaction and payment of the judgment by executing and delivering the promissory notes above described, the good faith of that transaction was hardly open to question, even though it gave the assured the advantage of collecting from appellant company the amount of insurance before the notes came due. So far as the record shows, the assured paid the judgment in good commercial paper, and there is nothing upon the face of the transaction to indicate that the arrangement was made for a fraudulent purpose." Herbo-Phosa Co. v. Philadelphia Casualty Co. (R. I.) 84 Atl. 1093. Here the assured executed its note in the proper sum to cover the judgment and costs, and the note was discounted at a bank, and the proceeds paid to satisfy the judgment. The court said: "The courts have held that a payment in cash is not necessary, and may be otherwise made, as, for instance, by a note, provided that the judgment against the insured is extinguished, and the transaction is in good faith."

Seattle \& S. F. R. \& Nav. Co. v. Maryland Casualty Co., 50 Wash. 44, 96 Pac. 509, 18 L. R. A. (N. S.) 121. Here also a note was given by the assured for the amount of a judgment obtained for personal injuries, covered by the policy, in full satisfaction thereof. The court declared: "The argument is made that there is no loss within the meaning of the policy until cash has been actually paid in sattsfaction of the judgment. The conveyance of property in satisfaction of the judgment would certainly establish a loss, at least to the extent of its value. The execution of a note in exchange for satisfaction is in legal effect equivalent to the exchange of property 
ment of the judgment; ${ }^{\mathbf{3 1}}$ and the insurance company will not be liable on its policy where the assured has merely given a bond of indemnity, but has not paid the amount of

therefor. It confers a right to invoke legal process to seize and levy upon property in value equal to the amount of the note."

In Allen v. Gilman, McNeil \& Co. (C. C.) 137 Fed. 136, affirmed by Allen v. Astna Life Ins. Co., 145 Fed. 881,76 C. C. A. 265,7 L. R. A. (N. S.) 958, the court declared that: "If the employer has available property, he must pay the writ in full. But if he is not in prosperous circumstances, and if, therefore, full satisfaction can scarcely be hoped for, the employe may be willing to accept part of his claim as complete payment, while the insured may be unscrupulous enough to seek to recover the face of the judgment from the company."

31 Stenbom v. Brown-Corliss Engine Co., 137 Wis. 564, 119 N. W. 308, 20 L. R. A. (N. S.) 956. Here the assured corporation was adjudged a bankrupt after the instant action had been brought by the injured employe. The receiver here was not appointed to administer the affairs of the insolvent corporation for the benefit of creditors generally, but was appointed in a proceeding supplementary to and in aid of execution issued at the instance of a single creditor, and for the sole purpose of collecting the judgment in this action. With the exception of the liability policy, all of the assets of the insolvent were turned over to the trustee in bankruptcy for the benefit of creditors having provable claims against it. The policy was, by its terms, of no value until the judgment of the injured employe was satisfied. The court said: "No good reason is apparent why the payment which the contract obligates the assured to make as a condition precedent to his right to maintain action upon the policy might not be made otherwise than in money, providing such payment is made and accepted in good faith and there is a bona fide settlement and satisfaction of the judgment secured by the injured employe. * * * Considering the purpose for which the receiver here was appointed, if he could pay the judgment by giving his note, and such note was received in satisfaction of the judgment, and it was satisfied, it would seem that the object for which he was appointed had been accomplished, and any further proceeding on his part was unnecessary to discharge his legitimate functions. However this may be, the proceeding was certainly novel. On its face the action was a mere subterfuge, resorted to for the purpose of making a nominal compliance with the terms of the insurance contract. The contract was one which the parties thereto had a right to make, and it would be trifling with its terms for a court to hold that the shadowy payment here attempted to be made conformed to 
the judgment. ${ }^{32}$ But the liquidation of a judgment by the stockholders of a corporation constitutes such a payment as will render the insurer liable. ${ }^{33}$

Insolvency of the Assured.-Inasmuch as these policies are now framed as contracts of indemnity against loss, rather than of insurance against liability, when payment of the judgment creditor is prevented by the bankruptcy or insolvency of the assured, the insurance company cannot be subjected to any liability on its policy. Manifestly liability cannot be enforced by the assured, since it has suffered no loss. Nor can it be enforced by the judgment creditor, since

its requirements. There was no bona fide payment of the judgment. The fictitious payment resorted to is too thinly veiled to stand the test of judicial scrutiny." See, also, Campbell v. Maryland Casualty Co. (Ind. App.) 97 N. E. 1026. Here an injured employé brought suit against the assured, the Clear Creek Stone Company, and recovered a judgment for $\$ 2,500$, which was appealed, and finally affirmed by the court of last resort. Before judgment was affirmed, the stone company became insolvent, and all its assets were taken under a mortgage foreclosure, and no assets or property came into the hands of the receiver. The receiver, under order of the court, borrowed sufficient money to pay the judgment and then commenced this action. The attorneys for the injured employe advanced the money, which was paid into court, and the clerk entered the judgment as satisfied, whereupon the money was paid to the attorneys of the employe who had advanced it. The court properly held that this did not constitute a payment of the loss within the meaning of the policy.

32 See O'Connell v. New York, N. H. \& H. R. Co., 187 Mass. 272, 72 N. E. 979. Here the conrt held that the insurance company was not liable by reason of a judgment obtained by a third person in an action defended by the company for bodily injuries caused by the negligence of the insured, if the judgment has been paid by the third person, and the insured, althongh he has given a bond of indemnity to the third person, has not paid the amount of the judgment.

33 West Riverside Coal Co. v. Maryland Casualty Co. (Iowa) 135 N. W. 414. The stockholders offered their stock as securlty for the note of the assured, and were in turn secured against loss by an assignment of the book accounts of the company. 
the policy contracts merely to indemnify the assured, and there is no privity of contract between the assured and the one who was injured through the contract. ${ }^{34}$

However, where the bankrupt has assets which are trans. ferred to a trustee in bankruptcy, such a transfer, by operation of the federal Bankruptcy Act, constitutes a payment of the judgment creditor within the requirement of the policy, and perfects the liability of the insurer for so much as the employé is entitled to receive from the bankrupt's estate. The liability of the insurance company passes by force of the Bankrupt Act to the trustee in bankruptcy as assets of the estate. The amount for which the insurer is liable will be determined by ascertaining what percentage all the assets of the bankrupt, exclusive of the policy, will pay on all the debts proved against the estate outside of the em-

34 Carter v. Atna Life Ins. Co., 76 Kan. 275, 91 Pac. 178, 11 L. R. A. (N. S.) 1155. Here an employe of the assured bridge company was injured, and brought suit against the company, which the insurer defended. While the action was pending, and before judgment was rendered, the bridge company was adjudged a bankrupt, and found to be without assets of any kind. The judgment creditor brought suit against the insurance company for the amount of his judgment against the bridge company. The court held that the creditor had no cause of action. "The contract," said the court, "was indemnity against loss from liability, and not insurance against liability. In its general features it provided for making good the loss suffered by the assured, or rather for reimbursing it to the extent of its loss. Until the assured had met with a loss there was no occasion to pay indemnity-no reason to reimburse untll something had been paid by the assured. * * * The obligations of the policy did not extend beyond the two contracting parties. The bridge company, on the one hand, was procuring indemnity to protect itself from loss, and the insurance company, on the other, was undertaking to make good the losses which the bridge company should be compelled to pay."

See, also, Allen v. Atna Life Ins. Co., 145 Fed. 881,76 C. C. A. 265, 7 L. R. A. (N. S.) 958, affirming Allen v. Gilman, McNeil \& Co. (C. C.) 137 Fed. 136; Frye v. Bath Gas \& Electric Co., 97 Me. 241, 54 Atl. 395, 59 L. R. A. 444, 94 Am. St. Rep. 500; Beyer v. International Aluminum Co., 115 App. Div. 853, 101 N. Y. Supp. 83; 
ployé's judgment, and the insurer is answerable for the same percentage of that judgment. ${ }^{35}$

Right of Injured Employé to Recover from the Insurance Company.-It must first of all be borne in mind that these policies of insurance are secured to reimburse employers for damages sustained by reason of injuries to others for which they may be legally responsible. The policies are written, not for the sake of injured employés, but for the benefit of employers, who have suffered loss by reason of their common-law or statutory liability. The premiums are paid by the employers, and the employers are the beneficiaries thereof. The policies now most commonly in force are contracts of indemnity against loss, and not of insurance against lia-

Burke v. London Guarantee \& Accident Co., 47 Misc. Rep. 171, 93 N. Y. Supp. 652, affirmed without opinion, 126 App. Div. 933, 110 N. X. Supp. 1124. Here the court said: "The fact that the insured became insolvent and could not pay the plaintiff's judgment against it gave her no claim, legal or equitable, against the insurer."

On the other hand, see Sanders v. Frankfort Marine, Accident \& Plate Glass Ins. Co., 72 N. H. 4S5, 57 Atl. 655, 101 Am. St. Rep. 688. Here the court held that the insurance company was not absolved from the obligation to satisfy the judgment against the assured by the fact that the insured has not paid the amount of the judgment against him, or is unable to do so by reason of insolvency. The court maintained that equity could require that the assets of a liability policy held by the assured be patd by the insurance company to the judgment creditor in satisfaction of his claim agaiust the insured. This case is against the weight of authority, and, in view of the fact that the policy was one of indemnity against loss rather than insurance against liability, is unsupported by logic or reason.

35 Travelers' Ins. Co. v. Moses, 63 N. J. Eq. 260, 49 Atl. 720, 92 Am. St. Rep. 663, overruling Beacon Lamp Co. v. Travelers' Ins. Co., 61 N. J. Eq. 59, 47 Atl. 579. In this case the court ruled as follows: "The obligation of the insurance company was with the lamp company only, and is explicitly defined by the contract, which limits it to such sum, not exceeding $\$ 5,000$, as the lamp company may have actually paid in accordance with the policy. No person claiming under this contract can enforce any larger obligation, for it rested wholly within the power of the contracting parties, subject only to public law, to fix the bounds of liability. The claim of 
bility. They are not subscribed to for the benefit of injured employés, and there is no privity between them and the employers. Therefore no action will lie under such policies until a loss has actually been suffered by the assured through the liquidation of a judgment of an injured employé, and then action can be brought only for the benefit of the assured. Therefore the judgment creditor will not be permitted to bring garnishment proceedings against the insurance company to compel the insurer to pay to him the amount of his judgment against the assured, who has defaulted in its payment. ${ }^{36}$ On the other hand, where the

the trustee or of Mary Bardzik, therefore, must have the same bounds. The lamp company has paid, but it has paid with property, and it remains to ascertain in money the amount of the payment. That can be done without difficulty, when all claims against the bankiupt estate are proved, and all the assets, outside of this obligation of the insurance company, have been converted into cash or definitely valued. Then can be ascertained what percentage all the assets, other than this obligation, will pay upon all the claims, other than the Bardzik judgment; and the same percentage of the judgment will be the amount of the liability of the insurance company, provided it does not exceed $\$ 5,000$, and if it does exceed $\$ 5,000$ the company will be liable for that sum. In this respect the present contract differs essentially from those wherein the insurer agrees to pay the damages for which the assured may become liable."

36 Allen v. Attna Life Ins. Co., 145 Fed. S81, 76 C. C. A. 265, 7 L. R. A. (N. S.) 958, affirming Allen v. Gilman, McNeil \& Co. (C. C.) 137 Fed. 136. Here the employer had gone into the hands of a receiver without having paid the judgment. The court said: "Until the judgment shall have been paid by the Gilman \& McNeil Co. * * * there exists no valid claim against the insurance company. The garnishment proceedings are therefore founded on a false theory. There is nothing due from the insurer to the assured. Consequently there is nothing that can be the subject of garnishment proceedings as against the insurer." Cushman v. Carbondale Fuel Co., 122 Iowa, 656, $98 \mathrm{~N}$. W. 509. The court here held: "The obligation of the guarantee company was for the protection of the fuel company alone. The plaintiff was not a party to the contract and had no legal rights thereunder. * * A court of equity can no more disregard the express provisions of the contract than could a court of law, and

FUller Acc.Ins.-30 
older forms of policies have been construed, not as contracts of indemnity against loss, but as agreements to insure

neither can make a new contract for the parties which would impose a liability not originally contracted for. * * * The only obligation of the guarantee company was to indemnify the fuel company against a 'loss actually sustained and paid in satisfaction of a judgment after trial of the issue.' This covenant is as explicit and certain as language could well make it, and, as between the parties to the contract, no recovery could be had against the guarantee company, because the judgment against the fuel company was not paid, and consequently the covenant was not broken. 'The same principle is recognized in 'Travelers' Ins. Co. v. Moses, 63 N. J. Eq. 260, 49 Atl. 720, $92 \mathrm{Am}$. St. Rep. 663, where a similar covenant was coustrued, but the judgment held paid. In Seeberger v. Wyman, 108 Iowa, 527, $79 \mathrm{~N}$. W. 290, the obligation was to save 'harmless from all liability'; and it was said that, this liability having been determined, the action on the bond could be maintained. The distinction between liability and actual loss or damage is well marked, and in the above case nothing further was decided than that there had been a breach of the precise covenant of the bond. * * $*$ It is further contended by the appellant that under section 4087 of the Code he is entitled to subject the liability of the guarantee company to the payment of his judgment. But, as we have already seen, no liability on the part of the company has yet arisen, and it must be true that, if the fuel company had no claim against the guarantee company which it could enforce, the plaintiff has none under this statute."

Carter v. Atna Life Ins. Co., 76 Kan. 275, 91 Pac. 178, 11 L. R. A. (N. S.) 1155. Here the assured became bankrupt during the pendency of the action in damages by the injured employe. The court held: "Aside from the fact that in its general characteristics the contract was one of indemnity, it contained the specific provision that no recovery could be had against the insurance company under the poli$c y$, unless the action was brought by the bridge company itself to reimburse it for the loss actually sustained and paid in satisfaction of a judgment. This provision leaves no doubt of the intention of the parties, which was that the insurance company was not required to pay anything because of the policy untli losses had been paid by the assured in satisfaction of a judgment. It is a provision which the parties had a right to insert in their contract. The obligations of the policy did not extend beyond the two contracting parties. * * This case is quite unlike those based on policles agreeing to pay damages for which the assured may become liable. * * * Most of the cases cited by plaintiff rest on contracts insuring against liability, some are affected to some extent by statutory provisions, and one, Sanders v. Frankfort Marine, Accident \& Plate Glass Ins. 
against liability, the judgment creditor has been permitted to recover in an action against the insurer when the judg-

Co., 72 N. H. 485,57 Atl. 655, 101 Am. St. Rep. 688, appears to be out of line with the current of authority."

Frye v. Bath Gas \& Electric Co., 97 Me. 241, 54 Atl. 395,59 L. R. A. 444, $94 \mathrm{Am}$. St. Rep. 500. Here an injured employe, who had recorered a judgment against the assured gas company, which became insolvent, brought a bill in equity praying that the insurance company be compelled to pay to the complainant the amount of his unsatisfied judgment. The court beld: "We are unable to perceive any ground upon which the bill can be sustained and the relief prayed for granted. The contract of the insurer was with the gas company to indemnify that company 'against loss' from liability for damages on account of bodily injuries accidentally suffered by an employe and caused by the negligence of the assured. The use of the word 'indemnify' shows the object and nature of the contract. It was to reimburse or make whole the assured against loss on account of such liability. There can be no reimbursement when there has been no loss. The contract of insurance contains nothing to show that it was the object or intention of the contracting parties that the insurer should guarantee the gas company's liability for negligence to its employés. It was not a contract of insurance against liability, but of indemnity against loss by reason of liability. * * * It was not obtained by the gas company for the benefit of its employes, but for its own benefit exclusively, to reimburse it for any sum that the company might be obliged to pay, and had paid, on account of injuries sustained by an employe through its negligence."

In Connolly v. Bolster, 187 Mass. 266, 72 N. E. 981, it was declared that a judgment secured for personal injuries against the assured did not make the insurer liable to the injured employe, and that the Massachusetts statute giving a creditor the right to reach and apply to the payment of a debt equitable assets of his debtor deals witl existing equitable rights and does not authorize a court of equity to complete inchoate rights to create property which then would be subject to attachment by trustee process in an action at law.

Burke v. London Guarantee \& Accident Co., 47 Misc. Rep. 171, 93 N. X. Supp. 652, affirmed without opinion 126 App. Div. 933, 110 N. Y. Supp. 1124. The court here declared: "The fact that the insured became insolvent and could not pay the plaintiff's judgment against it gave her no claim, legal or equitable, against the insurer, this defendant. There was no privity between the plaintiff and the defendant through the insurance contract. It was a matter between insurer and insured only." Clark v. Bonsal \& Co., 157 N. C. 270, 72 S. E. 954. Ford v. Atna Life Ins. Co. of Hartford, Conn. (Wash.) 126 Pac. 69.

Contra, see Sanders v. Frankfort Marine, Accident \& Plate Glass 
ment has not been liquidated by the assured. ${ }^{37}$ Where, by the entry of judgment against an employer in an action for damages by an injured employé, the indebtedness of an insurance company becomes absolute on a policy insuring the employer against liability for injuries, by statutory enactment in certain states, such indebtedness is subject to garnishment in a proceeding subsequently commenced by such employé against the insurance company as garnishee of the employer. ${ }^{38}$

Ins. Co., 72 N. H. 485, 57 Atl. 655,101 Am. St. Rep. 688. This case has been expressly disavowed in numerous decisions.

37 Anoka Lumber Co. v. Fidelity \& Casualty Co., 63 Minn. 286, 65 N. W. 353,30 L. R. A. 689 . In this case an employé was personally injured while his employer held an employers' liability policy. Before the employé commenced action against the employer to recover damages for such personal injuries, the employer made an assignment under the insolvency law. Judgment was afterwards rendered in such action in favor of the employe, and in an action upon the judgment by the assured employer against the insurauce company, the employe garnished the latter company and then intervened in the suit. The court held that the claim of the assured against the insurance company did not pass to the assignee by the assignment, and that the intervener is entitled to maintain his garnishee proceedings in the action to recover the amouut of his judgment.

In Beacon Lamp Co. v. Travelers' Ins. Co., 61 N. J. Eq. 59, 47 Atl. 579, the court declared that an injured employe, who has recorered judgment against the assured, may sue the insurer in equity to compel payment of the full amount of the judgment, despite the insolvency of the assured. The decision of the court seems to have been based on the theory that the insurer in a court of equity must be looked upon as the principal debtor while the iusured is the surets.

Fritchie v. Miller's Pennsylvania Extract Co., 197 Pa. 401, 47 Atl. 351. Here the court heid that an employe, who has recovered judgment for injuries against the insured, may issue an attachment execution and summon the insurance company as garnishee.

38 Hoven v. Employers' Liability Assur. Corp., 93 Wis. 201, $67 \mathrm{~N}$. W. 46,32 L. R. A. 3ss. The court specifically called attention to the fact that the policy here under suit was not a contract of indemnity against loss, but an agreement to indemnify against liability. The court said: "It will be seen that both the provisions in the body of the policy and the conditions indorsed thereon and made a part of it are inconsistent with any reasonable theory other than that the contract of insurance is one of indemnity against liability, and that 
Assignment of Causes of Action.-In the absence of an express condition to the contrary, a cause of action which has accrued may be assigned by the assured. Such an assignment does not conflict with a provision prohibiting an assignment of the policy by the assured without the consent of the insurance company. ${ }^{39}$

actual damages are not a condition precedent to the maintenance of an action thereon. It not only clearly contemplates that such an action may be brought before actual payment of the claim for damages by the assured, but by plain and unmistakable language it contracts to indemnify the assured against liability, not against damages."

39 Maryland Casualty Co. . Omaha Electric Light \& Power Co., 157 Fed. 514, 85 C. C. A. 106 . A provision in the policy forbade its assignment without the written consent of the insurance company. An employe had been injured. His administratrix had instituted a suit, and had prosecuted it to final judgment against the assured before the latter transferled its claim against the insurer, for reimbur'sement, to the plaintiff. The court said: "At that time the term of the policy had expired, and the character of the assured for integrity and prudence, on the strength of which the insurer might have relied in making its contract, could no longer affect its liability. The recognized reasons for the prohibition of assignments without the consent of the insurer had ceased. Its liability had become fixed, and like any other chose in action was assignable, regardless of the conditions of the policy in question. * * * In vlew of this conclusion the other contention of the defendant, based on the provision of the policy, to the effect that no action can be maintained against the insurer, except by the assured, after satisfaction by it of a judgment rendered against it, requires little consideration. On familiar principles the assignee stands in the shoes of the assignor, and must perform all the conditions precedent to recovery which the assignor was required to perform. The plain meaning of the provision in question, taken in connection with the established assignability of the claim to the plaintiff, is that to render defendant liable on the contract there must have been a loss to the assured, that loss must have been fixed by a final judgment, and that judgment must have been paid in order to constitute a loss within the terms of the policy. Such is the substance and meaning of the contract. Whether the loss is actually paid directly by the hand of the assured, or by some assignee of the claim for indemnity who, for value received from the assured, has assumed the judgment liability, is immaterial. 'Qui facit per alium facit per se.' The plaintiff paid the judgment against the assured as part consideration for a trans- 
Notice of Injury and Action for Damages.-Most policies of employers' liability insurance require the assured to give notice to the insurance company, within a specified time, of any injury to an employé upon which a possible claim for damages may be based, together with full particulars relating thereto. This requirement is similar to the usual condition in contracts of accident insurance by which the assured is required to give notice of any accident as a condition precedent to recovery under the policy. The purpose of this requirement is manifest. It is to enable the insurance company to investigate the facts and circumstances of the injury which may result in a claim for damages for which it may be made liable, and to permit it to better prepare a defense thereto. This requirement constitutes a condition precedent to the right of enforcing indemnity, and in the event of the failure to comply therewith the assured will be denied relief under the policy. ${ }^{40}$ Some policies require im-

fer of its assets, and that was payment by the assured within the purview of the policy."

40 Aronson v. Frankfort Accident \& Plate Glass Ins. Co., 9 Cal. App. 473, 99 Pac. 537, where the court said: "It was of the utmost importance to defendant to be immediately notitied of the accident, for the reason that, by the terms of the policy and upon such notice, it would become liable (if a liability existed) and the real party in interest. While the facts were fresh in the memory of witnesses, before they had been seen and ex parte statements taken in favor of the injured party, before there may have been inducements held out to them, it was the right of the defendant to have been notified and put upon its guard, if the assured desired to hold it liable. If notified immediately, the defendant might have settled for a small sum, if upon investigation it found that it was liable." Barclay v. London Guarantee \& Accident Co., 46 Colo. 558, 105 Pac. 865; London Guarantee \& Accident Co. v. Siwy, 35 Ind. App. 340, 66 N. E. 481. In Jefferson Realty Co. v. Employers' Liability Assur. Corp., 149 Ky. $741,149 \mathrm{~S}$. W. 1011, the policy required that notice be given within a "reasonable time." Here the assured, though in possession of the policy in issue, acted under a mistaken belief that the elevator in which the injury occurred was insured in another company, and gave an immediate notice to such other company, thereby oc- 
mediate notice. A notice presented within a reasonable time under all the circumstances of the case will be deemed a compliance with this condition. ${ }^{41}$ Under other poli-

casioning a delay of several months in notifying the defendant company. The court held that there could be no recovery and said: "There are cases holding that meritorious circumstances may extend beyond what would ordinarily be reasonable the time in which the insured may gire notice required by policies like this to be given within a reasonable time. But in this class of cases, with few exceptions, it was made to appear that the party whose duty it was to give notice was prevented by casualty or misfortune of some kind from giving it. * * * In our opinion it is wholly immaterial whether or not the appellee company was prejudiced by the unreasonable delay." Piercy v. Frankfort Marine, Accident \& Plate Glass Ius. Co., 127 N. Y. Supp. 354, 142 App. Div. 839. Traveler's' Ins. Co. v. Myers, 62 Ohio St. 529, 57 N. E. 458,49 L. R. A. 760. Here the court said: "In insurance of this character it is a matter of the first importance to the insurer, who may be forced to become the real defendant in a lawsuit against the insured employer, to be speedily informed of all the facts and witnesses concerning a possible litigation. In a very little time the facts may in a great measure fade out of memory, or become distorted, witnesses may go beyond reach, physical conditions may change, and, more dangerous than all, fraud and cupidity may have an opportunity to perfect their work. Therefore this stipulation is vital to the contract." Underwood Veneer Co. $\mathrm{r}$. London Guarantee \& Accident Co., 100 Wis. $378,75 \mathrm{~N}$. W. 996. The policy here in suit contained a clause providing that on the occurrence of an accident, and also on receipt of notice of a claim on account of an accident, the assured should give immediate notice thereof. This was held to be a condition precedent to the liability of the insurance company, even though the policy contained no forfeiture clause. Patton v. Employers' Liability Assur. Corp., Ltd., 20 L. R. (Ireland) 93; Victorian Stevedoring \& General Contracting Co., Ltd., r. Australian Accident Ins. \& General Guarantee Co., Ltd., 19 Victoria (Australia) 139.

41 Aronson v. Frankfort Accident \& Plate Glass Ins. Co., 9 Cal. App. 473, 99 Pac. 537, where the court held that a delay of nine months did not constitute "immediate notice" and reliered the insurance company from liability. Barclay v. London Guarantee \& Accident Co., 46 Colo. 558, 105 Pac. 865 , where the court held that under the clause demanding "immediate notice" the assured could take a reasonable time to procure such information as the requirement contemplates shall be furnished, and that with a sufficient explanation of the failure to give the required notice the contract would nevertheless be enforced, but that an inexcusable delay of several months would defeat a recovery. London Guarantee \& Accident Co. 
cies notice must be given within a prescribed period of time, which will be enforced unless to do so would work

v. Siwy, 35 Ind. App. 340,66 N. E. 481 , where there was a delay of a year. The court here said: "Under a policy like the one in question here, it was the right and duty of the company to assume the defense of all actions for damages growing out of personal injuries to the employes of the assured during the life of the policy. It had a right to pay a certain amount of money to the assured and be wholly discharged from liability under the policy. It had a right to settle or compromise with any employe claiming damages. It will thus be seen how material and important $i^{+}$was to appellant that it receive immediate notice of any claim arising under the policy. No sufficient excuse is shown by the evidence why such notice was not given." Rooney v. Maryland Casualty Co., 184 Mass. 26, 67 N. E. 882, where the condition was violated by a failure to notify the company until twenty-three days after the accident and twenty-two days after it was known to the assured. Smith \& Dove Mfg. Co. v. Travelers' Ins. Co., 171 Mass. 357, 50 N. E. 516. Here notice of the accident was given twenty-six days after it occurred, the intention of the assured to send an earlier notice having been interrupted by a strike of his employes, which caused him to forget the notice. The court said: "It is impossible to say that notice after a month's delay, due only to the forgetfulness of the agent in charge, is an 'immediate notice' in any sense. If the word 'immediate' is satisfied by the use of reasonable diligence on the part of the insured, such diligence is not made out by evidence that an agent upon whom he relied to give notice had a paramount, but not exclusive, interest in his head which drove out the contract's requirement and made him forget it."

Northwestern Tel. Exch. Co. v. Maryland Casualty Co., 86 Minn. $467,90 \mathrm{~N}$. W. 1110, where no notice of the accident was given until suit was brought a year later, because apparently the accident was trivial in its nature and not likely to result in a claim for damages. Columbia Paper Stock Co. v. Fidelity \& Casualty Co., 104 Mo. App. 157, 78 S. W. 320. Here the court said: "Provisions of this description also affecting the action of the assured, subsequent to the event, the subject of indemnity, and consequently after the loss, if any, has ensued, and the liability measurably attached, have received in this state a construction of the utmost liberality toward the beneficiary to obviate a forfeiture. Our conclusion, therefore, is that if no time is specified, or notice is required to be given immediately, notice given with diligence and in a reasonable time, due regard being had to the attending circumstances, is a legal compliance with such condition." Piercy v. Frankfort Marine, Accident \& Plate Glass Ins. Co., 127 N. Y. Supp. 354, 142 App. Div. 839, where there was a delay of four months in giving notice. Travelers' Ins. Co. v. Myers, 
62 Ohio St. 529,57 N. E. 458,49 L. R. A. 760 , where no proper notice was given for nine months after the accident.

Edgefield Mfg. Co. v. Maryland Casualty Co., 78 S. C. 73, 58 S. E. 969 . In this case the vice president and treasurer in charge of the mill was in extreme ill health, thongh trying to attend to the duties of his office, when the accident havpened to the employe. This official continued to grow worse, and died some little time thereafter. A temporary successor was placed in charge of the oflice. A month later he for the first time was made aware of the policy of easualty insurance by finding the contract among the payers of the company. On that day he at once gave notice of the accident and offered to send to the insurance company the summons which had been served on behalf of the injured employe. Not only had the vice president been sick and died, but the balance of the office force either had smallpox or had been quarantined on account thereof, and the mill was almost entirely at a standstill. The court held: "The stipulations that the insured should give immediate notice of an accident and full information concerning it, and send the summons immediately to the insurance company, means that these things should be done with reasonable promptness under the circumstances, not that they should be done literally without the lapse of any time. *** What is reasonable promptness under such a stipulation is usually a question of fact for the jury. * * * In view of these facts, it is evident a jury could not reasonably reach any other conclusion than that the delay was excusable, and the notice given and the summons sent with all promptness to be fairly expected and exacted." Underwood Veneer Co. v. London Guarantee \& Accident Co., 100 Wis. 378,75 N. W. 996 . Here an employe of the assured was injured, so that he was unable to perform any manual labor; but he made no claim for damages until nine months later, when the assured for the first time notified the company of the accident, though the policy required that immediate notice be given of any accident. Held, that notice was too late. Deer Trail Consol. Min. Co. v. Maryland Casualty Co., 36 Wash. 46, 78 Pac. 135, 67 I. R. A. 275, where a delay of eight months in giving the notice violated the policy, and the delay was not excused by the fact that one of the assured parties did not know of the accident, and the other did not know of the existence of the policy.

However, see Grand Rapids Electric Light \& Power Co. v. Fidelity \& Casualty Co., 111 Mich. 148, 69 N. W. 249. Here the policy required the assured, "upon the occurrence of an accident and upon notice of any claim on account of an accident," to give immediate notice in writing "of such accident or claim" to the company. The court held that the notice need not be given until there has been both an accident and a claim for damages by reason thereof, even though the assured knew of the injury at the time of its occurrence or immediately thereafter. This case was decided on the strength of Anoka Lumber Co. v. Fidelity \& Casualty Co., 63 Minn. 286, 65 N. 
an unconscionable hardship upon the assured and thus defeat recovery despite every reasonable diligence on his

W. 353, 30 L. R. A. 689. Here the clause in the policy read: "The assured, upon the occurrence of an accident, and upon notice of any claim on account of an accident, shall give immediate notice in writing of such accident or claim, with the fullest information available to the company." 'The court, holding that the assured need not give such notice until an accident has happened and a notice of claim been made on account thereof, declared: "The Fidelity Company contends that this provision requires notice to be given whenever any accident occurs, and also that another notice must be given whenever any claim on account of an accident is made. Opposed to this contention, it is asserted that notice is not required by the terms of such provision until there has been both an accident and a claim by reason thereof. We are of the opinion that the latter construction is the correct one. Nelson never made any claim against the lumber company for damages prior to September 13, 1893; and, upon such claim being made, the company immediately notified the insurance company of the accident and Nelson's clain. * * * If the injured party, Nelson, never made any claim against the lumber company on account of his injuries, it would be an idle ceremony for the company to give notice of the accident to the insurance company. It only concerned the company when it was notified by Nelson that he claimed damages against it on account of the injuries he had received. When it learned of the threatened liability, then it notified the responsible party in accordance with the terms of its poli$c y$, and that was all the notice required under the provisions of its. contract. We have no doubt as to the correctuess of the construction we have placed upon the provision of the policy we have quoted; but, if there were any doubt as to the meaning of the clause, then such doubt must be solved in favor of the insured. *** * We are not unmindful of the force of the appellant's contention that it would be of great benefit to have immediate notice of any accident, as well as of any claim, for the purpose of getting at the truth of the alleged incident, of finding witnesses who know the facts, and making preparations for the defense of any anticipated claim for damages. Other reasons might be readily suggested, but the insurance company must abide by its own terms, which it has deliberately expressed, and by the whole contract of which these terms are a part. Upon the other hand, it may be said that it might frequently be difficult for the employer to give immediate notice. Take, for instance, our lumbermen, where the employes are in the pine woods, a long distance from the employer's place of business or residence, and where it would, perhaps, on account of deep snows or want of rapid communication in traveling or by telegraph, be an impossibility to know of the accident for a long time, perhaps weeks or months, after its 
part. ${ }^{42}$ The policies usually demand notice within a week or ten days of the accident. ${ }^{43}$ In any event the duty of the assured to give notice of an accident does not arise until he himself has knowledge thereof. However, the assured is bound

occurrence. Under such a condition of things, a policy reruuiring immediate notice of the accident to the employe to be given to the insurance company by the employer would render the policy entirely useless. We might very well say that the provision under consllerattion does not need either construction or interpretation, but that the usual and ordinary meaning of it from a grammatical point of view is that which we have indicated and decided." The Anoka Iumber Company and the Grand Rapids Cases are out of harmony with the general trend of decisions and the reasonable theory on which the demand for notice is based, and on which the later and majority of cases turn.

42 Hope Spoke Co. v. Maryland Casualty Co. (Ark.) 143 S. W. 85, 38 L. R. A. (N. S.) 62 . In an interesting case the agent of the assured gave notice to the wrong insurance company, and thus notice to the insurer was delayed. The court held that the policy in sult did not make notice a condition precedent to liability, and that, the insurer having investigated the circumstances of the accident and having sustained no prejudice by reason of the delay, the policy was not vitiated. The court said: "Appellee received notice of the accident in time to make a full investigation, and to investigate to its satisfaction. It is not claimed that it suffered any loss or injury by reason of not having received the notice earlier. The defense is purely technical and without any substantial merit. To hold that the appellee should escape liability on account of the failure to receive notice strictly in accordance with the terms of the contract would be to absolve it from its just obligation on a point which was not in the slightest degree material to its rights." See, however, Jefferson Realty Co. v. Employers' Liability Assur. Corp., 149 Ky. 741, 149 S. W. 1011.

43 Victorian Stevedoring \& General Contracting Co., Ltd., v. Australian Accident Ins. \& General Guarantee Co., Ltd., 19 Victoria (Australia) 139. Here the policy required that written notice of the accident be sent to the insurance company within seren days thereafter. Notice was not given until thirty days thereafter, and the assured was not permitted to recover. Patton v. Employers' Liability Assur. Corp., Ltd., 20 L. R. (Ireland) 93. Notice in writing was required to be given within ten days after the occurrence of the accident. Verbal notice was given three days later, bnt no written notice was given. The court held the written notice within ten days a condition precedent to recorery. 
to exercise ordinary diligence and care in adopting measures likely to lead to his knowledge of the occurrence of accidents and claims for damages. ${ }^{44}$

44 Mandell v. Fidelity \& Casualty Co., 170 Mass. 173, 49 N. E. 110, $64 \mathrm{Am}$. St. Rep. 291. The policy here required immediate notice in writing of any accident be given by the assured to the insurance company. The accident in issue happened October 22,1895 . Norember 5 th the assured received a letter stating that a claim had been placed in the author's hands for settlement. The assured at once called on the writer, but did not locate him, and a few days later first learned that a man had been run over by one of his drivers. He thereupon ascertained the circumstances, and November 9th notified the insurance company in writing. The court said: "The construction of the policy adopted at the trial was that to comply with its requirements the plaintiff was bound to exercise ordinary diligence and care in adopting such measures as would lead to knowledge upon his part of the occurrence of accidents, and of claims for damages, by proper instructions to his employés and otherwise, and that he must give immediate notice, upon his earliest receipt of knowledge of an accident, or of information that a claim for damages was made, and that, if he did not know of the accident when it happened, he would not be required to give notice of its occurrence until immediately after he received information of it. This is a reasonable construction, having regard to the situation of the parties and the nature of the contract. It was extremely unlikely that the plaintiff would have personal knowledge of accidents caused by teams which were not under his personal care, but were driven by his servants through the streets of the city. The notice was not required to be given by the driver whose team might cause an accident, but by the plaintiff himself. It would therefore be impossible for notice to be given by the plaintiff until he had himself acquired information, and the requirement must be so construed that an effectual notice could be given in every instance. $* *^{*}$ The plaintiff was not chargeable with knowledge of the accident because his servants had such knowledge. Neither his drivers, stablemen, nor foreman were his agents for the purpose of giving notice to the company. They were concerned only with the transportation of merchandise and its incldents, and none of them were authorized or were expected by either party to the policy to do anything as his representatives with the defendant. There was no general agency conferred upon any of his employes. The plaintiff and defendant under such circumstances must be deemed to have intended that the notices would be given upon the kuowledge or information of the plaintiff himself." Plercy v. Frankfort Marine, Accident \& Plate Glass Ins. Co., 127 N. Y. Supp. 354, 142 App. Div. 839; Woolverton 
Notice of Claim for Damages.-Most policies, besides demanding notice of any accident, further require the assured to notify the insurance company of any claim for damages which may be presented as a result of the injuries referred to $i_{11}$ the first notice. ${ }^{45}$ The notices are required to be in writ-

v. Fidelity \& Casualty Co. of New York, 190 N. Y. 41, 82 N. E. 745, 16 L. R. A. (N. S.) 400 -in both of whlch the court held that it was the duty of the assured to exercise reasonable care and diligence to acquire information with respect to accidents and that he should so regulate his business as to be apprised of any accident with reasonable celerity.

45 Aronson v. Frankfort Accident \& Plate Glass Ins. Co., 9 Cal. App. 473, 99 Pac. 537. London Guarantee \& Accident Co. v. Siwy, 35 Ind. App. 340,66 N. E. 481 , where a delay of three months in giving notice to insurer of a claim brought by an injured employe was fatal. Grand Rapids Electric Light \& Power Co. v. Fidelity \& Casualty Co., 111 Mich. 148, 69 N. W. 249, supra; Anoka Lumber Co. v. Fidelity \& Casualty Co., 63 Minn. 286, 65 N. W. 353,30 L. R. A. 689, supra; Victorian Stevedoring \& General Contracting Co., Ltd., v. Australian Accident Insurance \& General Guarantee Co., Ltd., 19 Victoria (Australia) 139, supra. Underwood Veneer Co. v. London Guarantee \& Accident Co., 100 Wis. 37S, 75 N. W. 996. The court here said: "The reason for requiring such notice [of the accident] is obvious. It was to enable the defendant to investigate the facts and circumstances of the accident while they were fresh in mind, with the view of settling the loss, in case it should be so advised, and, in case of a contest, to be prepared to defend the same as stipulated in the policy. Accordingly the plaintiff was thereby expressly precluded from settling any claim or incurring any expense, without the consent of the defendant, except in case of absolute necessity. These things made it important for the defendant to be notified immediately, not only of the occurrence of the accident, but also that a claim for damages had been made by the injured person on account of the accident. 'The words 'and also', in the condition quoted, pretty clearly indicate that such notice of 'the occurrence of the accident' was to be followed by a further or additional notice of any claim made for damages, and each such notice was to be given immediately as therein required. In the two cases relied upon by counsel for plaintiff the condition did not contain the word 'also,' and in that respect are distinguished from the one at bar. Anoka Lumber Co. v. Fidelity \& Casualty Co., 63 Minn. 256, 65 N. W. 353, 30 L. R. A. 689; Grand Rapids Electric Light \& Power Co. v. Fidelity \& Casualty Co., 111 Mich. 148, 69 N. W. 249. Certainly we cannot hold, under the conditions in this policy, that the 
ing, and this condition will not be satisfied with a mere verbal notice. ${ }^{46}$

Waiver of Notice.-The requirement in the policy for notice of accident may be waived by any duly authorized agent of the company, either directly or indirectly. Any act of the insurer or its agent indicating that a compliance with the condition would not be insisted upon, or which puts the assured to any trouble or expense to establish his claim, or which prejudices him in his defense of the original action, will constitute a waiver on the part of the insurer. ${ }^{47}$ But where in any action the insurer expressly states that it does not forego compliance with the terms of the policy by the

notice of claim for damages, made for the first time nine months after the accident, satisfied the requirement that immediate notice should be given of the 'occurrence of the accident'; nor can we hold that such notice of the accident, given for the first time nine months after the occurrence of the accident, was an 'immediate notice' within the condition quoted, as those words have been repeatedly construed by this court. Kentzler v. American Mut. Acc. Ass'n, 88 Wis. 589,60 N. W. 1002,43 Am. St. Rep. 934. True, there is no forfeiture clause in the contract. Nevertheless, the plaintiff, in order to maintain this action, was bound to perform such condition precedent."

40 Patton v. Employers' Liability Assur. Corp., Ltd., 20 L. R. (Ireland) 93, supra.

47 Aronson v. Frankfort Accident \& Plate Glass Ins. Co., 9 Cal. App. 473, 99 Pac. 537; Barclay v. London Guarantee \& Accident Co., 46 Colo. 558, 105 Pac. 865, where after the agent of the insurer rightfully repudiated the ciaim, because of the failure to give notice, an examination of the circumstances of the accident did not constitute a waiver. Iondon Guarantee \& Accident Ins. Co. v. Siwy, 35 Ind. App. 340, 66 N. E. 481; Rooney v. Maryland Casualty Co., 184 Mass. 26, 67 N. E. 882. Travelers' Ins. Co. v. Myers, 62 Ohio St. 529,57 N. E. 458,49 L. R. A. 760. Here, during the life of the policy, an employe of the assured sustained injuries which the assured communicated verbaily to the local soliciting agent of the insurer. This agent told the assured not to take any steps in the matter, owing to the trivial nature of the accident, but to advise him in the event of any claim being made for damages. Acting under these instructions the assured gave the company no notice until nine 
assured there can be no waiver. ${ }^{48}$ Where a waiver of notice by the insurance company is relied upon by the assured, such waiver must be pleaded, and it cannot be, proven under an averment of performance. ${ }^{49}$ A waiver is the intentional relinquishment of a known right, and the burden is upon the party relying thereon to prove such waiver by evidence which does not leave the matter doubtful or uncertain. ${ }^{50}$ In the event of conflicting evidence, whether there has been a waiver is a question for the determination of the jury, and otherwise for the ruling of the court. ${ }^{51}$

Limitation of Time for Bringing Suit.-Most policies contain a provision that action by the assured to recover indemnity must be brought within sixty days of the date of the judgment secured by the injured employé. The length of time may vary in accordance with the express terms of the policy. ${ }^{2}$ The limitation runs from the day of the final

months later, when suit was brought. The court held that there had been no waiver of the requirement for immediate notice, since by the terms of the policy the local agent was without authority to waive or alter any of its conditions. Deer Trail Consol. Min. Co. v. Maryland Casualty Co., 36 Wash. 46, 78 Pac. 135, 67 L. R. A. 275.

48 London Guarantee \& Accident Ins. Co. v. Siwy, 35 Ind. App. 340, 66 N. E. 481 , where the insurance company defended the action against the assured after the assured had agreed that such action should not constitute a waiver of compliance with the terms of the policy.

49 Aronson v. Frankfort Accident \& Plate Glass Ins. Co., 9 Cal. App. 473, 99 Pac. 537; Barclay v. London Guarantee \& Accideut Co., 46 Colo.-558, 105 Pac. 865.

50 Aronson v. Frankfort Accident \& Plate Glass Ins. Co., 9 ,al. App. 473, 99 Pac. 537.

51 Aronson v. Frankfort Accident \& Plate Glass Ins. Co., 9 Cal. App. 473, 99 Pac. 537; Barclay v. London Guarantee \& Accident Co., 46 Colo. 558, 105 Pac. 865; Rooney v. Maryland Casualty Co., 184 Mass. 26, 67 N. E. 882 ; Deer Trail Consol. Min. Co. v. Maryland Casualty Co., 36 Wash. 46, 78 Pac. 135, 67 L. R. A. 275.

52 'Traveler's' Ins. Co. v. Henderson Cotton Mills, 120 Ky. 218, 85 S. W. 1090, 27 Ky. Law Rep. 653, 117 Am. St. Rep. 585, 9 Ann. Cas. 162. A condition in this policy that no action should be main- 
judgment by the court, and not from the day of the payment of the judgment by the assured. ${ }^{53}$

Some policies contain a condition expressly providing that the assured must bring action within a certain period of time from the date of the injury; if final judgment has not been rendered within that time an additional proviso permits the assured to bring action within a specified period after the termination of the suit by the injured employé. ${ }^{54}$

tained thereon unless brought within thirty days after payment of loss by the insured was held to be contrary to public policy and therefore vold.

53 People v. American Steam Boiler Ins. Co., 89 Hun, 456, 35 N. Y. Supp. 322; Id., 10 App. Div. 9, 41 N. Y. Supp. 631. The policy provided that the assured must bring action for indemnity within three years after the accident, but in the event a suit was then pending against the assured by an injured employe suit might be brought against the company "within six months from the termination of said suit." Final judgment was entered for the injured employé October 13, 1893, and judgment thereon paid October 28, 1893. The claim in suit was not presented until April 23, 1894. The court said: "The claim is that the assured had no cause of action until after it had paid the judgment, could not present a claim until then, and therefore had six months from the time its cause of action accrued within which to prosecute it. If this position be well taken, then the limitation provided for by contract was dependent upon the time of payment of the judgment, instead of upon the termination of the suit. And, as payment could be postponed by the assured for so long a period as it could arrange with its judgment creditor, the right to determine when the six months should begin to run would rest with the assured. But the language of the provision does not admit of such a construction. It provides that the period of six months shall date from the termination of the suit, not the date of payment. It was within the power of the assured, through a prompt payment of the judgment, to make both dates the same, and thus to secure, if desired, six months after the cause of action accrued within which to present its claim. But it had not the right to postpone the period by refusing to pay the judgment."

54 People v. American Steam Boiler Ins. Co., 10 App. Div. 9, 41 N. Y. Supp. 631 ; Id., 89 Hun, 456, 35 N. Y. Supp. 322. The policy provided that no suit under it should be maintained unless commenced within three years from the date of the accident, and that, in case an action was pending at the termination of the period of three years, a suit might be brought within six months from the termina- 
Agreement to Defend Suit.-Policies of employers' liability insurance generally contain an agreement upon the part of the insurer to defend the assured in any action brought by an injured employé for damages for injuries resulting from causes which impose either a common-law or statutory liability upon the assured, and for which the insurer may be liable to indemnify the assured under the policy. Coupled with this agreement is a proviso forbidding the assured to defend any action which may be brought by an employé, or to negotiate any settlement without the written consent of the insurer. Under such conditions the assured is deprived of the right to conduct the defense, or to do anything to protect his interest. ${ }^{55}$ Manifestly the purpose of this provision is to prevent connivance between the assured and the em-

tion of that action, and not later. An employe, who was injured in 1890 , brought suit in 1891 , and recovered judgment in 1892 , and the amount thereof, as reduced by the appellate court, was paid in November, 1892. In March, 1894, the assured presented its claim. The court held that, as the claimant had delayed sixteen months after the matter was decided by the appellate court, the delay was fatal to its right to recover. See, also, Creem v. Fidelity \& Casualty Co., of New York, 141 App. Div. 493, 126 N. Y. Supp. 555, affirming 132 App. Div. 241, 116 N. Y. Supp. 1042, where the policy provided that no action could be brought thereon after the expiration of three years from the happening of the accident, unless a suit was then pending against the assured, and in that case it must be brought within thirty days after judgment.

55 Rochester Min. Co. v. Maryland Casualty Co., 143 Mo. App. 555, $128 \mathrm{~S} . \mathrm{W} .204$. Here the insurance company under the terms of the policy undertook to defend the suit brought against the assured on account of the death of an employe covered by the policy. The insurance company appealed from the judgment, but failed to furnish an appeal bond in time to act as a supersedeas, so that the assured was forced to pay the judgment. The court held that, as this failure resulted in compelling the plaintiff to pay the judgment, it was practically the judgment of a court of last resort. The court said: "This provision of the policy robbed the plaintiff of any right or power to direct the defense in any particular, and left it powerless to do anything to protect its own interests without the express consent of the insurance company." See, also, Rosenbloom v. Maryland Casualty Co., 153 App. Div. 23, 137 N. Y. Supp. 1064.

Fuller Acc.INs.-31 
ployé, as a result of which the insurer would be compelled to pay an unwarranted indemnity. The right to defend the action for damages carries with it the right to appeal from the judgment of one tribunal to a higher tribunal. ${ }^{56}$

Where the insurance company in settlement of an action makes payment wrongfully, and the assured is still liable for a judgment to the rightful party to the action, the insurer must discharge this liability. ${ }^{57}$

If, despite the request of the assured, the insurance company refuses to accept an offer of compromise by the injured employé, and the employé secures a judgment against the assured in excess of the amount stipulated in the policy

56 Rochester Min. Co. v. Maryland Casualty Co., 143 Mo. App. 555, 128 S. W. 204, supra.

57 New Orleans \& C. R. Co. v. Maryland Casualty Co., 114 La. 153, 38 South. 89,6 L. R. A. (N. S.) 562 . Here the insurance comnany reserved the right to settle any claim for loss incurred up to a stated amount plus the costs. A loss was settled by the insurance company, ex parte, with the mother of a minor and the widow of an employe who was killed. The receipt purported to include the claim of the minor. However, the widow had not qualified as tutrix, and had no right at the time to sign a receipt in the capacity of tutrix. The widow then recovered in a suit brought as tutrix. The insurance company declined an offer of compromise with the tutrix, as urged by the assured, and on suit recovery was had agaiust the assured for a larger amount than that named in the compromise offer. The court declared: "The assurer must produce proof that proper payment has been made. If the company, in settling with one of the claimants, pays another illegally without obtaining legal evidence of the fact of payment, it cannot be heard to recover the amount thus illegally paid. * * * We have no hesitation in arriving at the conclusion that the insurance company should not be held liable for having declined to accept the terms of a compromise, which was less than the amount of the judgment subsequently reudered; but we do not think we should go further, and hold that the insurance company can make private compromises with claimants, and charge the amount as a credit in the suit in which the insured seeks to recover and sue on the policy it holds. * * * Negotiations and settlements of suits were left to the insurer. It has the right to decide upon the advisability of resisting the payment of a claim in suit, and the plaintiff appears to have consented not to interfere. The clause of the policy upon this subject has the appear- 
as the limit of the liability of the company, the insurer will not be liable to the assured for such excess, where manifestly the insurance company has in good faith rejected the offer.

The agreement of the insurance company to defend an action against the assured on account of an accident covered by the policy has its ordinary meaning, and does not import an agreement to successfully defend. Whether the insurance company is bound to pay the amount of the judgment will, of course, depend on the terms of its agrcement to indemnify the assured against loss. ${ }^{58}$

The refusal of the insurance company to make a defense because it disclaims any liability for damages occasioned to the plaintiff does not relieve it from the conclusiveness of the judgment rendered in such action. ${ }^{50}$

ance of being full and clear enough. It reserved the right absolutely not to be interfered with in settlements of suits. This it exercised. With the rights stipulated in the contract of insurance it had authority to refuse to compromise without apprehension of being held for the difference, if thereafter cast by judgment in a larger amount than that at which compromise was offered. * * * True, the insured must be held to good faith and intelligent action in the premises."

58 Connolly v. Bolster, 187 Mass. 266, 72 N. E. 981. Here the court expressly disavowed the theory that the word "defend" meant to "successfully defend," and that therefore it included an obligation on the part of the company to pay the judgment if the case defended resulted in a judgment adverse to the assured.

59 B. Roth Tool Co. v. New Amsterdam Casualty Co., 161 Fed. 709, 88 C. C. A. 569 . Here the insurance company refused to defend the action against the assured on the ground that the policy contained a warranty that explosives would not be used on the premises and that the injury to the employe arose from an explosion. The servant secured a judgment against the assured, who brought action on the policy. The court said: "lt is a well-settled general rule that, when one who has a right to recover over is sued, the judgment regularly rendered against him is conclusive upon the person liable over, provided notice of the suit be given to the latter and full opportunity afforded him to make defense. But, when the liability over is not as broad as the original liability, the plaintiff in the suit 
Where the insurance company by its contract agrees to defend actions against an employer for injuries to employés, and has conducted the defense of the case to the very day of trial, it will be estopped from claiming the conclusiveness of a judgment by default against the employer, who has by the company's failure to abide by the policy been denied a reasonable opportunity to prepare a defense to the action. ${ }^{60}$

Refusal of the Insurance Company to Defend.-Where the policy provides that the insurer will defend at its own cost any legal proceedings against the assured to enforce claims for injuries, but upon notice of suit the insurance company refuses to defend, the assured will be permitted to recover an

to recover over, if he relies on the adjudication made in the former case, must show that the very ground of liability against the indemnitor was found to exist and was necessarily determined by it. * * * The refusal by the casualty company to make the defense makes no difference in the conclusiveness of the judgment rendered in the case."

60 Glens Falls Portland Cement Co. v. Travelers' Ins. Co., $162 \mathrm{~N}$. Y. 399,56 N. E. 897 , affirming 11 App. Div. 411,42 N. Y. Supp. 285. Here the policy contained a clause exempting the insurance company from liability for losses sustained by the assured as a result of the violation of a so-called factory law governing the safeguarding of dangerous machinery, and another clause binding the insurance company to defend actions against the assured for injury to employés. The insurance company conducted the defense down to the eve of trial, and then withdrew on the ground that certain machinery which had not been properly guarded in accordance with the law was responsible for the injury, and therefore the insurer was not liable on the policy. The employer, being left no reasonable opportunity to prepare a defense in the action, was forced to permit the injured employe to take a judgment by default. The court said: "Had the insurance company continued its defense, it might have shown upon the trial that the cement company was free from negligence in the matter, and thus aroided a judgment against that company; but having withdrawn from the defense of that action improperly, and permitted judgment to go against the cement company by default, it is now estopped from claiming that the adjudication thus obtained precludes the plaintiff from insisting upon the indemnity which the defendant had contracted to render." 
allowance for such expenses as he may incur in making a proper defense, together with the amount of indemnity for which the company may be liable. ${ }^{81}$

A condition in the policy which expressly provides that the insurance company will defend any and all actions brought against the assured, and which forbids the assured to undertake the defense or negotiate any settlement, except at its own cost, without the written consent of the insurer, is legal, and will be enforced. A compliance with this condition is a condition precedent to the right of recovery under the policy, and a failure to respect its terms will destroy the right of action by the assured for indemnity. ${ }^{62}$ This stipulation may, however, be waived by the company. ${ }^{63}$

61 Mandell v. Fidelity \& Casualty Co., 170 Mass. 173,49 N. E. 110, 64 Am. St. Rep. 291. See, also, Ross v. American Employers' Liability Ins. Co., 56 N. J. Eq. 41, 38 Atl. 22.

62 Victorian Stevedoring \& General Contracting Co., Ltd., v. Australian Accident Insurance \& General Guarantee Co., Ltd., 19 Victoria (Australia) 139. Here the assured, hopeless of successfully defending the action of the injured employe, negotiated a compromise settlement with him without the consent of the insurance company, despite the condition in the policy that the insurance company should take on itself the settlement of any claim, and that the assured should not, except at its own cost, pay or settle any claim withont the written consent of the company. The court said: "It was quite reasonable to stipulate that the insured should not settle any claim without the consent of the company, and the insured here acted in complete defiance of it. The policy places the insured in a very favorable position. It does not matter to them what the injured person recovered, because they would recover it over again against the insurance company, who are the people manifestly interested in fighting the litigation and the object of the conditions seems very obvious - that the insurance company should be placed in a position to protect its own interests."

See, also, Wythe v. Manufacturers' Acc. Ins. Co., 15 Canada L. T. 86. The nolicy provided that "if any proceedings be taken to enforce any claim the company shall have the absolute conduct and control of defending the same throughout, in the name and on be-

63 London Guarantee \& Accident Co. v. Mississippi Cent. R. Co., 97 Miss. 165, 52 South. 787. 
Under the form of policy generally in vogue, which provides that no action will lie against the insurer for any recovery, unless brought by the assured to reimburse himself for loss actually sustained and paid in satisfaction of a judgment, the assured is not entitled to recover the cost of maintaining a successful defense to an action which has no legal basis. ${ }^{64}$ The action having been successfully defended, it is therefore established that no legal liability for damages rested upon the assured, and consequently there is no claim under the policy against the insurer.

half of the employer, retalning or employing their own solicitors and counsel therefor." The court held that "the plaintiff was not entitled, in the face of such a stipulation, to claim from the defendants the amount of a judgment obtained against him by an employe in an action defended by the plaintiff through his own solicitor and counsel, leaving the defendants to show as a defense or by way of counterclaim that they could have done better by defending it themselves; nor was an offer by the plaintiff at a time when the action was at issue, and on the peremptory list for trial the following day, to hand over the defense to the defendants' solicitors, a sufficient compliance with the condition."

64 Corneli v. Travelers' Ins. Co., 175 N. Y. 239 , 67 N. E. 578, reversing 66 App. Div. 559, 73 N. Y. Supp. 341. The plaintiff here had contracted to do the structural work of a building in process of erection in New York City. Before the work was entirely completed the building accidentally collapsed, and a large portion of the interior structure fell, and a number of persous were injured or killed. It was conceded that the accident was in no way due to any act or neglect of the plaintiff, who was a contractor only for the structural iron work. The owner of the bullding and all the contractors were sued either jointly or separately by the persons injured and by the representatives of those killed. Some eleven separate sults were commenced against the plaintiff in this action. Only two actions were brought to trial, in each case with a verdict for the plaintiff herein. The remaining actions were then abandoned. The costs and expeuses of this plaintiff in the defense of the suits and proceedings amounted to some $\$ 12,000$, for whlch he claimed the defendant was liable under the policy. The court said: "Thts clause stipulates for indemnity to the assured against actual legal liability, and does not cover groundiess or fictitious claims made against him. If the injuries did not occur under such circumstances as to impose a legal iiability upon the insured therefor, they are not within the protection of the policy. The eleven suits brought against the plaintiff had 
However, the refusal of the insurance company to defend a suit contemplated by the policy constitutes a breach of the contract, and will release the assured from the agreement not to settle the claim without its consent, and amounts to a waiver of the condition of the policy that the insurer will only be liable for judgment rendered against

no legal basis upon which to rest. They were simply groundless claims, with no basis of legal liability upon the plaintiff, as the result proved and as the present record conclusively shows. The stipulations of the contract exclude all liability on the part of the defendant for such elaims. The liability of the insured to be sued by irresponsible parties upon groundless claims is not within the indemnity clauses of the policy. That was a risk that was not contemplated by the parties. The plaintiff assumed all such risks himself, or, at least, the defendant did not assume them. * * * The defendant did not stipulate to indemnify the plaintiff against the costs and expenses of defending himself against fictitious or groundless suits. The protection afforded to the plaintiff by the policy was against some actual legal liability directly occasioned by his business operations. * * * of course, in deciding not to defend, the defendant had to take the chances on an adverse result. But we are not embarrassed in this case by any such question, since it appears that the suits defended were based upon a state of facts that imposed no liability upon the insured. It is not unusual for business men engaged in large operations to be sued by irreponsible parties upon claims having no legal or just basis, but against which they are compelled to incur large expenses in order to defend themselves. That is really what happened to the plaintiff in this case, and he must bear the loss unless it is fairly within the indemnity afforded to him by the defendant's contract, and we think it is not."

Henderson Lighting \& Power Co. v. Maryland Casualty Co., 153 N. C. 275,69 S. E. 234,30 L. R. A. (N. S.) 1105. The court here discussed this question at length in the following language: "The clause of the policy by which the defendant agreed to defend any suit brought against the assured refers explicitly to a suit brought 'to enforce a claim for damages on account of an accident covered by the policy, and in order to determine whether the casualty company was under any duty or obligation to defend the Briscoe suit, we must first ascertain whether the law imposed a liability upon the power company for the accident to him; for, if it did not, his claim is plainly not covered by the policy, as it refers to a claim founded upon a liability imposed by law, and not to false or fictitious claims. The indemnity is against loss from liability, and it would be stretching, if not perverting, the meaning of the words to extend the application to them to all suits, and require the casualty company to 
the assured after trial and judgment satisfied. ${ }^{65}$ It is, none the less, the duty of the assured to make the loss as small

defend them, without regard to the legal liability of the assured. An accident covered by the policy is one for which the assured is liable under the law, for it is so expressly stated in the policy. If, therefore, the casualty company refused to defend the Briscoe suit for any reason, it cannot be held liable for the expense of a defense or settlement made by the insured, unless in some way it is made to appear that the latter was liable to Briscoe. *** The defendant was not bound to defend a suit upon a claim not within the terms of its policy, and especially so in the case of a groundless claim. If not required to defend, it cannot be charged with the costs and expenses of a defense, or of a settlement made by the assured for its own benefit, however reasonable that settlement may be. To hold otherwise would impose upon the defendant a liability which it not only has not assumed by its contract with the assured; but which, by the very terms of the policy, is excluded therefrom. The costs and expenses incurred in defending against Briscoe's claim for damages were not the result of any legal wrong done by the power company to him for which it is indemnified, but of the claim for damages, pressed with commendable zeal, but misplaced confidence, by a plaintiff without a case, which would surely have judicially appeared if the power company had not settled, but defended to the end." However, see South Knoxville Brick Co. v. Empire State Surety Co. (Tenn.) 150 S. W. 92.

See, also, Creem v. Fidelity \& Casualty Co., 132 App. Div. 241, 116 N. Y. Supp. 1042, affirmed by 141 App. Div. 493, 126 N. Y. Supp. 555 ; Munson v. Standard Ins. Co. (C. C.) 145 Fed. 957; Id., 156 Fed. 44, 84 C. C. A. 210 ; Nesson v. United States Casualty Co., 201 Mass. 71, 87 N. E. 191, 131 Am. St. Rep. 390; Hudson River Tel. Co. v. Etna Life Ins. Co., 66 Misc. Rep. 329, 121 N. Y. Supp. 565, affirmed without opinion 138 App. Div. 931, 123 N. Y. Supp. 1121; Lawrence v. General Acc. Assur. Corp., 124 App. Div. 545, 108 N. Y. Supp. 939, affirmed without opinion 192 N. Y. 568, 85 N. E. 1112.

65 St. Louls Dressed Beef \& Provision Co. v. Maryland Casualty Co., 201 U. S. 173,26 Sup. Ct. 400, 50 L. Ed. 712. Here the insurance company refused to defend the suit against the assured on the ground that the accident was not within the risks assumed. The assured, to avoid heavy judgments, settled the suits out of court and sued the insurance company. The court said: "The defendant by its abdication put the plaintiff in its place, with all its rights. To limit its liabllity, as if its only promise was to pay a loss paid upon a judgment, is to neglect the meaning and purpose of the reference to a judgment, and even the words of the promise. The promise in form is to indemnify against loss by certain kinds of liability. The judgment contemplated in the condition is a judgment 
as possible, so far as it reasonably can, and to reduce the recovery to a just sum. ${ }^{68}$

Where the assured compromises a groundless claim, particularly when a judgment has been rendered in its favor by the courts, the insurance company will not be liable for the amount paid by the assured in settlement thereof. ${ }^{67}$

in a suit defended by the defendant in case it elects not to settie. The substance of the promise is to pay a loss which the plaintiff shall have been compelled to pay, after such precautions and with such safeguards as the defendant may insist upon. It saw fit to insist upon none. We assume that the settlement was reasonable, and that the plaintiff could not expect to escape at less cost by defending the suits. If this were otherwise, no doubt the defendant would profit by the fact. The defendant did not agree to repay a gratuity, or more than fairly could be said to have been paid upon compulsion. But a sum paid in the prudent settlement of a suit is paid under the compulsion of the suit as truly as if it were paid upon execution. *** If the defendant kept its contract, it would defend the suit, and the plaintiff would have no duties. If it refused to do as it had promised, we cannot think that it was entitled to complain that the plaintiff did not do it, when the interest of both was the other way."

6 6 Mandell v. Fidelity \& Casualty Co., 170 Mass. 173,49 N. E. 110, $64 \mathrm{Am}$. St. Rep. 291. Here the court sald: "It was the duty and the right of the plaintiff to take all reasonable means to reduce the recovery to a just sum, if the defendant, as it did, neglected or refused to defend the suit, although it had agreed that it would defend at its cost any legal proceedings against the assured to enforce claims for injuries." Southern Ry. News Co. v. Fidelity \& Casualty Co. of New York, 83 S. W. 620, 26 Ky. Law Rep. 1217. The court here declared: "Appellant * * * was bound to make the loss as small as possible, so far as it reasonably could, although appellee did not avail itself of the provision in the policy to personally condict the defense to the suit. Appellant might have compromised the claim, so that it acted in good faith and with reasonable prudence, such as a prudent person similarly situated would have done for himself. This would have bound appellee to pay to it the loss actually sustained, of which the compromise, if one was effected, as is charged, may have been taken into consideration as eridence of the actual loss sustained, but, of course, not conclusive evidence of it. Other evidence might also be admitted to show whether it was or was not a judicious and fair settlement."

67 Henderson Lighting \& Power Co. v. Maryland Casualty Co., 153 N. C. 275 , 69 S. E. 234,30 L. R. A. (N. S.) 1105 , supra. In this case 
The provision in the policy, however, which forbids the assured to settle any claim without the written consent of the insurer, does not prevent the payment of a judgment secured by an injured employé and affirmed by the court of last resort, and which by the terms of the policy is made a condition precedent to liability on the part of the insurance company. ${ }^{68}$

a boy was injured by falling into a shallow well of hot water on a narrow strip of land adjoining land owned by the power company, but over which the company had no control, concern, or responsibility. The power company was sued for damages, and upou appeal the Supreme Court held that it was not liable on the facts presented. Thereupon the assured compromised the case, and then brought this action against the indemnity company to recover the amount paid by it in compromise, with costs and reasonable attorney's fees. The court held that, inasmuch as the claim for damages was not the result of an "accident covered by the policy," the insurance company was not liable for the amount of the settlement made by the power company.

es Connolly v. Bolster, 187 Mass. 266, 72 N. E. 981 . Here the court said: "It [the clause forbidding the assured to defend or settle any claim] is plainly inserted as an additional obligation and privilege for the protection of the insurance company, on the assumption that it is for the pecuniary interest of the company to be given the conduct of and to defend the action, which is to fix its liability and the amount to be paid when liable, rather than to leave that matter to be dealt with by the several persons insured, respectively. This does not result in the necessity of writing into clause 2 the qualifying words 'until final judgment,' as the plaintiff contends, for when final judgment is rendered ordinarily all defense is at an end. Nothing remains but a writ of review or a writ of error, and if such a proceeding were necessary it might well be held to be covered by the obligation to defend. But when the defense is ended, and in spite of the defense judgment is rendered against the insured, there is nothing to do but pay."

Pickett v. Fidelity \& Casualty Co., 60 S. C. 477,38 S. E. $160,629$. Here the court held: "This provision does not relate to a settlement of a final judgment establishing the employer's liabllity to the injured employé, but relates to such a settlement of the claim for damages before judgment as would affect the right of the insured to a fair and full judicial investigation of the claim for damages, and was designed to prevent collusion between the insured employer and the injured employé, to the prejudice of the insurer. Under this provision, for illustration, the insured employer and the injured em- 
Limit of Liability of Insurer.-Most policies of insurance limit the liability of the insurer to a fixed sum for damages arising from an accident resulting in injuries to any one person and to a lump sum for all indemnity for which it may be liable during the life of the policy. ${ }^{60}$ And where the

ploye may not agree upon an amount as the damages sustained, and seek to bind the insurer without his consent, since the insurer, by the policy, has the right to conduct and defend the suit for damages; but we see no reason why the employer and the injured employe, pending a suit for damages, may not agree that, in the erent of a recovery after investigation exceeding the amount of the policy, such judgment shall be canceled by the proceeds of the policy, or the excess in the judgment over the amount of the policy shall be remitted or settled for a specified sum. If such an agreement could be in any sense a settlement before final judgment, it would not be a settlement of any claim at the expense of the insurer, since the insurer is not concerned with so much of the clalm as may upon final judgment exceed the amount of the policy."

a 9 Cudahy Packing Co. v. New Amsterdam Casualty Co. (C. C.) 132 Fed. 623; Maryland Casualty Co. v. Omaha Electric Light \& Power Co., 157 Fed. 514, 85 C. C. A. 106; Munro v. Maryland Casualty Co., 48 Misc. Rep. 183, 96 N. Y. Supp. 705. In Reigler v. Sherlock, 66 Ark. 215, 49 S. W. 1080, an employe sued the insured for two injuries occurring at different times, asking for a $\$ 5,000$ verdict in each case. He secured one verdict for $\$ 5,000$, though the verdict did not specify for which injury it was returned. The. policy of indemnity covered the second injury, but not the first. The court held that the judgment was insufficient to show that it was rendered on the injury covered by the policy.

See Rumford Falls Paper Co. v. Fidelity \& Casualty Co., 92 Me. 574,43 Atl. 503. The policy provided that the company's liability for an accident resulting in injuries to or the death of one person should be limited to $\$ 1,500$; and subject to the same limit for each person, its gross liability for a casualty resulting in injuries to or the death of several persons should be $\$ 25,000$. An injured employe offered to settle his claim in full for $\$ 1,000$. Despite the advice of the assured, the insurance company exercised its exclusive right to defend the suit, and on trial the employe recovered a judgment of $\$ 2,500$ and costs, which the insured paid. In an action by the assured to recover the money thus paid, the court held that under the policy the insurer could not be held liable for more than $\$ 1,500$ and the cost of defending the suit. The court clearly discussed the theory of limited liability as follows: "With reference to the general scope and purpose of the policy in suit, it is manifest from an examination of the whole instrument that, while it was 
policy thus nominates a fixed sum as the maximum amount of its liability the insurer will not be entitled to any deduction from its full liability by reason of a reduction in the judgment against the assured under a compromise thereof, where the amount paid by the assured equals or exceeds the face of the policy. ${ }^{70}$

designed to be a contract of indemnity to the limited amount agreed upon, it was not the intention of the parties to relieve the assured from all responsibility whatever for damages resulting from injuries to its employés. In the discussion of the first proposition set up in defense, it has been seen that the arbitrary exercise of the power retained by the defendant company to control settlements and legal proceedings might indeed in some cases involve the assured in greater loss than the forfeiture of the policy. On the other hand, if the policy should be construed to impose upon the defendant company the obligation either to pay the assured the sum of $\$ 1,500$, accept the employe's offer of settlement, or defend the legal proceedings at the peril of being compelled to pay the full amount of any judgment for damages and costs that might be recovered, it is to be feared that the assured, being in most instances under no liability to pay any part of the damages, would have little incentive to defend against the claim of injured laborers, however devoid of legal merit. There is also ground for apprehension that, under such a contract of indemnity, the sense of freedom from responsibility enjoyed by the assured would be such as to induce a relaxation of those rules of prudence and vigilance which are indispensable for the reasonable protection of the laborers engaged in its service. It was undoubtedly in contemplation of these things that the policy in suit was devised, with a view to an apportionment of the responsibility between the insurer and the insured. Whether the interests of the assured are in all respects sufficiently guarded by the stipulations in the contract it is unnecessary to consider. These corporations had the same right that individuals have to make their own contract. The court has no power to add to it or take from it. The first article in the policy declares that the defendant 'company's lia. bility for an accident resulting in injurles to or the death of one person is limited to $\$ 1,500$.' This language is clear and unambiguous, and would seem to be susceptible of only one interpretation. It measures the amount of the insurance, and limits the risk of the defendant company in case of accident and injury to one person. There is no other stipulation in the policy which is inconsistent with it."

70 Mears Min. Co. v. Maryland Casualty Co., 162 Mo. App. 178, $144 \mathrm{~S}$. W. 883 . In this case a judgment of $\$ 7,000$ had been obtained 
Where the amount of indemnity for any one accident is limited to a specified sum, it refers to an injury to a single individual, and not to an accident in which several individuals are injured at the same time. ${ }^{71}$

Immediate Surgical Relief.-Policies frequently authorize the assured to provide such immediate surgical relief as is imperative at the time of the accident. Under such a policy the assured becomes the agent of the insurer for the purpose of calling medical attendance in case of emergency, and the liability thus incurred is independent of the obligations otherwise enumerated in the policy. The theory of this provision, of course, is that by immediate medical attention for the employé the amount of liability may be decreased. ${ }^{72}$ The liability of the insurance company for the surgical or medical relief becomes fixed as soon as the surgical relief is provided. ${ }^{73}$

The clause contemplates medical assistance rendered for

against the assured on account of the death of an employe. The action was defended by the insurance company, and the judgment was affirmed on appeal. Later the judgment was compromised by the assured paying the claimant something over $\$ 5,000$, which was the amount of the liability policy. The court held that the insurer was not entitled to any deduction from its full liability on account of the compromise.

71 South Staffordshire Tramways Co. v. Sickness \& Accident Assurance Society, [1891] 1 Q. B. 402. See, also, Embler v. Hartford Steam Boiler Inspection \& Ins. Co., 158 N. Y. 431, 53 N. E. 212, 44 L. R. A. 512 .

72 Kelly v. Maryland Casualty Co., 89 Minn. 337, 94 N. W. 889. An employé, while working in the laundry of the assured, sustained injuries necessitating the amputation of an arm. Immediately after the accident the assured called a physician to attend to the injury. The court held that under the terms of the policy the provision for immediate surgical relief could be treated as an independent express authority, imposing upon the insurer a liability in addition to that otherwise provided for in the policy.

73 Fenton v. Fidelity \& Casualty Co., 36 Or. 283, 56 Pac. 1096, $4 \mathrm{~S}$ L. R. A. 770 . 
a reasonable time after the injury, and provides generally that notice shall at once be given the insurer of the fact, so that it may take the necessary steps to protect its own interests and secure such relief as it may desire for the injured employé. However, the provision does not contemplate that the medical assistance shall extend for a longer time than would be necessary for the insurance company to act. The particular conditions in each case must determine the action to be taken and the reasonableness of the relief afforded. However, it refers only to medical supplies and attention, and in no event would include the living expenses of the injured employé. ${ }^{74}$ At the same time the claim for medical and surgical aid arises under the policy, and is, therefore, subject to the limitation of time which governs

74 Employers' Liability Assur. Corp. v. Light, Heat \& Pंower Co., $2 S$ Ind. App. 437, 63 N. E. 54. Here the policy provided that, "if an accident is sufficiently serious to necessitate immediate medical assistance, the same may be rendered at the cost of the corporation, who will not, however, pay the cost for any subsequent medical ald, unless previously authorized by them." An employe of the assured was severely injured. His condition was serious, and immediately. medical attention was summoned. For five weeks the doctor's visits varied from two to four a day; then for a time the doctor made daily visits, and later the patient went to the doctor's office, until he was finally discharged as cured. The assured paid the doctor's bill, and also a drug bill of some size. The injured employe was a married man, without means of subsistence, and assured paid him $\$ 90.25$ in installments of $\$ 12$ per week; the money apparently being used for living purposes. The court here said: "The clause in question is intended to minimize the amount of liability, and the word 'immediately' is entitled to a liberal, rather than a strict, construction. It relates to a time after the accident. There must be, usually, some interval between the injury and the rendition of medical assistance. It cannot have been intended to designate only medical assistance tendered without the lapse of any appreciable time after the accident. When notice of the accident is furnished to the corporation, it is then in condition to protect its own interest, and to take such steps as may be necessary on account of the condition of the injured man, his inability to procure medical service upon his 
any action thereunder to recover indemnity for losses sustained by the insured. ${ }^{75}$

Liability for Costs.-Where the insurance company agrees to defend an action against the assured "at its own cost," this phrase is used to mean at its own expense, and will include whatever expenditure is necessary to defend the suit, such as court costs, attorney's and stenographers' fees, and the like, as well as the taxable costs of the action, although these may be in addition to the maximum sum

own credit, and the absence of any person charged with the duty of caring, or willing to care, for him. Until it has that notice, it is so manifestly in its interest that the person be not neglected that it may well be held that the word 'immediate' shall be construed liberally enough to cover the intervening time. * * * Such reasonable time could in no event extend beyond the period within which the notice of the accident was or should have been forwarded and such further interval as might have been necessary to enable the corporation to act in the matter. It might be very much less than this, depending in each case upon the particular conditions existing. The power to bind the corporation must be found in the written contract, which includes necessary medical attention. For such drugs or dressings only as were properly used as a part of the medical treatment authorized by the contract the appellant should pay, but not further. There is no rule of construction, known or suggested, admitting the inclusion of living expenses within the meaning of the term 'medical assistance." "

75 People v. American Steam Boller Ins. Co., 10 App. Div. 9, 41 N. Y. Supp. 631; Id., 89 Hun, 456,35 N.'Y. Supp. 322 . The court said: "The policy provided for reimbursement to the assured for medical ald furnished under such circumstances, *** and the breach of the contract by the insurance company in these respects would furnish a claim arising under and not outside of the policy; for by the terms of that policy any outlay for immediate medical or surgical relief was to be deemed part of the liabllity of the company under the policy, and its obligation to defend the sult is also one assumed by the policy, and any action for a breach of that contract would be necessarily one arising under and connected with the liability it assumed in the policy, and would, therefore, come under the limitation of time fixed for the beginning of a suit against the company." 
which it agrees in the policy to pay the assured in the event it should elect not to defend or settle the claim. ${ }^{76}$

76 Maryland Casualty Co. v. Omaha Electric Light \& Power Co.. 157 Fed. 514, 85 C. C. A. 106. The court here said: "The words employed are not the technical words familiar to the legal profession, such as 'at its own costs' in the plural, which are commonly used in court proceedings when treating of taxable costs, but they are 'at its own cost'-in the singular. They suggest the idea that the parties meant 'at its own expense,' generally speaking, rather than court costs merely. Again, the context shows that the parties intended them to have a more comprehensive meaning than court costs. They agreed in another clause of the same contract that the assured shall not settle any claim 'except at its own cost.' Here the words, which are the same as those now under consideration, are obviously employed in their common or colloquial, as distinguished from their technical, legal sense, meaning 'that which is expended; outiay of any kind, as of money, labor, time, or trouble.' Cent. Dict. Applied to settling a claim before suit was instituted, the words under consideration undoubtedly were intended to cover the outlay or expenditure of money necessary to do so. They could not contemplate technical costs of a lawsuit, because the clause last referred to does not contemplate the pendency of a lawsuit but only the making of a claim. Applied to defending a proceeding in court, the words 'at its own cost' must mean, in the light of the maxim 'noscitur a sociis,' and the technical language employed by the parties, an outlay or expenditure necessarily incident to making such defense, like the costs of court, attorney's fees, stenographer's fees, and the like. As modified by the condition just referred to, the contract is one of indemnity against loss to the extent of $\$ 5,000$, together with any further sum which the insurer, defending in the name of the assured, might force the assured to pay as outlays or expenditures incident to making the defense. It clearly indemnified against the court costs in question."

New Amsterdam Casualty Co. v. Cumberland Telephone \& Telegraph Co., 152 Fed. 961,82 C. C. A. 315,12 L. R. A. (N. S.) 478. The court here fully discussed the question in the following language: "The insurance was against two kinds of liability-one of which was for damages on account of bodily injury sustained by any person, and the other was for expenses in defending any suit brought therefor. Thls last provision was not included in the first, and, if it had not been expressly made, the insurance against the accident would not have included the cost and expenses of a suit to recover on account of it. They were not the necessary consequences of the accident, and so would not have been within the contemplation of the parties. For the same reason the restriction of the liability of 
The insurance company, however, is not liable to the assured for interest which may accrue on the judgment obtained by the injured employé. ${ }^{77}$

the company in respect to injuries resulting from an accident would not extend to costs and expenses of a suit; for such language, without more, would not import that the parties had that subject in contemplation, and there is abundant reason shown by the contract why it would be most unlikely that the parties should intend such a limitation. By one of the conditions of the insurance, the telephone company was prevented from making any settlement, or incurring any expense or interfering in any negotiation for settlement, or in any legal proceeding. If the casualty company should see fit to resist the claim, it could make any defense it pleased, hire such and as many lawyers as it wanted, and prolong the litigation to the last extremity. If its liability for the accident were converted into a fund for carrying on the contest, it could be done without the ordinary risks of litigation, and the only prospect for the assured would be in the remnant, if there should be any. A contract ought not to be construed to an absurd conclusion, if a reasonable one is possible. Moreover, a policy of insurance, prepared with much care for the interests of the insurer, should be construed favorably to the other party, if the language employed leaves the matter in doubt. These considerations lead us to think that, when the casualty company reserved all power of control of the defense to actions brought by injured persons to establish the liability for the accident and recover damages, and insured the telephone company 'against the expense of defending any suit for such damages,' although, it must needs be that the defense would be carried on in the name of the telephone company, and an adverse judgment would go against that company for damages and costs, yet in fact the casualty company would be defending the cause in its own interest, and for the purpose of performing its contract of indemnity against the expenses of any such suit, and at all stages of the litigation it would be for it to determine what expenses it would risk in the chances of defeating the claim. It makes no difference that ultimately a larger liability was established against the telephone company than the limit of insurance, for the casualty company reserved the right to make the defense, without regard to the amount claimed by the party injured by the accident, and the telephone company was as completely excluded in a case where the amount which might be recovered was as much as $\$ 25,000$ as where it might not exceed $\$ 5,000$. By its agreement it was exposed to the hazard of the course which the casualty company might see fit to pursue. If the defense proved successful, the casualty company would have done no

77 See footnote 77 on page 500 .

Fuller Acc.Ins.-32 


\section{Failure to Pay Premium.-Where a policy of employers'} liability insurance reserves to the insurer the right to cancel

more than it had agreed to do. If unsuccessful, still that company had done only that. There is no room for holding that the liability of the casualty company for the expenses of making the defense were at all dependent upon the result of the litigation."

In Coast Lumber Co. v. Atna Life Ins. Co. (Idaho) 125 Pac. 185, the court construed "costs and expenses" to mean "the amount paid counsel and to witnesses, and other court costs, and all costs and other expenses, including the taxable costs recovered by the plaintiff in said suit, if the defense made is unsuccessful." Atna Life Ins. Co. v. Bowling Green Gaslight Co., 150 Ky. 732, 150 S. W. 994. Here the policy contracted to pay an indemnity not in excess of $\$ 5,000$ and the "expenses of litigation" in addition thereto. Upon trial in the circuit court the injured empioye secured a judgment against the insured in the sum of $\$ 6,750$, and the insured at the request of the insurer prayed an appeal. The judgment was affirmed by the court of appeals, which in accordance with the law added to the judgment a penalty of 10 per cent. The insurer then paid the insured only the sum of $\$ 5,000$, and action was brought to recover interest on the $\$ 5,000$ from the date of the judgment in the lower court, the 10 per cent. damages awarded in the court of appeals, and the court costs. The court said: "The substance of the contract on the point under consideration is that the insurance company will pay $\$ 5,000$, and, in addition thereto, all costs and expenses of litigation, unless it elects to pay the $\$ 5,000$ and settle without litigation any claim asserted against the assured. If it does so. elect, then, in the words of the contract, it shall not be liable for further expense of litigation, after such payment shall have been made.' This being our construction of the policy, it follows that, if the words 'expense of litigation' fairly include interest, damages, and cost, the insurance company must pay the amounts adjudged against it. Counsel for appellant contends that the words 'expense of litigation' do not include any of the items we have mentioned and should be confined to the payment of attorney's fees, obtaining witnesses, securing bonds, and other like expenses incident to this class of suits; but to give the policy this construction would be to ignore, for the benefit of the insurance company, and to the prejudice of the assured, stipulations in the contract that are equally as binding upon it as the one fixing its liablity at $\$ 5,000$. The liability of the company is to be measured by ail of the undertakings of the policy, and not alone by one. * * * The insurance company had the undoubted right to compel the assured, against his will, to engage in litigation, or else forfeit the right to any part of the indemnity he had contracted for; and as it could, by electing to insist on litigation, burden the assured, against his consent, with the cost and expense of a lawsuit, the provisions of the policy should 
the policy for nonpayment of the premium, the exercise of that right by the insurer will not prevent the insured from

be liberally construed for his benefit. * * * The damages that the insured incurred in appealing the case and the interest on $\$ 5$,000 that accrued pending the appeal are as much a part of the expense of litigation as the court costs. No sound distinction can be made between these items of expense."

National \& Providence Worsted Mills v. Frankfort Marine, Accident \& Plate Glass Ins. Co., 28 R. I. 126, 66 Atl. 58. The court here said: "The items of costs and interest are not part of the cost of defense. A reasonable construction of the provisions of the policy that the insurance company should undertake the defense of the legal proceedings at its own cost is that it should be responsible for the employment of counsel, the fees of witnesses called in defense, and such other expenditures as are necessary to conduct the defense."

An interesting case is found in Brassil v. Maryland Casualty Co., 133 N. Y. Supp. 187, 147 App. Div. 815. Here the amount of the indemnity policy was $\$ 1,500$. The assured was sued by an injured employé, and the insurer, having rejected an offer of the employé before suit to settle for $\$ 1,500$, undertook the defense of the case. A judgment was recovered in the lower court for $\$ 6,500$. The insurer refused to prosecute an appeal, but offered to pay the assured the face of the policy if he would satisfy the judgment. Thereupon the assured substituted his own attorney and took an appeal. The case was later dismissed for failure on the part of the employe to prosecute. The court held that, although the policy should not render the insurance company liable to reimburse the assured, except for "loss actually sustained and paid by him in satisfaction of a judgment after trial of the issue," the insured was, under the circumstances, entitled to recover the expenses of the successful defense, on the ground that the insurer had made a breach of the obligation which it assumed when it elected to defend the suit, and that, aside from the terms of the policy, when the insurer elected to exercise its option to defend, a new contract came into existence, so that it no longer stood in the position of an indemnitor to the amount limited by the policy.

See, also, Cudahy Packing Co. . New Amsterdam Casualty Co. (C. C.) 132 Fed. 623; Travelers' Ins. Co. v. Henderson Cotton Mills, 120 Ky. 218, 85 S. W. 1090, 27 Ky. Law Rep. 653, 117 Am. St. Rep. 585, 9 Ann. Cas. 162 ; Davison v. Maryland Casualty Co., 197 Mass. 167, 83 N. F. 407 ; Conqueror Zinc \& Lead Co. v. Etna Life Ins. Co., 152 Mo. App. 332, 133 S. W. 156; Myton v. Fidelity \& Casualty Co., 117 Mo. App. 442, 92 S. W. 1149; Ross v. American Employers' Liability Ins. Co., 56 N. J. Eq. 41, 38 Atl. 22 ; Globe Nav. Co. v. Mary- 
recovering the amount of any liability which may accrue under the contract between the time of its issuance and can-

land Casualty Co., 39 Wash. 299, 81 Pac. 826; Pnget Sound Imp. Co. v. Frankfort Marine, Accident \& Plate Giass Ins. Co., 52 Wash. 124, 100 Pac. 190.

In New York, however, the courts have laid down the rule that the insurance company is not liable for the taxable costs of an action, where such a sum would bring its total liability to an amount greater than that specified in the policy as the limit of its obligation. Munro v. Maryland Casualty Co., 48 Misc. Rep. 183, 96 N. Y. Supp. 705; Fernald v. Providence Washington Ins. Co., 27 App. Div. 137, 50 N. Y. Supp. 838 ; McWilliams et al. v. Home Ins. Co., 40 App. Div. 400,57 N. Y. Supp. 1100. See, howerer, Brewster v. Empire State Surety Co., 130 N. Y. Supp. 439, 145 App. Div. 678.

77 Saratoga Trap Rock Co. v. Standard Acc. Ins. Co., 143 App. Div. 852,128 N. Y. Supp. 822. Here the court said: "Clearly the interest which accumulated on the judgment pending the appeal cannot be said to be any part of the cost of defense of the action which the insuring company agreed to pay. The agreement of the defendant was that, in case action was brought, it would 'at its own cost defend such suit' in the assured's name. While the accumulation of interest was an incident to the appeal, it was not a part of the cost of appeal, or the taxable costs, or of the defense of the action. There is no claim in the present case that there was any express promise to pay interest. * * * The contract embraced in the policy which the defeudant issued to the plaintiff is one of indemnity merely. It is not an agreement to save harmless, or to pay when liability shall be established. If the first part of the agreement was not qualified by a subsequent clause, and if the only provision contained in the policy was that the insuring company would indemnify the insured against loss by reason of liabllity because of an accident happening to its servant, obligation to pay wouid arise when judgment determining liability was entered against the assured (Stephens v. Pennsylvania Casualty Co., 135 Mich. 189, 97 N. W. 686, 3 Ann. Cas. 478), and whatever interest accrued in an ineffectuai effort to get rid of the judgment the insuring company would be bound to pay. But this broad part of the agreement is qualified by a subsequent provision of the policy that no action shall lie against the company to recover for any loss under the policy, unless it shall be brought by the assured for 'loss actually sustained and paid in money after actual triai of the issue.' This clause is a substantive part of the policy, and has the effect of changing the policy from one of indemnity when liability shall be established to one for indemnity for money paid out on the occurrence of a particular erent, to wit, pajment of the judgment obtained because of such liablity. The 
cellation, after the premium earned for that time shall have been deducted. ${ }^{78}$ However, a voluntary payment of an ad-

parties agreed, therefore, that the insuring company would indemnify the assured to the extent of $\$ 5,000$, not because of the establishing of liability, but from loss for money actually paid out on account of liability. Hence the assured had no claim against the insuring company until it had paid the judgment which was reudered against it. When it had paid such judgment, and only after it had done so, did it have the right to call upon the insurer to indemnify it to the extent of $\$ 5,000 . * * *$ While it seems inequitable to compel the plaintiff to pay the interest on the judgment accruing while the defendant was engaged in an ineffectual attempt to relieve itself from liability, the answer to it is that the parties otherwise agreed. By its agreement the plaintiff deprived itself of all right to interfere in the litigation, and could not compel payment from the insuring company until it had itself paid the judgment, and could not pay the judgment, except at its own peril, as long as the defendant desired to appeal. The cause of action did not arise against the defendant when judgment was entered against the assured, but only on payment of the judgment after the insuring company had done what it chose respecting an appeal. Interest, therefore, did not begin to run when judgment was entered, but only when the judgment was paid." Cannon Mfg. Co. v. Employers' Indemnity Co. (N. C.) 76 S. E. 536. Here the policy provided for a maximum indemnity of $\$ 5,000$. A judgment was obtained in the trial court against the insured for $\$ 4,951.40$ and $\$ 121.73$ costs. A new trial was refused on appeal by the indemnity company for the insured. Thereupon the assured paid the final judgment, the total sum being $\$ 5,363.62$. The insurance company insisted that it was not liable in excess of the $\$ 5,000$ named in the policy. The court, in an exceedingly interesting opinion, said: "The courts of this country have been divided upon this question: (1) One class of decisions holds that the indemnity company is liable for interest, although it is in excess of the limit fixed by the polfcy. (2) Another class of decisions holds that the indemnity company is liable for interest from the rendition of the final judgment by the supreme court. (3) The third class of decisions holds that, on account of the express terms of the contract limiting the amount to $\$ 5,000$, the indemnity company is not liable for any interest, if it carries it in excess of the limit fixed by the policy. * * * We candidly admit that the third class of decisions is largely in the majority. They all base their judgments upon the ground that it is "so nominated in the

78 American Employers' Liability Ins. Co. v. Fordyce, 62 Ark, 562, 36 S. W. 1051, 54 Am. St. Rep. 305. 
ditional premium on a casualty policy, in excess of what is due, made under a mistake of law, cannot be recovered. ${ }^{79}$

Policies of indemnity insurance generally require the assured to co-operate with and render all assistance in its power to the insurer in defending actions brought by injured employés and defended by the insurance company. This refers to furnishing information, assistance in securing witnesses, and the like, and does not contemplate any un-

bond.' We think the reasoning supporting the cases is technical, and at variance with the purpose and meaning of the bond, as well as elementary principles of justice. In effecting such insurance the plaintiff was not purchasing a lawsuit, but indemnity. Whlle it is provided that the defendant should have control of the litigation, it clearly was not contemplated that after judgment rendered the litigation should be indefinitely protracted at plaintiff's expense. * * * We think the decisions of the second class really are in accord with our views. They hold that the indemnity company is liable for interest from the time of the rendition of a final judgment by the appellate court."

See, also, Maryland Casualty Co. v. Omaha Electric Light \& Power Co., 157 Fed. 514, 85 C. C. A. 106, supra; Conqueror Zine \& Lead Co. v. Attua Life Ins. Co., 152 Mo. App. 332, 133 S. W. 156; Munro v. Maryland Casualty Co., 48 Misc. Rep. 183, 96 N. Y. Supp. 705, supra ; Brewster v. Empire State Surety Co., 130 N. Y. Supp. 439, 145 App. Div. 678; National \& Providence Worsted Mills v. Frankfort Marine, Accident \& Plate Glass Ins. Co., 28 R. I. 126, 66 Atl. 5S, supra.

79 Maryland Casualty Co. v. Little Rock Ry. \& Electric Co., 92 Ark. 306, 122 S. W. 994. An insurance company undertook to insure an electric light company from liability for damages on account of bodily injuries accidentally suffered by its employés while on duty. This company had at the time no power house and no employés in engine or boiler rooms. On a subsequent sale of the lighting business to another company, the paymeut of an additional premium did not extend its terms to cover employes of the transferee engaged in engine and boiler rooms. The court held: "In other words, the transfer of the policy did not extend its terms to cover a class of employes that were not included in the policy at the time of its execution. After the contract had expired, a payment of an additional premium was made on account of the report of the wages of a class of employés not covered by the terms of the policy. This act did not extend the terms of the policy. It was a voluntary payment, made under a mistake of law, and as such cannot be recovered." 
conscionable act. ${ }^{80}$ Similarly the assured is required to forward or deliver to the insurance company all writs, summonses, and other papers served on it in connection with any action for indemnity which may be covered by the policy. This, like other conditions of the policy, may, however, be waived by the insurer. ${ }^{81}$

80 Mears Min. Co. v. Maryland Casualty Co., 162 Mo. App. 178, $144 \mathrm{~S}$. W. 883 . Under such a condition in the policy, the assured was not required to boast of an insufficlent appeal bond, or its own insolvency, for the purpose of enabling the insurer to compromise a judgment, from the payment of which the assured was protected by the policy.

81 Sandoval Zine Co. v. New Amsterdam Casualty Co., 140 Ill. App. 247, affirmed by 235 Ill. 306, 85 N. E. 219. 



\title{
TABLE OF CASES CITED
}

\author{
[THE Figures REFER to PAGES]
}

A

Allen v. Gilman, McNeil \& Co., $457,461,463,465$.

Accident Ins. Co. $\mathbf{v}$. Crandal, 42, Allen v. Massachusetts Mut. Acc. $113,180$.

Accident Ins. Co. of North America $\nabla$. 'Bennett, 35, 102, 134, 135, 269.

Atna Life Ins. Co. v. Bethel, 76, $127,192,205,290,307,373,428$.

Aitna Life Ins. Co. v. Bowling Green Gaslight Co., 498.

Atna Life Ins. Co. V. Claypool, 13. Ass'n, 6, 8.

Alloway v. General Accident Ins. Co., 48, 240.

Alter v. Union Casualty \& Surety Co., 229, 231.

American Acc. Co. จ. Card, 378, 388, 395, 401.

Amerlcan Acc. Co. v. Fidler's Adm'x, 208, 411, 428.

American Acc. Co. $\nabla$. Reigart, 38.

American Acc. Co. of Louisville v. Carson, 36, 77, 270.

American Acc. Ins. Co. v. Norment, 73, 394.

American Casualty Ins. Co.'s Case, 439, 448, 451.

American Employers' Liability Ins. Co. v. Barr, 286.

American Employers' Liability Ins. Co. จ. Fordyce, 447, 453, $456,501$.

Anable v. Fidelity \& Casualty Co. of New York, 59, 211, 333.

Etna Life Ins. Co. v. Milward, $86,403$.

Etna Life Ins. Co. v. Vandecar, $30,64,80,272,334$.

Etna Life Ins. Co. of Hartford, Coun., v. Dorney, 201.

Avtna Life Ins. Co. of Hartford, Conn., v. Griffin, 204.

Albert v. Order of Chosen Friends, $304,433$.

Aldrich v. Mercantile Mut. Acc. Ass'n, 342.

Anderson v. Fetna Life Ins. Co., $324,422,425$.

Andrus v. Maryland Casualty Co., 444.

Anoka Lumber Co. จ. Fidelity \& Casualty Co., 440, 454, 468, 473, 477.

Anthony $\nabla$. Mercantile Mut. Acc. Ass'n, 101, 219, 248.

Appel v. Attna Life Ins. Co., 32.

Allen v. Atna Life Ins. Co., 457, Appel v. People's Surety of New $461,463,465$. York, 458.

FULler Aco.INs. 


\section{[The figures refer to pages]}

Applegate $\nabla$. Travelers' Ins. Co. of Hartford, Conn., 117.

Armstrong v. West Coast Life Ins. Co., 192, 206.

Aronson v. Frankfort Accident \& Plate Glass Ins. Co., 470, 471, 477, 478, 479.

Ashenfelter v. Employers' Liability Assur. Corp. of London, Eng., 223, 237, 259.

Atlanta Acc. Ass'n v. Alexander, 97, 196.

\section{B}

Bacon v. United States Mut. Acc. Ass'n, 38, 158, 179, 196.

Badenfeld v. Massachusetts Mut. Acc. Ass'n, 215, 219, 249, 252, 258, 264, 265, 430.

Bader v. New Amsterdam Casualty Co., 349.

Baehr v. Union Casualty \& Surety Co., 206, 325.

Bailey v. Interstate Casualty Co., 33.

Bakalars v. Continental Casualty Co., 142, 222, 258, 259.

Baldwin v. Fraternal Acc. Ass'n, 54, 299, 348, 430, 433.

Bane v. 'Travelers' Ins. Co., 22.

Banta v. Continental Casualty Co., 58, 210, 214, 334.

Barclay v. London Guarantee \& Accident Co., 470, 471, 478, 479.

Barry v. United States Mut. Acc. Ass'n, 29, 97, 123, 204, 366.

Batchelor v. Accident Ass'n, 154.

Bateman v. Travelers' Ins. Co., 237, 240, 255.

Baumister v. Continental Casualty Co., 70, 391.

Bawden v. London E. \& G. Assur. Co., 356.

Bayless v. Travelers' Ins. Co., 42, $105,157$.

Bayley v. Employers' Liability Assur. Corp., 12.

Beach v. Supreme Tent of Knights of Maccabees of the World, 293, 300, 308, 319.

Beacon Lamp Co. v. Travelers' Ins. Co., 457, 464, 468.

Bean v. Etna Iife Ins. Co., 8.

Bean v. Employers' Liability Assur. Corp., 257.

Bean v. Travelers' Ins. Co., 47, 322.

Beard v. Indemnity Co., 146, 167, 222.

Berger v. Pacific Mut. Life Ins. Co. of California, 34, 37, 276.

Berliner v. Travelers' Ins. Co., 54, $66,216,334,343$.

Berman v. Fraternities Health \& Accident Ass'n, 420.

Bernays v. United States Mut. Acc. Ass'n, 18, 120, 123, 128, 160.

Beyer v. International Aluminum Co., 457, 463.

Bickford v. Travelers' Ins. Co., 326.

Blehl v. General Accident Assur. Corp., 229.

Binder v. National Masonic Acc. Ass'n, 199, 318.

Bishop v. United States Casual-ty Co., 309.

Blackstone v. Standard Life \& Accident Ins. Co., 19, 42, 114, 180.

Bloom v. Franklin Life Ins. Co., $130,131,141,150$.

Blunt . Fidelity \& Casualty Co., 112, 118, 180.

Bogart v. Standard Life \& Accident Ins. Co., 63, 331.

Bon v. Railway Passengers' Assur. Co., 110.

Bonewell v. North American Acc. Ins. Co., 24.

Bothell v. National Casualty Co., 339.

Bowen v. Preferred Acc. Ins. Co., 409. 
[The figures refer to pages]

Bradley v. Mutual Ben. Life Ins. Co., 130.

Brassil v. Maryland Casualty Co., 499.

Braymer v. Commercial Mut. Acc. Co., 423.

Brendon v. Traders' \& Travelers' Accident Co. of New York, 71.

Brewster v. Enıpire State Surety Co., 500, 502.

Brink v. Guaranty Mut. Acc. Ass'n, 13, 14, 15, 19, 24, 44, 52, 413.

Brock จ. Brotherhood Acc. Co., 53.

Brotherhood of Railroad Trainmen v. Newton, 433.

B. Roth Tool Co. v. New Amsterdam Casualty Co., 443, 483.

Brown v. Fraternal Acc. Ass'n of America, 369, 393, 396.

Brown v. Pacific Mut. Life Ins. Co., 22.

Brown v. Rallway Passengers' Assur. Co., 63.

Brown v. United States Casualty Co., 73, 275.

Bryant v. Continental Casualty Co., 186.

Buffalo Steel Co. v. AEtna Life Ins. Co., 448.

Burke v. London Guarantee \& Accident Co., 457, 464, 467.

Burkhard $\nabla$. Travelers' Ins. Co., 167, 225, 227.

Burkhardt $\nabla$. Columbia Relief Fund Ass'n, 10 s.

Burkheiser v. Mutual Acc. Ass'n of the Northwest, 73, 316.

Burnett v. Railway Officials' \& Employés Acc. Ass'n, 76, 290, 291.

Bushaw v. Women's Mut. Ins. \& Acc. Co., 339, 423.

Butero v. Travelers' Acc. Ins. Co., 273, 275, 280, 281.

Button v. American Mut. Acc. Ass'n, 273.
Bylow v. Unlon Casualty \& Surety Co., 300.

\section{C}

Cady v. Fidellty \& Casualty Co. of New York, 17, 116.

Caldwell v. Iowa State Traveling Men's Ass'n, 81, 192, 205, 280.

Camden \& Atlantic Tel. Co. v. United States Casualty Co., 447.

Campbell v. Fidelity \& Casualty Co. of New York, 34, 146, 224, 245, 269.

Campbell v. Maryland Casualty Co., 454, 462.

Cannon Mfg. Co. v. Employers' Indemnity Co., 501.

Carnes v. Iowa State Traveling Men's Ass'n, 33, 81, 90.

Carpenter v. American Acc. Co., $15,45,225$.

Carr v. Pacific Mut. Life Ins. Co., 188.

Carter v. Atna Life Ins. Co., 457, $463,466$.

Cary v. Preferred Accident Ins. Co. of New York, 160, 195.

Cashman v. London Guarantee \& Accident Co., 442.

Central Acc. Ins. Co. v. Rembe, $159,266,267$.

Central Acc. Ins. Co. v. Spence, 11, 12, 13.

Champlin v. Railway Passengers' Assur. Co., 5S, 263.

Chatterton v. Central Acc. Ins. Co., 89.

Chevaliers $\nabla$. Shearer, 353.

Chicago, B. \& Q. R. Co. v. Olson, 320.

Chicago-Coulterville Coal Co. v. Fidelity \& Casualty Co. of New York, 449.

Cilley v. Preferred Acc. Ins. Co., $78,362$.

Clanton $\boldsymbol{v}$. Travelers' Protective Ass'n, 326, 368, 370, 399.

Clark v. Bonsal \& Co., 458, 467. 
Clark v. Brotherhood of Locomotive Firemen, 76.

Clark v. Employers' Liability Assur. Co., 185, 188, 364.

Cluff ₹. Mutual Ben. Life Ins. Co., 129.

Coad v. Travelers' Ins. Co., 303.

Coast Lumber Co. v. Etna Life Ins. Co., 498.

Cobb v. Preferred Mut. Acc. Ass'n, $31,40,18 \mathrm{~s}$.

Coburn v. Travelers' Ins. Co., 101, 280, 369, 405.

Coldham v. Pacific Mut. Life Ins. Co., 377, 425 .

Cole v. Insurance Co., 154.

Coles v. New York Casualty Co., 133.

Collins v. Bankers' Acc. Ins. Co., 137, 223.

Collins v. Fidelity \& Casualty Co., 35, 246.

Columbian Acc. Co. v. Sanford, 252, 259.

Columbia Paper Stock Co. v. Fidelity \& Casualty Co., 445, 472.

Commercial Travelers v. Barnes, 69.

Commercial Travelers' Mut. Acc. Ass'n v. Springsteen, 223, 260, 299, 413.

Conmercial Travelers' Mut. Acc. Ass'n of America v. Fulton, 99, 198.

Com. v. Philadelphia Inquirer, 2.

Comstock v. Fraternal Acc. Ass'n, $54,348,384$.

Conboy v. Railway Officials' \& IEmployés' Acc. Ass'n, 137, 231, 257.

Connolly v. Bolster, 457, 467, 483, 490.

Conqueror Zinc \& Lead Co. $\nabla$. Etna Life Ins. Co., 457, 499, 502.

Continental Casualty Co. v. Colvin, 192.
Continental Casualty Co. v. Deeg, 222.

Continental Casualty Co. v. Jennings, 260, 402.

Continental Casualty Co. $\mathbf{v}$. Johnson, 186.

Continental Casualty Co. v. Lindsay, 13, 388, 422, 425.

Continental Casualty Co. v. Lloyd, 103, 205, 207.

Continental Casualty Co. v. Mathis, 72, 195, 267, 381, 425, 436.

Continental Casualty Co. v. Morris, 275.

Continental Casualty Co. v. Ogburn, $70,411,428$.

Continental Casualty Co. v. Peltier, 200.

Continental Casualty Co. v. Semple, 205.

Continental Casualty Co. v. Wade, 71, 307, 326.

Cook v. Benefit League of Minnesota, 319.

Cook v. Standard Life \& Acc. Ins. Co., 150, 151, 405, 406.

Cooper v. Phœnix Accident \& Sick Ben. Ass'n, 309.

Corley v. Travelers' Protective Ass'n, 34, 37, 276, 319.

Cornelius v. Central Acc. Ins. Co., 282.

Cornell v. Travelers' Ins. Co. of Hartford, 425, 458, 486.

Cornwell v. Fraternal Acc. Ass'n, 139, 243.

Correll v. National Acc. Soc., 178, 36S, 411.

Cotten v. Fidelity \& Casualty Co., $18,22,50,217,238$.

Couadeau v. American Acc. Co., 81, 147, 152.

Cram v. Equitable Acc. Ass'n, 14, 44.

Crandal v. Accident Ins. Co., 42, 180.

Crane v. Standard Life \& Accident Ins. Co., 373. 
[The figures refer to pages]

Creem $\nabla$. Fidelity \& Casualty Co. of New York, 448, 458, 481, 488.

Crenshaw v. Pacific Mut. Life Ins. Co., 100, 320, 418, 421, 427.

Cronkhite v. 'Travelers' Ins. Co., 81.

Crotty v. Continental Casualty Co., 206, 288, 294, 368.

Cudahy Packing Co. v. New Amsterdam Casualty Co., 491, 499.

Cunningham v. Union Casualty \& Surety Co., 323.

Currie .v. Continental Casualty Co., 283, 428.

Cushman v. Carbondale Fuel Co. $457,465$.

\section{D}

Dabbert v. Travelers' Ins. Co., 209.

Dailey v. Preferred Masonic Mut. Acc. Ass'n, 14, 24, 44, 46, 49, 91, 217.

Da Rin v. Casualty Co. of America, 232, 400, 410, 413.

Davison v. Maryland Casualty Co., 499.

Dawson v. Accident Ins. Co. of North America, 76, 289, 290.

Deer Trail Consol. Min. Co. v. Maryland Casualty Co., 473, 479.

De Graw v. National Acc. Soc., 273.

De Greayer v. Fidelity \& Casualty Co., 246, 258.

Delaney v. Modern Accident Club, 97, 195.

De Loy v. Travelers' Ins. Co., 160, 171, 236.

Denison v. Masons' Fraternal Acc. Ass'n, 321.

Denoyer $\nabla$. First Nat. Acc. Co., $16,47$.

Depue v. Travelers' Ins. Co., 359, $424,436$.

De Van v. Commercial Travelers' Mut. Acc. Ass'n, 39, 152, 423.

Dezell v. Fidelity \& Casualty Co., $33,102,154,364,427$.
Diddle $\nabla$. Continental Casualty Co., 140, 230.

Dillon v. Continental Casualty Co., 222.

Dineen v. General Acc. Ins. Co. 13.

Dives v. Fidellty \& Casualty Co., 442.

Doody $\nabla$. National Masonle Acc. Ass'n, 348.

Dougherty v. Pacific Mut. Life Ins. Co., 173.

Dozler v. Fidelity \& Casualty Co. of New York, 186.

Driskell v. United States Health \& Accident Ins. Co., 43, 192, 203, 206.

Dulany v. Fidelity \& Casualty Co., 16, 312.

Duncan v. Preferred Mut. Acc. Ass'n, 111, 172, 227, 253, 260, $265,366$.

Dunn v. New Amsterdam Casualty Co., 67,335 .

Dunning $\nabla$. Massachusetts Mut. Acc. Ass'n, 309.

Dunshee v. Travelers' Ins. Co. of Hartford, 374.

Duran $\nabla$. Standard Life \& Accident Ins., 138, 141.

\section{$\mathrm{E}$}

Early v. Standard Life \& Accident Ins. Co., 153.

East Carolina R. Co. v. Maryland Casualty Co., 444.

Eaton v. Atlas Acc. Ins. Co., 54, $137,348$.

Edgefield Mfg. Co. v. Maryland Casualty Co., 458, 473.

Eggenberger $\nabla$. Guarantee Mut. Acc. Ass'n, 53, 120.

Embler v. Hartford Steam Roller Inspection \& Ins. Co., 493.

Employers' Liability Assur. Corp. $\nabla$. Anderson, 242, 407.

Employers' Liability Assur. Corp. v. Back, 341 . 


\section{[The flgures refer to pages]}

Employers' Liability Assur. Corp. v. Light, Heat \& Power Co., 494.

Employers' Liability Assur. Corp. v. Merrill, 2, 4, 440, 446.

Employers' Liability Assur. Corp. v. Rochelle, 9, 22, 23, 50, 100, 218, 426.

Equitable Acc. Ins. Co. v. Osborn, $32,37,170,231,272$.

Equitable Acc. Ins. Co. v. Sandifer, 108, 110, 215, 251.

Erb v. Commercial Mut. Acc. Co., 36.

Evarts v. United States Mut. Acc. Ass'n, 416.

Everson v. Casualty Co. of America, 282.

Everson v. General Accident, Fire \& Life Assur. Corp., 13, 14, 44, $349,376$.

Ewing v. Commercial 'Travelers' Mut. Acc. Ass'n, 285, 286, 373, 377, 388 .

\section{F}

Fairbanks Canning Co. v. London Guaranty \& Accident Co., 448.

Farner v. Massachusetts Mut. Acc. Ass'n, 34, 72, 160, 195, 266.

Farrell v. American Employers' Liability Ins. Co., 23.

Faulkner v. Grand Legion of Select Knights, 296.

Feder v. Iowa State Traveling Men's Ass'n, 31, 188.

Fenton v. Fidelity \& Casualty Co., $453,454,493$.

Fernald v. Providence Washington Ins. Co., 500.

Fetter v. Fidelity \& Casualty Co., 95, 98, 203, 207.

Fidelity \& Casualty Co. v. Ballard, 5.

Fidelity \& Casualty Co. v. Brown, $369,417$.

Fidelity \& Casualty Co. v. Chambers, 152, 191, 255.
Fidelity \& Casualty Co. v. Fordyce, 447, 454, 455 .

Fidelity \& Casualty Co. v. Johnson, 33, 269, 273.

Fidelity \& Casualty Co. $\nabla$. Lone Oak Cotton Oil \& Gin Co., 441, 442.

Fidelity \& Casualty Co. จ. Sittig, 101, 224, 233, 248, 258.

Fidelity \& Casualty Co. v. Weise, 373.

Fidelity \& Casualty Co. of New York v. Cooper, 82, 20S, 410, $412,417$.

Fidelity \& Casualty Co. of New York v. Getzendanner, 297.

Fidelity \& Casualty Co. of New York v. Hart, 86, 90, 295, 424.

Fidelity \& Casualty Co. of New York $\nabla$. Lowenstein, 163.

Fidelity \& Casualty Co. of New York v. Morrison, 61, 332.

Fidelity \& Casualty Co. of New York v. Phoenix Mfg. Co., 442.

Fidelity \& Casualty Co. of New York v. Smith, 279.

Fidelity \& Casualty Co. of New York v. Stacey's Ex'rs, 30.

Fidelity \& Casualty Co. of New York v. Teter, 55.

Fidelity \& Casualty Co. of New York v. Thompson, 268.

Fidelity \& Casualty Co. of New York v. Waterman, 162, 424.

Finley v. United States Casualty Co., 458.

Fischer v. Travelers' Ins. Co., 273, 275.

Fitton $\nabla$. Accidental Death Ins. Co., 197.

Fitzpatrick $\nabla$. North American Acc. Ins. Co., 436.

Flint v. Travelers' Ins. Co., 148.

Flower $\nabla$. Continental Casualty Co., 140.

Follette v. United States Mut. Acc. Ass'n, 19. 
[The flgures refer to pages]

Follis v. United States Mut. Acc. Ass'n, 152, 176, 256, 258.

Ford v. Aitna Life Ins. Co. of Hartford, Conn., 458, 467.

Ford v. United States Mut. Acc. Relief Co., 14, 44, 303, 340.

Foster v. Fidellty \& Casualty Co. of New York, 371, 373, 375, 406, 428.

Fowler v. Preferred Acc. Ins. Co., $5,6$.

Fox v. Masons' Fraternal Acc. Ass'n, 80, 343, 348, 431.

Frank Unnewehr Co. v. Standard Life \& Accident Ins. Co., 448.

Freeman v. Mercantile Mut. Acc. Ass'n, 95, 99, 127, 194.

Freeman v. 'Travelers' Ins. Co., $255,264,265$.

French v. Fidelity \& Casualty Co. of New York, 17, 24, 192.

Frink's Adm'r v. Brotherhood Acc. Co., 343.

Fritchie v. Miller's Pennsylvania Extract Co., 468.

Frye v. Bath Gas \& Electric Co., 457, 463, 467.

Fuller v. Locomotive Engineers' Mut. Life \& Accident Ins. Ass'n, 353.

Fuller Bros. Toll Lumber \& Box Co. v. Fidelity \& Casualty Co., 441.

Furbush v. Maryland Casualty Co., 35.

Furry's Adm'r v. General Accident Ins. Co., 145.

\section{G}

Gahagan v. Morrisey, 297, 352.

Gainor v. St. Lawrence Life Ass'n, 313.

Gale v. Mutual Aid \& Accident Ass'n, 126, 128.

Garcelon v. Commercial Travelers' Eastern Acc. Ass'n, 241, 258, 352.
Gardner v. United Surety Co., 33. Garvey v. Phœnix Preferred Acc. Ins. Co., 266.

General Accident Fire \& Life Assur. Co. v. Walker, 372, 437.

General Accident, Fire \& Life Assur. Corp. of Perth, Scotland, v. Homley, 204, 205, 206.

General Accident \& Life Assur. Corp. v. Meredith, 32, 70, 205.

Gentry v. Standard Life \& Accldent Ins. Co., 354.

Gibson v. American Mut. Life Ins. Co., 404.

Gilles v. United States Casualty Co., 373.

Gilmore v. Continental Casualty Co., 21.

Ging v. Travelers' Ins. Co., 274.

Glass ₹. Masons' Fraternal Acc. Ass'n of America of New York, 256.

Glens Falls Portland Cement Co. v. Travelers' Ins. Co., 484.

Globe Acc. Ins. Co. v. Gerisch, 85, $388,395$.

Globe Acc. Ins. Co. v. Helwig, 79, 322.

Globe Nav. Co. v. Maryland Casualty Co., 499.

Goetzman v. Connecticut Mut. Life Ins. Co., 135.

Goodson v. National Masonic Acc. Ass'n, 436.

Goodwillie $\nabla$. London Guarantee \& Accident Co., 449.

Gordon v. United States Casualty Co., 7, 306, 335.

Grand Lodge, Brotherhood of Locomotive Firemen, v. Orrell, 80, 296, 307, 421.

Grand Rapids Electric Light \& Power Co. v. Fidelity \& Casualty Co., 473, 477.

Grangers' Life Ins. Co. v. Brown, 286.

Grant v. North American Casualty Co., 392. 


\section{[The figures refer to pages]}

Gray v. Standard Life \& Accident Ins. Co., 446.

Gresham จ. Equitable Acc. Ins. Co., 132.

Griffin v. Western Mut. Benev. Ass'n, 134.

Grimes จ. Fidelity \& Casualty Co., 270, 328.

Guldenkirch $\nabla$. United States Mnt. Acc. Ass'n, 281, 282.

Guy v. United States Casualty Co., $379,384$.

\section{H}

Hagadorn $\nabla$. Masonic Equitable Acc. Ass'n of the World, 71, $420,421$.

Hall v. American Employers' Liabllity Ins. Co., 290, 291, 314.

Hall v. American Masonic Acc. Ass'n, 52, 82, 98, 194, 208, 346.

Hall $\nabla$. Western Travelers' Acc. Ass'n, 91.

Hamlyn v. Crown Accidental Ins. Co., 40.

Harper's Adm'r v. Phœnix Ins. Co., 133.

Hart v. National Masonic Acc. Ass'n, 356, 405.

Hastings $\nabla$. Bankers' Acc. Ins. Co., 324.

Hastings v. Travelers' Ins. Co., $31,189,362$.

Hatch v. Mutual Life Ins. Co., 128.

Hatch v. United States Casualty Co., 381.

Hause v. Standard Acc. Ins. Co., 9.

Hayes v. Continental Casualty Co., 327, 382.

Healey v. Mutual Acc. Ass'n of the Northwest, 41, 156.

Helntz v. Continental Casualty Co., 13.

Henderson v. 'Travelers' Ins. Co., 269.

Henderson Lighting \& Power Co. v. Maryland Casualty Co., 487, 489.

Hendrick v. Emplojers' Liability Assur. Corp., 59.

Herbert $v$. Standard Life \& ACcídent Ins. Co., 22.

Herbo-Phosa Co. v. Philadelphia Casualty Co., 460.

Herdic v. Maryland Casualty Co., $105,267$.

Hess จ. Preferred Masonic Mut. Ass'n of America, 46, 52, 101, 344, 345, 354.

Hess v. Van Auken, 46.

Hester v. Fidelity \& Casualty Co., $35,101,150,246,258,362$.

Hey v. Guarantors' Liability Indemnity Co., 30, 186.

Heywood v. Maine Mut. Acc. Ass'n, 371, 417.

Hill v. Hartford Acc. Ins. Co., 33, 42, 153.

Hill v. Travelers' Ins. Co., 76.

Hoffman v. Manufacturers' Acc. Indemnity Co., 5, 390, 394, 415.

Hoffman v. Michigan Home \& Hospital Ass'n, 312, 425.

Hoffman $\nabla$. Standard Life \& Accident Ins. Co., 52, 338, 345.

Hoffman v. Travelers' Ins. Co., 221.

Hohn v. Interstate Casualty Co., $301,413,417,421,425$.

Holiday $\nabla$. American Mut. Acc. Ass'n, 243, 258, 347.

Hollobaugh v. People's Ins. Ass'n, 308.

Home Mixture Guano Co. v. Ocean Accident \& Guarantee Corp., of London, Eng., 441.

Hooper v. Accidental Death Ins. Co., 303.

Hooper v. Standard Life \& Accldent Ins. Co., 83, 190, 199, 208.

Hope Spoke Co. v. Maryland Casualty Co., 475. 
[The figures refer to pages]

Horsfall v. Pacific Mut. Life Ins. Co., 32, 33, 40, 124, 373, 374, 380.

Houlihan v. Preferred Acc. Ins. Co. of New York, 361.

Hoven v. Employers' Liability Assur. Corp., 442, 455, 468.

Howe v. Provident Fund Soc., 321.

H. P. Hood \& Sons v. Maryland Casualty Co., 445.

Hubbard v. Mutual Acc. Ass'n, 99, 201.

Hudson River Tel. Co. v. Atna Life Ins. Co., 488.

Hughes v. Central Acc. Ins. Co., $373,422,425$.

Hull v. Equitable Acc. Ass'n, 214, 218.

Humphreys v. National Ben. Ass'n, 357.

Hunt v. United States Acc. Ass'n, $220,242$.

Hurt v. Employers' Liability Assur. Corp., 370, 410, 412, 416, 420.

Huston v. 'Travelers' Ins. Co., 210.

Hutchcraft's Ex'r v. Travelers' Ins. Co., 35, 36, 269, 275.

Hutchinson v. Supreme Tent of Knights of Maccabees of the World, 295, 354.

\section{I}

Illinois Commercial Men's Ass'n v. Tinsman, 264.

Industrial Mut. Indemnity Co. v. Hawkins, 294.

Industrial Mut. Indemnity Co. v. Watt, 119.

Interstate Casualty Co. v. Bird, $38,101,207$.

Irwin v. Phœnix Accident \& Sick Benefit Ass'n, 228.

Isitt v. Railway Passengers' Assur. Co., 194.

FULler ACc.INs.-33

\section{J}

James v. United States Casualty Co., 61, 299, 332.

Jamison v. Continental Casualty Co., 46, 48, 78, 93, 238, 240, 255, $258,363$.

Jarnagin v. 'Travelers' Protective Ass'n of America, 274.

Jarvis v. Northwestern Mut. Relief Ass'n, 77.

Jefferson Realty Co. v. Employers' Liabllity Assur. Corp., 470, 475.

Jenkin v. Pacific Mut. Llfe Ins. Co., 81, 119.

Jennings v. Brotherhood Accident Co., 306, 436.

Johanns v. National Acc. Soc., 140, 249.

Johnson v. Continental Casualty Co., 86, 206.

Johnson v. London Guarantee \& Accident Co., 52, 229.

Johnson v. New Amsterdam Casualty Co., 34, 184.

Johnson v. Standard Life \& Accident Ins. Co., 22.

Johnson v. Travelers' Ins. Co., 275.

Jones v. Commercial Travelers' Mut. Acc. Ass'n of America, 26, 436.

Jones v. Pennsylvania Casualty Co., 267.

Jones $v$. United States Mut. Acc. Ass'n of City of New York, 34, $135,150,231$.

\section{K}

Kasten v. Interstate Casualty Co. of New York, 158.

Keefer v. Pacific Mut. Life Ins. Co., 81, 84 .

Keeffe v. National Acc. Soc., 106, $228,245,430$. 
[The figures refer to pages]

Keene v. New England Mut. Acc. Konrad v. Union Casualty \& SureAss'n, 174, 221, 237, 252, 265, 328.

Keller v. Travelers' Ins. Co., 117, 329.

Kelley v. London Guarantee \& Accident Co., 443.

Kelly v. Maryland Casualty Co., 457, 493.

Kelsey v. Continental Casualty Co., 196.

Kennedy $\nabla$. Etna Life Ins. Co., 154.

Kennedy v. Fidelity \& Casualty Co., 457, 459.

Kenny v. Bankers' Accident Ins. Co. of Des Moines, 205, 346.

Kentucky Life \& Accident Ins. Co. v. Franklin, 55, 261, 265, $317,347$.

Kentzler v. American Mut. Acc. Ass'n, 378, 390, 478.

Kephart v. Continental Casualty Co., 220, 255.

Kimball v. Masons' Fraternal Acc. Ass'n, 372, 380.

King v. Travelers' Ins. Co., 57, $216,332$.

Kinney v. Baltimore \& 0 . Employés' Rellef Ass'n, 50, 177, 430.

Kirkpatrick $\nabla$. Atna Life Ins. Co., 58, 211, 280, 281, 332.

Kling v. Masons' Fraternal Acc. Ass'n, 81.

Klumb v. Iowa State Traveling Men's Ass'n, 86, 119.

Knapp v. Preferred Mut. Acc. Ass'n, 47, 303.

Knickerbocker Casualty Co. v. Jordan, 32, 39, 119, 182.

Knowlton v. Bay State Beneficiary. Ass'n, 4, 316, 323.

Knowlton v. Berkshire Health \& Accident Ass'n, 4.

Knowlton v. Equitable Acc. Ins. Ass'n, 316.

ty Co. of St. Louis, Mo., 32, 85, $86,373,378,388$.

\section{L}

Lampkin ₹. Travelers' Ins. Co., $280,405,424,425$.

Landis v. Standard Life \& Accident Ins. Co., 21, 23.

Landon v. Preferred Acc. Ins. Co., $81,86,182$.

Lane v. General Accident Ins. Co., 347.

Larkin v. Interstate Casuaity Co., 206.

Laventhal v. Fidelity \& Casualty Co. of New York, 70 .

Lawrence v. Accidental Ins. Co., 97.

Lawrence v. General Acc. Assur. Corp., 458, 488.

Lawrence v. United States Ins. Co., 184.

Legnard v. Standard Life \& Accident Ins. Co., 287, 389.

Lehman v. Great Eastern Casualty \& Indemnity Co. of New. York, 141, 173, 221, 253.

Lehman v. Great Western Acc. Ass'n, 31.

Letherer $\nabla$. United States Heaith \& Accident Ins. Co., 70.

Lewinthan v. 'Travelers' Ins. Co. of Hartford, Conn., 448, 458.

Lewis v. Brotherhood Acc. Co., 121.

Lewis v. Continental Casualty Co., 181.

Lieberman v. Columbia Nat. Life Ins. Co., 309.

Lilly v. Preferred Acc. Ins. Co., $66,67,332$.

Liston v. New York Casualty Co., 313.

Lobdiil v. Laboring Men's Mut. Aid Ass'n, 293, 303. 
[The figures refer to pages]

Ioesch v. Union Casualty \& Surety Co., 47, 86, 288, 342, 419.

Logan v. Fidelity \& Casualty Co., 1.

Iondon Guarantee \& Accident Co. v. Mississippi Cent. R. Co., 485.

London Guarantee \& Accident Co. v. Morris, 449.

London Guarantee \& Accident Co. v. Ogelsby, 442.

I ondon Guarantee \& Accident Co. v. Siwy, 470, 471, 477, 478, 479.

Long v. Traveler's' Ins. Co., 271.

Lord v. American Mut. Acc. Ass'n, $326,351$.

Lovelace v. Travelers' Protective Ass'n of America, 35.

Lovell v. Accident Ins. Co., 254.

Lowenstein v. Fidelity \& Casualty Co. of New York, 163.

Ludwig v. Preferred Acc. Ins. Co. of New York, 33, 202, 206.

Lyon v. Railway Passengers' Assur. Co., 79, 304, 368, 370, 373, 379.

\section{M}

McAuley v. Casualty Co. of America, $192,396$.

McCarthy v. Travelers' Ins. Co., 30, 32, 193, 207, 208.

McClure v. Great Western Acc. Ass'n, 170, 174, 412.

McCord v. Masonic Casualty Co., 368, 370, 419.

McCormack v. Illinois Commercial Men's Ass'n, 205.

McCullough v. Expressmen's Mut. Ben. Ass'n, 292.

McCullough $\nabla$. Railway Mail Ass'n, 43, 206.

McElfresh v. Odd Fellows Acc. Co., 362.

McFarland v. United States Mut. Acc. Ass'n, 373, 374, 392, 396, $401,413$.

McGlinchey v. Fidelity \& Casualty Co., 33, 39, 121, 187.
Mrglother $\nabla$. Provident Mut. Acc. Co., 33, 152.

McKinley v. Bankers' Ace. Ins. Co., 107, 306.

McNIahon v. Supreme Council, Order of Chosen Friends, 292, 295, $301,432,433$.

McMahon v. Travelers' Ins. Co., $22,23$.

McWilliams v. Home Ins. Co., 500.

Mady v. Switchmen's Union of North America, 86, 295, 353.

Mallory v. Travelers' Ins. Co., 32, $39,95,120,182$.

Mandell v. Fidelity \& Casualty Co., 476, 485, 489.

Manhattan Iife Ius. Co. v. Broughton, 113.

Manufacturers' Acc. Indemnity Co. v. Dorgan, 18, 32, 39, 96, 97, 147, 180, 205, 229.

Manufacturers' Acc. Indemnity Co. v. Fletcher, 373, 380, 384, 416.

Marceau v. Travelers' Ins. Co., 276.

Marshall v. Commercial Travelers' Mut. Acc. Ass'n, 75.

Martin v. Equitable Acc. Ass'n, $98,103,196,323,371,429$.

Martin $\nabla$. Manufacturers' Accident Indemnity Co., 98, 103, 196, 323, 422 .

Martin v. 'Traveler's' Ins. Co., 40. Marx v. Travelers' Ins. Co., 109, $213,214,251$.

Maryland Casualty Co. v. Burns, $206,385,395$.

Maryland Casualty Co. v. Chew, 297, 302, 349.

Maryland Casualty Co. v. Gehrmann, $19,318$.

Marylaud Casualty Co. v. Glass, 201.

Maryland Casualty Co. v. Hudglns, 157, 372, 380.

Maryland Casualty Co. v. Little Rock Ry. \& Electric Co., 502. 
Maryland Casualty Co. v. Omaha Electric Light \& Power Co., 469, 491, 496, 502.

Mason-Henry Press v. Etna Life Ins. Co., 448.

Masons' Fraternal Acc. Ass'n v. Riley, 281.

Mathers $\nabla$. Union Mut. Acc. Ass'n, 8.

Matson v. Travellers' Ins. Co., 279.

Matthes v. Imperial Acc. Ass'n, 137, 141, 224.

Maynard v. Locomotive Engineers' Mut. Life \& Accident Ins. Ass'n, 357, 363.

Maynard v. United States Health \& Accident Ins. Co., 436.

Meadows v. Pacific Mut. Life Ins. Co., 81, 101, 169, 172, 177, 253, 258, 260. 264, 265.

Mears Min. Co. v. Maryland Casualty Co., 492, 503.

Meech v. National Acc. Soc., 371, 419, 421, 428.

Meehan v. Traders' \& 'Travelers' Acc. Co., 153, 159.

Mellen v. United States Health \& Accident Ins. Co., 393, 422, 425.

Menneiley v. Employers' Liability Assur. Corp., 125, 164.

Mercier v. Travelers' Ins. Co., 365.

Merrill v. Travelers' Ins. Co., 69, 71.

Metropolitan Acc. Ass'n v. Bristol, 107.

Metropolitan Acc. Ass'n v. Clifton, 24.

Metropolitan Acc. Ass'n v. Froiland, 156, 424, 425 .

Metropolitan Acc. Ass'n v. Hilton, 342.

Metropolitan Acc. Ass'n v. Taylor, $86,175,220,255$.

Metropolitan Casualty Ins. Co. v. McAuley, 415.

Metropolitan Plate Glass \& Casualty Ins. Co. v. Hawes' Ex'x, 310.
Meyer v. Fidelity \& Casualty Co., $37,205$.

Miles v. Casualty Co. of America, 436.

Miller v. American Mut. Acc. Ins. Co., 4, 244.

Miller v. Fidelity \& Casualty Co., 34, 38, 157, 202.

Miller v. Interstate Casualty Co. of New York, 270.

Miller v. Maryland Casualty Co., $12,16,24$.

Miller v. Travelers' Ins. Co., 50, $209,219$.

Miner v. Travelers' Ins. Co., 98, 196.

Modern Woodmen Acc. Ass'n v. Kline, 9.

Miodern Woodmen Acc. Ass'n v. Shryock, 16, 19, 207.

Moge $\nabla$. Societe de Bienfaisance St. Jean Baptiste, 357.

Monahan v. Supreme Lodge of Order of Columbian Knights, $296,319,323$.

Moore v. Wildey Casualty Co., $417,421$.

Morel v. Mississippi Valley Iife Ins. Co., 221, 265.

Morris v. 'Travelers' Ins. Co., 130.

Morse v. Commercial Travelers' Eastern Acc. Ass'n, 259.

Morse v. Fraternal Acc. Ass'n, 339.

Mossop v. Continental Casualty Co., 144.

Mulville v. Pacific Mut. Life Ins. Co., 210, 264.

Munro v. Maryland Casualty Co., $491,500,502$.

Munson v. Standard Ins. Co., 488. Munz v. Standard Life \& Accident Ins. Co., 385, 390.

Murphey $\nabla$. American Mut. Acc. Ass'n, 14, 44.

Murray v. New York Life Ins. Co., 131. 
[The flgures refer to pages]

Mutual Acc. Ass'n of the Northwest v. Tuggle, 33, 41, 156.

Mutual Ben. Ass'n v. Nancarrow, $292,312,405$.

Mutual Life Ins. Co. จ. Terry, 114.

Myers v. Maryland Casualty Co., $374,419$.

Myler $\nabla$. Standard Life \& Accident Ins. Co., 219.

Myton v. Fidelity \& Casualty Co., 499.

\section{$\mathbf{N}$}

National Acc. Soc. v. Ralstin, 79.

National Acc. Soc. of City of New York v. Taylor, 45, 51, 344.

National Ass'n of Railway Postal Clerks v. Scott, 366.

National Ben. Ass'n ₹. Bowman, $136,149$.

National Ben. Ass'n v. Jackson, 240.

National Ben. Ass'n of Indianapolis v. Grauman, 98, 184, 368, 404.

National Life \& Accident Ins. Co. v. King, 311.

National Life \& Accident Ins. Co. v. Lokey, 140, 223, 246, 259.

National Masonic Acc. Ass'n v. Burr, 430.

National Masonic Acc. Ass'n v. McBride, 415.

National Masonic Acc. Ass'n v. Seed, 337, 412.

National Masonic Acc. Ass'n v. Shryock, 80, 84, 151, 198.

National Masonic Acc. Ass'n v. Terwilliger, 211.

National \& Providence Worsted Mills v. Frankfort Marine Accident \& Plate Glass Ins. Co., 499, 502.

Nax v. Travelers' Ins. Co., 32, $373,378,387,428$.

Neafie v. Manufacturers' Acc. Indemnity Co., 14, 45, 47, 300, 343.
Neill v. Order of United Friends, 305,354 .

Nesson v. United States Casualty Co., 457, 488.

New Amsterdam Casualty Co. v. Cumberland Telephone \& Telegraph Co., 496.

New Amsterdam Casualty Co. v. Shields, 205.

Newman v. Railway officials' \& Employés' Accident Ass'n, 362.

New Orleans \& C. R. Co. v. Maryland Casualty Co., 482.

New York Acc. Ins. Co. v. Clayton, $15,24,45$.

Niskern v. United Brotherhood of Carpenters and Joiners of America, 31.

North American Acc. Ass'n v. Woodson, 82, 208.

North American Acc. Ins. Co. v. Bowen, 21.

North American Acc. Ins. Co. V. Gulick, 78, 225, 237, 263.

North American Acc. Ins. Co. v. Rehacek, 12.

North American Acc. Ins. Co. v. Trenton, 24.

North American Life \& Accident Ins. Co. v. Burroughs, 30, 32, 33, $40,52,266,365$.

Northrup v. Railway Passengers' Assur. Co., 56, 58, 216.

Northwestern Benev. Soc. v. Dudley, 149, 276, 282.

Northwestern 'Tel. Exchange Co. v. Maryland Casualty Co., 472.

\section{O}

O'Connell จ. New York, N. H. \& H. R. Co., 458, 462.

Omberg v. United States Mut. Acc. Ass'n, 30, 33, 38, 83, 98, 158, 194, 209.

Order of United Commercial Travelers of America $\nabla$. McAdam, 152. 
[The figures refer to pages]

Orr v. Travelers' Ins. Co., 36, 273, $2 \pi 4$.

Osgood v. United States Health \& Accident Ins. Co., 167, 168, 175.

Overbeck v. Travelers' Ins. Co., $214,251$.

\section{$\mathbf{P}$}

Pacific Mut. Life Ins. Co. v. Adams, 259, 379, 388.

Pacific Mut. Life Ins. Co. v. Branham, 69, 307, 326, 416, 421.

Pacific Mut. Life Ins. Co. v. Snowden, 15, 45, 239, 241, 261.

Pacific Mut. Iife Ins. Co. V. Van Fleet, 12, 14, 346.

Pacific Mut. Life Ins. Co. of California $\nabla$. Howell, 176.

Palmer v. Commercial Travelers' Mut. Acc. Ass'n of America, 72 .

Patterson v. Ocean Accident \& Guarantee Corp., 82, 83, 208, $209,283$.

Patton v. Continental Casualty Co., 22.

Patton v. Employers' Liability Assur. Corp., 471, 475, 478.

Paul v. Travelers' Ins. Co., 30, $34,40,120,161$.

Payne v. Fraternal Acc. Ass'n of America, 10S, 111, 173, 253, 259, 264.

Peabody v. Fraternal Acc. Ass'n, 417, 421.

Peacock v. New York Life Ins. Co., 423.

Peck v. Equitable Acc. Ass'n, 206, 280.

Peele v. Provident Fund Soc., 32, 358.

Penfold v. Universal Life Ins. Co., 33, 114, 115, 153.

Penn v. Standard Life Ins. Co., 356.

Penn v. Standard Life \& Accident Ins. Co., 200, 356.

Pennington v. Pacific Mut. Life Ins. Co., 122, 304, 398.
People v. American Steam Boiler Ins. Co., 480, 495.

People's Acc. Ass'n v. Smith, 373, 376.

People's Ice Co. v. Employer's' Liability Assur. Corp., 441.

Pepper v. Order of United Commercial Travelers of America, 69, 71.

Perry v. Provident Life Ins. \& Inv. Co., 73, 74, 317.

Pervangher v. Union Casualty \& Surety Co., 364.

Peterson v. Modern Brotherhood of America, 355, 359.

Phelan v. Travelers' Ins. Co., 36, 274.

Phillipsburg Horse Car Co. v. Fidelity \& Casualty Co., 447.

Phillipy v. Homesteaders, 358.

Phœenix Accident \& Sick Ben. Ass'n v. Stiver, 34, 363, 415.

Pickett v. Fidelity \& Casualty Co.; $454,490$.

Pickett v. Pacific Mut. Life Ins. Co., 2, 34, 41, 120, 164.

Piercy v. Frankfort Marine, Accident \& Plate Glass Ins. Co., 471, $472,476$.

Piper v. Mercantile Mut. Acc. Ass'n, 175.

Pollock v. United States Mut. Acc. Ass'n, 33, 153, 272.

Popovitz v. United States Health \& Accident Ins. Co., 23.

Porter v. Casualty Co. of America, 86, 90.

Porter v. Preferred Acc. Ins. Co., 165, 301.

Potter r. Acc. Ins. Co. of Columbus, 301.

Powell v. Travelers' Protective Ass'n of America, 259.

Prader v. National Masonic Acc. Ass'n, 136, 147, 430.

Preferred Acc. Ins. Co. v. Barker, 402. 
[The figures refer to pages] .

Preferred Acc. Ins. Co. v. Fielding, 43, 78, s0, 81, 280, 373, 410.

Preferred Acc. Ins. Co. v. Gray, 80, 306.

Preferred Acc. Ins. Co. of New York v. Muir, 65, 179, 213, 251, 335.

Preferred Accident Ins. Co. of New York v. Robinson, 159.

Preferred Masonic Mut. Acc. Ass'n v. Jones, 71.

Preferred Masonic Mut. Life Ins. Co. v. Giddings, 3.

Preferred Mut. Acc. Ass'n v. Beidelman, 158.

Price v. National Acc. Soc., 47, 258, 348.

Price v. Standard Iife \& Accident Ins. Co., 227.

Pride v. Continental Casualty Co., 22.

Primrose v. Casualty Co., 67, 336.

Pritchett v. Continental Casualty Co., 22.

Providence Iife Ins. \& Inv. Co. of Chicago v. Martin, 45, 239, 262.

Provident Life Ins. Co. of Chicago v. Felunell, 45.

Provident Life Ins. \& Inv. Co. v. Baum, 375, 379.

Puget Sound Imp. Co. v. Frankfort Marine, Accident \& Plate Glass Ins. Co., 458, 500.

Putnam v. Phonix Preferred Acc. Ins. Co., 244.

Pyne v. Mutual Accident Co., 148.

\section{$\mathrm{R}$}

Railway Officials' Acc. Ass'n v. Armstrong, 363, 413, 423, 425.

Railway Officials' \& Employés' Acc. Ass'n v. Bradley, 341.

Railway Officials' \& Employés' Acc. Ass'n v. Coady, 205.

Rallway Officials' \& Employés' Acc. Ass'n v. Johnson, 186.
Railway Officials' \& Employes' Acc. Ass'n v. McCabe, 275.

Railway Officials' \& Employes' Acc. Ass'n of Indianapolis v. Drummond, 30, 101, 278.

Railway Ofticials' \& Employes' Ass'n v. Beddow, 363, 422, 428.

Railway Passengers' Assur. Co. of Hartford v. Burwell, 367, $373,375,394$.

Ramsey v. General Accident, Fire \& Life Ins. Co., 310, 411, 419.

Rayburn v. Pennsylvania Casualty Co., 300.

Rebman v. General Accident Ins. Co., 248.

Reed v. 'Tra velers' Ins. Co., 22, 23.

Reigler v. Sherlock, 491.

Reynolds v. Accident Ins. Co., 40, 152.

Reynolds v. Equitable Ace. Ass'n, $85,107,411,427,428$.

Rheinheimer v. Atna Iife Ins. Co., 192, 206, 266.

Rhodes v. Railway Passengers Ins. Co., 148, 297, 401.

Richards v. Travelers' Ins. Co., $30,36,47,65,239,279,363,405$.

Richardson v. Travelers' Ins. Co., 165.

Ripley v. Railway Passengers' Assur. Co., 30, 34, 61.

Ritter v. Preferred Masonic Mut. Acc. Ass'n, 72.

Roberts v. Atna Life Ins. Co., 23.

Robinson $\mathbf{v}$. United States Bener. Soc., 265.

Robinson $\nabla$. United States Mut. Acc. Ass'n, 34, 132.

Rochester Min. Co. v. Maryland Casualty Co., 481, 482.

Roger's v. Modern Brotherhood of America, 358.

Romayne v. Hawkeye Commercial Men's Ass'n, 101.

Rooney v. Maryland Casualty Co., $472,478,479$. 
[The figures refer to pages]

Root v. London Guarantee \& Accident Co., 121, 124, 286, 401.

Rorick v. Railway Officials' \& Employés' Acc. Ass'n, 74, 389, 391.

Rose v. Commercial Mut. Acc. Co., 106.

Roseberry $\nabla$. American Benev. Ass'n, 349, 379, 382.

Rosenberry v. Fidelity \& Casualty Co., 76, 290, 291, 314 .

Rosenbloom v. Maryland Casualty Co., 455, 481.

Ross v. American Employers' Liability Ins. Co., 448, 452, 485, 499.

Ross v. Modern Brotherhood of America, 355, 359.

Royle Mining Co. v. Fidelity \& Casualty Co. of New York, 439, 449.

Rudd v. Great Eastern Casualty \& Indemnity Co., 361.

Rumford Falls Paper Co. v. Fidelity \& Casualty Co., 491.

Rustin v. Standard Life \& Accident Ins. Co., 49, 92, 106.

\section{S}

St. Louis Dressed Beef \& Provision Co. v. Maryland Casualty Co., 488.

Sanders $\nabla$. Frankfort Marine, Accident \& Plate Glass Ins. Co., 464, 466, 467.

Sandoval Zinc Co. v. New Amsterdam Casualty Co., 503.

Saratoga Trap Rock Co. v. Standard Accident Ins. Co., 500.

Sargent v. Central Acc. Ins. Co., 243.

Sargent Mfg. Co. $\nabla$. 'Travelers' Ins. Co., 449.

Saveland $\mathbf{v}$. Fidelity \& Casualty Co., 298.

Sawtelle v. Railway Passengers' Assur. Co., 212, 221, 250.
Sawyer v. Equitable Acc. Ins. Co., 24.

Sawyer v. United States Casualty Co., 302.

Scales v. Masonic Protective Ass'n, 311.

Scarr, In re, 30, 32.

Scarritt Estate Co. v. Casualty Co. of America, 360, 444.

Scheiderer v. Travelers' Ins. Co., $252,272,398,405$.

Schmid v. Indiana 'Travelers' Acc. Ass'n, 190.

Schmidt v. American Mut. Acc. Ass'n, 338.

Schneider v. Provident Life Ins. Co., 221, 230, 231, 246, 263.

Schneps v. Fidelity \& Casualty Co. of New York, 314.

Schumacher v. Great Eastern Casualty \& Indenmity Co., 267.

Seattle \& S. F. R. \&.Nav. Co. v. Maryland Casualty Co., 458, 460.

Seeberger v. Wyman, 466.

Shader v. Railway Passengers' Assur. Co., 145, 146.

Shaffer v. Travelers' Ins. Co., 246.

Shanberg v. Fidelity \& Casualty Co., 27, 30, 189.

Sharpe v. Commercial Travelers' Mut. Acc. Ass'n, 187.

Shaw $\nabla$. Equitable Mut. Acc. Ass'n, 76, 291, 314.

Sheanon v. Pacific Mut. Life Ins. Co., 350.

Shelden v. National Masonic Acc. Ass'n, 428.

Shevlin v. American Mut. Acc. Ass'n, 230, 249.

Shirts v. Phœuix Accldent \& Sick Benefit Ass'n, 313.

Simmons $\nabla$. Western 'Travelers' Acc. Ass'n, 15, 16, 46.

Simons v. Iowa State Traveling Men's Ass'n, 399.

Simpkins v. Hawkeye Commercial Men's Ass'n, 33, 43, 160, 400. 
[The figures refer to pages]

Sinclair $\nabla$. Maritime Passengers' Assur. Co., 30, 185.

Sisson v. Supreme Court of IIonor, 351.

Small v. Travelers' Protective Ass'n, 248.

Smith v. Accident Ins. Co., 190.

Smith v. Atna Life Ins. Co., 33, S6, 111, 140, 211, 220, 232, 244, 250.

Smith v. Preferred Masonic Mut. Acc. Ass'n, 431.

Smith v. Preferred Mut. Acc. Ass'n, 237.

Smith v. Supreme Lodge of Order of Select Friends, 302, 354.

Smith \& Dove Mfg. Co. v. Travelers' Ins. Co., 472.

Smouse $\nabla$. Iowa State Traveling Men's Ass'n, 31.

Sneck v. Travelers' Ins. Co., 352.

Southard v. Railway Passengers' Assur. Co., 31, 8S.

Southern Ry. News Co. v. Fidelity \& Casualty Co. of New York, 489.

South Knoxville Brick Co. v. Empire State Surety Co., 488.

South Staffordshire Tramways Co. v. Sickness \& Accident Assur. Soc., 493.

Sroka v. Frankfort American Ins. Co., 450.

Spence v. Central Acc. Ins. Co., $10,13$.

Spicer v. Commercial Mut. Acc. Co., 300, 399.

Standard Accident \& Life Ins. Co. of Detroit, Mich., v. Wood, 13.

Standard Life \& Accident Ins. Co. v. Askew, 281.

Standard Life \& Accident Ins. Co. v. Carroll, 2, 337.

Standard Life \& Accident Ins. Co. v. Davis, 24, 416, 421.

Standard Life \& Accident Ins. Co. v. Fraser, 15, 51, 136.
Staudard IAfe \& Accídent Ins. Co. v. Jones, 111, 144, 240, 262. Standard Life \& Accident Ins. Co. v. Koen, 9, 50, 52, 342.

Standard Iife \& Accident Ins. Co. v. Jangston, 169, 25.3, 264 .

Standard Jife \& Accilent Ins. Co. v. I auderdale, 11, 12, 16.

Standard Isfe \& Accident Ins. Co. v. Martin, 18, 19, 340 .

Standard Jife \& Accident Ins. Co. v. Sale, $12,16,17,19$.

Standard Life \& Accident Ins. Co. v. Schmaltz, 33, 49, 92, 106, 414.

Standard Life \& Accident Ins. Co. v. Strong, 399, 401, 413, 415, 424. Standard Life \& Accident Ins. Co. v. Taylor, 342.

Standard Life \& Accident Ins. Co. v. Thomas, 207, 208, 424, 425.

Standard Life \& Accident Ins. Co. ₹. Thornton, 119, 213.

Standard Life \& Accident Ins. Co. v. Ward, 14, 44.

Standard Life \& Accident Ins. Co. of Detroit, Mich., v. McNulty, 58, 209, 211, 332 .

Standard Loan \& Accident Ins. Co. v. Thornton, 85, 425.

Stanton v. 'Travelers' Ins. Co., 199.

Star Acc. Co. v. Sibley, 55, 81, $119,346$.

Starling $\vee$. Supreme Council Royal Templars of Temperance, 90 , 305.

Starr v. Atna Life Ins. Co., 82, $84,170,177,208,209$.

Stenbom v. Brown-Corliss Engine Co., 458, 461.

Stephens v. Pennsylvania Casualty Co., 455, 500 .

Stephens r. Railway Officials' \& Employés' Acc. Ass'n, 270, 329.

Stevens v. Continental Casualty Co., 81, 280, 281, 282.

Stevers v. People's Mut. Acc. Ins. Ass'n, 351. 


\section{[The flgures refer to pages]}

Stone's Adm'rs v. United Statè Casualty Co., 15, 52, 265, 345.

Stout v. Pacific Mut. Xife Ins. Co., 86.

Stull v. United States Health \& Accident Ins. Co., 207.

Sudduth v. 'Travelers' Ins. Co., 284.

Sullivan v. Modern Brotherhood of America, 34, 43, 204, 356.

Summers v. Fidelity Mut. Aid Ass'n, 125, 196, 318, 364.

Sun Acc. Ass'n v. Olson, 124, 373, 404.

Supreme Council, Order of Chosen Friends v. Forsinger, 403, $432,433$.

Supreme Council, Order of Chosen Friends v. Garrigus, 35, 432, 433.

Supreme Court of Honor v. Turner, 351.

Supreme Lodge, Order of Select Friends v. Raymond, 431, 433.

Supreme Tent of Knights of Maccabees of the World v. Cox, 304.

Supreme Tent of Knights of Maccabees of the World v. King, 304.

Sutherland v. Standard Iife \& Acc. Ins. Co., 101, 150, 152, 264.

\section{$\mathbf{T}$}

Taliaferro v. Traveiers' Protective Ass'n, 35.

Taylor v. General Acc. Assur. Corp., 81, 86, 207.

Taylor v. Illinois Commercial Men's Ass'n, 14, 44.

Taylor v. Metropolitan Acc. Ass'n, 259.

Taylor v. Pacific Mut. Life Ins. Co., 81.

'Ten Broeck $\nabla$. 'Trarelers' Ins. Co., $82,208$.

'Tennant v. Travelers' Ins. Co., 183.
Terwilliger $\nabla$. National Masonic Acc. Ass'n, 211.

Thayer v. Standard Life \& Accident Ins. Co., 124, 299.

Theobald r. Railway Passengers' Assur. Co., 57.

Thomas v. Fidelity \& Casualty Co. of New York, 207.

Thomas v. Masons' Fraternal Acc. Ass'n, 53, 103, 223, 347.

Thompson v. Loyal Protective Ass'n, 46, 81, 122, 206, 337.

Thorne v. Casualty Co. of America, 337.

Thornton v. Travelers' Ins. Co., $99,101,197,369,371$.

Thurber v. Commercial Travelers' Mut. Acc. Ass'n, 103, 206.

Tinsman v. Iilinois Commercial Men's Ass'n, 264.

Tooley v. Railway Passengers' Assur. Co., 57, 61, 108, 260.

'Traders' \& Travelers' Acc. Co. v. Wagley, 172, 253, 259.

Traiser v. Commercial 'Travelers' Eastern Acc. Ass'n, 206.

'Travelers' Ins. Co. v. Austin, 62, 330.

'Travelers' Ins. Co. v. Ayers, 125, 163.

'Travelers' Ins. Co. v. Bingham, 206.

Travelers' Ius. Co. v. Bright, 440, 441.

'Tra velers' Ins. Co. v. Brookover, 211.

'Travelers' Ins. Co. v. Clark, 223.

Tra velers' Ins. Co. v. Dunlap, 41, 156.

'Travelers' Ins. Co. v. Harvey, 147, $151,190,425$.

'Travelers' Ins. Co. v. Heuderson, 269.

'Travelers' Ins. Co. v. Henderson Cotton Mills, 479, 499.

Travelers' Ins. Co. v. Houston, 276. 
[The figures refer to pages]

Travelers' Ins. Co. v. Hunter, 98, 194.

'Travelers' Ins. Co. v. Jones, 23, 237.

'Travelers' Ins. Co. v. Leibus, 13.

Travelers' Ins. Co. v. McCarthy, $273,275$.

'Travelers' Ins. Co. v. McConkey, $119,275$.

Travelers' Ins. Co. v. McInerney, 205.

Travelers' Ins. Co. v. Melick, 181, $207,407$.

Travelers' Ins. Co. v. Moses, 457, 464,466 .

Travelers' Ins. Co. v. Mosley, S2, 208.

Travelers' Ins. Co. v. Murray, 105, 196, 208.

Travelers' Ins. Co. v. Myers, 471, $472,478$.

'Travelers' Ins. Co. v. Nax, 373, 374.

Traveler's' Ins. Co. v. Randolph, 108, 109, 212, 220, 236, 250, 264.

Travelers' Ins. Co. v. Rosch, 39.

'Travelers' Ins. Co. v. Seaver, 139, 228.

'Travelers' Ins. Co. v. Selden, 30, 99, 184.

'Travelers' Ins. Co. v. Sheppard, 403.

Travelers' Ins. Co. v. Snowden, $24,210,219,239,259,354$.

'Traveler's' Ins. Co. v. Thornton, $79,326,369,371$.

Travelers' Ins. Co. v. Wild River Lumber Co., 447.

Travelers' Ins. Co. v. Wyness, 101, $279,280$.

'Travelers' Ins. Co. of Hartford v. Ebert, 322.

'Travelers' Preferred Acc. Ass'n v. Kelsey, 51, 344.

Travelers' Preferred Acc. Ass'n v. Stone, 212, 248, 272.

'Travelers' Protective Ass'n v. Gilbert, 160 .
Travelers' Protective Ass'n of Ameriea v. Langholz, 275.

Travelers' Protective Ass'n of America v. Small, 227, 247, 261.

'Travelers' Protective Ass'n of America v. Weil, 279.

Trew v. Railway Passengers' Assur. Co., 40, 182.

Trippe v. Provident Fund Soc., $388,390,417,421$.

Trone v. General Ace. Assur. Colp., 41, 122, 165.

Tucker v. Mutual Ben. Life Ius. Co., 39, 234.

Turner v. American Casualt5 Co., 25.

Turner v. Fidelity \& Casualty Co., 299.

Tuttle v. 'Travelers' Ins. Co., 175, $256,265$.

\section{U}

Underwood Veneer Co. v. London Guarantee \& Accident Co., 471, $473,477$.

Union Casualty \& Surety Co. v. Goddard, 55, 119, 244, 347.

Union Casualty \& Surety Co. v. Harroll, 35, 235.

Union Casualty \& Surety Co. v. Mondy, 82, 120, 124, 127, 208, $414,426$.

Union Cent. Life Ins. Co. v. Hollowell, 286.

Union Mut. Ace. Ass'n v. Frohard, 51, 55, 345.

United Benev. Soc. v. Freeman, $370,384,420$.

United States Casualty Co. v. Campbell, 10, 13.

United States Casualty Co. . Hanson, 101, 104, 126, 264, 301, 388.

United States IIealth \& Accident Ins. Co. v. Bennett's Adm'r, 12, 17.

United States Health \& Accident Ins. Co. v. Clark, 24, 422, 424. 
[The figures refer to pages]

United States Health \& Accident Washington v. Union Casualty \& Ins. Co. v. Harvey, 266.

United States Mut. Acc. Ass'n v. Barry, 29, 32.

United States Mut. Acc. Ass'n $\nabla$. Hubbell, 30, 32, 39, 238.

United States Mut. Acc. Ass'n v. Millard, 133, 302.

United States Mut. Acc. Ass'n v. Newman, 125, 160, 166.

United States Mut. Acc. Ass'n of City of New York v. Kittenring, 7.

Unthank v. Travelers' Ins. Co., 32, 427.

Utter v. Travelers' Ins. Co., 136, 277.

\section{$\mathrm{V}$}

Van Bokkelen v. Travelers' Ins. Co., 65, 334.

Van Eman v. Fidelity \& Casualty Co., 82, 208, 393, 398, 403.

Van Slooten v. Fidelity \& Casualty Co., 117, 329.

Vernon $\nabla$. Iowa State Traveling Men's Ass'n, 82, 101, 202, 207, 208, 267.

Vess v. United Benev. Soc., 71.

Victorian Stevedoring \& General Contracting Co. v. Australian Accident Ins. \& General Guarantee Co., 447, 471, 475, 477, 485.

Voluntary Relief Department of Pennsylvania Lines West of Pittsburg v. Spencer, 100, 257.

\section{W}

Wall v. Continental Casualty Co., 296.

Wallace $\nabla$. Employers' Liability Assur. Corp., 60, 333.

Ward จ. Atna Life Ins. Co., 199.

Ward's Adm'r v. Preferred Acc. Ins. Co., 49, 108, 337.

Washburn v. United States Casvalty Co., 24.

\section{Surety Co., 273.}

Wehle v. United States Mut. Acc. Ass'n, 40, 96, 126, 181, 285, 287, 366.

Weidner v. Standard Life \& Accident Ins. Co., $275,350$.

Weinschenk $\nabla$. Atna Life Ins. Co., 175.

Western Commercial Travelers' Ass'n v. Smith, 29, 32, 98, 195, 392.

Western Travelers' Acc. Ass'n v. Holbrook, 397, 415.

Western Travelers' Acc. Ass'n v. Tomson, 426.

Westmoreland v. Preferred Acc. Ins. Co., 41, 105, 166.

West Riverside Coal Co. $\nabla$. Maryland Casualty Co., 462.

Whalen v. Equitable Acc. Co., 420. Whalen v. Peerless Casualty Co., 141, 222.

Wheeler v. Fidelity \& Casualty Co. of New York, 333.

Wheeler v. United States Casualty Co., 9.

White v. Standard Life \& Acci= dent Ins. Co., 199.

Whitehouse v. 'Travelers' Ins. Co., 124.

Whiteside v. North American Acc. Ins. Co., 380, 384.

Whitfield ex rel. Hadley v. Etna Life Ins. Co., 117, 330.

Whitlach $\nabla$. Fidelity \& Casualty Co., 78.

Whitney $\mathbf{v}$. National Masonic Acc. Ass'n, 430.

Wilcox v. Central Accident Ins. Co. of Pittsburg, 171, 234, 256.

Wildey Casualty Co. v. Sheppard, $55,243,258,347,392,409,417$.

Wilkinson v. Atna Life Ins. Co., $80,81,360$.

Wilkinson v. Travelers' Ins. Co., $55,94,103$. 
[The figures refer to pages]

Willard v. Masonic Equitable /Woodmen Acc. Ass'n v. Pratt, 370, Acc. Ass'n, 257. $382,390$.

Williams v. Preferred Mut. Acc. Woolverton v. Fillelity \& Casualty Ass'n, 68, 70. Co. of New York, 476.

Williams v. United States Mut. Acc. Ass'n, 234, 252, 254.

Worcester \& S. St. R. Co. v. Travelers' Ins. Co., 450.

Wilson v. Northwestern Mut. Acc. Ass'n, 46, 48, 92, 240, 263.

Worthen v. Massachusetts Ben. Life Ass'n, 323.

Windle v. Empire State Surety Co., 70, 367, 370.

Winspear v. Accident Ins. Co., 40, 183.

Wright v. Fraternities Health \& Accident Ass'n, 13.

Wright v. Sun Mut. Iife Ins. Co., $119,173$.

Wolcott v. United Life \& Accident Ins. Co., 298.

Wollman v. Fidelity \& Casualty Co. of New York, 441.

Wood v. General Acc. Ins. Co. of Philadelphia, 63, 331.

Wood v. Massachusetts Mut. Acc. Ass'n, 325.

Woodall v. Pacific Mut. Life Ins. Co. of San Francisco, 400, 414, 425.

Wythe v. Manufacturers' Acc. Ins. Co., 485.

\section{$\mathbf{Y}$}

Yale v. Travelers' Ins. Co., 245.

Yancy v. Atna Life Ins. Co., 50, $89,93,177,340$.

York v. Railway Officials' \& Employés' Acc. Ass'n, 21, 23.

Woodmen Acc. Ass'n v. Hamilton, $316,326$.

Young v. Travelers' Ins. Co., 298, $402,408$. 



\section{INDEX}

[THE figures Refer to PAges]

\section{ACCIDENT,}

\section{A}

See External and Violent Means of Injury. Asphyxiation, 28, 34, 39, 40.

Bite of $\mathrm{dog}, 33$.

Blindness resulting from infection, 34 .

Blood poison caused by, 32 .

Blood poison from needle, 33.

Cold bath, shock from, 34 .

Defined, 27.

Disease distinguished from, 178 et seq.

Drowning, 32, 39.

Fall from horse, 32.

Fall from train, 33.

Fall in baseball game, 33.

Fall by stumbling, 32 .

Fright, death from, 33.

Gas, death from inhalation of, 28.

Intentional injuries, 34-37.

Kïck of horse, 28.

Lightning, death from, 28.

Lynching by mob, 33.

Presumption of, 81 .

Presumption of, as against suicide, 81, 118, 119.

Poison taken by mistake, 33.

Ruptured blood vessel, 32 .

Serum, injection of, causing death, 33.

Sting of insect, 33 .

Strain, 32.

Suicide, 42, 43.

Swallowing bard food, injuries from, 34.

Voluntary act, 30.

What constitutes, 27 et seq.

Fuller Acc.Ins. 
[The figures refer to pages]

ACCIDENTAL INJURIES, burden on insured to show, 80.

ACCIDENTAL MEANS, defined, 27 et seq.

Distinguished from accident, 27 et seq.

ACCIDENTS, right of recovery for two, 323, 324.

ACID, burns from, as injury "from contact with poisonous substance," 159.

ACT OF GOD, delay in paying premiums, 20.

ADULTERY as violation of law, 135.

AGE, false representations concerning, in application, 13.

Limitations in policies, 9 .

AGENTS,

Classification of insured determined by, 14, 15.

Mistakes of, how far binding on insurer, 25.

Nonpayment of premiums, waiver by, 21.

Notice and proofs of loss, waiver by, 410, 411.

Proofs of loss, transmission, 396.

Representations of, regarding duration of policy, 6 et seq.

Representations and warranties, power to waive, 24, 25.

AMPUTATION, specific conditions regulating, 353, 354.

Disability from, 354.

ANASTHETIC, death from, 40, 105, 161, 166, 201.

APOPLEXY, death from, 184.

Result of accident, 194.

APPLICATION,

Accuracy of statements contained therein, 10 et seq.

Age, false statement concerning, 13.

Beneficiary, false relationship asserted, 13.

Burden of proof to establish fraud or untruthfulness in replies, 12.

Compensation refused for prior disability, 13.

Concealment, 13-19.

Condition to contract, 10.

Determining commencement of risk, 6 .

Evasive answers, 14.

Facts not within knowledge of assured, 11, 12.

Fraudulent intent in answering interrogatories, 12.

Good faith in answering questions, 12.

Habits of assured, knowledge of agent concerning, 150 . 
[The flgures refer to pages]

\section{APPLICATION-Continued,}

Income, false reply concerning amount of, 13.

Matters of opinion, 11, 12.

Modifications in replies, 11 .

Occupation of assured, falsely represented, 13, 14

other insurance held by applicant, 16.

Part of contract of insurance, 10 .

Presumption of good faith and truthfulness in replies, 12.

Questions for jury, 12.

Questions material to risk, 10 et seq.

Rejection of prior application, 13.

Relationship of beneficiary to applicant falsely stated, 13.

Representations, 10 et seq.

Temperance and habits of applicant, 16.

Truthfulness of statements therein, 10.

Waiver of misrepresentions and false warranties, $2 t$ et seq.

ARM, broken, what constitutes, 358 .

ASPHYXIATION, as an accident, 28, 34 .

Accident by external and violent means, 39, 40.

ASSIGNIENT of causes of action in employers' liability insurance, 469.

AUTOPSY, right to perform on body of assured, 283-28s.

Exclusive right not given insurer, 288.

Notice of, to insurer, 287, 288.

Not included in right to "examine body," 283.

\section{B}

BATH producing heart dilation, 34 .

BED, confinement to, see Confinement to House and Bed.

BENEFICIARIES, 434, 435.

Death of before assured, 435 .

Designated beneficiary, 434, 435 .

Notice of death or injury given by, upon death of assured, 389.

Parties to contracts, 4.

Policy payable to estate of assured, 434.

Policy, right to dispose of by testament, 435 .

Relationship, warranty, 13.

Substitution of, 435 .

Wife subsequently divorced, 435.

FULLER Acc.Ins.-34 
BICYCLE RIDING not voluntary exposure to unnecessary danger, 245.

BITE OF DOG, 34.

BITE OF SNAKE, 38.

BLANK FORMS for proof of death or injury, reservation of rights by insurer in furnishing, 419.

Waiver by neglect or refusal of insurer to furnish, 414, 415 .

BLINDNESS, 356-358.

Accident from external and violent means, 43 .

Infection producing, 34 .

BLOOD POISON,

Abrasion from new shoes, 32.

Cutting corn resulting in, 32 .

Needie prick causing, 33.

Needle prick resulting in, as accident from external and vlolent means, 43.

Snake bite, 38 .

Sting of insect, 33, 38 .

As excepted risk, 265-268.

Accldent causing blood poison, insurer liable, 194, 266.

Operation for disease causing blood poison, insurer not liable, 266, 267.

Profession, blood poison suffered by doctors in course of, 267, 268.

BLOOD VESSEL, ruptured by wrenching of body, 32 .

\section{BODILY INFIRMITIES,}

Chronlc diseases, 17.

Knowledge of applicant concerning, 17.

Organic disorders, 17.

Temporary ailments not included, 17.

BODILY INJURIES, liability policy covering does not include death, 450.

BODY OF THE ASSURED, right to examine, 283-288.

Autopsy, notice of, to insurer, 287, 288.

Exhumation ordered to prevent fraud, 286, 287.

Exhume, dissect or perform autopsy, not included by phrase "examine body," 283 et seq.

Request for opportunity must be made within reasonable time, 284 et seq.

What included in, 283. 
[The figures refer to pages]

BRAKEMAN not a passenger under double indemnity clause, 330 .

BROKEN LEG, what constitutes, 355.

BULL FIGHTING as voluntary exposure to unnecessary danger, 244.

BURGLARS, murder by, as intentional injury, 278, 279.

BURNING BUILDING, increased liability of insurer for death or injury of insured within, 360 .

What constitutes, 360 .

BURNS by acid or metal, as accident by external and violent means, 43.

BUSINESS, visiting place of, not confinement to house, 313.

BY-LAWS, AMENDMENTS TO, affecting existing contracts, 90, 91. Contract of insurance affected by, 318, 319.

CANCELLATION OF POLICY,

\section{C}

Conditions enforcing, strictly construed, 26.

Fraud as an element in, 26.

Limitations governing, 26.

Nonpayment of premiums, 26.

Notice of, to insured, 26.

Option of insurer, 26.

Unearned premiums returned to insured, 26.

CARS, MOVING, entering or leaving, 57, 58, 209-220.

Negligence, not question of, 210.

Occupation, a risk of, $217,218$.

Railroad employés excepted from condition, 217, 218.

Stations, boarding and alighting from cars at, 210, 211.

CARS, PLATFORMI OF MOVING, standing on, 212-220.

Burden of proof, 219.

Corporation rules, violation of, 214, 215.

Locomotive, riding on, 215.

Necessary occupancy of, will not excuse insurer, 213 et seq.

Occupation, riding on platform a risk of, 217 .

Railroad employés excepted from condition, 217, 218.

Temporary occupancy of, 213.

What included by, 212 et seq.

CAUSA PROXIMA, NON REMOTA, SPECTATUR, 94 et seq.

Defined, 95.

Disease when considered, 97 et seq.

Efficient cause, 95 et seq. 


\section{CHANGE OF OCCUPATION,}

See Occupation.

CHLOROFORM administered to perform operation, 41.

CHOKING from food as accident, 38.

CIRCUMSTANTIAL EVIDENCE, when sufficient where policy requires direct proof, 102.

\section{CLASSIFICATION OF OCCUPATION, 43-55.}

Baggage checker, 50.

Change of, in absence of condition limiting, 43, 44 .

Change of, what constitutes, 43 et seq.

Excepted risk incident to occupation of insured, 48, 49.

Fixed by agent of insurer, 45.

General classification, 47.

Not a warranty of future occupation, 45 .

Policy not invalidated by slight discrepancy in, 44 .

Purpose of, 44.

Railway conductor, 49.

Railway employés, 49, 50.

Warranty covering, 43, 44.

\section{COMMENCEMENT OF RISK,}

Acceptance of application, 6.

Date of, 6 et seq.

Issuance and delivery of policy determining, 6 .

Parol evidence to explain omission or ambiguity, 8, 9.

Special endorsement determining, 6.

Waiver of policy provisions by agent of insurer, 7 .

COMPENSATION refused for prior disability, 13.

CONCEALMENT,

Age, faise statements regarding, in application, 13.

Application formeriy rejected, 13.

Bodily infirmities not temporary aflments, 17.

Evasive replies to questions in application, 14.

Good health not literaily construed, 17.

Habits, answers concerning, 16.

Income, amount of, 13.

Knowledge of applicant concerning his physical condition, 17.

Material facts in appilcation, 13.

Occupation of applicant, 13 et seq.

Previous disability, compensation for, 13.

Previous injury, what constitutes, 17, 18. 
[The flgures refer to pages]

CONCEALMENT-Continued,

Relationship of beneficiary, 13.

Temperance of applicant, replies regarding, 16 .

When policy avoided by, 18.

CONDUCTOR, RAILIVAY, when injured in line of occupation, 49.

CONFINEMENT TO HOUSE AND BED, 308-313.

Bed, confinement to, more strictly construed, 313 .

Business, visiting place of, may defeat recovery, 313.

City, visiting another, for treatment may not defeat recovery under polley, 312.

Doctor's office, visiting, will not necessarily defeat recovery, 311, 312.

Evidence of disability, 310 .

Health policies, condition in, more strictly construed, 309.

Porch, sitting on, will not defeat recovery, 310 .

Yard, ability to be about, will not defeat recovery, 310.

What constitutes, 310-313.

CONSTITUTION, amendments, 90, 91.

CONTINGENT LIABILITY, not recognized in employers' liability insurance, 450.

CONTRACT OF INSURANCE,

Application, 10.

Defined, 1, 2.

Duration of, 6 .

Favorably construed for insured, 86 .

Nature of, 1, 2.

Parol, 5.

Parties to, 4, 5.

Scope of, 3, 4.

Statutory limitations, 3, 4.

CORPORATIONS, violation of rules of, an excepted risk, 108-112.

Employés deemed familiar with rules of corporation, 111.

Enforcement of rules by corporation, 108 et seq.

Ignorance of insurer of rules, 108.

Platform of cars, riding on, 109, 110.

Pleading, 112.

Railroad tracks, crossing, 111.

COSTS OF SUIT, liabllity of insurer for in employers' liability insurance, $495-497$.

Interest on judgment obtained by employê, 497 . 
[The figures refer to pages]

cosTs OF sUIT-Continued,

Successful defense by insured, liabllity for costs of, 486 .

What included by, 495 et seq.

\section{D}

DAYS OF GRACE, payment of premiums, 20.

\section{DEATH,}

After ninety days does not affect weekly indemnity, 316, 317.

Distinguished from total disability, 289-291.

Immediate, defined, 68-76.

Liability for weekly indemnity and for death, $\mathbf{7 4}$.

Ninety days, death within, 72, 73 .

Policy lapsing within, after accident, 73 et seq.

Not a total disability, 314.

Notice of, see Notice of Loss.

Proofs of, see Proofs of Loss.

Time within which death must ensue after accident, 68-76.

DECLARATIONS, res gestæ, 81-84.

DEFENSE of suit by insured forbidden by policy of liability insurance, $481,482$.

Waiver of condition by insurer, 485 .

DELIRIUM FROM FEVER, 188.

Preventing compliance with condition requiring notice of injury, 381.

DENIAL OF LIABILITY as wairer of notice and proofs of death or injury, 424-427.

Reasons assigned for, 425 .

When made to serve as waiver of condition, 425, 426

DESERTION FROM ARMY as violation of law, 135, 136.

DISABILITY,

Death ensuing after ninety days, 74, 75 .

Death not disabllity, $75,76$.

Distinguished from death, 289-291.

Immediate, defined, 68-76.

Pleading, 79.

Question for jury, 80.

Time within which, must ensue, 68-76.

DISABILITY, TOTAL,

See Total Disability. 
[The figures refer to pages]

DISEASE, when contracted in course of employment, liability for in employers' liability Insurance, 445.

DISEASE OR BODILY INFIRMITY, accident distinguished from, 178-209.

Accident aggravated by, 98 .

Accident distinguished from disease, 178 et seq.

Accident not result of sickness, 191.

Anrsthetic, death from, 201.

Apoplexy, death from, 184.

Apoplexy result of accident, 194.

Blood poison result of accident, 194.

Burden of proof, 207.

Court, when question of law for, 206.

Delirium from fever, 188.

Disease aggravated by accident, 193, 198.

Disease aroused by accident, 192.

Disease not mere temporary disorder, 179.

Disease or accident, no presumption, 207.

Disease result of accident, 191 et seq.

Drowning an accident, 181-183.

Epilepsy cause of death, 182-184.

Epilepsy, death from, in water, 182, 183.

Erysipelas following accident, 190.

Erysipelas result of accident, 195.

Evidence, 207, 208.

Fright result of accident, 187.

Heart, rupture of, caused both by accident and disease, 200, 201.

Hernia, 196, 197.

Insanity or mental infirmity, 180.

Jury, questions for, 205.

Latent disease, 99.

Limited liability for death caused in part by disease, 204.

Pneumonia result of accident, 193.

Proximate cause of death, 97, 98.

Res gestæ, 227.

Rheumatism resulting from accident, 194.

Somnambulism, accident during attack of, 189.

Sunstroke not an accident, 185, 186.

Symptoms, evidence regarding, 208.

DOCTOR'S OFFICE, visiting, as continement to house, 311, 312.

DOG BITE, 34. 
[The figures refer to pages]

DOUBLE INDEMNITY CLAUSE, 327-336.

Baggage car, riding in, 67.

Boarding or alighting from moving car, excepted, 57, 58.

Entering or learing car, 331 et seq.

Express car, riding in, 67 .

Learing train at intermediate stations, 58-60.

Mail car, riding in, 67.

Passenger, what is, 330 et ser.

Public conveyance, what constitutes, 330 et seq.

Riding on platform of cars, 64,65 .

Steamboat, when riding on, 67 .

Taxicab, when riding in, 67.

Trarelers' policies, $5 \overline{5}$ et seq.

DROWNING as an accident, 32, 39.

Accident by external and riolent means, 39.

Disease, death from, distinguished from drowning, 181-183.

Excepted risk, 96, 97.

DUE DILIGENCE for one's safety, 260-264.

Burden of proving, 263.

Contributory negligence not synonymous with failure to exercise, $262,263$.

Emergency excusing risks, 261.

Jury, question for, 264.

Occupation involving danger, 261.

Ordinary care of prudent person, 260.

What constitutes, 2 ;0-264.

DURATION OF CONTRACT,

Acceptance of application, 6.

Delivery and acceptance of policy, 6 .

Expiration before death, 73 .

Fixed by special endorsement, 6.

Repugnant conditions concerning, 7.

$\mathbf{E}$

EARNING POWER of assured as test of disability, 295.

ELEVATORS, accidents in, 359.

What constitutes being in, 359 .

EMERGENGY, excusing failure to use due diigence, 261 .

Excusing voluntary exposure to danger, 233. 
[The figures refer to pages]

EMPLOYE, order on employer for premiums, 21.

Right of injured, to garnishee insurance company not given by liability policy, 461-468.

Statutory provisions permitting garnisbment, 468 .

EMPLOYE, RAILROAD, when a passenger, 62,63 .

\section{EMPLOYERS' LIABILITY INSURANCE,}

Assignment of causes of action forbidden by policy, 469 .

Buildings, unoccupied or uncompleted, $443,444$.

Contingent llability not recognized, 450.

Contract, validity of, $438,439$.

Costs of suit, liability of insurer for, 495-497.

Death, liability for, not included by liability for bodily injuries, 450.

Defined, 438, et seq.

Disease the result of employment, 445 .

Employe, right of, to garnishee insurance company, 461-168.

Explosives, warranty against use of, 443.

Fellow servants, 444.

Indemnity against loss sustained, 455-458.

Injuries in line of duty, $4+3$.

Insolvency of insured, 462-164.

Insured, obligation of, to co-operate with insurer, 502, 503.

Liability, insurance against, 451-455.

Liability of insurer, limit of, 491-493.

Liability under policy, when attaches, 451 et seq.

Limitations in contract, 440 et seq.

Notice of claim for damages against insured, 477, 478 .

Notice of injury of employé, 470-476.

Ordinary repairs, what are, $440,441$.

Payment of loss, what constitutes, 458-462.

Payroll under liability policies, 442.

Premiums, failure to pay, 498 et seq.

Refusal of insurance company to defend, 484-490.

Suit against insured, agreement of insurer to dęfend, 481-484.

Suit on policy, limitation of time for bringing, 479,480 .

Surgical relief, $493-495$.

Violation of law, persons employed in, as excepted risk, $47-450$.

Waiver of notice, $478,479$.

ENGINEER, not a passenger within double indemnity clause, 330 .

ENTERING CAR, included in "riding as a passenger," 331. 
EPILEPSY, death from, 182-184.

ERYSIPELAS, following accident, 190, 195.

ESTOPPEL, element of waiver, 24, 410.

EVIDENCE, rules of, 80-86, 364-366.

Burden of proof, accidental injuries, 80 .

Change of occupation, 349 .

Diligence, 263.

Disease or infirmity, 207.

False representations, 12.

Injuries on railroad bed or bridge, 177, 178.

Intentional injuries, 280.

Intoxication, 150.

Leaving moving train, 219.

Poison, 160, 161.

Suicide, 119.

Violation of law, 141.

Voluntary exposure to unnecessary danger, 258.

Waiver of notice of injury, 479.

Warranties and representations. 15.

Circumstantial evidence, 102.

Construction of contract, 86.

Direct and affirmative evidence, 85.

Intentional injuries, 271, 280-282.

Intoxication, 150-152.

Jury, question for, $85,86,365,366$.

Pleadings must conform to, 364 .

Presumptions, accident, 81 .

Cause of death, 81 .

Good faith and truthfulness of applicant, 12.

Intentional injuries, $279,280$.

Murder, 81.

Suicide, 81, 118, 119.

Proofs need not strictly conform to, 365 .

Proofs of loss as, $406-409$.

Res gestæ, 81-84, 227.

EXCEPTED RISKS, 87 et seq.

Accident aggravating disease, 98.

Accident distinguished from bodily infirmity or disease, 178-209.

Amendments to by-laws affecting existing contracts, 90, 91.

Blood poison or septicæmia, 265-268.

Body of assured, right to examine, 283-288. 
[The figures refer to pages]

EXCEPTED RISKS-Continued,

Causa proxima, non remota, spectatur, 94, 95.

Cause of death or injury, 94.

Construed in favor of insured, 89.

Corporation rules, violation of, 108-112.

Disease aggravating accident, 98.

Disease cause of death, 97-99.

Drowning proximate cause of death, 96, 97.

Due diligence for one's safety, failure to use, 260-264.

Entering moving cars, 209-220.

Exceptions, scope of, 88, 89.

External and visible signs of injury, 119-128.

Firearms, manufacture, sale, handling, etc., 103.

Incident to occupation of assured, 91-93.

Inconsistent with occupation of insured, 91-93.

Inhaling gas, 161-166.

Insane, injuries received while, 112.

Intentional injuries, 268-28\%.

Intoxication, 141-152.

Leaving moving cars, 209-220.

Locomotive, riding on, 107, 108.

Medical treatment for disease, death from 104, 105.

Occupation of insured, excepted risk incident to, 48-50.

Platform of moving cars, standing on, 212-220.

Pleading, 100-102.

Questions for jury, 80.

Railroad bed of bridge, injuries sustained on, 166-178.

Seas, death or injuries suffered by insured beyond, 282, 283.

Suicide, 112-119.

Surgical operation, death from, 104, 105.

Steeplechase riding, 111.

Taking poison, 152-161.

Violation of a law, 128-141.

Voluntary exposure to unnecessary danger, 220-260.

Voluntary overexertion, 105-107.

Wild or uninhabited regions, trip into, 104.

EXCEPTED RISKS IN EMPLOYERS' IIABILITY POLICIES, VIO-

lation of law, employés working in, 447-450.

EXHUMATION of body of insured not included in right to examine, 283.

Fraud, ordered to prevent, 286, 287. 
[The figures refer to pages]

EXPIRATION OF POLICY, liability for death, 73.

Liability for previous accident, $315,316$.

Liability for subsequent accident, released by, 316.

EXPLOSIVES, warranty against use of, in liability policies, 443.

EXTERNAL AND VIOLENT MEANS OF INJURY, condition regarding, 37 et seg.

Asphyxiation, 40, 41.

Blindness from infection, 43.

Biood poison from needie, 43.

Burns of acid or metal, 43.

Drowning, 39.

Examples of, 37 et seq.

Fall, 37.

Food lodged in internal organs, 38.

Fright, 39.

Insects, sting of, 38 .

Poison taken by mistake, 41.

Purpose of condition, 37.

Question for jury, 43.

Scaiding water, 43.

Snake bite, 38 .

Strain, 39.

Suicide, $42,43$.

EXTERNAL AND VISIBLE SIGNS OF INJURY, condition demanding,

Burden of proof on insured, 127, 128.

Dead body as externai and visible sign, 120, 121.

Hernia, 124.

Lack of, on body of insured, 119, 120.

Limited iiability in absence of, 127.

Need not be immediately visibie, 121 .

Need not be permanent, 122 .

Nosebleed, 124.

Outward indications of internal injuries, 126, 127.

Pallor, 123, 124.

Refers only to nonfatal injuries, 120.

What constitutes such signs of injury, 123, 124.

EYE, LOSS OF,

Accident from external and violent means, 43.

Infection causing, 34.

Total disability caused by, 356 .

What constitutes, $356,357$. 
[The figures refer to pages]

EYESIGH'T, LOSS OF, 356, 357.

EYEWITNESS, assured himself may be, 78,79 .

FALL, 32, 33, 37.

FIGIITING, injury result of, 131.

Occasioned in line of duty, 133, 134.

Self-defense, 132, 134.

Violation of law, 131.

Voluntary exposure to unnecessary danger, 245, 246.

FINANCIAL CONDITION of insured as inducement to intentional injuries, 271.

FIREARMS, handling of, an excepted risk, 103.

FISHING, as change of occupation, $54,55,344,345$.

FLAGMAN not a passenger under double indemnity clause, 330.

FOREIGN COUNTRIES, injuries received in, 282, 283.

FORFEITURE OF POLICY,

Act of God or law prevents, when causing delay in premium payments, 20.

Days of grace for payment of premiums, 20.

Nonpayment of premiums, 19-21.

Waiver of, by insurer or his ageut, 21 .

FRAUD,

Application tainted with, 10-12.

Cancellation of policy because of, 26.

Policies avoided by, 10-12.

FRIGH'T, result of accident, 33, 39, 187.

\section{G}

GARNISHMENT PROCEEDINGS, right of injured employe to bring against liability insurance company, 464-468.

Statutory provisions permitting, 468.

GAS, INHALING, as an accident, $28,34,40$.

As excepted risk, 161-164.

Anæsthetic, death from, 166.

Construction of clause, 161 et seq.

"Gas in any form or manner" construed, 164, 165.

Voluntary and intelligent act, 161 et seq. 
[The figures refer to pages]

GOOD FAITH, warranties, 12.

GROUNDLESS SUITS against insured in liability insurance, 486, 489.

\section{$\mathrm{H}$}

HABITS, false warranties or representations concerning, 16.

HAND, LOSS OF, disability of insured from, 354 .

What constitutes, 351 et seq.

HEALTH, representations or warranties concerning, 16, 17.

Warranties not literally construed, $\mathbf{1 7}$.

HEART, rupture of, 28, 29.

HERNIA,

External and visible sign of injury, 124, 125.

Result of accident, 196, 197.

HORSE,

Fright by being thrown from, 32 .

Kick of, as an accident, 28.

HORSE RACING as violation of law, 139.

Not voluntary exposure to unnecessary danger, 244.

HOUSE, CONFINEMENT TO,

See Confinement to House and Bed.

HUNTING,

Occupation, change of, not deemed, 54, 55, 344, 345 .

Violation of law, 136.

Voluntary exposure to unnecessary danger, when, 243, 244.

\section{I}

IGNORANCE of cause of death preventing compliance with condition requiring notice of death, $386-389$.

of existence of policy preventing compliance with condition requiring notice of injury or death, 385 .

IMMEDIATELY,

Death or disability immediately following accident, 68-76.

Defined, 68-76.

IMMEDIATE NOTICE of death or injury, 372-380.

Beneficiary, failure of, to give notice, 380 .

Cause of death determined by autopsy, 376, 377.

Disability of assured preventing required notice, 379 . 
[The figures refer to pages]

IMMEDIATE NOTICE-Continued,

Disappearance of insured, 377.

Due diligence must be shown, 379 .

Four months' delay may prevent recovery, 374.

"Immediate" synonymous with "as soon as possible," 375.

Jury, when question for, 372, 374.

Policy, existence of, unknown, 378.

Purpose of, 373, 374.

Reasonably construed, 372 .

Serious nature of accident not at once apparent, $\mathbf{3 7 5}$.

Ten days, notice within, may constitute compliance, 374.

What constitutes, 372 se seq.

IMPOSSIBILITY of giving notice within specified time, 380-390.

Ability of insured to direct another to give notice, 382-384.

Beneficiary, notice by, upon death of assured, 389 .

Delirium of assured, 381.

Disability of assured through injury, 381.

Ignorance of cause of death, 386-389.

Ignorance of existence of policy, 385 .

Removal of disability, time within which notice may be given after, 390.

INCOME, false representation in application concerning, 13.

INDEMNITY, POLICY OF, against loss sustained by insured, 455458.

Liability of insurer attaches only with payment of judgment by insured, 456 et seq.

Payment of judgment condition precedent to liability of insurer, 457, 458.

INFORMATION, further, waiver of requirements of policy for notice and proofs of loss by request for, 416-420.

Reservation of rights by insurer when demanding, 419.

INJURY, NOTICE OF,

See Notice of Loss.

INJURY, PROOFS OF,

See Proofs of Loss.

INSANITY,

Injuries resulting from, 180.

Injuries received during, an excepted risk, 112.

Intentional injuries affected by, 275, 276.

INSECT, sting of, 33, 38, 158. 
INSOLVENCY of insured in employers' liability insurance, 462-464.

Amount of liability of insurer determined by relation of assets of insured to all the debts, 463.

Liability of insurer, when released by, 462, et seq.

INTENTIONAL INJURIES,

Accident, when held to be, 34-36.

Condition exempting, 35-37, 268-282.

Insanity determining intent, $36,37$.

Pleading, 77, 78.

As an excepted risk, 268-282.

Burden of proof, 280.

Evidence pertaining thereto, 271, 281, 282.

Financial condition of assured as inducement to causing, 271.

Injuries intentionally inflicted by third persons, insurer not

liable for, 273 et seq.

Injury must result from act and be intended, to excuse insurer from liability, 277.

Insanity of person inflicting injuries, $275,276$.

Intentional injury as an accident, 34-36, 268 et seq.

Intoxication of person inflicting injuries, 276 .

Jury, question for, 281, 282.

Liability limited in case of, 275 .

Liability of insurer for, in absence of condition, 34 et seq., 273.

Murder, 274.

Occupation, risks of, will not make insurer liable when policy excepts, 270.

Presumption as to, 279, 280.

Robbers, murder by, 278, 279.

Threats, evidence of, 281.

Voluntary approach to danger not synonymous with, 272 .

INTEREST on judgment of employé, liability of insurance company for, 497.

INTOXICATION, governing intention of person inflicting injuries upon insured, 276.

Violation of law, 131, 136, 149.

As an excepted risk, 141-152.

Burden of proof, 150.

Death from medical treatment for alcoholism, 148.

Evidence as to intoxication, 151, 152.

Fraudulent concealment of, 148. 
[The figures refer to pages]

INTOXICATION-Continued,

Habits of insured, knowledge of agent, 150.

Injuries, result of, 146, 147.

Intentional injuries affected by, 149,276 .

Pleading, 150, 151.

Violation of law, 131, 136, 149.

What constitutes, 142.

"While under the influence of intoxicants" distinguished from, $143,147$.

IVY, poison from, 159.

\section{$\mathrm{J}$}

JUDGMENT, conclusiveness of, against insurer in liablity insurance, $483,484$.

KNOWLEDGE,

\section{K}

Bodily infirmities, 17.

Cause of death, as affecting notice, 386-389.

Existence of policy, 385 .

Waiver as affected by, 24, 25, 419.

Warranties, 11, 12.

\section{L}

LABOR, ability to perform, affecting total disability, 293 et seq.

LEAVING CAR, included in "riding as a passenger," 331, 332.

Moving cars, 57, 58, 209-2\%0.

LEG, BROKEN, what constitutes, 358.

LIABILITY,

Amount of, contingent upon character and result of injury sustained, 315, 316.

Amount of, determined by occupation of insured, 336-349.

Arbitration of, 430-433.

Arbitration, when enforceable, 431.

By-laws of insurer affecting, 318, 319.

Fixed at time of accident, 315, 316.

Invalid, clause compelling arbitration, 430, 431.

LIABILITY OF ASSURED, in employers' liability insurance,

Cause of action when complete, 452 et seq.

Contingent upon happening of accident to employe, 451.

Fuller Acc.Ins.-35 
LIABILITY OF ASSURED-Continued,

Fixed upon judgment by highest court against insured, 451 et seq.

Insurance against liability, 451-455.

LIABILITY OF INSURER in employers' liability insurance,

Limit of, $491-493$.

Single accident, limited in amount for, 493.

LIGH'TNING, death from, as an accident, 28.

LIMBS, LOSS OF, 350 et seq.

Disability of insured from, 354 .

Use of limbs artificially restored, 351.

What constitutes, 350 et seq.

\section{LOCOMOTIVE,}

Not a conveyance provided for passengers, 215.

Riding on an excepted risk, 107, 108.

What constitutes, 107, 108.

LYNCHING by mob as an accident, 33 .

MAIL,

\section{$\mathbf{M}$}

Notice of premiums, 20.

Payment of premiums, 20.

Proofs of loss delivered by, 396.

Sending of notice and proofs of loss by, 396 .

MAIL CLERK, not a passenger, 63, 64, 330.

MANUAL LABOR, ability to perform, affecting total disability, 299, 300.

MEDICAL TREATMENT, as an excepted risk, 104, 105, 153, 154.

MEDICINE, overdose of, taken by accident, 153, 154.

MENTAL DISABILITY, included in Total Disability, 292.

- MISREPRESENTATIONS in application for policy,

See Representations; Warranties.

Agent, insured not bound by misrepresentations of, 24 .

Waiver by insurer, 24.

MOVING CARS, entering or leaving, 57, 58, 209-220, 331, 332.

MURDER, as an intentional injury, 274, 278, 279.

Presumption against, 81 . 


\section{$\mathbf{N}$}

NINETY DAYS, death within, 72, 73.

Policy lapsed before expiration of, after accident, 72-76.

NONPAYMENT OF PREMIUMS,

Act of God or the law preventing, 20.

Cancellation of policy by, 26.

Days of grace for payment, 20 .

Notice of maturity of premiums when required, 20 .

Notice not required for forfeiture, 19, 20.

Waiver of, by agent, 21.

When policy forfeited because of, 19-21.

NOTICE OF CLAIM FOR DAMAGES against assured required by policies of employers' liability insurance, 477, 478 .

Written notice of claim required, 477 .

NOTICE OF INJURY in employers' liability insurance, 470-476.

Condition precedent to right of recovery against insurer, 470 .

Diligence, assured bound to exercise, to give notice, 475,476 .

Immediate notice, what constitutes, 471.

Knowledge of assured of accident, 475 .

Purpose of, 470.

Waiver of notice, 478, 479.

NOTICE OF LOSS in accident insurance, 367 et seq.

Administrator, notice by, 395 .

Condition precedent to right of action, 368 et seq.

Condition requiring, liberally construed, 369, 370.

False statements in, 401, 402.

Immediate notice, $372-380$.

Local agent may transmit, 394.

Method of computing time, 391, 392.

Mistakes in, through ignorance, 401.

Pleading of, 404, 405 .

Purpose of, 368.

Second injury, notice of, 399 .

Service of, what constitutes proper, 395-398.

Statutory regullations governing, 371,372 .

Sufficiency of, 398-402.

Third party may furnish, 393 .

Third party, notice by, at risk of insured, 394 .

Waiver of, 409 et seq.

When required to be furnished, $370-372$. 
[The figures refer to pages]

NoTICE OF LOSS-Continued,

Where to be delivered, 397 .

Who may furnish, 392-395.

Written, when required, 395 .

OCCUPATION,

See Classification of Occupation.

Ability to follow another. affecting total disability, 304, 305.

Ability to perform any duties of, affecting permanent or continuing disability, 306.

Act incident to another occupation does not change, 51 et seq. Amount of liability determined by, 336-349.

Burden of proof in change of, 349 .

Change of, manner of determining, 341 .

Change of, must be completed and not merely contemplated, 54 .

Change of, no limitation upon, in absence of condition in policy, $43,44$.

Change of, question for jurs, 340 .

Classification of, determined by agent, 45.

Determined by agent of insurer, 14 .

Disability determined by, 294, 303, 304 .

Entering and learing moving cars, part of risks of, 217, 218.

Evidence, admission of, relating to, 349 .

Excepted risk incident to, 91-93.

Excepted risk inconsistent with, $\mathbf{5 9}$.

Excepted risk increasing hazard of, 340.

Exposure by, to intentional injuries, 270.

False answer concerning, in application, 13, 14.

False warranty concerning, 44.

Fishing for recreation, not change of, 54, 55 .

Fishing, when change of, 54, 55.

Hunting for recreation, not change of, 54, 55 .

Hunting, when change of, $\overline{54}, \overline{5} 5$.

Insurer bound by its own classitication, 335, 339 .

Insurer liable when excepted risk incident to occupation of insured, $48,49$.

Jury, question for, 348, 349 .

No warranty as to change of in application, 45.

"Occupation" defined, 343, 344.

Ordinars acts of life not included in, 345, 346. 
[The figures refer to pages]

OCCLPATION-Continued,

Policy not inralidated by slight discrepancy concerning in application, 44.

Premiums determined by, 336.

Purpose of classification, 44.

Railway conductor, duties of, affecting risks, 49.

Railway employés, duties of, affecting risks, 49, 50 .

Recreation, acts of, not change of, 54, 5.5.

Regular business and not occasional acts referred to, 15.

Retired, 47 .

Risks of, 43-45, 337 .

Sports, not a change of, 344, 345 .

Temporars change of, when insurer not liable, 52.

Warranty covering. 43, 44.

OPERATION, death as the result of. 105 .

Right of recorery for second, 324.

ORDINARY REPAIRS, what constitute, under employers' liability policy, 40,41 .

\section{P}

PAIN, as evidence of total disabillty, 301.

PALENESS, as external and visible sign of injury. 123, 124.

PAROL CONTRACTS. 5.

PAROL EVIDENCE admitted to explain but not alter prorision of policy concerning commencement of risk, 8,9 .

PARTIES to contract of insurance,

Beneficiary, 4, 5.

Policy holder, 4, 5.

PASSENGERS,

Alighting from or boarding moring car, $\tilde{5} \boldsymbol{\tau}, 58$.

Baggage car, riding in, $6 \pi$.

Defined, 61-63.

Double indemnity clause, $32 \pi-336$.

Employes of a railroad generally not, 61, 62 .

Entering or learing car, 56, 331 et seq.

Express car, riding in, 67 .

Learing car, terminating character as, 332, 333.

Learing train at intermediate station, 5s-60.

Mail car, riding in, 67.

Mail clerk on duț not, 63,64 . 
PASSENGERS-Continued,

Pleading, 67.

"Riding as a passenger" what included by, 331 et seq.

Steamboat, riding on, 67 .

Taxicab, riding in, 67.

Termination of journey, 55, 56, 60 .

Transfer from train to train or boat, 56, 58 .

What constitutes, 330 et seq.

When relationship terminated, 61.

PASSENGER CONVEYANCE, 64.

See Public Conveyance.

Baggage car not, 67.

Express car not, 67.

Mail car not, 67.

Platform of railway car, 64.

Steamboat, 67.

Taxicab, 67.

PAYMENT,

See Premiums.

PAYMENT OF LOSS in employers' liability insurance, 458 et seq.

Cash payment not essential, 459.

Defined, 458 et seq.

Good faith required. 459.

Promissory notes as, 459.

What constitutes, 458-462.

Wrong party, payment to, 482.

PAYMENT OF POLICY in accident insurance, 435, 436.

Fraud in payment, 436.

Interest, when attaches to amount of policy, 438.

Mistake, payment by, 436.

Time within which payment should be made, 435.

Wrong party, payment to, 436.

PAY ROLL of insured under liability policies, 442.

PERMANENT OR CONTINUING DISABILITY, 306-308.

Death, clause does not cover, 307.

Jury, question for, 308.

Occupation, ability to perform any part of duties of, 306 .

Relapse, insurer not liable for, 307.

What constitutes, 306-308. 
[The figures refer to pages]

PHYSICAL CONDITION OF INSURED,

Knowledge of applicant regarding, 17.

Warranties or representations concerning, 17.

PHYSICIAN, liability of insurer when insured under care of, 327.

PHYSICIAN OR SURGEON, treatment by, determining amount of liabllity of insurer, 319.

PLATFORM OF CARS, riding on, 64, 65.

Excepted risk, 109, 110.

Vestibuled train, $65,66$.

Violation of law, 140.

Violation of rules of corporation, 109, 110.

PLEADING, 76-80, 362-366.

Allegations of complaint, 76,362 .

Allegations, sufficiency of, 76, 362-364.

Cause of injury, 67, 76.

Disability, 79.

Excepted risks, allegations concerning, 100-102.

Eyewituess, 78, 79.

Intentional injuries, 77,78 .

Intoxication, 150, 151.

Notice of loss, 404,405 .

Proofs of loss, 404, 405 .

Occupation when injured more hazardous than that under which insured was classified, 77.

Self-inflicted injuries, $77,78$.

Suicide, 77.

Value of time of insured, 79.

Voluntary exposure, 78, 257, 258.

Waiver of notice of proofs of injury or death, 428, 429.

Wrong cause of death or injury alleged in, 77.

PNEUMONIA resulting from accident, 193.

POISON, taken by mistake, 33.

Death by external and violent means, 40.

Taking, an excepted risk, 152-161.

Acid, burns from, 159.

Blood poisoning developing in wound, 159.

Burden of proof, 160,161 .

Illinols rule governing poison, 154-157.

Ivy, poison from, 159.

Missouri rule governing poison, 154-157. 
POISON-Continued,

Overdose of medicine, 153, 154.

Poison taken by mistake, 153 et seq.

Sting of insect or bite of reptile, 158 .

What included by, 152.

PORCH, sitting on, as confinement to house, 310 .

POST MORTEM, right to perform on body of assured, 283-288.

Not included in rlght to "examine" body, 283.

\section{PREMIUMS,}

Days of grace for payment of, when given, 20 .

Extension of time for payment of, 20.

Forfeiture of policy by nonpaynent, 19-21.

Maturity, notice of, how given, 20.

Maturity, requirement of notice, 19, 20.

Nonpayment of, 19-21.

Notice and proofs of death or injury not waived by acceptance of further, 421.

Notice of maturity not required, 19, 20.

Notice of, when required to forfeit policy for nonpayment of premium note, 19, 20.

Orders for payment of premiums in term policies to be presented by insurer, 21, 22.

Payable by installments, 9.

Payable in mamner prescribed by policy, 20 .

Payment, by third person, 4.

Payment of, in term policies, 21, 22.

Payment of, in ter'm policies, how defaulted, 21, 22.

Payment of, in term policies, at risk of insured, 21, 22.

Payment of, in term policles, what constitutes, 22.

Policy when forfeited by failure to pay, 19-21.

Return on cancellation, 26.

Waiver of forfeiture for nonpayment, 21.

When delay in payment excusable, 20.

Where payable, 20.

PREMIUMS ON LIABILITY POLICIES, failure to pay, 498 et seq. Payment of, by mistake, 501, 502.

PREVIOUS INJURY OR DISABILITY, warranties or misrepresentations regarding, $17,18$.

Answer liberally construed, 17, 18.

What constitutes such injury or disability, 17, 18.

PRIVATE CONVEYANCE, walking is not traveling by, 61 . 
[The figures refer to pages]

PROOFS OF LOSS, 367 et seq.

Administrator, furnished by, 395 .

Admissible in evidence merely to show compliance with condition requiring, 406.

Amount of proof required, 402-404.

Attending physician, affidavit of, required, 404.

Condition liberally construed, 369, 370.

Condition precedent to right of action, 368 et seq.

Continued disability, 399, 400.

Evidence, proofs of loss as, 406-409.

Evidence, statements in proofs of loss against interest, 407.

Evidence, statements in proofs of loss not conclusive against beneficiary, 407-409.

Local agent may transmit, 394.

Mail, delivery by, 396.

Method of computing time, 391, 392 .

Pleading, 404, 405.

Purpose of, 368.

Reasonable proof sufficient to satisfy requirement, 402, 403 .

Service of, what is proper, 395-398.

Statutory regulations governing time for furnishing, 371, 372.

Sufficient proof, what constitutes, 398-402.

Third party may transmit, 393-395.

Third party, proofs furnished by, at risk of insured, 394.

Waiver, 409 et seq.

When not required, 367 .

When required under policy, 370-372.

Where to be delivered, 397.

Who may furnish, 392-395.

Writing, when required to be in, 395 .

PROXIMATE CAUSE, 69, 70.

PUBLIC CONVEYANCE,

Chartered train or boat, 67 .

Double indemnity for injurles while riding in, 327-336.

Platform of car, riding on, 64, 333 et seq.

Steamboat when a public conveyance, 67,335 .

Taxicab as a public conveyance, 67, 335, 336.

Vestibuled trains, platform of, 65,66 .

Walking is not traveling by private or public conveyance, 61 .

What may constitute, 60, 61, 64, 330 .

PUBLIC HIGHWAY, what constitutes, 361.

Railroad station platform may constitute, 361 . 
QUESTIONS FOR JURY,

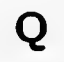

Change of occupation, 340.

Diligence, 264.

Disease or infirmity, 205, 206.

Disability, 80.

Excepted risks, 80, 85.

External and violent means of injury, 43.

Immedlate notice of injury, $372,374$.

Intentional injuries, 281, 282.

Occupation, 348, 349.

Permanent or continuing disability, 308.

Total disability, 305 .

Voluntary exposure to unnecessary danger, 259.

Waiver of notice and proofs of death or injury, 428, 429, 479.

Warranties and representations, 12.

\section{$\mathbf{R}$}

RAILROAD BED OR BRIDGE, injuries sustained on, as excepted risk, $166-178$.

Accidentally upon track, insurer liable, 170.

Burden of proof, 177, 178.

Employes of railroad excepted from condition, 176, 177.

Highway, crossing tracks at, 171, 172.

Injury must result from act to excuse insurer, 167.

Lawfully on track, 171.

Purpose of condition, 167.

Right of way by user over rallroad tracks, 173 et seq.

Roadbed defined, 168, 169.

Station, crossing tracks at, 171, 172.

RAILROAD EMPLOYÉS,

Baggage checkers of transfer company may be, 50 .

Crossing railroad tracks not a voluntary exposure to unnecessary danger, 254 et seq.

Excepted from conditions of policy, 49.

RAILROAD TRACKS, CROSSING,

Excepted risk under policy, 111.

Required by duties of occupation, 254 et seq.

Violation of law, 140, 141.

Voluntary exposure to unnecessary danger, 252 et seq. 
[The figures refer to pages]

RECOVERY, RIGH'T OF, for more than one accident, $323,324$.

Amount of, for disability contlnuing after payment of loss by insurer, 325, 326 .

RECREATION, ACTS OF, do not constitute an occupation, 54, 34, 345.

Voluntary exposure to unnecessary danger while engaged in, 242 et seq.

REFUSAL of insurance company to defend sult against insured in employers' liability insurance, 484-490.

Breach of policy, 487 .

Duty of insured to make loss small, 488.

Recovery by insured, 484 et seq.

Successful defense by insured, liability for costs of, 486 .

REJECTION of previous application of insured for insurance, 13.

RELAPSE, insurer not liable for, under permanent or continuing disability clause, 306-307.

\section{REPRESENTATIONS,}

Age, false statements concerning, 13.

Agents, limitations on authority, 24, 25.

Agents, power to waive misrepresentations, 24, 25.

Beneficiary, false relationship asserted, 13.

Bodily infirmity not a mere temporary ailment, 17.

Declarations in application when considered, 10-12.

Defined, 10-12.

Evasive replies, 14.

False representations, policies avoided by, 18 .

Fraudulent intent, 12.

Good health not literally construed, 17.

Habits, answers concerning, 16.

Income, incorrect representations regarding, 13.

Jury, questions for, 12.

Knowledge of applicant concerning his physical condition, 17.

Matters of opinion, 11.

Modifications in replies, 11.

Occupation, false answers regarding, 13-15.

Occupation, slight discrepancy in description, 14.

Other insurance, 16 .

Personal knowledge, statements based upon facts not within, 11.

Presumption of law as to truthfulness and good faith of replies, 12.

Previous disability, compensation refused for, 13 . 
REPRESENTATIONS-Continued,

Previous injury, what constitutes, 17, 18.

Rejection of prior application, 13 .

Reliance on representations by insurer, 12.

Source of contract, 10.

Statutory regulations, 11.

Substantially true, 10 .

Temperance, answers concerning, 16.

Waiver, 24-26.

Warranties, when constituting, 10-12.

REPTILE, bite of, 158.

RES GEST Æ, 81-84.

Physicians, evidence of, 83.

What constitute, 82-84.

RHEUMATISM, result of accident, 194.

ROADBED of railroad, $168,169$.

ROBBERS, injuries inflicted by, 349 .

Murder by, as intentional injury, 278, 279.

ROBBERY, as violation of law, 134 .

\section{S}

SALARY of insured determining amount of liability of insurer, 320-322.

SCALDING WATER, burns by, as accident by external and violent means, 43.

SEAS, death or injuries beyond, an excepted risk, 282, 283.

Insular possessions of the United States, 282.

What included in term, 282, 283.

SEPTICAMIA,

See Blood Poison.

SETTLEMENT by insured forbidden by policy of liability insurance, 481, 485.

Waiver of condition by insurer, 485 .

SHOCK as an accidental injury, 34.

SICKNESS, delay in paying premiums, 20.

SLEEP WALKING, injury during, 189.

SNAKE BITE as accident, 38.

SOMNAMBULISM, injury during, 189. 
[The figures refer to pages]

SPORTS, exposure to danger while engaged in, 242 et seq.

Not a change of occupation, 344 .

STEAMBOAT as a public conveyance, 67, 335.

STEEPLECHASE RIDING as excepted risk, 111.

.Voluntary exposure to unnecessary danger, 244.

STING causing blood poison, 33, 38.

STRAIN as accident by external and violent means, 32, 33, 39.

SUICIDE,

Accident by external and violent means, 42 .

Burden of proof in defense of, 119.

Excepted risk, 112-119.

Liability for amount of preminms only, 118.

Presumption against, 81, 118, 119.

"Sane or insane," 114, 115.

Statute forbidding pleading of, as a defense to liability under policy, 116-118.

When insurer liable for, 112, 113.

SUIT,

Against insured in liability insurance, agreement of insurer to defend, 481-484.

Insured forbidden to defend or settle, 481.

Judgment, conclusiveness of, against insurer, 483.

Refusal of insurer to defend, 483 et seq.

On accident insurance policy, 437.

Conditions limiting place of bringing, 437 .

Time within which suit may be brought, 436,437 .

Where to be brought, 437.

On policy of employers' liability insurance, limitation of time for bringing, 479, 480 .

Policy may determine bringing, 479.

SUNDAY LAWS, breach of, as violation of law, 136-138.

SUNSTROKE, not an accident, 185, 186.

SURGICAL OPERATION, an excepted risk, 104.

SURGICAL RELIEF, immediate, liability for under policy of lia-

bility insurance, 493-495.

Living expenses not included by, 494.

Notice to insurer, 494.

Relief must be reasonable and immediate, 494 .

SURGICAL TREATMENT, an excepted risk, 157. 


\section{$\mathbf{T}$}

TAXICAB, as a public conveyance, $67,335,336$.

TEMPERANCE,

Total abstinence not required, 16.

Warranties or representations concerning, 16.

TERII OF POLICY, condition requiring policy to be in effect certain time before accident, 318.

TERM POLICIES, 21-23.

Acceptance of order does not constitute payment of premium, 21.

Default in payment of premiums by withdrawal of entire amount of wages, 22.

Default in payment of premium by termination of employment, 22.

Distinguished from continuing poiicies, 23.

Failure of insurer to present premium orders, 21, 22.

Invalidated by failure to leave installment with employer, 21, 22.

Payment not defaulted until pay day, 21, 22.

Payment of premium not evidenced by continued employment of insured, 22.

What are, 21-23.

THREATS, to inflict injuries, evidence of, 281.

TIME,

For giving notice and proofs of injury or death, conditions of policy regulating, 391,392 .

Method of computing, 391, 392.

Of death or disability after accident, 68-76.

TOTAL DISABILITY, 291-305.

Absolute, disability need not be, 297, 298.

Capability of assured, disability dependent upon, 294, 295.

Construction of provision, liberal, 296, 297.

Death is not, 314.

Defined, 292 et seq.

Earning power of assured as test of, 295.

Heipless, assured need not be ent1rely, 292 et seq.

Insanity, 292.

Jury, question for, 305.

Labor, ability of insured to perform, 293 et seq.

Loss of time, insurance against, 303. 
[The figures refer to pages]

TOTAL DISABILITY-Continued,

Manual labor, ability to perform, 299, 300.

Mental disability included by, 292.

Occupation, ability of insured to follow another, affecting disability, 304, 305 .

Occupation, disability determined by, 294, 303, 304 .

Pain affecting disability, 301.

Portion of face of policy, optional payment of, 322,323 .

Renewed disability from same accident, further recovery for, $325,327$.

Sick, policies analogous to, 291 .

Substantial duties of occupation, ability of insured to perform, $297,300,302$.

Wages, difference in, as evidence of disability, 300 .

What constitutes, 292 et seq.

TRAVELERS' POLICIES, 55-67.

TRAVELING,

Alighting from or boarding moving car, 57, 58.

Alighting from train at intermediate stations, 58-60.

Baggage car, riding in, 67.

Express car, riding in, 67.

Fall from train, 33.

Mail car, riding in, 67.

Platform of cars, riding ou, 67.

Steamboat, riding on, 67 .

Taxicab, riding in, 67.

Termination of journey by leaving conveyance, 55, 56, 60 .

Transfer from train to train or boat, 56, 58.

What constitutes, 55 et seq.

TRAIN,

Boarding or leaving moving, as voluntary exposure to unnecessary danger, 246 et seq.

Riding on platform of moving, when voluntary exposure to unnecessary danger, 250, 251.

TRIBUNALS, agreement to submit elaims to, 431.

Condition requiring strictly construed, 432.

Decisions of, how far conclusive, 433.

TRIVIAL ACTS, ability to perform, affecting total disability, 297 et seq. 
UNCOMPLETED BUILDINGS, warranty concerning, in liability policies, 443, 444.

UNINHABITED REGIONS, adventures into, an excepted risk, 104.

UNOCCUPIED BUILDINGS, warranty concerning, in liability policies, 443, 444.

\section{VIOLATION OF LAT,}

\section{V}

An excepted risk in accident policies, 128-141.

Adultery, 135.

Army, desertion from, 135, 136.

Burden of proof on insurer, 141.

Crossing raiiroad tracks, 140, 141.

Determined by facts in individual cases, 129 .

Drunkenness, 131.

Fighting, 131.

Fighting in line of occupation of insured, 133, 134.

Fighting in self-defense, 132, 134.

Horse racing, 139.

House of ill fame, visiting, 135.

Hunting, 136.

Insurer liable where act is merely preparatory to, 139.

Intoxication, 136, 149.

Known and intentional, vioiation must be, to excuse insurer, 131.

Leaving train in motion, 140.

Purpose of exception, 128.

Riding on platform of moving cars, 140 .

Robbery, 134.

Sunday laws, breach of, 137, 138.

When policy not avoided by, 129 et seq.

An excepted risk in employer's' liability policies, 447-450.

Statutes, breach of, 448-450.

VOLUNTARY EXPOSURE to unnecessary danger an excepted risk, 220-260.

Bicycie riding generally not, 245 .

Bull fighting, 244.

Burden of proof, 258.

Consciousness of danger a necessary condition to, 221-226. 
[The figures refer to pages]

\section{VOLUNTARY EXPOSURE-Continued,}

Contributory negiigence not synonymous with, 220.

Convenience not justification for, 234.

Custom among others in same occupation, 241.

Danger must be apparent, 221-226.

Doctor reaching patient, 233.

Exposure must be voluntary, 231, 232 .

Fighting when constituting, 245, 246.

Horseback riding not generally, 244.

Horse racing not generally, 244.

Hunting, 243.

Inadvertent exposure, 235.

Jury, question for, 259.

Occupation, exposure to danger a feature of, 236-240.

Peril, situations of, 232.

Pleading, 78, 257, 258.

Proximate cause of accident, 241, 242.

Railroad tracks, crossing, as exposure, 252 et seq.

Railroad tracks, crossing, as duty of occupation, 254 et seq. Reckless conduct, 235.

Sports, exposure to danger in, 242 et seq.

Steeplechase riding, 244.

Train, boarding or leaving, moving, 246 et seq.

Train, riding on piatform of moving, 250, 251.

Unexpected danger, 231, 232.

Urgent necessity, work of, 233.

Validity of exception, 220.

What constitutes, 220-260.

VOLUNTARY OVER-EXERTION an excepted risk, 105-107.

Bicycle riding generally not, 106.

Lifting weight, generally not, 106.

\section{W}

WAGES affecting question of total disability of insured, 300 . I'ayment of premiums, 21.

WAIVER,

Agent, acts of, when sufficient to constitute, 24.

Commencement of risk, provisions determining, 7.

Consideration not essential to, 24.

Estoppel as a feature of, 24.

Fuller Acc.Ins.-36 
WAIVER-Continued,

False representations waived by inducing insurer to undergo expense and trouble, 25.

False representations waived by treating policy as in force, 25.

Forfeiture for nonpayment of premiums, 21.

Knowledge of facts essential to, 24, 25.

Methods of, 25, 26.

Mistakes of agent of insurer, 25.

Warranties or false representations, 24-26.

Of notice and proofs of death or injury, 409 et seq.

Agent, power of, 410, 411.

Blank forms for notice or proofs, neglect or refusal to furnish, 414, 415.

Denial of liability, $424-427$.

Estoppel as a feature of, 410 .

Fallure to object to defects in notice or proofs, 421-424.

Further information, waiver by request of insurer for, 416420.

Insufficiency of notice or proofs, insured not advised of, 412.

Jury, when question for, 428, 429.

Knowledge of facts essential to, 419.

Methods of, 411 et seq.

Pleading, 428, 429.

Refusal to accept proofs, 414.

Requirement of proofs or notice not insisted on by agent, 411.

Request for further information, 412, 413.

Reservation of contract rights by insured defeating, 419 .

Subsequent premiums, acceptance of, does not constitute, 421.

What constitutes, 409 et seq.

Of notice of injury in employers' liability insurance, 478, 479.

Burden of proof, 479 .

Jury, question for, 479.

What constitutes, 479 .

WARRANTIES,

Accuracy of, 10.

Age, falsely stated, 13.

Answers "full and correct," 13.

Avolding policles when material thereto, 18.

Beneficiary, false relationship asserted, 13.

Bodlly infirmities not temporary ailments, 17. 
[The figures refer to pages]

WARRANTIES-Continued,

Breach of conditions of application, 11, 12.

Defined, 10.

Distinguished from representations, 10.

Evasive replies to questions, 14.

Fraudulent intent, 12.

Good bealth not literally construed, 17.

Habits, answers regarding, 16.

Health, answers regarding, 16.

Income, untrue answers concerning, 13.

Jury, question for, 12.

Knowledge of applicant concerning physical condition, 17.

Knowledge of applicant, facts not within, 11.

Lack of knowledge of applicant concerning statements, 12.

Materiality of statements in application, 10-12.

Occupation falsely represented, 13-15.

Occupation, slight discrepancy regarding, 14.

Opinion, matters of, 11.

Other insurance concealed, 16.

Presumption of truth and good faith, 12.

Previous disability, compensation refused for, 13.

Previous injury, what constitutes, 17, 18.

Rejection of prior application, 13.

Representations distinguished from, 10.

Statements in application when held, 10, 11.

Statutory regulations concerning, 11.

Temperance, answers regarding, 16.

Untruthfulness of facts warranted, 11.

Waiver of false warranties, 24-26.

When representations become warranties, 10,11 .

WEEKLY INDEMNITY,

Death of insured after ninety days, 316, 317.

Liability for, when accrued, 317.

Recovery for death and weekly indemnity, 74.

WITNESSES,

Competency of assured, 79.

Eyewitnesses, 78, 79.

\section{Y}

YARD, ability to be about, affecting confinement to house, 310 . 






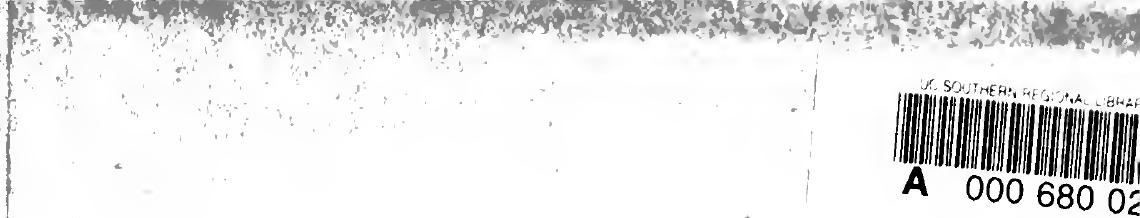




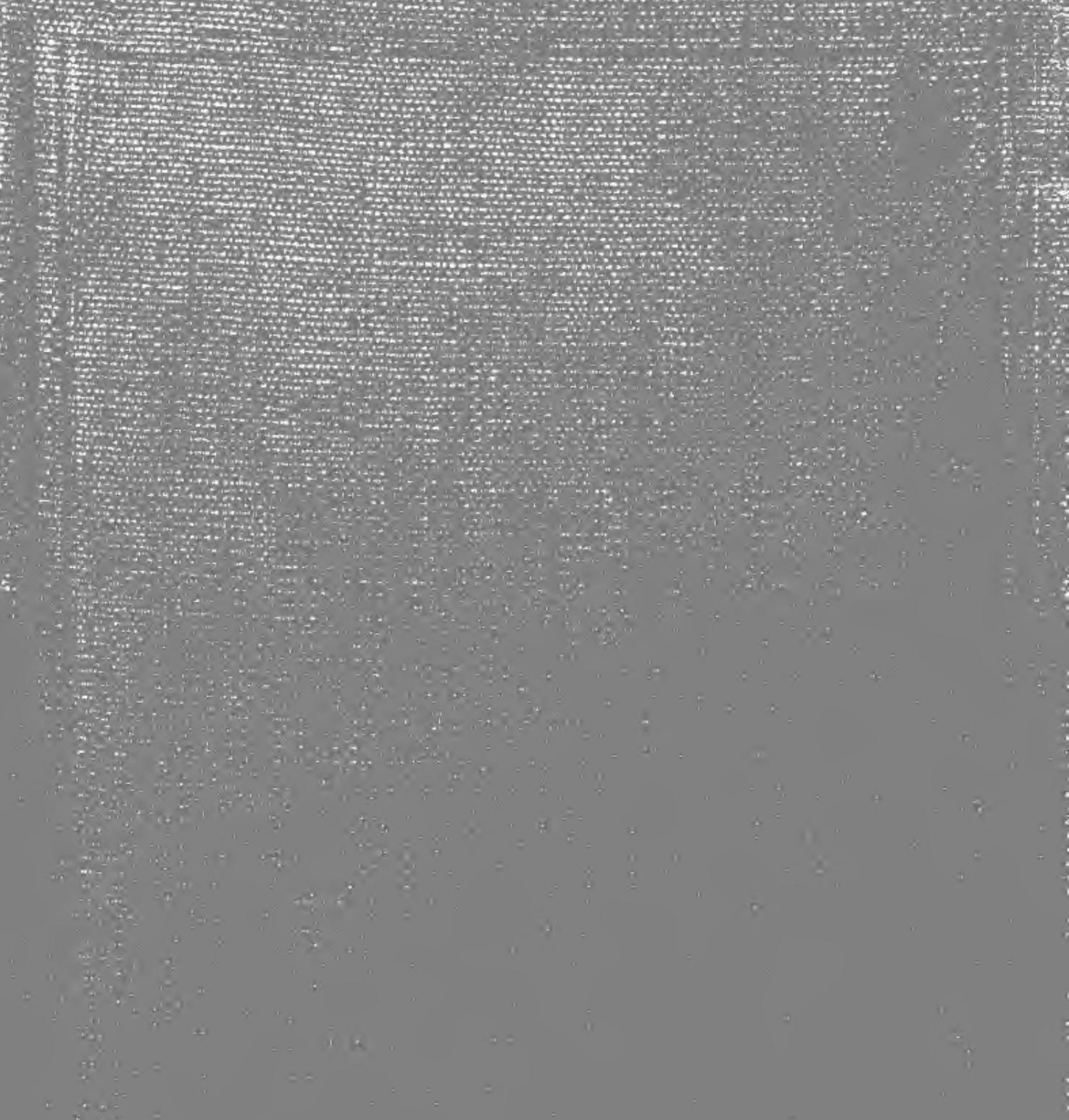

